

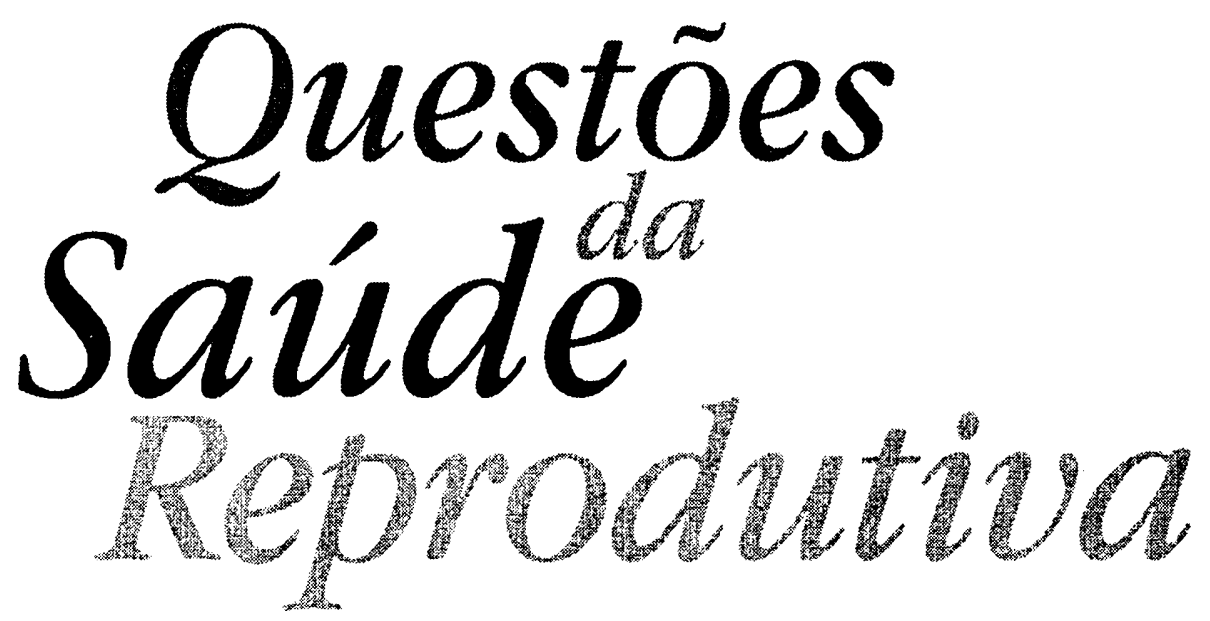




\section{FUNDAÇÃO OSWALDOCRUZ}

Presidente

Eloide Souza Garcia

Vice-Presidente de Ambiente, Comunicação e Informação Maria Cecilia de Souza Minayo

\section{EDITORAFIOCRUZ}

Coordenadora

Maria Cećlilia de Souza Minayo

Conselho Editorial

Carlos E. A CoimbraJr.

Carolina M. Bori

Charles Pessanha

Hooman Momen

Jaime L. Benchimol

Joséda Rocha Canvalheiro

Luiz Femando Femeira

Minam Struchiner

Paulo Amarante

Paulo Gadeh ha

Paulo Marchion Buss

Vanizz Macêdo

Zigman Brener

Coordenador Executivo

João Carlos Canossa P. Mendes 


\section{Karen Giffin}

\section{Sarah Hawker Costa}

Organizadoras
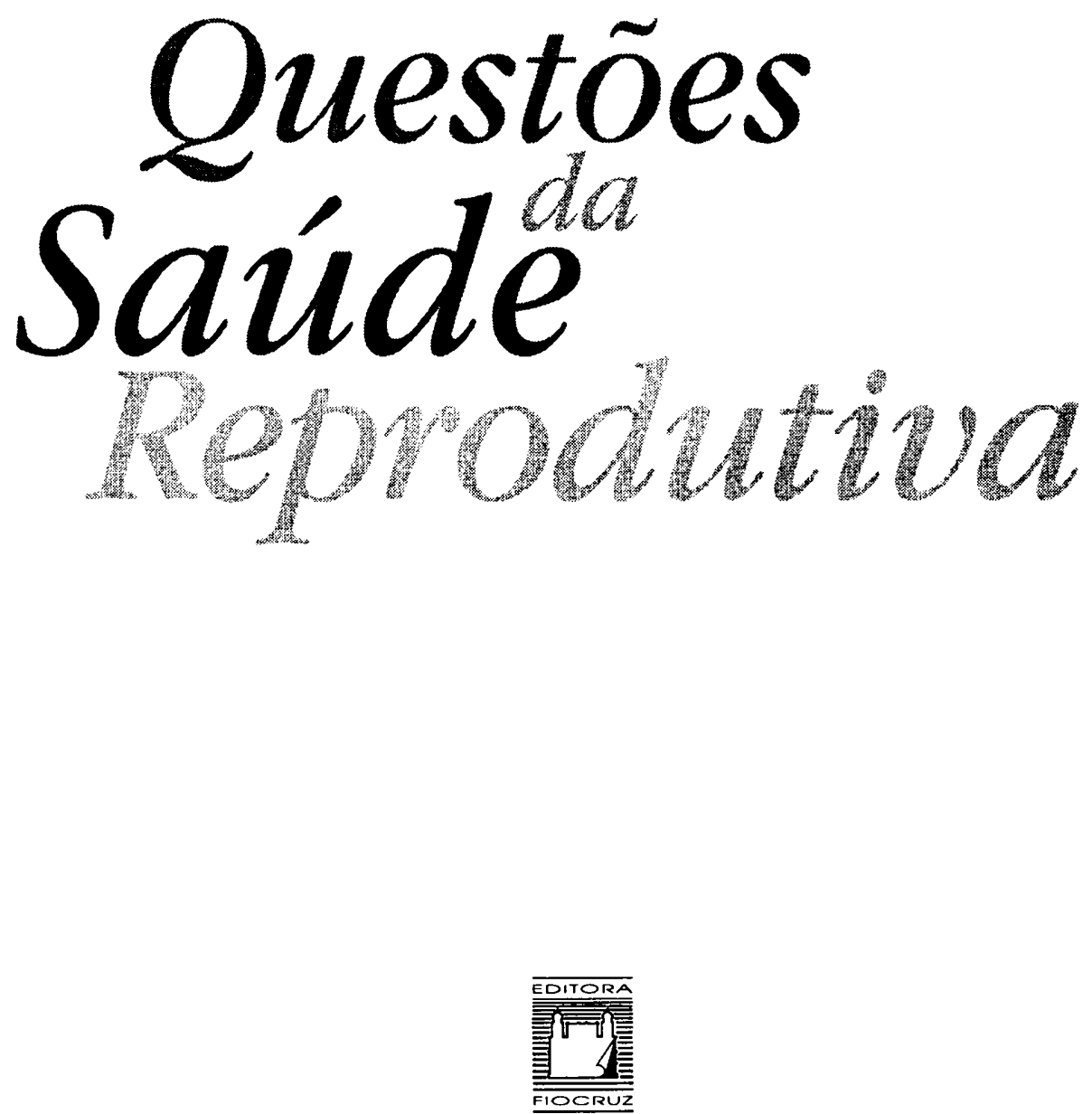
Copyright 1999 dos autores

Todos os direitos desta edição reservados à

FUNDAÇÃOOSWALDO CRUZ / EDTORA

ISBN: 85-85676-61-2

Projeto Gráfico

Adriana Carvalho Peixotoda Costa

Editoração Eletrônica

Adriana Carvalho Pexixoto da Costa e Angélica Mello

Capa

Adriana Carvalho Peixoto da Costa e Angélica Mello

Fotos de Capa

Jeremy Homer (Panos Pictures) e Alvaro Funcia (fotos cedidas pelos projetos Escolas Promotoras de Saúde, 1997 e Gravidez e Infecção pelo HIV, 1999 -CSE-GSF, em parceria com a SDE/ENSP/FiocRUZ, este último com financiamento da Fundação Mac Arthur) e Annual Report'95.

Copidesque e Preparação de Originais

Femanda Veneu

Revisão

Patricia Coetho

Catalogação-na-fonte

Centro de Informação Científica e Tecnológica

Biblioteca Lincoln de Freitas Filho

G457q Giffin, Karen (Org.)

Questões da saúde reprodutiva. / Organizado por Karen Giffin

e Sarah Hawker Costa. - Rio de Janeiro: Editora FlocRUz, 1999.

468p., il., tab., graf.

1. Saúde reprodutiva. 2 . Indicadores de morbi-mortalidade.

I. Costa, Sarah Hawker (org.)

$$
\text { CDD-20.ed. }-612.6
$$

1999

Editora Fiocruz

Rua Leopoldo Bulhões, 1480, térreo-Manguinhos

21041-210-Rio de Janeiro - RJ

Tel: (21) 560-6608 ramal 3030

Fax: (21) 560-6608 ramal 2009 


\section{Autores}

Ana Amélia Camarano - Demógrafa com doutorado em Estudos Populacionais pela University of London. Coordenadora da Área de Estudos Populacionais do Instituto de Pesquisa Econômica Aplicada da Presidência da República (IPEA). Editora da Revista Brasileira de Estudos Populacionais.

Ana Cristina C. Vaz Reis - Nutricionista com especialização e mestrado em Saúde Pública. Assistente de pesquisa do Núcleo de Gênero e Saúde da Escola Nacional de Saúde Pública da Fundação Oswaldo Cruz (Ensp/Fiocruz).

Ana Flávia Pires Lucas D’Oliveira - Médica sanitarista. Doutoranda em Medicina Preventiva/Universidade de São Paulo (USP). Coordenadora do Programa de Atenção à Mulher do Centro de Saúde Escola Samuel Bransley Pessoa/Departamento de Medicina Preventiva da Faculdade de Medicina da USP.

Ana Maria Costa - Médica sanitarista especialista em Políticas Sociais e Saúde da Mulher. Foi coordenadora da equipe que elaborou o Palsm e coordenadora nacional deste Programa no âmbito do Ministério da Saúde. Coordenadora do Núcleo de Estudos de Saúde Pública da Universidade de Brasília (UnB).

Aurelio Molina - Médico, especialista em Tocoginecologia, mestre em Ginecologia (UFR), mestre e Ph.D em Planejamento Familiar pela University of Leeds (Inglaterra), Professor Adjunto da Universidade de Pernambuco (UPE), titular do Colégio Brasileiro de Cirurgiões. Coordenador do Mestrado em Ginecologia e Obstetrícia da Faculdade de Ciências Médicas da UPE. 
Catherine M. Lowndes - PhD. em biologia molecular. Pesquisadora do Groupe de Recherche en Epidemiologie, Université de Laval, Québec, Canadá, onde faz pesquisa sobre AIDS/DST no Brasil e na África.

Célia Regina de Andrade-Assistente social. Mestranda e pesquisadora do Departamento de Epidemiologia e Métodos Quantitativos em Saúde (DEMQS) da ENSP/Frocruz, com trabalhos sobre epidemiologia cardiovasculare saúde da mulher.

Diana do Prado Valladares - Sanitarista, mestre em antropologia médica. Gerente do Programa de Saúde da Mulher da Secretaria Municipal de Saúde do Rio de Janeiro.

Dóra Chor-Médica. Doutora em Saúde Pública pela Faculdade de Saúde Pública da USP. Pesquisadora do Departamento de Epidemiologia e Métodos Quantitativos em Saúde (DEMQS) da ENSP/FrocrUz.

Eleonora D'Orsi-Médica, pesquisadora do Núcleo de Gênero e Saúde e doutoranda em epidemiologia da ENSP/Frocruz, com estudo sobre cesáreas e qualidade da assistência ao parto.

Eleonora Menicucci de Oliveira-Socióloga. Pós-Doutorado na Clínica Del Lavoro Luigi Derote da Universitá Degli Studi di Milano. Professora Livre Docente em saúde coletiva da Universidade Federal de São Paulo (UNIFESP)/Escola Paulista de Medicina. Coordenadora do Centro de Estudos em Saúde Coletiva-UNIFESP/EPM. Pesquisadora do Conselho Nacional de Desenvolvimento Tecnológico,(CNPq) e da Fundação de Amparo à Pesquisa do Estado de São Paulo (FAPESP). Diversas publicações na área do Trabalho-Saúde-Gênero.

Elisabeth Meloni Vieira-Médica sanitarista, especialista em Saúde Pública. Mestre em Medicina Preventiva/USP, PhD em Pesquisa Aplicada a Estudos Populacionais/ University of Exeter, Inglaterra. Docente da Faculdade de Medicina da USP de Ribeirão Preto.

Elza Berquó - Demógrafa, coordenadora da Área de População e Sociedade do Centro Brasileiro de Análise e Planejamento (CEBRAP) e do Programa de Saúde Reprodutiva e Sexualidade do NEPo/UniCamp. Presidente da Comissão Nacional de População e Desenvolvimento.

Estela Maria Leão de Aquino - Professora adjunta do Instituto de Saúde Coletiva da Universidade Federal da Bahia (ISC/UFBA); coordenadora do Programa de Estudos em Gênero, Mulher e Saúde (MUSA/ISC/UFBA); coordenadora do Grupo de Trabalho Gênero e Saúde da Associação Brasileira de Pós-Graduação em Saúde Coletiva (ABRASCO); integrante da Comissão Intersetorial de Saúde da Mulher do Conselho Nacional de Saúde. 
Fátima Oliveira - Médica. Integrante da Comissão Nacional de Ética cm Pesquisa do Ministério da Saúde (Conep/MS), da coordenação nacional da União Brasileira de Mulheres (UBM), do Conselho Diretor da Comissão de Cidadania e Reproduçãoe da Rede Nacional Feminista de Saúde e Dircitos Reprodutivos. Conselhcira doConselho Municipal dos Direitos da Mulher-Belo Horizonte/MG.

Herton Ellery Araújo-Mestre cm Ciências Econômicas pcla UnB. Técnico em Planejamento e Pesquisa da Coordenadoria de Estudos Populacionais do IPEA/Brasília.

Isabella Gomes Carneiro - Mestre em Ciências - Economia do Consumidor pela University of Maryland -College Park, MD; Doutora em Demografia pela Universidade Estadual de Campinas. Consultora/Assistente de Pesquisa do IPEA.

Jacqueline Pitanguy-Socióloga e cientista política. Fundadora e diretora da ONG CEPIA (Cidadania, Estudo, Pesquisa, Informação, Ação). Ex-presidente do Consclho Nacional dos Direitos da Mulher (1986-1989). Integrante do Conselho Consultivo do Allan Guttmacher Institute, do Inter-American Dialogue e do Human Rights Council. Integrante do Consclho Diretor da Comissão de Cidadania e Reprodução.

Kaizô Iwakami Beltrão-Engenheiro mecânico. PhDcm Estatística pela Universidade de Princeton, EUA. Superintendente da Escola Nacional de Ciências Estatísticas/Instituto Brasileiro de Geografia e Estatística (ENCE/IBGE).

(Org.) Karen Giffin, PhD em Sociologia pela University of Toronto; Pós-Doutorado do Departamento de Antropologia, University of California, Berkeley. Professora e Pesquisadora Titular do Departamento de Ciências Sociais; coordenadora do Núcleo de Gênero c Saúde, EnSp/Frockuz. Integrante da Comissão de Cidadania e Reprodução e do Grupo de Trabalho Gênero e Saúde da ABRasco.

Kátia Silveira da Silva - Médica epidemiologista, mestrc em Saúde Pública. Integrante do Comitê de Prevenção e Controle da Mortalidade Materna do Estado do Rio de Janeiro. Assessora da Direção do Instituto Fernandes Figueira/Fıocruz.

Leila Linhares Barsted - Advogada, diretora da CePiA (Cidadania, Estudo, Pesquisa, Informação, Ação). Editora da revista Estudos Feministas (UFRJ).

Lilia Blima Schraiber - Doutora e livre-docente em Medicina Preventiva pcla USP. Professora Associada do Departamento de Medicina Preventiva da Faculdade de Medicina da USP. Especialista em Saúde Pública e Planejamento em Saúde pela FSP da USP. Supervisora do Centro de Saúde Escola Samuel B. Pessoa, pesquisadora do CNPq, coordenação de pesquisa $\mathrm{cm}$ violência, gênero e dircitos humanos. 
Lilian Fátima Barbosa Marinho - Enfermeira, mestre em Saúde Comunitária, pesquisadora do Programa de Estudos em Gênero, Mulher e Saúde (MuSA/ISC/Urba); técnica da Fundação Nacional de Saúde (FNS/MS).

Lynn D. Silver - Professora adjunta da Faculdade de Ciências da Saúde e Centro de Estudos Avançados e Multidisciplinares da Universidade de Brasília (UnB) e Coordenadora de Pesquisa em Saúde do Instituto Brasileiro de Defesa do Consumidor (IDEC).

Margareth Arilha - Psicóloga, pós-graduanda do Programa de Psicologia Social da PUC-SP. Pesquisadora e diretora da Estudos e Comunicação em Sexualidade e Reprodução Humana (Ecos). Secretária-Executiva da Comissão de Cidadania e Reprodução. Integrante do Conselho Nacional de Saúde.

Maria de Jesus Mendes da Fonseca - Estatística. Mestre em Saúde Pública. Pesquisadora do Departamento de Epidemiologia e Métodos Quantitativos em Saúde da ENSP/FroRUZ

Milena Piraccini Duchiade-Médica. Mestre em Saúde Pública pela Ensp/Frocruz. Pesquisadora do Departamento de Epidemiologia e Métodos Quantitativos em Saúde da ENSP/FIOCRUZ

Regina Helena Simões Barbosa - Psicóloga, mestre e doutoranda em Saúde Pública. Professora do Departamento de Medicina Preventiva e pesquisadora do Núcleo de Estudos de Saúde Coletiva da Universidade Federal do Rio de Janeiro (NESC/UFRJ). Desenvolve atividades de ensino, pesquisa e extensão na área de Gênero e Saúde, em especial no campo de prevenção de DST/ArDs.

(Org.) Sarah Hawker Costa-Mestrado em demografia médica da University of London, D.Phil. em Saúde Pública, University of Oxford. Professora e Pesquisadora Titular do Departamento de Epidemiologia e Métodos Quantitativos (ENSP/FIOcRUZ). Assessora de Programas na Fundação Ford no Brasil, na área de Saúde Reprodutiva.

Rosalina Jorge Koifman - Médica, com mestrado em Medicina Social. Diretora do Departamento de Epidemiologia da Secretaria Municipal de Saúde do Rio de Janeiro de 1981 a 1990. Pesquisadora titular no Departamento de Epidemiologia da EnSP/FIOCRuz, onde desenvolve atividades de ensino e pesquisa em Epidemiologia do Câncer.

Sergio Koifman-Médico com doutorado em Medicina Preventiva na USP. Pesquisador titular no Departamento de Epidemiologia ENSP/FIOCRUZ, participando de atividades de ensino e pesquisa em Epidemiologia do Câncer. 
Simone Grilo Diniz - Médica sanitarista. Mestre e doutoranda em Medicina Preventiva pela USP. Fundadora e integrante do Coletivo Feminista Sexualidade Saúde. Trabatha com pesquisa, assistência, capacitação e politicas públicas em violência, saúde reprodutiva e sexual.

Sonia Corrêa - Arquiteta com especialização em antropologia. Fundadora da ONG feminista SOS-Corpo-Gênero-Cidadania. Integrante do Conselho Diretor da Comissão de Cidadania e Reprodução e da Comissão Nacional de População e Desenvolvimento. Coordenadora do projeto associado Instituto Brasileiro de Análises Sociais e Econômicas - Development Alternative with Women for a New Era (IBASE-DawN) Iniciativa Gênero.

Suzana Kalckmann - Bióloga, com especialização em Saúde Pública pela Faculdade de Saúde Pública (USP), mestre em Epidemiologia pela Escola Paulista de Medicina (UNFESP). Pesquisadora do Núcleo de Investigação em Saúde da Mulher e da Criança do Instituto de Saúde da Secretaria de Estado da Saúde de São Paulo. Integrante do Grupo de Estudos sobre Sexualidade Masculina e Patemidade (GeSmap). Coordenou o primeiro estudo sobre o preservativo feminino no Brasil.

Thália Velho Barreto de Araújo-Médica. Mestre em Epidemiologia (LSHTM/University of London). Doutoranda em Saúde Coletiva (ISC/UFBA). Professora assistente do Departamento de Medicina Social da Universidade Federal de Pernambuco (UFPE). Pesquisadora visitante na Maternal and Child Epidemiology Unit, London School of Hygiene and Tropical Medicine, University of London (1990). 



\section{Sumário}

(4)
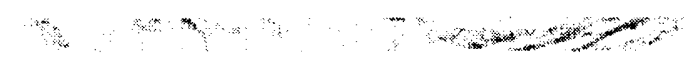

Apresentação

Parte I- História, Politica, Concetos

1. O Movimento Nacional c Internacional de Saúde c Dircitos Reprodutivos Jacqucline Pitanguy

2. "Saúdc Reprodutiva", Gênero e Sexualidade:

legitimação e novas interrogações

Sonia Corrêa

3. Família, Sexualidade e Reprodução no Direito Brasileiro

Leila Linhares Barsted 51

4. AMedicalização do Corpo Feminino

Elisabeth Meloni Vieira

5. Corpo e Conhecimento na Saúde Sexual: uma visão sociológica

Karen Giffin 


\section{PARTE II-CONIROLE DA FECUNDDADE}

6. Tendências da Fecundidade Brasileira no Século XX: uma visão regional

Ana Amélia Camarano, Herton Ellery Araújo \& Isabella Comes Carneiro

7. Ainda a Questão da Esterilização Feminina no Brasil

Elza Berquó

8. Laqueadura Tubária:

situação nacional, internacional e efeitos colaterais

Aurelio Molina

9. Métodos de Barreira Controlados pela Mulher

Suzana Kalckmann

10. Aborto Provocado:

a dimensão do problema e a transformação da prática

Sarah Hawker Costa

PARTE III-MORBI-MORTALDADE

11. Padrões e Tendências em Saúde Reprodutiva no Brasil: bases para uma análise epidemiológica

Estela Maria Leão de Aquino, Thália Velho Barreto de Araújo \& Lilian Fátima Barbosa Marinho

12. A Mortalidade Materna no Brasil no Período de 1980 a 1993

Kátia Silveira da Silva, Eleonora D'Orsi, Catherine M. Lowndes \& Ana Cristina C. Vaz Reis

13. Incidência e Mortalidade por Câncer em Mulheres Adultas no Brasil Sergio Koifman \& Rosalina Jorge Koifman

14. Doenças Sexualmente Transmissíveis na Mulher Catherine M. Lowndes 
15. Ardse Saúde Reprodutiva: novos desafios

Regina Helena Simões Barbosa

IV-SERVÇCSOS DE SAÚDE

16. Direito à Saúde ou Medicalização da Mulher?

Implicações para avaliação dos serviços de saúde para mulheres

Lynn D. Silver

17. Desenvolvimento e Implantação do PASM no Brasil

Ana Maria Costa

18. Violência de Gênero, Saúde Reprodutiva e Serviços

Ana Flávia Pires Lucas D'Oliveira \& Lilia Blima Schraiber

19. Ações de Contracepção e Assistência ao Parto:

a experiência do Rio de Janeiro

Diana do Prado Valladares

20. A Atenção Integral e a Caixa de Pandora:

notas sobre a experiência do Coletivo Feminista Sexualidade Saúde

Simone Grilo Diniz

V-SAÚdE REPRODUTIVA E GRUPOS SOCIASS

21. Condições de Saúde de Funcionários de Banco Estatal: aspectos ligados à reprodução

Dóra Chor, Maria de Jesus Mendes da Fonseca, Milena Piraccini Duchiade,

Célia Regina de Andrade \& Kaizô I wakami Beltrão

22. O Recorte Racial/Étnico e a Saúde Reprodutiva: mulheres negras

Fátima Oliveira 
23. O Drama da Mulher no Mundo do Trabalho:

o ser e o estar

Eleonora Menicucci de Oliveira

24. Homens, Saúde Reprodutiva e Gênero:

o desafio da inclusão

Margareth Arilha 


\section{Apresentação}

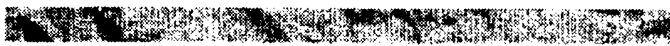

Concebemos este livro como demonstração do esforço conjunto da Academia, serviços e movimento sociais na luta pela saúde. Nosso desejo foi produzir um recurso para a preparação de novos profissionais, um volume em que se apresentasse uma visão abrangente da realidade do nosso assunto, compondo um quadro histórico-políticoconceitual da Saúde Reprodutiva.

Embora autoras e autores não tenham sido orientados para reunir as questões da saúde reprodutiva sob uma bandeira única, isto aconteceu: os artigos têm como fio condutor a noção da saúde integral, que veio a público no Brasil em 1983, com a formulação de uma proposta oficial, o Programa de Assistência Integral à Saúde da Mulher (PaISM), que continua sendo uma utopia do movimento de mulheres e um projeto coletivo que norteia ampla participação, apesar dos tempos dificeis da luta sanitária no Pais.

Nesta apresentação, é desaconselhável simplificar uma realidade feita tanto de idéias que avançam quanto de cifras de morbi-mortalidade que atestam a degradação da saúde. E desnecessário resumir os trabalhos que, juntos, descrevem fatos, analisam conceitos, rcportam experiências, levantam desafios e fazem sugestões, em uma clura demonstração da importância e da vitalidade de nossa história acumulada.

Karen Giffin
Sarah HawkerCosta 




\section{O Movimento Nacional e Internacional de Saúde e Direitos Reprodutivos}

然.

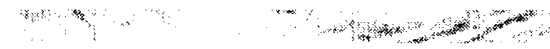

ter.

Jacqueline Pitanguy

\section{Contexto}

A visibilidade da mulher na esfera pública do cenário internacional constitui um dos principais fenômenos políticos da segunda metade deste sćculo. Isto deve-se tanto a um significativo aumento da presença feminina em partidos, parlamentos e cargos executivos, quanto à sua participação em diversas entidades da sociedade civil - movimentos sociais, Organizações Não-Governamentais (ONGs), associações de classe, sindicatos etc.

Sobre a participação feminina nos parlamentos curopeus, chama atenção a posição de destaque que detém nos países nórdicos, especialmente na Noruega, onde, desde a década de 80, as mulheres ocupam mais de 30\% das cadeiras do Lcgislativo. As recentes cleições da Inglaterra e da França fortaleceram sua presença neste espaço político. Na Inglaterra, a participação feminina na Câmara dos Comuns dobrou; na França, as mulheres precncheram $23 \%$ das vagas para candidatos c aumentaram significativamente sua presença no parlamento $\mathrm{cm}$ cargos de primeiro escalão do Executivo.

Esta crescente presença das mulheres nos canais institucionais do poder não se restringe nem à Europa, nem ao ocidente. Nos Estados Unidos, apesar de ainda não ultrapassarem $12 \%$ da representação no Congresso, entre os anos 80 e 90 , elas mais do que dobraram sua presença no Legislativo Federal. Em diversos países da América Latina vem ocorrendo fenômeno semclhante, inclusive no Brasil, onde, apesar de ostentarem ainda uma taxa muito baixa, alcançaram, na década de 90 , sua maior participação no Congresso Nacional - cerca de $8 \%$. 
Com exceção dos países árabes, onde a cultura afasta as mulheres da esfera pública, em diversos países da Ásia e da África houve, nesta década, significativo aumento de sua presença no Legislativo. Cabe assinalar que, nos que integravam o antigo bloco socialista europeu, a participação da mulher nos parlamentos vem decaindo nos últimos anos.

Se esta tendência - a maior presença das mulheres nos legislativos - não conduz, necessariamente, a plataformas comuns, uma vez que as agendas políticas tecem-se sobretudo a partir de princípios e conjunturas partidárias, é indicativa de um fenômeno talvez ainda mais importante - o de uma profunda mudança na percepção social do papel da mulher na sociedade. Atribuímos aos movimentos de mulheres, e particularmente ao feminismo, a responsabilidade principal por esta mudança.

A reivindicação, por estes movimentos, de um espaço próprio na dinâmica do poder suscita a necessidade de uma redefinição do conceito de atuação política. A análise dos significados e alcances desses movimentos deve incorporar novos instrumentos e indicadores, na medida em que se pretende interpretar um tipo de ação política cuja base organizacional se fundamenta, sobretudo, na solidariedade advinda da projeção política de uma identidade coletiva.

Calcados basicamente no estabelecimento de agendas e plataformas comuns de luta sem maiores entraves originados da dinâmica político partidária local, tais movimentos vêm construindo alianças e tecendo estratégias nacionais e internacionais com surpreendente agilidade. Não pretendemos questionar a importância do sistema partidário, mas tão-somente indicar que o próprio conteúdo de sua agenda política implica possibilidades e limites diversos. No entanto, salientamos o caráter imprescindível e insubstituível dos partidos políticos em qualquer projeto democrático; e ressaltamos o perigo em sobrevalorizar a capacidade das ONGs, especialmente na prestação de serviços, pois estas organizações não podem - nem devem - substituir o Estado.

Assistimos, especialmente nos anos 90, a uma crescente globalização dos movimentos sociais, interligados pelos meios de comunicação e com idéias em constante circulação por meio de redes, grupos e organizações nacionais e internacionais. Discutem-se propostas, reflexões, estratégias em inúmeros seminários, conferências. Fóruns e associações diversos são instituídos para canalizar e sistematizar este fluxo constante de troca.

\section{A América Latina e o Brasil}

O continente latino-americano tem compartilhado experiências econômicas e políticas semelhantes. Nos anos 60, realizaram-se eleições presidenciais em diversos países - Argentina, Bolívia, Brasil, Chile, Peru, Uruguai, Colômbia - além do México e alguns países da América Central. A estas eleições sucederam-se golpes militares responsáveis pela instalação de regimes autoritários que perduraram ao longo das décadas seguintes. 
Estes são também anos de resistência c exílio e coincidem com o amadurecimento do feminismo na Europa e Estados Unidos, onde despontou como movimento de grande visibilidade e impacto no final dos anos 60.

Na década de 80, diversos países da América Latina viveram profunda crise econômica, refletida na taxa média negativa de crescimento $(8,3 \%)$ observada na região entre 1981 e 1989.

As trajetórias, no continente, voltam a convergir na década de 80 e início dos anos 90 , com a democratização das instituições políticas, a hegemonia do modelo neoliberal, a reforma do Estado, o avanço da globalização. Alguns países lograram controlar as elevadas taxas de inflação que caracterizaram os anos anteriores. Poucos, como o Chile, conseguiram manter elevados índices de crescimento do Produto Interno Bruto.

A dinâmica do movimento de mulheres no continente também apresenta convergências e semelhanças, na medida em que os parâmetros básicos de sua atuação se inserem na lógica dos processos políticos e econômicos mais amplos.

No final dos anos 70 e início dos 80 , com o surgimento de movimentos sociais na esfera pública dos diversos países, a arena política latino-americana incorpora novos atores e amplia sua agenda. Estas novas formas de organização política cresceram, se afirmaram fora dos marcos tradicionais dos partidos ou dos sindicatos e trouxeram para o debate público temas referentes a saúde e direitos reprodutivos, que, até então, não eram considerados 'próprios' desse espaço.

Em praticamente todos os países latino-americanos, as relações de gênero têm demarcado espaços normativos, existenciais e simbólicos, calcados na exclusão, na hierarquia e na desigualdade do feminino frente ao masculino. Para as mulheres organizadas em movimentos, grupos e ONGs, a democracia não se refere apenas ao exercício da cidadania na esfera pública, mas também às relações na vida cotidiana, no trabalho, na família, na saúde, na educação. O slogan Democracia en la plaza y en la casa, das feministas chilenas, exemplifica bem esta proposta de requalificação do conceito de democracia.

Em um período de repressão e violência do Estado contra o Legislativo, a imprensa, as organizações civis e os sindicatos, o movimento de mulheres latino-americano traz a questão de gênero para a esfera pública, alargando as discussões sobre poder, cidadania e desigualdade, que caracterizavam a agenda oposicionista.

No Brasil, durante seus primciros anos de atuação política, o feminismo buscou construir uma base organizacional apoiada em grupos autônomos e, ao mesmo tempo, expandir seu alcance levando suas propostas a organizações de classe, sindicatos, universidades. Neste período, o movimento enfrentava dois grandes desafios: alcançar visibilidade como um novo ator político, e dar legitimidade à sua plataforma de 
maneira que esta fosse encampada por outros atores, como os partidos e setores do Executivo. O movimento feminista brasileiro destacou-se por sua visibilidade e impacto, tendo sido um dos primeiros a conquistar espaços governamentais' .

Durante os processos de democratização, que se estendem ao longo da década de 80 e início dos anos 90 , ocorrem as primeiras experiências de elaboração de políticas públicas com perspectiva de gênero, bem como o crescimento da presença da muTher no Legislativo e em cargos do Executivo. No Brasil, a primeira deputada federal foi eleita em 1933. Até 1990, apenas 82 mulheres tiveram assento no Legislativo federal, ao passo que 5.062 homens se elegeram. Mais da metade das mulheres (52) foi eleita entre o final da década de 80 e início dos anos 90 , coincidindo com a visibilidade das questões de gênero trazidas para o cenário político do País pelo feminismo. É interessante recordar que, no Brasil, o grande salto em termos de participação da mulher no Congresso Nacional ocorreu nas eleições de 1986 . O movimento de mulheres mostrava-se sumamente vigoroso e o Conselho Nacional dos Direitos da Mulher e conselhos estaduais lançaram a campanha 'Constituinte para valer tem que ter palavra de mulher ${ }^{2}$.

A interlocução do movimento de mulheres com outros atores políticos, como os partidos, outros movimentos sociais, os sindicatos, a Igreja Católica e entidades diversas da sociedade civil-inclusive as voltadas para a defesa dos direitos humanos-, obedece, via de regra, a duas coordenadas básicas: o contexto político mais amplo e a temática específica colocada pela agenda feminista.

No Brasil, durante os anos 70, independentemente da pauta em questão, era praticamente inexistente a interlocução com o Executivo, tanto em âmbito federal quanto estadual. De fato, o govemo mantinha com o movimento de mulheres a mesma atitude que caracterizava sua relação com a sociedade civil em geral: via com desconfiança e considerava potencial ameaça à ordem.

Neste período, entretanto, o movimento busca outros parceiros e alianças. Estabelece articulações importantes com a universidade - onde futuramente despontariam diversos núcleos de estudos da mulher-e procura sensibilizar a imprensa para que divulgue de forma menos preconceituosa e simplista a agenda feminista.

Com relação ao Legislativo, o movimento de mulheres tenta estabelecer uma ponte, enviando, em 1976, projeto de reformulação do Código Civil no capítulo da família, para abolir a figura do homem como chefe da sociedade conjugal. Ao mesmo tempo,

\footnotetext{
' Para uma análise do movimento de mulheres no Brasil, recomendo a leitura de Alvarez, S. Engedering Democracy in Brazil, Princeton, New Jersey University Press, 1990. Para uma análise mais especifica, sobre mulheres e saúde, ver PrtanGuY, J. Feminist Politics and Reproductive Rights, the case of Brazil, In: SEN, G. \& Snow, R. Power and Decision: the social control of Reproduction, Boston: Harvard University Press, 1994.

2 Ver Ptianguy, J. Movimientos de Mujeres y Pbliticas en Brasil. In: Nihout, G.; Vargas, V. \& Wieringa, S. Triángulo de Poder. Bogotá, Ed. Tercer Mundo, 1996, e Fucso/CEPu. Mujeres Latino Americanas en Cifras: Brasil. Santiago, Ed. Flacso, 1993.
} 
estabelece articulações com a oposição, visando a incluir alguns temas de sua agenda na sua plataforma eleitoral para as eleições parlamentares de 1978, cujo resultado marca o processo de abertura no Legislativo.

As tentativas de estabelecer conexões e alianças com a oposição - organizada na frente partidária do $\mathrm{MDB}$, em partidos clandestinos, ou no sistema pluripartidário pós1978 - seguiam a dinâmica derivada das duas coordenadas básicas anteriormente indicadas: a conjuntural e a temática. Do ponto de vista da conjuntura, a maioria dos partidos de oposição via o feminismo com certa desconfiança, particularmente porque o movimento poderia representar uma ameaça à 'união das esquerdas', desviando-as do inimigo principal, representado pelo Estado ditatorial. Do ponto de vista temático, algumas reivindicações eram incorporadas, outras rejeitadas, sobretudo em função de seus efeitos nas alianças estratégicas dos partidos com alguns setores, dentre os quais destacava-se a Igreja.

Deste modo, utilizando uma terminologia religiosa, diríamos que alguns temas como a violência doméstica - "chegaram antes ao céu", sendo incorporados ao discurso político de ampla gama de setores. Outros ficaram em uma espécie de "limbo político", onde costumam permanecer assuntos sem legitimidade suficiente para serem ouvidos, como os relativos à contracepção; outros, como o aborto e a sexualidade, permaneceram no "inferno", abrigo de temas tabus e malditos da sociedade.

Estas diferenças na incorporação social da agenda das mulheres não se circunscrevem ao Brasil. Na maior parte da América Latina, a introdução no discurso político mais amplo de questões temáticas abordadas pelas feministas obedeceu, e ainda obedece, a ritmos e alcances diversos. Pode-se analisar sob esse ponto de vista o tema do aborto, por exemplo. Em Cuba, o abortamento voluntário é legal ${ }_{;}$em diversos países do continente, a resistência ao debate público sobre o abortamento tem sido ainda mais profunda do que no Brasil. Na Argentina e no Chile, onde realizaram-se importantes avanços no combate à violência doméstica, a interrupção voluntária da gravidez é, ainda hoje, proibida em qualquer circunstância, mesmo em situações de risco de vida da mulher.

Nos anos 80, cresce a influência de feministas em partidos da oposição brasileira, notadamente o PMDB e o PT. Com a realização de eleições para governadores, em 82, e a vitória da oposição em estados como São Paulo, Minas Gerais e Rio de Janeiro, são criados os primeiros espaços govemamentais, denominados conselhos, com o objetivo de propor e implementar políticas públicas com perspectiva de gênero. São implantadas, também, as primeiras Delegacias Especializadas no Atendimento às Mulheres Vítimas de Violência (Deams).

Com a redemocratização dos países do Cone Sul, observa-se fenômeno semelhante. Estabelece-se o Servicio Nacional de la Mujer (SERNAM) no Chile, e Institutos de la Mujer na Argentina e no Uruguai. Recentemente, no Paraguai e na Bolívia também foram instituídos órgãos semelhantes. 
Cabe ressaltar que, ao instituir tais cspaços, os governos latino-americanos atendem não só a demandas dos movimentos de mulheres, mas também a recomendações das Nações Unidas. De fato, de 1975, Ano Internacional da Mulher, a 1985, ocasião da Conferência da Mulher cm Nairóbi, sucedem-se os apelos da Organização das Nações Unidas (ONU) para a criação de state machineries que viabilizassem o desenvolvimento de políticas públicas para a promoção da mulher.

\section{A trajetória brasileira ${ }^{3}$}

No Brasil, o percurso de mulheres feministas para o interior do Estado não se fez sem debates, desafios c temores. Tratava-se de "ocupar" cspaços ainda marcados pela herança de décadas de autoritarismo, durante as quais os aparelhos de Estado foram colocados a serviço de governos militares. Tal debate foi particularmente intenso quando um grupo de feministas articulou, cm 1985, com o candidato da oposição à presidência, Tancredo Neves, a criação, na esfera federal, do Conselho Nacional dos Dircitos da Mulher (CNDM).

Podem-se distinguir três tendências básicas no movimento de mulheres a este respeito. Uma ć intcgrada por aquelas que apóiam a criação do Conselho e se propõcm a ter um envolvimento dircto na sua formulação c gestão. Outra - parcela significativa -, apesar de apoiar a idćia do estabelecimento deste c de outros conselhos, não sc propõe a participar diretamente dos mesmos. Finalmentc, um grupo de feministas se coloca contra a instituição destes órgãos, pelo perigo da cooptação e eventuais amcaças à autonomia do movimento.

De qualquer forma, é possível sugerir que cspecialmente a segunda metade dos anos 80 marca um período fundamental de formulação c implantação de políticas públicas com perspectiva de gênero no Brasil.

Particularmente marcante foi a atuação, cm parceria com o CNDM, de conselhos estaduais e municipais e do movimento de mulheres durante o processo constitucional. A significativa maioria de propostas das mulheres foi incluída na Constituição de 1988.

À desarticulação do CNDM, cm 1989, scguiram-se as clcições presidenciais (no mesmo ano), c a concomitante desestruturação de setores importantes do aparetho estatal, especialmente os ligados a educação c saúde.

\footnotetext{
${ }^{3}$ Costaria de salientar que minha análise sobre movimento de mulheres e politicas públicas no Brasil necessita da objetividade resultante de um distanciamento imparcial. Trata-se de narrar um processo do qual fui e sou protagonista - como militante do feminismo, na década de 70; presidente do Conselho Nacional dos Direitos da Mulher, entre 86-89; c diretora de uma ONG, desde o início dos anos 90. Consciente deste fato, esforço-me, entretanto, para situar a lógica dos acontecimentos além de biografias.
} 
A agenda feminista foi sustentada, até 1995, na esfera governamcntal, basicamente pela atuação do Fórum de Conselhos Estaduais da Mulher, que agiu como instância principal de coordenação nacional. A partir de então, o CNDM vem sendo reestruturado, apesar de ainda não contar com dotação orçamentária nem quadro técnico-administrativo próprio. Outras instâncias federais, como o Conselho de População e Desenvolvimento, foram instituídas.

A sociedade civil dos anos 90 tem se caracterizado pela presença de ONGs, atuando profissionalmente no desenvolvimento de programas ligados às agendas dos movimentos sociais. Articulando-se cada vez mais em redes nacionais, regionais e internacionais, tais organizações têm tido presença marcante no cenário internacional, particularmentc em questões ligadas a meio ambiente, paz, saúde, e direitos humanos, sexuais e reprodutivos.

Com relação às articulações internacionais dos movimentos sociais e das ONGs, acreditamos ser possível distinguir alguns momentos básicos, a partir do contexto político mais amplo. Entre os anos 60 e início dos 70, a América Latina, e particularmente os países do Cone Sul, se aproxima pela vivência comum de governos ditatoriais militares. A perseguição política e a supressão de liberdades civis fundamentais dão início à migração de intelectuais, políticos e opositores do regime autoritário-que se deslocam, principalmente, do Brasil para o Chile e para a Argentina - até que os golpes militares ocorridos posteriormente nestes países estabelecem um novo fluxo migratório em direção à Europa e a outros continentes.

Envolvidos basicamente em projetos de oposição aos regimes militares, estabelecem-se redes informais importantes de comunicação entre militantes políticos da América Latina. Para muitos deles, o exílio na Europa coincide com a sua sensibilização para questões ligadas aos direitos das mulheres e ao meio ambiente - então de grande relevância no cenário político daqueles países. No Brasil, a anistia de 1979 deu novo impulso aos temas que os movimentos sociais já vinham abordando, especialmente os relacionados à ecologia e ao feminismo.

Durante os anos 80, a circulação regional e internacional do movimento de mulheres tende a ser menos intensa, sobretudo porque, tanto no Brasil como em outros países do continente, enfrentava-se o desafio de conquistar e consolidar espaços no interior do Estado, desenvolvendo políticas públicas em meio a uma das mais graves crises econômicas já vivenciadas.

Já os anos 90 coincidem com uma crescente internacionalização dos movimentos sociais e das ONGs, pelo uso intensivo dos novos meios de comunicação e da proliferação de redes, fóruns e articulações estratégicas regionais e internacionais. Essa capacidade de articulação e pressão responde pelo surgimento de novos atores internacionais que, agindo na arena das Nações Unidas, alcançam expressiva visibilidade e conseguem levar suas propostas para as conferências internacionais da ONU organizadas nesta década. 


\section{Movimento de mulheres e saúde reprodutiva no Brasil}

Foge ao alcance deste texto recuperar o debate sobre população no Brasil. Entretanto, deve-se ressaltar que a história do movimento feminista está profundamente ligada ao debate sobre controle de população c planejamento familiar. Trazendo para o cenário político temas ligados à saúde da mulher, reafirmando o direito de opção sobre a vida reprodutiva e sexual como valores centrais da cidadania feminina, e reivindicando uma atitude do Estado coerente com estes princípios, as feministas criticavam as tendências pró ou antinatalistas calcadas em preceitos religiosos, econômicos ou geopolíticos, ou em metas demográficas.

Entre as militantes brasileiras, já cm meados da década de 70 , havia acordo quanto ao fato de que questões relativas à sexualidade e aos direitos reprodutivos - cntre os quais o de interromper voluntariamente a gravidez - cram não só centrais, mas estruturantes da própria ética feminista. A ordem de prioridade destes temas, no entanto, não cra consenso. Alguns grupos consideravam fundamental manter a aliança com a lgreja e com setores da oposição avessos a tais temáticas, ao passo que outros não se propunham a abrir mão desses temas, quc consideravam centrais na construção da identidade política do feminismo. Como ilustração, pode-se lembrar que, ao se propor a realizar pesquisa sobrc sexualidade feminina, em 1977, o CERES, grupo feminista do Rio de Janeiro, vivenciou uma série de debates com outras integrantes do movimento sobre a propriedade de se tratar a temática naquele momento. Posteriormente, a pesquisa deu teve como resultado o livro Espelho de Vênus, publicado pela editora Brasiliense cm 1981.

Tais tensões tendem a diminuir à medida que o processo de democratização avança; o campo de interlocutorcs aumenta; a Igreja perdc importância; propostas do feminismo são incorporadas a plataformas de partidos e cstabclecem-se parcerias com alguns sctores do Executivo.

Particularmente relevantc foi a articulação entre a universidade, algumas feministas c o Ministério da Saúdc que veio a resultar no Programa de Assistência Integral a Saúde da Mulher (PAISM). Inspirado em princípios gerais da luta maior pela democratização do País e respeito às libcrdades individuais c civis, o PAISM foi, também, influenciado pclos movimentos sanitaristas e de saúde pública, especialmente na adoção de uma perspectiva intcgral de saúde. Divulgado em 1983, representava um exemplo raro de colaboração cntrc Estado e socicdade civil, constituindo-sc cm uma das primeiras iniciativas governamentais de incorporação de princípios feministas em políticas públicas de saúde. No entanto, apesar de trazcr uma perspectiva intcgral e compreensiva, c colocar o planejamento familiar na ótica da saúdc, o PAISM não trata do abortamento, nem mesmo para fazcr cumprir a legislação vigente. 
Entre 1983 e 1987-quando o PAISM é finalmente regulamentado pelo antigo INAMPS-, cresce a participação do movimento de mulheres no espaço público, e os vários consethos da mulher incorporam a saúde reprodutiva em seus programas de ação.

A luta do movimento de mulheres pela inclusão desses princípios no discurso governamental e em amplos setores da sociedade se dá em meio a profundas transformações demográficas, resultantes tanto da queda das taxas de mortalidade - característica das décadas de 50 e 60 - quanto do acentuado declínio das taxas de fecundidade verificado a partir dos anos 70. As taxas de crescimento populacional decresceram de mais de 3\% ao ano, entre 1950 e 1960, para 2,9\% na década seguinte e 1,8\% entre 1985 e 1990.

Nesta transição, refletiu-se mais o impacto das políticas populacionais vigentes de facto no País do que os princípios feministas já incorporados em leis, normas e programas governamentais. Chama-se atenção para o descompasso entre discurso e realidade que parece acompanhar a história política e social do País. Exemplo claro é a distância entre o discurso oficial sobre a regulação da fecundidade e as práticas vigentes neste campo. Durante os anos 60 e início dos 70, a posição oficial do Brasil tendia ao natalismo. Influenciado pela Igreja Católica, amparado nas elevadas taxas de crescimento do PIB verificadas durante o 'milagre econômico', e em preocupações militares geopolíticas de ocupação territorial, o governo descartava as posições neomalthusianas prevalentes em países do hemisfério norte, ao mesmo tempo em que fazia "vista grossa" às entidades de planejamento familiar que operavam no País.

De fato, já desde meados dos anos 60 essas organizações vinham atuando no Brasil para controlar o crescimento populacional. À medida que o modelo econômico demonstrava sinais de enfraquecimento, diminuía o apoio governamental a posições pró-natalistas, ao mesmo tempo em que as entidades privadas ampliavam seus programas, multiplicados com o auxílio de convênios municipais e estaduais. Entretanto, só em 1977 o governo apresenta um programa na área de saúde reprodutiva, o Programa de Prevenção de Gravidez de Alto Risco (PPGAR), seguido do Programa Nacional de Serviços Básicos de Saúde (PrevSAúdE), de 1980, que praticamente não 'saíram do papel'.

O movimento feminista, reconhecendo o direito das mulheres de vivenciarem a maternidade como opção - com acesso à informação, à contracepção segura e ao tratamento da infertilidade, ao pré-natal e ao parto em condições adequadas, bem como à interrupção voluntária da gravidez, ao tratamento às seqüelas do abortamento provocado, à prevenção do câncer mamário e cérvico-uterino- luta para que o Estado desenvolva ações propositivas em saúde reprodutiva.

Parcela significativa deste movimento está consciente de que a resposta do governo à situação vigente no País não poderia consistir apenas em ações de orientação demográfica. À ótica intervencionista e parcial das entidades privadas, seccionando o útero como objeto de controle, caberia oferecer uma alternativa às mulheres que desejassem regular sua fecundidade. 
Diversos fatores respondem pelo significativo aumento da demanda por contracepção no País. A acelerada urbanização, responsável pelo deslocamento da população aos centros urbanos, intensifica-se nos anos 70. Paralelamente, a mídia representa papel cada vez mais relevante na difusão dos chamados valores da 'modernidade', em que a família nuclear de dois filhos corresponde ao tipo ideal de organização.

É também neste período que cresce significativamente a participação da mulher no mercado de trabalho, ao mesmo tempo em que não há investimentos públicos em uma infra-estrutura de equipamentos sociais necessários para maior socialização do cuidado das crianças. É importante ressaltar que o movimento feminista sempre levantou as 'bandeiras' da creche e da pré-escola como pontos centrais em sua plataforma política. Na década de 80, tanto o CNDM como os conselhos estaduais instituem comissões específicas para atuar nesta área. Além de produzir material educativo sobre creches $\mathrm{e}$ pressionar diretamente os órgãos da administração federal a implementarem a lei de creches, o CNDM realizou acordo com o Banco Nacional de Desenvolvimento Econômico e Social (BNDES) que previa que, na avaliação de empréstimos solicitados por empresas, essas deveriam comprovar o cumprimento da legislação referente a creches para os filhos dos seus funcionários, além dos requisitos de praxe. O acordo é considerado uma iniciativa pioneira em políticas públicas com perspectiva de gênero.

Elaborado desde 1983, o PAISM corria o risco de 'ficar no papel', seguindo o destino dos programas anteriores. Sua regulamentação transforma-se, então, em um dos principais objetivos do CNDM, agindo em consonância com o movimento de mulheres. Dentre as ações conjuntas desenvolvidas destaca-se a elaboração da "Carta das Mulheres Brasileiras aos Constituintes" - redigida em reunião de mulheres no Congresso Nacional em 1986, e distribuída em todo o país e entregue ao deputado Ulysses Guimarães em março de 1987. Neste documento, endossavam-se duas premissas básicas: a de que a saúde era um direito de todos e dever do Estado, e de que a mulher tinha direito à atenção a sua saúde, independentemente de seu papel de mãe. Lutava-se pela reafirmação dos princípios de atenção integral em uma perspectiva compreensiva da saúde da mulher. E enfatizava-se, ainda, sua oposição à coerção de entidades públicas ou privadas, nacionais ou internacionais, impondo ou negando o acesso aos meios de regulação da fecundidade.

No documento já estão contidos princípios básicos que sustentariam a luta feminista na década de 90 e seriam assegurados na Conferência Internacional de População e Desenvolvimento (CIPD) do Cairo em 1994: a afirmação de que a mulher tem odireito de exercer uma autoridade sobre seu corpo, tomando decisões sobre sua vida sexual e reprodutiva, e de que o Estado tem o dever de fornecer os meios para que esta autoridade seja, de fato, exercida, ampliando, portanto, sua ação no campo da saúde.

A trajetória da regulamentação do PaISM e de sua implementação (ainda em curso) é indicativa do peso relativo das questões referentes a saúde e direitos reprodutivos na agenda política do governo e no discurso da sociedade. A Igreja Católica sempre acom- 
panhou pari passu os desdobramentos do PAISM, interferindo, inclusive, em iniciativas do próprio CNDM junto aos ministérios da Saúde e da Previdência Social. Como exemplo, recorda-se o episódio da publicação de 5 milhões de exemplares de uma cartilha sobre contracepção elaborada no âmbito do PASM. OCNDM havia negociado esta edição e sua distribuição com o Ministério da Previdência, quando, por interferência direta da Igreja - que alegava que a cartilha mencionava o DIU, dispositivo considerado abortivo-o Ministério recuou de seu compromisso. Finalmente, depois de intensas pressões do movimento de mulheres e do CNDM, foi publicado um número significativamente menor do livreto.

O episódio é revelador do campo de forças em se que se movem as ações governamentais na área da saúde reprodutiva. Pode-se interpretá-lo de duas maneiras: como um fracasso da força política das mulheres diante da Igreja, e como um incidente revelador da expressão que a agenda feminista já alcançara - já que, mesmo diante da pressão da Igreja, não foi possível ao governo recuar totalmente, ignorando as demandas deste outro ator político no campo da saúde e direitos reprodutivos.

Outros temas de saúde reprodutiva que mobilizaram o movimento feminista na década de 80 seriam a supervisão da produção de métodos hormonais de contracepção, e a proibição da comercialização de produtos em fase de testes. O Norplant foi objeto de debates e embates entre uma parcela do movimento feminista e profissionais da saúde ligados ao Population Council que desenvolviam um projeto de experimentação com este contraceptivo hormonal na Universidade de Campinas (UNICAMP). Tanto o CNDM quanto o movimento de mulheres atuaram exigindo maior controle na experimentação destas drogas, levando o Ministério da Saúde a cancelar a permissão para sua testagem.

Se este episódio demonstrou visibilidade e impacto sobre políticas públicas abordadas por feministas, tornou cvidente a necessidade do estabelecimento de mais canais de comunicação com os profissionais da saúde, especialmente os médicos ginecologistas e obstetras. Este tipo de interlocução viria a ser desenvolvido na década de 90 por diversas ONGs de mulheres. A Cidadania, Estudo, Pesquisa, Informação, Ação (CEPIA), por exemplo, tem atuado junto aos médicos, em iniciativas que envolvem a Associação dos Médicos Residentes (AmererJ) e o Conselho Regional de Medicina do Rio de Janeiro (CREMERJ). Além disso, desenvolve um curso sobre medicina e cidadania na Faculdade de Medicina da UFR, dentre outras atividades desenvolvidas por outras organizações e redes.

Ao longo do processo de democratização do País, cresce a movimentação das organizações de saúde no sentido de traçar caminhos para a saúde pública. Em outubro de 1986, realiza-se, em Brasília, a Conferência Nacional de Saúde, que teria influência decisiva na formulação da saúde como um direito do cidadão e um dever do Estado, posteriormente incorporado à Constituição de 1988. Outro marco importante do cncontro: pela primeira vez, a saúde da mulher mereceu destaque em mesa especial. 
Em 1987, o CNDM, com a estreita colaboração de movimentos de mulheres de todo o País, organiza, juntamente com o Ministério da Saúde, a I Conferência Nacional de Saúde da Mulher. Oencontro reuniu aproximadamente 3 mil participantes em Brasília e reafirmou os princípios da "Carta das Mulheres Brasileiras aos Constituintes" e as diretrizes do PaISM. Merecem destaque outros dois pontos colocados em discussão na Conferência. O primeiro, avaliado como avanço considerável, foi a proposta de descriminalização do abortamento, um problema de saúde pública que não havia sido tratado pelo PAISM. O segundo referia-se ao abuso das esterilizações, que já respondiam por percentuais muito elevados (48\%) dentre os recursos contraceptivos utilizados pelas mulheres casadas ou unidas entre 15 e 49 anos de idade. O debate sobre a esterilização ocupará espaço importante da agenda feminista nos anos 90 , respondendo por tensões internas no movimento e levando ao estabelecimento de articulações diversas com setores do Legislativo.

Com relação ao abortamento - tema ainda tabu e oculto-, cabe ressaltar que os anos 80 correspondem a um momento de visibilização do tema. A partir de episódios de flagrantes policiais em clínicas clandestinas e da abertura de processos penais contra mulheres e médicos ocorridos no início da década no Rio de Janeiro, o movimento feminista traz à luz a questão, ainda relegada aos porões do debate público. Escrevendo para jornais, organizando mesas-redondas, visitando as mulheres que respondiam a processos penais, as feministas conseguem incluir o abortamento voluntário nas temáticas que integravam a agenda política do País nos anos 80 .

Ao mesmo tempo, o CNDM pressionava os ministérios da Saúde e da Previdência para fazer cumprir a lei, de forma a que atendessem às mulheres que solicitassem o abortamento nos casos de estupro e risco de vida. Em âmbito estadual, mulheres organizadas em grupos autônomos articulavam-se com parlamentares e conselhos estaduais, apresentando projetos de regulamentação do atendimento ao aborto legal. No Rio de Janeiro, por exemplo, a deputada Lúcia Arruda, do PT, apresentou proposta inicialmente aprovada pela Assembléia Legislativa e posteriormente revogada pelo governador do Estado por influência direta da Igreja. A regulamentação seria aprovada em 1987.

A articulação entre o movimento de mulheres, o CNDM, conselhos estaduais e o Congresso Nacional alcançou seu auge durante o Congresso Constituinte. Em 1985, o CNDM lança a campanha "Constituinte Pra Valer tem que ter Direitos da Mulher", que percorre os estados colhendo reivindicações e propostas que seriam incorporadas à "Carta das Mulheres Brasileiras aos Constituintes".

Ao longo do processo constituinte, o CNDM enviou mais de 120 propostas e emendas substitutivas ao Congresso Nacional. Na área da saúde reprodutiva, cabem dois destaques com relação à atuação das mulheres. Um diz respeito ao artigo 226, parágrafo $7^{\mathfrak{Q}}$ da Constituição Federal, que situa o acesso ao planejamento familiar na esfera de direitos, com a concomitante criação de deveres por parte do Estado. O outro se refere 
à ausência, no texto constitucional, de uma proposição apresentada pela Igreja Católica e por setores evangélicos relativa à defesa da vida desde a concepção. A possibilidade da inclusão desta proposição e o terrível retrocesso que representaria propiciaram uma articulação estratégica entre o CNDM e os movimentos de mulheres, que colheram as assinaturas necessárias para apresentar uma emenda popular de descriminalização do abortamento. A emenda seria contraposta à posição da Igreja, fortalecendo indiretamente a posição do CNDM - que argumentava não ser o aborto matéria constitucional - posição triunfante após longos embates, confrontos e discussões com setores conservadores.

A Constituição também incluiu, na ótica da descentralização, um novo projeto organizacional de atendimento à saúde, o Serviço Único de Saúde (SUS), que, em princípio, viabilizaria a implementação do PAISM, atendendo às peculiaridades e necessidades locais. Hoje, sente-se a necessidade de realizar estudos mais detalhados e pontuais, recuperando a história do PAISM nos diversos estados, com especial atenção aos princípios de integralidade que o orientaram.

Em 1989, o CNDM lança a campanha nacional "Maternidade, Direito e Opção" para avançar a implementação do PAISM e a discussão sobre abortamento, e organiza reunião no Congresso Nacional em que, pela primeira vez, o movimento de mulheres, parlamentares, médicos, profissionais da saúde, acadêmicos e executores de políticas públicas discutem temáticas cruciais da saúde da mulher, com ênfase especial à questão do aborto.

O contexto geral da política brasileira era, no entanto, cada vez mais conservador. No âmbito do Executivo federal, o Ministério da Reforma Agrária havia sido desestruturado, crescia a oposição parlamentar e popular ao governo Sarney, a crise econômica e inflacionária continuava a aprofundar-se-apesar dos sucessivos planos de estabilização. As relações entre movimentos sociais e governo, ainda frágeis após tantos anos de divórcio entre Estado e sociedade civil, se viam ameaçadas ou rompidas.

OCNDM, que mantinha laços com o movimento de mulheres rurais e trabalhara com o Ministério da Reforma Agrária na edição de um livro documentando a violência contra mulheres e crianças no campo, sente o poder dos setores conservadores, recebendo pressões do Ministério da Justiça para que tal publicação não fosse divulgada. Com o apoio do ministro Marcos Freire, que viria a falecer pouco depois, o projeto é, entretanto, levado adiante.

Outro momento de confronto entre o CNDM e o Ministério da Justiça aconteceu durante a comemoração oficial dos 100 anos de abolição da escravidão. Na ocasião, o CNDM foi diretamente admoestado pelo ministro da Justiça pelo lançamento da campanha "Mulher Negra, 100 Anos de Discriminação, 100 Anos de Afirmação" e pela organização do "Tribunal Winnie Manela" - que, apesar das pressões contrárias de diversos setores do Executivo, realizou-se em novembro de 1988. 
Estes episódios, dentre outros, ilustram o quadro conjuntural que agudizou as pressões contra o CNDM, por estar, também, levando adiante o debate público sobre o aborto, outra temática - se não mais maldita, ainda incômoda - a ser relegada ao limbo político. Apesar das pressões, o CNDM organiza, em julho de 1989, um debate televisivo com os candidatos à presidência da república, que respondem a perguntas específicas enviadas por representantes de movimentos de mulheres e de conselhos estaduais e municipais. Dentre as várias perguntas, uma foi apresentada pelo CNDM e endereçada a todos os candidatos, e pedia seu posicionamento diante do tema aborto.

Foge aos propósitos deste artigo analisar a resposta de cada candidato. Ressalta-se que aquele momento representou uma vitória das mulheres que, na sociedade civil ou no governo, lutaram para trazer o tema a debate público. Também vale lembrar que a temática do aborto esteve praticamente ausente da discussão da sociedade nas eleições presidenciais de 1994.

\section{Os anos 90 e a internacionalização do movimento de mulheres}

No Brasil, a experiência de elaboração de políticas públicas com perspectiva de gênero em articulação com o movimento de mulheres se vê profundamente afetada com a desestruturação do CNDM. Os conselhos estaduais, por meio do Fórum de Conselhos, mantêm uma articulação nacional, mas o desenvolvimento de projetos na esfera federal é praticamente interrompido durante os anos Collor, o governo Itamar e os primeiros anos do mandato de Fernando Henrique Cardoso.

Na sociedade civil, cresce o número de ONGs e proliferam as redes que procuram articular demandas e estratégias de ação em torno de agendas comuns que, muitas vezes, ultrapassam as fronteiras nacionais.

No campo da saúde reprodutiva, a principal rede atuante no Brasil é a Rede Nacional Feminista de Saúde e Sexualidade e, no âmbito da América Latina e do Caribe, a Rede de Saúde das Mulheres Latino-Americanas e do Caribe. Destacam-se ainda espaços multidisciplinares como a Comissão de Cidadania e Reprodução, sediada no Brasil; o CEDES, na Argentina; O IsIs, no Chile; e grupos com representação em diversos países das Américas, como o das Católicas pelo Direito de Decidir, entre outros.

Desde as décadas anteriores, já crescia no País o número de mulheres negras organizadas em movimentos e ONGs voltadas para a questão da saúde. Com relação às indígenas, a visibilidade e impacto de suas organizações é mais significativa em países andinos e na América Central do que no cone sul, inclusive no Brasil.

Destacam-se, ainda, inúmeras redes e grupos internacionais, sediados principalmente nos Estados Unidos e na Europa, mas também na África e Ásia e interconectados com diversas ONGs e movimentos dos diversos continentes. 
Uma das principais características das atuais relações entre movimentos de mulheres e políticas de saúde é que, nesta década, passam por uma espécie de triangulação. Os princípios norteadores de políticas nacionais são também propostos, discutidos e acordados em âmbito global, a partir da interlocução de grupos de mulheres organizados internacionalmente com agências das Nações Unidas, instituições de apoio multi e bilateral, organismos transnacionais e governos nacionais, entre outros.

Recupera-se, aqui, de maneira breve, o papel desempenhado pelas mulheres no âmbito das Nações Unidas, por seus efeitos multiplicadores tanto na conceituação de princípios internacionais de direitos humanos quanto no delineamento de políticas públicas. É possível distinguir duas direções que se entrecruzam e reforçam mutuamente: a participação em conferências específicas, e a presença de mulheres em conferências temáticas diversas.

A Conferência Internacional da Mulher, realizada na China, em 1995, insere-se em um processo que se estende ao longo das últimas décadas, traçando um caminho iniciado no México, em 1975, ocasião da I Conferência Internacional da Mulher. Neste percurso seguiram-se as conferências de Copenhagen, em 1980, e a de Nairóbi, em 85.

Nessas conferências, mulheres de todo o mundo, trabalhando dentro de delegações oficiais ou em fóruns não-governamentais, levaram para o cenário da ONU questionamentos fundamentais da condição e da cidadania feminina. Dois documentos são conseqüência particularmente importante deste percurso: a "Convenção para a Eliminação de todas as Formas de Discriminação contra a Mulher", de 1979; e o "Plano de Ação de Nairóbi", de 1985 (Nairobi Forward Looking Strategies).

Nos anos 90, a ONU realizou cinco reuniões temáticas internacionais em que as questōes relativas a gênero, eqüidade e direitos humanos foram reafirmadas e reforçadas mutuamente. Nas Conferências de Meio Ambiente e Desenvolvimento (Rio-92), Direitos Humanos (Viena-93), População e Desenvolvimento (Cairo-94), e nas reuniões da Cúpula Social (Copenhagen-95) e do Habitat (Istambul-96), as mulheres foram protagonistas no processo de alargamento da definição tradicional de direitos humanos enunciado nas declarações e planos de ação resultantes desses encontros.

A Conferência Internacional de Meio Ambiente e Desenvolvimento aconteceu no Rio de Janeiro em 1992 e constitui um marco. Pela primeira vez, ampliou-se o espaço de participação - como observadores - das ONGs nas discussões governamentais e alargou-se o espectro das credenciadas para assistirem a tal evento. Apesar de as Nações Unidas ainda colocarem barreiras à participação não-governamental, abriu-se importante espaço, alargado nas reuniões posteriores.

Cabe destacar o papel relevante desempenhado pelas ONGs específicas de meio ambiente ao longo do processo preparatório da Rio-92. Organizadas em fóruns nacionais, regionais e internacionais, foram protagonistas na Conferência. 
Também o movimento de mulheres organizou-se, nacional e internacionalmente, para desempenhar papel destacado na Conferência, promovendo reuniões preparatórias e inúmeros debates e eventos na "tenda planeta fêmea". Participaram mulheres de diversos países e evidenciaram-se algumas divergências internas do movimento, particularmente com relação a formas de abordagem ao binômio mulher-natureza, visto por algumas a partir de uma perspectiva mais histórica do que por outras, identificadas com o ecofeminismo.

A Rio-92 inaugurou uma aproximação maior entre sociedade civil e governos, e na Agenda 21, daí resultante, incorporaram-se contribuições importantes das ONGs.

Em 1993, realizou-se, em Viena, a Conferência Internacional de Direitos Humanos. A dificuldade em discutir o tema no cenário das Nações Unidas ficou evidenciada pelo fato de que 25 anos separavam esta da última conferência organizada pela ONU sobre Direitos Humanos, realizada em Teerã, em 1968. É importante lembrar que a linguagem internacional de direitos humanos é forjada na arena política da ONU, onde a soberania, legislação e cultura nacionais, religiões e desigualdades sociais desempenham papel fundamental na definição das fronteiras e possibilidades do alcance desta linguagem. A permanente tensão entre universal e particular-que permeia o cenário da ONU - é particularmente aguda neste âmbito.

Foi ampla, coordenada e exitosa a mobilização feminina durante a preparação da reunião de Viena. Sob o lema "os direitos das mulheres são direitos humanos", lançou-se vigorosa campanha internacional, colhendo milhares de assinaturas para que as violações contra os direitos das mulheres passassem a ser tratadas como violações aos direitos humanos. Durante a Conferência, organizou-se um tribunal simbólico. Mulheres de todo o mundo narraram as violências de que tinham sido vítimas e que, apesar de representarem flagrante desrespeito à sua cidadania e integridade pessoal, não eram consideradas atentatórias aos direitos humanos nos tratados e convenções da ONU. Dentre as principais conquistas das mulheres, destaca-se o reconhecimento da violência doméstica como uma questão de direitos humanos.

Para efeito dos temas discutidos aqui, destaca-se como um exemplo histórico do poder de pressão das mulheres, e de sua capacidade de organização, a Conferência Internacional de População e Desenvolvimento (CIPD), realizada em 1994 no Cairo.

A reunião estabelece um novo paradigma, deslocando as temáticas de população da esfera demográfica para a esfera de direitos, discutindo, de forma central, teses relativas a saúde e direitos reprodutivos e colocando o empowerment da mulher como um valor em si mesmo e como variável estratégica.

Mais do que em qualquer das conferências anteriores, o Vaticano colocou-se como adversário das propostas da agenda feminista desde os encontros preparatórios até a realização da reunião. Diretamente apoiado por países como Argentina, Nicarágua e 
Honduras; timidamente contestado por outros, como Chile, Bolívia e Equador; e mais explicitamente distanciado de países como Brasil e México, foi eficaz em impedir que a América Latina atuasse em bloco na discussão.

Desde a conferência anterior de população, realizada em 1984, no México, o grupo G-77 - dos países subdesenvolvidos-já não encontrava consenso em questões relativas a temáticas de saúde reprodutiva, planejamento familiar, políticas populacionais... A impossibilidade de agir como um bloco nestas questões, também verificada noCairo, evidencia a dificuldade de estabelecer uma matriz de atuação conjunta que englobasse esses assuntos.

Durante o período de organização para a Conferência do Cairo, estabeleceu-se no Brasil uma articulação bastante produtiva entre movimentos de mulheres e o governo, representado pelo Itamaraty. Assim como a Rio-92 representou um momento importante de abertura à presença das ONGs como observadoras, Cairo avançou no sentido de que inúmeros países - inclusive o Brasil -incorporassem representantes de ONGs a suas delegações, permitindo participação de forma mais direta nas discussões e decisões tomadas no âmbito oficial. Dentre as organizações internacionais de mulheres ativas na preparação de conferências internacionais cabe destacar o papel da Women Environment Development Organization (WEDO), na Rio/92, e da International Women's Health Coalition - Coligação Internacional pela Saúde da Mulher (IWHC), para o Cairo.

\section{Cairo: a importância do Brasil}

A delegação brasileira no Cairo atuou de forma bastante ágil, eficiente e coordenada, desempenhando papel reconhecidamente importante para fazer avançar questões de saúde e cidadania que já havíamos incorporado em propostas constitucionais, legislações e programas vigentes no Brasil. Com relação a esta conferência, cabe ainda destacar sua importância como momentum para a realização de dois importantes eventos no País que destacaram-se por sua magnitude e impacto.

O primeiro foi o Encontro Nacional Mulher e População, Nossos Direitos para Cairo'94. Realizado em setembro de 1993, no Congresso Nacional, em Brasília, foi organizado por uma comissão formada por sete organizações nacionais, tendo o Centro Feminista de Estudos e Assessoria (CFEMEA) como secretaria executiva local e a CEPIA como secretaria nacional ${ }^{4}$. O evento propiciou a oportunidade de dar maior visibilidade a questões de população, pois, ao longo de sua preparação, foram divulgados inúmeros documentos e declarações relativos a saúde reprodutiva, gênero e população.

\footnotetext{
4 A Comissão organizadora deste encontro era formada pela Comissão de Cidadania e Reprodução, Coletivo Feminista Sexualidade e Saúde, SOS Corpo, Associação Brasileira de Estudos Populacionais e Geledés, além da Cepia e do CFEmeA.
} 
O encontro reuniu aproximadamente 550 participantes de todo o País. Alćm de debates e discussões temáticas, redigiu-se e aprovou-se em plenário a "Carta de Brasília", contendo princípios nortcadores e rcivindicações das mulheres brasileiras. Depois de encaminhado a autoridades, o documento foi distribuído e divulgado entre as diversas organizações do País.

Osegundo evento realizou-se no Rio de Janeiro, em janeiro de 94. Com o nome Saúde Reprodutiva e Justiça: Conferência Internacional de Saúde da Mulher, reuniu aproximadamente 250 mulheres de 89 países. Depois de cinco dias de discussão em plenárias c grupos de trabalhos, redigiu-se uma declaração contendo princípios e propostas básicas consensuais ao movimento internacional de mulheres e saúde reprodutiva. A rcunião foi organizada por um comitê internacional c teve como sccretarias a CEPIA c a IWCH.

O encontro teve repercussões positivas. Considerado a principal conferĉncia internacional preparatória feminista, fortaleceu as redes já existentes, agilizou canais de interlocução, permitiu que o movimento internacional listasse suas principais posições e propostas nesta área e, sobretudo, demonstrou aos demais interlocutores o poder de mobilização das mulheres.

AConferência de Beijing, em 1995, também ofercceu oportunidade importante para que, em diversas partes do mundo, as mulheres se organizassem em redes e articulações, participando em debates nacionais e internacionais, elaborando documcntos c cstabclecendo interações com governos.

Durante as Conferências do Cairo e de Beijing, diversas articulações internacionais de mutheres trabalharam junto às delegações oficiais, procurando introduzir princípios consensuais do Movimento, nos planos de ação e declarações dali resultantes. Dentre estas, cabe destacar a atuaçãodo Health, Empowerment, Rights and Accountability (HERA) edo WEDO.

No Brasil, durante o processo preparatório de Beijing, estabeleceu-se uma articulação nacional de mulheres que organizou divcrsos encontros, debates e documentos. Retomou-se a interlocução do movimento de mulheres com o Itamaraty na preparação do documento oficial e represcntantes de ONGs fizeram parte da delegação oficial do País. Com mais de 80 integrantes, a delegação brasileira era a maior da América Latina c uma das maiores entre todos os países. No entanto, bastante heterogênea, com pessoas pouco familiarizadas com os temas debatidos, não agiu com a mesma rapidez do que no Cairo - o que não impediu que o Brasil se alinhasse, mais uma vcz, com os pontos básicos da agenda feminista.

Muito relevantc foi a presença das brasileiras em Huariou, no fórum paralelo das ONGs, organizando mesas, participando de debates e tendo presença marcante nos eventos latino-americanos e internacionais.

A Confcrência de Beijing não só reforçou conquistas anteriores, como avançou cm relação à saúde reprodutiva. Um exemplo: sobre o abortamento, o Plano de Ação incorporou o parágrafo 8.25 da Conferência do Cairo - que situa o aborto como questão de 
saúde pública e conclama os governos a atenderem às mulheres que solicitem a interrupção da gravidez nas circunstâncias previstas em lei e a todas as mulheres com conseqüências de abortamento. Avançou, ainda, ao solicitar que os governos revejam as punições sobre mulheres que se submetem ao abortamento voluntário.

Sem pretender entrar em análises detalhadas dos resultados destas conferências, gostariamos de salientar seu impacto em termos de ampliaro marco intemacional de direitos humanos e fornecer instrumentos que permitam legitimare apoiar o trabalho desenvolvido pelos movimentos e organizações de mulheres no plano nacional.

De uma concepção ligada às liberdades e direitos civis tradicionais, característicos da 'primeira geração' de direitos humanos - calcada em uma conceituação de humanidade apoiada na figura abstrata do homem - avançamos para a inclusão dos direitos sociais, habilitantes do exercício de outros direitos e para os chamados direitos de segunda e terceira geração.

Tal avanço vem sendo feito a partir de dois movimentos aparentemente opostos, mas, de fato, complementares: a especificação da esfera de direitos e a universalização de sua aplicação. Por especificação deve-se entender o distanciamento cada vez maior da figura abstrata do homem e a redefinição do conceito de humanidade a partir da acentuação de diferenças por critérios de sexo, raça, etnia etc. que, ao longo dos séculos, vêm demarcando espaços de maior ou menor cidadania ${ }^{5}$.

Ao mesmo tempo em que se especificam os sujeitos de direitos, também incluemse novas temáticas na esfera destes direitos, como a saúde e a saúde reprodutiva.

$\mathrm{Na}$ virada do século, as mulheres enfrentam desafios resultantes de seu próprio avanço. No Brasil, coloca-se o desafio fundamental de fazer valer as leis já existentes em matéria de saúde e diretos reprodutivos - várias organizações têm trabalhado para isto, com especial ênfase ao cumprimento da legislação relativa ao abortamento legal. Abremse, também, outros campos de atuação e reflexão, em que ainda é tímida a presença das mulheres, como em relação ao HIV/Ams.

Paralelamente, as mulheres continuam a influenciar as políticas públicas, ocupando cargos em comissões e órgãos governamentais, trabalhando em conselhos e entidades ligadas a profissionais da saúde, levando as discussões de Cairo e Beijing para espaços acadêmicos e hospitalares e tentando influir na formação médica.

Ainda há muito por fazer neste percurso. Parafraseando um trecho de Alice no País das Maravithas, "às vezes corremos para ficar no mesmo lugar". Recentes desdobramentos no Congresso Nacional relativos ao abortamento e o veto já derrubado do Presidente da República a parágrafos fundamentais relativos à regulamentação da esterilização corro-

\footnotetext{
5 Para uma análise sobre novas formulações de direitos humanos, ver Bobbio, N. A Era dos Direitos, Rio de Janeiro: Ed. Campus, 1992. Com relação do papel das mulheres nesta reconceituação, vide Pitancuy, J. From Mexico to Beijing, A New Paradigm, in Health and Human Rights, Harvard School of Public Health, v.1, n.4, p. 19.
} 
boram csta imagem de um enorme esforço para 'permanccer'. Entretanto, em uma perspectiva histónica, deve-se reconheccro imenso avanço do movimento de mulheres e seu desenvolvimento cm termos da ampliação da cidadania da mulherc, mais especificamente, dos seus direitos na árca da reprodução.

Como dizia o poeta, "caminhante, não há caminho, caminho se faz ao andar...".

\section{Referências Bibliográficas}

AlvaREZ, S. Engedering Democracy in Brazil - women 's movements in transilion in Politics. Princeton: Ncw Jersey University Press, 1990.

FLACSO \& CEPIA. Mujer en Cifrasen America Latina. Santiago do Chile: Flacso, 1993.

Jeus, E. \& HeRSHBERG, E. (Eds.) Constructing Democracy - human rights, ailizenship and society in Latin America. Boulder: Westview Press, 1996.

Prangur, J. Políticas Públicas y Ciudadania. Isis International Ediciones de Mujeres, $\mathrm{n}^{2} 13$.

PITANGUY, J. On the Road to Cairo. Development $n^{\circ} 1$. Journal of Society for International Development, 1994.

PIANGUY, J. Feminist politics and reproductive rights: the casc of Brazil. In: SEN, G. \& SN'OW, R. Power and Decision: the social control of Reproduction. Boston: Harvard University Press, 1995.

PTANGuY, J. Movimiento de Mujeres y Políticas Publicas en Brasil. In: VARGAS, G. (Ed.). Trángulo del Poder. Bogotá: Ed. Tercer Mundo, 1996.

Revista Estudos Feministas. v. 2 (2), 1994. Rio de Janeiro: Universidade Federal do Rio de Janeiro. 


\section{"Saúde Reprodutiva", Gênero e Sexualidade: legitimação e novas interrogaç̧ões}

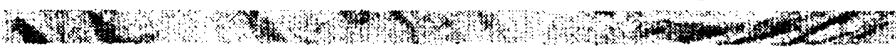

Sonia Corrêa

\section{Primeiras palavras}

Um modo de vida está envelhecendo. Essa transformação pode ser tão radical porém igualmente tão gradual - como foi a transição da sociedade medieval à moderna. Esse estado de transição faz com que certas formas de pensamento sejam possiveis e necessárias, enquanto se excluem outras (...). (Flax, 1992)

Saúde reprodutiva, gênero e sexualidade são termos que até pouco tempo circulavam quase exclusivamente no campo acadêmico e entre os movimentos sociais, mas hoje experimentam um processo de legitimação. É expressão disto sua inclusão nos programas de ação da Conferência Internacional de População e Desenvolvimento (CIPD), no Cairo, em 1994; da Cúpula Mundial de Desenvolvimento Social (CMDS), em Copenhagen, 1995; e da IV Conferência Mundial sobre a Mulher (CMM), em Pequim, 1995. Estes termos têm se tornado correntes em textos e análises internacionais, mas a absorção de seus significados pelos organismos políticos e as mentalidades continua heterogênea nos contextos nacionais. Se é vital seguir disseminando estas definições, também é fundamental precisar seus conteúdos, pois nesta nova etapa de legitimação e vulgarização tendem a ocorrer simplificações e distorções.

É preciso, também, reconhecer que as articulações teóricas entre estas definições são complexas. Continuamos debatendo se saúde reprodutiva é um conceito, um campo, ou, simplesmente, um recorte de investigação. Gênero é uma categoria firmada

\footnotetext{
*Apresentado no Seminário do Programa de Saúde Reprodutiva e Sociedade Colégio do México em novembro de 1996.
} 
para a análise das relações sociais, porém, na prática, tem inspirado aplicações diferenciadas e, eventualmente, contraditórias. O estatuto de 'sexualidade' é ainda mais controvertido, pois se aplica com base nos mais diversos enfoques: da concepção psicanalítica aos usos convencionais da sexologia. Nas atuais circunstâncias de 'legitimação' somos tentados a firmare proteger estas definições, neutralizando as interrogações que se levantam em relação a elas. A nosso ver, porém, é necessário manter esta instabilidade e abertura conceitual.

Este artigo procura mapear esta revolução semântica recente e identificar novos olhares conceituais com relação a gênero e sexualidade. As reflexões que se seguem estão organizadas em dois blocos. No primeiro, examina-se o itinerário de construção de definições que se legitimaram recentemente, como que se desprendendo de saúde reprodutiva: saúde sexual e direitos reprodutivos e sexuais. Na segunda seção, concentra-se a atenção na teorização sobre gênero e sexualidade. Examina-se a possibilidade/ necessidade de distinção entre sistema de gênero e sistema de sexualidade e exploramse questões que se apresentam com relação a gênero e sexualidade.

\section{De saúde reprodutiva a direitos sexuais: desfazendo a indistinção}

Os recentes documentos internacionais - especialmente da CIPD e de Beijing legitimaram mais do que 'saúde reprodutiva'. Hoje estão consagradas as noções de direitos reprodutivos, saúde sexual e conteúdos relativos aos direitos sexuais. Essas definições estavam como que protegidas sobo grande' guarda-chuva' de saúde reprodutiva. Hoje é possível precisar o conteúdo de cada uma delas. Entretanto, esta nova etapa do debate apresenta uma nova tendência à indistinção: estas definições têm sido aplicadas como se fossem intercambiáveis. Um exemplo: o documento nacional brasileiro que se prepara como Plano de Igualdade e Oportunidades incluía direitos reprodutivos na seção sobre saúde, mas não faz menção a eles na seção sobre direitos humanos.

Uma estratégia possível para resgatar a singularidade de cada definição é reconstruir a trajetória de sua elaboração. Entre os anos de 80 e os 90 , os esforços para legitimar 'saúde reprodutiva' articularam as motivações de distintos interesses e atores políticos. Se a noção foi desenvolvida no âmbito das instituições vinculadas ao sistema internacional de planificação familiar e, mais especialmente, da Organização Mundial da Saúde (OMS), esforços similares tiveram lugar na esfera dos movimentos de mulheres. O diálogo entre esses dois 'mundos' está na base do consenso que se legitimaria no Cairo, em 1994. Dois elementos principais possibilitaram o estabelecimento desta ponte: a crítica com relação às vertentes biomédicas, que dominavam (dominam) a pesquisa sobre reprodução humana, e o questionamento dos argumentos lineares que justificavam políticas de população e programas verticais (e ineficazes) de planificação familiar. 
A genealogia do conceito de direitos reprodutivos se localiza, predominantemente, em um marco 'não-institucional'. Sua formulação se inicia na luta pelo direito ao aborto e anticoncepção nos países industrializados. Sua primeira instância foi o consenso político de um encontro feminista internacional, relativamente marginal aos debates institucionais do período-Internacional Women's Health Meeting, Amsterdã, 1994 (ver Corrêa \& Reichmann, 1994; García-Moreno \& Claro, 1994). Nessa ocasião, se produziu um pacto, ainda que provisório, entre feministas do norte e do sul, de que essa era uma terminologia adequada aos fins políticos do movimento.

Entre 1984 e sua consagração no Cairo (1994), o conceito foi refinado em colaboração com ativistas e pesquisadoras/es do campo dos direitos humanos. Uma contribuição fundamental pode ser encontrada no esforço realizado por Freedman \& Isaacs (1992) ao identificar, em documentos históricos das Nações Unidas, definições cujos conteúdos estariam virtualmente relacionados a 'direitos reprodutivos'. Cook (1994) é outra referência fundamental. Suas análises procuram articular as necessidades reprodutivas das mulheres em termos de direito à saúde.

Ao longo da última década, os movimentos de mulheres, nos vários continentes, continuaram debatendo os problemas derivados da aplicação da noção de direitos reprodutivos e sua articulação com saúde reprodutiva. São exemplos disso os debates da Rede Internacional de Mulheres pelos Direitos Reprodutivos, os esforços da Rede Development Alternatives with Women for a New Era (DAWN) em relação ao Cairo e o projeto Intemational Reproductive Rights Research and Action Group (IRRRAG). O vínculo entre saúde e direitos reprodutivos, em uma perspectiva que integra premissas de desenvolvimento eqüitativo e direitos humanos, ancorou o consenso entre os movimentos de mulheres e foi elaborado no documento Declaração do Rio em um encontro internacional realizado no Rio de Janeiro, em 1994, em preparação para a Conferência do Cairo. Dois elementos foram cruciais nessa passagem: a premissa de indivisibilidade dos direitos humanos e a noção de 'um ambiente favorável' para o exercício destes direitos (condições econômicas, sociais e políticas). Este consenso foi a alavanca política que possibilitou revisar, na CIPD, o paradigma neomalthusiano do debate sobre população.

Já o adjetivo 'sexual' eclodiu nos cenários de politização de saúde e direitos reprodutivos muito mais tarde. Nós, feministas, o 'agarramos' praticamente às portas do Cairo. Segundo Petchesky (1996), os direitos sexuais são "a criança mais jovem nos debates internacionais sobre o significado e a prática dos direitos humanos, em particular dos direitos humanos das mulheres". Durante o processo de preparação para a CIPD, algumas delegações oficiais (Noruega e Suécia, por exemplo) introduziram saúde sexual em alguns parágrafos do Programa de Ação. Porém, a inclusão do termo 'direitos sexuais' no $§ 7.3$ da CIPD - em que se definem os direitos reprodutivos - foi uma estratégia de negociação. A inclusão de 'sexual' visava a radicalizar a linguagem para reter os 'direitos reprodutivos' no texto final. Em setembro de 1994, a adoção de direitos 
sexuais não foi expcrimentada como 'derrota' pelas feministas, entrc outras razõcs, porque as que scguíamos de perto as ncgociações sabíamos como havia sido difícil legitimar dircitos reprodutivos.

Entretanto, um parágrafo sobre dircitos sexuais seria aprovado um ano mais tarde no Plataforma de Ação de Beijing. Em setcmbro de 1995, a grande controvérsia nas ncgociações se deu cm torno a explicitar-sc ou não o termo 'dircitos sexuais', que não foi adotado no texto final. $O \S 96$, porém, delimita os conteúdos do que scriam esses dircitos, em um marco que tem como referência principal as relações heterossexuais. Porém, se consideramos a pouca maturidade da claboração conceitual sobre dircitos sexuais no campo feminista e a composição dos países que negociaram o texto, este resultado é de algum modo extraordinário':

Os direitos humanos das mulheres incluem seu dircito a ter controle sobre as questôes relativas à scxualidade, incluída sua saúde sexual c reprodutiva, a decidir livrementc a respcito dessas questões, sem verem-se sujcitas à cocrção, à discriminação ou à violència. As relações sexuais c a reprodução, incluído o respeito à integridade da pessoa, exigem o respeito c o consentimento recíprocos ca vontade de assumir conjuntamentc a responsabilidade das conseqüências do comportamento sexual (Conselho Nacional dos Direilos da Mulher, Plataforma de Ação de Pequim, Seção C, §96).

Analogamente ao que se observou com relação a saúde e direitos reprodutivos, o desenvolvimento das noções de saúde e dircito sexual tem gencalogias distintas: uma que é mais, outra menos institucional. Saúde sexual foi também objeto de uma definição da OMS motivada pelo reconhecimento da crise da pandemia de HIV-Aids. Antes de sua incorporação aos documentos de Cairo c Bcijing, a definição opcrou (c continua operando) como um 'guarda-chuva' para pesquisas e ações no campo da sexualidade. Já a cvolução política c discursiva de "dircitos sexuais" transcorreu sob a consigna de mudanças políticas c culturais de corte radical nas sociedades mesmas. A noção foi formulada em duas frentes: scria inevitável que as reflexões feministas no âmbito da articulação entre sexualidade, reprodução c desigualdade entre os gêneros - particularmente vigorosa nos Estados Unidos, Europa c América Latina - conduzisse à formulação dos dircitos scxuais; e contabilizam-sc os csforços conccituais c políticos dos movimentos gay c lésbico, que se amplificaram enormemente na última década.

\footnotetext{
: Participaram das negociaçõcs informais sobre o parágrafo: União Européia, cujo porta-voz era o ministro holandès, Estados Unidos, Irã, Marrocos, Egito, a região africana, da qual o Senegal era porta-voz, o Caribe e vários países latino-americanos. Evidentemente que a motivação destes atores era muito diversa. A posição da L'nião Européia, especialmente Holanda, para assegurar a inclusão de dircitos sexuais na Plataforma estava informada por un compromisso doméstico com o movimento homossexual. Os países africanos se moviam a partir das agendas de erradicação do casamento infantil e da mutilação genital. Os países islàmicos mais liberais lutaram por uma definição mais fraca para evitar reações fundamentalistas na volta de Beijing. O Caribe e alguns países latino-americanos defendiam o parágrafo como princípio democrático. Os Estados L'nidos mantiveram um 'baixo perfil' nas negociações, em função da pressão republicana no Congresso.
} 
O novo consenso é híbrido, necessariamente frágil e não elimina tensões conceituais, políticas e problemas de comunicação entre os atores e interesses que mobilizaram o debate e legitimação destas definições. Em vários contextos nacionais, as políticas de saúde reprodutiva que se implementam, pós-Cairo e Pequim, estão-se desenhando como meras re-interpretações semânticas, ou adequações, das ações convencionais do materno-infantil ou de planificação familiar. Esta orientação minimiza - quando não oculta - a perspectiva dos direitos reprodutivos. Observa-se, também, no plano das instituições, que os termos 'saúde' e 'reprodutivo' são mais facilmente aceitos do que 'direitos' e 'sexuais', que soam mais radicais e impertinentes.

Rance (1996), por exemplo, descreve como na Bolívia do período pós-Cairo, a iniciativa da maternidade segura tende a excluir as mulheres em situação de aborto incompleto. No que se refere à saúde sexual, as distorções podem ser ainda mais problemáticas. Vance (1996) argumenta que a noção está sendo traduzida, nos Estados Unidos, por setores conservadores como: "reprodução no casamento, abstinência e limitações no acesso à informação sobre sexualidadc, homossexualidade, aborto."

\section{Gênero e sexualidade: fusão versus distinção dos sistemas}

Uma importante barreira em nosso esforço de compreender as relações de gênero é a dificuldade de compreender a articulação entre sexo e gênero (Flax, 1992).

$\mathrm{Na}$ seção precedente buscou-se identificar alguns requisitos de discernimento conceitual que se fazem necessários, na era pós-Cairo e pós-Pequim, para qualificar a investigação e ação política que se desenvolvem a partir das definições de saúde e direitos sexuais e reprodutivos. Exploram-se, agora, os desafios conceituais que emergem à medida que se firma a definição de direitos sexuais.

Petchesky (1996) identifica uma tendência nas campanhas internacionais sobre os direitos das mulheres em enfatizar os horrores - como mutilação genital e o tráfico de meninas -, capitalizando a imagem das mulheres como vítimas no terreno da sexualidade. Para a autora, a força destes discursos faz com que não seja acidental, ou surpreendente, que, em Beijing, "o es pectro de corpos sexualizados anelando o prazer tenham permanecido ocultados sob os debates". Embora a aprovação do $\$ 96$ da Plataforma de Ação de Beijing seja, de algum modo, extraordinária, penso, como Petchesky, que as dinâmicas da negociação das Nações Unidas são insuficientes para explicar o que aconteceu com o prazer e com os corpos nos recentes debates internacionais.

As razões que podem explicar tal ocultação devem ser buscadas no "pano de fundo" de teorias que fundem gênero e sexualidade. O conteúdo dessa seção foi originalmente desenvolvido em outro artigo (Corrêa, 1996), no qual se exploram perspectivas avançadas por Parker (1990) e Rubin (1984), propondo a distinção entre os sistemas de gênero 
e sexualidade. Nesta nova etapa de elaboração, foram incorporadas as reflexões de outras/os autoras e autores que orientam suas investigações na mesma direção².

\section{Itinerários teóricos}

O campo em que se construíram as definições de direitos sexuais e reprodutivos foi influenciado, nos últimos vinte anos, pelas teorias pós-estruturalistas (pós-modernas ou construtivistas). O arsenal analítico da construção (e desconstrução) social - linguagem, discurso, diferença - iriam fertilizar este debate. Foi nessa confluência que se engendrou a categoria "sistema de gênero" (Rubin, 1975). Tal como definido por Rubin e aperfeiçoado por Barbieri (1993), sistema de gênero é:

A totalidade dos arranjos através dos quais uma sociedade transforma a sexualidade biológica em atividades humanas e nas quais as necessidades humanas são tanto satisfeitas quanto transformadas. O poder do gênero opera mais fortemente nas etapas reprodutivas da vida quando os meios para o controle da sexualidade, reprodução e acesso ao trabalho estão localizados e funcionam de modo mais claro e agudo.

Entretanto, em um trabalho subseqüente, Rubin (1994) refaria seus próprios percursos teóricos caminhando para conceituar a sexualidade como esfera autônoma na qual se constroem e se transformam relações pessoais, sociais, culturais e políticas. A autora sustenta que "gênero e sexualidade constituem a base de duas arenas distintas das práticas sociais". Isso significa reconhecer que a construção das identidades de gênero, das normas e da assimetria das relações entre homens e mulheres não sobredeterminam, necessariamente, as manifestações do desejo, as práticas eróticas das pessoas e as experiências do prazer.

Parker (1992), estudando práticas homossexuais masculinas na cultura brasileira, utiliza um esquema tripartite em que se diferenciam e se articulam os sistemas de gênero, da sexualidade e o erótico. Em sua formulação, o sistema da sexualidade nomeia um terreno normativo em que se situam a doutrina religiosa, a perspectiva biomédica e os demais dispositivos que reconfiguram continuamente as representações sobre sexualidade. O sistema erótico designa a esfera em que se movem os jogos

\footnotetext{
${ }^{2}$ Com intensidades diferentes essa proposição pode ser identificada em Vance (1996), Flax (1992), Dowsett (1996) e Petchesky. Petchesky sugere que essa armadilha deriva do economicismo ainda subjacente nos esforços intelectuais do feminismo com relação a gênero e sexualidade. Essa conclusão se vê informada, sobretudo, por uma avaliação crítica do discurso feminista no mundo em desenvolvimento. Dowsett, por sua vez, atribui tal captura dos "corpos em sexualidade" e do "big-bang do prazer" às teorias pósestruturalistas. Sua elaboração sugere que o poder, a amplitude e a profundidade dos dispositivos de controle da sexualidade não são tão extensos como sugere Foucault. As duas visões não devem ser tomadas como opostas, mas sim como percepções corretas mas que olham o "problema" a partir de diferentcs pontos de vista: o sul e o norte, o homossexualismo masculino, o feminismo.
} 
corporais, imaginários e afetivos do que chamamos sexualidade. Vance (1996) vai na mesma direção, ao sugerir que a distinção entre gênero e sexualidade é necessária como estratégia para desconstruir a convergência entre naturalização (religiosa) e biologização (científica) dos gêneros e da sexualidade.

Dowsett (1996) radicaliza, de forma peculiar, a proposta de diferenciação. Seu exercício toma como ponto de partida 'o jogo dos corpos' (bodyplay) e vira de cabeça para baixo a idéia de construção social da sexualidade desenvolvida por Foucault (1982, 1984 , 1985). A partir de estudos com homens que fazem sexo ocasional com outros homens, propõe que pensemos em uma construção sexual da sociabilidade. E sugere que - no contexto dos corpos em jogo erótico - o gênero, como representação dos papéis passivo e ativo, pode converter-se em banalidade. A idéia implícita é de que nos encontros eróticos as duas (ou mais pessoas) podem sempre, potencialmente, ser agentes ativos e criativos na busca do prazer ${ }^{3}$.

Tomando-se esses autores e autoras como referência, parece cada vez mais urgente, na era pós-Pequim, afastar-se da premissa segundo a qual "uma teoria da sexualidade poderia derivar da teoria de gênero" (Rubin, 1984). A fusão conceptual entre gênero e sexualidade torna muito problemática nossas operações teónicas e políticas em relação aos direitos sexuais.

Contudo, nãoé tarefa simples distinguir relações de gênero, sexualidade e erotismo, pois em todas as formações socioculturais atuam sistemas de representação muito coesos que ordenam gênero, reprodução e sexualidade em articulação com a economia e o poder. Se nos fixarmos no exemplo da cultura ocidental, Costa (1996), em um texto brilhante, demonstra como o sistema metafísico pré-iluminista não enfatizava, como se fez posteriormente, a diferença sexual entre homens e mulheres. Seu paradigma do corpo era o masculino. O corpo das mulheres era representado como um corpo masculino invertido e menos perfeito, no qual o pênis e os testículos estavam para dentro. Costa demonstra como o modelo dos dois sexos (two sex model) - hoje hegemônico--, antes de se conformar como discurso científico, resultou de uma operação 'ideológica' do liberalismo iluminista, que visava a solucionar uma contradição de fundo:

Aigualdade (iluminista) estava fundada na premissa de que todo individuo era possuidor da mesma faculdade da Razão e de um mesmo corpo natural que a abrigava (...). Marcar o corpo com a diferença dos sexos significou instaurar a desigualdade, a descontinuidade, aoposição onde havia uma controversa e incômoda igualdade juridico-política.

Essa acentuação da diferença sexual do corpo dos homens e das mulheres foi precedida pela cristalização de uma determinada concepção de sexo. O sexo, tal como construído pelos filósofos oitocentistas, é uma força vital que se faz mais presente e

\footnotetext{
'A reflexão de Dowsett é construída a partir das pesquisas com homens homossexuais em que o gênero desempenha um papel distinto do que no contexto de outras relações. Isso indica a necessidade de 'repensar-se' seu esquema quando estejamos elaborando ou investigando sobre a sexualidade entre homens e mulheres e mulheres e mulheres.
} 
manifesta nas mulheres. Segundo Rousscau (In Laqueur, citado por Costa): "O macho (humano) somente é macho em certos momentos. A fêmea é fêmea toda a sua vida (...). Tudo constantemente evoca a cla seu sexo". A partir daí concebeu-se as mulheres como estando mais habilitadas à vida privada (e não para a vida pública como os homens), mais fracas e histéricas, não em conseqüência de um 'déficit da Razão', mas sim em função da excessiva impregnação sexual de seus corpos: "As mulheres seriam identificadas por sua sexualidade e seu corpo, os homens pelo seu espírito e energia" (Costa, 1996). Em etapas subseqüentes seriam investigadas e mais bem elaboradas as provas anatômicas (médico-científicas) dessa diferenciação radical que persiste até hoje.

Ao 'modelo dos dois sexos' corresponderia a sexualidade 'monolítica' que foi objeto das análises de Foucault: a sexualidade monopolizada pelo casal. Nesse espaço de intimidade, a sexualidade guarda um sentido procriativo dominante e desempenha um papel crucial como mediação entre os dois "opostos complementares" em que se haviam convertido homens e mulheres. Trata-se, além do mais, de uma representação da sexualidade que tem como expressão máxima as formas e substâncias do corpo feminino, o que justificaria, na cultura ocidental moderna, o controle das manifestações sexuais e eróticas femininas. Tal representação, sobretudo, ancora uma marcada ideologia da inversão sexual. O inverso do "Homem" iluminista não seria a "Mulher", mas sim o homossexual, cujo "corpo de homem será o portador da sexualidade feminina que havia de ser criada" (Costa, 1996).

Em função da hegemonia desta construção sociocultural é impossível distinguir sistemas de gênero, de sexualidade e de erotismo sem desconstruir os complexos nós que os sustentam. Uma primeira estratégia nessa direção seria desdramatizar a diferenciação sexual entre os gêneros. É tempo de acompanhar a postulação de Flax (1992), quando afirma que as diferenças entre homens e mulheres são menos relevantes do que sugerem as normas, representações, símbolos e práticas dominantes ${ }^{4}$. Também se faz necessário romper com as representações monolíticas da sexualidade e erotismo intrínsecas do 'modelo dos dois sexos': é preciso alterar a linguagem do singular para o plural, de sexualidade para sexualidades.

A idéia de sexualidades múltiplas va de soi quando olhamos a realidadc à luz da teorização e da pesquisa que têm como foco as práticas homossexuais. Porém, a noção de sexualidades plurais deve ser também explorada nocampo das relações heterossexuais, o que permitiria descrever e analisar com mais precisão as práticas sexuais, o erotismo e o prazer nas distintas etapas da vida humana: infância, adolescência, vida adulta, terceira idade. Esta inflexão também pode enriquecer os estudos acerca dos sistemas de gênero e sexualidade em outras formações socioculturais, inclusive nos casos em que se observam fusões ou sobreposições com o modelo ocidental.

\footnotetext{
4 A mesma perspectiva pode ser identificada nos trabalhos de outras autoras/autores, como por exemplo, Badinter em "O um e o outro" ou Philippe Aric̀s quando sugere que caminhemos para uma forma de unissexualidade (citado em História da Vida Privada, v.5, 1996).
} 


\section{Desafios políticos}

Em um plano político, a desconstrução do 'modelo dos dois sexos' contribui para a cristalização da premissa da igualdade - política, jurídica, social e econômica entre os gêneros - persistentemente neutralizada pela hipervalorização da diferenciação sexual entre homens e mulheres. Também amplia as referências conceituais no que se refere à 'desconstrução do masculino'. Diante da insistente problematização, biologização e medicalização do feminino e dos "invertidos", o masculino (o Homem do Iluminismo) continua sendo percebido e tratado como um fato fixo e imutável. Este congelamento dificulta o mapeamento dos impactos pessoais e sociais derivados da construção social do masculino. Desconstruir o modelo dos dois sexos implica admitir que "homens e mulheres são prisioneiros de seus gêneros. O fato de que os homens sejam os tutores de uma totalidade social não nos autoriza a afirmar que eles também não sejam submetidos às regras dos sistemas de gênero" (Flax, 1992), e que tais regras têm sempre um custo.

A distinção entre os sistemas de gênero e sexualidade é também imprescindível para sedimentar as premissas dos princípios de direitos sexuais, resgatando a perspectiva de emancipação no terreno da sexualidade. Revigorar a idéia de emancipação sexual não significa um retorno acrítico ao ideário da liberação sexual dos anos 60. Mas, como sugere Petchesky (1996), no debate desses anos o discurso feminista foi capturado por novas espirais discursivas que terminaram por distanciá-lo de um elemento fundacional do imaginário político feminista: a busca da sexualidade prazerosa. A distinção entre gênero e sexualidade é um passo crítico para identificar, aceitar e tornar visível o agenciamento sexual, o erotismo e o prazer das mulheres, que foram, de algum modo, submergidos na lógica do poder e na dominação dos sistemas de gênero. Este caminho, inclusive, pode prevenir o deslizamento de nossos discursos quanto à vitimização das mulheres, facilmente capturada por estratégias moralizantes (Corrêa, 1996).

Este deslocamento, sobretudo, pode alimentar cristalização discursiva e política da noção de "justiça erótica" formulada por Rubin (1984), que se deve aplicar tanto ao domínio das relações pessoais como à esfera pública. Retomando as idéias desenvolvidas sobre direitos reprodutivos (Corrêa \& Petchesky, 1994; Corrêa \& Reichmann, 1994), o pleno exercício dos direitos sexuais exige um 'ambiente favorável', em que as práticas individuais sejam inspiradas pelo princípio de respeito à integridade corporal e à vontade do 'outro' (da 'outra'); em que as condições sociais, econômicas e culturais conduzam à igualdade entre os gêneros, à liberdade de orientação sexual e à não-discriminação; em que as práticas sexuais individuais não estejam sujeitas a coerção moral ou legal. 


\section{Referências Bibliográficas}

BARBIER, T. de. Gender and population policies: some reflection. Reproductive Health Matters. n²1, May, 1993.

Cook, R. Women's Health and Humans Rights. Genebra: World Health Organization, 1994.

CORREA, S. \& PETCHESKY, R. Reproductive and Sexual Rights: a feminist perspective. In: SEM, G., GERMAINE, A\&CHEN, L. (Org.) Iopulation Policies Reconsidered: health, empowerment and rights. Boston: Harvard School of Public Health, 1994.

CORREA, S. \& REICHMANN, R. Population and Reproductive Rights: feminist perspectivs from the south. London: ZED Books, 1994.

CORRĖA, S. Gênero e sexualidade: sistemas autônomos ou idéias fora do lugar? In: BARBOSA, R. \& PARKER, R. Sexualidades Brasileiras. Rio de Janeiro: Relume Dumará, 1996.

COSTA, J. O Referente da Identidade Homossexual. In: BARBOSA, R. e PARKER, R. Sexualidades Brasileiras. Rio de Janeiro: Relume Dumará, 1996.

DowSETr, G. Bodyplay: Corporeality in a Discursive Silence. In: Re-Conceiving Sexualities -International Seminar on Gender, Sexuality and Sexual Health, 1996, Rio de Janeiro.

Foucautr, M. História da Sexualidade I: a vontade de saber. Rio de Janeiro: Graal, 1982.

FoucAuUt, M. História da sexualidade II: o uso dos prazeres. Rio de Janeiro: Graal, 1984.

FoucAurr, M. História da sexualidade: o cuidado de si. Rio de Janeiro: Graal, 1985.

FLAX, J. Pós-modernismo e as relações de gênero na teoria feminista, In: HolandA, H. (Org.). Pós-modernismo e Política. Rio de Janeiro: Rocco, 1992.

FREEDMAN, L. P. \& IsAaCS, S. L. Human Rights and reproductive choice. Studies in family planning, $24(1): 18-30,1993$.

FundaÇÃo OsWALO CRUz (Fiocruz). IV Conferência Mundial sobre a Mulher - Pequim. Rio de Janeiro: Editora Fiocruz, 1996.

Garcia-Moreno, C. \& Claro, A. Challenges From the Women's Health Movement: women's rights versus population control, In: SEM, G., GERMAINE, A \& $C_{\text {HEN, }}$ L. (Eds). Population Policies Reconsidered: health, empowerment, and rights. Boston: Harvard University Press, 1994.

PETCHESK, R. Sexual Rights: inventing a concept, mapping and intemational practiox. In: Re-Conceiving SexualitiesInternational Seminaron Gender, Sexuality and Sexual Health. 1996, Riode Janeiro. (Mimeo.)

PARKER, R. Bodies, Pleasures and Passions: sexual culture in contemponary Brazil. Boston: Beacon Press, 1990.

RANCE, S. Maternidade Segura, Aborto Inseguro: impacto de los discursos en las políticas y en los servicios, In: Seminário Saúde Reprodutiva na América Latina e Caribe: temas e problemas. 5-7/Out/1996, Caxambu, Brasil. (Mimeo.) 
RUBIN, G. The Traffic in Women: notes for a political towards and anthropology of women. Nova York: Columbia University Press, 1975.

RUBIN, G. Thinking of Sex: notes for a radical theory of the politics of sexuality, In: VANCE, C. Pleasure and Danger. exploning sexuality. Nova York: Routledge and Kegan, 1984.

VANCE, C. Thinking Sex, Gender and Health. In: Re-Conceiving Sexualities - International Seminar on Gender, Sexuality and Sexual Health. 1996, Rio de Janeiro. (Mimeo.) 



\section{Família, Sexualidade e Reprodução no Direito Brasileiro}

1.

Leila Linhares Barsted

\section{Contexto: ambiguiidades e impasses}

O objetivo deste capítulo é apresentar uma síntese de alguns impasses da legislação brasileira sobre família, sexualidade e reprodução. Situamos esses impasses em um quadro mais abrangente-a própria sociedade brasileira, com suas ambigüidades entre moderno e tradicional, público e privado, liberdade e autoritarismo, igualdades e diferenças, universalização e particularização e tantas outras.

Buscamos examinar esses impasses do ponto de vista ideológico, com suas repercussões legais, particularmente a partir da perspectiva dos direitos reprodutivos, noção implicitamente declarada no texto da constituição brasileira de 1988 por pressão do movimento feminista. Analisaremos alguns argumentos utilizados na configuração do discurso jurídico sobre família, sexualidade e reprodução, na hipótese de que esse discurso tenha incorporado os paradoxos da tese democrática como um todo.

Situando as temáticas da família e da reprodução no quadro mais abrangente da cultura política brasileira, começamos por constatar que é longa e fértil, na tradição das ciências sociais de nosso país, a discussão sobre as características autoritánias do Estado. Na década de 80 , com o fim da ditadura militar, desvendou-se e recuperou-se a perspectiva de que esse autoritarismo não era um elemento apenas constitutivo do Estado, mas, também, parte da formação cultural brasileira, permeando toda a sociedade. Essa constatação, do que parecia específico à civilização ocidental nos trópicos, tem sido destacada na análise de sociedades complexas consideradas fundadoras dos princípios da modernidade (Dumont, 1985) e estimuladora dos debates sobre os rumos da própria modernidade. 
No caso brasileiro, várias características poderiam ser apontadas para o delineamento de uma cultura e de um Estado autoritários. Procuramos destacar, na análise do discurso legal sobre família, sexualidade e reprodução, como as noções de direitos individuais e direitos sociais têm sido metamorfoseadas para se tornarem compatíveis com o autoritarismo, reforçá-lo, ou, até mesmo, suavizá-lo.

De forma simplificada, poderíamos dizer que, no Brasil, os direitos individuais foram entendidos, historicamente, comodireitos das elites, e os direitos sociais, que são introduzidos basicamente a partir da década de 30, como direitos dos pobres. Retirou-se das camadas populares o direito à individualidade, remetendo-as, necessariamente, para a esfera do coletivo ou, muitas vezes, do corporativismo. Não há indivíduos, mas grupos. Essa consideração pode ser exemplificada na legislação trabalhista das décadas de $30 \mathrm{e}$ 40, inspirada em modelos de sistemas capitalistas mais humanizados, de países europeus, onde os trabalhadores conquistaram mais direitos desde o século XIX, e no modelo corporativista fascista, inspirado no Código Del Lavoro italiano, da época de Mussolini.

Nessa perspectiva, a configuração híbrida dos direitos sociais levou ao surgimento de uma noção de cidadania intrinsecamente presa à atividade laboral. O cidadão era, nas classes populares, o trabalhador possuidor de uma carteira de trabalho, partícipe obrigatório de uma corporação sindical e profissional. Essa cidadania, já caracterizada como cidadania de segunda classe (Santos, 1979), deixava de lado e remetia para uma cidadania de terceira classe os indivíduos das camadas populares que não tivessem os vínculos corporativos. Para eles, a legislação penal, elaborada em 1940 e em 1941, inspirada no Código Rocco-também da Itália de Mussolini -, previa o crime de "vadiagem". Esses eram os 'desviantes' de uma ordem que se pretendia reguladora do progresso, da família e dos valores morais e que se delineia em uma profusão legislativa a partir, principalmente, da década de 30 . Os discursos proferidos pelo presidente Vargas nesse período (que se estende até 1945) eram dirigidos aos 'trabalhadores do Brasil' e grande ênfase era dada a sua atuação como o 'pai dos pobres', em uma comparação entre a nação e a família, entidades constituintes de um todo, sem margem para os desviantes, fossem eles os desempregados-vadios, os comunistas, os integralistas ou os 'diferentes' (de um modo geral, vistos como portadores de ideologias 'exóticas').

Estabelecendo paralelos, tanto o Estado como a família, pensada como celula mater da sociedade, não suportavam aqueles que não se adequassem às suas normas - os desviantes e organizavam-se de forma vertical e autoritária sob a égide do pai. Para as elites, a cidadania não se relacionava, e não se relaciona até hoje, com a participação no mundo do trabalho ou à filiação à entidades corporativas, mas à existência de capital e de status suficientes para eximir-se dos rigores da lei penal -destaca-se que os individuos portadores de diploma universitário acusados de terem cometido crimes têm direito à prisão especial enquanto aguardam julgamento. Seu principal instrumento de afirmação de direitos é o Código Civil, posteriormente comentado. 
Configuram-se, dessa maneira, três níveis de cidadania (o que significa a total deturpação deste conceito, que pressupõe a inexistência de hierarquias): o cidadão de primeira classe, orientado pelos princípios do Código Civil e merecedor de direitos individuais (entre eles, até 1988, os homens aparecem com mais direitos do que as mulheres, em particular no que diz respeito à família); o cidadão de segunda classe, regido pela Legislação Trabalhista, merecedor dos direitos sociais, inclusive o direito de rescindiro contrato de trabalho de sua esposa sob o argumento de proteção da família; e o cidadão de terceira classe, sujeito às penalidades do Código Penal - penas que têm conseqüências específicas sobre o corpo feminino, como é o caso da criminalização do aborto.

Deve-se destacar também que outros clementos surgiam para deturpar a constituição de cidadãos: as práticas e a ideologia do favor, sintetizadas nas expressões "aos amigos tudo, aos inimigos a lei", "quem tem padrinho não morre pagão" ou "uma mão lava a outra". A prática do favor e da pessoalidade das relações acabava por apagar a individualidade, mesmo entre as clites, e reforçava o pertencimento ao grupo (network) dos amigos e dos afilhados como elemento fundamental na configuração de um lugar social. Longe de uma fidelidade à res publica, as elites tornaram-se fiéis aos seus grupos de referência. Evidentemente, esse padrão enraizou-se na cultura brasileira e passou a ser adotado também entre as camadas populares, reforçando, inclusive, os esquemas corporativistas.

Na realidade, os ideais democráticos de liberdade e igualdade, de existência de cidadãos sujeitos de direitos e obrigações, constituíam-se em mera declaração formal de princípios, sem maior compromisso com a prática efetiva dessa base legal. Esse fenômeno, que não é invenção brasileira (Duarte et al., 1993), encontra em nosso país suas peculiaridades. Os ideais democráticos estão presentes em todos os discursos da política brasileira, inclusive nos provenientes dos setores autoritários. Têm sido extremamente operacionais, dando ao Estado e à sociedade contornos de modernidade, ofuscando suas caracteristicas hierarquizadoras e discriminatórias. Exemplo disso é a declaração, em todas as constituições da República, desde 1891, da igualdade de direitos entre os cidadãos e das formas democráticas de organização do Estado. É de se destacar, também, que só a partir da Constituição de 1946 foi incluído um capítulo referente aos direitos sociais, bastante ampliado na Constituição de 1988. Nas constituições de 1891, 1934 e 1937 estão declarados os direitos e garantias individuais, sem referência aos direitos sociais. Tal omissão pode ser explicada: a questão social e as reivindicações por direitos trabalhistas, até a década de 30, eram consideradas casos de polícia, transgressões inaceitáveis pelo Estado e pelas elites dirigentes. Os desviantes eram não apenas os 'vadios', mas os trabalhadores, as classes consideradas perigosas.

É curioso observar também que os setores críticos do autoritarismo do Estado tenham dedicado sua maior atenção à análise das legislações penal e trabalhista e detidose muito pouco na discussão do Código Civil brasileiro. Implicitamente, esses setores, 
identificados com as causas populares, não consideravam o Código Civil um instrumento que pudesse beneficiar o cidadão comum, independentemente de sua qualificação como trabalhador '. Esse Código não foi objeto de análises mais substanciais pelo pensamento político brasileiro, deixando-se de discutir o lugar que os direitos individuais ocupam em nossa sociedade. Curiosamente, as feministas é que vêm propondo mudanças na parte relativa ao direito de família do Código Civil para retirar-lhe as características discriminatórias entre homens e mulheres.

Essas considerações iniciais sobre como germinaram, ou não, em solo brasileiro os ideais da democracia, que simbiose se produziu sob o sol tropical entre cidadania e 'ideologia do favor', podem ser compreendidas analisando-se as inúmeras inquietações da sociedade brasileira a partir da República.

Nesse artigo, para atingir o objetivo delineado em seu início, examinamos não só o discurso jurídico do Legislativo e do Judiciário, mas, também, o de outros atores - como o movimento feminista - sobre família, sexualidade e reprodução, procurando observare analisar como o debate sobre essas temáticas está permeado pelas ambigüidades presentes nas discussões sobre a democracia no Brasil.

O direito brasileiro é analisado como um dos discursos que normatizam as relações familiares, a sexualidade e a reprodução. Tal exercício implica análise de legislações diversas, em momentos distintos de nossa história social.

O discurso jurídico brasileiro, considerado aqui não somente na sua face legislativa, mas também na doutrina e na jurisprudência sobre esses temas, não só trata de repressões. Sobretudo, atua como elemento que reproduz e reforça os modelos hegemônicos que orientam e normatizam as relações sociais.

É importante destacar que não se pode pensar o direito abstraído das relações de poder entre as classes, os sexos e raças/etnia. O legislador e o jurista atuam de acordo com as relações de poder estabelecidas em cada contexto histórico, seja como um freio às transformações sociais, em resposta a uma sociedade em mutação, ou, ainda, em uma postura de vanguarda como elemento propulsor de novos valores, de nova ética social. Para criação de consenso, a instância jurídica atua como mecanismo pedagógi$\mathrm{co}$, socializando os agentes sociais, produzindo crenças e sentimentos comuns (Barsted, 1987). No entanto, o direito permite, também, a existência de contradições e, até mesmo, aceita pretensões surgidas daqueles que não estejam no topo da hierarquia social.

A estrutura da família, a vivência da sexualidade e da reprodução, tal como historicamente se apresentam no direito brasileiro, não são o simples reflexo da forma concreta de relacionamento social. São, antes, a codificação de uma visão de mundo marcada por discursos híbridos que incorporam princípios igualitários e não-igualitários entre

\footnotetext{
' Os direitos individuais, em particular nas questões relativas à famillia, têm sido historicamente buscados pelas mulheres, particularmente por aquelas dos setores populares.
} 
classes, sexo e raça/etnia. Nessa visão de mundo sobre família, sexualidade e reprodução está presente a preocupação com a legitimação legal dos laços familiares; com a transmissão de bens através da herança a ser recebida por herdeiros legítimos; com padrões de moralidade relativos à sexualidade cà reprodução.

Tomando-sc como marco a proclamação da República, podemos identificar, pelo menos, duas grandes fases onde essa visão de mundo se atualiza: a primeira, a partir de 1917, com a entrada em vigor do Código Civil. A segunda, a partir de 1977, com a chamada Lci do Divórcio e completada em 1988 com a aprovação da nova Constituição Federal. Essas fases apresentam nuances que tornam mais ou menos rígido o discurso jurídico. No entanto, de modo geral, são cocrentes com os processos sociais em curso c a ideologia hegemônica de cada época.

\section{Lei, família e reprodução: 1917-1977}

O marco inicial desse período ć o Código Civil, promulgado em 1916. Expressão do Código de Napoleão nos trópicos, constituiu-se em instrumento de afirmação da liberdade, do rcinado do consentimento, do repúdio à coação, do respcito aos contratos $\mathrm{c}$ às obrigações daí decorrentes. Por cssc Código, a cidadania configura-se a partir da capacidade civil plena aos 21 anos, do gozo da razão e da liberdade para consentir e contratar.

É o Código Civil que mais explicita, em relação aos demais, o modclo jurídico da família brasilcira, calcada no modclo idealizado c vivido, cm certa medida, pelas famílias da clitc burguesa no País. Desde sua claboração, ainda no final do século XIX, o Código Civil incorporou o discurso científico no que se refere à importância da higienização da família c o papel da mulher para concretização desse aspecto (Aric̀s, 1978; Donzelot, 1979). A conformidade a este modelo ć que tornará as relações entre os sexos legítimas ou não. Deve-sc reconhecer que o texto original, ao longo dos anos, sofreu inúmcras altcrações, particularmente a partir da década de 70, em decorrência tanto das novas relações cconômicas e sociais como da ação de atores diversos, dentre os quais o movimento feminista.

Apesar de reconhecer para homens e mulheres, brancos e ncgros, a partir dos 21 anos, a igualdade quanto à capacidade civil plena, o Código apresentava, até $1962^{2}$, mensagens diferenciadas, mesmo na clite, para homens c mulheres, se casados fossem. Reafirmando as assimetrias de gênero, desenhava um modelo de mulher sempre necessitada de proteção masculina, seja do pai ou do marido. Assim, como por um passe de mágica, a mulher maior de 21 anos, dotada formalmente de plena capacidade civil, perdia esse atributo ao contrair matrimônio, ficando reduzida a uma capacidade relativa e necessitando de consentimento do marido para a prática de diversos atos da vida civil.

\footnotetext{
2 Ver o Estatuto Civil da Mulher Casada, de 1962
} 
Deve-se lembrar também que, até 1932, a mulher maior de 21 anos, mesmo solteira e, portanto, com plena capacidade civil, não se constituía ainda cidadã, sujeito de plenos direitos, já que lhe era vedado o direito ao sufrágio universal. A cidadania, pensada em uma lógica do individuo, para as mulheres era mediada pela família, pelo coletivo privado. Na realidade, as mulheres foram tratadas, pela razão iluminista, como categorias sociais secundárias, dependentes de suas famílias de origem ou de seus maridos, os chefes de família (Rousseau, ao se dirigir às virtuosas cidadãs suiças, explicitava que sua cidadania se construía por meio de sua tarefa educadora dos homens, como mães e esposas).

Embora, em tese, o Código Civil também fosse dirigido às camadas populares, não encontrava ressonância prática em seu cotidiano, ao contrário das legislações penal e trabalhista da década de 40 . Para as classes populares - às quais não havia herança de bens materiais a ser transmitida -, as relações de concubinato e o controle sobre as mulheres mostrava-se menos rígido. Dessa maneira, o Código Civil pouco incidia sobre o cotidiano de suas vidas. E, mesmo não se atualizando na vivência das classes populares, representa o discurso hegemônico sobre o exercício 'normal' da sexualidade e da reprodução e da constituição da família. Por este motivo, há uma história legal da família no Brasil que pode ser contada tanto por seus efeitos sociais e políticos como pelo seu efeito ideológico.

Nessa primeira fase, poderíamos dizer que o discurso legal sobre a família como locus legítimo da reprodução é extremamente reducionista. O modelo apresentado é o da família monogâmica, patriarcal, nuclear. A família se desenvolvia sob a linhagem legal do pai, o que consistia no reconhecimento dos filhos nascidos somente dentro do casamento e nunca fora dele. O registro de filho nascido fora do casamento, para os homens casados, só poderia ser feito por meio de ação judicial de investigação de paternidade, e somente para habilitação em herança. Deve-se destacar que para a mulher era vedada a ação de investigação de maternidade para reconhecimento de filho nascido fora do casamento, mesmo para habilitação em herança. Esperava-se da mulher recato e fidelidade absoluta quando casada e, quando solteira, a manutenção de sua virgindade até o casamento legal. Somente em 1942 foi editada lei de reconhecimento-somente de paternidade-de 'filhos ilegítimos', nascidos fora do casamento, continuando vedada a ação de investigação de maternidade.

Marcado pelo positivismo, o Código Civil, com a redação de 1916, buscava padrões de nomalidade que afastassem a família dos 'estados patológicos'. Apesar de a ideologia positivista refutar a influência da Igreja Católica nas questões do Estado no que se refere à familia, espaço coletivo privado, o modelo positivista pouco diferia da família cristã, católica, pautada por padrões do Código Canônico.

A lei civil dedicou à família todo um capítulo que regulava temas de várias ordens, como indicação de impedimentos absolutos e relativos para casar; definição da idade legal para o casamento diferenciada para homens e mulheres, dando a elas uma maior 
precocidadc; definição das condiçõcs para a dissolução da sociedade conjugal; autorização para transmissão do pátrio poder para o novo marido de mulher viúva sobre os filhos 'nascidos do leito anterior'; inclusão como cláusula de anulação de casamento a constatação, pelo noivo, da não-virgindade da mulher. Com a prcocupação de ser cocrente com o saber científico c de cvitar "cfeitos dos cruzamentos consangüíneos", dentro de uma lógica da higicnização da família, o Código não apenas proíbe o incesto, como define regras de relacionamento sexual entre parentes, incluindo a proibição de casamento entre tios c sobrinhos (revogada em 1941). A prcocupação com a 'higienização da família' foi reforçada pela Constituição Federal de 1934.

Outras temáticas são normatizadas, como as relativas ao reconhecimento de dircitos diferenciados (na maioria não-igualitários), entre os cônjuges na constância do casamento c na sua dissolução, particularmentc os relativos à guarda dos filhos, dentre outros. A presunção de cônjugc inocente na dissolução do casamento assegurava à mulher casada o 'dircito' de continuar mantendo o nome do marido, pensão alimentícia e a guarda dos filhos. Por longa data, as decisões dos tribunais brasilciros csperavam da mulher 'desquitada' comportamento exemplar quanto ao recato sexual.

O Código Civil cm outros capítulos tem inúmeras disposições sobre família, sexualidade e reprodução: a que reconhecc o nascimento com vida como o início da vida civil; a que obriga a mulher viúva a esperar 10 meses após do óbito do marido para poder contrair novas núpcias (para certificar a origem da prolc); a que permite aos pais deserdarem filha que não tenha comportamento 'honesto' (honestidade compreendida como comportamento sexual adequado a uma mulher de 'família'), dentrc outras.

Fazendo-se uma síntese do conteúdo da orientação do Código Civil, podemos dizer que o único modelo lcgalmente assumido para a definição de família cra o formado pclo casamento perante autoridade judiciánia, hicrárquico entre marido c mulher, bem como entre linhagem paterna e linhagem matema. Isso significa que a palavra do pai vale mais do que a da mãe e que os avós paternos têm mais poderes do que os matemos. Aos homens cabc a chefia da sociedade conjugal, a administração dos bens do casal c dos bens particulares da mulher-mesmo quando vigora o regime de separação total de bens-, a representação legal da família, a decisão sobre fixação de domicílio e a autoridade máxima sobre os filhos.

Ainda pclo Código Civil, com a redação de 1916, o marido era o "provedor" da manutenção da família, cnquanto à mulher cabia "velar" por sua direção moral. A lei reproduz c reforça os papéis de gênero culturalmente atribuídos a homens e mulheres. Essa orientação, conccbida a partir das famílias de clite, é dirigida, também, às familias das classes populares, muitas das quais, na ćpoca, nem sempre tinham os homens presentes e eram sustentadas somentc por mulheres.

Em grande medida, o Código sofrcu, cm 1962, uma importante alteração através do chamado Estatuto Civil da Mulher Casada. Pela redação, a mulher casada teria a mesma capacidade civil do homem. No entanto, continua a ser considerada mera colaboradora 
do marido na constância do casamento e a manter um papel secundário no que tange ao exercício do pátrio poder e definição do domicílio conjugal. Essa lei aparentemente criou outros benefícios para as mulheres, como o instituto dos 'bens reservados da mulher casada', definidos como os provenientes de sua profissão lucrativa e dos quais podia dispor livremente sem passar pela administração do marido. Por esse Estatuto, a mulher viúva que se casa em segundas núpcias não perde o pátrio poder sobre os "filhos do leito anterior"; presume-se que foi "autorizada pelo marido para a compra (...) a crédito (...), para obter empréstimo (...)". No entanto, a possibilidade de eximir-se, por intermédio de pacto nupcial, da obrigatoriedade de colocar seus rendimentos na manutenção da família e a presunção de 'autorizada pelo marido' define que o modelo de família continuava sendo o das famílias da elite. Além disso, sua base econômica continuava nas mãos do marido, cujo papel de único provedor não se alterava, bem como era mantida a representação sobre a mulher, ainda uma 'colaboradora', embora lhe fosse reconhecida a missão precípua e fundamental de moralizadora junto à família.

Outros marcos importantes, nessa primeira fase, e que reafirmam os princípios da legislação civil, foram o Código Penal, de 1940, e a Consolidação das Leis do Trabalho (CLT), de 1943.

O Código Penal reforça a importância da família ao criar quatro capítulos a seu respeito. O primeiro trata dos crimes contra o casamento, punindo, dentre outros comportamentos, a bigamia e o adultério; o segundo trata dos "crimes contra o estado de filiação" e pune comportamentos como o "parto suposto e outros fingimentos" e da sonegação de estado de filiação, que implica em "deixar em asilo de expostos ou outra instituição de assistência filho próprio ou alheio, ocultando-lhe a filiação (...)". O terceiro capítulo trata dos "crimes contra a assistência familiar", no qual se sobressai a punição do comportamento de "abandono de família" que inclui os crimes de "abandono material", "entrega de filho menor a pessoa inidônea" e "abandono intelectual". O quarto capítulo trata dos "crimes contra o pátrio poder, tutela ou curatela" no intuito de dar proteção penal aos menores de 18 anos ou àqueles legalmente interditados.

Houve inovações, também, quanto à punição do adultério. No Código anterior, ainda do final do século passado, o adultério masculino só se configurava se o marido tivesse ou mantivesse 'concubina', ao passo que para a mulher bastava uma única infidelidade conjugal. Em 1940, o legislador considerou como adultério a 'simples infidelidade', seja do marido ou da esposa, para configuraro adultério (Hermann \& Barsted, 1995). No entanto, apesar da mudança da lei, o adultério masculino sempre foi visto com mais complacência no âmbito do poder judiciário, que julgava com mais severidade o adultério feminino. A preocupação com a legitimidade da prole e a visão de que as mulheres honestas eram necessariamente castas reforçava essa maior severidade. Uma das conseqüências dessa concepção era a aceitação da tese da legítima defesa da honra que absolve até hoje, em muitos lugares do País, maridos que assassinaram esposas 
consideradas adúlteras (Hermann \& Barsted, 1995). No caso do aborto, o Código acatou duas situações como passíveis de realização legal: $\mathrm{cm}$ caso de risco de vida para a mãe e em caso de gravidez resultante de estupro. Além da piedade para com a vítima, explicitada na exposição de motivos do Código, o legislador também se preocupava com a legitimidade e higienização da prole, que não poderia ser assegurada caso essa fosse proveniente de um estupro. Ainda em relação ao estupro, o Código adota uma posição curiosa. Por exemplo: pune o aborto como crime contra a vida e deixa de punir o estuprador que se casar com sua vítima. O crime de estupro não é considerado como um crime contra a pessoa e sim como um crime contra os 'costumes'. Por se tratar de um crime de ação privada, somente a vítima pode ou não denunciá-lo. Tal lógica pode ser explicada porque o legislador entendia que sendo um crime que poderia afetar a 'honra' da vítima, deveria ser mantido em segredo, e a honra poderia ser restituída se o culpado com ela se casasse.

O Código prevê, ainda, no que diz respeito à família, que ocorra um aumento de pena nos crimes praticados contra "ascendente, descendente, irmão ou cônjuge" ou com "abuso de autoridade ou prevalecendo-se (o agente) de relações domésticas, de coabitação ou de hospitalidade". Na realidade, como a família era culturalmente pensada ainda como espaço da privacidade, a violência doméstica, em vez de ser um crime mais grave, acabou sendo tratada como um não-crime.

$\mathrm{Na}$ lei penal há uma distinção entre sujeito ativo e sujeito passivo. Na maioria dos crimes, homens e mulheres podem ser ativos ou passivos, quer sejam autores ou vítimas, respectivamente. No entanto, o Código define alguns crimes cujos sujeitos não são indiferenciados. A mulheré sempre explicitamente sujeito ativo nos crimes de infanticídio c aborto e sujeito passivo dos crimes de estupro, rapto e sedução. Também sob o argumento de proteção da família e de controle da sexualidade e da reprodução, o Código Penal reafirma o valor da "mulher honesta" e da virgindade ao punir a "posse sexual mediante fraude", o rapto e a sedução somente se a vítima for 'mulher honesta' definida, evidentemente, segundo os padrões de moralidade sexual que orientavam e ainda orientam, em certa medida, a sociedade brasileira - se solteira, virgem; se casada, recatada.

Em complementação ao Código Penal foi elaborada, em 1941, a Lei de Contravenções Penais, que dentre seus artigos previa punição para a propaganda e a fabricação de métodos anticoncepcionais e abortivos. Nova lei, de 1979, deixa de considerar contravenção a propaganda e o fabrico de métodos anti-concepcionais.

Também na década de 40 foram elaboradas as legislações trabalhista e previdenciária, frutos tanto da pressão do operariado como da ação patcrnalista do Estado autoritário. Nessa época, houve uma verdadeira exaltação à 'família brasileira', sempre presente nos discursos de Vargas. Ao lado de inúmeros direitos e obrigações, essa legislação sinaliza o incentivo à procriação, com a instituição de novos direitos como o salário-família, o auxílio-maternidade e a licença-maternidade; medidas protetoras para as trabalhadoras gestantes e a obrigatoriedade de creches em empresas empregadoras de mulheres 
em idade reprodutiva. Considerando a mulher no mesmo patamar dos menores, a CLT, em seu texto original, criou uma série de restrições ao trabalho feminino-que começaram a ser eliminadas nos anos $70 \mathrm{e}$ foram definitivamente afastadas com a Constituição Federal de 1988, que manteve apenas as restrições relativas ao trabalho da mulher gestante-e incluiu a possibilidade de o marido rescindir o contrato de trabalho de sua mulher "quando a sua continuação for suscetível de acarretar ameaças ao vínculos da família" - este dispositivo, pouco utilizado, também foi revogado em 1988.

Em trabalho anterior (Barsted, 1987), destacávamos que o discurso legal na área do trabalho não encontrou a mesma eficácia dos discursos dos Códigos Civil e Penal. A contradição entre moralidade burguesa, compatível com as legislações penal e civil, e a racionalidade do sistema produtivo deu às regras de direito trabalhista em geral, e em particular no que se refere às mulheres, uma quase ineficácia. Na realidade, a lei criada com o intuito de compatibilizar a função primordial da mulher - o cuidado com a família-com uma função produtiva na esfera do mercado mostrou-se, nesse sentido, inoperante. As regras do direito do trabalho perdem a sua coerência com os demais Códigos no que diz respeito à família, sem, contudo, perder sua eficácia ideológica no que concerne à visão de fragilidade feminina e à função primordial da mulher. $\mathrm{O}$ trabalho feminino externo à casa, na década de 40 , era visto, para as mulheres de elite, como um desvirtuamento das 'habilidades domésticas e naturais femininas'; para integrantes das classes populares, como instrumento 'moralizante', em contraposição aos cortiços, conforme as palavras de um empresário do início do século ${ }^{3}$. Nesse contexto, a renda feminina continuava a ser representada pela sociedade como 'complementar'. Por este motivo, as mulheres trabalhadores não mereceriam salários maiores, apesar da crescente necessidade dessa 'ajuda' nos orçamentos familiares. Continuava imperando para ricas e pobres a ideologia do homem "provedor" e da mulher "colaboradora" e esteio moral da família, mesmo que na vivência das famílias das classes populares esses papéis de gênero não se configurassem.

Também a partir da década de 40, algumas modificações podem ser observadas na legislação, mas a ideologia sobre as relações de gênero não sofre alterações. A legislação civil passou gradativamente a não discriminar direitos de filhos nascidos dentro ou fora do casamento e, ao longo das duas décadas seguintes, decisões de tribunais e leis complementares possibilitaram que seus benefícios fossem estendidos para mulheres que viviam maritalmente sem que tivessem contraído casamento perante autoridade judiciária. Nesse sentido, foi cunhada a expressão "direitos da companheira", em oposição à anterior estigmatização da "concubina teúda e manteúda".

\footnotetext{
3 Ver a respeito depoimento de Jorge Street (PINHEIRO \& HALL, 1981). Esses autores reuniram importantes documentos históricos do período de 1889 a 1930, sobre as condições de vida e trabalho da classe operária brasileira.
} 
Familia, Sexualidade e Reprodução...

\section{Lei, familia e reprodução: 1977-1997}

Nesses últimos vinte anos, em que pese ainda a força da ideologia que orientou os códigos Civil e Penal, uma série de mudanças legislativas possibilitou alterações importantes na conformação da família e nos padrões de sexualidade e reprodução, timidamente ensaiadas com o Estatuto Civil da Mulher Casada, de 1962.

Na década de 70, a adoção do divórcio, pela Lei 6.515, de 1977, alterou, em muito, dispositivos do Código Civil, apesar da forte oposição da Igreja Católica. Deve-se ressaltar que a lei só foi aprovada pelo fato de a votação ter sido por voto secreto. Introduziu-se, por exemplo, no que concerne à guarda dos filhos, a perspectiva de privilegiar o interesse dos filhos menores, em detrimento dos interesses pessoais de pai e mãe. Apesar disso, na aplicação da lei, o Poder Judiciário manteve, muitas vezes, uma visão moralizante assimétrica no que concerne à avaliação dos comportamentos dos ex-cônjuges, exercendo uma pressão maior sobre as mulheres. Nessa década, o aumento da inserção das mulheres no mercado de trabalho em muito ajudou à mudança de percepção da mulher como mera colaboradora. Isso ocasionou a desobrigação legal do homem em continuar sempre como provedor da mulher. O intenso processo de urbanização, a introdução de contraceptivos desde a década de 60 - que dissociaram reprodução e sexualidade-, a influência das mensagens do movimento feminista, a importância das mensagens da mídia, dentre outros fatores, alteraram fortemente os padrões de moralidade sexual. Divorciados, os cônjuges ficavam como se solteiros fossem, podendo contrair ou não novas núpcias. No entanto, nos processos judiciais de separação ou divórcio, muitos juízes esperavam que as mulheres exercessem sua sexualidade com 'recato' e discrição para que mantivessem a guarda dos filhos (Pimentel, Giongi \& Piovesan, 1993).

A partir da década de 70, em particular na década de 80, com a redemocratrização do País, as temáticas da sexualidade e da reprodução passaram a ser discutidas com muita regularidade no Congresso Nacional, envolvendo questões como controle da natalidade, políticas populacionais, planejamento familiar, assistência à saúde materna, aborto $^{4}$ e esterilização e, mais recentemente, novas tecnologias reprodutivas.

AConstituição Federal de 1988 incorporou muitas das demandas do movimento de mulheres. No que se refere à família, reconheceu a igualdade entre os cônjuges e as novas modalidades de instituição familiar (como a formada pela união estável entre homem e mulher e pela comunidade formada por qualquer dos pais e seus descendentes) e se comprometeu à criação de mecanismos para "coibir a violência no âmbito de suas relações". Quanto ao status dos filhos, a Constituição reconheceu que os filhos "havidos ou não da relação do casamento", inclusive os adotivos, terão os mesmos direitos e qualificações e proibiu qualquer designação discriminatória relativas à filiação.

${ }^{4}$ Sobre os diversos projetos de legalização do aborto nas décadas de 70 e 80, ver BARSTEd, 1992. 
No campo da reprodução, o artigo $226, \S 7^{\circ}$ da Constituição Federal declara que "fundado nos princípios da dignidade da pessoa humana e da paternidade responsável, o planejamento familiar é livre decisão do casal, competindo ao Estado propiciar recursos educacionais e científicos para o exercício desses direitos, vedada qualquer forma coercitiva por parte de instituições oficiais ou privadas".

De certa forma, as normas constitucionais e o debate sobre as questões relativas a família, sexualidade e reprodução significam posições e pressões diferenciadas sobre o Estado, expressas por distintos atores sociais e com diferentes argumentos. Os avanços nesse campo refletem as pressões do movimento feminista e a forma como essas questões têm sido colocadas nos países hegemônicos ocidentais e nas orientações das diversas conferências internacionais em que esses temas têm sido discutidos. Um olhar comparativo poderia nos apontar para o adiantado de nossa legislação em relação a esses temas: antes da Conferência do Cairo, em 1994, e de Beijing, em 1995, a legislação brasileira reconhecia a igualdade entre homens e mulheres, incorporava a perspectiva de saúde no sentido de sua integralidade, inclusive no que se refere especificamente às mulheres ${ }^{5}$, reconhecia direitos reprodutivos, exceto no que se refere ao aborto, e novas formas de família.

O debate sobre família, sexualidade e reprodução incluiu ainda, além do contínuo posicionamento das feministas, as pressões de inúmeros outros atores, como as agências pró-controle da natalidade, os militares, os religiosos, os médicos e demais profissionais da saúde, juristas, acadêmicos e mídia, dentre outros.

Esses temas amplamente debatidos ao longo das duas últimas décadas nem sempre se atualizam nas decisões do Poder Judiciário e na produção jurisprudencial. O reconhecimento de direitos advindos da união estável, a partir de leis recentes da década de 90, ainda encontra decisões discordantes quando do tratamento de casos concretos pelo Poder Judiciário. Da mesma forma, a regulamentação dos direitos reprodutivos, a partir do $\S 7^{\circ}$ do artigo 226 , também constituiu-se em processo demoradoe tumultuado. Depois de seis anos de tramitação no Congresso Nacional, o Projeto de Lei que regulamentava esse parágrafo do artigo 226 da Constituição foi finalmente aprovado com o texto da Lei 6.293/95. No entanto, submetida à apreciação presidencial para ser sancionada, surpreendentemente teve vários artigos vetados. Essa lei, apesar de incorreções (fruto das negociações necessárias para sua tramitação no Congresso) incorporou propostas do movimento de mulheres. Esse movimento, após o veto presidencial, caracterizado como um "descuido" pelo governo, teve de manter ativa sua mobilização para conseguir, após mais de um ano, que o Congresso rejeitasse o veto e considerasse aprovado o texto integral da lei.

\footnotetext{
s Deve-se mencionar que o texto original do Programa de Assistência Integral à Saúde da Mulher (PaISM) ć de 1983.
} 
Também na área dos direitos reprodutivos e sexualidade, os projetos de lei sobre a descriminalização do aborto, ampliação de seus permissivos ou regulamentação do exercício do direito ao abortamento legal previsto no Código Penal encontram uma enorme dificuldade de caminhar para debate e aprovação-por força, particularmente, da ainda importante pressão da Igreja Católica sobre o Estado brasileiro no que se refere à sexualidade e à reprodução. A partir da intensificação das novas tecnologias reprodutivas e dos recursos de medicina fetal inicia-se o debate sobre a oportunidade ou não de regulamentação dessa área. Até o momento, a única regulamentação existente ć a que proíbe o recurso à chamada 'barriga de aluguel'.

A entrada das DST/ArDs no debate sobre saúde permitiu que a sexualidade passasse a ser discutida de forma mais explícita em toda a sociedade e obrigou que o repensar sobre reprodução não se esgotasse no direito de ter ou não filhos. Portarias ministeriais, especialmente do Ministério da Saúde, foram elaboradas para incluir o condom como preservativo indispensável não apenas dentro da lógica da anticoncepção mas, particularmente, na prevenção da AIDs. Outras áreas legislativas - que tradicionalmente não tratavam da temática - passaram a fazê-lo. Destacam-se a legislação relativa a segurosaúde, seguro de vida, legislação previdenciária e trabalhista e as obrigações de responsabilidade civil por contaminação via transfusão de sangue, dentre outras.

Ainda no âmbito da sexualidade fora dos padrões tradicionais previstos pelo Código Civil, referência deve ser feita à apresentação, e posterior retirada de pauta, de projeto de lei para o reconhecimento da união civil entre pessoas do mesmo sexo, tema que motivou acalorados, e nem sempre adequados, debates entre os legisladores.

AConstituição revogou todos os dispositivos docapítulo relativo à família que implicam na assimetria entre os cônjuges. No entanto, estão em vigor outros dispositivos da parte geral ou da parte relativa à sucessão que exprimem, ainda, discriminações de gênero.

Apesar das alterações sofridas em sua parte geral em 1984, o Código Penal ainda mantém intactos na sua parte especial (que define os crimes e as penas) dispositivos que apresentam discriminações de gênero no que se refere à moral sexual. Essas discriminações têm grande incidência nas decisões judiciais, em particular do Júri Popular, nos chamados 'crimes passionais', em que as mulheres e homens ainda são avaliadas e julgados com base nos estereótipos de gênero, fundamentados em uma moral sexual anterior à proclamação da República.

\section{Consideraçōes finais}

A partir da Constituição de 1988, pode-se afirmar que consolidou-se no direito brasileiro uma nova perspectiva sobre família, sexualidade e reprodução, apesar das incompletudes, limitações e restrições legais. Ainda seria precoce dizer que a mudança 
legislativa sobre tais temas tenha impactado todo o aparato do Poder Judiciário e que as decisões tomadas nessa instância não sejam mais influenciadas pela matriz ideológica do Código Civil. Há, claramente, uma tendência da legislação em reconhecer a igualdade e a eqüidade entre homens e mulheres e a incorporar, de forma mais rápida ou mais lenta, dispositivos menos preconceituosos no campo da sexualidade e da reprodução. A rapidez desses processos muito tem a ver com as transformações de ordem macroestrutural da sociedade e com o desempenho e poder dos diferentes atores sociais que têm influenciado a produção legislativa e jurisprudencial.

No debate sobre família, sexualidade e reprodução, o movimento feminista tem apresentando importantes contribuições aos parlamentares e influenciado nos avanços legislativos, destacando-se as preocupações com a defesa de direitos sociais, coletivos e individuais de homens e mulheres. Encontra-se incluído nessa preocupação, particularmente, o direito à saúde (inclusive à saúde reprodutiva) - particularmente das mulheres pobres, que no caso do aborto, por exemplo, não podem recorrer às clínicas particulares de boa qualidade, utilizadas, apesar de ilegais, por mulheres dos setores de média e alta renda. O discurso feminista apresenta-se, dessa forma, compatibilizando o ideal individual de liberdade com princípios de ordem social.

Nesse debate, a Igreja Católica joga em um papel de opositor importante às propostas feministas. Para a Igreja, o que está em jogo nesse debate não é a defesa dos direitos individuais ou sociais, mas a defesa do dogma que reforça a idéia de um padrão único de família e de uma sexualidade limitada ao exercício da reprodução. A reprodução, por sua vez, deve se dar, preferencialmente, no âmbito das relações conjugais. Em nome desses dogmas, a Igreja rejeita o aborto, por considerá-lo um crime contra a vida (posição reforçada pelo Código Penal).

Outro ator que tem contribuído e influenciado esse debate, especialmente a partir do início da década de 90 , é o setor médico. Na área da reprodução, o Conselho Federal de Medicina (CFM) e alguns conselhos regionais e associações médicas têm apresentado propostas de ampliação dos permissivos legais para a realização do abortamento no caso de comprovada anomalia fetal grave. O argumento apresentado pelo CFM pode ser visto sob dois ângulos. Como a defesa de um direito individual e social da mulher ou do casal de desejarem prole sadia; e a defesa do avanço científico e da atuação de profissionais e clínicas quejá realizam esses abortos sem considerarem a prática uma transgressão à ética médica. Ou seja, já existe no Brasil avançada tecnologia de deteç̧ão de anomalias fetais que fica lançada ao campo da ilegalidade com a atual legislação sobre o aborto. Dessa forma, as corporações médicas não necessariamente se juntam às feministas na defesa da legalização mais ampla do aborto, mas limitam-se à defesa do chamado 'aborto piedoso' como aplicação do conhecimento científico aceito comoético por grande parte da comunidade médica e do aborto para preservara saúde da mulher, tendência incorporada pela Comissão instituída peloPoder Executivo para elaboraro texto do anteprojeto de Reforma do Código Penal. 
Essas diferentes posições e impasses que surgem no debate sobre família, sexualidade e reprodução são fundamentais na definição dos rumos que a legislação brasileira vai tomar. Voltando ao nosso ponto inicial, esse debate aponta para a dificuldade de articulação entre a defesa de direitos individuais e coletivos em uma sociedade marcada por enormes discriminações sociais, sexuais e raciais. E revela uma tendência autoritária da sociedade e do Estado brasileiros em tentar resolver com a lei penal as questões sociais ou os supostos desvios de conduta socialmente desejáveis.

Na realidade, no Brasil, a articulação entre os direitos individuais e os direitos coletivos tem se dado mais como uma oposição do que como uma complementariedade. Há uma forte tendência histórica dos mais diversos setores da sociedade de considerarem as demandas por direitos individuais como uma demanda do liberalismo burguês. É nesse ponto que a luta do movimento feminista em torno do slogan "nosso corpo nos pertence" foi considerada, por alguns setores progressistas, como pouca oportuna ou, usando uma terminologia contemporânea, como "politicamente incorreta", diante das temáticas consideradas sociais.

Dessa forma, longe de se complementarem como pilares básicos da democracia, direitos individuais e direitos coletivos foram se tornando quase conceitos antagônicos para os setores progressistas preocupados com o caráter excludente do Estado brasileiro em relação às grandes massas empobrecidas da população.

Analisar a contradição entre liberdade e repressão, que tem caracterizado o debate sobre família, sexualidade e reprodução no País, implica, também, aprofundar a compreensão dos impasses da questão democrática em uma cultura marcada por forte tendência autoritária e hierarquizante. Progressistas ou conservadores, os indivíduos e os grupos que debatem os temas da família, da sexualidade e da reprodução estão permeados pelas ambigüidades entre o tradicional e o moderno. Consensos e dissensos, na realidade, expressam as composições resultantes da convivência de referências culturais distintas.

\section{Referências Bibliográficas}

ARies, P. História Social da Criança e da Familia. Rio de Janeiro: Zahar Editores, 1978.

BARSTED, L. L. Permanência ou mudança: a legislação sobre família no Brasil In: RBBERO, I. (org.) Sociedade Brasileira Contemporânea: familia e valores. Rio de Janeiro: Loyola/CentroJoãoXXIII, 1987.

BARSTED, L. L. Legalização e descriminalização do aborto no Brasil: 10 anos de luta feminista. Revista Estudos Feministas, O(0):397, 1992.

Códico Civi e Legislação em Vigor. Organização, seleção e notas de Theotonio Negrão, com a colaboração de José Roberto Ferreira Gouvêa. $17^{\mathrm{a}}$ ed. atualizado até 5 jan. 1998. São Paulo: Saraiva, 1998. 
Código Penal. Obra coletiva de autoria da Editora Saraiva, com colaboração de Antonio Luiz Toledo Pinto e Márcia Cristina Vaz dos Santos Windt. 36 ed. São Paulo: Saraiva, 1998.

Doxzelot, J. A. A Policia das Famílias. Rio de Janeiro: Graal Editores, 1979.

DuARTE, L. F. D. et al. Vicissitudes e limites da conversão à cidadania nas classes populares brasilciras. Revista Brasileira de Ciências Sociais (22):5, 1993.

Dumont, L. O Individualismo: uma perspectiva antropológica da ideologia modema. Rio de Janeiro: Rocco, 1985.

HERMAN, J. \& BARSTED, L.L. OJudiciário e a Violência Contra a Muther: a ordem legal e a (des)ordem familiar. Rio de Janeiro: CEPIA, 1995.

Pimentel, S.; Giorgi, B. \& Piovesan, F. A Figura/Personagem Mulherem Processosde Família. São Paulo: S. A. Fabris Editor, 1993.

PINHEIRO, P. S. \& HALL, M. A Classe Operária: condições de vida e de trabalho, relações com os empresários e o Estado. São Paulo: Brasiliense, 1981.SANTOS, W. G. dos. Cidadania e Justiça: a política social na ordem brasileira. Rio de Janciro: Ed. Campus, 1979.

SANTOS, W. G. dos. Cidadania e Justiça: a politica social na ordem brasileira. Rio de Janeiro: Ed. Campus, 1979. 


\section{A Medicalização do Corpo Feminino}

Elisabeth Meloni Vieira

A tese da medicalização da sociedade ocidental tem sido discutida por vários autores desde a década de 70. Illich (1975) foi provavelmente o mais famoso destes autores. Medi-calizar significa o processo de transformar aspectos da vida cotidiana em objetos da medicina de forma a assegurar conformidade às normas sociais (Miles, 1991).

Para tratar a condição do corpo feminino na medicina temos de resgatar sua dimensão social, ou seja, a articulação que se estabelece entre condição orgânica feminina e condição social de gênero. A medicalização desse corpo particulariza-se nas implicações específicas da reprodução humana, relacionada por assim dizer à sua condição orgânica. Essa afirmação significa, sobretudo, a maneira específica pela qual o corpo feminino vem sendo tratado pela medicina a partir do momento em que se transforma em seu objeto de saber e prática.

Foucault (1982) analisa a natureza política da medicina na sociedade capitalista como uma estratégia de controle social que começa com o controle do corpo. Discutindo a temática da sexualidade que emerge como um objeto político nas sociedades ocidentais no século XVII, ele questiona se o controle da sexualidade e reprodução não teria implicações sociais para assegurar o controle populacional; reproduzir a força de trabalho; reproduzir os modos que as relações sociais são estabelecidas, de forma a garantir que se tenha uma sexualidade socialmente útil e politicamente conservadora (Foucault, 1980a). É neste contexto que olhamos para a medicalização do corpo feminino, 
entendendo-a como um dispositivo social que relaciona questões políticas - como o controle populacional - aos cuidados individuais do corpo da mulher, normalizando, regulando c administrando os aspectos da vida rclacionados à reprodução humana.

\section{A natureza feminina}

O processo histórico de medicalização do corpo feminino passa, necessariamente, pela idéia de que existe uma natureza biológica determinante e dominante da condiç̧ão feminina. É justamente por meio dessa concepção que a medicina poderá sc apropriar do corpo das mulheres.

A idéia de natureza feminina bascia-sc cm fatos biológicos que ocorrem no corpo da mulher-a capacidade de gestar, parir c amamentar. Na medida em que essa determinação biológica parece justificar plenamente as questões sociais que envolvem este corpo ć que ela passa a ser dominantc, como explicação legítima c única sobre estes fenômenos. Daí decorrem idéias sobre a maternidade, instinto matcrnal e divisão scxual do trabatho como atributos "naturais c essenciais" à divisão de gênero na sociedade.

A natureza feminina faz parte do conjunto de concep̧̧ões pelas quais a identidade de gêncro c suas implicações são construídas na socicdade c na cultura. Para De Romani (1982), tratar a identidade de gênero de mancira a-histórica e atemporal tem como finalidade rcafirmar o fixo, o imutável, o cterno, o natural desta condição, estabclecendo um discurso que desloca a assimctria sexual do plano das relações concretas para o plano da natureza. Scgundo a autora, a cficiência dessa idcologia consiste na introjeção desse caráter supostamente essencialista, a partir do qual são construídas verdades absolutas (porque 'naturais'), de forma que não scria possível ultrapassar a condição natural de sexo.

Segundo Bonder (1984), a crença naturalista cstabelecc uma relação de causalidade lógica entre o potencial biológico da mulher de gerar filhos e o cuidado e criação das crianças como atividade feminina. $\Lambda$ mística maternal estabelece o potencial para a maternidade como fato fundamental para a constituição da feminilidade c identidade da mulher. A maternidade, ou mclhor, a 'natureza maternal', seria, então, um fator nuclear do qual decorreria uma série de atributos de personalidade c conduta da mulher que lhe scriam 'naturais', negando-se persistentemente as intermediações da cultura nestc âmbito. As concep̧̧̃es que sc constroem sobre a natureza feminina impõem, para o saber mćdico, esforços considerávcis para desenvolvero conhecimento sobre as especificidades biológicas da condição feminina, como pressuposto do movimento maior de transformação social que ocorreu a partir do sćculo XVIII, mudando a relação da prática médica com o corpo feminino. 


\section{O nascimento da obstetrícia}

A produção de idéias médicas sobre o corpo feminino não se fez de forma teórica e isolada da tomada deste corpo como objeto da prática médica. Por quase três séculos, os médicos se prepararam para ocupar o lugar das parteiras e efetivamente transformaro parto em um evento médico. A medicalização do corpo feminino se estabelece no século XIX, em meio aos discursos de exaltação da maternidade. No entanto, esse processo teve início trezentos anos antes da institucionalização do parto como evento hospitalar e do estabelecimento da obstetrícia como disciplina médica.

Embora a antigüidade grega clássica já tivesse registrado algum interesse médico nessa área, ele se manteve sepultado durante séculos, atéo Renascimento (Mello, 1983). Por um longo período, partejar foi uma tradição exclusiva de mulheres. A partir do século XVI, essa tradição começa a sofrer regulamentações, governamentais ou da igreja, submetendo as parteiras das cidades européias a exames prestados diante de comissões municipais ou eclesiásticas. O ponto fundamental dessa regulação relaciona-se à garantia do estado emergente e da igreja de que não seriam realizados abortos e infanticídios. Exigia-se da parteira examinada pelas comissões a profissão da fé cristã, o saber batizar o recém-nato moribundo, e moral e reputação ilibadas. Essas regulamentações coincidiram com o processo de perseguição das feiticeiras - entre elas, muitas parteiras (Mello, 1983).

Vários autores afirmam que neste processo houve a execução de milhares de pessoas na Europa Ocidental - de 70 a 90\%, mulheres -, principalmente entre 1563 e 1727 (Turner, 1987). Para Ehrenreich \& English (1976), a caça às bruxas e a extinção das curandeiras e parteiras fazem parte da história de exclusão das mulheres da prática médica como estratégia do Estado e da Igreja para monopolizar o saber acerca da cura das doenças, e legitimá-lo por meio das universidades criadas no Renascimento. Ao tornar-se uma profissão alicençada pela autoridade da linguagem técnica e educação universitária, a medicina transformou-se em atividade reservada aos homens, já que nesta época apenas eles poderiam ter acesso à educação. A situação das parteiras e curandeiras ameaçava o monopólio deste saber. Embora o caça às bruxas não tenha acabado com parteiras e curandeiras, conseguiu transformar sua prática em atividades suspeitas.

A regulamentação da prática de partejar exigia que as parteiras chamassem cirurgiões para assisti-las. Esses profissionais controlavam o uso do fórceps, mas a sua falta de prática e de conhecimento gerava situações contraditórias. Até 1750, as parteiras representavam o melhor em termos de conhecimento e práticas até então existentes (Shorter, 1982). Somente no século XVIII os estudantes de medicina passam a freqüentar as maternidades européias. 
A competição entre médicos e parteiras estendeu-se durante séculos. Os textos médicos instruindo parteiras caracterizavam-se pela sátira e condenação à sua ignorância. Elas também publicaram suas experiências e enfrentaram contendas com médicos (Mello, 1983). Embora muitas parteiras tenham ficado famosas - e eram, com certeza, muito competentes - não chegaram a formar nenhuma corporação profissional, como se entende hoje. Durante o século XVIl, as parteiras tentaram várias vezes juntar-se ao Colégio do Físicos, sem obter sucesso. Sem acesso ao conhecimento, às universidades - subordinadas aos cirurgiões e físicos -, elas foram aos poucos tendo usurpada sua hegemonia da prática obstétrica (Mello, 1983). Com o advento do capitalismo industrial, a prática médica se consolidou como exercício monopolizado dos médicos e, assim, legitimado e reconhecido. Na segunda metade do século XVIII, já havia se tornado prática ter um médico assistindo ao parto na Inglaterra. Na competição do mercado, que viria então a se instalar, a prática das parteiras foi, progressivamente, colocada na marginalidade (Mello, 1983).

O desenvolvimento da obstetrícia como conhecimento médico foi uma tarefa árdua para médicos e mulheres, já que houve muitos conflitos e dificuldades. A etimologia da palavra 'obstetrícia' - originada do latim obstetricum, significa "estar diante de" (obs); "mórbido, tétrico" (tetricum) - expressa, em si mesma, um dos aspectos que a apropriação dessa área do saber trouxe para os médicos da época, diante de situações que tecnicamente não dominavam. Até o século XVIII, o parto foi vivido como um perigo de morte real, sendo a mortalidade materna bastante elevada na Europa Ocidental.

A medicina necessitou de todo o século XIX para desenvolver técnicas cirúrgicas, anestésicos e o uso da assepsia para efetivamente dominar esta prática. O processo de hospitalização do parto foi fundamental para apropriação do saber nesta área e para o desenvolvimento do ensino médico. Segundo Foucault (1980b), foi a partir do século XVIII que as instituições hospitalares incorporaram características diferentes daquelas que até então faziam delas um abrigo para pobres, doentes e desvalidos.

Até 1880, as salas cirúrgicas não tinham assepsia. A bacteriologia foi fundamendal para o desenvolvimento do hospital moderno e as medidas higiênicas adotadas tiveram sucesso no combate à infecção puerperal. Em conseqüência dessa prática, o índice de mortalidade diminuiu, contribuindo para a aceitação dos hospitais pela sociedade (Rosen, 1980). Além disso, a utilização de anestésicos contribuiu para o desenvolvimento das técnicas cirúrgicas obstétricas, que até então apresentavam alta mortalidade. Segundo Shorter (1982), no século passado a palavra 'cesariana' era sinônimo de sentença de morte.

A medicalização intensa que sofre o corpo feminino no século XIX, quando aliada ao discurso de exaltação da maternidade, compõe um processo que, segundo alguns autores, teria mudado substancialmente a valorização da vida feminina na sociedade 
ocidental, na medida cm que permitiu o desenvolvimento de técnicas que aumentaram a sobrevida materna. Até então, o parto tcria sido vivido como um cvento em que o medo da mortc ou a tortura do fórceps não cra apenas um mito (Shorter, 1982).

No Brasil, a assistência ao parto, até o século XIX, é desenvolvida por parteiras, também conhecidas por aparadciras ou comadres, já que era comum torná-las madrinhas dos filhos por elas partcjados. Debret, em 1839, afirmou que mesmo no século XIX muito poucas parturientes ricas e nobres do Rio de Janeiro procuravam a assistência de um médico, c ainda assim, "por ostentação ou em casos difíceis" (Santos Filho, 1947).

Em 1809, ano scguinte à formação dos cursos médicos, as artes obstétricas começam a ser ministradas na Escola do Rio de Janciro como conhecimcnto pertinente à cadeira de cirurgia. Em Salvador, entretanto, a disciplina passou a ser ministrada apenas em 1819 (Mott, 1988). Ressalta-se que o estudo das artes obstétricas permaneceu por décadas como um estudo tcórico, cm que sc utilizavam bonccos para simulação de situações práticas.

Em 1832, as academias mćdico-cirúrgicas foram transformadas em faculdades de medicina c iniciaram-se cursos de parteiras para mulheres, com duração de dois anos (Mott, 1988). Apesar dessa reforma, as aulas continuavam precárias, e os cursos, rudimentares. Até o final do século XIX, muitos médicos formavam-se sem jamais terem visto um parto ou procedido a um exame obstétrico: o parto continuou sendo atributo de parteiras diplomadas ou práticas. O ensino prático da obstctrícia encontrou várias dificuldades além da falta de recursos e investimentos nas escolas médicas. Entre elas, o aspecto competitivo da prática liberal c a resistência das mulheres em usar hospitaise enfrentar o olhar masculino. Luis Álvares dos Santos, memorialista da Faculdade de Medicina da Bahia, afirma que as mulheres da época preferiam morrer de moléstias do útero a screm curadas por médicos (Mott, 1988). As irmãs de caridade que atendiam às parturientes cram proibidas, por regra, de olharem as partes pudendas, e o trabalho de parto sc fazia às escuras.

O ensino prático da disciplina demorou muito a ser implantado nas escolas médicas. Data de 1911 o cstágio na cnfermaria de obstetrícia para estudantes da Faculdade de Medicina do Rio de Janciro, apesar de o socorro obstétrico hospitalar ter sido instituído em 1830 (Magalhães, 1922). O discurso médico da mctade do século XIX relativo à obstetrícia caracteriza-se pela defesa da hospitalização do parto e da criação de maternidades e ainda coloca em dúvida a compctência das parteiras. Tal fato leva à defesa do cnsino médico e à necessidade de domínio da obstetrícia diante da resistência das mulheres em utilizar os hospitais. Essa resistência fundamentava-sc na tradição dos hospitais de serem abrigos para pobres, na moralidade da ćpoca e nos perigos das artes obstétricas rudimentares de então.

As primeiras enfermarias obstćtricas nos hospitais do Rio de Janeiro eram locais que fundamentalmente serviam para abrigar mulheres sem condições de parir no domicílio, seguindo a tradição dos hospitais de abrigos aos pobres. Entretanto, mesmo antes 
da fundaçãoda primeira matemidade pública no Riode Janeiro, tem-se notícia de casas de saúde e pequenas maternidades particulares, montadas para atender à clínica privada, principalmente à escravatura, já que os senhores cuidavam das escravas parturientes, garantindo o capital representado por elas e seus filhos (Magalhães, 1922).

Além das dificuldades técnicas e da moralidade vigente à época, o desenvolvimento da obstetrícia viveu conflitos na sua institucionalização como disciplina médica-entre eles, a noção de que a prática obstétrica seria uma prática menor dentro da própria medicina. Esse conflito estava provavelmente relacionado, entre outras razões, ao fato de o partejar ter sido até então uma prática de mulheres. Paradoxalmente, por esse motivo, e no afã de controlar tal prática, os médicos eram contundentes em relação às parteiras, atacando-as em seus discursos e submetendo-se às suas regulamentações, transformando-as de usurpadas em usurpadoras. Azevedo (1847:1) exemplifica bem esta atitude:

E o que diremos d'essas mulheres, que envoltas em negras e nojentas mantilhas, percorrem as ruas dessa populosa cidade, inculcando-se por desgraça nossa hábeis parteiras, tendo estampado na frente de suas casas o sagrado símbolo da redenção, a cruz, fazendo capacitar a muitos do povo crédulo, que possuem segredos transmitidos pela Providência capazes de tornar fácil o parto mais laborioso, quantas vezes essas verdadeiras mercenárias the não querem impor leis?

Até o final do século XIX, ainda se discutia nas Academias a quem competia a responsabilidade de cuidar dos partos. O Real Colégio do Médicos de Londres chegou a declarar oficialmente, nessa época, que cuidar de partos não era mister digno de um médico ou cirurgião - que deveriam restringir-se aos partos difíceis e perigosos, a aplicar o fórceps e executar cesarianas (Santos Filho, 1947). Havia indignidade, quem sabe até desonra, em assumir um trabalho que por tradição era considerado feminino.

Fernandes (1924:81) comenta que, pela obstetrícia ser considerada uma especialidade 'menor', para ela se dirigiam os incompetentes, e que, por isso, o mau desenvolvimento da prática provocava desastres: "Se se iniciassem um dia os processos por crime de fórceps, de pituitrina e de cureta, não sei quantos presídios seriam necessários".

A pouca valorização da obstetrícia dentro da própria medicina relaciona-se à misoginia que Knibiehler \& Fouquet (1983:257) identificam nas origens da medicina modema. De acordo com elas, o esteriótipo da mulher médica exige sua masculinização: "A perda da feminilidade seria o castigo reservado às audaciosas culpadas de se imiscuir numa arte reservada aos homens".

O que certamente foi o caso de madame Durocher, uma das mais famosas parteiras estrangeiras no Rio de Janeiro, que chegou ao Brasil em 1816 e diplomou-se no Curso de Obstetrícia da Faculdade de Medicina em 1834. Segundo Santos Filho (1947:201): "Ela exerceu sua profissão no Rio, mercê de seu tipo masculinizado, de sua vestimenta e de seus hábitos (andava sozinha por toda a cidade a qualquer hora do dia ou da noite) ganhou a alcunha de mulher-homem". 
Dela, se dizia: "Madame Durocher era um tipo bizarro de criatura insexuada que usava gravata, cartola e barbicha" (Santos Filho, 1947).

Apesar dos conflitos internos no meio médico e das resistência das mulheres, 0 parto transformou-se em ato médico. As mulheres puderam voltar a partejar, agora como novo status de médicas. Oacesso das mulheres ao ensino médico no Brasil ocorre em 1889. O saber que havia sido expropriado das parteiras resguarda-se, agora, na legitimidade de uma ciência e de sua suposta neutralidade, que por meio do poder médico poderá exercer o controle social sobre o gênero feminino, em que pese o fato de ser essa profissão, e em particular essa especialidade, eminentemente masculina em nossa sociedade.

\section{A assistência médica à mulher}

Se a medicalização estende-se, ampliando a jurisdição da prática médica, incorporando novas teses ao campo de normatividade da medicina desde o século XIX, também se amplia a assistência médica, através de serviços que florescerão no século XX.

Parece claro que essas duas dimensões da medicina são interconexas: em se ampliando o campo de sua competência, produzem-se progressivas pressões por ampliação correlata do acesso e do consumo dos serviços de prática médica; e o consumo ampliado da assistência médica possibilitará que a medicina tenha seu monopólio validado e os limites daquela competência serão continuadamente expandidos. Por isso, ao estabelecer o monopólio de sua competência acerca do feminino, deve-se ainda tratar das repercussões que tal jurisdição trouxe no plano da produção e distribuição da assistência médica para as populações.

Por meio de um examè dessa natureza podem-se evidenciar também as questões e as características que o movimento de expansão da produção e distribuição da assistência médica introduz na relação medicina-feminino social, participando da medicalização deste.

Os serviços, que até o século XX realizavam-se pela medicina privada na forma liberal ou da filantropia, terão seu acesso ampliado, no reconhecimento da produção de serviços de assistência médica como demanda social. Isto se dá com o surgimento de uma 'medicina pública', que se produz pela interferência do Estado na organização social dessa para normalizar sua produção face ao conjunto da população. Essa 'medicina pública' expande-se com o desenvolvimento da assistência à saúde coletiva, que se traduz em práticas sanitárias e/ou serviços e programas específicos de assistência médica, no interior da saúde pública; e na criação de serviços, sobretudo do seguro social, que visam exclusivamente permitir o consumo de uma assistência individual no cuidado à saúde, como a prática da medicina liberal (Donnangelo \& Pereira, 1979).

Em relação ao corpo feminino, depois da consolidação dos seus cuidados como área do conhecimento e da prática médica, a partir do século XIX, a sociedade vive a expansão da assistência nessa área, apoiada inicialmente pelas teses da higiene social. 
A assistência ao parto e ao pré-natal achava-se institucionalizada e bastante difundida na Europa Ocidental no início do século XX. Na Inglaterra, em 1911, um movimento propiciou apoio financeiro do governo para que as autoridades locais instalassem clínicas pré-natais; em 1927, existiam 600 dessas clinicas em funcionamento (Gomez, 1988). Na França, Pinard liderou o movimento médico para o cuidado pré-natal, cujo modelo médico nasceu na maternidade Baudelocque. Foi ele também que imprimiu à puericultura prestígio e dinamismo, fundando o Instituto de Puericultura e impondo a disciplina do meio acadêmico (Knibiehler \& Fouquet, 1983).

A assistência pré-natal nasce associada à idéia de puericultura 'intra-útero' e ao conceito de saúde materno-infantil. Alguns autores referem-se à exaltação da matemidade no discurso médico da época e à difusão da assistência pré-natal e ao parto como relacionadas ao despovoamento da Europa Ocidental nas duas primeiras décadas do século XX (Knibiehler \& Fouquct, 1983). A medicalizaçãoda matemidade surge baseada no estereótipo da 'natureza feminina', em uma época em que ser mãe transforma-se de destino em dever patrótico. Mais tarde, o projeto de medicalização do corpo feminino será justificado pelas preocupações eugênicas com a formação da sociedade (Knibiehler \& Fouquet, 1983).

No Brasil, do ponto de vista do cuidado individual, a expansão dos serviços de saúde relaciona-se a criação e ordenação dos serviços médicos na sociedade, que se inicia na década de 30, como se refere Donnangelo (1975). As origens do processo histórico que cria no Brasil a Previdência Social estão relacionadas às necessidades de preservação e reatualização da força de trabalho, associada ao controle do fator trabalho nas relações entre produtividade do trabalhadore a formação do capital, mediada pelo Estado.

Do ponto de vista da saúde coletiva, a ampliação da assistência à saúdeem relação ao corpo feminino e seus problemas aconteceu a partirda expansão de serviços e programas operados pela rede de serviços da saúde pública e que visavam à saúde materno-infantil, mais tarde conceituada nos textos de políticas públicas de saúde como atenção ao binômio mãe-filho (Lima, 1989). A partir da década de 20, o grupo matemo-infantil seria alvo de ações sistematizadas por parte do Estado. A preocupação com este segmento emerge com a necessidade de controle da população trabalhadora, a partir da expansão cafeeira e do início da industrialização. Nesta época, inserem-se no cenário nacional a regulamentação da licença à gestante e à puérpera e a proibição do trabalho fabril para menores de 12 anos (Gomez, 1988).

\section{A medicalização da anticoncepção}

A concepção de maternidade permanece praticamente intocada desde o século XIX, já que a atenção médica se justifica apenas em função da capacidade reprodutiva da mulher. Até a década de 60 , a visão da atenção médica à mulher por parte das políticas públicas privilegia o ciclo gravídico puerperal, justificando-se pela mortalidade infantil. A partir de então, há o renascimento da teoria que explica as altas taxas de mortalidade 
ea baixa qualidade de vida pelo aumento populacional conseqüente aos altos índices de natalidade. Também nos anos 60 as agências internacionais começam a investir maciçamente no desenvolvimento da pesquisa de métodos anticoncepcionais, principalmente a partir da divulgação de estatísticas alarmantes relativas ao crescimento populacional no Terceiro Mundo. As idéias veiculadas pelo movimento de birth control, do final do século XIX, pelos neomalthusianos - durante longo tempo vistas como obscenas, mantendo-se alijadas da medicina - ressurgem agora nas pesquisas médicas nas universidades, respaldadas pelo interesse científico (Barroso \& Amado, 1988).

No Brasil, embora as políticas públicas de saúde continuem privilegiando o ciclo gravídico puerperal, nessa mesma época irão surgir as entidades que desenvolvem ações de planejamento familiar visando basicamente a anticoncepção (Senna, 1988). Vale ressaltar que é nos anos 60 que se inicia o progressivo decréscimo nas taxas de fecundidade da população brasileira, relacionadas à urbanização e à formação dos pólos industriais que alterarão significativamente o padrão familiar em relação ao número de filhos (Merrick \& Berquó, 1983).

A disseminação de idéias e práticas referentes ao desenvolvimento e à necessidade de tecnologia realizada pelas entidades de planejamento familiar e pelas escolas médicas foram fundamentais para consolidar e ampliar a medicalização no que se refere ao controle da reprodução. São idéias e práticas que, tomando o corpo feminino apenas do ponto de vista de sua capacidade reprodutiva, na dualidade de 'ser mãe/não ser mãe', e responsabilizando as mulheres exclusivamente pela prática contraceptiva, transformaram as expectativas femininas em relação à vida reprodutiva. Ou seja, a dor do parto deu lugar a um evento cirúrgico, e a possibilidade de procriar ao desejo da esterilização. Neste âmbito, observa-se o aumento progressivo das cesarianas no Brasil. Entre $1970 \mathrm{e}$ 1987, o índice subiu de 15\% para 31\% (Ratner, 1996). Em 1992, o percentual no Estado de São Paulo foi estimado em 53\% (Faúndes \& Cecatti, 1993). Embora não tenha atingido esta cifra, a Pesquisa Nacional sobre Demografia e Saúde (PNDS) revela o índice médio de 36,4\% de cesarianas para todo o Brasil (BEMFAM -DHS, 1996), o mais alto do mundo. Em 1986, 29\% das mulheres brasileiras em união sexual estavam esterilizadas (Oliveira \& Simões, 1988); em 1996, este índice cresceu para 40\% (BЕмғAM-DHS, 1996). Com exceção da região Nordeste, as cirurgias cesarianas têm sido o principal acesso para a maioria dos casos de esterilização.

O modelo médico para tratar dessa questão se constrói, também, por ser uma prática que soube captar e oferecer resposta aos anseios sociais que se definiram a partir da falta de alternativas para a resolução dos problemas da área.

A tecnologia médica expande as promessas iniciais da medicalização, comprometendo-se com a resolução de todos os problemas da saúde. Sua utilização ampliada, contudo, irá produzir um quadro contraditório na situação da assistência médica e a distribuição dos recursos: coloca a si própria como tecnologia eficaz e eficiente para 
todos, mas é incapaz de definir sob que limites essa promessa pode ser, de fato, cumprida. Toma-se a mortalidade materna como exemplo da contradição que se quer apresentar: além de ser considerada alta e subenumerada, o evento mais imediato relacionado a esta, o parto, apresenta-se extremamente medicalizado, se levados em conta os índices de cesarianas - provavelmente, contribuindo para sua ocorrência.

No caso da esterilização feminina, sua associação com cesarianas desnecessárias aumenta o risco de morbi-mortalidade materna devido a infecção puerperal, riscos cinúrgicos e anestésicos, embolismo pulmonare complicações nas gravidezes subseqüentes (Faúndes \& Cecatti, 1993). Volochko (1996) afirma que poderia haver uma redução de $28,5 \%$ na mortalidade materna, caso as cesarianas desnecessárias não fossem realizadas. Um estudo realizado na cidade de São Paulo, em 1988, mostrou que um terço da mortalidade materna porcausas obstétricas diretas decorria delas, realizadas com o objetivo da esterilização (Volochko, 1992).

Em outros termos, trata-se do fato de que, no processo de medicalização do feminino social (o que de resto cabe à medicalização em geral), não se dá a consciência das contradições inerentes à própria medicalização. No âmbito da reprodução humana criaram-se expectativas qualitativas e quantitativas que não são cumpridas nos mesmos termos, haja vista as insuficiências e limites da prática médica concreta. Além do mais, quando se elege a reprodução como o foco das questões femininas, opera-se na medicalização uma redução da problemática do feminino social ao problema da concepção, parto e contracepção. Deixa-se de se tratar e enfrentar, com igual atenção e de forma articulada com a própria reprodução, outros problemas referentes à condição feminina, que vão desde a sexualidade até a patologia do útero. Por exemplo: o diagnóstico precoce do câncer do aparelho reprodutor feminino, que aparece como terceira causa de morte para essa população, é insuficientemente realizado.

Observa-se, dessa forma, que o controle populacional, no Brasil, vem sendo realizado efetivamente no âmbito da prática médica pela medicalização do corpo feminino e pelo tipo específico de assistência médica produzida - que emerge não mais como um ponto de política demográfica, mas como problema para o qual são propostas resoluções cirúrgicas ou ginecológicas, reduzindo-o a questões técnicas veiculadas por um modelo médico. Isso possibilita que a sociedade organize seus contingentes populacionais lançando mão do predomínio técnico-científico para administrar a reprodução humana.

A medicalização do planejamento familiaré apenas um dos aspectos desse processo da vida reprodutiva da mulher. Esse fenômeno se expressa em termos de tecnologia, ao invés de humanização, educação e informação, substituindo um programa que deveria estar fornecendo escolhas e informações. Configura-se como uma estratégia da 'modernidade', expressando a idéia de que a tecnologia sempre oferece a melhor solução (em termos de alta eficácia e bem-estar), baseado em um modelo que não estabelece como prioridade a saúde e os direitos humanos. 
De um lado extremanente medicalizado. De outro, sem efetivo acesso universal aos cuidados médicos nas sociedades concretas. É assim que se apresenta o corpo feminino, produto de uma medicalização que privilegia a reprodução, ou sua negação. Esseéo prisma fundamental pelo qual o corpo feminino vem sendo tratado. Isso não significa que outros aspectos desse corpo não sejam passíveis de medicalização, de fato o são, como no caso da Medicina estética, que amplia cada vez mais sua competência. Como afirma Illich (1975:59):

Todas as idades são medicalizadas tal como sexo, quociente intelectual ou cor da pele. Desde que as mulheres do século XIX quiseram se afirmar, formou-se um grupo de ginecologistas: a própria feminilidade transformou-se em sintoma de uma necessidade médica tratada por universitários evidentemente do sexo masculino. Estar grávida, parir, aleitar são outras tantas condições medicalizáveis, como são a menopausa ou a presença de um útero que o especialista decide que é demais.

\section{Referências Bibliográficas}

AzEvEDO, C.F.S.X. Consideracões Gerais sobre Certas Dificuldades que o Médico Parteiro Pouco Experiente Encontra no Exercicio de seu Ministério, 1847, Tese inaugural. Rio de Janeiro: Faculdade de Medicina do Rio de Janeiro.

Barroso, C. \&Amado, T. A Ideologia da Pesquisa em Contracep̧ão. In: Semináro Nacional dos Direttos ReProdutivos, São Paulo: Fundação Carlos Chagas, 1988. (Mimeo).

Bonder, G.Allusãoda Naturalidadeda Matemidade. Cademos Edipuc, RiodeJaneiro, 1984 (Mimeo.) DE Romant, J.P. Mulher. Natureza e Sociedade, In: Luz, M. (Org.), O Lugar da Muther. estudos sobre a condição feminina na sociedade atual. Rio de Janeiro: Graal, 1982, p.59-71.

Donnancelo, M.C.F. \& Pereira, L. Saúdee Sociedade, São Paulo: Livraria Duas Cidades, 1979.

Donnanceeo, M.C.F. Medicina e Sociedade: o médico eseu mercado de trabalho. São Paulo: Pioneira, 1975.

EHRENRECH, B. \& ENGLSH, D. Witches, Midwives and Nurses: a history of women healers. Londres: Writers and Readers Publishers Cooperative, 1976.

FAÚNDES, A. \& CECCATT, J.G. Which Policy for Caesarian Sections in Brazil? An analysis of trends and consequences. Heallh Policy and Planning, 8 (1):33-42, 1993.

Fernandes, C.R. OProblema Pré-Natal, 1924. Tese inaugural. Rio de Janeiro: Faculdade de Medicina dó Rio de Janeiro.

Foucaurs, M. A História da Sexualidade I: a vontade de saber. Rio de Janeiro: Graal, 1980a.

FoucAult, M. O Nascimento da Clínica. 2ed. Rio de Janeiro: Forense-Universitária, $1980 \mathrm{~b}$.

Foucaurs, M. Microfisica do Poder. 3.ed. Rio de Janeiro: Graal, 1982. 
GomEs, F.Z.Mutheres e Criancas Primeiro: o caráter da intervenção do Estado no grupomaterno-infantil da Colônia ao Milagre Brasileiro, 1988. Dissertação de Mestrado. São Paulo: Faculdade de Saúde Pública, Universidade de São Paulo.

luich, l. A Expropriação da Saúde. Rio de Janeiro: Nova Fronteira, 1975.

KNIBIEHLER,Y. \& FouQuet, C. La Femmeet les Medecins. Paris: Hachette, 1983, p. 257.

LıMA, M.R. Atenção Pré-Natal: avaliação da proposta de alendimento de grupo, 1989. Dissertação de Mestrado. São Paulo: Faculdade de Medicina, Universidade de São Paulo.

MAGNLHÃES, F. A Obstetríia no Brasil, Rio de Janeiro: Leite Ribeiro, 1922.

Meuo, V.H. Evoluscão Histónica da Obstetrícia: a marginalidadesocial das parleiraseda mulher, 1983. Dissertaçãode Mestrado. Belo Horizonte: Faculdade de Medicina, Universidade Federal de Minas Gerais.

MERRCK, T \& BERQUO, E. The Determinants of Brazil's Recent Rapid Dedinein Fertility. Committeeon Population and Demography. Report n²3. Washington, DC: National Academy Press, 1983.

MILEs, A. The medical control of women In: MIIES, A. Women, Health and Medicine. Philadelphia: Open University Press, Milton Keynes, 1991.

Mort, M. L. B. OAborto Terapêticono Pensamento Médico Baiano (Séc.XIX), Departamento de História da Faculdade de Filosofia, Letras e Ciências Humanas da USP, 1988. (Mimeo).

OlNEIRA, L. A P. \& SIMŌes, C. C. DA S. As informaçōes sobre Fecundidade, Mortalidade e Anticoncep̧ãonas PNADs. In: SAWYER, D.O (Org.) PNADs em foco: anos 80. São Paulo: Abep, 1988, p.183-225.

RATnER, D. Cesária: bem de consumo? In: Reuniāo Anual DASBPC, 48ª 1996, PUC São Paulo.

Rosen, G. Da Polícia Médica à Medicina Social. Rio de Janeiro: Graal, 1980.

Santos FilHo, L. História da Medicina no Brasil. v. 2. São Paulo: Brasiliense, 1947.

SENNA, D.M. Contracepsão: percepsão e prática, 1988. Dissertação de Mestrado. São Paulo: Faculdade de Medicina, Universidade de São Paulo.

SHORTER, E. A History of Women's Body, London: Penguin, 1982.

Sociedade CmL de Bem-Estar Familar no Brasil (Bemfam)-DHS. Pesquisa Nacional sobre Demografiae Saúde 1996. Relatório Preliminar, Macro International, Inc., 1997.

TURNER, B. Medical Power and Social Knowledge. London: Sage, 1987.

Volochко, A. Mortalidade de Mulheres: mortalidade materma, SUS-4, 1988, 1992. Disscrtação de Mestrado. São Paulo: Faculdade de Saúde Pública, Universidade de São Paulo.

VolochKo, A. O Cenário Cultural do Nascimento e Parto em São Paulo. In: ReuniÃo ANUAL DA SBPC, 48 1996, PUC São Paulo. 


\section{5 \\ Corpo e Conhecimento na Saúde Sexual: uma visão sociológica}

W

Karen Giffin

\section{Introdução}

Pretendo, aqui, explorar relações entre o ressurgimento do feminismo nos anos 60 , a transformação do paradigma científico (a crise da razão) e a definição de direitos sexuais.

Capra identifica, nesta mudança de paradigma, uma transformação profunda de percepção nas sociedades ocidentais, apontando o feminismo como um movimento de "minorias criativas", entre outros que desafiam o velho paradigma (Capra, 1982:26). Enquanto ele explica o engajamento das mulheres no novo paradigma "holístico e ecológico" como função de valores advindos da sua antiga identificação com a natureza, discutirei suas atividades teóricas/conceituais, argumentando que o feminismo está re-inventando uma ciência não-binária ${ }^{1}$ como parte de uma ampla luta social pela resignificação. Mesmo com contestações internas, e em um processo não-linear ${ }^{2}$, está superando o binarismo com um novo paradigma de conhecimento que é relacional e dialético, e que reconhece diferenças sem ser relativista.

Excluídas das atividades científicas (a não ser como objeto da ciência binária), as mulheres, quando entraram neste campo, fundiram sujeito e objeto em busca explícita do autoconhecimento, objetivo até então ausente na epistemologia científica (Code, 1991).

\footnotetext{
'Marilyn Frye (1996) recupera o termo "dualismo", argumentando que "dualidades genuínas... são plurais e abertas, não representam uma totalização...".

2 Não estou argumentando que existe somente um feminismo, mas que as variadas vertentes compõem um campo de referência para todas, apesar das suas "crises de identidade" (termo usado por Alcoff, 1988). Na minha discussão, a ênfase é dada às idéias provenientes da linha de teoria feminista às vezes denominada standpoint.
} 
A sexualidade, um dos primeiros assuntos a serem interrogados neste processo é também um dos mais perigosos, dada sua importância nas relações homem/mulher mais íntimas, onde o 'outro' pode também ser visto como 'minha cara-metade'. Agora colocada na agenda feminista como direito, a definição da saúde sexual não tem avançado além do abstrato, apesar do novo perigo da ADs feminilizada, da prostituição infantil internacionalizada no turismo sexual, da violência sexual globalizada contra mulheres e crianças etc.

Pretendo mostrar o lugar das experiências reprodutivas e sexuais femininas na conformação do novo paradigma, recuperando sua importância no desenvolvimento de uma ciência da práxis e da ética. Argumentarei que é preciso usar esta ciência para reforçar valores femininos na sexualidade. Senão, reproduziremos uma sexualidade conceituada no velho paradigma e baseada na separação corpo/ mente, que está sendo representada como (e transformada em) mercadoria na sociedade de consumo atual.

Nas palavras de Rosi Braidotti (1994:95):

o movimento de mulheres colocou na agenda questōes sérias com respeito às estruturas, os valores, e os fundamentos teóricos do sistema que elas, e outras minorias, estão sendo convidadas a integrar. A linha de frente deste questionamento é tanto éticopolítico como epistemológico: qual o preço da 'integração'? Quais os valores que mulheres feministas propõem ao velho sistema? Quais representações de si mesmas vão opor àquelas já estabelecidas?

\section{Ciência e gênero}

Já não é novidade apontar que condição essencial à epistemologia e à ciência até então dominante é a ontologia cartesiana do sujeito científico que, capaz de superar seus valores e sua condição corporificada, se separa do seu objeto. Este paradigma binário procede pela separação e hierarquização não só de sujeito/objeto, subjetividade/objetividade, mas, também, de mente/corpo, razão/emoção, ideal/material, cultu$\mathrm{ral} /$ natural, social/biológico e homem/mulher, vistas como categorias opostas e estanques. Separando teoria/prática e ciência/sociedade, separa também a ciência da política, dos valores e da ética, almejando conhecimentos tidos como objetivos, abstratos e universais, produzidos em um espaço fora da vida social normal ${ }^{3}$. Dialeticamente, onde mais avançou, acabou por produzir o início da sua própria negação: na física quântica.

\footnotetext{
'A discussão desta questão importante na história das ciências sociais não será recuperada aqui.
} 
Também dialéticas foram a contestação da perene identificação da mulher com o biológico/natura//corpo/emoção e a descoberta da sua condição de objeto de uma ciência "androcêntrica", que permitiu ao feminismo perceber a relação de duas vias entre conhecedor e objeto conhecido. Isto é: os homens, ao fazerem esta ciência, (re)produzem a hierarquização dos gêneros; definindo "a outra", definem a si mesmos, (re)produzindo seu próprio poder. É uma produção saber/poder baseada nestas representações diferenciadas, em que o sujeito e o conhecimento são mutuamente constituídos.

O feminismo confrontou esta ciência e a definição naturalizada da identidade feminina com a análise da sua própria vivência. Este movimento significa uma subversão do modelo de conhecimento anterior em vários níveis, iniciado com o objetivo do autoconhecimento, da fusão de sujeito e objeto, mencionado anteriormente. Ao contrário do método científico, o processo começou com os grupos de reflexão (consciousness-raising): em vez do isolamento cognitivo do indivíduo (ou da mente) pensante, a formação de uma coletividade com uma práxis. Aqui, os insumos do processo são as vidas cotidianas das participantes, especialmente suas próprias vivências corporais mais íntimas na área da sexualidade/reprodução que tinham sido silenciadas socialmente. Estas vivências corporais - da menarca, menstruação, sexualidade, contracepção, aborto, gestação e parto - serviram de parâmetro de diferenciação aguda dos homens e, por isso mesmo, facilitaram a auto-identificação entre as mulheres, cujas diferenças sociais eram freqüentemente grandes. A partir disto, o processo de inclusão da questão da mulher em muitas disciplinas acadêmicas subverteu a tendência à especialização e fragmentação que predomina na ciência binária e promoveu uma conversa com muitas vozes e perspectivas, capaz de compor uma visão nova, pluralista e multifacetada.

Desta forma, nasceram juntas a percepção da opressão e da possibilidade de transformação: a partir da auto-identificação coletiva como "mulher", elaboração de uma crítica ao significado naturalizante/biologizante de "mulher". Esta crítica estabeleceu "mulher" como categoria política, com uma proposta de produção de conhecimento em que o objeto a ser estudado (mulher) ao mesmo tempo deve ser re-significado.

Dos grupos de reflexão, surgiu um grito de guerra: "o pessoal é político!". Esta formulação sintetiza um questionamento do velho paradigma de conhecimento, cujos múltiplos significados estão sendo elaborados ainda hoje (Frye, 1996). Nas palavras de Sandra Harding (1986:251): "Nunca, nem nos nossos sonhos mais desvairados, imaginávamos que teríamos que reinventar tanto a ciência como a própria teorização, para entender a experiência social de mulheres."

Podemos dizer que estes grupos viveram uma experiência algo contraditória nos termos das dicotomias: a partir da examinação de experiências vividas como altamente subjetivas e individuais (inclusive corporais) a "construção social" de gênero foi per- 
cebida. A subjetividade, que seria um fenômeno individual, foi revelada como também coletiva; e coletivamente caracterizada como sem poder, subordinada, ou desvalorizada, mas, ao mesmo tempo, como tendo o potencial de transformar esta própria definição.

Nesse processo, enquanto o conhecimento gerado a partir da reapropriação da vivência própria é o ponto de partida, há uma relação não determinante entre estas experiências e a "mulher" transformada/resignificada. Em uma formulação posterior: "homem" e "mulher" são categorias ao mesmo tempo "vazias" (pois não têm contéudo fixo) e "transbordantes" (como todos os conceitos, em iluminando alguns aspectos da realidade, escondem outros) (Scott, 1989). São criados com "conteúdos" variados através da história, mas nas suas variadas versões patriarcais, sempre como criações dos homens (identidade na diversidade).

O conceito de "gênero", portanto, insiste analiticamente na importância da relação, do social e do poder, mas deixa em aberto o conteúdo empírico que é historicamente (re)elaborado - agora fora e dentro dos estudos de gênero. Do ponto de vista desse processo, as categorias analíticas da teoria feminista, como todos os conceitos, devem ser vistas como produções situadas historicamente.

Os estudos de gênero procedem à investigação de relações mutuamente constituídas (ou dialéticas) entre os termos do binarismo: se o pessoal é político, então, individual/social, biológico/social, subjetividade/objetividade, ideal/material, razão/emoção, público/privado, produção/reprodução etc., são todos passiveis de ser estudados como mutuamente constituídos. Oque o velho paradigma separou, o novo está relacionando-e de uma forma dialética.

A reapropriação da própria vivência é uma rejeição do conhecimento objetivo do velho paradigma, como produto e como processo. Desta maneira, o autoconhecimento almejado é tanto um fenômeno coletivo como individual: "eu como mulher". Tanto o sujeito como o objeto deste processo são coletivos, compostos a partir do auto-reconhecimento como "mulher" em ambos os níveis.

Foi esta práxis que levou ao aparecimento analítico posterior de "outras" mulheres (lésbicas, negras, do terceiro mundo etc.) e à necessidade/possibilidade de incorporação destes outros pontos de vista numa elaboração continuada - de experiências "de mulheres", no âmbito que, todas concordam, ainda é o feminismo (ou, mesmo, os feminismos: identidade na diversidade).

Esta identidade na diversidade foi, desde o início, algo a ser re/construído politicamente. Como abordado por Teresa de Lauretis (1994), este é um conhecimento pessoal, intimo, analítico e político:

o método analítico e critico feminista (é) a prática da autoconscientização. Pois a compreensão da condição pessoal de ser mulher em termos sociais e políticos e a constante revisão, reavaliação e reconceitualização dessa condição vis-à-vis a compreensão que outras mulheres têm das suas posições sociossexuais geram um modo de apreender a realidade social como um todo que é derivado da conscientização de gênero (...). 
Nas palavras da Donna Haraway (1994), "a experiência das mulheres" é uma "ficção" (o conteúdo varia) e um "fato político crucial" (ainda assim, permite a auto-identificação e o engajamento no feminismo).

O conhecimento não transcende, mas está enraizado em vivências e interesses e no mundo social.

emerge uma visão de fatos objetivos, abertos a múltiplas interpretações, analisáveis de várias perspectivas. Fatos podem mudar e evoluir em processos de interpretação e crítica; então 'realidade' è aberta à estruturação social (...) fatos (...) são tanto subjetivos quanto objetivos. (Code, 1991:45)

É importante observar que, ao mesmo tempo em que esta visão desconstrói o paradigma científico anterior, concluindo que a subjetividade é uma parte integral do conhecimento objetivo, tampouco coaduna com o relativismo do pós-modernismo radical que não permite uma tomada de posição ética (Lengermann \& NiebruggeBrantley, 1990). Isto, porque a subjetividade no feminismo é coletiva e estruturada socialmente por meio de experiências de mulheres, sendo ao mesmo tempo dedicada à transformação das estruturas de subordinação.

Os conhecimentos, assim como as experiências, são parciais mas coletivos, situados pelas estruturas sociais (gênero, raça/etnia, classe etc.) que se entrecruzam nas identidades individuais e coletivas das mulheres. Não são nem abstratos e universais e nem referidos a uma subjetividade individual e/ou fragmentada.

Somente o processo histórico permitiu avançar para o delineamento desta perspectiva, em que a subjetividade humana é concebida como propriedade emergente de uma experiência historicizada, produto do engajamento contínuo na realidade social, um lugar de construção mútua de conhecimentos e de valores (Alcoff, 1988). Se esta práxis feminista antecedeu sua própria teorização, como argumentado por Frye (1996), isto é apenas coerente com sua visão epistemológica/ontológica em que o conhecimento e o conhecedor se constroem mutuamente.

Imaginar, nos anos 90, que o sujeito do feminismo dos anos 60-70 era transparente ou inocente é uma posição que desconhece sua própria história e as dificuldades envolvidas em enfrentar esta complexidade e lutar para criar, de dentro das contradições da ordem patriarcal/industrial/capitalista vigente, o que nela era irrepresentável: a mulher sujeito da significação (que significa, em vez de ser significada por outros).

\section{Corpo e poder na sociedade capitalista}

Se, no início do processo, a maior parte das investigações foi dedicada a esmiuçar as estruturas de subjugação e a falta de poder, isto foi historicamente necessário para poder percebê-las e desmascarar o sistema de sexo-gênero que foi criado e negado no 
velho paradigma. Não era a mulher a "rainha do lar", espaço ideologicamente equacionado com a criação dos filhos e com os valores supostamente mais importantes nas sociedades de tradição patriarcal? Não foram elas, inclusive, vistas como símbolos do amor e da moral? Não eram "damas primeiro"?

A resposta feminista foi: sim e não! A base da primeira ressignificação foi necessariamente uma identificação e uma recusa, tanto das fraquezas como dos poderes dados pela ordem patriarcal. À luz do capitalismo então em pleno vigor, ser "rainha do lar" já não satisfazia.

Nos grupos de reflexão, as vivências corporais especificas de mulheres na menarca, na menstruação, na sexualidade, na gestação e parto, na contracepção e no aborto levaram o movimento ao consenso nas demandas para o controle do corpo por meio da contracepção e do direito ao aborto legal (e, na sua formulação atual, para a saúde sexual e reprodutiva).

Em contraste, a temática da legislação trabalhista específica criou uma polêmica e representou um dilema que ilustra bem o cerne de uma ambivalência feminista com respeito às especificidades do corpo feminino: reivindicar direitos específicos no trabalho poderia servir para aumentar a discriminação contra mulheres; ignorar as diferenças significaria escamotear uma desvantagem das mulheres perante as exigências feitas dos trabalhadores em geral.

O controle do corpo reivindicado tem, então, múltiplos significados. Expressa uma consciência nova do corpo colonizado por outros - homens, corporação médica, cientistas, por exemplo-representantes da tradição de poder patriarcal. Explicita um desejo por uma igualdade na sexualidade separada da reprodução, livre da ameaça da gravidez indesejada. Controlar a fecundidade é, por outro lado, condição para uma igualdade maior na esfera profissional, em que o papel feminino na reprodução humana significa interromper carreiras, diminuir o tempo e a energia disponível para o trabalho remunerado, enfim, significa concorrer em condições desiguais no mercado de trabatho, nestas sociedades organizadas conforme as exigências da produção.

É importante lembrar que a saída da subordinação era conceitualizada globalmente na demanda feminista para igualdade nos termos dos valores de fato dominantes nestas sociedades, todos localizados na esfera pública: emprego, renda, escolaridade, profissão, representação política. Seria necessário (tanto ideológica como materialmente) conquistar este espaço, mesmo se não suficiente. Se as feministas brasileiras foram a esta luta pública "carregando consigo, escondidas, as raízes no privado" (Oliveira, 1983), isto ilustra uma postura bem mais geral que predominou no início do movimento: as especificidades femininas vistas como "desvantagens", pois assim são na sociedade em que a reprodução é subordinada à produção (Chahaud \& Fougeyrollas-Schwebel, 1987) e os valores dominantes são referidos à esfera pública. 
Apesar da importância das experiências corporais específicas na conformação das identidades individuais e das subjetividades, que são percebidas como sendo também sociais e coletivas, a especificidade do corpo feminino é desvalorizada na teoria (no conceito de gênero) e na rejeição da identidade de reprodụtora.

Poderemos dizer que, neste processo, o feminismo reconheceu o corpo feminino para dizer "não" a ele? Não é isto o que se exige nas sociedades que subordinam a reprodução à produção, organizadas em função do lucro e não da qualidade de vida da população? Não é este um preço da integração na esfera pública deste sistema?

Aceitar a identificação do feminino com a esfera de reprodução (a mulher como mãe) e enfatizar os valores considerados femininos pela ordem vigente (as relações familiares e interpessoais, o cuidar do outro, a afetividade etc.) não seria aceitar o status $q u o$ ? Do ponto de vista dos valores patriarcais, sim. Mas do ponto de vista da organização material da sociedade capitalista/industrial, que é caracterizada pelo processo de individualização da força de trabalho e fragmentação das estruturas familiares, lutar pela valorização da esfera de reprodução representaria uma verdadeira inversão da ordem vigente.

O movimento de mulheres surgiu dentro deste processo histórico de radical reorganização das sociedades ocidentais. Enquanto os valores patriarcais são compativeis com a importância da família como base organizadora da produção material e da reprodução humana, o processo de industrialização retira a produção da família, tornando-a uma instituição dependente (Giffin, 1994). Isto provoca grandes transformações, tanto na base dos poderes masculinos (e femininos) anteriores, como no significado dos corpos na produção material e na reprodução humana: a importância da força física na produção, assim como a importância da geração de filhos, são relativizadas neste sistema, agora no processo de globalização.

\section{$O(s) \operatorname{corpo}(s)$ no(s) conhecimento(s)}

A crise da razão é conseqüência do privilégio dado, historicamente, ao puramente conceitual ou mental, em detrimento ao corporeal; isto é ... a inabilidade dos conhecimentos ocidentais em conceber seus próprios processos de produção (material), processos que simultaneamente são baseados em, e negam, o papel do corpo. (Grosz, 1993)

No paradigma dominante, a oposição dos termos binários razão/emoção, mente/ corpo ou consciência/corpo permitiu privilegiar a idéia do "puramente mental" na produção do conhecimento. Entre as muitas conseqüências disto, três devem serdestacadas.

Em primeiro lugar, a ciência é considerada como um plano transcendente, abstraída da vivência concreta de homens e mulheres, e, portanto, livre de valores e subjetividades. Tais conhecimentos, não sendo "localizáveis", são "irresponsáveis" em termos 
éticos (Haraway, 1988). Em contraste, os conhecimentos "situados" do feminismo explicitam os seus interesses.

Em segundo lugar, os sujeitos humanos, neste modelo, são representados como essencialmente solitários, isolados e auto-suficientes (Code, 1991:52). Além do individualismo:

a ilusão objetivista torna a refletir uma imagem do eu (self) como autônomo: uma imagem do indivíduo 'para si própria' (...). É este investimento na impessoalidade (...) que constitui a arrogância particular (...) do homem moderno, e ao mesmo tempo revela sua subjetividade peculiar. (Keller, In: Lengermann \& Niebrugge-Brantley, 1990)

Aprender a não perceber nossas emoçôes torna mais plausível "o mito da investigação desapaixonada" (Jaggar, 1989). É neste sentido que toda epistemologia (teoria do conhecimento) implica uma ontologia (visão do ser conhecedor).

Embora este paradigma se presuma universal, o feminismo aponta que este ideal de objetividade (e sua crise) é - simbólica e historicamente - referido ao masculino e, na vida social, "reflete a auto-suficiência para a qual os meninos são preparados" (Code, 1991; ver também Bleier, 1984). Não há como ignorar, porém, que esse estilo de subjetividade, individualista e impessoal, e os seus objetos de conhecimento também poderiam representar um preço da integração de mulheres nas atividades de produção do conhecimento, sob o velho paradigma. Ao menos, coloca uma contradição para quem valoriza as questões da reprodução, do cuidar e do amar. Haraway (1990) aponta que as premissas de individualismo e auto-suficiência colapsam mais dramaticamente na reprodução humana (ver também Schott, 1993).

Finalmente, em terceiro lugar, a desvalorização do corpo e das emoções nesta visão do conhecimento é generalizada para outros aspectos da vida nas sociedades onde este paradigma é dominante. Na síntese de Marilena Chauí, a herança cartesiana "reprime o corpo através da sua concepção do conhecimento". Recuperado no interior da ideologia burguesa, como conjunto de processos fisiológicos, o corpo é coisificado, transformado em mercadoria, na compra e venda de força de trabalho e de sexo (Chaui et al., 1981).

E quais as implicações para a sexualidade? Muriel Dimen (1989) refere-se à "redução do desejo" nas sociedades modernas, patriarcais e individualistas e à ambivalência do relacionar-se (relatedness), que é visto como "dependência" neste contexto que valoriza a autonomia e a impessoalidade. Ela pergunta:

Onde há (...) espaço para a intimidade, para o conhecimento e expansão do eu que é alcançado através do conhecimento do outro? De que maneira são criadas expectativas de prazer sensual, nesta economia que explora as pessoas e a natureza, ao mesmo tempo em que promove o enriquecimento pessoal?

Maria Rita Kehl argumenta que o grito de desejo dos anos 60 foi assimilado pelo capitalismo, em que o sexo é elemento de adaptação à sociedade de consumo. Nestas sociedades, o corpo-máquina é vigiado pela consciência, e as defesas neuróticas são 
reforçadas em um sexo-teatro que "serve basicamente a um empobrecimento afetivo da relação sexual" (Chauí et al., 1981; ver também Feuerstein, 1994). Ainda na tradição de Marcuse, Ilene Philipson aponta que o capitalismo moderno moldou a sexualidade e a idéia de liberação sexual para seus próprios fins, e que a ideologia do playboy, que promove o sexo sem compromisso afetivo, tem avançado desde os anos 50 (Philipson, 1984). Em vez de "relações" sexuais, a sociedade de consumo promove "atos" sexuais dirigidos a objetos sexuais (Mantega, 1979).

Do ponto de vista dos gêneros, a tradição patriarcal identifica o masculino com a razão, regulador e conhecedor da sexualidade feminina, que é objeto deste conhecimento no paradigma binário: "sexualidade e conhecimento estão numa dinâmica recíproca de poder e legitimação mútua para os homens" (Breitenberg, 1993).

Apesar de assegurar o poder social, alguns custos da identificação masculina com esta razão (binária) são sugeridos por Victor Seidler. Sendo que as emoções são desvalorizadas e identificadas com o feminino, ameaçam a identidade de gênero masculina. Em função disto, os homens temem a intimidade, preferindo mantero autocontrole sobre as emoções, o que é considerado, inclusive, como "maturidade moral". Neste cenário, a sexualidade para os homens é "transformada em 'performance' e separada da intimidade e do contato pessoal" (Seidler, 1987; para alguns dados atuais, ver Bozon, 1995).

Nesta tradição, a sexualidade feminina tem sido definida (pelos homens) "tanto em oposição como em relação à masculina" (Lauretis, 1993). Vista historicamente como passiva e voltada para a reprodução, não há concepção do desejo feminino; a sexualidade feminina valorizada responde aos desejos de outros, não é um desejo ativo (Rubin, 1975; Holland et al., 1994; Haraway, 1994).

Nas palavras de Teresa de Lauretis (1994), a subjetividade feminina hoje emergente se encontra en-gendrada em uma relação com a sexualidade que é absolutamente irrepresentável nos termos dos discursos hegemônicos sobre a sexualidade e sobre o gênero. Sendo uma visão de "outro lugar", é um "ponto cego" que não é reconhecido como representação.

Já para Philipson (1984), onde o sexo impessoal é visto como norma, odesejo sexual de mulheres - que freqüentemente é caracterizado pela aversão ao sexo impessoal e pela necessidade de uma intimidade e de uma proximidade - é visto como inadequado. Uma análise do "discurso ausente do desejo feminino" nos Estados Unidos conclui que este discurso teria de ser baseado nos significados construídos socialmente pelas mulheres, $\mathrm{e}$ teria de levar em conta a sua "consciência dual", expressão da dialética que existe entre seus desejos e as definições dominantes do masculino e do feminino (Fine, 1988).

No paradigma binário, incapaz de conceber uma integração consciência/corpo ou razão/emoção, a sexualidade é entendida como fenômeno natural e biológico que, junto com as emoções, é banida do plano descorporificado do conhecimento tido como abstrato e universal. 
No pós-modernismo de Deleuze, Foucault, Derrida e Lyotard, o determinismo discursivo - ver o corpo como apenas um efeito de práticas discursivas de sujeitos desengendrados (Schott, 1993) - é revelado como perfeita imagem invertida do velho paradigma (Haraway, 1988) e nova expressão do antigo hábito masculino de transformar mulheres em metáfora (Braidotti, 1994).

Negando o gênero, ou seja, a história da opressão e da resistência política das mulheres e a contribuição epistemológica do feminismo para a redefinição da subjetividade e da socialidade, estas teorias desconstroem o sujeito de tal maneira a "reposicionar a subjetividade feminina dentro do sujeito masculino, seja lá como for definida". (Lauretis, 1994). Nas palavras de Susan Bordo (1993), insistir na total indeterminação de significados no mundo social representa, também, "uma fantasia de escapar da condição situada da humanidade" (a fantasy of escape from human locatedness).

Na teoria feminista, em contraste, o corpo é visto como "interface entre o material e o simbólico" (Schott, 1993) e a sexualidade é conceitualizada como "fenômeno relacional", "um interface com o mundo e com outras pessoas e ... densa zona de interação" (Bleier, 1984), uma forma de relação com o mundo que é tanto corporal como aprendida.

Nesse processo dialético, emerge um novo sujeito da significação, que insiste em que processos corporais diferenciados por sexo são inevitavelmente significados em todas as culturas (Grosz, 1993) e que o corpo não pode ser pensado, a não ser como masculino ou feminino (Krais, 1993). Este sujeito explora "as raízes sensuais e emocionais da cognição" (Schott, 1993) e o "potencial epistêmico das emoções" (Jaggar, 1989). Nas palavras de Scheper-Hughes \& Lock (1987):

as emoções envolvem tanto sentimentos, como orientaçōes cognitivas, moralidade pública, e ideologia cultural ... provêem um importante 'elo perdido' capaz de relacionar corpo e mente, indivíduo, sociedade, e corpo político ... são o catalisador que transforma conhecimentos em compreensão humana...

Estas conceitualizações são instrumentos de conhecimento que refletem os significados dados a experiências corporais de mulheres; dependem destas experiências para dizer que os corpos e as emoções são importantes no conhecer e nos conhecimentos. Recuperando o corpo não somente como objeto conhecido, mas como aspecto do sujeito que sente, conhece, e age eticamente (Sobchack, 1995), re-coloca a ciência como empreendimento necessariamente expressivo de valores, seja de forma oculta (no velho paradigma), seja explicitamente (no paradigma emergente).

O que é a saúde sexual no entender deste sujeito da significação, que percebe a dialética entre indivíduo/coletivo, mente/corpo e razão/emoção?

Negando corpos, emoções, sentimentos e valores como fontes de conhecimento, o paradigma binário produz uma fragmentação da própria experiência e do autoconhecimento (Seidler, 1987). A linguagem dos direitos individuais e da autono- 
mia, além de abstrata e individualista, reflete os valores sexuais que estão sendo promovidos na sociedade de consumo, em que os atos sexuais são referidos a objetos sexuais.

$\mathrm{Na}$ fragmentação produzida pelo espelho binário, o masculino é representado como sexualmente ativo, mas incapaz de uma relação íntima; o feminino como voltado para as relações íntimas, mas não como sujeito sexual. A teoria feminista aponta a possibilidade de ambos serem sujeitos sexuais voltados para o autoconhecimento através do conhecimento do outro, na relaşão sexual.

Então, se a energia dita sexual é a energia das relações, o desejo esta necessidade, e o contato sensual um meio direto material de comunicar, menos 'dividido', mais direto que as palavras ... se então o corpo comporta um orgasmo de relações, por que não aspirar a gozar em todos os sentidos, de preferência? (Rochefort, 1978)

\section{Referências Bibliográficas}

ALCoFf, L. Cultural Feminism versus post-structuralism: the identity crisis in feminist theory. Signs, 13(3):405-435,1988.

BLEIER, R. Science and Gender. a critique of biology and its theories on women. Oxford: Pergamon Press, 1984.

BORDo, S. Unbearable Weight: feminism, westem culture, and the body. Berkeley: University of California Press, 1993.

Bozon, M. Amor, sexualidade e relações sociais de sexo na França contemporânea. Revista Estudos Feministas, Ano 3(1):122-135, 1995.

BRADOTn, R. Nomadic Subjects: embodiment and sexual difference in contemporary feminist theory. New York: Columbia University Press, 1994.

BREIENBERG, M. Anxious Masculinity: sexual jealousy in early modern England. Feminist Studies, 19(2):377-398, 1993.

CAPRA, F. O Ponto de Mutação: a cultura, a sociedade e a ciência emergente. São Paulo: Imago, 1982.

Chahaud, D. \& Fougerrollas-Schwebet, D. Sobre a Autonomia Relativa da Produção e da Reprodução. In KARTCHevSKY-BurPORT, A. et al. O Sexodo Trabalho. São Paulo: Paz e Terra, 1987.

CHAUI, M.; KeHL, M. R. \& WEREBE, M. J. Educação Sexual: instrumento de democratização ou de mais repressão?. Cadernos de Pesquisa, 36:101-1-3, 1981.

CODE, L. What Can She Know? feminist theory and the construction of knowledge. Ithaca/London: Cornell University Press, 1991.

Dimen, M. Power, sexuality and intimacy. In: JAGGAR, A. \& BORDo, S. Gender/Body/Knowledge. Rutgers: The State University Press, 1989. 
Feurrsten, G. A Sexualidade Sagrada. São Paulo: Siciliano, 1994.

FINE, M. Sexuality, schooling and adolescent females: the missing discourse of desire. Harvard Educational Review, 58:29-53, 1988.

FRVE, M. The necessity of differences; constructing a positive category of women. Signs, 21(4):991-1010, 1996.

GIFFIN, K Esfera de reprodução em uma visão masculina: considerações sobre a articulação da produção e da reprodução, de classe e de gêncro. Physis, 4(1):23-40, 1994.

Grosz, E. Reason and knowledge: feminism and the crisis of reason. In: ALCOF, L. \& POTtER, E. (Eds.) Feminist Epistemologies. London: Routledge, 1993.

HARAWAY, D. Situated knowledges: the science question in feminism and the privilege of partial perspective. Feminist Studies, 14(3):575-599, 1988.

Haraway, D. Investment Strategies for the envolving portfolio of primate females. In: JACOBUS, M.; KelLER, E. F. \& SHUTtLEWORTH, S. Body Politics: women and the discourse of science. New York/London: Routledge, 1990.

HARAWAY, D. Um manifesto para os cyborgs: ciência, tccnologia, e feminismo socialista na década de 80. In HOLLANDA, H. Tendências e Impasses: ofeminismo como crítica da cultura. Rio de Janeiro: Rocco, 1994.

HaRDING, S. The Science Question in Feminism. Ithaca: Cornell University Press, 1986.

HaRDING, S. A instabilidade das categorias analíticas na teoria feminista. Estudos Feministas, Ano 1(1):7-32, 1993.

Holland, J. et al. Power and desire: the embodiment of female sexuality. Feminist Review, 48:21-38, 1994.

JAGGAR, A. Love and knowledge: emotion in feminist epistemology. In: GARRY, A. \& PEIRCE, M. Women, Knowledge and Reality. Massachusets: Unwin Hyman, 1989.

KELLER, E. F. Reflections on Gender and Science. New Haven: Yale University Press, 1985.

KRAS, B. Gender and symbolic violence: female oppressioin in the light of Pierre Bourdieu's theory of social practice. In CALHOUN, C.; PUMA, E. \& POSTONE, M. Bourdieu: critical perspectives. Chicago: University of Chicago Press, 1993.

LAURETIS, T. de. A Tecnologia do Gênero. In: HolandA, H. Tendências e Impasses: o feminismo como crítica da cultura. Rio de Janeiro: Rocco, 1994.

LENGERMANN, P. \& NEBRUGGE-BRANTLY, J. Feminist sociological theory: the near-future prospects. In RrzzR, G. Frontiers of Social Theory: the new synlhesis. New York: Columbia University Press, 1990. 
ManteGa, G. Sexo e poder nas sociedades autoritárias. In: ManteGA, G. (Org.) Sexo e Poder. Brasília: Brasiliense, 1979.

Marcuse, H. The One-Dimensional Man. Boston: Beacon Press, 1964.

OuveirA, R. D. de. As pedras nos bolsos do feminismo. Novos Estudos Cebrap, 2(3):35-38, 1983.

Philipson, I. Comment. In: Ferguson, A. The Feminist Sexuality Debates. Signs, 10(1):106135,1984 .

ROCHeFORT, C. O mito da frigidez feminina. In DuRAND, E. (Org.) Liberacãoda Muther: ano zero. Belo Horizonte: Interlivros, 1978.

RUBiN, G. The traffic in women. In: Rerter, R. Towards and Anthropology of Women. New York: Monthly Review Press, 1975.

SCHEPER-Hughes, N. \& LOCK, M. The mindful body: a prologomenon to future work in medical anthropology, Medical Anthropology Quarterly, 1(1):06-41, 1987.

ScHort, R. Ressurrecting Embodiment: towards a feminist materialism. In: ANTHONY, L. \& WITT, C. (Eds.) A Mind of One's Own: feminist essays on reason and objectivity. Boulder: Westview Press, 1993.

Scotr, J. Gênero; uma Categoria Útil para Análise Histórica. Tradução SOS Corpo, Recife, 1989. (Mimeo.)

SEIDLER, V. Reason, desire and male sexuality. In: CAPIAN, P. The Cultural Construction of Sexuality, London/New York: Routledge, 1987.

SOВСАаСK, B. Beating the Meat/ surviving the text, or, how to get out of this century alive, Body and Society 1(3-4):205-14. 



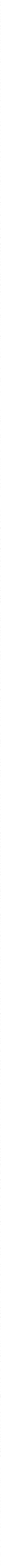





\section{Tendências da Fecundidade Brasileira no Século XX:} uma visão regional'

13.

Ana Amélia Camarano, Herton Ellery Araújo \& Isabella Gomes Carneiro

\section{Introdução}

Neste trabalho pretende-se analisar a evolução da fecundidade na s cinco grandes regiões brasileiras ao longo do século XX e identificar alguns dos determinantes próximos que possam explicar as tendências observadas. Por determinantes próximos, a literatura considera os fatores que incidem diretamente nos níveis de fecundidade, como casamento, anticoncepcão, aborto e amamentação' .

O esforço de analisar as tendências históricas da fecundidade no Brasil esbarra na escassez e na dificuldade de comparabilidade de informações. A fonte tradicional de mensuração dos niveis de fecundidade é o Registro Civil. Esta fonte, até recentemente, apresentava problemas de cobertura do fenômeno, tanto pelo não-registro como pelo registro atrasado. Desta maneira, a maioria dos trabalhos sobre o tema baseia-se em informações censitárias. As primeiras perguntas sobrc fecundidade foram introduzidas no censo de 1940. Conseqüentemente, pouco se conhece sobre as suas tendências no Brasil antes da década de 30.

A história descrita aqui inicia-se com o comportamento reprodutivo das mulheres nascidas entre 1890-95-que viveram a maior parte da sua experiência reprodutiva na segunda década deste século-e se encerra com a experiência reprodutiva de mulheres

\footnotetext{
- Este trabalho integra o Projeto "Mudanças no Comportamento Reprodutivo das Mulheres Brasileiras ao longo do Século XX: uma visão estadual", em andamento no Instituto de Pesquisa Econômica Aplicada da Presidência da República (IPEA).

${ }^{1}$ Para maior discussão sobre o assunto, consultar BonGaARTs (1978).
} 
nascidas entre 1970-75. Uma vez que as informações agregadas no âmbito nacional mascaram importantes diferenças regionais, a análise apresentada está desagregada pelas cinco grandes regiões. Os dados utilizados são provenientes dos censos demográficos de 1940 a 1991 e das Pesquisas Nacionais sobre Demografia e Saúde (PNDS) de 1986 e 1996.

Além desta introdução, o trabalho inclui quatro seções: tendências das taxas de fecundidade total das coortes sintéticas; a fecundidade marital total e o impacto do casamento e da anticoncepção nas taxas de fecundidade; mudanças no padrão de formação de família; e síntese dos principais resultados.

\section{Tendências temporais da fecundidade}

Nesta seção analisa-se uma série histórica de taxas de fecundidade baseadas em dados censitários: as taxas das coortes sintéticas, utilizando o método de Brass ${ }^{2}$. Elas se referem às taxas de fecundidade total das coortes de mulheres nascidas nos qüinqüênios compreendidos entre 1890 e $1975^{3}$ e são apresentadas no Gráfico 1. Para o País como um todo, a taxa de fecundidade total, ou seja, a média de filhos tidos por mulher ao final da vida reprodutiva, passou de 6,2 entre as mulheres nascidas em 1890-95 para 2,5 entre as nascidas entre 1970 e 75 .

\section{Gráfico1 - Taxas de fecundidade das coortes sintéticas: Brasil}

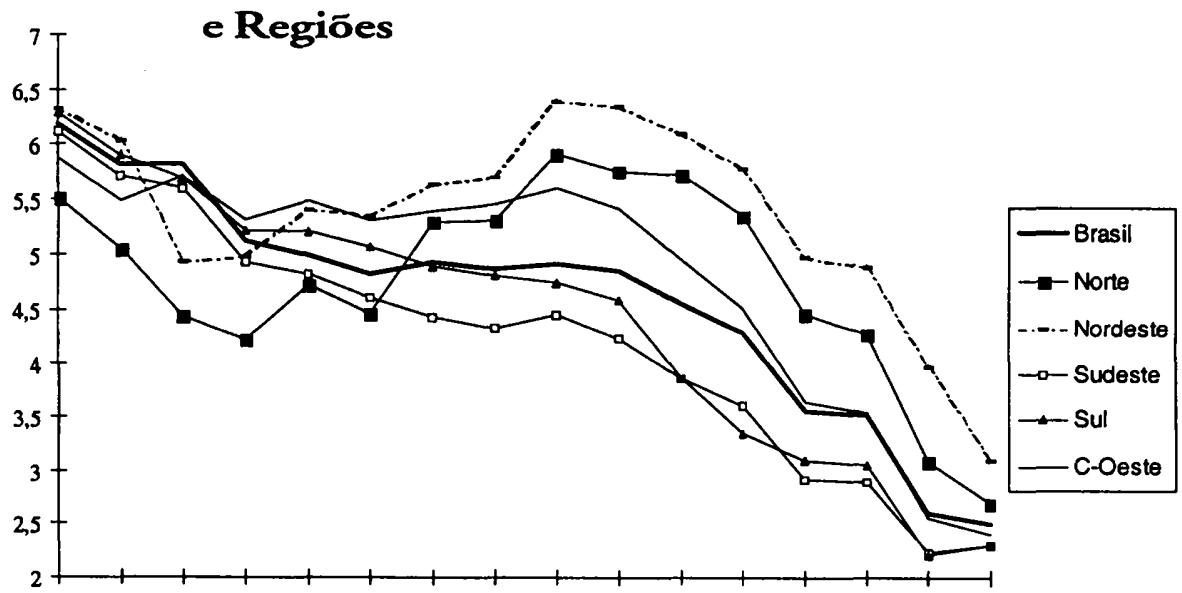

1890- 1895- 1900- 1905-1910- 1915- 1920- 1925- 1930- 1935- 1940- 1945- 1950- 1955- 1965- 1970 -

$\begin{array}{llllllllllllllll}95 & 1900 & 05 & 10 & 15 & 20 & 25 & 30 & 35 & 40 & 45 & 50 & 55 & 60 & 70 & 75\end{array}$

2 Vide Brass (1985), p. 69-70.

s Por coorte, entende-se um grupo de mulheres nascidas em um mesmo qüinqüênio. 
Apcsar de a fccundidade ter experimentado uma queda bastante cxpressiva, esta não foi monotônica, e na intensidade foi variada. Podem-se obscrvar, também, acréscimos $\mathrm{cm}$ algumas coortes. A fecundidade das cinco primeiras coortes apresentou declínio, interrompido por um aumento da fecundidade cxibido pelas sexta c nona coortes. A partir daí, observou-se uma queda acentuada nos níveis de fecundidade, mas com intensidade diferenciada. A maior variação (redução de 24,2\%) foi verificada entre as coortes nascidas entre 1945-50 e 1950-55.

As tendèncias mostradas pelas estimativas do Brasil mascaram grandes variaçõcs regionais, como se pode concluir analisando o Gráfico 1 . O declínio da fecundidade observado entre as cinco primciras coortes foi conscqüência da redução da fecundidade das mulheres das regiões Norte, Sudeste c Sul. O que se verificou entre as coortes nascidas no mesmo período c residentes nas regiões Nordeste e CentroOcstc foi um aumento da taxa de fecundidade, que resultou em uma intcrrupção da queda da fecundidade da coorte 1900-05 para o País. As mulheres nascidas entre OS anos 20 c 40 apresentaram a fecundidade estável, com uma leve tendência ascendentc. O aumento foi mais intenso nas regiões Norte c Nordestc.

O declínio observado a partir da coorte nascida em 1945-50 foi extensivo a todas as áreas, mas com ritmo diferenciado. Entre a primcira coorte, foi mais intenso nas regiões Sul, Sudeste c Centro-Ocstc. Nas coortes scguintes, a queda foi mais intensa nas regiões Sul, Centro-Oeste e Norte. Por sua vcz, as mulheres nordestinas experimentaram uma queda acelcrada de sua fecundidade a partir da coorte nascida $\mathrm{cm}$ 1950-1955. As maiores taxas de fecundidade são verificadas nesta região; as menorcs, no Sul e Sudeste. Os diferenciais relativos continuam clevados.

O declínio da fecundidade não foi homogênco nem cntre as regiões que compõem o País nem entre os grupos etários. No Gráfico 2, apresentam-sc as taxas de fccundidade das mulheres de 15 a 19 anos para os qüinqüênios compreendidos cntre 1975 e 1995. Observou-se cste acréscimo em todas as regiõcs, com excç̧ão do Centro-Oeste. Em quase todas as regiões o maior crescimento foi vcrificado no último qüinqüênio da década de 80 . Isto só não ocorreu no Norte, ondc o maior incremento foi observado cinco anos antes. 


\section{Gráfico 2 - Taxas de fecundidade das mulheres de 15 a 19 anos}

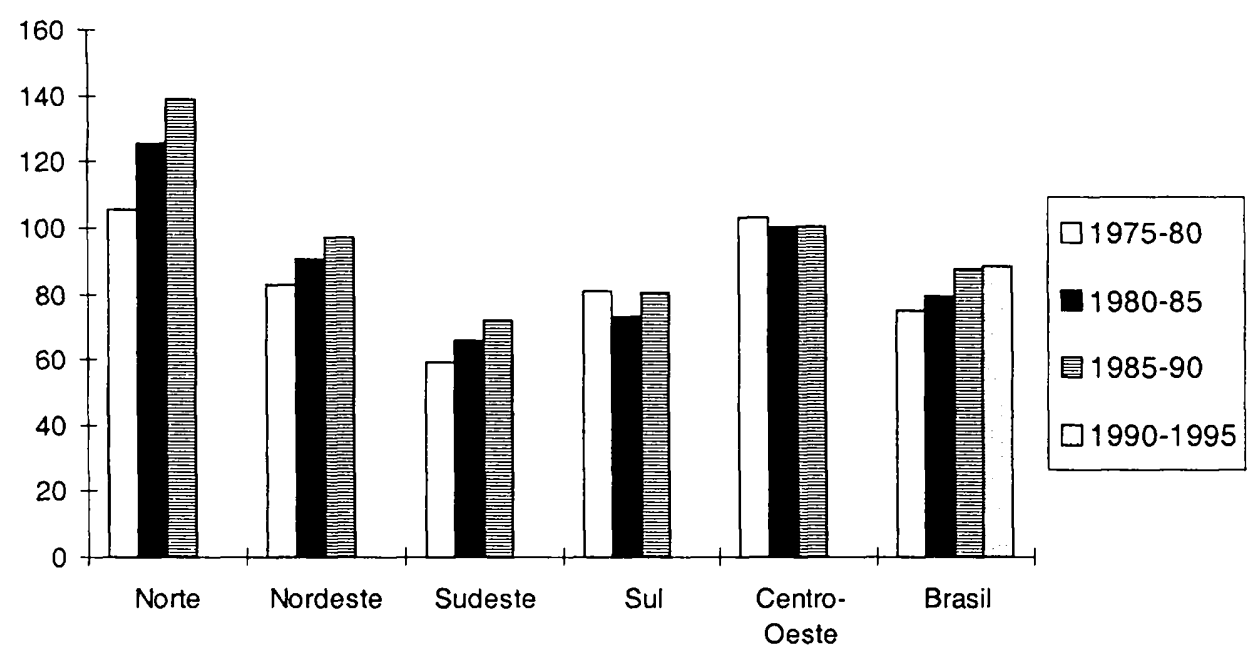

\section{Os determinantes próximos da fecundidade}

\section{Casamento}

Aqui, analisa-se o impacto do casamento e da anticoncepção nas tendências da fccundidade. Inicia-sc pelo efcito do casamento através da cvolução das taxas de fecundidade total marital por períodos, utilizando-sc a metodologia de Frias \& Olivcira (1981:82-84) para o cálculo das taxas específicas de fecundidade. Elas foram divididas pela proporção de mulheres casadas para obter as taxas de fecundidade marital ${ }^{4}$. As taxas são decenais $\mathrm{c}$ se referem à média de filhos tidos ao final do período reprodutivo por mulher casada. Elas medem a fecundidade do período 1930-35 até 1990-1995 (Tabcla 1).

\footnotetext{
+ Por mulheres casadas, compreendem-se também as solteiras com filhos, o que foi feito tentando captar ao máximo as uniões consensuais. Ressalta-se, no entanto, que a definição censitária de mulhercs casadas tem modificado ao longo do tempo, o que afeta o cálculo das taxas de fecundidade maritais.
} 


\section{Tabela 1 - Taxas de fecundidade marital total. Brasil e gran- des regióes - 1930-1995}

\begin{tabular}{lcccccc}
\hline Período & Norte & Nordeste & Sudeste & Sul & Centro-Oeste & Brasil \\
\hline $1930-35$ & 12,4 & 12,6 & 9,5 & 9,9 & 10,2 & 11,2 \\
$1940-45$ & 11,1 & 12,2 & 8,5 & 8,8 & 9,5 & 10,1 \\
$1950-55$ & 10,0 & 12,3 & 8,6 & 8,4 & 9,3 & 9,6 \\
$1960-65$ & 12,3 & 13,4 & 9,7 & 9,4 & 10,4 & 10,7 \\
$1970-75$ & 9,3 & 10,8 & 6,9 & 6,8 & 8,0 & 8,1 \\
$1980-85$ & 5,9 & 6,6 & 4,2 & 3,8 & 4,5 & 4,8 \\
$1990-95$ & $5,0^{1}$ & 5,4 & 3,7 & 3,5 & 3,7 & 4,2 \\
\hline
\end{tabular}

Fonte: IBGE, vários censos demográficos e PNDS, 1996.

'Excluídas as áreas rurais.

A taxa de fecundidade total marital do Brasil declinou de 11,2 filhos por mulher, em 1930-35, para 4,2 no primeiro qüinqüênio da década de 90 . Este decréscimo não foi linear. Observou-se um aumento, entre 1950-55 e 1960-65, de 9,6 para 10,7 filhos por mulher. A tendência geral é compatível com o comportamento da taxa de fecundidade total mostrada no Gráfico l. Isto sugere que variaçōes nos níveis de fecundidade podem ser afetadas pelo casamento, mas há outras variáveis importantes intervindo no processo.

Para avaliaro efeitode variações no casamento, também chamado de 'nupcialidade' nas tendências da fecundidade, utilizou-se a metodologia proposta por Bongaarts (1978) para calcularoíndice inibidordonão-casamento $\left(C_{m}\right)$ nas taxas de fecundidade total. Na Tabela 2 , indica-se a proporção das taxas de fecundidade reduzida pelo não-casamento. Isto foi feito comparativamente a uma taxa de fecundidade total de 15,3. Ou seja, supondo uma taxa de fecundidade máxima de 15,3, que seria observada caso todas as mulheres se casassem; se nenhuma usasse métodos anticoncepcionais e tampouco amamentasse, o índice mencionado mediria a proporção da taxa de fecundidade total que difere deste valor pelo não-casamento.

\section{Tabela 2 - Indice inibidor do não-casamento $\left(C_{m}\right) \%$. Brasil e regiōes - 1930-35 a 1990-95}

\begin{tabular}{lccccccc}
\hline Regiōes & $1930-35$ & $1940-45$ & $1950-55$ & $1960-65$ & $1970-75$ & $1980-85$ & $1990-95$ \\
\hline Norte & 42,6 & 46,9 & 58,1 & 58,0 & 63,1 & 59,1 & $54,7^{1}$ \\
Nordeste & 51,5 & 53,5 & 56,9 & 55,3 & 58,1 & 57,1 & 57,5 \\
Sudeste & 58,7 & 57,4 & 56,6 & 52,7 & 55,4 & 56,7 & 59,8 \\
Sul & 57,6 & 63,0 & 63,4 & 62,1 & 62,5 & 63,4 & 65,6 \\
Centro-Oeste & 56,1 & 60,2 & 64,4 & 61,8 & 61,4 & 61,9 & 62,7 \\
Brasil & 55,7 & 57,3 & 60,8 & 55,7 & 59,2 & 59,3 & 60,0 \\
\hline
\end{tabular}

Fonte: IBGE, vários censos demográficos e PNDS, 1996.

'Excluídas as áreas rurais da Região Norte. 
As variações em $C_{m}$ durante o período não foram muito expressivas quando se considera todo o País. O efeito inibidor do não-casamento oscilou entre 55,7\% e 60,8\% no período estudado, o que significa uma queda no efeito inibidor de $44,3 \%$ para $39,2 \%$ da fecundidade natural. Entre 1930-45 e 1940-55, evidencia-se uma diminuição do efeito inibidor de variações no casamento - denominado efeito nupcialidade - e da fecundidade total. Ou seja, mais mulheres se casaram, mas tiveram menos filhos. $O$ mesmo aconteceu entre 1960-65 e 1970-75. Se a nupcialidade não tivesse aumentado, a queda da fecundidade total teria sido maior.

Já no periodo de 1940-45 a 1950-55, o efeito nupcialidade diminuiu e a fecundidade marital aumentou. Isto sugere que as mulheres estão casando mais, o que resulta na anulação de parte do efeito do controle da fecundidade marital e no aumento da taxa de fecundidade total. Na década de 70, a fecundidade caiu. Em parte, isso se deve a uma diminuição no número de casamentos. No entanto, este efeito foi menor comparadoà magnitude da queda da fecundidade. Isto mostra que outros fatores foram responsáveis pela queda da fecundidade observada nestes períodos.

As tendências observadas nas cinco regiões brasileiras não divergiram muito da média nacional. As variações na fecundidade marital foram no mesmo sentido cm todas as regiões, ou seja, decresceram entre 1930-1955, cresceram na década seguinte e decresceram a partir daí. As diferenças são observadas somente no ritmo. Isto mostra que a nupcialidade desempenhou um papel importante nos diferenciais regionais de fecundidade. Em esfera regional, as variações em $\mathrm{C}_{\mathrm{m}}$ foram bem mais expressivas. $\mathrm{Na}$ região Norte, variou entre $42,6 \%$ e 63,1\%. Esta variação foi monotônica entre 1930-35 e 1970-75, explicando parte do aumento da fecundidade total observado no período. A partir dai, tanto a nupcialidade quanto a fecundidade diminuíram. O mesmo aconteceu nas regiões Norte e Centro-Oeste, com intensidades diferentes. Na regiãoSul, observou-se um aumento quase monotônico nos valores $\mathrm{de}_{\mathrm{m}}$, sugerindoque a queda da fecundidade total deveu-se praticamente à atuação de outros fatores que o não-casamento.

\section{Controle deliberado da fecundidade}

Infelizmente, não há dados disponiveis que permitam o cálculo de uma série histórica sobre os outros determinantes próximos das taxas de fecundidade. Uma tentativa de medir a existência (ou não) de controle deliberado da fecundidade para o País e as cinco regiões no periodo 1930-85 é feita no Gráfico 3. Este apresenta estimativas do índice $m$ de controle da fecundidade proposto por Coale \& Trussel (1974) eque indica o grau em que as mulheres encerram sua vida reprodutiva antes do final biológico (menopausa), o que é assumido como indicação de controle voluntário do processo reprodutivo. A queda da fecundidade está claramente associada ao aumento de $m$. A tendência apresentada pelo Brasil é a da existência de um encerramento cada vez mais precoce da vida 
reprodutiva, medido pelo crescimento de $m$, embora os anos 50 apresentem um declínio no índice. Note-se que este foi o período em que se verificou um aumento das taxas de fecundidade.

\section{Gráfico 3-Indice de controle da fecundidade ( $m$ )}
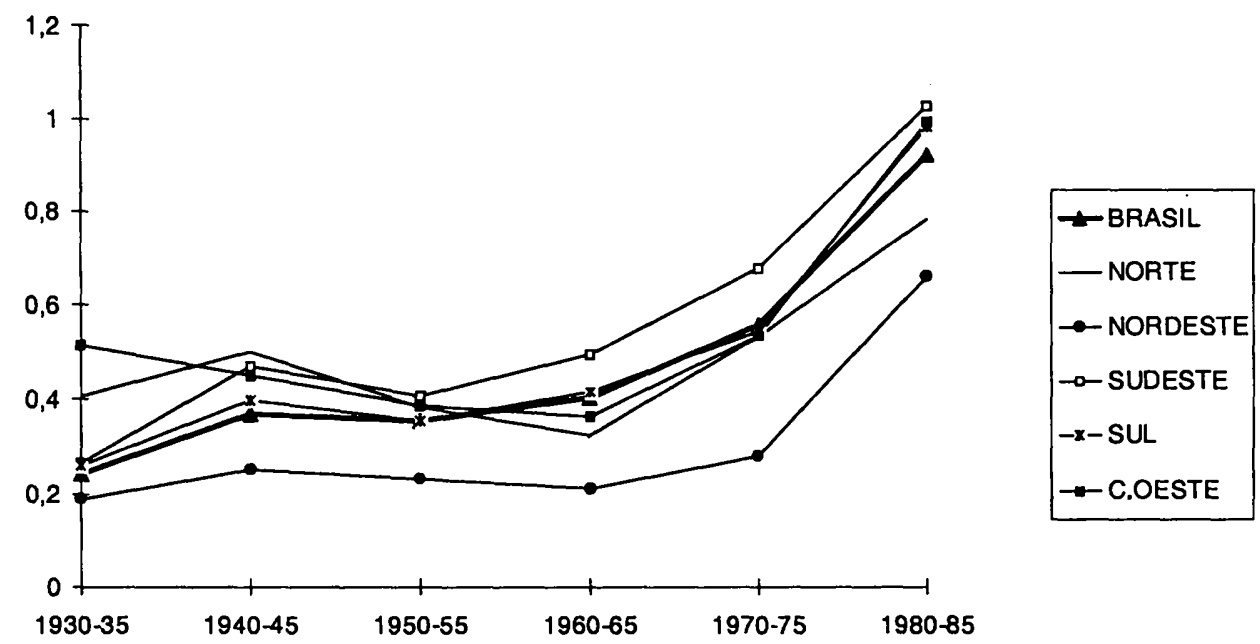

No Gráfico 3, também se encontram as estimativas de $m$ para as cinco grandes regiões. No primeiro periodo considerado, década de 30, observou-se, com exceção da região Centro-Oeste, um aumento no indicador em todas as demais, sendo que isto se deu com maior intensidade no Sudeste c Norte. Na década de 40, apenas o Sudeste e o Sul experimentaram um aumento do controle deliberado da fecundidade. $O$ aumento da fecundidade verificado em quase todas as áreas, no final dos anos 40 e início dos 50, parece ter sido resultado de uma redução do índice de controle da fecundidade. Isto pode ser observado em todas as regiões, embora menos acentuadamente no Nordeste e Centro-Oeste. Nos anos 60, este índice cresceu em todas as áreas. Esta tendência se intensificou nas décadas de 70 e 80 .

Com exceção do Nordeste (onde foram encontrados valores para $m$ inferiores a 0,25 a partir dos anos 40), observaram-se valores de $m$ acima de 0,25. De acordo com Coale \& Trussel, este ć um indicador da existência de controle deliberado da fecundidade. Curiosamente, foram as regiões Norte e Centro-Oeste as que apresentaram os maiores valores de $m$ no início do período analisado. Este resultado é 
coerente com o fato de que se verifica, nas duas áreas, as menores taxas de fecundidade total no período. No entanto, para o mesmo período, os valores de $M^{5}$ indicavam níveis de fecundidade mais clevados do que o natural. Isto pode ser explicado por problemas na definição de mulheres casadas pelos vários censos c, também, indicar um alto índice de mortalidade masculina (e a conscqüente viuvez, que levaria as mulheres a sc retirarem da vida reprodutiva mais precocemente).

O controle deliberado da fecundidade é excrcido por meio de mćtodos anticoncepcionais e aborto. Amamentação e abstinĉncia sexual são consideradas práticas contraccptivas, mas não deliberadas. No caso brasileiro, como o período de amamentação tem sido curto, esta variável tem exercido um efeito pequeno nos níveis de fecundidade. Em relação ao aborto, cabe dizer que as estatísticas são precárias, e a prática do aborto provocado é uma estratégia de controle da fecundidadc. A análise que se segue restringe-se ao efeito do uso de anticoncepcionais nos níveis de fecundidade.

\section{Anticoncepção}

Os primeiros dados sobre anticoncepção foram recolhidos no País em 1986, pela Pesquisa de Saúde Materno-Infantil e por um suplemento cspecial da Pesquisa Nacional por Amostra de Domicílios (PNAD). A segunda iniciativa foi a Pesquisa Nacional de Demografia e Saúde (PNDS), realizada cm 1996. No Gráfico 4, observa-se o uso de anticoncepcionais pelas mulheres casadas por tipo de método usado no momento das pesquisas. Em 1986, aproximadamente $66 \%$ das mulheres alguma vez unidas (ou seus parceiros) cstavam usando algum método. O índice alcançou $76,7 \%$ dez anos mais tarde. Esta taxa de prevalência é alta, se comparada à de países que já atingiram baixos níveis de fecundidade.

\footnotetext{
${ }^{5} M$ é outro índice proposto por Coale \& Trussel, que compara o nível de fecundidade a um padrão considerado de fecundidade natural, ou seja, ausência de controle deliberado da fecundidade. As duas regiōcs que apresentaram altos valores de $m$ revelam valores de $M$ acima de 1 , ou seja, acima do nivel de fecundidade considerado como natural.
} 


\section{Gráfico 4 - Distribuição percentual das mulheres unidas por método anticoncepcional utilizado - Brasil 1986-96}

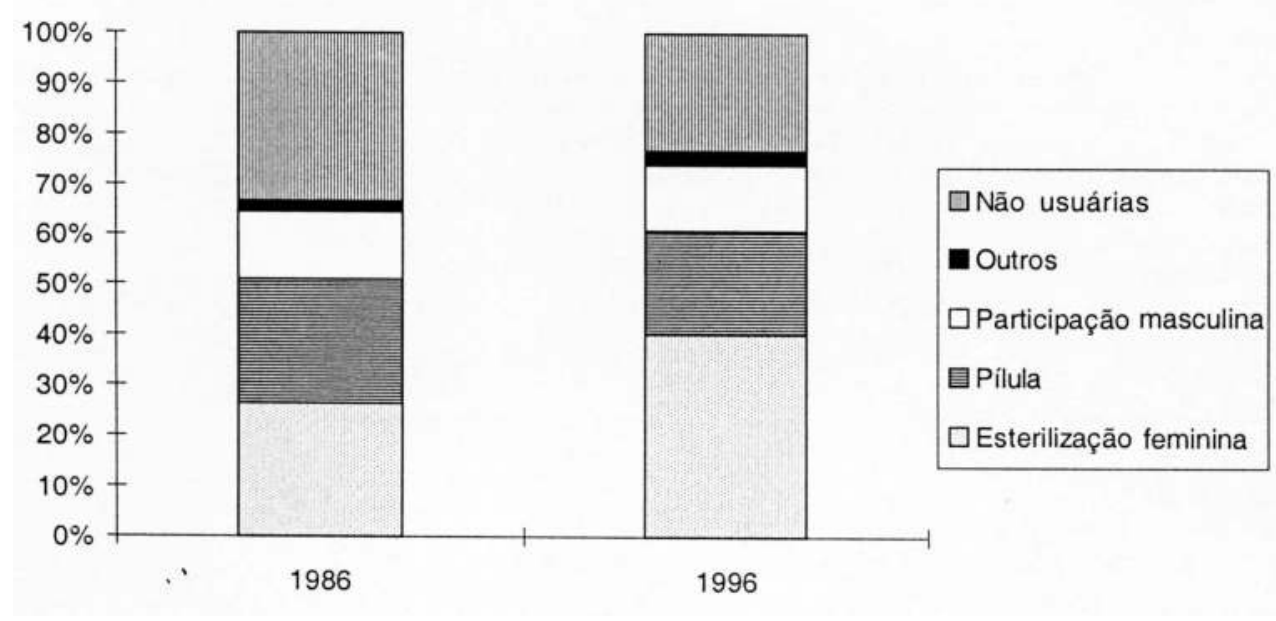

A esterilização foi o método preferido, seguido da pílula. Mais expressivo do que o aumento nas taxas de utilização de métodos foi o incremento observado na proporção de mulheres unidas esterilizadas - de $27 \%$ para $40,1 \%$ entre as duas pesquisas. O uso da pílula diminuiu no período (este método era usado por $25 \%$ das mulheres casadas, e passou a ser utilizado por $21 \%$ ). Outro crescimento observado foi no uso de métodos que contam com a participação masculina, de $11,1 \%$ para $14,1 \%$. Dentro deste grupo, houve um incremento da esterilização masculina e do uso do condom e uma redução no coito interrompido e abstinência periódica.

As diferenças regionais na proporção de usuárias são grandes, o que explica os diferenciais encontrados nas taxas de fecundidade (Tabela 3). A maior proporção de usuárias em 1986 foi verificada na região Sul $(74,4 \%)$. A menor, no Nordeste $(52,9 \%)$. Dez anos depois, as maiores proporções de usuárias foram observadas no Centro-Oeste $(84,5 \%)$. A menor proporção continuou a ser verificada no Nordeste $(68,2 \%)$ - o que equivale a dizer que aproximadamente $32 \%$ das mulheres casadas não faziam uso que qualquer método no período pesquisado nesta região. 


\section{Tabela 3 - Uso de métodos anticoncepcionais pelas mulheres alguma vez unidas, segundo as cinco regiōes (\%) $-1986 / 1996$}

\begin{tabular}{|c|c|c|c|c|c|c|c|c|c|}
\hline Métodos & Nordeste & Sudeste & Sul & $\begin{array}{c}1986 \\
\text { Centro-Oeste }^{2}\end{array}$ & Norte $^{3}$ & $\begin{array}{r}19 \\
\text { Nordeste }\end{array}$ & $\begin{array}{l}96 \\
\text { Sudeste }\end{array}$ & Sul & Centro-Oeste \\
\hline Total & 52,9 & 69,7 & 74,4 & 62,1 & 72,3 & 68,2 & 79,4 & 80,3 & 84,5 \\
\hline Esterilização & 24,6 & 29,9 & 18,3 & 42,0 & 51,3 & 43,9 & 37,8 & 29,0 & 59,5 \\
\hline Pilua & 17,3 & 24,3 & 43,0 & 12,4 & 11,4 & 12,7 & 21,7 & 34,1 & 16,1 \\
\hline $\begin{array}{l}\text { Método com } \\
\text { participação }\end{array}$ & & & & & & & & & \\
\hline masculina' & 9,5 & 13,2 & 12,5 & 6,3 & 6,4 & 9,1 & 15,8 & 14,9 & 7,0 \\
\hline Outros & 1,6 & 2,3 & 2,1 & 1,6 & 3,5 & 2,5 & 4,1 & 2,3 & 1,9 \\
\hline Não-usuárias & s 47,1 & 30,2 & 25,6 & 37,9 & 27,7 & 31,8 & 20,6 & 19,7 & 15,5 \\
\hline
\end{tabular}

Fonte: PNDS, 1986 e 1996.

Notas:

'Incluídos coito interrompido, esterilização masculina, abstinência e condom.

${ }^{2}$ Incluída a região Norte.

${ }^{3}$ Excluídas as áreas rurais da região Norte.

A composição dos métodos utilizados também varia regionalmente. A esterilização foi o método escolhido por mulheres de todas as regiões em 1986, com exceção das residentes na região Sul, que preferiram a pilula. O acréscimo verificado nas taxas de prevalência se deveu ao aumento na proporção das mulheres esterilizadas observado em todas as regiões. Isto foi feito em detrimento do uso da pílula, que só aumentou na região Centro-Oeste. Tanto em 1986 como em 1996 a pílula figurou como o método preferido apenas entre as mulheres da região Sul. Métodos que contavam com a participação masculina tiveram o seu uso aumentado nas regiões Sudeste, Sul eCentro-Oeste.

\section{Padrão de formação de famúlia}

As mudanças na fecundidade foram acompanhadas de alterações no padrão de formação de famílias. Estas são analisadas pelas taxas de progressão a uma dada parturição, ou seja, a uma dada ordem de nascimento. As taxas de progressão indicam a proporção de mulheres com $n$ filhos que tiveram pelo menos mais um filho. Consideradas um bom indicador da existência (ou não) de controle deliberado da fecundidade, estas taxas medem se as famílias decidem o tamanho de sua prole tendo em conta o número de filhos já existentes. Neste trabalho, as taxas de progressão foram calculadas para as mulheres casadas, entre 50 e 59 anos, ou seja, aquelas que já completaram a sua 
vida reprodutiva. Foram analisados dados dos censos demográficos de 1950, 1960, 1970 e da PNAD de $1995{ }^{6}$, que se referem às mulheres casadas nascidas em 1890-1900 (CN1), 1900-10 (CN2), 1910-20 (CN3), 1920-30 (CN4) e 1935-40 (CN5). No Gráfico 5 , observam-se as taxas de progressão para as mulheres do Brasil como um todo.

\section{Gráfico 5 - Taxas de progressão a uma dada parturição - Brasil Mulheres de 50 a 59 anos}

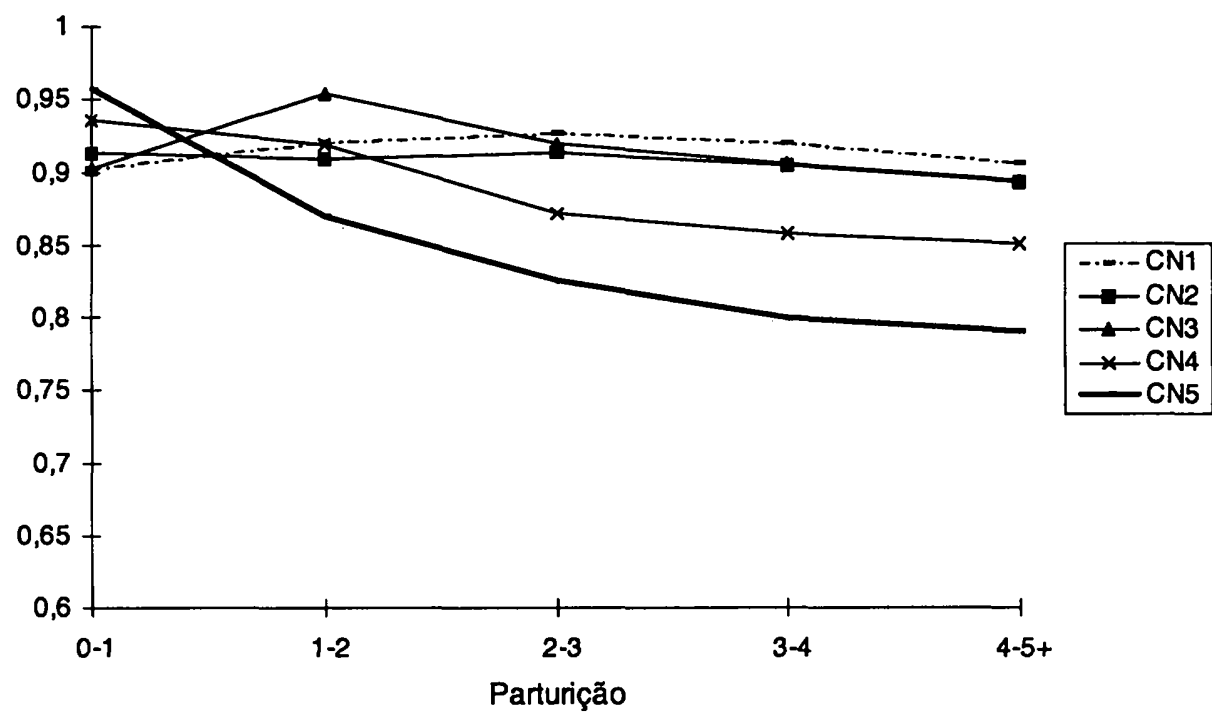

A linha pontilhada mostra as taxas de progressão da primeira coorte de mulheres (nascidas entre 1890 e 1900). A linha forte contínua, para a última coorte, que engloba as nascidas entre 1935-45. No Gráfico 5, revela-se uma redução nas taxas de progressão e uma mudança na forma da curva de côncava à convexa, o que sugere a existência de controle da fecundidade por número de filhos já tidos. As mudanças parecem começar na coorte que nasceu em 1910-19, que apresentou um aumento na proporção de mulheres com um filho que tiveram o segundo. A partir daí, as outras taxas declinaram com a parturição, mostrando um comportamento influenciado por esta. Em relação à coorte anterior, para cada ordem de nascimento, as taxas de progressão aumentaram, o que pode explicar o aumento da fecundidade verificado no final dos anos 40 e 50.

\footnotetext{
- Neste caso, não foram utilizados os dados do Censo Demográfico de 1991, pela dificuldade de processá-los.
} 
Mudanças no comportamento reprodutivo causadas pelo número de filhos existentes são nítidas a partir da coorte nascida em 1920-29 e reforçadas pela coorte seguinte. Elas são traduzidas poruma redução da proporção de mulheres que tiveram filhos de parturição mais elevada. Observou-se uma redução temporal nestas taxas, com exceção da relativa ao primeiro filho. O aumento das taxas de progressão ao primeiro filho tanto pode estar associado a variações em nupcialidade, esterilidade primária e nati-mortalidade, como ser indicador de alguns erros na codificação dos dados censitários anteriores a 1980.

Nos Gráficos de 6 a 10, observam-se as taxas de progressão para as regiões Sudeste, Sul, Centro-Oeste, Nordeste e Norte, respectivamente. A ordem escolhida visa a mostrar uma seqüência de estágios de transição da fecundidade. Dois pontos são comuns a todas as regiões: a transformação da curva de côncava em convexa e o aumento da progressão ao primeiro filho, ou seja, o aumento da proporção de mulheres casadas que se tornaram mães.

No Gráfico 6, encontram-se as taxas de progressão da região Sudeste, que apresentou mudanças mais significativas. $O$ formato da curva das três primeiras coortes foi côncavo, o que indica ausência de controle por parturição, ou seja, não há indicações de que estas mulheres decidissem o seu comportamento reprodutivo pelo número de filhos existentes. Verificou-se um aumento da proporção de mulheres com um filho que tiveram o segundo, o que pode explicaro aumento da fecundidade observado no final dos anos 40 e início dos 50.

\section{Gráfico 6 - Taxa de progressão a uma dada parturição. Região Sudeste - mulheres de 50 a 59 anos}

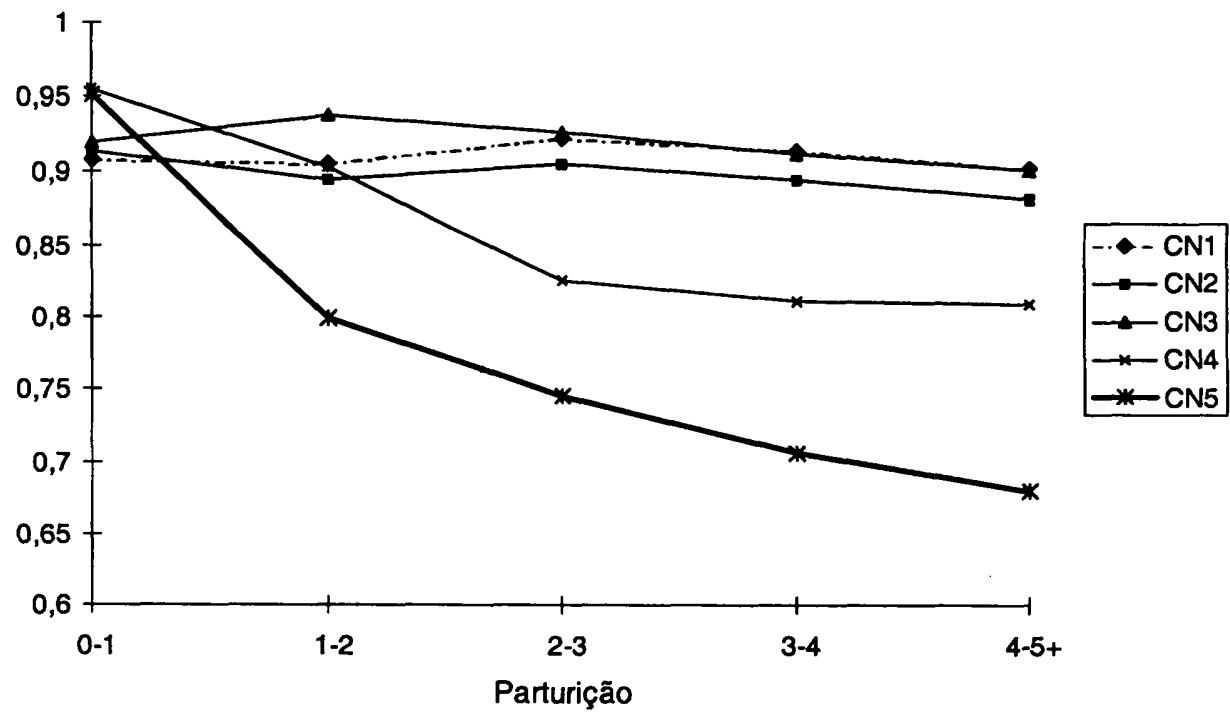


Observa-sc uma modificação no comportamento reprodutivo a partir da coorte de mulheres nascidas em 1920-30, a CN4. Esta curva apresenta um comportamento convexo, indicando a existência de um regime de fecundidade dependente da parturição. Com exceção da progressão para o primeiro filho, todas as taxas declinaram, decréscimo mais cxpressivo à medida que a ordem de nascimento aumentava. O cfeito da parturição se fez sentir mais intensamente na progressão para o terceiro filho, ou scja, as taxas diminucm à medida que a parturição aumenta, scndo o cfeito mais expressivo o provocado pelo segundo filho. Foram relativamente poucas as mulheres com dois filhos que tiveram o terceiro. A partir daí, o cfeito parturição é menos significativo - o gráfico indica que, a partir do terceiro, as mulheres continuam a ter filhos. Isto, provavelmente, ć resultado de um 'efeito coortc'. Algumas mulheres interrompem a vida reprodutiva com dois filhos, c as que têm o segundo filho prosseguem para parturições mais elevadas.

A última coorlc, nascida quinzc anos depois da antcrior, mostrou uma redução expressiva em todas as taxas de progressão, com exceção da primcira. Neste caso, o efcito parturição parece mais expressivo na progressão para o segundo filho, indicando uma preferência por famílias de apenas um filho. As taxas de progressão declinam com a ordem de nascimento, como sugere a teoria clássica da transição demográfica. Quanto maior o número de filhos, menor a probabilidade de a muther ter um filho adicional.

No Gráfico 7, encontram-sc as taxas de progressão para a região Sul. As duas primciras coortes apresentam um comportamento muito semelhante ao obscrvado na região Sudeste. As mudanças nesta área começaram a se fazer sentir na terceira coorte, ou scja, entre as mulheres nascidas entre 1910-20. A partir daí, as taxas de progressão declinavam com o aumento da parturição e já se pode inferir uma certa preferência por famílias de dois filhos. A quarta coorte mostra uma redução nas laxas a partir da progressão para o terceiro filho comparativamente à terccira. Este decréscimo é muito mais expressivo comparando-se a quinta com a quarta coortes. Observa-se uma inflexão na taxa de progressão para o quarto filho, o que pode indicar um efeito coorte, provocado pelas mulheres mais velhas. Nesta coorte, também sc obscrva um aumento na proporção de mulheres que se tornaram mães. 
Gráfico 7- Taxa de progressão a uma dada parturição. Regiāo Sul - mulheres de 50 a 59 anos

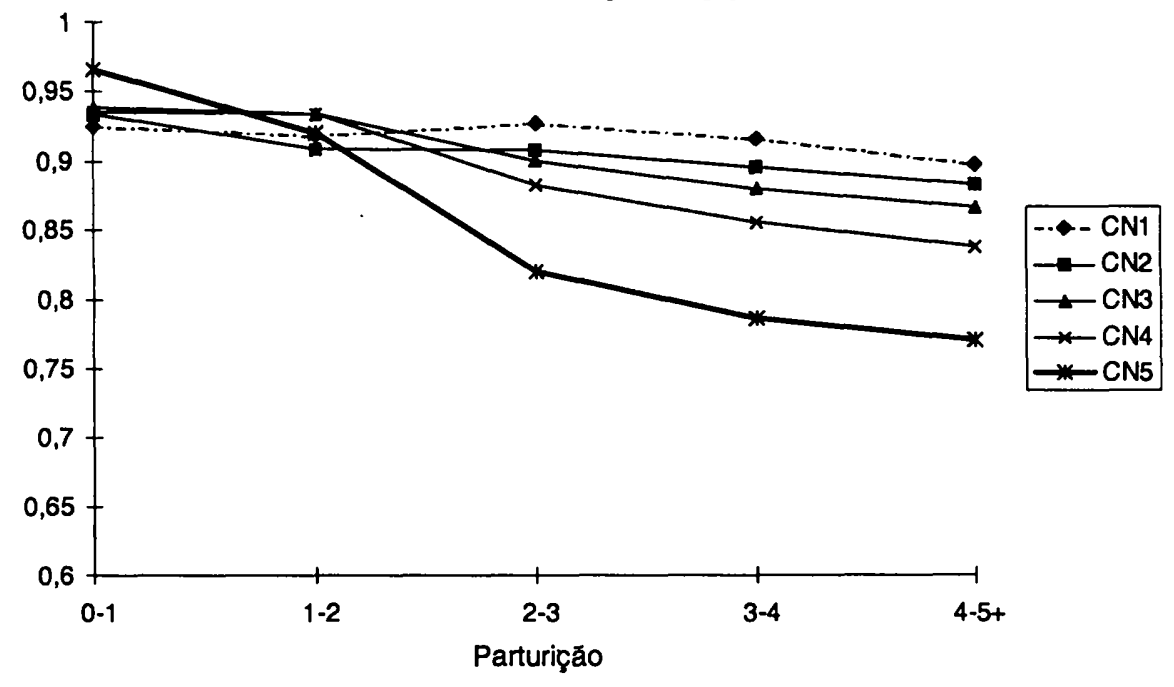

Opadrãode formação de família das mulheres da regiãoCentro-Oeste está apresentado noGráfico 8. Em relação à primeira coorte, a segunda e a terceira apresentaram um leve acréscimo na taxa de progressão para o primeiro filho e um decréscimo nas progressões para o terceiro equarto filhos. Observa-se uma leve mudança de formato da curva na quarta coorte, com uma redução das taxas de progressão ao quarto filho. As mudanças ficam bem evidentes na quinta coorte, onde se nota uma preferência por famílias de três filhos. Observa-se também um aumento na proporção de mulheres que se tornaram mães.

Gráfico 8 - Taxa de progressão a uma dada parturição. Região

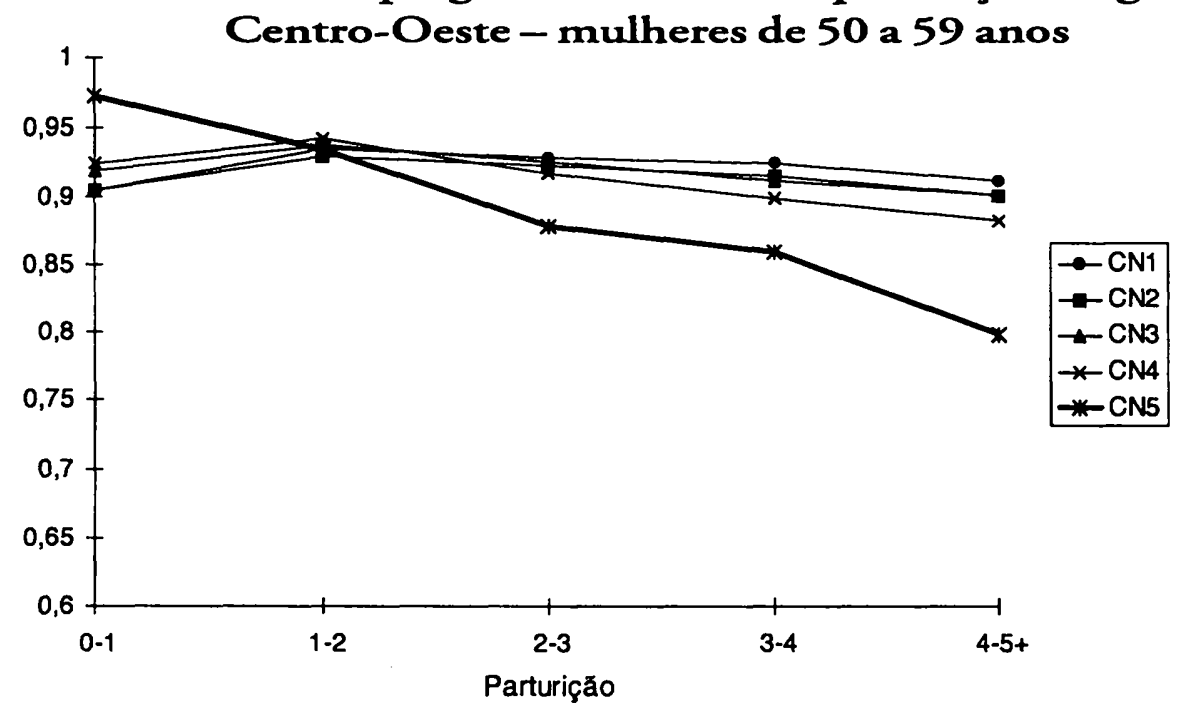


No Nordeste, tem se observado um aumento na proporção de mulheres casadas que se tornaram mães (Gráfico 9). Isto só não se verificou entre a coorte nascida em 191019 , que apresentou um aumento na proporção de mulheres com um filho que tiveram o segundo. Mudanças no formato da curva, tal como preconizadas pela teoria da transição demográfica, começam a ser indicadas pela coorte nascida em 1920-29: observase uma leve preferência por famílias de dois filhos. A última coorte mostra um aumento da proporção de mulheres que tiveram filhos e uma redução na probabilidade de as que tinham três passarem a ter quatro filhos.

\section{Gráfico 9 - Taxa de progressão a uma dada parturição. Regiāo Nordeste - mulheres de 50 a 59 anos}

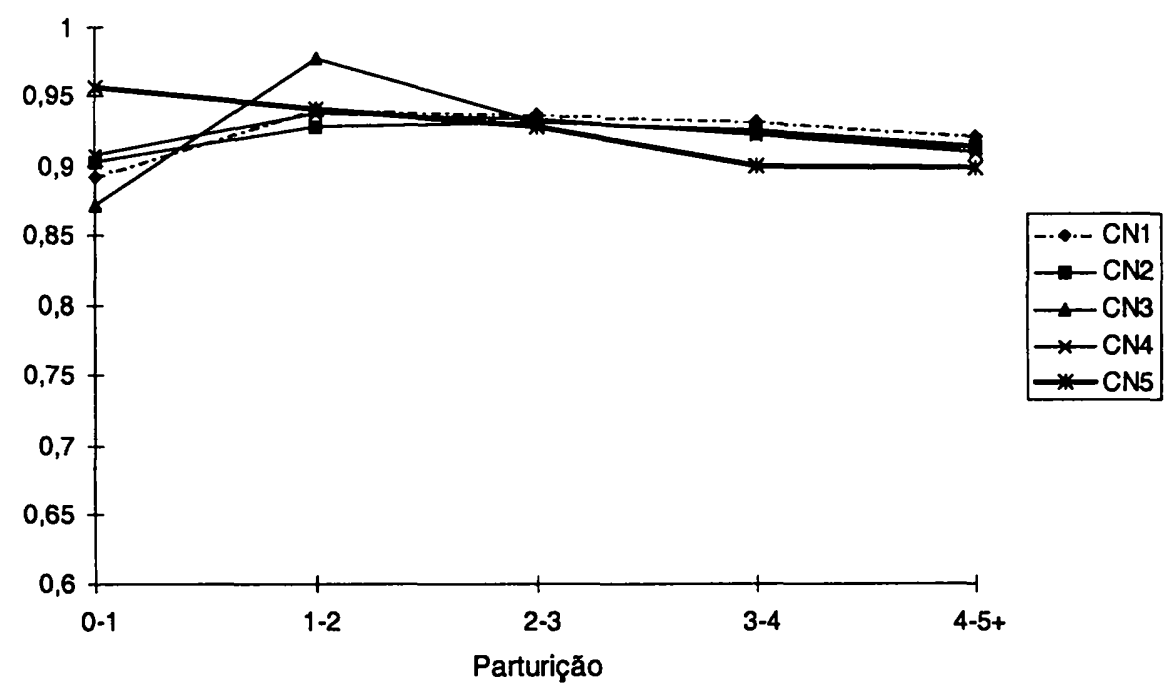

No Gráfico 10, encontram-se as taxas de progressão por parturição para as mulheres nortistas de 50 a 59 anos. Também se observa um aumento na proporção de mulheres que tiveram filhos, tendo sido este aumento progressivo no tempo. Mudanças no formato da curva apareceram na quarta coorte, mas com sentido oposto ao preconizado pela teoria da transição demográfica. Aumentou a proporção de mulheres com dois filhos que tiveram o terceiro. Por outro lado, a última coorte mostra indicações de uma preferência por famílias com dois filhos, tendo apresentado um aumento na proporção de mulheres casadas que tiveram o primeiro filho. 


\section{Gráfico 10 - Taxa de progressão a uma dada parturição. Regiáo Norte - mulheres de 50 a 59 anos}

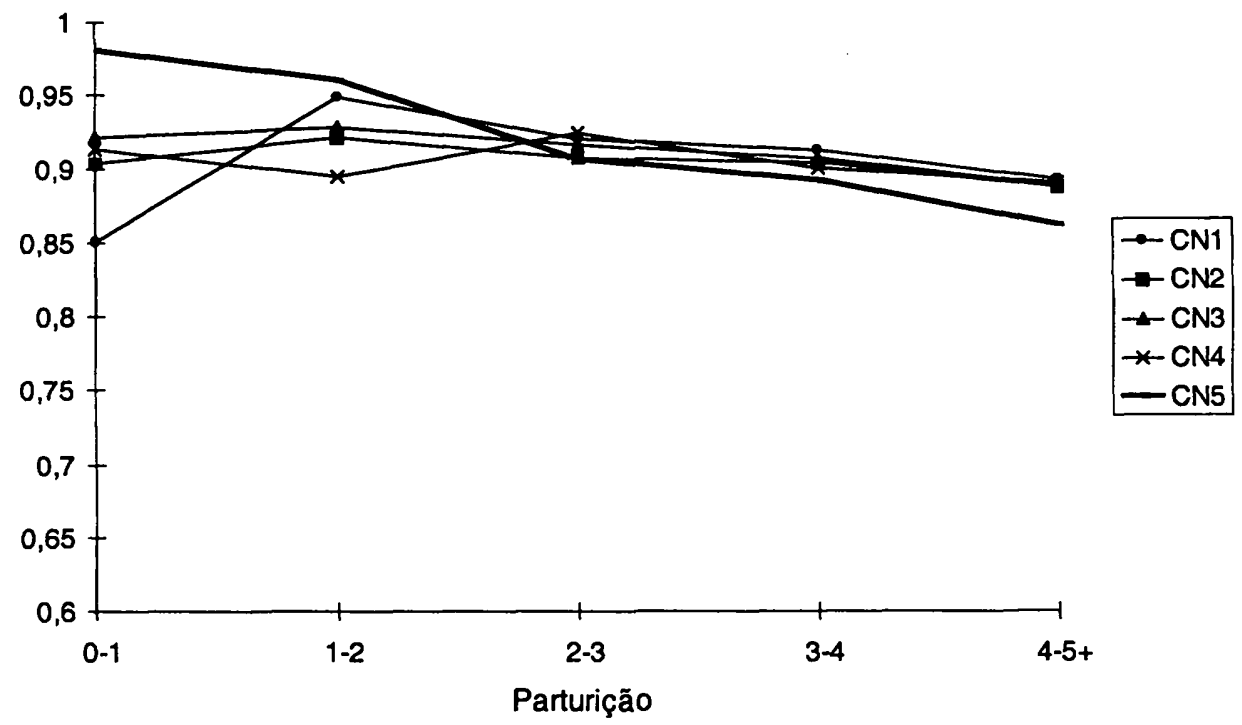

\section{Conclusão}

O trabalho mostrou a evolução das taxas de fecundidade total de 17 coortes de mulheres nascidas entre 1890 e 1975, para o Brasil e para todas as cinco grandes regiões. A fecundidade apresentou uma tendência generalizada de queda, principalmente a partir das mulheres nascidas entre 1940-45. Não obstante, esta queda foi intercalada por movimentos ascendentes, o que ocorreu em todas as regiões. Este incremento foi mais evidente na fecundidade marital. Isto significa que o aumento na taxa de nupcialidade contribuiu para impedir maiores quedas na taxa de fecundidade total.

Ao se analisarem as trajetórias da fecundidade das regiões, comparadas à trajetória do Brasil, nota-se uma grande variação regional, principalmente até a coorte nascida em 1940-45. A partir desta, no entanto, todas as regiōes apresentam fortes diminuiçōes na fecundidade e, nesta década, as variações foram exclusivamente determinadas pelo efeito dos fatores ligados à anticoncepção, ao passo que o efeito nupcialidade agiu em sentido contrário à queda da fecundidade. Apenas na década de 70 o efeito nupcialidade contribuiu para a queda de fecundidade.

A queda da fecundidade foi acompanhada de uma mudança no padrão de formação de família, observando-se uma forte tendència à preferência por famílias com dois filhos em média. Regionalmente, estas preferências são diferenciadas: na região Sudes- 
te, há indicações de que o tamanho de família preferido é a de um filho; no Sul, a de dois filhos; na Nordeste, é a de três filhos.

Para concluir, ressalta-se que a fecundidade da mulher brasileira já atingiu níveis próximos aos de reposição, principalmente nas regiões Sul e Sudeste. O efeito imediato desse processo é a redução do crescimento populacional seguida de mudanças na distribuição etária no sentido de um envelhecimento.

\section{Referências Bibliográficas}

BONGARTS, J. A Frameworkfor analysing the proximatedelerminants of Fertility. Population and Development Review, 4(1):105-132, 1978.

Brass, W. P/F Synthesis and Parity Progression Ratios. In: CENTRE For PopULAmonStudies. Advances in Methods for Estimating Fertility and Mortality from Limited and Defective Data. London: London School of Hygiene \& Tropical Medicine, 1985, p. 69-74.

COALE, A. \& Trussel, J. Modeling Fertility Schedules: variations in the age structure of childbearing in human populations. Population Index (40):185-258, 1974.

FRIAS, L.A.M. \& OLIVEIRA, J.C. Níveis, tendências e diferenciais de fecundidade no Brasil a partir da década de 1930. Revista Brasileira de Estudos Populacionais, 8(1/2):72-119. Campinas: Associação Brasileira de Estudos Populacionais (ABEP), 1991. 



\section{Ainda a Questão da Esterlização Feminina} no Brasil

Elza Berquó

\section{Introdução}

Segundo projeções das Nações Unidas, o mundo em desenvolvimento abrigará 2,458 bilhões de mulheres no ano 2000, das quais 1,255 bilhões, ou seja, $51 \%$, estarão em idade reprodutiva (15-49 anos) (United Nations, 1996).

O cenário contraceptivo na virada do século refletirá principalmente o desejo de regulação da fecundidade, a disponibilidade de métodos contraceptivos e o acesso aos meios de evitar uma concepção, que prevalecerão dentre esses bilhões de mulheres na idade reprodutiva que farão parte das populações do chamado Terceiro Mundo.

Os últimos dados mundiais disponíveis sobre uso de anticoncepcionais mostram $57 \%$ de usuários correntes de algum método (Tabela 1). Como se vê, esta proporção varia de $72 \%$ a $54 \%$, quando se passa das regiões mais desenvolvidas para aquelas em desenvolvimento. Também os níveis de preferência e/ou de disponibilidade são diversos em relação dos vários métodos.

Com base nestas médias, pode-se prever que haverá 678 milhões de usuárias de algum método anticoncepcional, dos quais 36\%, isto é, 244 milhões, serão mulheres esterilizadas. Isto significa que, do total de mulheres unidas e na idade reprodutiva, 20\% já terão posto fim ao processo reprodutivo. 


\section{Tabela 1 - Proporção de uso corrente de métodos contraceptivos entre mulheres unidas, em idade reprodutiva -1994}

\begin{tabular}{lrcr} 
Métodos & Mundo & Regiōes mais desenvolvidas & Regiöes menos desenvolvidas \\
\hline Esterilização feminina & 17 & 8 & 20 \\
Esterilização masculina & 5 & 4 & 5 \\
DU & 12 & 6 & 14 \\
Pilula & 8 & 16 & 6 \\
Condom & 5 & 14 & 3 \\
Naturais (") & 8 & 22 & 5 \\
Outros (**) & 2 & 2 & 1 \\
Algum método & 57 & 72 & 54
\end{tabular}

(*) Inclui: abstinência periódica ou total, tabela, coito interrompido, ducha, métodos folclóricos.

(**) Inclui: injetáveis, diafragmas, capas cervicais e espermicidas.

Fonte: World Contraceptive Use 1994, Population Division - United Nations.

No Brasil, onivel deusodecontraceptivos vem semantendoem patamares elevados eascendentesnosúltimosdezanos, tendopassadode 70\%em 1986 para 76,7\%, em 1996 (BEMEM, 1996)este último já ultrapassandoa média observada nas regiões mais desenvolvidas (Tabela 1).

De acordo com os dados de 1996, estima-se que, do total de 39,993 milhões de mulheres brasileiras na idade reprodutiva projetado para o ano 2000 (Camarano \& Beltrão, 1997), 30,675 milhões demandarão algum método anticoncepcional.

Tentaremos atualizar o panorama nacional quanto ao uso de contraceptivos, dando destaque à esterilização feminina que também no País, como veremos, encabeça a lista dos métodos anticoncepcionais. Procuraremos caracterizar os padrões e tendências desta prática, buscando contribuir para uma maior compreensão das questões relacionadas à saúde reprodutiva das mulheres brasileiras.

\section{O cenário da contracepção no Brasil}

No País registra-se elevada proporção de uso de métodos contraceptivos, isto é, 76,7\% das mulheres em idade reprodutiva e unidas são usuárias de algum método (Tabela 2).

O elevado índice de uso atual de métodos anticoncepcionais por mulheres unidas torna-se ainda mais eloqüente quando se toma em consideração que dentre as nãousuárias encontram-se mulheres que não podem mais conceber - em função da menopausa, de histerectomias ou, ainda, por infertilidade decorrente de outras causas. De acordo com a Pesquisa Nacional sobre Demografia e Saúde (PNDS) de 1996, 23,3\% das mulheres unidas de 15 a 49 anos não estavam usando nenhum método para evitar 
uma concepção. Deste total, 16,4\% declararam-se menopausadas ou histerectomizadas. Incluindo-se as que declararam ter dificuldades para engravidar, este percentual chega a 30,5\%. Ou seja, seria de todo fundamental que as proporções de uso fossem calculadas apenas para mulheres aptas a conceber, o que via de regra não é o caso dos dados disponíveis das diversas pesquisas.

Concentrou-se ainda mais, nos últimos dez anos, o uso no País dos chamados métodos modemos. Das usuárias (incluindo também métodos usados pelos parceiros), 89,7\% recorreram a eles em 1986, percentual que cresceu para 91,7\% em 1996 (Tabela 2). Pouco se alterou, entretanto, a posição relativa dos métodos usados no total de mulheres unidas. A esterilização feminina, no topo da lista, seguida pela pílula, e esta pelo condom, caracterizou 1986 e 1996. A exceção foi a vasectomia, mais freqüente do que o DIU em 1996.

\section{Tabela 2 - Proporção de uso atual de métodos contraceptivos entre mulheres atualmente unidas. Brasil}

\begin{tabular}{lccc}
\hline Métodos & $\begin{array}{c}\text { Mulheres unidas } \\
\text { de 15-54 anos } \\
\text { PNAD-86 }\end{array}$ & $\begin{array}{c}\text { Mulheres unidas } \\
\text { de 15-49 anos } \\
\text { PNDS-96 }\end{array}$ & $\begin{array}{c}\text { Mulheres unidas de 15-49 anos e } \\
\text { usuárias de algum método } \\
\text { PNDS-96 }\end{array}$ \\
\hline Algum método & 70,0 & 76,7 & 100,0 \\
Métodos modernos & 62,8 & 70,3 & 91,6 \\
Esterilização feminina & 31,1 & 40,1 & 52,3 \\
Pilua & 28,7 & 20,7 & 27,0 \\
Condom & 1,3 & 4,4 & 5,7 \\
DU & 1,1 & 1,1 & 1,4 \\
Vasectomia & 0,6 & 2,6 & 3,4 \\
Outros (") & 0,0 & 1,3 & 1,7 \\
Métodos tradicionais & 6,0 & 6,1 & 8,0 \\
Abstinência periódica (**) & 4,3 & 3,0 & 4,0 \\
Coito interrompido & 1,7 & 3,1 & 4,0 \\
Outros (**) & 1,2 & 0,3 & 0,4 \\
\hline
\end{tabular}

Notas:

(") Inclui Norplant, injetáveis e métodos vaginais.

("*) Inclui tabela, billings e temperatura.

(**) Inclui todos os métodos folclóricos.

Fonte: PNAD-86; PNDS, 96.

Quanto aos níveis de preferência, a esterilização feminina ganhou mais adeptas, crescendo de $31,1 \%$ a 40,1\% no período considerado. Ganharam também o condom e a vasectomia. Em contraposição, a pílula teve aceitação declinante no mesmo período.

Dentre os métodos tradicionais, enquanto a abstinência periódica perdeu na preferência, o recurso ao coito interrompido cresceu de $1,7 \%$ para 3, 1\%. Na Tabela 2 demonstra-se também que, dentre usuárias de algum método, a esterilização feminina responde por mais de $50 \%$. Dez anos antes, o índice era $44,4 \%$. 
Interessante observar também como se comportam as mulheres mais jovens, em especial as não-unidas, mas sexualmente ativas, uma vez que parte daquclas $\mathrm{cm}$ união cstarão considerando a possibilidade de ter filhos. Ao se analisarem os dados da Tabela 3 , percebe-se que, para as não-unidas, a proporção de uso de algum método corresponde a 66\%, 83,5\% e 79,4\%, nos grupos etários 15-19, 20-24 c 25-29 anos, respectivamente, valores sempre superiores aos correspondentes, pela ordem, para as mulheres unidas. Além de elevadas, em especial a partir dos 20 anos, as freqüências de uso atual refercmse a métodos modernos. O uso da pílula predomina cntre as jovens, scjam unidas ou não. Já o recurso ao condom ć três vezes mais freqüente entre as não-unidas, cmbora scu uso seja considerado ainda pouco expressivo, quando se levam em conta os riscos do HIV. Como se sabe, desdc o início dos anos 90 a cpidemia de Ains tem se expandido entre mulheres c, segundo a Uivads (The Joint United Nations Programme on HIV/AIDS), 40\% das novas infeç̧ões que ocorrem no mundo atingem o sexo feminino, comprometendo preponderantemente aquelas na faixa dos 15 aos 25 anos.

\section{Tabela 3 - Uso atual de contraceptivos para mulheres unidas e sexualmente ativas não-unidas, segundo a idade. Brasil - 1996}

\begin{tabular}{lrrrrrr}
\hline Método & \multicolumn{3}{c}{ Unidas } & \multicolumn{3}{c}{ Não-unidas sexualmente ativas } \\
\cline { 2 - 7 } & $15-19$ & $20-24$ & $25-29$ & $15-19$ & $20-24$ & $25-29$ \\
\hline Algum método & 54,1 & 66,0 & 77,6 & 66,0 & 83,5 & 79,4 \\
Métodos modernos & 47,2 & 61,6 & 70,1 & 61,0 & 75,5 & 74,8 \\
Pilula & 36,1 & 39,5 & 32,9 & 36,7 & 49,8 & 27,8 \\
Condom & 6,4 & 5,0 & 5,4 & 19,7 & 17,8 & 14,9 \\
Esterilização feminina & 0,4 & 11,4 & 26,9 & 0,0 & 2,1 & 25,6 \\
Injeções & 3,1 & 3,6 & 2,0 & 4,6 & 4,4 & 3,3 \\
Outros & 0,0 & 2,1 & 2,9 & 0,0 & 1,4 & 3,2 \\
Métodos tradicionais & 6,3 & 4,1 & 7,3 & 5,1 & 7,9 & 4,6 \\
\hline
\end{tabular}

Fonte: PNDS, 1996.

Entre as unidas, de 20 a 24 anos, a esterilização já representa 11,4\% no rol dos contraceptivos, freqüência esta de $2 \%$ dentre as não-unidas. Na faixa etária scguinte, dos 25 aos 29 anos, as proporçõcs se igualam, independentemente de a mulher estarou não unida.

Ressalte-sc que não cstar unida no momento da cntrevista não significa nunca tcr estado unida, ou seja, esta categoria pode abranger soltciras, separadas, divorciadas ou até viúvas. Daí porque a estcrilização pode ter ocorrido durante uma união já desfeita.

Outro aspecto no panorama contraceptivo no País é o generalizado uso de métodos $\mathrm{cm}$ todas as regiões, variando de $68,2 \%$ no Nordeste a $84,5 \%$ no Centro-Ocste (Tabcla 4). Esta variaçãode 16,3 pontos percentuais reduz-se bastante quando se observa 
a proporção de usuárias qu coptam por métodos modemos. Com efeito, é de apenas 5,4 pontos percentuais esta diferença, estando as proporções sempre acima de $90 \%$. Mesmo nas áreas rurais, o recurso aos métodos modernos chega a $88,4 \%$.

Doângulo dos diferenciais por anos de estudo, observa-se que são as mulheres com maior escolaridade, $11 \%$, e as analfabetas, $12 \%$, as que mais recorrem aos meios tradicionais de evitar uma gravidez, certamente por motivos diversos. As primeiras, por disporem de maiores informações; as segundas, por não disporem nem de informações nem de recursos para a compra de anticoncepcionais ou para pagar cirurgias contraceptivas.

Olhando o rol de métodos tradicionais de que lançaram mão estas mulheres, verifica-se que a tabcla, billings ou temperatura foram os preferidos das mais escolarizadas, predominando o coito interrompido entre as analfabetas.

\section{Tabela 4 - Uso atual de métodos modernos* de anticoncepção entre mulheres unidas, para algumas características selecionadas. Brasil - 1996}

\begin{tabular}{lccc}
\hline Características & Algummétodo & Métodos modernos & $\begin{array}{c}\text { Proporção de uso de métodos } \\
\text { modernos entre usuárias }\end{array}$ \\
\hline Região & & & \\
\hline Rio de Janeiro & 83,0 & 76,2 & 91,8 \\
São Paulo & 78,8 & 71,5 & 90,7 \\
Sul & 80,3 & 72,7 & 90,5 \\
Centro-Leste & 77,8 & 70,8 & 91,0 \\
Centro-Oeste & 84,5 & 81,0 & 95,9 \\
Nordeste & 68,2 & 62,3 & 91,3 \\
Norte ("*) & 72,3 & 68,1 & 94,2 \\
\hline Situação do domicilio & & & \\
\hline Urbano & 78,7 & 72,6 & 92,2 \\
Rural & 69,2 & 61,2 & 88,4 \\
\hline Anos de educação & & & 88,3 \\
\hline Nenhum & 64,1 & 56,6 & 92,0 \\
$1-3$ & 69,2 & 63,7 & 91,7 \\
4 & 75,0 & 68,8 & 93,0 \\
$5-8$ & 80,1 & 74,5 & 90,7 \\
$9-11$ & 83,1 & 75,4 & 89,0 \\
\hline 12 ou mais & 85,7 & 76,3 & \\
\hline
\end{tabular}

(") Inclui pílula, DIU, injeções, métodos vaginais, condom, esterilização feminina e vasectomia.

("*) Inclui somente áreas urbanas.

Fonte: PNDS, 1996. 


\section{A esterilização feminina}

Dados recentes indicam que $40,1 \%$ das mulheres brasileiras, unidas e em idade reprodutiva, estavam esterilizadas em 1996. Este índice variou de 29,0\% no Sul a 59,5\% na Região Centro-Oeste (Tabela 5). Com exceção do Rio de Janeiro, pode-se dizer que a esterilização é maior nas regiões menos desenvolvidas do país. Já não há diferencial marcante entre mulheres vivendo no campo ou nas cidades.

Os anos de escolaridade constitucm um diferencial quanto ao recurso a essa prática, passando de 45,7\%, para analfabetas, a 35,7\%, para aquelas com 12 anos ou mais anos de instrução a proporção de esterilizadas.

Como se pode observar na Tabcla 5 , o leque de alternativas contraceptivas fecha-sc cada vez mais, por conta do papel que a esterilização feminina vem ocupando no conjunto de métodos. Esta prática, que respondia, cm 1986, por 49,5\% dos métodos modernos, passou a concentrar $57,0 \%$ das usuárias cm 1996. Esta concentração ć mais acentuada nas regiõcs Nordeste (70,5\%), Nortc (75,3\%) c Centro-Oeste (73,5\%).

\section{Tabela 5 - Esterilização feminina entre mulheres unidas, segundo algumas características. Brasil - 1996}

\begin{tabular}{c} 
Características Esterilização feminina $\begin{array}{c}\text { Esterilização feminina em relação aos } \\
\text { métodos modernos (\%) }\end{array}$ \\
\hline
\end{tabular}

\begin{tabular}{lll}
\hline Região & & \\
Rio de Janeiro & 46,3 & 60,8 \\
São Paulo & 33,6 & 47,0 \\
Sul & 29,0 & 40,0 \\
Centro-Leste & 38,8 & 54,8 \\
Nordeste & 43,9 & 70,5 \\
Norte & 51,3 & 75,3 \\
Centro-Oeste & 59,5 & 73,5 \\
\hline Situação do domicílio & & \\
\hline Urbano & 40,6 & 55,9 \\
Rural & 38,0 & 62,1 \\
\hline Anos de educação & & \\
\hline Nenhum & 45,7 & 80,7 \\
$1-3$ & 44,9 & 70,5 \\
4 & 40,4 & 58,7 \\
$5-8$ & 36,9 & 49,5 \\
$9-11$ & 38,8 & 51,4 \\
12 ou mais & 35,7 & 46,8 \\
\hline
\end{tabular}

Fonte: PNDS, 1996. 
É impressionante a situação das mulheres analfabetas, em geral as mais pobres, para as quais o recurso à esterilização representa praticamente toda a possibilidade de uso de métodos modernos.

A esterilização acontece cada vez mais cedo na vida das mulheres. A PNDS de 1996 revela que a idade mediana à esterilização foi igual a 28,9 anos, o que significa que as mulheres estão recorrendo a esta prática mais cedo do que há dez anos, quando este indicador foi de 31,4 anos. Verifica-se, observando os dados contidos na Tabela 6, que uma quinta parte do total de mulheres já estava esterilizada, em 1996, antes dos 25 anos, perfazendo com o grupo etário seguinte $57,1 \%$, ou seja, referem-se a esterilizações recentes.

\section{Tabela 6-Distribuição percentual das mulheres esterilizadas, segundo a idade à época da cirurgia. Brasil - 1996}

Idade à esterilização em anos

$\%$ de mulheres esterilizadas

\begin{tabular}{lr}
\hline Menos de 25 & 20,5 \\
$25-29$ & 36,6 \\
$30-34$ & 27,9 \\
$35-39$ & 12,2 \\
$40-44$ & 2,6 \\
$45-49$ & 0,1 \\
\hline TOTAL & 100,0 \\
\hline
\end{tabular}

Fonte: PNDS, 1996.

Em trabalhos anteriores já chamamos a atenção para o abuso dos partos cesáreos no País e demonstramos a alta e peculiar associação entre cesárea e esterilização (Berquó, 1993). Da mesma forma, diversos autores (Barros et al., 1991; Faúndes \& Cecatti, 1991) vêm também denunciando esta situação de alta prevalência de parto cirúrgico para abrigar uma contracepção cirúrgica, visto que esta última ainda não é permitida por ferir o Código Penal Brasileiro e o Código de Ética Médica ${ }^{2}$.

Dados da Pesquisa Nacional por Amostra de Domicílio (PNAD)-96 vêm mostrar que $58,8 \%$ das esterilizações foram realizadas durante uma cesárea; $15,1 \%$, logo depois do parto vaginal; e 25,9\% em outra ocasião, por laparoscopia ou por mini-laparotomia. $\mathrm{Na}$

\footnotetext{
I Pelo Código Penal Brasileiro, elaborado em 1940, Art. 129, §2O. Inciso III, a esterilização é crime por ser considerada uma lesão corporal de natureza gravissima, quando resulta na perda ou inutilização da função reprodutiva. Neste sentido, a pena correspondente é de reclusão de 2 a 8 anos.

${ }^{2}$ Cap.VI - Da Responsabilidade Médica, Art.52 - "A esterilização é condenada, podendo, entretanto, ser praticada em casos excepcionais, quando houver precisa indicação, referendada por dois médicos, ouvidos em conferência".
} 
Tabela 7 é possível apreciar os altíssimos índices de esterilização durante um parto cesáreo, principalmente para o Rio de Janciro, São Paulo e a Região Sul. O Nordeste chama a atenção, em especial, pelo menor índice, o que nos leva a concordar com a interpretação de que está sendo montado um esquema de oferta dirigida à esterilização, principalmente nas regiões menos desenvolvidas (Perpétuo, 1996). Tendo em conta as altas taxas de esterilização nestas regiões, o não uso da cesárea como locus cirúrgico para sua realização pode vir a beneficiar as mulheres, reduzindo seus riscos associados às cesárcas.

\section{Tabela 7 - Distribuição percentual das esterilizaçōes por ocor- rência durante um parto cesáreo ou fora do parto, se- gundo regiōes e situaçōes do domicílio. Brasil - 1996}

\begin{tabular}{lccc}
\hline Características & No parto cesáreo & Depois do parto normal & Em outra ocasião \\
\hline Região & & & \\
Rio de Janeiro & 71,9 & 8,3 & 19,4 \\
São Paulo & 74,4 & 8,8 & 16,9 \\
Sul & 67,6 & 14,7 & 17,7 \\
Centro-Leste & 54,7 & 15,2 & 30,0 \\
Nordeste & 43,2 & 18,8 & 37,8 \\
Norte & 55,1 & 25,2 & 19,8 \\
Centro-Oeste & 58,0 & 17,9 & 24,1 \\
\hline Situação do domicílio & & & \\
\hline Urbano & 61,8 & 13,8 & 33,3 \\
Rural & 45,6 & 21,4 & 33,1 \\
\hline
\end{tabular}

Por dispor de informações sobre anticoncepção cm quatro pontos temporais, 1980, 1986, 1991 e 1996, o Nordeste permite uma análise da tendência dos índices de esterilização.

Em 1986, 53\% das nordestinas unidas, cm idade reprodutiva eram usuárias de algum método e $25 \%$ estavam esterilizadas. Dentre as usuárias, esta prática representava 47\%. Em 1996, a proporção de uso subiu para 68\% (Tabela 4) e 44\% estavam esterilizadas. Dentre cstas, 64\% das usuárias já haviam encerrado o processo reprodutivo.

Para uma análise mais aprofundada sobre csterilização no Nordeste, conta-se com um estudo comparativo entre 1980 e 1991 (Perpétuo, 1996). Os dados de 1980 refercmse à Pesquisa sobre Saúde Materno-Infantil (PSMIPF/80) que cobriu Rio Grande do Norte, Paraíba, Pernambuco c Bahia. Com o fim de manter a comparabilidade, a autora trabalhou também com as quatro unidades da Federação na PNDS-91 - que, como sc recorda, cobriu todo o Nordeste.

De acordo com os dados apresentados na Tabcla 8, cm 1980, a esterilização era marcadamente maior nas áreas urbanas, entre as mulheres com maior escolaridadc, c nas famílias com mais recursos. Onzc anos mais tarde, ainda se mantêm estes dife- 
renciais, mas são muito menos marcados do que no periodo anterior. Foi exatamente nas áreas rurais, nos contextos mais pobres e entre mulheres com menor escolaridade onde sc deram os maiores aumentos relativos nas taxas de esterilização. Como diz Perpétuo (1996): "Em 1991, o aumento do recurso à cirurgia é uma tendência da qual participam todas as mulheres. A csterilização estendeu-sc a todas as camadas."

Salienta-se, também, que a idade à esterilização caiu de 31,0 anos, em 1980, para 28,2 anos, em 1991 .

\section{Tabela 8 - Taxas de esterilização (\%) entre mulheres de 15 - 44 anos, que tiveram filhos nos 5 anos anteriores à pesquisa, segundo características selecionadas}

\begin{tabular}{lrrr}
\hline Características & 1980 & 1991 & Diferença relativa 80/91 (\%) \\
\hline Situação do Domicílio & & & \\
\hline Urbano & 16,6 & 31,9 & 92 \\
Rural & 6,4 & 23,8 & 272 \\
\hline Anos de Educação & & & \\
\hline $0-3$ & 9,2 & 23,7 & 158 \\
$4-7$ & 15,7 & 31,6 & 101 \\
8 e mais & 22,4 & 34,7 & 55 \\
\hline
\end{tabular}

Renda Familiar

(em salário mínimo)

\begin{tabular}{lrrr}
\hline$<2$ & 9,6 & 25,9 & 332 \\
$2-4$ & 19,4 & 29,1 & 50 \\
$5 e+$ & 25,6 & 37,7 & 47 \\
\hline TO T A L & 11,9 & 28,6 & 140 \\
\hline
\end{tabular}

Fonte: PNDS, 1996.

Embora ainda elevadas, as proporções de esterilizações realizadas durante uma cesárea foram-se reduzindo no período. De fato, de 65, 1\%, em 1980, passou a 59,8\% em 1991, continuando a declinarem 1996, para atingir 43,2\% (Tabela 7).

Em trabalhos anteriores (Morell, 1994; Berquó, 1996) em que se buscou comparar as taxas de estcrilização cntre mulheres brancas e negras, não se cncontraram diferenças. Referiam-se a São Paulo, em 1986 1992. Trabalhando com a PNad-86, Morell (1994) encontrou, para o estado, taxas de 27,9\% e 22,2\%, para brancas enegras, respectivamente. Estas taxas passarama $30,5 \%$ c 18,7\%, respectivamente, na Grande São Paulo. A Tabela 9 contrasta cstes índices, segundo anos de escolaridade da mulher, mostrando, em primeiro lugar, que a esterilização decrescia com o aumento da instrução, tanto para mulheres brancas como para as negras. Em segundo lugar, que as taxas foram sempre superiores para as mulheres brancas. 


\section{Tabela 9 - Prevalência de uso de métodos anticoncepcionais por escolaridade e cor. Mulheres unidas de 15 - 49 anos. Grande São Paulo - 1996}

\begin{tabular}{llcc}
\hline Anos de Educação & Uso e métodos usados & Cor branca & Cor negra \\
\hline Sem instrução e & Usam & 62,9 & 40,9 \\
menos de 1 ano & Plula & 18,7 & 15,6 \\
& Esterilização & 34,5 & 21,2 \\
& Outros & 9,7 & 4,1 \\
& Não usam & 37,1 & 59,1 \\
\hline De 1 a 3 anos & Usam & 72,2 & 65,4 \\
& Pilula & 22,1 & 37,2 \\
& Esterilização & 36,7 & 21,9 \\
& Outros & 13,4 & 6,3 \\
\hline \multirow{2}{*}{ anos } & Não usam & 27,8 & 34,6 \\
\hline & Usam & 69,4 & 64,1 \\
& Pilula & 22,9 & 35,2 \\
& Esterilização & 36,8 & 19,3 \\
& Outros & 9,6 & 9,6 \\
& Não usam & 30,6 & 35,9 \\
\hline \multirow{2}{*}{8 anos } & Usam & 66,8 & 67,2 \\
& Pilua & 30,7 & 43,2 \\
& Esterilização & 29,7 & 12,6 \\
\hline ou mais anos & Outros & 6,5 & 11,4 \\
& Não usam & 33,2 & 32,8 \\
\hline
\end{tabular}

Fonte: MOREL, 1994.

Usando dados da Pesquisa sobre Saúde Reprodutiva da Mulher Negra, conduzida no município de São Paulo, em 1992, Berquó (1996) tampouco encontrou diferença estatística entre as taxas de esterilização para mulheres brancas e negras, considerando extratos de renda e diferentes niveis de instrução.

A PNDS-96 permite atualizar a situação da esterilização por cor, para todo o País. Analisando-se os dados contidos na Tabela 10, percebe-se queé um pouco mais elevado para as brancas o uso de algum método, embora para as negras os métodos modernos representem $92,8 \%$ do total de uso, proporção ligeiramente maior do que a correspondente para as brancas, uma vez que estas incluem, mais do que aquelas, os métodos tradicionais em seu repertório contraceptivo. Se o leque de alternativas para regular a concepção fechou-se nos últimos anos, como já salientado anteriormente, não há dú- 
vida de que foi para as mulheres negras onde esta concentração foi mais acentuada. Basta notar que a esterilização e a pílula $(61,1 \%)$ respondem por $88,9 \%$ dos métodos modernos, enquanto que para as brancas, em conjunto, estes dois métodos $(60,8 \%)$ correspondem a $84,0 \%$ dos modemos.

Tabela 10 - Proporção de uso atual de métodos contraceptivos entre mulheres atualmente unidas, por cor. Brasil, PNDS-1996

\begin{tabular}{lcc}
\hline Métodos & Branca & Negra \\
\hline Algum Método & 80,1 & 74,0 \\
\hline Métodos Modernos & 72,4 & 68,8 \\
Esterilização Feminina & 37,7 & 42,3 \\
Pllula & 23,1 & 18,8 \\
Condom & 5,3 & 3,7 \\
Vasectomia & 3,6 & 1,8 \\
DU & 1,4 & 0,9 \\
Inję̧öes & 1,2 & 1,3 \\
\hline Métodos Tradicionais & 7,5 & 4,9 \\
Abstinência Periódica & 3,7 & 2,3 \\
Coito interrompido & 3,8 & 2,6 \\
Outros & 0,1 & 0,5 \\
\hline
\end{tabular}

Quanto à esterilização, foi maior para as mulheres negras, tanto no campo como nas cidades (Tabela 11). Esta superioridade não se verificou em todas as regiões ou unidades da Federação, como Rio de Janeiro, Sul e Nordeste.

Tabela 11 - Esterilização feminina entre mulheres unidas, de 15-49 anos, por cor, segundo algumas características. Brasil - 1996

\begin{tabular}{lcc}
\hline Características & Branca & Negra \\
\hline Região & 47,5 & 45,4 \\
Rio de Janeiro & 33,6 & 34,1 \\
São Paulo & 29,1 & 29,0 \\
Sul & 37,5 & 40,0 \\
Centro-Leste & 44,3 & 43,8 \\
Nordeste & 50,3 & 51,6 \\
Norte & 58,1 & 60,3 \\
Centro-Oeste & & \\
\hline Situação do Domicilio & 38,4 & 42,8 \\
Urbano & 34,7 & 40,5 \\
Rural & & \\
\hline
\end{tabular}


Procurando analisar uma eventual correlação entre anos de estudos atingidos pelas mulheres e a prevalência de esterilização, verifica-se que, para as mulheres brancas, a prática da esterilização diminui sistematicamente quando aumenta o nível de instrução (Tabela 12). É preciso não perder de vista que este recurso contraceptivo começou nas camadas mais altas, atingindo aos poucos as classes populares e já começa a perder a preferência das primeiras. Para as mulhcres negras, esta correlação negativa ocorre só até a categoria 5 a 8 anos de estudo. No grupo com o maior nível, isto é, com 9 ou mais anos de instrução, dá-sc o contrário, ou seja, cresce a proporção de esterilizadas.

\section{Tabela 12-Proporção de mulheres de 15-49 anos esteriliza- das, por cor, segundo anos de estudo e situação de domicúlio. Brasil - 1996}

\begin{tabular}{|c|c|c|c|c|c|c|}
\hline \multicolumn{3}{|c|}{ Anos de estudo Todas as mulheres } & \multicolumn{2}{|c|}{ Mulheres alguma vez unidas } & \multicolumn{2}{|c|}{ Mulheres atualmente unidas } \\
\hline & Brancas & Negras & Brancas & Negras & Brancas & Negras \\
\hline $\begin{array}{l}\text { Analfabeta e } \\
\text { de } 1 \text { a } 3\end{array}$ & 38,6 & 39,5 & 44,4 & 43,8 & 44,7 & 45,3 \\
\hline 4 anos & 34,0 & 30,7 & 40,1 & 39,4 & 40,6 & 40,3 \\
\hline 5 a 8 & 23,5 & 23,4 & 34,3 & 38,2 & 34,9 & 38,9 \\
\hline 9 ou mais & 19,9 & 23,1 & 33,2 & 41,7 & 34,6 & 43,3 \\
\hline Urbano & 26,0 & 28,4 & 37,5 & 41,5 & 38,4 & 42,7 \\
\hline Rural & 26,0 & 28,9 & 34,0 & 39,0 & 34,7 & 40,6 \\
\hline TOTAL & 26,0 & 28,4 & 36,9 & 41,1 & 37,7 & 42,2 \\
\hline
\end{tabular}

Fonte: PNDS, 1996.

Outro ponto a salientar é que para as mulheres com menores recursos educacionais, brancas e negras não diferem quanto à prática de esterilização. É dentre as que têm maior nível educacional que as negras apresentam taxas mais elevadas de esterilização do que as brancas.

\section{A 'cultura' da esterilização}

O recurso à esterilização segue seu curso como se já fizesse parte de um processo natural que leva todos os anos coortes de mulheres na idade reprodutiva a encerrarem definitivamente sua capacidade reprodutiva. 
As dificuldades que ainda enfrentam os serviços públicos de saúde para oferecerem um conjunto de métodos contraceptivos acabam por colocar as mulheres diante de uma perigosa encruzilhada: ou ser esterilizada, ou provocar aborto (ainda clandestino e, portanto, pouco seguro), ou prosseguir com uma gravidez indesejada.

Daí as altas taxas de anticoncepção cirúrgica, realizadas por ocasião do último parto, via cesárea (Tabela 7), testemunha da cumplicidade médico-paciente.

$\mathrm{Na}$ Pesquisa São Paulo - 1992, um terço das mulheres declararam que engravidaram pensando em se submeter à esterilização durante uma cesárea. Alguns elementos colhidos nesta mesma pesquisa levam a pensar em um processo de difusão da esterilização entre mulheres, de mãe para filha, de irmã para irmã, de amiga para amiga, isto é, uma verdadeira 'cultura' de regulação da capacidade reprodutiva, por intermédio de uma prática definitiva. De fato, Berquó (1996) encontrou que 52\% das já esterilizadas eram filhas ou irmãs de esterilizadas, refletindo uma propagação familiar inter e intrageracional.

Por outro lado, os elevados percentuais de mulheres que se dizem satisfeitas com a esterilização, por volta de 80\% (Vieira \& Ford, 1996) em diversas pesquisas realizadas no País, representam um efeito-demonstração para outras mulheres.

Evocando a segurança do método, ou o não ter mais que se preocupar com o uso de outros meios ou por já terem o número desejado de filhos, estas mulheres acabam por influenciar outras no entorno de suas vidas cotidianas. Acaba, assim, pesando pouco os relatos sobre arrependimento após uma esterilização (Vieira \& Ford, 1996), porque são vistos como um problema da outra, o qual não acontecerá com ela.

Os quase dois terços de mulheres esterilizadas que declararam que aconselhariam outras mulheres a recorrerem à esta prática, juntamente com o desejo expresso por $40 \%$ das mulheres jovens de a ela recorrerem futuramente reforçam a interpretação de que a difusão vinda do passado e intensificada no presente continuará avançando no futuro.

Esta rede familiare social envolvida neste processo permeia gerações, raças e todos os setores sociais. Dela faz parte também a cumplicidade médica. Seu vigor poderá ser atenuado quando recursos de saúde reprodutiva disponíveis, livres de discriminação, permitirem que escolhas informadas dêem às mulheres possibilidade de exercerem seus direitos sexuais e reprodutivos. 


\section{Referências Bibliográficas}

BARROS, F.C. et al. Epidemics of caesarean sections in Brazil. Lancet, 338(20):167-169,1991.

BERQUÓ, E. S. Brasil, um caso exemplar - anticoncepção e parto cirúrgicos - à espera de uma ação exemplar. Estudos Feministas, 1(2): 366-381, 1993.

BERQuó, E. S. Female Sterilization and Race in Brazil. In: REICHEMANN, R. (Org.) Racial Relations in Brazil. Michigan: Michigan University Press, 1996 (no prelo)

Camarano, A. A. \& Beltrão, K I. O futuro da população brasileira e suas implicações para a formulação das políticas sociais. Como vai? Bopulação Brasileira, Brasília, DF: Ano Il-Nº 1 , p.1,Jan/Abr-97.

FAÚNDES A., \& CECATT, J.B. A operação cesárea no Brasil. Incidência, tendências, causas, conseqüências e proposta de ação. Cademos de Saúde Pública 7(2):150 -173, abr/jun. 1991.

MoReLL, M. G. G. Anticoncepção em São Paulo em 1986: prevalências e características. A Fecundidade da Mulher Paulista. Informe Demográfico, São Paulo: FundaçãoSistema Estadual de Análise de Dados/SP-Seade (25), 1994.

PERPÉTUO, I. H.O. Uma década de esterilização feminina no Nordeste. In: Encontro Nacional de Estudos Populacionais, $X$ Anais. Caxambu: Associação Brasileira de Estudos Populacionais (ABEP), v. 4, 1996.

Sociedade Civil de Bem-Estar Familar no Brasil (Bemfam). Pesquisa Nacional sobre Demografia e Saúde. Brasília: Bemfam, 1996.

UNITED NATONs. Family Planning, Health and Family Well-Being. NewYork: United Nations, 1996.

VIEIRA, E. M. \& FoRd, J. N. Regret after Female Sterilization Among Low-Income Women in São Paulo, Brazil. Intemational Family Planning Perspectives, 22(1), Mar. 1996. 


\section{Laqueadura Tubária:}

situação nacional, internacional e efeitos colaterais

多

Aurelio Molina

\section{Introdução}

A esterilizaçãofemininaéum procedimentomédico (cinúrgico, químico ou radioativo) que termina com a possibilidade de fertilização, por intermédio de alterações anatômicas ou funcionais em qualquer parte do sistema reprodutivo da mulher.

A técnica mais comum de esterilização é a laqueadura tubária, ou esterilização tubária, que envolve o bloqueio das trompas de Falópio. Este bloqueio geralmente é conseguido pela oclusão das tubas com ligaduras (pontos), clips, anéis ou eletrocoagulação.

Nos últimos 35 anos, principalmente nos anos 70 e 80, houve um acentuado aumento, em âmbito mundial, do uso da esterilização como forma de controle da fertilidade. No Brasil, a esterilização emergiu como a forma de contracepção mais usada entre as mulheres em união, apesar de proibida pelas leis federais e pelo Código de Ética Médica.

Nesse capítulo, de maneira sumária, discutiremos alguns aspectos relacionados com a laqueadura tubária, basicamente a única forma de esterilização feminina usada no Brasil, fazendo um breve histórico dessa cirurgia e contextualizando-a nos planos internacional e nacional. Também abordaremos brevemente os possiveis determinantes e os efeitos colaterais mais comumente associados a esta técnica contraceptiva, discutindo as bases hormonais e mecanismos fisiopatológicos, além das possíveis conseqüências de longo prazo para a saúde da mulher. No fim, apresentamos uma nova técnica cirúrgica que pode diminuir esses efeitos indesejados, e que também torna mais fácil a reversão da ligadura, quando solicitada. 


\section{Breve histórico da laqueadura tubária}

A esterilização tubária é uma operação relativamente nova. Como método de controle da fertilidade, é, em verdade, uma técnica do século XX. Entretanto, suas origens estão no século XIX, mais precisamente em 1809, quando Haighton realizou experimentos seccionando as tubas de coelhas. Em seres humanos, Blundell, em Londres, em 1823, é considerado pelos ingleses o pioneiro da ligadura tubária (Pai, 1974). Entretanto, como não há publicação específica na literatura médica provando tal fato, outros autores, principalmente americanos, consideram que foi Lungren (1881), nos Estados Unidos, o primeiro a realizar uma ligadura tubária. Sua experiência é descrita como uma esterilização tubária em que foram utilizados fios de seda para amarrar as tubas de uma paciente que já tinha realizado duas operações cesarianas (Siegler, 1980).

No início do século XX, a esterilização cirúrgica passou a ser praticada mais rotineiramente, mas basicamente por razões eugênicas, tais como retardo mental severo. Somente a partir de 1930, com os avanços da clínica cirúrgica e com o advento das sulfonamidas e da penicilina, o uso desta operação começou a ser ampliado. Entretanto, sua história continuou ligada ao Movimento Eugênico até que, com os abusos do nazismo, a prática passou a ser questionada e foi temporariamente abandonada (Potts \& Diggory, 1983).

O 'renascimento' desse procedimento cirúrgico ocorreu nos anos 60, quando houve um grande interesse pela esterilização voluntária, principalmente por questões populacionais, mas, também, devido à introdução de novas tecnologias, como a laparoscopia, bem como de técnicas mais simples (minilaparotomias) e mais efetivas. A partir dos anos 70, essa técnica cirúrgica se sedimentou como prática contraceptiva, chegando à decada de 90 como a forma de contracepção mais usada mundialmente (WHO, 1992).

\section{A laqueadura no plano internacional e no Brasil}

Em 1981, Stepan calculou que pelo menos 260 milhões de casais em todo o mundo haviam se submetido a algum tipo de esterilização. Mais recentemente, autores como Ross (1992) acreditam que a esterilização (masculina e feminina) é, atualmente, o meio de controle da fertilidade mais utilizado em todo o mundo.

Em relação à esterilização feminina, desconhece-se o número exato de mulheres que se submeteram à ligadura tubária em todo o mundo. Para Bially (1994), seriam mais de 100 milhões. Segundo Ross (1992), esse número chegaria aos 138 milhões. 
Em países do Terceiro Mundo, existe uma clara tendência em favor da esterilização como opção contraceptiva. Mauldin \& Segal (1988) investigaram 35 dos 58 países menos desenvolvidos. Metade deles mostrou uma sensivel mudança no uso dos métodos ao longo do tempo. O padrão mais comumente encontrado foi o de uma mudança de um método reversível para outro definitivo, quando este estava disponível (Tabela 1).

\section{Tabela 1 - Tendências na prevalência da esterilização entre usuários de métodos contraceptivos. Países me- nos desenvolvidos - 1975-1987}

\begin{tabular}{lrr}
\hline País & Prevalência inicial & Última prevalência \\
\hline Kenya & $12 \%(1978)$ & $16 \%(1984)$ \\
Mauricius & $0 \%(1975)$ & $5 \%(1985)$ \\
Tunisia & $26 \%(1978)$ & $35 \%(1983)$ \\
Colombia & $7 \%(1976)$ & $28 \%(1986)$ \\
Rep. Dominicana & $36 \%(1975)$ & $68 \%(1986)$ \\
El Salvador & $52 \%(1978)$ & $68 \%(1985)$ \\
México & $8 \%(1976)$ & $36 \%(1987)$ \\
Bangladesh & $10 \%(1975)$ & $38 \%(1985)$ \\
Indonésia & $0 \%(1976)$ & $4 \%(1987)$ \\
Coréia do Sul & $38 \%(1979)$ & $60 \%(1985)$ \\
Sri Lanka & $32 \%(1975)$ & $50 \%(1987)$ \\
Taiwan & $26 \%(1976)$ & $44 \%(1985)$ \\
Tailândia & $34 \%(1978)$ & $46 \%(1987)$ \\
\hline
\end{tabular}

Fonte: MAULDIN \& SEGAL, 1988, Prevalence of Contraceptive Use: trends and issues.

Este fenômeno não ocorreu somente nos países do Terceiro Mundo. Nos Estados Unidos, o número de esterilizações também cresceu. Em 1977, Hulka, da Associação para a Esterilização Voluntária, estimou que mais de oito milhões de homens e mulheres na América do Norte tinham sido esterilizados cirurgicamente. Doze anos depois, Pratt (1989) considerou que a esterilização cirúrgica tinha se tornado a prática contraceptiva mais comum entre homens e mulheres casados.

Ainda com relação às mulheres americanas, Bacharach, em 1984, já afirmava que, nas duas décadas anteriores, teria havido mudanças substanciais nas práticas contraceptivas, particularmente um importante aumento no uso da pílula e da esterilização, ao passo que o uso dos métodos mais tradicionais, tais como o condom, tabela e diafragma tinha declinado. Rutkow, em 1986, foi outro autor que não só reafirmava que a ligadura tubária estava entre os procedimentos cirúrgicos mais comuns nos Estados Unidos como também incluía a histerectomia.

Em 1992, Ross estimou que, mundialmente, $20,1 \%$ de todos os casais casados em idade reprodutiva tinham optado por esterilização, dos quais $15,7 \%$ seriam mulheres e $4,4 \%$ homens. Esses números seriam maiores nos países em desenvolvimento, 
com percentuais de 22,3\% de mulheres e 11,4\% de homens. Especificamente em relação à esterilização feminina, os dados levantados por esse autor mostram que o percentual de mulheres esterilizadas no Terceiro Mundo era duas vezes maior do que nos países desenvolvidos (17,8\% e 7,6\%, respectivamente) (Tabela 2).

Tabela 2 - Percentual de mulheres casadas com idade entre 1549 anos usando algum método contraceptivo, por método e grau de desenvolvimento dos países, 1990

\begin{tabular}{lccc}
\hline Método & Mundo & $\begin{array}{c}\text { Paises } \\
\text { desenvolvidos }\end{array}$ & $\begin{array}{c}\text { Países em } \\
\text { desenvolvimento }\end{array}$ \\
\hline Esterilização & 20,1 & 11,4 & 22,3 \\
feminina & 15,7 & 7,6 & 17,8 \\
masculina & 4,4 & 3,8 & 4,5 \\
DU & 10,9 & 5,4 & 12,3 \\
Hormonal & 8,6 & 14,4 & 7,1 \\
Pílulas & 7,7 & 14,3 & 6,0 \\
Injetáveis & 0,9 & 0,1 & 1,1 \\
Condom & 5,4 & 15,1 & 2,9 \\
Outros & 8,0 & 16,1 & 5,9 \\
\hline TOTAL & 53,0 & 62,4 & 50,5 \\
\hline
\end{tabular}

Fonte: Ross, J.A., 1992. Sterilization: past, present, future.

Os últimos dados do Population Reference Bureau (1998) oferecem uma visão geral sobre o uso de contraceptivos na América Latina. Como podemos observar na Tabela 3 , em 10 dos 15 países com dados disponíveis, a esterilização feminina já é a prática contraceptiva mais utilizada entre as mulheres casadas.

Tabela 3 - Percentual de uso de contraceptivos e método mais utilizado, mulheres casadas. América Latina

\begin{tabular}{|c|c|c|c|}
\hline \multirow[t]{2}{*}{ País } & \multicolumn{2}{|c|}{$\%$ Que usam contraceptivo } & \multirow[t]{2}{*}{ Método mais utlilizado } \\
\hline & todos & modernos & \\
\hline Costa Rica & 75 & 65 & esterilização feminina \\
\hline El Salvador & 53 & 48 & esterilização feminina \\
\hline Guatemala & 31 & 27 & esterilização feminina \\
\hline Honduras & 47 & 34 & esterilizacão feminina \\
\hline México & 65 & 56 & esterilização feminina \\
\hline Nicarágua & 49 & 45 & esterilização feminina \\
\hline Panamá & - & - & esterilização feminina \\
\hline Argentina & - & - & - \\
\hline Bolívia & 45 & 18 & ritmo \\
\hline Brasil & 77 & 70 & esterilização feminina \\
\hline Chile & - & - & - \\
\hline
\end{tabular}




\begin{tabular}{lccc}
\hline País & \multicolumn{2}{c}{ \% Que usam contraceptivo } & Método mais utlilizado \\
\cline { 2 - 4 } & todos & modernos & \\
\hline Colômbia & 72 & 59 & esterilização feminina \\
Equador & 57 & 46 & esterilização feminina \\
Guiana & - & - & pílula \\
Paraguai & 51 & 41 & pílula \\
Peru & 59 & 33 & ritmo \\
Uruguai & - & - & pílula \\
Venezuela & - & - & \\
\hline
\end{tabular}

Fonte: Population Reference Burcau, 1998, 1998: Las Mujeres de Nucstro Mundo.

No Brasil, os últimos 30 anos mostraram um aumento ainda mais marcanteda prevalência da cstcrilização feminina, basicamente a laqucadura tubária, tomando-a, hoje, a prática contraceptiva mais utilizada. Ainda que o número total de mulheres brasilciras cstcrilizadas scja incerto, cstima-sc que girasse em torno dos 5 milhõcs, cm 1986 (BEMFAM, 1987) c, possivelmente, tenha atingido a marca de pelo menos 9,5 milhões cm 1997 (UNFPA, 1994).

Esses números são realmente impressionantes. Uma pesquisa realizada cm 1986 pelo IBGE mostrou que $44,4 \%$ das mulheres brasilciras que usavam algum método contraccptivo tinham optado pcla cstcrilização. Esses dados geraram fortes protcstos da sociedade civil organizada, do movimento de mulheres c de organizações ligadas aos dircitos humanos, culminando com o estabelecimento de Comissões Parlamentares de Inquérito no Congresso Nacional e em nível dos estados.

Apesar de toda a polêmica c debates ocorridos no início da década de 90, nova pesquisa nacional realizada cm 1996 (BEMFaM, 1997) mostrou um agravamento dessa distorção, havendo um aumento da prevalência da cstcrilização feminina (Tabela 4).

\section{Tabela 4 - Percentual de mulheres casadas com idade entre 15-49 anos, usando algum método contraceptivo, por método. Brasil - 1986 e 1996}

\begin{tabular}{lrr}
\hline & \multicolumn{2}{c}{$\%$} \\
\cline { 2 - 3 } Método & 1986 & 1996 \\
\hline Esterilização & 44,4 & 49,2 \\
Pllula & 41,0 & 28,5 \\
Tabela & 6,2 & 3,6 \\
Coito interrompido & 2,5 & 3,8 \\
Condom & 1,8 & 7,7 \\
DUU & 1,5 & 1,4 \\
Vasectomia & 0,9 & 2,8 \\
Injetáveis & - & 2,0 \\
Diafragma/espuma & - & 0,2 \\
Outros & 1,7 & 0,3 \\
\hline
\end{tabular}

Fontc: Berquó, E. A Esterilização Feminina no Brasil Hoje, 1989; Pesquisa Nacional sobre Demografia e Saúde, 1996, Beman, 1997. 
Outra deformação do uso da ligadura tubária entre nós se refere à idade ao ser esterilizada. Em 1986, a média quando da ligadura tubária era de 31,5 anos (Arruda, 1987). Vieira (1994), em 1992, encontrou um índice ainda mais baixo (27,5 anos), na região metropolitana de São Paulo. No entanto, Berquó (1986) mostra que muitas mulheres foram esterilizadas nos seus 20 anos e algumas quando ainda eram adolescentes (Tabela 5).

\section{Tabela 5 - Idade quando da esterilização. Frequiência por grupo etário. Brasil - 1986}

\begin{tabular}{lc}
\hline Idade & $\%$ \\
\hline$<25$ & 16,1 \\
$25-29$ & 23,8 \\
$30-34$ & 37,7 \\
$35-39$ & 18,7 \\
$>40$ & 3,7 \\
\hline
\end{tabular}

Fonte: Berquó, E. I Seminário sobre Esterilização Feminina e Masculina, 1986.

\section{Determinantes da laqueadura tubária}

Os determinantes da laqueadura tubária em nosso meio podem ser colocados em quatro grandes grupos: Estruturais Internacionais, Estruturais Nacionais, Socioculturais e Pessoais, formando um modelo teórico diagramático (Figura 1) que ajuda a compreensão da complexidade e das inter-relações desses determinantes em âmbito nacional.

\section{Figura 1 -Modelo teórico diagramático dos determinantes da escolha da ligadura tubária. Brasil}

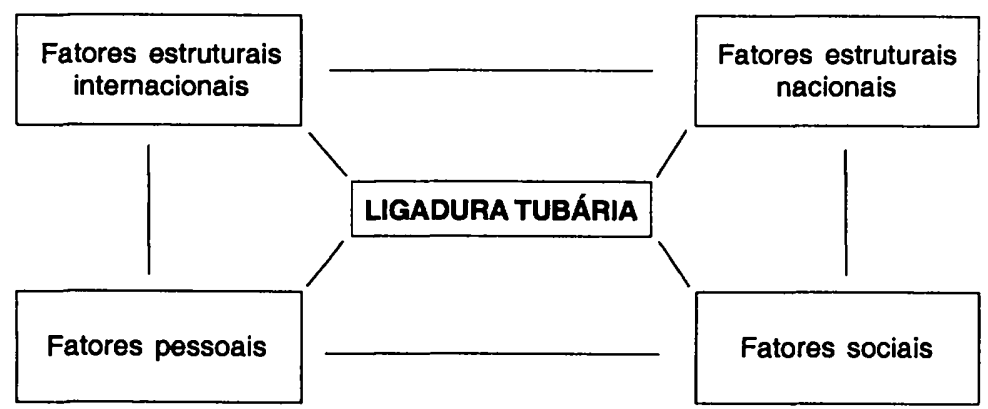


Como o estudo aprofundado desse tema não é o objetivo deste texto, citaremos apenas alguns dos determinantes que compõem cada grupo e que estão envolvidos no complexo processo de escolha da laqueadura tubária, processo que também envolve os princípios da teoria de escolha racional, além dos modelos de escolha contraceptiva e aspectos especificos relacionados à decisão individual.

Os fatores estruturais internacionais seriam aqueles que, por meio de políticas populacionais, organizações governamentais e não-governamentais, exerceriam uma forte influência em favor da escolha da laqueadura tubária como forma de contracepção. São os fatores políticos e econômicos internacionais, além dos neomalthusianos e suas teorias catastróficas, em que o crescimento populacional nos países do Terceiro Mundo é sempre apontado como a causa dos problemas ambientais mundiais.

Ainda nesse grupo, e não menos importante, podemos incluir o Movimento de Controle da Natalidade e o Movimento Eugênico (racismo internacional), que, desdeo início da sua história, advogaram a esterilização feminina, inclusive compulsoriamente.

Entre as causas demográficas internacionais devemos considerar que o problema populacional vivido pela China, região subasiática (Índia e Bangladesh) e Nigéria serviu para generalizações não científicas do mito da explosão populacional e da necessidade de medidas contraceptivas coercitivas urgentes, principalmente as esterilizações em massa. São, também, parte desse grupo de fatores as correntes migratónias de países de Terceiro Mundo para os países desenvolvidos, que foram responsabilizadas pelo agravamento de tensões sociais, colociando lado a lado trabalhadores de baixa renda e uma elite racista, na reivindicação de leis de imigração mais duras e de programas de controle populacional nos países do Terceiro Mundo.

Um outro grupo de determinantes, denominados por nós fatores tecnológicos em nível internacional, são aqueles relacionados tantoà ausência de investimentos e avanços na contracepção masculina quanto, ao contrário, à melhoria das técnicas e abordagens cirúrgicas de laqueadura tubária (laparoscopias, minilaparotomias) que influenciaram fortemente para a alta prevalência da esterilização feminina.

Com relação aos fatores estruturais brasileiros, pode-se afirmar que a ausência de claras políticas populacionais e a falta de uma política de planejamento familiar deram espaço para que poucas, mas poderosas ONGs, associando-se, muitas vezes, a governos estaduais e municipais, não só realizassem, mas, principalmente, treinassem e oferecessem material cirúrgico-inclusive laparoscópios - para laqueaduras em todo o País.

Muitos políticos profissionais praticaram troca de votos por laqueadura, embora alguns se defendam, afirmando que apenas davam uma resposta a uma demanda reprimida. Entretanto, a maioria assume, claramente, uma postura controlista, pois acreditavam estar ajudando a resolver, com tal prática, problemas socioeconômicos. 
A importante migração interna de áreas mais desfavorecidas para as mais ricas, principalmente para as das regiões metropolitanas, e a rápida urbanização que aconteceu no País podem ser classificados como determinantes demográficos, pois colaboraram para a sensação de uma explosão demográfica e da necessidade de um controle populacional por parte significante da sociedade brasileira.

Ainda dentro desse grande grupo de fatores estruturais nacionais, determinantes econômicos, como os baixos salários dos médicos, que viam na laqueadura tubária uma oportunidade de um honorário extra, ajudam a explicar a alta prevalência da técnica. A miséria em que vive parcela significativa da população também levou as mulheres a optarem por essa cirurgia, vista por muitas como uma saída para tal situação.

Os fatores educacionais (inadequado currículo médico, treinamento médico falho e desvirtuado, baixo nível educacional da população, crise universitária, ausência ou desinformação sobre planejamento familiar e a ausência de educação sexual nas escolas) e os relativos à saúde, como o desconhecimento dos efeitos colaterais da ligadura, a conveniência, as práticas inadequadas e os preconceitos por parte dos profissionais da saúde, poderiam ser citados como exemplos de fatores estruturais brasileiros. Também se incluem nesse grupo, sendo considerados co-fatores da alta incidência da laqueadura tubária no Brasil: o financiamento insuficiente do sistema de saúde; a baixa qualidade dos serviços oferecidos nas unidades de saúde; a alta incidência de cesarianas; a dificuldade de acesso aos serviços de planejamento familiar; a falta de opções contraceptivas, incluindo a masculina; as políticas de saúde equivocadas - como a não implantação de programas de planejamento familiar-; a falta de investimento na aquisição ou produção de métodos não permanentes; e a não legalização do aborto.

Como exemplos de fatores socioculturais, citaríamos a mudança do status da mulher dentro da sociedade brasileira, principalmente sua importante presença no mercado de trabalho; o papel da mídia; os estímulos coercitivos em locais de trabalho; e o machismo, que sedimentou entre os homens a idéia de que contracepção era assunto apenas das mulheres. Ainda dentro desse grupo, é importante lembrar a medicalização dos problemas sociais, em que o planejamento familiar foi 'vendido' para a sociedade como instrumento de solução de problemas sociais, e não como um direito reprodutivo. Ressaltamos, ainda, a ausência de suporte para as mulheres trabalhadoras - como as creches - e as crenças, mitos e desinformações que diminuíram o uso de outras opções contraceptivas.

Por último, relacionamos a opção pela laqueadura tubária a fatores que foram agrupados como de 'caráter pessoal'. Nesse grupo, salientam-se os fatores ligados à informação-ou falta de -, como o desconhecimento, por parte da população, dos efeitos colaterais da ligação; e aqueles relacionados à contracepção, mais especificamente, os efeitos colaterais dos outros métodos contraceptivos, o desconhecimento 
de outros métodos - o que leva a um baixo uso e baixa aderência à maioria deles além da praticabilidade, custos e eficácia de cada método, e da contra-indicação de outros métodos ou de uma nova gestação. O número e as complicações relacionados com gestações e partos anteriores podem também estar relacionados com a escolha da laqueadura, assim como aspectos envolvidos com as relações maritais, como estabilidade e intercomunicação. Aspectos demográficos - tamanho familiar ideal, idade e sexo dos filhos, assim como a idade individual também podem ser incluídos nesse grupo.

\section{Efeitos colaterais}

Em função da alta prevalência da esterilização feminina na população brasileira, qualquer efeito colateral desse método pode ter um impacto considerável na saúde da população. Vários estudos, nos últimos 50 anos, foram conduzidos para avaliar as possíveis seqüelas da esterilização. As anormalidades mais comumente descritas como associadas à ligadura tubária são as alterações menstruais; maior incidência de histerectomias; dores pélvicas; alterações na libido, no ato sexual, emocionais, e no relacionamento do casal; doenças funcionais da mama, câncer da mama, dores lombares e alterações na lactação. Entretanto, muitos desses estudos são criticados por falhas metodológicas e resultados conflitantes com outras pesquisas.

O grupo de alterações mais bem estudadas é o daquelas concernentes às alterações menstruais e ao aumento da incidência de histerectomias. Muitos desses trabalhos apresentam problemas metodológicos, como ausência de grupo-controle, ou grupocontrole inadequado; pequeno tamanho amostral; falta de ajustamento quanto à idade e ao tipo de método contraceptivo anterior (principalmente a pílula); além de potenciais vícios de seleção, de lembrança (recall bias), de observação e de follow-up. Também é preciso ressaltar que em muitos estudos comparativos não foram usados testes de significância estatística.

Existem, também, na literatura-principalmente até a década de 80 -trabalhos que não demonstram aumento na incidência de alterações menstruais nas pacientes esterilizadas, ou a atribuem, principalmente, à parada do uso de contraceptivos orais (Chamberlain, 1976; Bhiwandiwala, 1983; Rulin, 1985). Porém, em muitos desses trabalhos, o período de follow-up foi inferior a dois anos (Rubistein, 1979; DeStefano, 1983).

Em outros estudos revisados, apesar de encontrarmos uma incidência importante de alterações menstruais (Jensen, 1957; Lu, 1967; Stergachis, 1990), ou uma diferença significativa entre os grupos (Rulin, 1993), os autores concluíam de forma diversa, revelando, pelo menos, um viés de autor. 
O resultado de uma revisão bibliográfica para trabalhos com achados positivos para alterações menstruais e aumento de histerectomias relacionadas com a laqueadura tubária é apresentado no Quadro 1.

É importante afirmar que a qualidade dos trabalhos dos últimos oito anos reforça a possibilidade de uma associação causal entre a laqueadura tubária e alterações menstruais e aumento do risco de futuras histerectomias, principalmente após cinco anos da cirurgia e em pacientes mais jovens.

\section{Quadro 1 - Trabalhos com achados positivos para alteraçóes menstruais e aumento de histerectomias associa- das à laqueadura tubária}

\begin{tabular}{|c|c|c|c|c|c|c|}
\hline Autor/Ano & Seqüela & $N$ & Desenho & AvT* & p & folw-up \\
\hline Willians, 1951 & $\begin{array}{l}\text { sangramento uterino } \\
\text { anormal }\end{array}$ & 200 & $\begin{array}{l}\text { coorte retrosp } \\
+ \text { compar }\end{array}$ & não & não & $10 a$ \\
\hline Prystowsky, 1955 & alterações menstruais & 1830 & coorte retrosp & nåo & não & 4-14 a \\
\hline Jensen, 1957 & distúrbios menstruais & 734 & coorte retrosp & nāo & năo & $8 a$ \\
\hline Powell, 1962 & alterações menstruais & 112 & coorte retrosp & năo & não & $10 \mathrm{a}$ \\
\hline Sacks, 1962 & hipermenorréia & 100 & coorte retrosp & não & não & $6-16 a$ \\
\hline Rakshitt, 1966 & $\begin{array}{l}\text { menorragia ou mens- } \\
\text { truações prolongadas }\end{array}$ & 172 & coorte retrosp & não & não & $4-13 a$ \\
\hline Lu, 1967 & $\begin{array}{l}\text { minimas desordens } \\
\text { menstruais }\end{array}$ & 1055 & coorte retrosp & não & nāo & $8 a$ \\
\hline Haynes, 1970 & $\begin{array}{l}\text { hemorragia uterina } \\
\text { disfuncional }\end{array}$ & 489 & coorte retrosp & não & não & $3,5 \mathrm{a}$ \\
\hline Steptoe, 1971 & $\begin{array}{l}\text { aumento da } \\
\text { menstruaçăo }\end{array}$ & 278 & coorte retrosp & não & não & $1 a$ \\
\hline Smith, 1971 & menometrorragia & 161 & coorte retrosp & nāo & não & $3,3 a$ \\
\hline Mulldon, 1972 & $\begin{array}{l}\text { maior ne de tratamentos } \\
\text { cirúrgicos ginecológicos }\end{array}$ & $s^{374}$ & coorte retrosp & não & não & $>10 a$ \\
\hline Roe, 1972 & $\begin{array}{l}\text { sangramento uterino } \\
\text { anormal }\end{array}$ & 235 & coorte retrosp & não & não & $>1,5 \mathrm{~m}$ \\
\hline Akhter, 1973 & alteraçōes menstruais & 200 & coorte retrosp & não & não & $12 \mathrm{~m}$ \\
\hline Neil, 1975 & $\begin{array}{l}\text { sangramento menstrual } \\
\text { aumentado pp pela } \\
\text { laparoscopia }\end{array}$ & 454 & $\begin{array}{l}\text { coorte retrosp } \\
+ \text { control }\end{array}$ & não & $<0,001$ & $10-28 \mathrm{~m}$ \\
\hline Lawson, 1979 & $\begin{array}{l}\text { perda menstrual } \\
\text { aumentada }\end{array}$ & 530 & coorte retrosp & $\operatorname{sim}$ & não & $6 m$ \\
\hline Baggish, 1979 & $\begin{array}{l}\text { aumento do fluxo } \\
\text { e da duração }\end{array}$ & 500 & coorte retrosp & $\operatorname{sim}$ & não & $3-5$ a \\
\hline
\end{tabular}




\begin{tabular}{|c|c|c|c|c|c|c|}
\hline Autor/Ano & Seqüela & $\mathbf{N}$ & Desenho & AVT* & $p$ & folw-up \\
\hline Jackson, 1980 & $\begin{array}{l}\text { aumento de menorragias } \\
\text { e histerectomias }\end{array}$ & 831 & coorte retrosp & năo & não & $>5 a$ \\
\hline Riedel, 1981 & $\begin{array}{l}\text { desordens menstruais } \\
\text { e histerectomias com } \\
\text { esterilizaçäo de alta } \\
\text { freqüência }\end{array}$ & 644 & coorte retrosp & sim & não & $2 \cdot 10 a$ \\
\hline Vessey, 1983 & $\begin{array}{l}\text { aumento de interna- } \\
\text { çōes hospitalares } \\
\text { devido a problemas } \\
\text { menstruais }\end{array}$ & 2.243 & $\begin{array}{l}\text { coorte retrosp } \\
+ \text { control }\end{array}$ & $\operatorname{sim}$ & ns & $6 a$ \\
\hline DeStefano, 1985 & $\begin{array}{l}\text { ciclos menstruais } \\
\text { anormais }(O R=2,77)\end{array}$ & 719 & coorte/controle & sim & $\operatorname{sim}$ & $8 a$ \\
\hline Kjer, 1990 & $\begin{array}{l}\text { maior } n^{e} \text { de histerec- } 1 \\
\text { tomias por irregulari- } \\
\text { dade menstruais em } \\
\text { mulheres mais jovens }\end{array}$ & 10.104 & coorte/controle & não & $<0,01$ & $7 a$ \\
\hline Stergachis, 1990 & $\begin{array}{l}\text { risco aumentado de } \\
\text { histerectomia ( } R R=1,6) \\
\text { pp em mulheres jovens } \\
(\mathrm{RR}=3,4)\end{array}$ & $\underbrace{7.414}$ & $\begin{array}{c}\text { coorte retrosp } \\
+ \text { control }\end{array}$ & $\operatorname{sim}$ & sim & $>10 a$ \\
\hline Wilcox, 1992 & $\begin{array}{l}\text { fluxo e dor menstrual } \\
\text { aumentada, mais epi- } \\
\text { sódios de sangramento } \\
\text { (spot), após } 5 \text { anos }\end{array}$ & 5.070 & coorte prospect & $\operatorname{sim}$ & sim & 5 a \\
\hline Goldhaber, 1993 & $\begin{array}{l}\text { risco aumentado de } \\
\text { histerectomia pp em } \\
\text { jovens (RR=2,45) e } \\
\text { após } 7 \text { anos }\end{array}$ & 39.502 & $\begin{array}{l}\text { coorte retrosp } \\
+ \text { control }\end{array}$ & $\operatorname{sim}$ & sim & $>7 a$ \\
\hline Rulin, 1993 & $\begin{array}{l}\text { maior prevalência de } \\
\text { histerectomia }\end{array}$ & 500 & $\begin{array}{l}\text { coorte prospect } \\
+ \text { control }\end{array}$ & $\operatorname{sim}$ & $<0,02$ & $4,5 \mathrm{a}$ \\
\hline $\begin{array}{l}\text { Martinez-Schnell, } \\
1993\end{array}$ & $\begin{array}{l}\text { disfunção menstrual } \\
\text { pp após } 5 \text { anos }\end{array}$ & 5000 & $\begin{array}{l}\text { coorte/ } \\
\text { comparação }\end{array}$ & $\operatorname{sim}$ & $\operatorname{sim}$ & $5 a$ \\
\hline
\end{tabular}

"AJT = ajustamento para possíveis fatores de confusão principalmente prévio tipo de contracepção; $\mathrm{p}=$ utilização de métodos estatísticos de significância; ns = não significante; folw-up=follow-up; $a=a n o s ;$ $\mathrm{m}=$ meses; $\mathrm{OR}=$ odds ratio.

Coorte retrospectivo (HENNEKENS, 1987) = coorte histórico (FIETCHER, 1988) = prospective histónico (MAUSNER, 1985), follow-up retrospectivo.

Coorte prospectivo (HENNEKENS, 1987) $=$ coorte contemporâneo (FLETCHER, 1988) $=$ coorte $=$ estudos de follow up prospectivo $=$ forward studies (ABRAMson, 1990) $=$ longitudinal.

As bases fisiopatológicas para essas alterações foram estudadas por vários autores e vêm apontando alterações na função ovariana após a laqueadura tubária, causadas possivelmente por insuficiência vascular, congestão venosa, alterações no sistema linfático e lesões neuroendócrinas locais em decorrência de traumatismos no mesosalpinge, em conjunto ou isoladamente (Quadros 2 e 3 ). 


\section{Quadro 2-Bases hormonais das seqüelas de longo prazo, ligadura tubária. Literatura internacional - 1966-1988}

\begin{tabular}{|c|c|c|}
\hline Autor & Ano & Principais alterações encontradas \\
\hline Chakravarty & 1966 & hiperestrogenismo \\
\hline Ringrose & 1974 & alterações do corpo lúteo e alterações proliferativas de endométrio \\
\hline Berger & 1978 & menores níveis de progesterona plasmática \\
\hline Radwanska & 1979 & $\begin{array}{l}\text { diminuição da concentração de progesterona no período médio da } \\
\text { fase lútea }\end{array}$ \\
\hline Donnez & 1981 & $\begin{array}{l}\text { diminuição do valor médio da progesterona no período médio da fase } \\
\text { lútea }\end{array}$ \\
\hline Alvarez-Sanchez & 1981 & redução do LH pré-ovulatório e do 17B-estradiol \\
\hline Corson & 1981 & diminuição dos valores médios da concentração de estradiol \\
\hline Hargrove & 1981 & diminuiçāo do nível de progesterona \\
\hline Radwanska & 1982 & diminuição do valor médio da progesterona no meio da fase lútea \\
\hline Cristofaro & 1982 & alteraçōes endometriais compativeis com insuficiência da fase lútea \\
\hline Otubu & 1984 & $\begin{array}{l}\text { menor número de corpos lúteos e nível de progesterona (pesquisa em } \\
\text { animal) }\end{array}$ \\
\hline McComb & 1984 & diminuição do número de ovulações (pesquisa em animal) \\
\hline Cattanach & 1985 & diminuição da concentraçăo de estrógeno na ovulaçăo \\
\hline Cattanach & 1988 & redução da excreção urinária de estrógenos na fase média lútea \\
\hline Hakverdi & 1994 & deficiência da fase lútea $\theta$ anovulação \\
\hline
\end{tabular}

\section{Quadro 3- Hipóteses postuladas para os efeitos de longo prazo,} ligadura tubária. Literatura internacional - 1966-1988

\begin{tabular}{|lll|}
\hline Autor & Ano & Hipóteses \\
\hline Chakravarty & 1966 & hiperplasia do estroma cortical do ovário \\
Lu \& Chun & 1967 & degeneração cística e disfunção ovariana \\
Ringrose & 1974 & torsão intermitente do ovário \\
Neil & 1975 & interferência na irrigação sangüínea dos ovários \\
Berger et al. & 1978 & deficiência ovulária \\
Radwanska et al. & 1979 & lesão da função ovariana \\
Donnez et al. & 1981 & alteração no fluxo sangũíneo auxiliar do ovário \\
Alvarez-Sanchez & 1981 & alteração na função ovariana \\
Hargrove \& Abraham & 1981 & função lútea anormal \\
Riedel et al. & 1981 & restrição do fluxo sangüineo para os ovários \\
Radwanska et al. & 1982 & anovulação e disfunção lútea \\
Cristofaro et al. & 1982 & fase lútea pobre \\
Otubu \& Winston & 1984 & lesão da função ovariana \\
Cattanach & 1985 & hipertensão vascular em nível do ovário \\
Cattanach & 1988 & redução da função ovariana \\
\hline
\end{tabular}


Essas evidências nos dão sustentação para uma base teónica que indica, em termos de longo prazo, riscos de alterações psíquicas, menopausa precoce e/ou sintomas climatéricos, aumento da osteoporose, aumento do risco de doenças do aparelho cardiovasculare aumento de cânceres hormônio-dependentes, que merecem estudos epidemiológicos específicos (Figura 2).

Considerando o número de brasileiras, em sua maioria saudáveis (mesmo levando em conta as possíveis críticas metodológicas em alguns dos artigos revisados), que vêm sendo submetidas à esterilização tubária, qualquer desses efeitos de longo prazo pode ter um importante impacto na saúde da população feminina, além de um custo econômico adicional no sistema de prestação de serviços.

\section{Figura 2-Modelo diagramático dos riscos téricos de mé- dio e longo prazos da laqueadura tubária}

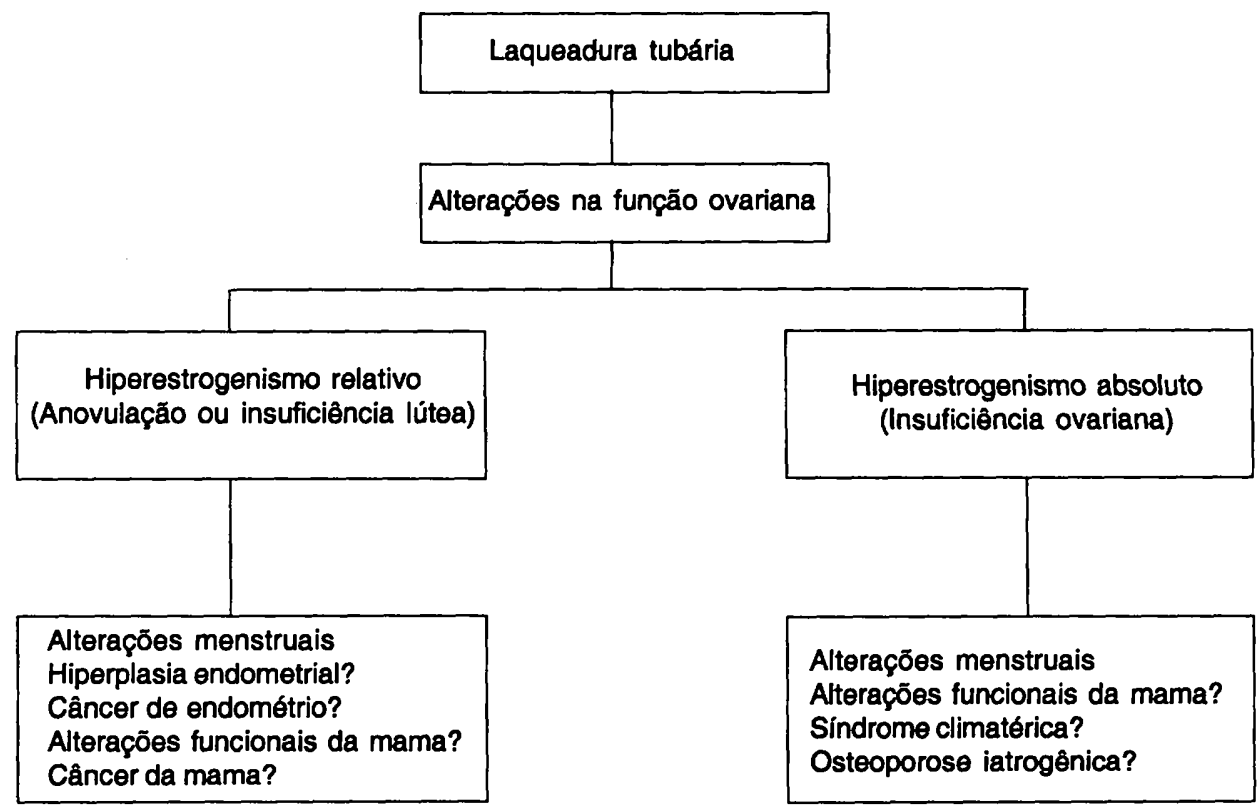

Com base nesses achados e no modelo teórico, além do crescente número de mutheres que se arrependem e vêm solicitando a reversão da laqueadura tubária, desenvolvemos uma nova técnica de laqueadura, que é mais fácil de ser realizada e que agride menos o tecido tubário e o mesosalpinge -área por onde passa parte da vascularização e inervação ovariana. Além disso, esta técnica facilita a recanalização cirúrgica das trompas, possibilitando maior sucesso em termos de futuras gestações e uma menor chance de gravidez ectópica tubária, complicação associada às reversões. 
Esta cirurgia, denominada Molina e Costa, consiste em bloquear as trompas de Falópio por meio de quatro ligaduras (pontos) ao nível do istmo (parte mais estreita da trompa) e uma mínima excisão de segmento de trompa, preservando a vitalidade do mesosalpinge. Após a apreensão da tuba com uma pinça de Allis ou Kelly, duas ligaduras, com fio absorvivel, são realizadas de cada lado da pinça, em uma distância de cerca de 0,5 a 1,0 cm entre as mesmas, seguidas de uma excisão do segmento da trompa entre esses pontos em forma de $V$, sem atingir o mesosalpinge. Os dois orificios do oviduto que ficaram expostos com a excisão são também ligados com fio absorvível.

\section{Conclusóes e sugestóes}

A prevalência da laqueadura tubária no Brasil, que aumentou de 7,1\%, em 1975, para 49,2\%, em 1996, revela uma distorção do planejamento familiar entre nós. Esses números reforçam a idéia de que a luta pela implantação de um programa de assistência integral à saúde da mulher, como o PASM, continua atual e importantíssima dentro da ótica dos direitos reprodutivos.

Com relação aos determinantes da laqueadura, é importante que se tenha em mente que uma enorme gama de fatores estão interconectados em um complexo relacionamento. As classificações apresentadas nesse texto são apenas uma tentativa de simplificação e de didatismo de uma complexa realidade, podendo esses determinantes ser agrupados de forma diferente da que apresentamos aqui. Entretanto, apesar dessas dificuldades, este modelo é a primeira tentativa na literatura de se relacionar, sistematizar e integrar todos os possíveis macro e micro determinantes da ligadura tubária na realidade brasileira, e pode servir como um instrumento para a compreensão e transformação dessa inaceitável realidade. O grande número de determinantes reforça a visão de que, para a reversão da distorção da alta prevalência da esterilização feminina entre nós, se faz necessária uma estratégia integrada que atue em vários setores da sociedade.

É também importante alertar pesquisadores, profissionais da saúde e a população feminina sobre os riscos teóricos a que estão expostas as pacientes submetidas à laqueadura tubária, para que sua decisão quanto ao uso dessa forma de contracepção cirúrgica seja a mais bem esclarecida possivel.

Principalmente no contexto brasileiro-em que a contracepção é feita sem o oferecimento de exames de prevenção, supervisão e acompanhamento, e a população feminina vem sendo esterilizada em uma faixa etária bastante jovem - se faz necessário o financiamento de futuras pesquisas para o esclarecimento das implicações dessa cirurgia na saúde feminina. A plausibilidade do modelo teórico apresentado neste texto reforça que o mesmo deva ser usado como ponto inicial para futuras pesquisas. 
Sugerimos que essas informações científicas devam constar do consentimento livree informado para todas as pacientes descjosas de screm submetidas à laqueadura tubária, bem como fazer parte dos manuais de plancjamento familiar do Ministério da Saúde.

Finalizando, cm rclação à cirurgia de Molina e Costa, parece-nos que é a melhor opção dentro do atual estágio de conhecimento dos cfeitos colaterais da laqueadura tubária e do nível de arrependimento, constatado em diversas pesquisas, entre as mutheres que se submcteram à csterilização tubária.

\section{Referências Bibliográficas}

AbRuison, J.H. Survey Methods in Community Medicine. Churchil Livingstone, 1990.

AKHTER, M.S. Vaginal versus abdominal tubal ligation. Study at Victoria Gencral Hospital. American Joumal of Obstetrics and Cynecology, 115:491-496, 1973.

Alvarez-SAichez, F; SeGal, S.J. \& BraChe, V. Pituitary-ovarian function after tubal ligation Fertility and Sterility, 36:606-609, 1981.

ARRLDA, J. M. A Pesquisa Nacional Sobre Saude Matemo-Infantile Planejamento Familiar, Brasil, 1986, Rio de Janciro: Bemfam c IRD, 1987.

Bacharach, C.A. Contraceptive Practice Among American Women; 1973-1982. In: Family Planning Perspectives, 16:253-259, 1984.

BAGGISH, M.S. ct al Complication of Laparoscopy Sterilization. Comparison of two Methods. In: Obsterics and Gynecology, 54:54-59, 1979.

BERGER, G.S; RADWANSKA, E. \& HAMMOND, J.E. Possible Ovulatory Deficiency After Tubal Ligation. In:American Journal of Obstetric and Cynecology, 132:699-700, 1978.

Bemfam. Pesquisa Nacional sobre Saúde Materno-Infantil e Plancjamento Familiar. PNSMIPH-Brazil, 1986. Rio de Janeiro: 1987.

Bemfam. Pesquisa Nacional Sobre Demografia e Saúde-1986. Rio de Janeiro: 1997.

Bhiwandiwala, P.P.; Mumford, S.D. \& Feldoi.um, P. Menstrual Pattern Changes Following Laparoscopic Sterilization With Different Occlusion Techniques: a review of 10,004 cases. In: American Joumal of Obstetrics and Cynecology, 145:684-694, 1983.

Berquó, E. I Seminário Sobre Esterilização Feminina c Masculina, São Paulo, 1986. In: Saúde da Mul.her, Diretto a ser Conquistado. Brasília: Consclho Nacional dos Dircitos da Mulher, Mar/ 1989.

Berquó, E. A Estcrilização Feminina no Brasil Hoje. In: EN contro Interiacional Saúde da MulHer: UM DIRETO A SER CONQUTSTADO. Brasília: jun.1989. 
BIALY, G. \& AIEXANDER, N.J. Contraceptive Development: what we can achieve. In: Challenges in Reproductive Health Research, Biennial Report, 1992-94, Geneva: WHO, 1994.

CattanaCh, J.F. Oestrogen Deficiency After Tubal Ligation. In: Lancet, 1:847-849, 1985.

Cattanach, J.F. \& Milne, B.J. Post-Tubal Sterilization Problems Correlated With Ovarian Steroidogenesis. In: Contraception, 38:541-550,1988.

CHAKRAVARTY, S. Joumal of Obstetrics and Gynaecology of India, 12:448,1966.

CHAMBERLAIN, G. \& Fourkes J. Long Term Effects of Laparoscopic Sterilization on Menstruation. In: Southem Medical Joumal, 69:1474-1475, 1976.

Corson, S.L. et al. Hormonal Levels Following Sterilization and Hysterectomy. In:Joumal of Reproductive Medicine, 26:363-370, 1981.

CRISTOFARO, D. et al. Endometrial Pathological Changes After Fallopian Ring Tubal Ligation. In: Endoscopy, 14:139-140, 1982.

DeStefano, F.; Huezo, C.M. \& Peterson, H.B. Menstrual Changes After Tubal Sterilization, Obstetrics and Gynecology, 62:673-681, 1983.

DeStefano, F.; Perlman J.A. \& Peterson H.B. Long-Term Risk of Menstrual Disturbances After Tubal Sterilization, American Joumal of Obstetrics and Gynecology, 152:835-841, 1985.

DonNEzJ. et al. Luteal Function After Tubal Sterilization. In:Obstericsand Gynecology, 57:65-70, 1981.

Fletcher, R.H., Fletcher, S.W. \&WaGner, E.H. Clinical Epidemiology, Willians and Wilkins, 1988.

GOLDHABER, M.K. et al. Long Term Risk of Hysterectomy Among 80,007 Sterilized and Comparison Women at Kaiser Permanent, 1971-1987. In: American Joumal of Epidemiology, 138:508-521, 1993.

HAIGHTON, J. An Experimental Inquiry Concerning Animal Impregnation. In: Philos Transactions of Royal Society of London, 18:1 12, 1809.

HAKVERd A.U. et al. Changes in Ovarian Function After Tubal Sterilization. In: Advances in Contraception, 10:51-56, 1994.

Hargrove, J.T. \& Abrahan, G.E. Endocrine Profile of Patients With Post-Tubal Ligation Syndrome. In: Joumal of Reproductive Medicine, 26:359-362, 1981.

HAYNES, D.M. \&WoLfE, W.M. Tubal Sterilization in an Indigent Population. Report of Fourteen Years' Experience. In: American Journal of Obstetrics and Gynecology, 106:1044-1053, 1970.

HenNeKEns, C.H. \& Buring, J.E. Epidemiology inMedicine. Boston/Toronto: Little, Brown and Company, 1987.

HuLKA, J. F. Current Status of Elective Sterilization in the United States. In: Fertility and Sterility, 28:515, 1977. 
JACKSON, P. \& LANDER, J.L. Female Sterilisation: a five-year follow-up in Auckland. In: New Zealand Medical Joumal, 91:140-143, 1980.

JENSEN, F. \& LESTER, J. Ten Years of Tubal Sterilization by Madlener Method. In: Acta Obstetríio et Gynecologica Scandinavica, 36:324-339, 1957.

KER, J.J. \& KNUDSEN, L. Hysterectomy Subsequent to Laparoscopic Sterilization. In: European Joumal of Obstetrics, Gynecology, and Reproductive Biology, 35:63, 1990.

LaWSON, S. \& Cole, R.A. The Effect of Laparoscopic Sterilisation by Diathermy or Silastic Bands on Post-Operative Pain, Menstrual Symptoms and Sexuality. In: British Joumal of Obstetrics and Gynaecology, 86:659-663, 1979.

LIskin, L. et al. Minilaparotomy and Laparoscopy: safe, effective and widely used. In: Population Reports (C), n. 9, 1985.

LUNGREn, S.S. A Case of Caesareian Section Twice Successfully Performed on The Same Patient. In: American Joumal of Obstetrics and Gynecology, 14:78, 1881.

Lu, T. \& Chan, O. A Tong-Term Follow-up Study of 1,055 Cases of Postpartum Tubal Ligation. In: Joumal of Obstetrics and Gynaecology of the British Commonwealth, 74:875-880, 1967.

Martinez-SchnelL, B. et al. Evaluating the Effects of Tubal Sterilization on Menstrual Function: selected issues in data analysis. In: Statistics in Medicine, 12:355-363, 1993.

Maurdin, W.P. \& SEGAL, S.J. Prevalence of Contraceptive Use: trends and issues. In: Studies in Family Planning, 19:335, 1988.

MAUSNER, S.J. \& KRAMER, S. Epidemiology. AnIntroductory Text. Philadelphia: W.B. Saunders Company, 1985.

MCCOMB P. \& DelBekE, L. Decreasing the Number of Ovulation in The Rabbit With Surgical Division of The Blood Vessels Between the Fallopian Tube and Ovary. In: The Journal of Reproductive Medicine, 29:827-829, 1984.

MunDoon, MJ. Gynaecological Illness After Sterilization. In: BritishMedical Joumal, 1:84-85, 1972.

NeIL, J.R.; Noble, A.D. \& HAMmOND G.T. Late Complication of Sterilization by Laparoscopy and Tubal Ligation. In: Lancet, 2:699-670, 1975.

OTUBU, J.A.M. \& WINSTON, R.M. Ovarian Function After Salpingostomy in Mechanically Induced Hydrosalpinges in Rabbits. In: Fertility and Sterility, 41:1 1S, 1984.

PAI, D.N. Keynote Adress: voluntary sterilization as a component of family planning program in advances in voluntary sterilization. ProceEding of THE SECOND INTERNATIONAL CONFERENCE ON VOUUNTARY STERILZATON, Excerpta, 1974.

Potts, M. \& DigGory, P. Textbook of Contraceptive Practice. Cambridge: Cambridge University Press, 1983. 
POWELL, L.C. Cesarean Section Sterilization. Hysterectomy or Tubal Ligation? In: Obstetrics and Gynecology, 19:387-396, 1962

Pratt, W.F. \& Bacharach, C. What do Women Use When They Stop Using the Pill? In: Family Planning Perspective, 19:257, 1987.

Prystowsky, H. \& Eastman, N.J. Puerperal Tubal Sterilization. In: Journal of the American Medical Association, 11:463-467, 1955.

RADWANSKA, E; BERGER, G.S. \& HAMMOND, J. Luteal Deficiency Among Women with Normal Menstrual Cycles, Requesting Reversal of Tubal Sterilization. In: Obstetrics and Gynecology, 54:189-192, 1979.

RADWANSKA, E; BERGER, G.S. \& HAMmOND, Evaluation of Ovarian Function after Tubal Stcrilization. In: Joumal of Reproductive Medicine, 27:376-384,1982.

RaksHr, B. The Physical and Mental State Following Sterilization. In: Joumal of Obstetrics and Gynecology of India, 16:427, 1966.

ReEel, H-H.; AHRENS, H. \& SEMM, K Late Complications of Sterilization According to Method. In: Joumal of the Reproductive Medicine, 26:354-358, 1981.

RiNGROSE, C.A. Post-Tubal Ligation Menorrhagia and Pelvic Pain. In: Intermational Journal of Fertility, 19:168, 1974.

ROE, R.E.; LAROS R.K. \& WORK, B.A. Female Sterilization: the vaginal approach. In: American Joumal of Obstetrics and Gynecology, 112:1031-1036, 1972.

Ross, J.A. Sterilization: past, present, future. In: Studies in Family Planning, 23:187-198, 1992.

RadwansKa, E; BerGer G.S. \& HAMmond, J. Luteal Deficiency Among Women with Normal Menstrual Cycles, Requesting Reversal of Tubal Sterilization In: Obstetrics and Gynecology, 54:189-192, 1979.

RuBINSTEN, L.M.; BENAAIIN L. \& KIEINKOPF V. Menstrual Pattems and Women's Attitudes Following Sterilization by Falope Rings In: Fertility and Sterility, 31:641-646, 1979.

RuLin M.C. et al. Post-tubal Sterilization Syndrome: a misnomer. In: American Journal of Obstetrics and Gynecology, 151:13-19, 1985.

RuLIN, M.C. Long-Term Effect of Tubal Sterilization on Menstrual Indices and Pelvic Pain. In: Obstetrics and Gynecology, 82:118, 1993.

RutKow, I.M. Obstetrics and Gynaccologic Operations in the United States. In: Obstetrics and Gynecology, 67:755-759, 1986.

SACKS, S. \& LACROIX, G. Gynaecologic Sequelae of Post-partum Tubal Ligation. In: Obstetrics and Gynecology, 19:22-27, 1962. 
SiEgler, A.M. \& GruneBAum , A. The 100th Anniversary of Tubal Sterilization. In: Fertility and Sterility, 34:610-613, 1980.

SMmH, R.A. \& SYMmONDS, R.E. Vaginal Salpingectomy (Fimbrectomy) for Sterilization. In: Obstetrics and Gynecology, 38:400-402, 1971.

StEPAN, J.; KeLOG E.H \& PorrROW, P.T. Legal Trends and Issues in Voluntary Sterilization. In: Bopulation Reports (E), nº, 1981.

STERGASHIS, A. et al. Tubal Sterilization and Long-Term Risk of Hysterectomy. In: Joumal of the American Medical Association, 264:2893-2898, 1990.

STEPTOE, P.C. Recent Advances in Surgical Methods of Control of Fertility and Infertility. In: British Medical Bulletin, 26:60-64, 1970.

UNFPA. Necessidades Contraceptivas ede Gerenciamento Logístico no Brasil. RELATÓRIO TÉCNICO n² 1 . New York: United Nations Population Funds, 1994.

VESSEY, M. et al. Tubal Sterilization: Findings in a Large Prospective Study. In: British Joumal of Obstetrics and Gynaecology, 90:203-209, 1983.

Vieira, E.M. A Esterilização Feminina de Mulheres de Baixa Renda em Região Metropolitana do Sudeste do Brazil e Fatores Ligados à Sua Prevalência. In: Revista de Saúde Pública, 28 (6): 440-448, 1994.

Wucox, L.S. et al. Menstrual Function after Tubal Ligation. In: American Joumal of Epidemiology, 135:1368-1381, 1992.

WIwAMS, E.L; JONES, H.E. \& MERRL, R.E. The Subsequent Course of Patients Sterilized by Tubal Ligation. In: American Joumal of Obstetrics and Gynecology, 61:423-426, 1951.

WHO. Female Sterilization: aguide to provision of services. Geneva: World Health Organization, 1992. 



\section{Métodos de Barreira Controlados pela Mulher}

1.7\%

Suzana Kalckmann

Apresentamos, aqui, uma síntese sobre a atuação dos métodos de barreira controlados pelas mulheres (diafragma e preservativo feminino) a partir dos resultados obtidos com os estudos que realizamos sobre essas práticas contraceptivas. Esperamos contribuir, assim, para a ampliação das discussões no campo da saúde da mulher e dos direitos reprodutivos, considerando-se que o uso de métodos de barreira, atualmente, é a única possibilidade de prevenção ao HIV (além da abstinência e monogamia absolutas), e que ter controle sobre seu uso pode ser uma forma de fortalecer as mulheres no terreno da sexualidade.

\section{Breve histórico sobre os métodos de barreira}

As mulheres sempre buscaram práticas que thes possibilitassem o controle sobre o número de filhos e a época em que desejavam tê-los. Ao longo da história, encontramos relatos sobre a adoção de grande diversidade de práticas contraceptivas, entre as quais predominam as barreiras femininas. Como exemplos, citamos o uso de tampões intravaginais - de folhas mascadas ou de pasta composta de goma, mel, excrementos de crocodilo, entre outros-, registrado em papiros egípcios datados dos séculos XVIII eXVI a.C. Na Grécia antiga, as mulheres usavam tampões de confecção caseira com ácido tânico (Bruce \& Schearer, 1979). Em Atenas, por volta de 500 a.C., eram utilizados ungüentos à base de chumbo. Entre chinesas da dinastia Hia, sudanesas e maias, há registros do uso de rolhas de argila. No Japão antigo, prostitutas introduziam esponjas do mar, polpa de romã ou figos, macerados de variadas folhas e películas de bambu embebidas em óleo para evitar a gravidez (Rousselle, 1984; Population Reports, 1985). 
Em 1838, Frederick Adolphe Wilde criou o capuz cervical de látex, precursor moderno do diafragma, a partir de um molde de cera do colo do útero. Há registros mais antigos indicando o uso de muitos outros similares, produzidos com diferentes materiais, como marfim, prata, ouro, borracha etc. O diafragma, ou pessário de Messinga, foi descrito pela primeira vez cm 1880 pelo médico alemão Hasse, tendo sido bastante difundido na Holanda e na Alemanha no final do século XIX (Population Reports, 1985). O diafragma e o capuz cervical ganharam maior popularidade quando Margareth Sanger os levou para os Estados Unidos, em 1920.

Os movimentos sociais que atuavam em sindicatos, especialmente socialistas e anarquistas, estimularam a criação de clínicas de planejamento familiar, destacando-se nesse período a atuação de Emma Goldmann, que contribuiu ativamente para a divulgação e a ampliação do uso do diafragma e do capuz cervical entre as trabalhadoras (Bandler, 1990). Nos Estados Unidos e na Europa, no começo do século, apesarde os dados sobre o uso do diafragma não serem sistemáticos e nem sempre separados dos referentes ao capuz cervical, existem indícios de que seu uso chegou a atingir números significativos da população.

Durante a primeira metade do século XX, os diafragmas e condons foram os anticoncepcionais mais usados nos EUA. Em 1955, o diafragma era o método de escolha de 25\% dos casais brancos, casados, que praticavam anticoncepção (Population Reports, 1985). Porém, a partir da década de 60, com a entrada em cena dos anticoncepcionais orais e dos dispositivos intra-uterinos, a sua prevalência foi decrescendo de forma inversamente proporcional (Instituto de Saúde, 1988). Nas duas últimas décadas, entretanto, diversos estudos vêm demonstrando que esses métodos, considerados modernos e de alta eficácia, apesar de adequados e eficazes para determinados casais, podem ser contra-indicados para outros e, portanto, não esgotam as necessidades universais de contracepção.

A divulgação dessas informações, aliada às idéias básicas dos movimentos feminista e ecológico, na década de 70, provocou a retomada do uso do diafragma em vários paíscs do Primeiro Mundo. Essa busca por novas práticas contraceptivas vem sendo norteada pelo desejo das mulheres de ampliar seu autoconhecimento, tornando-as mais autônomas no controle da própria fertilidade e na busca de menor risco para a saúde.

Além disso, o surgimento da AIDS, nos anos 80, e o seu crescimento alarmante entre as mulheres - principalmente pela transmissão sexual - trouxeram novos elcmentos às pesquisas em contracepção, explicitando a necessidade de avaliação dos métodos, não apenas pela sua capacidade de prevenir gravidez indesejada, mas, também, por serem capazes de evitar as doenças sexualmente transmissíveis, inclusive Aidș'. Essa realidade conduziu ao resgate e à reavaliação dos antigos métodos de barreira, como o diafragma, e ao desenvolvimento de novos, como o preservativo feminino.

\footnotetext{
' Um panorama da situação da epidemia de ADs entre as mulher pode ser encontrado em Quebrando o Silêncio: mulheres e alds no Brasil. PARKER \&Galvão, 1996.
} 
Rosemberg et al. (1992) chamam a atenção para a análise de 5.681 consultas a uma clínica de doenças sexualmente transmissíveis de Nova York, nas quais encontraram riscos significativamente menores para a gonorréia e para a tricomoníase entre as usuárias de métodos de barreira controlados por mulheres (capa cervical e diafragma).

O uso de métodos vaginais de barreira não tem sido estimulado em países do Terceiro Mundo, embora sejam de fácil entendimento para sua aplicação, reconhecidos como inócuos à saúde (devido à ausência de efeitos sistêmicos) e garantam maior proteção quanto à prevenção de DST/ArDs. No Brasil, a tendência de aumento na escolha do diafragma não se verificou, pois o acesso ao método sempre foi limitado e o número de suas usuárias nunca chegou a ser significativo. Esse fato é reflexo das políticas internacionais, que nos últimos trinta anos estimularam, principalmente nos países do Terceiro Mundo, o desenvolvimento e a adoção de métodos de longa duração e cujo controle 'independe' de suas usuárias. Os métodos que se vinculam diretamente com a sexualidade c exigem mudanças comportamentais - como os de barreira - recebem poucos estímulos e são considerados ineficazes pela comunidade científica, em geral, por estarem sujeitos à 'baixa capacidade intelectiva' da nossa população.

Atualmente, no Brasil, 76,7\% das mulheres em união, de 15 a 49 anos, utilizam alguma prática contraceptiva. O uso da pílula e da esterilização feminina correspondem a 20,7\% e 40,1\%, respectivamente. Os métodos vaginais (diafragma, espumas e óvulos espermicidas) são usados por apenas $0,1 \%$. Estes últimos são desconhecidos por grande parte da população, comodemonstraram os dados da pesquisa Demographic and Health Surveys (DHS)/96, em que apenas 44,5\% das mulheres entrevistadas (entre 15 e 49 anos) afirmaram ter ouvido falar sobre esses métodos, enquanto praticamente todas declararam conhecer a pílula $(99,6 \%)$, o preservativo masculino $(98,6 \%)$, a esterilização feminina (94\%) e os injetáveis $(84,3 \%)$ (DHS-BEMFAM, 1996).

\section{- Diafragma}

O diafragma é um artefato côncavo de borracha ou de silicone com bordas flexíveis que, colocado adequadamente, recobre o colo do útero, ajustando-se entre a parede posterior da vagina e a curvatura atrás do púbis. Ao recobrir o colo do útero, forma uma barreira mecânica, impedindo a passagem dos espermatozóides para o interior do útero (Figura 1). 
Figura 1 - Colocação e posição adequada do diafragma

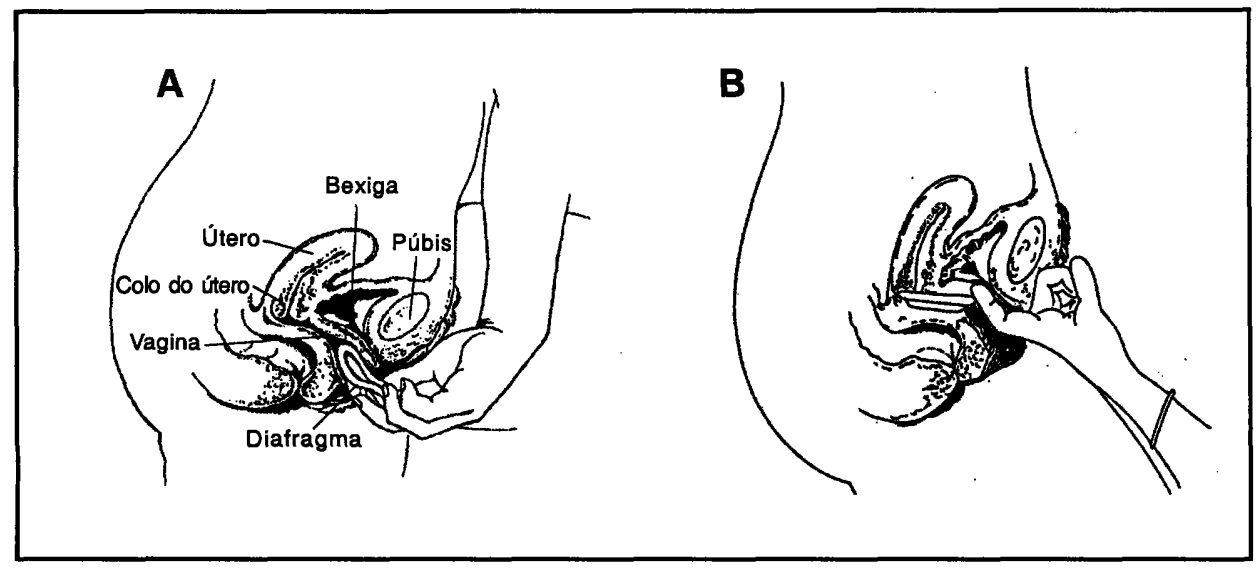

Fonte: Population Reports, 1985.

Atualmente, este método é produzidoem vários tamanhos padronizados, que variam de 50 a 105 mm de diâmetro, possibilitando seu ajuste às diferentes mulheres. Otamanho adequado é aquele cuja medida corresponde à distância que vai da curvatura do osso púbico até o fundo do saco-posterior da vagina e não incomode a usuária (Tatum \&Connell, 1981; Population Reports, 1985).

Apesar de algumas divergências, na maioria dos estudos recomenda-se que o diafragma seja utilizado em associação a um espermicida, que deve ser colocado em sua borda (Tatum \& Connell, 1981; SES/SP, 1986). Os espermicidas são agentes químicos que tornam os espermatozóides inativos. Atualmente, os mais utilizados são surfactantes, que destroem a membrana celulardo espermatozóide. Omais popularéo Nonoxynol 9 (N9), que, além de seu efeito espermicida, tem se mostrado ativo in vitro contra vários agentes causadores de DST, incluindo gonococos, Treponema pallidum, Trichomonas vaginalis, vírus do herpes simples tipo 2, hepatite B, citomegalovírus e o HIV. Persistem dúvidas quanto à concentração mínima necessária de N9 no produto para que o nível adequado de ação no meio vaginal seja mantido com segurança, pois altas concentrações podem provocar lesões na mucosa, o que aumentaria o risco para o HIV (Edelman \& Thompson, 1982; Population Reports, 1985; Rosemberg et al., 1992). Os espermicidas encontram-se disponíveis sob a forma de espumas, gel, cremes, esponjas e filmes. No Brasil, sua disponibilidade é restrita. O Nonoxynol 9 está presente em um creme produzido pela Fundação para o Remédio Popular (cuja fabricação foi interrompida) e em um creme importado, que vem sendo comercializado há pouco tempo (Lago, 1996). Algumas farmácias de manipulação preparam o produto. 
Para a maioria das usuárias, o uso do diafragma associado ao espermicida não causa efeitos colaterais sérios, tornando-o indicado para muitas mulheres que não podem usar outros métodos em função de contra-indicações ou riscos. No entanto, algumas situações devem ser identificadas e consideradas durante a sua prescrição, tais como: mulheres que nunca tiveram relação sexual; anomalias anatômicas da vagina, do colo ou do útero, como prolapso uterino; grandes colpocistoceles ou colpo-retoceles; fístulas genitais; retroversão uterina; septos vaginais etc.; infecções não tratadas do útero ou da vagina; no primeiro mês pós-aborto; alergia à borracha ou aos espermicidas; nas seis primeiras semanas pós-parto (segundo alguns autores, nos três primeiros meses); e nos casos de infecções urinárias crônicas e de repetição (Population Reports, 1985; SES/SP, 1986; Hatcher et al., 1988). Atualmente, Ferreira (apud Araújo, 1993) está desenvolvendo o monitoramento do uso do diafragma sem espermicida e uso contínuo (com a recomendação de que o diafragma seja retirado uma vez ao dia, durante o banho, e recolocado), o que, segundo o autor, elimina as dificuldades de método coito-dependente (aquele que exige colocação antes ou no momento da relação), garantindo, portanto, maior eficácia.

No Brasil, o conhecimento e o acesso ao diafragma sempre foram muito limitados, restringindo-se a alguns serviços especiais e a Organizações Não-Governamentais (ONGs) feministas. Apenas a partir de 1988 foi iniciada a produção nacional de diafragmas, pela Semina ${ }^{2}$. Conseqüentemente, há poucas informações sobre sua aceitação e seu uso. Contudo, os raros estudos evidenciam que muitas mulheres optam pelo método, quando o conhecem e têm acesso a ele nos serviços (Araújo et al., 1993). No estudo longitudinal Aceitabilidade do diafragma entre usuárias de Serviços Públicos de São Paulo ${ }^{3}$, realizado em cinco serviços públicos de saúde, o diafragma foi escolhido por 10,3\% das 2.044 mulheres que optaram por algum método no periodo (Lago et al., 1995). A maioria das mulheres que o escolheram referiu experiência contraceptiva anterior negativa, principalmente com queixas de efeitos colaterais $(77,4 \%$ relataram problemas com o uso da pílula) e falhas (26,3\% referiram gravidez indesejada com uso de algum método). Informações coerentes com a 'preocupação com a saúde', que levaram $40 \%$ das mulheres ao diafragma. Outras $30 \%$ chegaram a ele por exclusão das outras possibilidades. A maioria $(68,8 \%)$ diz que aprendeu, sem problemas, o manuseio do método durante o treinamento inicial no centro de saúde; 31,4\% afirmaram ter dificuldades para aprender e/ou entender as orientações recebidas (Kalckmann et al., 1997a).

Embora a maioria tenha referido muitas vantagens na utilização do diafragma especialmente relacionadas à ausência de cfeitos colaterais - as dificuldades e os aspectos negativos levaram muitas ao abandono do método. No seguimento do primeiro

\footnotetext{
2 Empresa paulistana que desenvolveu e comercializa o diafragma de silicone e espiral de metal tratado, nos tamanhos 60 a $85 \mathrm{~mm}$.

${ }^{3}$ Estudo realizado entre agosto de 1989 a agosto de 1991, por equipe do NISMC, do Instituto de Saúde, SES/SP. Ver, para mais detalhes, LAGO et al, 1995.
} 
ano, observou-se uma taxa acumulada de descontinuidade de $74,3 \%$, para a qual as interrupções ocorridas até três meses após a escolha contribuíram com $55 \%$. As razões alegadas foram de diferentes naturezas, mas, no total, predominaram as relacionadas à influência dos parceiros e às dificuldades de manuseio. Além disso, as mulheres que procuraram outros serviços e/ou farmácia foram desestimuladas a continuarem com o método. Diante desse panorama, concluiu-se que a atividade de planejamento familiar deveria ser redimensionada, aprofundando-se as ações educativas e/ou orientações para as usuárias de diafragma e atividades direcionadas aos parceiros, a fim de possibilitar maior retaguarda para a continuidade de uso.

\section{- Preservativo feminino}

A versão moderna do preservativo feminino foi colocada no mercado suíço com o nome de Femidom em 1992. Atualmente, é comercializado em vários outros países da Europa e nos Estados Unidos, onde o Food and Drug Administration (FDA), órgão do governo norte-americano responsável pela fiscalização de medicamentos e alimentos aprovou sua comercialização em 1993, com o nome Reality, após a realização de um estudo controlado (Farr et al., 1994). Segundo o FDA, o seu tempo de validade é de 60 meses após a fabricação (WHO/HRP, 1997).

No Brasil, o Ministério da Saúde autorizou a sua comercialização em dezembro de 1997, também sob a marca comercial Reality. Antes deste período, seu uso foi limitado aos estudos que estavam sendo desenvolvidos para avaliar sua aceitação no País ${ }^{4}$ (Kalckmann et al., 1997b).

O preservativo feminino é um tubo de poliuretano fino, resistente, transparente e pré- lubrificado, com cerca de $16 \mathrm{~cm}$ de comprimento por $7,8 \mathrm{~cm}$ de largura. Tem dois anéis flexíveis, também de poliuretano. Um deles fica solto dentro do tubo e serve para ajudar na colocação e fixação do preservativo junto ao colo uterino. O outro anel forma a bainha externa do preservativo que, quando colocado, cobre parte da vulva (Figura 2). Deve ser usado uma única vez. O poliuretano resiste mais do que o látex às condições pouco favoráveis de armazenamento, especialmente ao calor e ao uso simultâneo com lubrificantes.

\footnotetext{
${ }^{4}$ Estudo Multicêntrico AIDSCAP, Women's Initiative, Family Health International.
} 
Figura 2 - Preservativo feminino, colocação e retirada

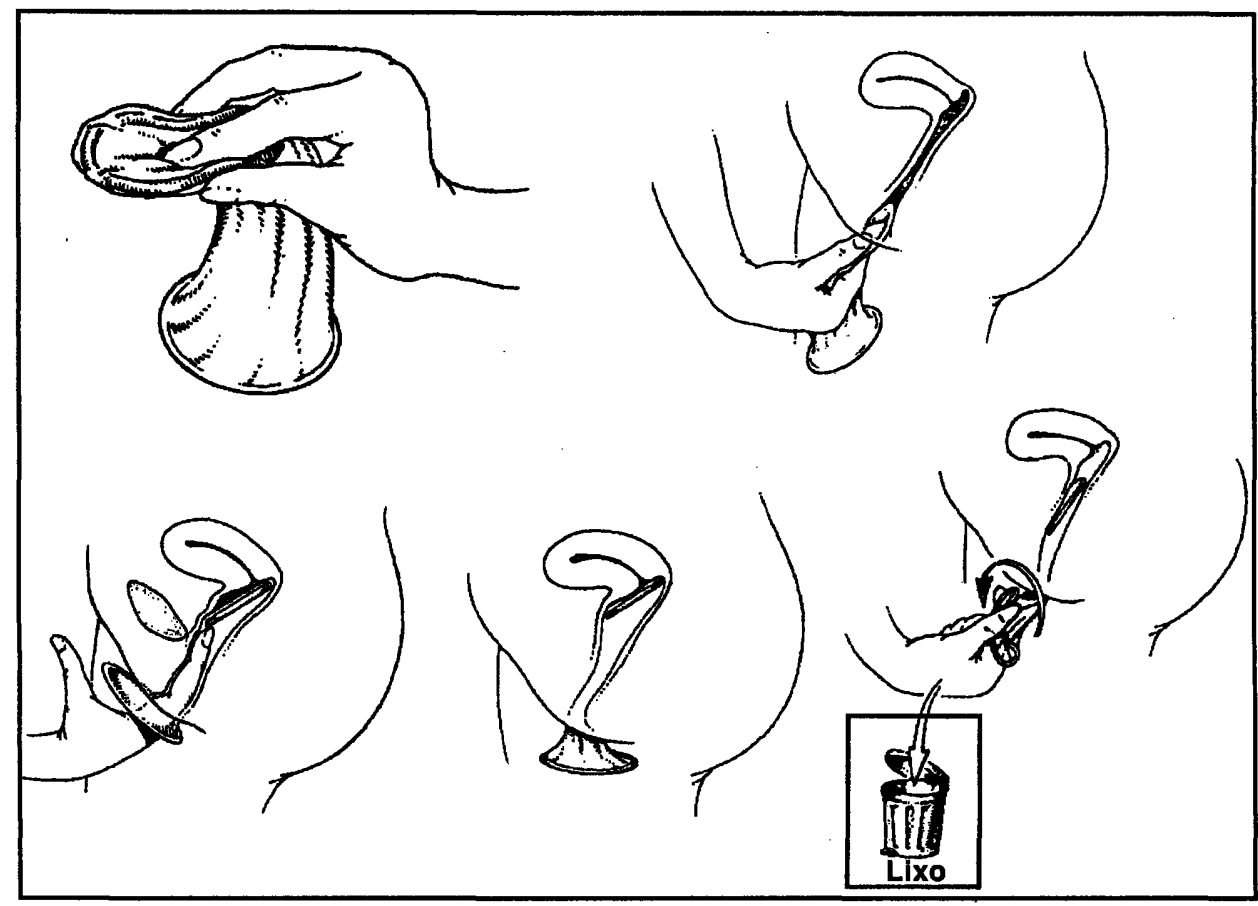

Fonte: Instruções de uso Reality, Lab. Chartex, 1996.

O preservativo feminino apresenta vantagem adicional em relação ao diafragma, pois, ao recobrir totalmente a vagina, confere proteção contra as DST, inclusive AIDs. Estudos in vitro confirmaram que ele consiste em uma barreira física a microrganismos causadores de DST. Voeller et al. (1991) demonstraram que o poliuretano usado é impermeável a gases, líquidos e microrganismos (incluindo o citomegalovírus, vírus da herpes, vírus da hepatite B e HIV).

Um estudo objetivando comparar a presença de trauma vaginal ou vulvar e mudanças na flora vaginal após o uso de preservativo feminino e diafragma foi desenvolvido por Soper et al. (1991) e avaliou 30 mulheres. Não foram detectados trauma e mudança com o uso do preservativo; com o diafragma, no entanto, verificou-se mudança na flora vaginal. Em outro estudo, Soper et al. (1993), mediram a taxa de reinfecção por Trichomonas vaginalis em 54 mulheres que usaram o preservativo feminino e em outras 50 que foram grupo controle. Entre as mulheres que usaram o preservativo em todas as relações, nenhuma foi infectada, ao passo que $14 \%$ das mulheres do grupo de controle e das que usaram o preservativo de forma irregular se infectaram. 
Até o momento, foram realizados estudos de aceitabilidade do condom feminino em vários países, com diferentes metodologias e populações, que, apesar da diversidade, mostram a interferência de fatores sociais, econômicos e culturais na aceitação e no uso deste método.

Ford \& Mathie (1993), em estudo com 214 usuárias de 17 clínicas de planejamento familiar da Grã-Bretanha, relatam que 53\% o consideraram neutro, e 39\% bom após três meses de uso. Muitas mulheres tiveram dificuldade para persuadiro parceiro a usá-lo. Jenkins et al. (1995) entrevistaram 224 mulheres. Cinqüenta e sete por cento preferem o preservativo feminino ao masculino e $40 \%$ são indiferentes. Segundo Bounds et al. (1992), a partir de um estudo na Grã-Bretanha, 71\% das 106 mulheres que experimentaram relataram dificuldades para a sua colocaçãotodas moravam com seus parceiros. Em Camarões, Monny-Lobé et al. (apud WHO, 1997) analisaram a aceitação do preservativo feminino por 40 profissionais do sexo, verificando que $63 \%$ preferiram o preservativo feminino ao masculino, $16 \%$ o masculino e $21 \%$ eram indiferentes.

As opiniões sobre o preservativo feminino são bastante diversificadas. Uma mesma característica ć considerada positiva por determinada mulher e/ou casal e negativa por outro. Para algumas mulheres, por exemplo, a lubrificação do preservativo feminino facilita a penctração, melhorando a relação; para outras, há excesso de lubrificação, o que interfere de forma negativa ou impede a relação. Apesar das diferenças, a maioria dos estudos aponta como características positivas:

- conferir maior autonomia à mulher;

- propiciar e/ou facilitar a comunicação sobre prevenção de gravidez e DST;

- não provocar efeitos colaterais;

- não interromper a relação, pois pode ser colocado previamente;

- não alterar a sensibilidade;

- propiciar maior tempo no pós-coito.

Os aspectos negativos apontados são:

- incômodo provocado pelo anel externo;

- redução do prazer sexual;

- interferência na estética;

- deslocamento durante a relação;

- resistência por parte do parceiro.

O fato de o condom feminino 'retornar' à mulher a responsabilidade da contracepção e da prevenção foi apontado como positivo por algumas mulheres e casais; para outros, como negativo.

Entre as restrições a esse método destaca-se o seu alto custo (cerca de $U \$ 2,50$, três vezes o valor do preservativo masculino, nos Estados Unidos), o que é um obstáculo 
importante para sua massificação, principalmente nos países pobres. Ex̀istem iniciativas para avaliar sua reutilização, embora os riscos associados provavelmente não justifiquem a economia (WHO/HRP, 1997).

\section{As barreiras intravaginais são seguras?}

Como se pode observar pelo Quadro 1, as taxas de falha dos métodos de barreira feminino variam muito e refletem a diversidade de metodologia e populações, mas se referem principalmente à forma como são usados. Há que se considerar que a ideologia que perpassa os serviços provedores interfere diretamente na segurança e na eficácia dos métodos, não apenas pela regularidade de sua oferta, como também pela forma como são apresentados e pela qualidade das orientações que fornecem à população. Destaque-se que, além da motivação do casal, são necessárias soluções rápidas para eventuais problemas que possam surgir durante a fase de adaptação.

\section{Quadro 1 - Alguns resultados de estudos sobre eficácia de métodos de barreira intravaginais}

\begin{tabular}{|c|c|c|c|}
\hline Método & Referência & $\mathrm{N}^{\circ}$ de mulheres & Índice de falhas \\
\hline Diafragma & $\begin{array}{l}\text { Lago et al., São Paulo, Brasil, } 1991 \\
\text { Vessey et al., Grã-Bretanha, } 1976 \\
\text { Lane et al., EUA, 1976 } \\
\text { Vessey \& Wiggins, Inglaterra, } 1974 \\
\text { Araújo et al., Belo Horizonte, Brasil, } 1993 \\
\text { Araújo et al., São Paulo, Brasil, } 1993 \\
\text { Araújo et al., Campinas, Brasil, } 1993 \\
\text { Bottona, Camocim, Brasil, 1 ano } \\
\text { Hall, New York, 1973 } \\
\text { Bounds \& Guilleband, Grã-Bretanha, } 1984 \\
\text { Mclntire \& Higgins, EUA, 1986 } \\
\text { Trussel et al., EUA, } 1994 \\
\text { Tietze \& Lewit, EUA, } 1967\end{array}$ & $\begin{array}{r}194 \\
4217 \\
2168 \\
4052 \\
166 \\
118 \\
114 \\
104 \\
347 \\
123 \\
717 \\
717 \\
1197\end{array}$ & $\begin{array}{r}(1) \\
1,9-5,5 \\
2,1 \\
2,4 \\
2,4 \\
6,2 \\
9,1 \\
2,9 \\
10,6 \\
10,9 \\
12,9 \\
3,1-4,7 \\
17,9\end{array}$ \\
\hline $\begin{array}{l}\text { Preservativo } \\
\text { feminino }\end{array}$ & $\begin{array}{l}\text { Farr et al., EUA, México, Rep. Dominicana, } 1994 \\
\text { Bounds et al., Grã-.Bretanha, } 1992\end{array}$ & $\begin{array}{r}28 \\
106\end{array}$ & $\begin{array}{r}2,6-9,5 \\
\text { média } 4,3 \\
15,0\end{array}$ \\
\hline Esponja & Trussel et al., EUA, 1994 & 720 & $8,5-8,8$ \\
\hline $\begin{array}{l}\text { Capa } \\
\text { cervical }\end{array}$ & Trussel et al., EUA, 1994 & 687 & $1,7-2,7$ \\
\hline
\end{tabular}

Nota:

(1) A taxa de efetividade de uso do diafragma foi calculada com seguimento das usuárias por meio de visitas domiciliares. Este monitoramento contribuiu para que a proporção de falhas encontradas tenha sido maior do que a dos outros estudos nacionais realizados nos serviços. Adaptado de: Instituto de Saúde, 1988. 
Quando se analisam os resultados sobre a segurança contraceptiva de um método, é fundamental que se tenham claros os critérios adotados para definir a população usuária, o que se entende por uso e por descontinuidade do uso, e como foram calculadas as taxas de falhas. Isso parece óbvio, mas nem sempre os artigos explicitam csses dados. Encontram-se, em vários deles, comparações, muitas vezes com viés ideológico, entre 'eficácia teórica' e/ou 'uso perfeito' (que considera apenas as falhas ocorridas entre aquelas que fizeram o uso consistente c adequado) e 'eficácia prática' ou 'efetividade' (que considera o total de usuárias, independentemente da forma como se deu o uso). Outro aspecto importante é o período considerado para o cálculo de falhas - no período inicial, especialmente nos primeiros seis meses, a proporção de falhas é, normalmente, maior do que nos períodos subseqüentes.

Apenas para exemplificar, a eficácia teórica da pílula é de $99,9 \%$, fato sempre citado quando se fala sobre sua segurança. No entanto, alguns estudos apontam taxas elevadas de ocorrência de gravidez entre as usuárias desse método. Vale citar aqui alguns dados: em um estudo realizado em Fortaleza, 12\% das mulheres hospitalizadas pós-aborto usavam pilula quando engravidaram (apud Giffin \& Costa, 1996); em estudo realizado na Grande São Paulo, das 51 mulheres que engravidaram em uso de método, 24 (47\%) consideram que a pílula falhou (Kalckmann, 1995); em recente pesquisa populacional realizada nacionalmente, entre as razões alegadas para a interrupção da pílula nos últimos cinco anos, a falha do método foi referida por $11,4 \%$ de suas usuárias, similar à falha atribuída no mesmo estudo ao condom masculino $(11,7 \%)$ (DHS/BemfaM, 1996). Tais resultados demonstram que, apesar da alta 'eficácia teórica', a pílula falha, quando tomada de forma inadequada e sem orientações, ou seja, quanto à 'eficácia prática', no cotidiano, sua segurança pode ser comprometida.

Os resultados obtidos por Farr et al. (1994), em um estudo multicêntrico realizado nos Estados Unidos, Mćxico e República Dominicana evidenciam a diferença entre a 'efetividade' e a 'eficácia em uso perfeito' do preservativo feminino. A taxa de gravidez em uso desse método foi de $12,4 \%$ entre as americanas e $22,2 \%$ entre as latinas, resultando uma taxa de falha de $15 \%$ nos primeiros seis meses. Neste estudo, não houve atividades de aconselhamento durante o seguimento. A eficácia em uso perfeito (eficácia teórica), definido como o uso de preservativo feminino em todas as relações, foi de $2,6 \%$ entre as americanas e $9,5 \%$ entre as latinas, com uma taxa de falha de 4,3 por 100 mulheres, no mesmo período. Além disso, é importante procurar maiores informações sobre a população estudada, antes de se fazerem generalizações. Os achados de Farr, por exemplo, ao serem comparados, exigem cautela mais de $40 \%$ das participantes usavam preservativo masculino antes de sua inclusão no estudo; mais de $90 \%$ das americanas e $50 \%$ das latinas usavam, pelo menos eventualmente, outros métodos de barreira. 
A diversidade de desenhos (estruturas de pesquisa) e a ausência de informações sobre a metodologia adotada pelos estudos tornam muito difícil a comparação entre eles, mas levam a concluir que a segurança do diafragma e do preservativo feminino é comparável a de outros métodos, desde que usados adequadamente. Atualmente, diante do quadro epidemiológico da Aids e das demais DST, é fundamental que qualquer discussão sobre a segurança dos métodos contraceptivos considere também sua capacidade de proteção contra essas doenças ${ }^{5}$.

\section{Quadro 2 - Eficácia contraceptiva durante o primeiro ano de uso}

\begin{tabular}{|lrcc|}
\hline Método & \multicolumn{2}{c|}{$\begin{array}{c}\text { Gravidez } \\
\text { No primeiro ano uso (\%) }\end{array}$} & $\begin{array}{c}\text { Continuidade de uso no } \\
\text { primeiro ano (\%) }\end{array}$ \\
\cline { 2 - 3 } & Uso ${ }^{(1)}$ & Uso Perfeito & \\
\hline Nenhum & 85,0 & 85,0 & - \\
Preserv.feminino sem espermicida & 21,0 & 5,0 & 56,0 \\
Preserv.masculino sem espermicida & 12,0 & 3,0 & 63,0 \\
Espermicida & 21,0 & 6,0 & 43,0 \\
Diafragma com espermicida & 18,0 & 6,0 & 58,0 \\
Capa cervical com espermicida & & & \\
Multípara & 36,0 & 20,0 & 45,0 \\
Nulipara & 18,0 & 9,0 & 58,0 \\
Esponja & & & 45,0 \\
Multipara & 36,0 & 20,0 & 58,0 \\
Nulipara & 18,0 & 9,0 & 72,0 \\
Contraceptivo oral - Combinado & 3,0 & 0,1 & 85,0 \\
Implant-Norplant & 00,9 & 0,09 & 70,0 \\
Contraceptivo injetável - Depo Provera & 0,03 & 0,03 & 78,0 \\
DIU-Copper T380A & 0,08 & 0,06 & 100,0 \\
Laqueadura / Vasectomia & 0,4 & 0,4 & \\
\hline
\end{tabular}

Fonte: Adaptado de WHO. The female condom, 1997, versão preliminar.

Notas:

Considera-seototal de mulheres que se dizem em usodométodo, independente da adequaçãoou nãodesse uso. Considera-se apenas as mulheres que referem uso adequado do método.

\section{Primeiras experiências com preservativo feminino no Brasil}

"O Preservativo Feminino como Método Controlado pelas Mulheres" ${ }^{6}$ é o primeiro estudo sobre o tema realizado no Brasil, visando a apresentá-lo às mulheres; descrever suas impressões de uso; identificar fatores que facilitam ou dificultam seu uso; avaliar

\footnotetext{
5 Para maior aprofundamento ver LAGO, 1996.

- No Brasil, este estudo, conhecido como Projeto Beija-flor, foi realizado pelo Instituto de Saúde, Mulher, Criança, Cidadania e Saúde (MCCS) e Associação Saúde da Família, no periodo de fevereiro de 1996 a janeiro de 1997, na cidade de São Paulo, sob a coordenação de Suzana Kalckmann.
} 
como o método interfere no processo de negociação sexual; sondar as opiniões dos parceiros; e verificar o papel das atividades educativas e de apoio contínuo de pares na dinâmica de uso.

Nesse estudo exploratório, com abordagem quantitativa e qualitativa, as participantes foram recrutadas em reuniões realizadas em diversas regiões do município de São Paulo, muitas delas com o apoio de ONGs. Nessas reuniões foram dadas explicações detalhadas sobre o estudo e sobre o preservativo feminino, além de promoverem-sc discussões sobre DST/AIDS, contracepção e fisiologia feminina. Na mesma ocasião, as participantes que preenchiam a ficha de recrutamento recebiam uma caixa de preservativo feminino (Reality, com seis unidades ${ }^{7}$ ) e eram convidadas a voltar à rcunião de decisão.

As reuniões de decisão foram realizadas, em média, cerca de 20 dias após o recrutamento. As participantes, após ler, discutire assinar o consentimento informado ${ }^{8}$, decidiam se desejavam continuar no estudo. Os critérios de inclusão eram, então, revistos. Nos casos afirmativos, uma entrevistadora treinada realizava a entrevista individual inicial e fornecia uma agenda com as instruções de uso do método, e a participante era alocada em um dos oito grupos formados, segundo faixa etária e nível socioeconômico. Cada grupo se reuniu quatro vezes (grupos focais inicial e final e duas sessões de apoio) e as participantes responderam a uma entrevista individual final. Os critérios de elegibilidade: ser sexualmente ativa; morar na Grande São Paulo; ter idade cntre 18 e 40 anos; não desejar ficar grávida nos seis mescs subseqüentes e concordar em participar das atividades do estudo.

No total, 394 mulheres participaram das reuniões de recrutamento, das quais 126 (32\% das recrutadas) voltaram para as reuniões de seleção, sendo que 11 delas não obedeciam aos critérios de elegibilidade. Assim, 15 mulheres foram incluídas, responderam à entrevista inicial e foram alocadas em um dos oito grupos formados. Destas, 12 (10\%) não participaram de nenhuma atividade de grupo e foram consideradas como perda. Foram incluídas 103 mulheres, com tempo médio de observação de dois meses.

De acordo com a entrevista inicial, a média de idade foi de 26,6 anos $( \pm 6,9)$. A média de anos concluídos de escolaridade foi de 10,4 anos $( \pm 3,9)$ e $77,5 \%$ desenvolviam atividade remunerada. A maioria $(94,2 \%)$ tinha um parceiro auto-referido como principal, com média de 8,1 relações sexuais por mês; 77,7\% tinham conhecimento básico sobre Alds; $80,6 \%$ referiram já ter conversado com seus parceiros sobre o assunto; $84,5 \%$ declararam grande necessidade de se prevenir do HIV. Chama a atenção a proporção de gravidez anterior, em uso de práticas contraceptivas: $25 \%$ do total de mulheres. Os métodos apontados como responsáveis por falha foram a pílula $(31,4 \%)$ e abstinência periódica $(22,8 \%)$.

\footnotetext{
${ }^{7}$ Os preservativos foram doados pelo governo dos Estados Unidos - Usaid.

${ }^{8}$ Documento com todas as informações sobre o preservativo feminino e o desenvolvimento do estudo.
} 
A motivação alegada para entrarem no estudo foi o desejo de encontrar uma nova alternativa contraceptiva e a curiosidade. De início, poucas falaram sobre a necessidade de se proteger contra as DST/AIDS (resposta espontânea no recrutamento).

De modo geral, a avaliação final das participantes foi positiva. $75 \%$ (72) referindo seu uso ao final do estudo, das quais $33 \%$ (24) em uso exclusivo. Entre os atributos positivos predominaram os referentes:

- a ser confortável (30,5\%);

-à autonomia para as mulheres conferida pelo método $(27,4 \%)$;

-à proteção tanto contra a gravidez quanto contra as DST $(22,1 \%)$;

- à não-alteração da sensibilidade (20\%);

- a ser de fácil manuseio (16,8\%).

- e a consistir em uma alternativa ao preservativo masculino para prática de sexo mais seguro $(14,7 \%)$.

Outro aspecto positivo apontado nas discussões em grupo foi o fato deste método facilitar a negociação de seu uso, por ser novidade e não ter, portanto, o mesmo significado negativo do preservativo masculino.

De modo geral houve um estranhamento inicial - o condom feminino foi considerado grande e desajeitado. No final, apenas $22,1 \%$ consideraram esse aspecto negativo. Nos grupos ocorreram muitas discussões a esse respeito, com posições divergentes. Algumas mulheres ponderaram que a interferência na estética comprometia a possibilidade de seu uso; outras consideraram esse aspecto algo superável, que gradativamente seria incorporado.

Outros atributos negativos foram: difícil manuscio (15,8\%) e incômodo provocado pelo anel externo $(11,6 \%)$. Muitas mulheres $(46 \%)$ tiveram dificuldades iniciais para a colocação do preservativo. No entanto, $87,5 \%$ afirmaram que, a partir da terceira colocação, passaram a manuseá-lo com facilidade. Outros obstáculos ao uso foram o deslocamento durante a relação $(15,2 \%)$ e o excesso de lubrificante (11\%).

A participação em grupos de apoio, com outras mulheres da mesma faixa etária e nível socioeconômico, mostrou-se fundamental para a superação das dificuldades iniciais. Nessas discussões afloraram temas referentes à dificuldade de negociação de uso do método com o parceiro.

Em síntese, a avaliação final demonstra que o preservativo feminino pode ser uma alternativa para muitos casais, mas que, para sua utilização de forma adequada e contínua, é necessário propiciar espaços para a troca de informações e experiências. 


\section{Conclusōes}

Os métodos femininos de barreira podem e devem ser uma escolha adequada para determinados perfis de mulheres, tanto pela sua ação contraceptiva, quanto pela proteção que oferecem - no caso do preservativo feminino - em relação à prevenção das DST/ AiDs. Mais do que isso, deve-se propriamente destacar que o preservativo feminino representa uma importante alternativa para a prevenção na transmissão sexual do HIV. Contudo, alguns aspectos devem ser considerados. As mulheres que escolhem os métodos femininos de barreira adotam práticas distintas dos padrões culturalmente vigentes no Brasil, centrados na alta eficácia da pílula c da esterilização feminina. Portanto, além das dificuldades individuais vividas para o enfrentamento de um método novo, elas sofrem o ônus de optarem por um caminho contrário ao da maioria, o que exige maior conviç̧ão para a continuidade de uso. Diante desse quadro, os serviços de saúde provedores deveriam prestar uma atenção especial a essas mulheres, principalmente no período inicial de adaptação ao método, um momento crítico para a sua manutenção.

Apesar de esses métodos conferirem maior autonomia às mulheres, a percepção dos parceiros em relação a eles se mostrou fundamental para a continuidade de uso, indicando que as barreiras vaginais sob controle feminino podem facilitar a negociação sexual, mas não eliminam a necessidade de comunicação entre o casal.

Por fim, faz-se necessário, mais do que concluir, explicitar alguns desafios, que dependem essencialmente de vontade política. A expressiva maioria das mulheres brasileiras depende dos serviços públicos para o atendimento à sua saúde.

Como compatibilizar a realidade atual dos serviços públicos a essa necessidade de apoio e respostas imediatas geradas pelo uso dos métodos de barreira? Que estratégias podem ser adotadas para ampliar a divulgação desses métodos e como garantir subsídios para que possam ter continuidade?

Diante desses desafios, é urgente que esforços sejam concentrados na ampliação do número e da diversidade de estudos sobre os métodos de barreira vaginal, seguros, eficazes e cuja aceitabilidade pelos casais assegure a prevenção da gravidez indesejada, das DST e da AIDS.

\section{Referências Bibliográficas}

Arsújo, M. J. O. et al. Avaliação clínica do diafragma vaginal em três contextos brasileiros. Femina, 21:463-472, 1993.

BANDLER, R. Diafragma: uma proposta educativa de contracepsão. Recife: SOS Corpo/Grupo de Saúde da Mulher, 1990. 
Bounds, W.; Guilebaud, J. \& Newman, G. B. Female Condom (Femidom). A clinical study of its use-effectiveness and patient acceptability. British Journal of Family Planning, 18:36-41, 1992.

BRUCE, J. \& SCHEARER, S. B. Contraceptives and Common Sense: conventional methods reconsidered. New York: The Population Council, 1979.

CAMPBELL, P. Efficacy of female condom. Lancet, 341:1155, 1993.

Edelman, D. A. \& Thompson, S. Vaginal contraception: an update. Contraceptive Delivery Systems, 3 (2): 75-81, Apr. 1982.

FARR, G. et al. Contraceptive Efficacy and Acceptability of the Female Condom. American Joumal of Public Heallh, 84:1960-1964, 1994.

FORD, N. \& MATHE, E. The acceptability and experience of the female condom. Femidom among family planning clinic attenders. British Journal of Family Planning, 19:187-192, 1993.

GIFFin, K. \& Costa, S. As práticas contraceptivas e o aborto no Brasil. In: Reflexões sobre gênero e fecundidade no Brasil. São Paulo: Family Health International, Projeto de Estudos da Mulher, 1996

HATCHER, R. et. al. Contraceptive Technology. 14th revised edition. Atlanta: Printed Matter, Inc, 1988.

InSTTIUTO DE SAÚDE. Diafragma: uma escolha possivel. São Paulo: Divisão de Saúde da Mulher e da Criança, Secretaria de Estado da Saúde/SP, 1988.

Jenkns, C.; SimBa, N. \& AISA, M. A Study of the Acceptability of the Female Condom in Urban Papua New Guinea. Unpublished, 1995.

KaLCKMANN, S. A. Dinâmica de Uso do Diafragma como Método Contraceptivoentre Usuárias de Serviços Públicos, 1995. Dissertação de Mestrado. São Paulo: Escola Paulista de Medicina, Universidade Federal de São Paulo.

KaLCKMANn, S. et al. O Diafragma como Método Contraceptivo: a experiência de usuárias de Serviços Públicos de Saúde. Cademos de Saúde Pública, 13 (4); 647-657, out./dez. 1997a.

KaLCKMAnN, S. et al. O Preservativo Feminino como Método Controlado pelas Mulheres. Relatónio Final. São Paulo, 1997b. (Mimeo).

LAGO, T. G. et al. Acceptability of Diaphragm Among Low-income Women in São Paulo. International Family Planning Perpectives, 21:1 14-1 18, 1995.

LAGO, TG. Opções Contraceptivas em Tempos de AIDs. In: PARKER, R. \& GALVão, J. (Orgs). Quebrando o Silêncio. Mutheres e Ains no Brasil. Rio de Janeiro: Relume-Dumará, ABIA, IMS/UERJ, 1996.

LANE, M. E., ARCEO, R. \& SOBRERO, A. J. Sucessful use of the diaphragm and jelly by a young population. Report of a clinical study. Family Planning Perspectives 8, $n^{\circ}$ 2: 81-86, 1976. 
PARKER, R. \& GALVÃO, J. (Orgs). Quebrando o Silêncio. Mutheres e Ams no Brasil. Rio de Janeiro: RelumeDumará, ABIA, IMS/UER, 1996.

POPUlation REPORTS. Novidades em Anticoncepção Vaginal, série $\mathrm{H}, \mathrm{n}^{\circ} 7$ (fev.), Baltimore: John Hopkins University, 1985.

ROSEMBERG, M. J. \& Gollub, E. L. Commentary: methods women can use that may prevent sexually trasmitted disease, including HV. American Joumal of Public Health, 82 (1 1): 14731478, 1992.

Rousselle, S. Pornéia. Sexualidade e amorno mundo antigo. São Paulo: Brasiliense, 1994.

SCHILING, R. F.; EL BASSEL, N. \& LeEPER, M. A. Acceptance of the Female Condom by Latin and African-American Women. American Joumal of Public Health, 81:1345-1346, 1991.

Secretaria de Estado da Saúde de São Pauro (Ses/SP). Subprogramade SaúdedaMulher. Normas Técnicas de Planejamento Familiar. São Paulo: 1986.

Sмmн, C. et al. Female Barrier Contraceptive. Lancet, 341:696, 1993.

SOPER, D. E; BROCKWELL, N. J. \& DAITON, H. P. Evaluation of the Effects of a Female Condom on the Female Genital Tract. Contraception, 44:21-29, 1991.

SOPER, D. E. et al. Prevention of Vaginal Trichomoniasis by Compliant use of the Female Condom. Sexually Transmitted Diseases, 20:137-139, 1993.

TATUm, H. J. \& Connel, E. B. Barrier Contraception: a comprehensive overview. Fertility and sterility, 36 (1): 1-12, Jul. 1981.

TieTzE, C. \& LeWI, S. Comparison of Three Contraceptive Methods: diaphragm with jelly or cream, vaginal foam and jelly cream alone. The Joumal of Sex Research, 3:295-311, 1967.

TRUSSELL, J. et al. Comparative contraceptive efficacy of the female condom and other barrier methods. Family Planning Perspectives, 26:66-72, 1994.

Voeuer, B.; Coutrer, S. L. \& MAYHAN, K. G. Letters to the Editor. Gas, dye and viral transport through polyurethane condoms. Journal of the American Medical Association 266(21):29862987, 1991.

WORID HEALTH ORGANZATION (WHO), HRP, UNDP, UNFPA, World Bank. The Female Condom: a review, preview copy, Geneve: WHO, 1997. 


\section{0}

\section{Aborto Provocado:}

a dimensão do problema e a transformação da prática

Sarab Hawker Costa

\section{Introdução}

Nas últimas décadas, a maioria dos países do mundo tem apresentado a tendência de liberalizar as leis de aborto, ao passo que o Brasil continua a restringir severamente a interrupção voluntária da gravidez. O principal efeito destas medidas legais restritivas não é a redução da prática do aborto, e sim a exacerbação das desigualdades socioeconômicas que permeiam nossa sociedade. Em grande parte do País - especialmente nas grandes cidades - mulheres com recursos financeiros têm acesso a serviços relativamente seguros e modernos. Em contraposição, as pobres são forçadas a recorrer a abortos realizados sob condições anti-higiênicas por pessoas não treinadas ou obrigadas, elas mesmas, a praticá-lo. Estas práticas inseguras - muitas vezes desencadeadas por diversos meios, progressivamente mais perigosos - causam complicações que resultam em uma proporção substancial das admissões ginecológicas em hospitais e constituem uma das principais causas da mortalidade materna.

Neste capitulo, analisa-se o aborto provocado no País e apresenta-se um panorama que procura discutir seus determinantes e os impactos causados à saúde da mulher pobre pela prática insegura do abortamento. Recorre-se a dados de estatísticas governamentais, pesquisas de base populacional e estudos hospitalares com pacientes em abortamento-mais especificamente, focaliza-se em pesquisa realizada no Rio de Janeiro, em 1991 (também denominada, neste artigo, como o 'estudo' ou 'pesquisa' do Rio). Utilizando uma combinação de métodos quantitativos equalitativos, foram entrevistadas na época 1.608 mulheres admitidas em sete hospitais da rede pública com diagnósticos relacionados ao abortamento. 


\section{A dimensão do problema}

As limitações metodológicas para a condução de pesquisas sobre o aborto induzido em um contexto em que a prática é ilegal são bastante conhecidas (Population Council, 1989; Barreto, 1992). O sub-registro e a classificação errônea são freqüentes e devem-sc ao receio da mulher em admitir o ato ilegal; à relutância dos profissionais da saúde em registrar corretamente o evento nos prontuários hospitalares, por causa das sanções legais aplicáveis; ou, ainda, à soma das duas hipóteses.

Mesmo assim, inquéritos populacionais documentam uma alta prevalência do aborto ilegal. A proporção de entrevistadas que admitem um ou mais abortos varia entrc $9 \% \mathrm{e}$ $24 \%$, de acordo com pesquisas do final dos anos 60 e início dos 70 (Rodrigues et al., 1981; Rodrigues; Morris \& Janowitz, 1984). A incidência de gravidezes terminando em aborto foi de 6\% em São Paulo em 1965 e de 11\%, em 1978 (Milanesi, 1975; Nakamura et al., 1980). Uma taxa mais alta foi reportada em favelas do Rio de Janeiro, em 1984: $23 \%$ de todas as gravidezes resultaram em aborto induzido, com o número médio de abortamentos da ordem de 2,1\% por mulher (Martins et al., 1991). Estudo semelhante, feito em 1988 com 3.764 mulheres residentes na área metropolitana do Rio de Janeiro registrou que $22 \%$ das gravidezes ocorridas nos 12 meses antecedentes à pesquisa resultaram em aborto - 52\% deles provocados (Oliveira \& Jourdan, 1989). Em um trabalho em cinco favelas de Belo Horizonte (MG), 30\% das mulheres declararam haver provocado um aborto (Silva, 1984).

Em pesquisas dos anos 90 , constatou-se que um número relativamente grande de mulheres a cada ano experimenta abortos repetidos. O estudo nos hospitais do Rio revelou que $26 \%$ de mulheres haviam provocado pelo menos um aborto anteriormente; $12 \%$ tiveram pelo menos três. Ao se re-entrevistar uma subamostra destas mulheres seis meses depois, detectou-se que $12 \%$ estavam grávidas e $3 \%$ haviam realizado outro aborto induzido no período (Costa, 1995). Em estudo semelhante conduzido em Fortaleza, Ceará, verificou-se um índice de $22 \%$ de mulheres internadas com histórico de aborto anterior (Misago, 1994).

Além de informações sobre abortamentos efetivamente realizados, alguns estudos ressaltam que as tentativas também são em numerosas. No Rio de Janeiro, em 1991, entre o grupo de parturientes entrevistadas, $18 \%$ relataram tentativas malsucedidas de abortar (Costa, 1995).

A despeito de algumas imperfeições, encontram-se disponiveis desde 1991 estatísticas oficiais compiladas pelo Ministério da Previdência sobre as admissões nos serviços circunscritos ao serviço público no País, incluindo os serviços privados contratados pelo antigo Instituto Nacional de Assistência Médica e Previdência Social (INAmps). A Tabela 1 mostra que um total de 241.945 mulheres com diagnóstico relacionado ao aborto foram tratadas em 1997 pela rede pública no Brasil. Os dados também sugerem 
a existência de um decréscimo sistemático no número de mulheres que procuram hospitais por complicações relacionadas ao aborto em todas as regiões brasileiras, com um declínio total da ordem de $20 \%$ em anos recentes.

\section{Tabela 1 - Internaçōes por diagnoses relacionadas ao abortamento (CID 630-639) por regiāo e ano de internação}

\begin{tabular}{lccccc}
\hline Região & $1993(\mathrm{n})$ & $1994(\mathrm{n})$ & $1995(\mathrm{n})$ & $1996(\mathrm{n})$ & $1997(\mathrm{n})$ \\
\hline Norte & 19.782 & 19.474 & 18.552 & 16.121 & 15.683 \\
Nordeste & 114.432 & 117.993 & 102.473 & 92.362 & 91.676 \\
Sudeste & 123.088 & 125.788 & 112.128 & 99.938 & 99.614 \\
Sul & 25.455 & 26.132 & 21.782 & 18.966 & 20.311 \\
Centro-Oeste & 15.338 & 16.329 & 13.967 & 14.019 & 14.661 \\
\hline TOTAL & 298.095 & 305.716 & 268.902 & 241.406 & 241.945 \\
\hline
\end{tabular}

Fonte: Ministério da Saúde/ Fundação Nacional da Saúde/Centro Nacional de Epidemiologia.

Como as informações hospitalares são colhidas considerando o aborto ilegal, normalmente não apresentam distinção entre abortos induzidos e espontâneos. Pelos registros oficiais, menos de 1\% dos atendimentos traz a classificação 'aborto induzido' (Tabela 2).

\section{Tabela 2-Número de internaçōes por abortamento em hospi- tais públicos do Brasil - 1997, por tipo de aborto}

\begin{tabular}{lrr}
\hline Tipo de Aborto & $\mathbf{n}$ & $\%$ \\
\hline Retido (632) & 63.069 & 27,4 \\
Espontâneo (634) & 140.983 & 61,3 \\
Induzido legalmente (635) & 198 & 0,1 \\
Induzido sem indicação legal (636) & 1.102 & 0,5 \\
Aborto não-especificado (637) & 22.703 & 9,9 \\
Outros diagnósticos ligados ao aborto (ICD 630-631. 638-639) & 1.844 & 0,8 \\
\hline TOTAL & 229.899 & 100 \\
\hline
\end{tabular}

Fonte: Ministério da Saúde/ Fundação Nacional da Saúde/Centro Nacional de Epidemiologia.

Antes de qualquer ajustamento, o número de mulheres admitidas em hospitais públicos com diagnóstico relacionado ao aborto representava aproximadamente $0,8 \%$ da população feminina de 15 - 49 anos de idade em 1993, diminuindo para 0,6\% em 1996, com taxas mais altas observadas nas regiões Norte e Nordeste-0,8 e 0,6\%; e 1,1\% e $0,8 \%$, respectivamente (Tabela 3 ). 


\section{Tabela 3 - Taxas de internação por abortamento, por região e ano*}

\begin{tabular}{lcccc}
\hline Região & 1993 & 1994 & 1995 & 1996 \\
\hline Norte & 0,82 & 0,79 & 0,75 & 0,62 \\
Nordeste & 1,12 & 1,07 & 0,92 & 0,82 \\
Sudeste & 0,69 & 0,83 & 0,62 & 0,55 \\
Sul & 0,39 & 0,42 & 0,35 & 0,30 \\
Centro Oeste & 0,56 & 0,60 & 0,50 & 0,49 \\
\hline TOTAL & 0,75 & 0,76 & 0,66 & 0,58 \\
\hline
\end{tabular}

Fonte: Ministério da Saúde/ Fundação Nacional da Saúde/Centro Nacional de Epidemiologia.

Nota:

(*) Com base no número de internações por abortamento (CID 630-639) dividido pela população feminina da faixa etária de 15-49 anos.

Taxas significativamente mais altas de hospitalização por diagnósticos ligados ao aborto são encontradas entre mulheres nas faixas etárias dos 15 aos 19 e dos 20 aos 29 anos, se comparadas às mulheres com mais de 30 anos. Isto se justifica pela alta incidência de esterilização feminina que atinge a população feminina desta faixa etária (em especial com mais de 40 anos), eliminando os riscos de engravidar.

Comose mostra na Tabela 4, opercentual de internação para mulheres entre 20 e 29 anos na Região Nordesteem 1996 era de 1,3\%, sendoqueem dois Estados, BahiaeSergipe, oíndice alcançou 1,9\% (Tabela 4). Na Região Norte, o estadodoAcre apresentou taxas ainda superiores: para ogrupo entre 15 e 19 anos, era de 1,5\%; e de 2,1\% para as mulheres entre 20 e 29 anos. Diante da ausência de dados similares para o setor privadode saúde-financiadodiretamente peloconsumidor-estes números devem subestimara extensãoe seriedadedo problema.

\section{Tabela 4 - Taxas de aborto no ano de 1996 por região e faixa etária*}

\begin{tabular}{lccccc}
\hline Região & $15-19$ & $20-29$ & $30-39$ & $40-49$ & Total \\
\hline Norte & 1,45 & 0,93 & 0,40 & 0,15 & 0,62 \\
Nordeste & 0,79 & 1,34 & 0,64 & 0,23 & 0,82 \\
Sudeste & 0,59 & 0,83 & 0,46 & 0,14 & 0,55 \\
Sul & 0,31 & 0,44 & 0,28 & 0,12 & 0,30 \\
Centro Oeste & 0,56 & 0,74 & 0,35 & 0,11 & 0,49 \\
\hline TOTAL & 3,65 & 4,24 & 2,13 & 0,75 & 2,78
\end{tabular}

Fonte: Ministério da Saúde/ Fundação Nacional da Saúde/Centro Nacional de Epidemiologia.

Nota:

(*) Com bàse no número de internações por diagnoses ligadas ao aborto (CID 630-639) classificação realizada pela população feminina do mesmo grupo etário. 
Dados sobre admissões hospitalares no setor público também indicam que mulheres com complicações de abortamento constituem uma proporção substancial de todas as pacientes obstétricas. Por exemplo, no Estado do Rio de Janeiro, admissões por abortamento foram responsáveis por 14\%de todos os procedimentos obstétricos (partos normais e cesarianas e admissões por abortamento) em 1995; e 16\% na área metropolitana do Rio de Janeiro.

É importante enfatizar que estes números fornecem apenas um painel fragmentado da situação, porque os dados sobre admissões por abortamento, partos e outros procedimentos obstétricos no setor privado não estão disponiveis e inexistem estudos para avaliar a cobertura e a qualidade dos dados oficiais. Ressalta-se também que os estudos hospitalares, cuja cobertura é limitada, podem apresentar uma visão distorcida e não representativa do universo.

$\mathrm{Na}$ ausência de fontes mais adequadas, pesquisadores do Instituto Alan Guttmacher (AGI) têm tentado estimar o número de abortos induzidos no País, tendo como base informações sobre internações hospitalares fornecidas pelo Datasus. Depois de separar os abortos induzidos dos espontâneos, os investigadores multiplicam o número de abortamentos induzidos segundo proporção estimada destes casos que requerem internação. O número é ajustado também por classificação errônea e subenumeração. Com base nesta metodologia, o número de abortos induzidos no Brasil em 1991 foi de 1.443.350, correspondendo a uma taxa anual de 3,7 abortamentos por 100 mulheres entre 15 e 49 anos; e segundo os autores, $31 \%$ de todas as gravidezes resultaram em aborto por ano (AGI, 1994; Singh \& Wulf, 1994).

Singh \& Sedgh (1997), analisando admissões hospitalares entre o fim da década de 70 e início dos 90, detectaram tanto o incremento nos índices de aborto quanto do uso de métodos contraceptivos em várias regiões do País no período. Outra conclusão é a de que o aborto corresponde a aproximadamente 13\% do declínio da fertilidade ao longo das duas últimas décadas.

Em uma tentativa mais recente de estimar o número total de abortamentos no Brasil, Corrêa \& Freitas (1997) tomaram como base de informação o número de curetagens pós-aborto realizadas nos hospitais públicos, aplicando um fator de correção moderado (uma para cada 3,5 abortos) para os anos de 1994-1996. Os números obtidos foram $921.100,811.700$ e 728.100 , respectivamente. Embora possivelmente subestimando o número de abortos induzidos - por ter sido usado o número de curetagens, em vez do número de internações por abortamento - este trabalho indica que o número de interrupções voluntárias da gravidez decresceu sistematicamente no período.

Os dados do Datasus (Brasil, MS/FNS, 1992) sobre internações por abortamento também nos permitem estimar os custos destes tratamentos para o Estado. Costa (1995) calculou que os hospitais públicos do Rio gastaram em média US\$485,00 por paciente para tratar as 23.753 mulheres internadas por complicações de abortamentos, um total de US\$11.425.000) em 1991; e que o custo de uma curetagem no setor público era de 
US\$184,00-valorbem inferior ao custo do tratamento para uma internação média de 2,1 dias. Ampliando-se os cálculos, conclui-se que a quantia seria suficiente para o Estado garantir a realização de 62.600 abortos seguros (91\% dos 68,649 abortos estimados para o estado do Rio de Janeiro no ano de 1991). O estudo mostrou ainda que, ao reduzir o custo de aborto para o valor cobrado pelas clínicas privadas citadas pelas mulheres na pesquisa - US\$ 120 em média - seria possível ao governo oferecer aborto seguro para todas as mulheres que procuraram o recurso e garantir-lhes US $\$ 37$ para o planejamento familiar. Ou seja: a provisão de serviços de aborto seguros e contraceptivos de qualidade não se limita a uma questão meramente financeira. Trata-se de um problema profundamente enraizado, em que se sobressai a discriminação social e cultural.

Os atestados de óbito confirmam a magnitude do problema. As mortes relacionadas com o aborto corresponderam a $11 \%$ da mortalidade materna no Brasil entre 1991 e 1993. Dados sugerem que esta proporção tem decrescido desde a década de 80 (Tabela 5). Cabe lembrar que o grupo de causas específicas denominado 'aborto' inclui mole hidatiforme, gravidez ectópica, e os abortos espontâneos, induzidos e não-específicos, eque representa a quinta causa mais freqüente de morte materna no País. O percentual variou entre 8,7 (1980) e 5,2 (1993) óbitos maternos para cada 100 mil nascidos-vivos. Em 1993, os abortos induzido e não-especificado corresponderam à metade dos óbitos maternos deste grupo. A maioria das regiões e estados segue este padrão. No entanto, existem situações muito particulares, em que o aborto assume um papel mais relevante. Investigação conduzida pela Vigilância Epidemiológica da Secretaria de Saúde no Recife em 1994 e 1995 constatou ser a primeira causa de óbitos maternos na cidade, ao lado de outras causas diretas. Em Salvador, a partir de informações de prontuários, laudos do Instituto Médico Legal (IML) e entrevistas apontou-se o aborto como a principal causa de morte materna, correspondendo a $37 \%$ de todos os óbitos. Naquela capital, o coeficiente específico por aborto foi de 52,8 por mil nascidos-vivos. Um alto índice foi detectado antes dos 20 anos de idade (Massachs, 1995).

\section{Tabela 5 - Mortalidade materna no Brasil. 1979-1993}

\begin{tabular}{|c|c|c|c|c|c|c|c|c|c|c|}
\hline Motivo & $\begin{array}{c}1979 \\
n\end{array}$ & $\begin{array}{c}1981 \\
\%\end{array}$ & $\begin{array}{c}1982 \\
n\end{array}$ & $\begin{array}{c}1984 \\
\%\end{array}$ & $\begin{array}{c}1985 \\
n\end{array}$ & $\begin{array}{c}1987 \\
\%\end{array}$ & $\begin{array}{c}1988 \\
n\end{array}$ & $\begin{array}{c}1990 \\
\%\end{array}$ & $\begin{array}{c}1991 \\
n\end{array}$ & $\begin{array}{c}1993 \\
\%\end{array}$ \\
\hline bol & 1060 & 1 & 862 & 14 & 71 & 13 & 593 & 1 & 5 & 11 \\
\hline 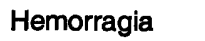 & 1.525 & & & 1 & Y & & & & & 16 \\
\hline $\begin{array}{l}\text { Toxemias } \\
\text { Complicaçōes }\end{array}$ & 2080 & 27 & 61 & ח & 158 & 28 & 1.425 & 28 & 1.31 & 28 \\
\hline puerpérias & 1.38 & 18 & 996 & 16 & 879 & 16 & 802 & 16 & 70 & 15 \\
\hline & 1.544 & & 27 & 20 & & 0 & & & & 20 \\
\hline- & 156 & 2 & 191 & 3 & 359 & 6 & 425 & 8 & 448 & 10 \\
\hline OTAL & 7.750 & 100 & 6.373 & 100 & 5.618 & 100 & 5.062 & 100 & 4.692 & 100 \\
\hline
\end{tabular}

Fonte: Ministério da Saúde/ Fundação Nacional da Saúde/Centro Nacional de Epidemiologia. 
Complicações não-fatais do aborto são até mais difíceis de serem medidas do que a mortalidade, mas são muito mais comuns. A base de dados Datasus indica que $86 \%$ das 241.945 admissões em 1996 decorrentes de abortamentos foram tratadas porcuretagem (CID 630-639)-o quarto procedimento médico ou cinúrgico mais freqüenteem todo o País. Uma análise mais aprofundada da morbidade a partir dessas informações nãoé possível.

\section{Prática do aborto}

Parece claro que o método utilizado para induzir o aborto afeta tanto a extensão quanto o tipo de complicação. Pesquisas de 1984 em favelas do Rio de Janeiro demonstram que a inserção de sondas corresponde a apenas $12 \%$ de todos os métodos, mas foi relativamente mais perigosa; que $50 \%$ dos abortamentos induzidos por este método resultaram em complicações, em comparação com os $27 \%$ causados pela indução medicamentosa (por injeções ou via oral). O uso de sondas foi associado a uma alta taxa de infecções e perfurações uterinas (Martins et al., 1991). Estudos hospitalares da década de 80 confirmam a alta prevalência dos métodos invasivos. Em 1981, no Sul do Brasil, ficou demonstrado que 52\% das mulheres induziram o aborto via inserção de sonda e $4 \%$ pela inserção de objetos sólidos (Boehs et al., 1983). Estudo de 1988 no Nordeste (Welkovic; Costa \& Leite, 1991) também revelou alta proporção de mulheres (69\%) que induziram o aborto por meio da inserção de sonda.

Relatórios mais recentes informam que a prática do aborto tem sofrido grandes alterações, e drogas com propriedades abortivas - principalmente o misoprostol (análogo sintético da prostaglandina E1) - assumiram importante papel neste cenário (Coelho, 1991). Vendida com o nome Cytotec, a droga é licenciada para o tratamento de úlceras gástricas e duodenais. Como todas as prostaglandinas, o misoprostol estimula a atividade uterina tanto quando utilizado isoladamente ou em associação com a mifepristona (RU 468), ou methrotrexate (Norman; Thong \& Baird, 1992; Aubeny \& Baulieu, 1991; El-Rafaey et al., 1995). O uso indevido da droga foi relatado pela primeira vez no Nordeste, em Fortaleza, Ceará. Inquérito dos prontuários de uma maternidade indicaram a citação do misoprostol em $12 \%$ dos casos de aborto induzido tratados na cidade em 1988. Até 1990, o percentual alcançou 70\% (Barros, 1991). Em 1991, relatórios de várias partes do País confirmaram o amplo uso da droga como um abortivo. $\mathrm{O}$ rápido aumento também foi detectado em Goiânia, no Centro-Oeste - a venda misoprostol entre 1987 e 1989 triplicou, mantendo-se em um padrão estável até 1991 (Viggiano et al., 1996). 
Farmácias, médicos, as mulheres e a mídia foram os responsáveis pela disseminação da informação sobre a droga. A pesquisa de 1991 nos hospitais do Rio de Janeiro revelou que a maior parte das mulheres que usou o misoprostol (84\%) tomou conhecimento do medicamento por amigos, parentes ou colegas. Uma minoria - 10\% - teve como fonte o farmacêutico. É importante ressaltar que embora o misoprostol seja aprovado para o tratamento de úlceras gástricas em 60 países, no Brasil foi reconhecido, primeiramente, por seus efeitos abortivos (Barbosa \& Arilha, 1993).

A publicação de informações sobre o uso maciço da droga, em particular pcla imprensa, nos primeiros meses de 1991, deu margem a um debate intenso sobre o assunto. Alguns médicos e grupos de mulheres sugeriram que a disponibilidade do Cytotec era benéfica, porque outros métodos de indução ao aborto eram comparativamente mais perigosos. Também argumentou-se que a morbidade relacionada aos abortamentos diminuiu desde que a droga passou a ser utilizada. Do outro lado, instituições e grupos ligados à vigilância sanitária defenderam a retirada do Cytotec do mercado, por estar sendo vendido somente por scus efeitos colaterais - a indução do aborto. Ao mesmo tempo, relatos sobre efeitos adversos resultantes da exposição pré-natal a altas doses do misoprostol também contribuíram para o 'clima negativo' na época (Schonhofer, 1991; Fonseca et al., 1993).

A controvérsia resultou em uma intensa campanha contra o medicamento. Em julho de 1991, o Ministério da Saúde alterou os regulamentos de comercialização do medicamento, em uma tentativa de restringir seu uso como abortivo. Assim, o misoprostol poderia ser vendido apenas $\mathrm{cm}$ farmácias que retêm a receita médica para uso oficial. Em quatro estados (Minas Gerais, São Paulo, Rio de Janeiro e Ceará) as restrições foram ainda mais severas (IDEC, 1997).

É importante lembrar que a maior parte das informações sobre o uso da droga se origina em estudos hospitalares. Ressalta-se que os dados se referem às mulheres que tomaram o medicamento e, depois, procuraram auxílio do hospital. Isto pode acarretar uma visão muito distorcida da droga como um abortivo: não existem dados sobre as mutheres que ingeriram o remédio e não procuraram o hospital; sobre as situações em que o aborto se concretizou sem complicações aparentes; ou, ainda, sobre os casos em que a gravidez teve continuidade.

O estudo do Rio, por exemplo, mostrou que mais da metade das mulheres com aborto induzido (57\%) relataram o uso da droga isolado ou em combinação com outro método. Outros $13 \%$ declararam o uso de medicamentos que não conseguiam identificar pelo nome. Conclui-se que a utilização poderia ser de aproximadamente $70 \%$ (Tabela 6). Métodos tradicionais (chás de ervas, sonda, exercícios e pressão abdominal) corresponderam a 18\% de todos os métodos reportados (Costa, 1993). 


\section{Tabela 6 - Distruibuição de 803 mulheres com casos de abor- to induzido com base no método usado e enfermi- dade causada}

\begin{tabular}{|c|c|c|c|c|c|c|c|}
\hline \multirow[b]{2}{*}{$\begin{array}{l}\text { Métodos } \\
\text { de Aborto }\end{array}$} & \multicolumn{7}{|c|}{$\mathrm{n}$ (\% de mulheres) } \\
\hline & $\begin{array}{c}\text { Número } \\
(\%)\end{array}$ & $\begin{array}{c}\text { Sangramento } \\
\text { Intenso }\end{array}$ & Infecções & Lesões & $\begin{array}{l}\text { Colapso } \\
\text { Sistêmico }\end{array}$ & \begin{tabular}{|l|} 
Transfusão \\
de Sangue
\end{tabular} & Curetagem \\
\hline $\begin{array}{l}\text { Cytotec } \\
\text { Sozinho } \\
\text { Com outros } \\
\text { métodos } \\
\end{array}$ & $\begin{array}{r}365(45,5) \\
93(11,6) \\
\end{array}$ & $80(19,2)$ & $90(19,7)$ & 0 & $6(1,3)$ & $6(1,3)$ & $388(84,7)$ \\
\hline $\begin{array}{l}\text { Outros } \\
\text { medicamentos } \\
\text { não-identifi- } \\
\text { cados }\end{array}$ & $100(12,5)$ & $23(24,7)$ & $21(21,0)$ & 0 & 2 & 2 & $84(84,0)$ \\
\hline Chás & $85(10,6)$ & $16(21,9)$ & $17(20,0)$ & 0 & $4(4,7)$ & $4(4,7)$ & $71(83,5)$ \\
\hline Injeçōes & $70(8,7)$ & $15(23,4)$ & $14(20,0)$ & 0 & 0 & 0 & $59(86,8)$ \\
\hline Sonda & $36(4,5)$ & $5(15,6)$ & $19(52,8)$ & $3(9,4)$ & 1 & $4(11,1)$ & $30(83,3)$ \\
\hline $\begin{array}{l}\text { Clínicas de } \\
\text { aborto }\end{array}$ & $21(2,6)$ & 1 & $9(42,9)$ & 0 & 2 & 0 & $12(60,0)$ \\
\hline $\begin{array}{l}\text { Pressāo abdo- } \\
\text { minal e exer- } \\
\text { cícios violentos }\end{array}$ & $15(1,9)$ & $3(21,4)$ & $2(13,3)$ & 0 & 2 & 1 & $11(73,3)$ \\
\hline $\begin{array}{l}\text { Permanganato } \\
\text { de potássio } \\
\text { intravaginal }\end{array}$ & $6(0,7)$ & $3(50,0)$ & 0 & $3(50,0)$ & 2 & 0 & $3(50,0)$ \\
\hline Objetos sólidos & $3(0,4)$ & 0 & 2 & 2 & 0 & 0 & $3(100,0)$ \\
\hline Outros & $9(1,1)$ & 1 & $3(33,3)$ & 0 & 0 & 0 & $7(77,8)$ \\
\hline $\begin{array}{l}\text { Todos os } \\
\text { métodos }\end{array}$ & 803 & $147(20,1)$ & $177(22,0)$ & $8(1,0)$ & $19(2,4)$ & $17(2,1)$ & $666(83,3)$ \\
\hline
\end{tabular}

Fonte: COSTA, 1995.

Não é de estranhar que 70\% das mulheres tenham obtido o medicamento em farmácias. Calcula-se que a metade delas foi aconselhada sobre as doses e recebeu instruções para procurar auxílio médico apenas depois de o sangramento ter início. O misoprostol foi lembrado por ser muito mais barato do que as clínicas clandestinas (média de US\$ 6 o comprimido, versus US $\$ 144$ ). Ao responder sobre a razão da escolha, $28 \%$ apontaram a droga como o método mais acessível; $14 \%$, o mais seguro; e $13 \%$, o mais barato. Para $25 \%$, o misoprostol era o único método conhecido. Uma pequena proporção (1 1\%) já tinha usado a droga como abortivo anteriormente. Em contraste, $71 \%$ das usuárias de clínicas relataram ter escolhido o método por ser mais seguro. A sonda foi considerada pela maioria das usuárias o mais barato dos métodos, mas pouco seguro. 
Apesar das vantagens apontadas - que motivaram a escolha-a maioria das mulheres entrevistadas no Rio informou que o Cytotec não era o método preferido para induzir o aborto. Muitas delas falaram que a experiência com o misoprostol foi negativa, por causa das dores que sentiram e da necessidade de cuidados médicos e de uma curetagem. Elas declararam desconhecer o processo físico desencadeado pelo medicamento e o tempo necessário para o início do aborto. Se não encontrassem dificuldades financeiras c outros obstáculos (como a legislação), $77 \%$ das mulheres teriam realizado o aborto com um médico - neste caso, a segurança foi citada por $87 \%$ (Costa, 1995). Resultados similares foram obtidos em estudo qualitativo realizado em São Paulo, no mesmo período (Barbosa \& Aritha, 1993).

A despeito dos esforços do governo para limitar o uso do misoprostol, estudos em Fortalcza, Goiânia e Recife (Fonseca et al., 1996; Viggiano ct al., 1996; c Molina et al., 1996) entre 1992 e 1996, indicam que entre $49 \%$ e $89 \%$ das mulheres hospitalizadas após tentativas de aborto induzido reportaram o uso da droga (Tabela 7).

\section{Tabela 7 - Uso do misoprostol entre mulheres hospitalizadas devido ao aborto induzido em quatro cidades brasileiras. 1991-1996}

\begin{tabular}{|c|c|c|c|c|}
\hline $\begin{array}{l}\text { Cidade e período } \\
\text { de estudo }\end{array}$ & $\begin{array}{c}\text { № de mulheres } \\
\text { com aborto } \\
\text { induzido (n) }\end{array}$ & $\begin{array}{c}\text { Usou } \\
\text { Misoprostol } \\
\text { (\%) }\end{array}$ & $\begin{array}{l}\text { Uso via oral e } \\
\text { vaginal } \\
(\%)\end{array}$ & $\begin{array}{c}\text { Com infecção } \\
(\%)\end{array}$ \\
\hline Rio de Janeiro $1991^{(1)}$ & 603 & 57,0 & 29,0 & 20,0 \\
\hline Fortaleza 1992-3(2) & 1369 & 66,0 & 90,0 & 9,0 \\
\hline Goiânia 1994(3) & 256 & 49,0 & 75,0 & 9,0 \\
\hline Recife $1995-6^{(4)}$ & 41 & 89,0 & 83,0 & 15,0 \\
\hline
\end{tabular}

Fontes:

(1) COSTA \& VESSEY, 1993.

(2) FONSECA et al., 1996.

(3) Viggiano et al., 1996.

(4) Molina et al., 1996.

Mesmo com a nova regulamentação, a farmácia continuou sendo a principal fonte de acesso à droga. Pesquisa em 194 farmácias de 41 bairros do Recife, Pernambuco, em 1996, revela que em $26 \%$ dos estabelecimentos visitados, o misoprostol foi comprado sem receita médica e que nas farmácias menores o acesso foi facilitado (Molina et al., 1997). Além disso, comprovou que o custo do medicamento tem aumentado. Aproximadamente metade das entrevistadas pagou entre US $\$ 30$ e US\$40, por quatro comprimidos - pelo menos cinco vezes mais caro do que em 1991 (Costa, 1995). 
Mudanças na prática de uso da droga também têm sido relatadas. O estudo do Rio detectou doses de um a 64 comprimidos (200 a 16.000 microgramas) -sendo a dose média de 4 comprimidos. A mesma fonte revela que $65 \%$ das usuárias tomaram o remédio via oral; $29 \%$ fizeram uso oral e intravaginal $;$ e $6 \%$ apenas vaginal (Costa \& Vessey, 1993 ). Trabalhos realizados entre 1992 e 1996 indicam que uma proporção significativamente maior de mulheres induziu o aborto com quatro comprimidos administrados simultaneamente via oral e intravaginal em Fortaleza, Goiânia e Recife (Tabela 7). O conceito de que a via de administração vaginal é mais eficiente para a evacuação do conteúdo uterino também está estabelecido em estudos clínicos (Bugalho et al., 1994).

Apesar dos riscos potenciais de automedicação em grande escala, dados indicam que as complicações por abortamento são significativamente menos severas entre as mulheres que usaram o misoprostol do que entre as usuárias de sonda ou outros métodos invasivos. Oestudo nos hospitais públicos do Rio mostrou que $19 \%$ das mutheres que usaram misoprostol se apresentavam com sangramento intenso; $20 \% \mathrm{com}$ sinais clínicos de infecção; $1 \%$ necessitava de transfusão de sangue; e $85 \%$ foram tratadas com curetagem (Tabela 8). Proporções mais altas ( $\mathrm{p}<0.0005$ ) do grupo que relatou o uso da sonda se apresentavam com sinais de infecção, necessitavam de sangue ou tinham lesões físicas (Costa \& Vessey, 1993). Três mortes foram registrados pelo estudo entre prováveis usuárias do misoprostol: duas por assepsia; uma por ruptura do útero.

Os estudos mais recentes também relatam taxas de complicações menores entre as usuárias do misoprostol. O índice de infecção nas pesquisas de Fortaleza e Recife foi, conforme a Tabela 7, respectivamente de $9 \%$ e $15 \%$, mais baixo do que o percentual verificado no Rio. Isto possivelmente reflete o maior conhecimento do método por parte da populaçãoe dos profissionais da saúde responsáveis pelos pacientes. Estes números contrastam dramaticamente com os encontrados na Região Nordeste em 1988 (portanto, antes da disseminação do uso do misoprostol). Foram entrevistadas 494 mulheres - 33\% estavam infectadas; $41 \%$ tiveram sangramento intenso; $12 \%$ receberam transfusão; e $21 \%$ apresentavam lesões fisicas (todas decorrências do uso elevado de métodos invasivos de indução ao aborto).

Argumenta-se que, cmbora as complicações decorrentes do uso do misoprostol possam ser menos severas, o uso amplo do medicamento pode ter causado um aumento no número de admissões relacionadas ao abortamento e curetagens (Coelho et al., 1993). A falta de dados confiáveis, no entanto, torna impossível avaliar se o aumento foi verificado nos hospitais estudados no Rio de Janeiro. Mas na pesquisa de Goiânia para o período de 1987-1991 não foi encontrada qualquer associação entre o incremento na venda do misoprostol e admissões hospitalares (Viggiano et al., 1996).

A pesquisa do Rio sugere que o uso do misoprostol diminuiu depois das alterações na legislação; e que aumentou o número de mcdicamentos não-identificados e injeções. Detectou-se também um aumento proporcional no uso de chá de ervas e sonda. Ainda que estes dados não forneçam um quadro completoda situação, tendem a apoiara idéia 
de que o misoprostol pode ter substituído alguns dos métodos mais perigosos de abortoe que o controle do medicamento poderia resultar no incremento da incidência de complicações severas. Em Campinas, observaram-se um pequeno-mas significativo-aumento no índice de complicações depois das restrições governamentais sobre a venda do Cytotece um aumentotripliçadodo número de mortes matemas no mesmo período (Gabiatti, 1994).

Das 1.608 pacientes entrevistadas no Rio sobre o último aborto ou tentativa de abortamento, 96 relataram a utilização do medicamento. Do total, 13 (14\%) disseram que a droga falhou e 83 (87\%) declararam succsso ou sangramento. Quase metadc (44 ou $46 \%$ ) reccbeu tratamento hospitalar; enquanto 38 (40\%) tiveram de evacuar o útero. Isto sugere que o misoprostol induz o aborto completo em quase metade das mulheres que dele fazem uso. Ressalta-se que é necessário ter cautela ao se compararem os resultados obtidos em estudos hospitalares aos provenientes de ensaios clínicos, em virtude das óbvias diferenças na estrutura das investigações. No cntanto, o nível de sucesso é coincidente com o verificado em dois outros estudos (Coelho et al., 1993; Crenin \& Vittinghoff, 1994). Duas investigações sobre o uso intravaginal do misoprostol para indução ao aborto no primeiro trimestre de gravidez indicaram taxas de aborto completo de 34\% e 43\%. Esta proporção cresceu quando os autores resolveram aumentar o período entre a administração do medicamento e a realização das curetagens (Bugalho et al., 1996; Carbonnel et al., 1997). Torna-se conveniente enfatizar que muitas brasileiras usam o medicamento para induzir o sangramento, facilitando o acesso à curetagem nos hospitais públicos. Muitas mulheres que se automedicam com o misoprostol possivelmente procuram o hospital nas primeiras horas, ou assim que o sangramento se inicia. Mesmo na ausência de intervenção médica, uma proporção desconhecida destas mulheres poderia experimentar o processo completo de abortamento.

\section{Aborto e contracepção}

No Brasil, a prevalência contraceptiva em si não é nem um bom indicador do acesso feminino às informações e serviços de planejamento familiar, nem um estimador eficaz da prevenção de aborto. Pesquisas nacionais de 1986 demonstraram que $95 \%$ das mulheres conheciam a pílula e a laqueadura tubária; aproximadamente $70 \%$ das casadas do Sul e 50\% do Nordeste utilizavam algum tipo de método contraceptivo-uma taxa de prevalência comparável à de muitos países desenvolvidos (Arruda et al., 1987; Oliveira \& Simões, 1989). Os mesmos estudos expuseram que a esterilização e a pílula correspondem por pelo menos $80 \%$ de todos os métodos de contracepção utilizados. Dez anos depois, revelou-se em uma pesquisa que o uso de métodos contraceptivos cresceu; que a dependência da pílula e a esterilização feminina se mantiveram; e que o uso de outros métodos modemos de contracepção permanecia limitado (Bemfam, 1996). 
Em relação às pesquisas locais, dados indicam que mais de $90 \%$ das usuárias da pílula compraram os medicamentos em farmácias - a maioria sem receita médica, mesmo devendo ser utilizados sob orientação médica - o que pode causar problemas: a automedicação faz com que aproximadamente um quarto das usuárias não usem a pílula corretamente, e uma significativa proporção utiliza-se do método mesmo quando contra-indicado (Costa et al., 1990).

Neste contexto, é evidente que muitas mulheres levariam a termo uma gravidez indesejada, diante da necessidade de optar por levá-la até o final ou não. Números do estudo realizado no Rio de Janeiro em 1991 demonstram que 37\% das mulheres hospitalizadas em conseqüência de um aborto inseguro utilizavam algum método contraceptivo no mês anterior ao da gravidez; aproximadamente três quartos utilizavam um método moderno (60\% via oral; $10 \%$ injetáveis; e $4 \%$ preservativo); e 25\% usavam métodos tradicionais (tabela ou coito interrompido).

Também evidenciam que o uso da contracepção cresceu com a idade: mulheres mais velhas tinham uma probabilidade maior de estar usando métodos menos efetivos, o que provavelmente reflete a oferta limitada de métodos contraceptivos destinados a elas. Perguntadas sobre a razão de engravidarem apesar de estarem-se utilizando da contracepção, 33\% não tinham idéia; mais da metade (55\%) atribuiu o fato a falhas ou uso incorreto do método; e apenas $4 \%$ disseram não saber fazer o uso correto do método escolhido. Enquanto o estudo demonstrou um alto índice de não-aderência à prescrição para todos os grupos de idade, mulheres com menos de 19 anos aparentemente encontravam maior dificuldade do que as dos outros grupos ctánios. Inesperadamente, entretanto, mais da metade das mulheres que disseram não saber utilizar corretamente o método tinham 30 anos ou mais. Entre aquelas que fizeram uso da contracepção no passado, 46\% citaram 'medo dos efeitos colaterais' ou 'problemas ligados à saúde' como as razões principais de não terem usado qualquer método na ocasião desta gravidez. Entre as que nunca usaram contracepção, quase um quarto $(24 \%)$ relatou a falta de conhecimento (a maioria com menos de 25 anos) ou acesso a serviços de contracepção (Costa, 1995).

Embora se imagine que o uso incorrcto ou inconsistente seja alto entre o grupo de mulheres que engravidaram usando a pílula, este fenômeno não se restringe aos pacientes de abortamento. Pesquisa realizada entre mulheres de baixa renda no Rio de Janeiro revelou que $23 \%$ das usuárias de pílulas utilizavam o método incorretamente-em dias alternados ou somente depois do ato sexual. A maioria delas sabia como tomaro medicamento, mas optou por não seguir as instruções por várias razões, como evitar os efeitos colaterais ou reduziro seu custo. O mesmo estudo revelou que $21 \%$ das entrevistadas com histórico de aborto induzido faziam uso da contracepção quando engravidaram (Costa et al., 1990).

É interessante observar que pesquisa realizada no Rcino Unido com mulheres que abortaram demonstrou que mais de um terço fazia uso da contracepção no mês em que conceberam (Griffiths, 1990; Duncan et al., 1990) - uma proporção muito seme- 
thante à verificada no Rio de Janeiro. Em contraposição, quase a metade das mulheres que procuraram os serviços de abortamento usava o preservativo como forma usual de contracepção e menos de $2 \%$ utilizava-se de medicamentos via oral.

Pesquisas recentes tornam explícita a relação entre 'ter informação' sobre os métodos e o seu uso correto c consistente. Measham (1976), comparando usuárias que compraram medicamentos em farmácias ou outros locais que não os serviços de planejamento familiar àquelas que receberam as pílulas de médicos, descobriu que os efeitos colaterais eram duas vezes mais altos entre o grupo que se automedicou do que entre o que obteve a contracepção por meio do médico. O mesmo estudo demonstrou que a escassez de pontos de referência para acompanhamento médico impossibilitou a quase dois terços das que se automedicavam a procura de auxílio diante do surgimento de problemas. Estas mulheres, inevitavelmente, viveram taxas de descontinuidade mais elevadas do que as usuárias dos serviços médicos. Potter et al. (1988), também estudando a adesão de usuárias à contracepção oral e as características de distribuição do sistema, descobriram que a má qualidade de informação por parte dos profissionais da saúde estava associada com altos índices de descontinuidade nos primeiros meses a partir da aceitação do uso do método. A má qualidade do conhecimento sobre o uso correto e os riscos e benefícios da contracepção pode não apenas ocasionar o abandono do método, mas também deter o seu uso definitivamente.

\section{Determinantes do aborto induzido}

Os motivos que levam as mulheres a se expor aos riscos de uma gravidez indesejada e ao aborto têm sido objeto de muito interesse e especulação. Muitas das pesquisas neste campo têm sido realizadas sem se enquadrarem a uma abordagem teórica específica. Os modelos utilizados enfatizam desde os fatores individuais-estado emocional ou características de personalidade - até variantes situacionais e sociais (Luker, 1977; Morrison, 1985; Beck \& Davies, 1987).

No Brasil, investigações sobre os motivos pelos quais as mulheres abortam - da mesma maneira que outros problemas ligados à saúde - têm como foco o papel dos fatores externos e problemas fundamentais e imediatos, associados à baixa renda $\mathrm{e}$ à falta de serviços básicos de saúde e educação (Viel, 1975). Em grande parte destes estudos, têm sido utilizados métodos demográficos e epidemiológicos descritivos.

Milanesi (1975) descobriu razões econômicas como motivo principal para a indução ao aborto, em pesquisa realizada em São Paulo em 1969 - o mesmo foi registrado duas décadas depois por Martins et al. (1991) entre mulheres residentes $\mathrm{cm}$ favelas do Rio de Janeiro. 
A natureza da relação da mulher com seu parceiro também tem sido destacada como um fator importante. A instabilidade da relação ou a falta de apoio emocional e econômico por parte do companheiro ao tomar conhecimento da gravidez têm sido mencionados pelas mulheres como uma das razões para abortar (Costa et al., 1987; Paiewonsky, 1993). Em 1991, no estudo do Rio, 39\% das entrevistadas relataram que elas ou os companheiros simplesmente não queriam um filho naquele momento ou mais filhos no futuro; e $27 \%$ falaram que não tinham condições econômicas para criar outro filho. Mulheres no auge do período reprodutivo mais freqüentemente citaram razões econômicas ou o desejo de não ter mais filhos, sugerindo que suas preocupações variam de acordo com a etapa de sua vida reprodutiva.

Em uma tentativa de conhecer as possíveis associações entre os fatores de risco para o aborto induzido, a pesquisa realizada nos hospitais públicos do Rio de Janeiro comparou um grupo de mulheres hospitalizadas após a realização de abortos inseguros com um grupo que decidiu levar a gravidez a termo, pareados segundo idade e número de filhos tidos. Uma análise multivariada revelou a situação conjugal como maior fator de risco independente para aborto induzido que resultou em hospitalização. Os dados sugerem que as mulheres que vivem sozinhas têm uma probabilidade cinco vezes maior de viver um aborto induzido do que as casadas. Um risco muito alto também foi associado à condição de trabalho da mulher. As que trabalhavam fora de casa tinham 3,5 vezes mais probabilidade realizar um aborto do que as donas de casa - ainda em relação a estas, as estudantes apresentaram uma probabilidade quatro vezes mais alta. Os resultados também sugerem que mulheres com história de pelo menos um aborto anterior têm duas vezes maior probabilidade de serem hospitalizadas por um aborto induzido do que as que não têm este histórico. Este achado está de acordo com outros estudos que mostram que o risco de abortamento repetido é maior do que a possibilidade de um primeiro aborto (Tietze, 1978; Forrest \& Henshaw, 1984). Além disso, a pesquisa do Rio revelou que mulheres que experimentaram um intervalo muito curto entre a gravidez anterior e a atual apresentavam um risco alto de hospitalização por aborto induzido. 


\section{Tabela 8-Resultados obtidos por análise multivariada de diversos fatores de risco do aborto induzido}

\begin{tabular}{|c|c|c|c|}
\hline Fator de Risco & Taxa & $\begin{array}{l}\text { Intervalos } \\
95 \%\end{array}$ & $\begin{array}{c}\text { Probabilidade/ } \\
\text { Taxa Estatística (P) }\end{array}$ \\
\hline \multicolumn{4}{|l|}{ Estado civil } \\
\hline Casada & 1,00 & - & $c^{2}=84,39$ \\
\hline Com companheiro & 1,44 & $0,98-2,11$ & df 2. $p<.001$ \\
\hline Solteira & 5,64 & $3,54-8,96$ & \\
\hline \multicolumn{4}{|l|}{ Função } \\
\hline Dona de casa & 1,00 & - & \\
\hline Trabalhando fora & 3,53 & $2,57-4,85$ & $c^{2}=77,62$ \\
\hline Desempregada/procurando emprego & 2,31 & $1,24-4,30$ & df $3 . p<.001$ \\
\hline Estudando & 4,16 & $1,87-9,26$ & \\
\hline \multicolumn{4}{|l|}{ Intervalo entre a última gestaçāo em anos } \\
\hline Primeira gestação & 1,00 & - & \\
\hline $3+$ & 0,85 & $0,48-1,51$ & $c^{2}=53,80$ \\
\hline $1-2$ & 0,84 & $0,49-1,43$ & df $3 . p<.001$ \\
\hline$<.1$ & 5,24 & $2,59-10,60$ & \\
\hline \multicolumn{4}{|l|}{ Abortos induzidos anteriores } \\
\hline Sim & 1,00 & - & $c^{2}=14,53$ \\
\hline Não & 2,14 & $1,43-3,19$ & df $1 . p<.001$ \\
\hline \multicolumn{4}{|l|}{ № de métodos contraceptivos usados } \\
\hline Método nunca usado & 1,00 & $1,17-2,80$ & \\
\hline 1 & 1,81 & $1,50-4,01$ & $c^{2}=19,02$ \\
\hline $2-3$ & 2,45 & $1,72-5,12$ & df $3 . p<.001$ \\
\hline $4+$ & 2,97 & - & \\
\hline
\end{tabular}

Fonte: CosTA, 1995.

Enquanto os casos e controles foram muito similares a respeito da idade de início do primeiro uso da contracepção, outras variáveis relacionadas à prática contraceptiva encontraram-se associadas ao risco de aborto induzido, como alguma experiência com a contracepção e o número de métodos utilizados. Pode-se argumentar que o risco mais baixo observado entre mulheres que nunca fizeram uso de qualquer método estava relacionado ao seu desejo de engravidar. Em outras pesquisas, constata-se que na proporção em que aumentam a motivação da mulher em regular sua fecundidade e o uso de contraceptivos as taxas de aborto também podem aumentar, pelo menos temporariamente (Requena, 1968; Singh \& Sedgh, 1997). O elevado risco de aborto induzido, observado no estudo do Rio, à medida que as mulheres usaram mais métodos contraceptivos tende a confirmar esta teoria. Mais importante, nestes dados, é a sugestão de que o aborto não era utilizado como forma de contracepção, mas como último recurso para as mulheres que tentavam evitar a gravidez. Além disso, a maioria de casos 
e controles estudados usaram contracepção oral como seu primeiro método ( $84 \%$ e 87\%, respectivamente); e que pela escolha de métodos eficazes reversíveis ser tão limitada no País, mulheres que não podem usar, ou decidem não usar a pílula são obrigadas a utilizar métodos menos eficazes, como tabela e coito interrompido. As tentativas de regular a fecundidade com métodos que não a pílula inevitavelmente resultam em altos índices de falhas e exposição aumentada para a gravidez indesejada e o aborto.

\section{Comentários finais}

No Brasil (e maior parte da América Latina), o aborto é uma questão extremamente delicada e controversa. Ao mesmo tempo em que o índice exato de abortamentos é desconhecido, é evidente que um grande número de mulheres em todo o País são hospitalizadas a cada ano em função de complicações de procedimentos abortivos inseguros. Pesquisas sugerem que o número de internações hospitalares deles decorrentes tem aumentado desde o final da década de 70 até o início dos anos 90 , quando começou a decrescer. Seja como for, é preciso cuidado ao se analisar estas tendências. $\mathrm{O}$ número de mulheres que necessitam de cuidados médicos representa uma proporção desconhecida do universo total que induz o aborto. Também é pequeno o conhecimento sobre as mulheres que induzem o abortamento e não recebem qualquer atenção médica, porque não necessitam, por não terem acesso aos serviços de saúde, ou por morrerem antes de recebê-la.

As alterações dos métodos de indução ao aborto ocorridas nos últimos anos-e, em particular, o uso intensivo da prostaglandina misoprostol em todo o Brasil a partir do final dos anos 80 -ocasionaram mudanças tanto na incidência quanto no tipo de complicações. Muito embora o misoprostol não seja muito eficaz na indução de um aborto completo quando utilizado isoladamente-ou, mais importante, se a dose, ea forma de administração não forem apropriadas -, muitas mulheres fazem uso da droga apenas para induzir o início do sangramento e facilitar seu acesso aos serviços de saúde para a realização de uma curetagem. Dados também sugerem que a automedicação gerou um amplo espectro de práticas no início da 'epidemia' mas, com o decorrer do tempo, aparentemente, tanto as usuárias quanto os balconistas das farmácias e profissionais da saúde adquiriram mais experiência em relação ao método abortivo, possibilitando sua melhor administração e condução de tratamento. Concomitantemente, é possível supor que as mulheres não solicitaram auxílio tão cedo ou tão freqüentemente após o uso da droga.

A despeito dos riscos potenciais associados a um ensaio não-controlado desta dimensão, estudos hospitalares indicam que complicações por aborto provocado são significativamente menos severas em mulheres que usaram o misoprostol comparadas 
a usuárias de métodos invasivos. Isto pode reduzir o custo do tratamento destas complicações e, a longo prazo, a morbidade relacionada ao aborto - ainda que a maioria das mulheres admitidas nos hospitais continue a ser submetida à evacuação do útero e, como conseqüência, estejam expostas a riscos associados a este procedimento.

A experiência brasileira com aborto é mais uma lembrança sobre como as mulheres, ao enfrentar uma gravidez indesejada, são levadas ao aborto ilegal, independentemente dos riscos a sua saúde. Ela aponta a nccessidade urgente de se dirigir a questão crítica do comportamento de fecundidade das mulheres para uma abordagem mais ampla de saúde e direitos reprodutivos. Nos últimos anos, pouca atenção vem sendo dada à saúde do povo brasileiro. A falha dos serviços públicos em responder aos cuidados médicos mais básicos criou um vácuo que vem sendo preenchido em parte pelo setor privado. Ao se apoiar em uma estrutura não-médica para solucionar os problemas em regular sua fecundidade, as mulheres têm progressivamente obtido acesso aos modernos avanços tecnológicos referentes à contracepção e, mais recentemente, aborto médico, fora de um programa integral de saúde. Iniciativas de utilizar a contracepção sob estas condições desfavoráveis estão associadas a altos índices de inconsistência e incorreção no uso dos métodos anticoncepcionais. Diante das barreiras enfrentadas para o controle da fecundidade de maneira efetiva e segura, as mulheres se encontram, freqüentemente, presas a um ciclo trágico que repete a gravidez indesejada e o aborto. Paradoxalmente, o desejo intenso demonstrado pelas mulheres brasileiras de regular sua fertilidade tem forçado sua exposição aos riscos de uma gravidez ou aborto.

A melhoria da contracepção pode auxiliar muito a redução do nível de gravidez indesejada. Porém, muitos fatores sociais, culturais e econômicos conspiram para dificultar a decisão de adotar a contracepção e seu uso efetivo. Especialmente para as mulheres pobres. Os papéis e responsabilidades das mulheres estão mudando: a vida em grandes cidades brasileiras é freqüentemente precária, e a estabilidade econômica cada vez mais elusiva em tempos de globalização. Muitos dos constrangimentos sobre a mulher somente poderão ser removidos a partir de uma mudança fundamental da ordem econômica e social.

Independentemente destas mudanças, formuladores de políticas e gestores públicos poderiam implementar medidas que teriam um maior impacto sobre a habilidade das mulheres para planejar melhor suas gravidezes. Melhorias na disponibilidade e qualidade de informação e os serviços de contracepção nos hospitais públicos são passos que devem ser dados imediatamente. No entanto, reavaliar a legislação que mantém medidas punitivas contra as mulheres que se submetem ao aborto e os médicos que os praticam é essencial. Convém ressaltar que estas duas iniciativas foram recomendações aprovadas pelo governo brasileiro durante a Conferência sobre População e Desenvolvimento, realizada no Cairo, em 1994. 


\section{Referências Bibliográficas}

ALANGUTTMACHER INSTIUIE (AGI). AbortoClandestino: uma realidadelatino-americana. New York/Washington: The Alan Guttmacher Institute, 1994.

ARRUDA, J. M. et al. Pesquisa Nacional Sobre Saúde Materno-Infantile Planejamento Familiar, Brasil 1986. Rio de Janeiro: Bemfam, 1987.

AUBENY, E. \& BAUULU, E. E. Contragestation with RU 486 and an orally active prostaglandin. Comptes Rendus del' Academie de Science III, 312:539-546, 1991.

BARBOSA, R. M. \& ARILHA, M. The Brazilian experience with Cytotec. Studies in Family Planning, 24(4):236-240, 1993.

BARRETO, T. et al. Investigating induced abortion in developing countries: methods and problems. Studies in Family Planning 23 (3):159-170, 1992.

BARROS, J. A. C. A medicalização da mulher no Brasil. In: WolfFers, I.; HARDON, A. \& JANSSEN, J. (Eds.) OMarketing da Fertilidade. São Paulo: Ed. Hucitec, 1991.

BECK, J. G. \& DAVIES, D. K. Teen contraception: a review of prospectives or compliance. Archives of Sexual Behaviour (16): 337-368, 1987.

Bemfam. Sociedade Civil de Bem-Estar Familiar no Brasil. Pesquisa Nacional sobre Demografia e Saúde - 1996, Rio de Janeiro, BemfaM, 1997.

Boens, A. E. et al. Aborto provocado: um estudo epidemiológico descritivo de uma maternidade de Florianópolis, Santa Catarina. Ciência e Cultura 35(4): 501-508, 1983.

BRASIL. Ministério da Saúde / Fundação Nacional da Saúde. Datasus. Sistema de Informação Hospitalar do Sistema Único de Saúde (SIH/SUS). Brasília: 1992.

BuGALHO, A. et al. Induction of labor with intravaginal misoprostol in intrauterine fetal death. American Joumal of Obstretics and Ginecology, 171: 538-541, 1994.

BugaLHO, A. et al. Evaluation of the efficiency of vaginal misoprostol to induce first trimester abortion. Contraception 53: 243-246, 1996.

CARBONEL, J. L. L. The use of misoprostol for termination of early pregnancy. Contraception 55: 165-168, 1997.

CoelHo, H. L. L. O que está em jogo no caso Cytotec. Ciência Hoje 13(76): 60-62, 1991.

CoelHo H. L. L. et al. Misoprostol and illegal abortion in Fortaleza, Brazil. Lancet, 341:12611263, 1993.

CORREA, S. \& FRETAS, A. Atualizando os dados sobre a interrupção voluntária da gravidez no Brasil. Estudos Feministas, 5(2):389-395, 1997. 
CostA, S. H. et al. Family planning practice in a low income community in Rio de Janeiro. A survey carried out with the support of the World Health Organization. Final Report. Rio de Janeiro. World Health Organization (WHO), March 1987.

Costa, S. H. et al. Family planning among low income women in Rio de Janeiro: 19841985. International Family Planning Perspectives, 16(1):16-22, 1990.

COSTA, S. H. \& VESSEY, P.V. Misoprostol and illegal abortion in Rio de Janeiro, Brazil. Lancet, 341:1258-1261, 1993.

COSTA, S. H. The Determinants and consequences of induced abortion in Rio de Janeiro, Brazil, 1995. Tesede doutorado (Doctor of Philosopy Thesis). Oxford: Faculty of Clinical Medicine, University of Oxford, 1995.

CRENIN, M. D. \& VITTINGHOFF, E. Methotrexate and misoprostol vs misoprostol alone for early abortion. Joumal of the American Medical Association (JAMA), 272:1190-1 195, 1994.

DUNCAN G. et al. Termination of pregnancy: lessons for prevention. British Journal of Family Planning 15:112-117, 1990.

EL-RAFAEY, H. et al. Induction of abortion with mifepristone (RU 486) and oral or vaginal misprostol. New England Medical Joumal, 332: 983-987, 1995.

FONSECA, $W$. et al. Congenital malformation of the scalp and cranium after failed first trimester abortion attempt with misoprostol. Clinical Dysmorphology, 2:76-80, 1993.

FonsECA, W. et al. Determinantes do aborto provocado entre mulheres admitidas em hospitais em localidade da região Nordeste do Brasil. Revista de Saúde Pública, 30 (1):13-18, 1996.

FORREST, J. D. \& HENSHAW, S. K. Repeat abortion: the current state of knowledge. Background paper for a Conference on Repeat Abortion. New York: The Allan Guttmacher Institute, February 16-17, 1984.

Gabiatri, J. R. E. Características das Mulheres, Freqüência, Complicações e Custos do Aborto: suas variações de acordo com a comercialização do Misoprostol em Campinas, 1994. Tese de mestrado. Campinas: UNCAMP.

GRFFTHS, M. Contraceptive practices and contraceptive failures among women requesting termination of pregnancy. British Journal of Family Planning, 16:16-18, 1990.

InSTIUUTO BRASILERO DE DEFESA Do CONSUMidor (IDEC). Sociedade Brasileira de Vigilância de Medicamentos. Relatório Técnico sobre o Misoprostol. Comissão Técnica de Assessoramento em Assuntos de Medicamentos e Correlatos, Brasilia: Julho, 1997.

LUKER, K. Contraceptive risk taking and abortion. Studies in Family Planning, 8:190-196, 1977.

MARTINS, I. R. et al. Aborto induzido em mulheres de baixa renda: dimensão de um problema. Cademos de Saúde Pública, 7(2): 251-266, 1991. 
MASSACHS, G. C. Mortalidade Matema. Salvador, 1993, 1995. Dissertação de Mestrado. Instituto de Saúde Coletiva da Universidade Federal da Bahia.

MeASHAM, A. R. Self-subscription of oral contraceptives in Bogota, Colombia. Contraception, 13(3):333-340, 1976.

MIIANESI, M. L. O aborto provocado. Estudo retrospectivo em mulheres não-solteiras, de 15 a 49 anos, residentes no distrito de São Paulo, em 1965. São Paulo: Livraria Pioneira Editora, 1975.

MisaGo, C. et al. Determinants of induced abortion among poor women admitted to hospitals in Fortaleza, Northeastern Brazil. In: ENCUENTRO DE INVESTIGADORES SOBRE ABORTOINDUCIDO en America Latina y el Caribe. Santa Fé de Bogotá, Colômbia, 1994.

Mouina, A. et al. Aborto provocado com misoprostol entre mulheres de baixa renda em Recife. Ginecologia e Obstetricia, 18: 29-33, 1996 (Anais).

Mouna et al. Acesso ao misoprostol para interrupção da gravidez indesejada do Grande Recife In: XII Jornada Pernambucana de Ginecologia E Obstetrícia. Recife: Março, 1997.

MORRISON, D. M. Adolescent contraceptive behaviour: a review. Psychological Bulletin, 98:538$568,1985$.

Nakamura, M. S. L. et al. Contraceptive use and fertility levels in São Paulo State, Brazil. Studies in Family Planning, 11 (8): 236-246, 1980.

NORMAN, J. E.; THONG, K. J. \& BAIRD, B. T. Uterine contractability and induction of abortion in early pregnancy by misoprostol and mifepristone. Lancet, 16:1233-1236, 1991.

OuvERA, L. A. P. \& SIMÕES, C. C. S. Asinformações sobrefecundidade, mortalidadee anticoncepsãonas PNAD's. Fundação Instituto Brasileiro de Geografia e Estatística/Departamento de Pesquisas Economicas (IBGE/DPE). Rio de Janeiro, № 15, Junho, 1989.

OLVErra, M. I. \& Jourdan, A. M. Inquérito de morbidade por doenças diarréicas e infecções respiratórias agudas em crianças menores de 5 anos e utilização de serviços de prénatal e planejamento familiar na Zona Oeste (XVII RA) do Município do Rio de Janeiro. Relatório técnico do projeto ASC/28287 da Organização Panamericana de Saúde (OPAS), setembro 1989.

PaIEWONSKY, D. Determinantes sociales y consecuencias del aborto inducido en la Republica Dominicana. Preliminary Report on a Hospital Survey, Project No 89085, funded by World Health Organization (WHO). Santo Domingo: Institute of Population Studies and Development Profamilia, 1993.

Population Council. Methodological issues in abortion research. In: Coeytaux, F; Leonard, A. \& RoYsTON, E. (Eds). Proceedings of a seminar presented under the Population Council's Robert H. Ebert Program on Critical Issues in Reproductive Health. New York: Population Council, 1989. 
POTIER, L. et al. Oral contraceptive compliance in rural Colombia: knowledge of users and providers. International Family Planning Perspectives, 14(1): 27-31, 1988.

ReQuena, B.M. The problem of induced abortion in Latin America. Demography, 5:785-799, 1968.

RODRIGUES, W. et al. General presentation of maternal and child health and family planning surveys, Table 7. In: International Union for the Scientific Study of Population and the Associacao Brasileira de Estudos Populacionais (ABEP) Sao Paulo, August 5-8, 1981 (Paper).

Rodrigues, W; MORRIS, L. \& JANOWIz, B. Pesquisa sobre materno-infantil e planejamento familiar, Região Sul, 1981. Rio de Janeiro: Sociedade Civil de Bem-Estar Familiar no Brasil (BemғaM), 1984.

SCHONHOFER, P. S. Misuse of misoprostol as an abortifacient may induce malformations. Lancet, 337:1534-1535,1991.

Silva, L. M. A reprodução e o trabalho da mulherda favela. Belo Horizonte: Centro de Desenvolvimento e Planejamento Regional (CEDEPLAR)/UFMG, 1984.

SINGH, S. \& SEDGH, G. The relationship of abortion trends in contraception and fertility in Brazil, Colombia and Mexico. International Family Planning Perspectives, 23: 4-14, 1997.

SINGH, S. \& WUrF, D. Estimated levels of induced abortion in six Latin American countries. Intemational Family Planning Perspectives, 20(1):4-13, 1994.

THONG, K. J. \& BARD, D. T. Induction of abortion with mifepristone and misoprostol in early pregnancy. British Joumal of Obsterrics and Gynecology; 99: 1004-1007, 1992.

TietzE, C. Repeat abortions - why more? Family Planning Perspectives, 10:286-288, 1978.

VIEL, B. Patterns of induced abortion in Chile and selected other Latin American countries. Pan American Health Organization (PAHO). Scientific Publication, NN 306. Washington DC, 1975.

VIGGIANO, M. G. C. et al. Disponibilidade de misoprostol e complicações de aborto provocado em Goiânia. Jomal Brasileiro de Ginecologia, 106 (3):55-61, 1996.

Welkovic, S.; Costa, C. F. F. \& LeIre, J. M. Características clínicas e epidemiológicas de 494 casos de abortamento. Revista Brasileira de Ginecologia e Obstetrícia. 


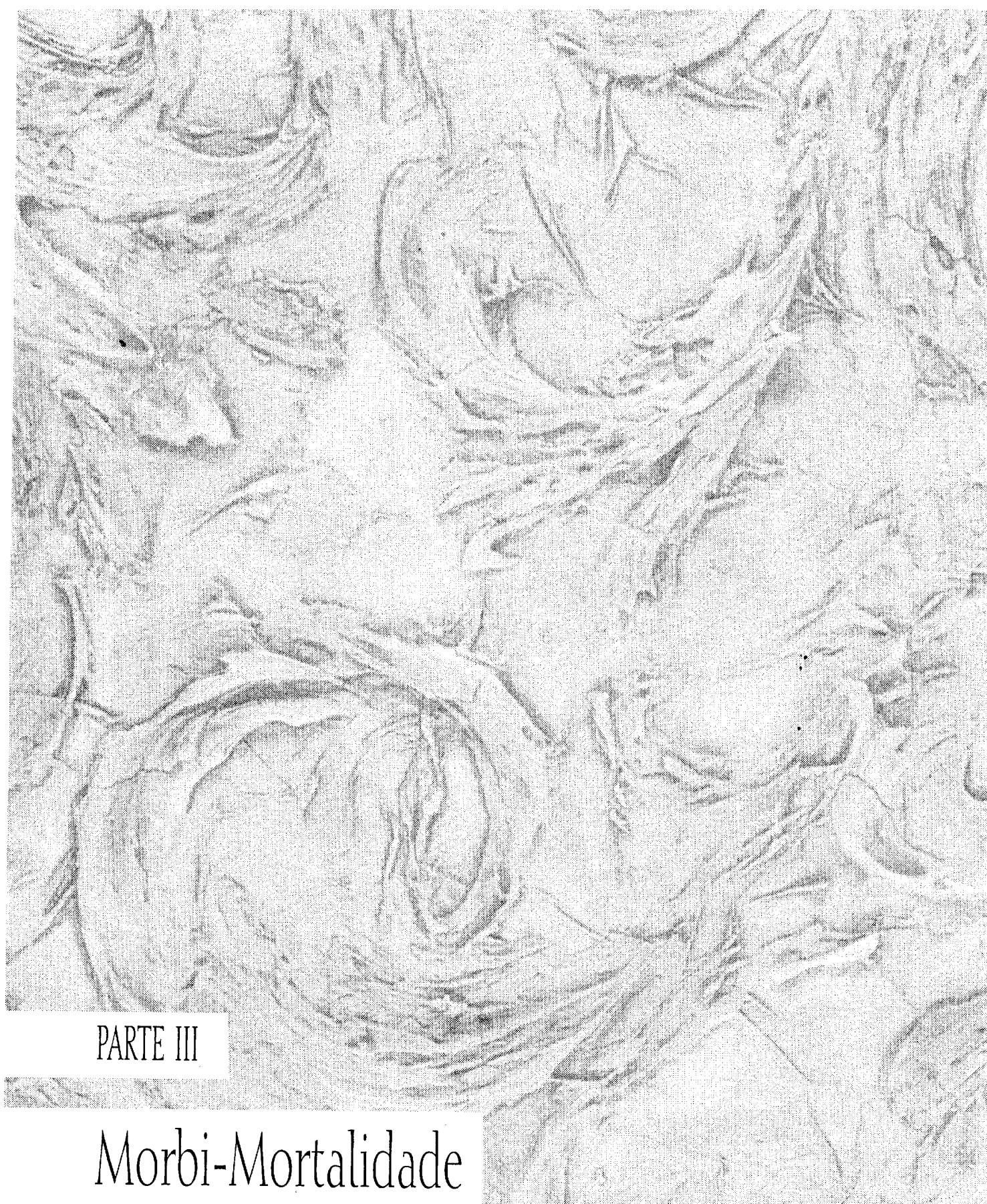





\section{Padrões e Tendências em Saúde Reprodutiva no Brasil: bases para uma análise epidemiológica}

Estela Maria Leäo de Aquino, Thália Velho Barreto de Araújo \& Lilian Fátima Barbosa Marinbo

\section{Introdução}

Nas últimas décadas, o Brasil vem passando por profundas transformações demográficas e epidemiológicas. Do ponto de vista da saúde reprodutiva, nos anos 80, dois fatos foram particularmente marcantes: a drástica mudança no padrão de procriação e o aparecimento da Aids.

O primeiro envolveu uma redução da taxa de fecundidade de 4,5 filhos por mulher, em 1980, para 2,5, em 1991 (IBGE, 1994). Essa queda acentuada e vertiginosa se deu por meio do uso generalizado de métodos efetivos de controle da procriação - com a pílula e a esterilização cirúrgica sendo os mais usados (Berquó, 1993) - bem, como pelo recurso ao aborto, muitas vezes como método habitual (Allan Guttmacher Institute, 1994). É importante destacar que a queda da fecundidade não ocorreu igualmente em todas as faixas etárias, sendo observado o incremento de gestações em adolescentes, inclusive as menores de 15 anos (Simões \& Oliveira, 1988; Brasil, 1989; BEMFAM/DHS, 1997).

Quanto ao surgimento da AIDS, o primeiro caso detectado no Brasil foi em um homem, em 1980; apenas três anos depois, foi notificado o primeiro caso em uma mulher, quando já registravam-se 31 homens na mesma condição (Castilho et al., 1992). Desde então, a notificação de Aids em mulheres vem aumentando de modo acelerado, chegando-se, em 1991, a uma relação de menos de cinco homens para cada mulher. Apesar de algumas controvérsias, existe um consenso de que a relação 
heterossexual ć o modo de transmissão mais importante para a feminização da epidemia no País (Brasil, 1997). Além de grande desinformação, para muitas mutheres, o medo de se infectar é menor do que o medo de comprometer seu relacionamento com o parceiro ao admitir a possibilidade de relações extraconjugais (Barbosa, 1993).

Articulando-se os dois fatos marcantes da década, conforma-se um quadro de saúde em que ganham relevância os aspectos relacionados à sexualidade e aos efeitos da contracepção, cm substituição àqueles relativos à concepção, à gravidez e ao parto-que constituíram a preocupação da maioria dos estudos epidemiológicos até bem recentemente (Aquino et al., 1995). Por outro lado, questões como a gravidez na adolescência e o crescimento da AIDS em mulheres impõem a necessidade de se estudaro papel dos parceiros masculinos para uma adequada compreensão do problema. A magnitude e a relevância desses problemas e a velocidade das transformações no padrão epidemiológico, no Brasil, têm justificado a realização de inúmeras pesquisas sobre o tema, com uma influência cada vez maior das contribuições feministas, especialmente aquelas advindas das ciências humanas. Como resultado, constata-se uma mudança qualitativa nos estudos, que buscam compreender aspectos ligados à sexualidade no contexto de relações de gênero desiguais e hierárquicas, em que as mulheres ocupam o pólo dominado. Essas novas abordagens vêm, pouco a pouco, substituindo o tradicionalmente hegemônico enfoque materno-infantil, marcado pelo interesse primordial pela saúde das crianças (Aquino et al., 1995).

Apesar da sensível mudança na produção científica, especialmente na década de 90, a incorporação das teorias de gênero no campo da saúde, em particular na Epidemiologia, ainda se faz de modo incipiente, com forte concentração regional (Aquino et al., 1995). À insuficiência de estudos sobre o tema alia-se o fato de que os dados secundários são limitados e de qualidade muitas vezes questionável, especialmente em algumas regiões do País. Embora produzidos em grande quantidade, em um aparente paradoxo, são subutilizados, o que diminui a possibilidade de que sejam apcrfeiçoados. Essa subutilização pode ser atribuída, em parte, a dificuldades de acesso aos bancos de dados, a problemas de compatibilização dos dados de diferentes fontes e a outros, inerentes ao sistema de informações em saúde (Moraes et al., 1994); outra parte da subutilização, provavelmente, decorre da falta de capacitação de potenciais usuários/as - especialmente os que se cncontram fora do âmbito acadêmico - para a análise espacial e temporal de dados agregados, de modo a identificar e monitorar tendências nos padrões de saúde reprodutiva no Brasil.

Neste artigo, pretendemos sistematizar e discutir conceitos que têm embasado a análise epidemiológica em saúde reprodutiva, apresentando as principais fontes de informação disponíveis no País, levantando questões e apontando caminhos na reflexão sobre o tema. 


\section{Saúde/morbidade reprodutiva: revendo conceitos}

A reprodução humana, as doenças associadas à reprodução biológica e as suas repercussões sobre a saúde de homens e mulheres têm sido objeto de estudo de diversas áreas do conhecimento. Na demografia, por exemplo, enfatiza-se o estudo da fecundidade e o seu impacto sobre a dinâmica populacional. Em posição diametralmente oposta, a medicina, por meio de suas disciplinas clínicas, em especial a ginecologia e a obstetrícia, é geradora de um outro tipo de saber, centrado no indivíduo e com base na fisiopatologia dos processos reprodutivos.

No plano internacional, o aporte da epidemiologia na saúde reprodutiva data de um período relativamente recente, estando os estudos, de modo geral, relacionados à investigação do risco de patologias específicas associado ao uso de métodos contraceptivos (Wingo et al., 1996). No propósito de construção de um saber epidemiológico nessa temática, tem-se delimitado um novo campo, a chamada 'epidemiologia reprodutiva', conceituada como a aplicação de conceitos e métodos originados naquela disciplina ao "estudo de temas relativos à forma de elevar ao máximo a saúde reproduliva do homem e da mulher" (Wingo et al., 1996:1).

Um dos aspectos de fundamental importância para consolidação dessa nova área de pesquisa consiste na necessidade de explicitar um conceito de saúde reprodutiva que permita sua delimitaçãocomocampo de investigação científica. Na literatura especializada, registra-se a existência de variadas definições, com ampla difusão em um periodo recente. No entanto, por sua recorrência, dois elementos parecem nucleá-las: o primeiro consiste na equiparação da saúde reprodutiva à ausência de enfermidade associada ao processo de reprodução biológica; o segundo refere-se ao enfoque privilegiado (quando não exclusivo) na figura da mulher.

Nas múltiplas definições presentes na literatura, evidencia-se uma grande variabilidade na amplitude das formulações empregadas ao tratar do tema. Por exemplo, em manual da Organização Mundial da Saúde (OMS) sobre "epidemiologia aplicada à saúde reprodutiva", transparece a ênfase nos aspectos funcionais biológicos, delimitados ao período reprodutivo de diferentes dimensões em homens e mulheres, ao definir-se que:

a saúde reprodutiva humana começa com o crescimento e desenvolvimento sexual que se manifesta na puberdade, prossegue durante toda a vida do homem e termina com a menopausa na mulher. Sobre a saúde reprodutiva influem a fecundidade e as decisões relacionadas com a atividade sexual, a gravidez e a anticoncepção. (Wingo et al, 1996:1) 
Em outras duas definições, expressam-se a autodeterminação e o poder, remetendo a concepção de saúde reprodutiva para o campo dos direitos de cidadania, mas confundindo-se com o conceito de direitos reprodutivos ' ${ }^{\prime}$. Assim, para Fathalla (apud Graham \&Campbell, 1991:6), saúde reprodutiva significa que:

as pessoas teriam capacidade de reproduzir, bem como de regular sua fertilidade, mediante o conhecimento mais pleno possivel das consequeências pessoais e sociais de sua decisão, tendo acesso aos meios necessários para implementá-la; que as mulheres sejam capazes de vivenciar a gravidez e o parto em segurança; e que o resultado da gravidez seja a sobrevivência da mãe e da criança em situação de bem-estar. Além disso, os casais deveriam ser capazes de ter relações sexuais livres do medo de uma gravidez não desejada e de contrair doenças.

Da mesma forma, para Germain (apud Graham \& Campbell, 1991:6), saúde reprodutiva implicaria em conferir às mulheres o poder de:

regular sua própria fertilidade de maneira segura e eficaz, concebendo um filho quando desejassem, interrompendo gestações não desejadas, e levando à termo aquelas desejadas de permanecer livre de doenças, seqüelas, medo, dor ou morte associada à reprodução e à sexualidade; de ter e criar filhos saudáveis.

Aliada à ausência de um conceito unívoco de saúde reprodutiva, percebe-se, entre os autores, uma dificuldade de estabelecer uma distinção clara entre este e os de 'saúde materna' e 'saúde da mulher' (Graham \& Campbell, 1991; Fortney, 1995). A partir da sistematização das pesquisas de base populacional sobre saúde reprodutiva, publicadas entre 1980 e 1995, Fortney (1995) ilustra essas inconsistências conceituais ao evidenciar que, entre essas, seis relacionavam-se apenas à morbidade obstétrica; uma somente às patologias ginecológicas; duas incluíam os dois tipos de enfermidade; e outras duas, as enfermidades ginecológicas e aquelas relacionadas ao uso de contraceptivos. Alguns desses estudos englobavam ainda outros tipos de doenças que, por sua natureza, poderiam ser classificadas como não-reprodutivas.

Diante da necessidade de operacionalizar o conceito, a saúde/morbidade reprodutiva tem sido comumente relacionada ao chamado 'período reprodutivo' das mulheres, considerado como o que se estende de 15 a 49 anos de idade. Mais recentemente, este período tem sido redefinido para 10 a 44 anos de idade, para permitir acompanhar a tendência ao início precoce da vida sexual e de redução no número de filhos. Ainda nessa perspectiva, outras alternativas de recorte têm sido propostas para

\footnotetext{
${ }^{1} \mathrm{Na}$ Conferência Internacional sobre População e Desenvolvimento (Cairo, 1994) e na IV Conferência Mundial sobre a Mulher (Beijing, 1995), estabeleceu-se que os direitos reprodutivos têm por base "o reconhecimento do direito fundamental de todos os casais e indivíduos a decidir livre e responsavelmente o número de filhos e o intervalo entre eles, e a dispor da informação e dos meios para tal e o direito de alcançar o nivel mais elevado de saúde sexual e reprodutiva. Inclui também o direito a tomar decisões referentes à reprodução sem sofrer discriminação, coações nem violência" (Themis, 1997:74).
} 
a demarcação do início do período de tempo a ser considerado, entre elas, a entrada na adolescência (Evans et al. apud Graham \& Campbell, 1991), a ocorrência da menarca (Wingo, 1996), o começo da vida sexual ou a conjugalidade (Evans et al. apud Graham \& Campbell, 1991). A construção de uma definição operacional com base em um intervalo de idade resultaria na exclusão de agravos que, embora relacionados à função reprodutiva da mulher, ocorreriam fora dos limites do período, a exemplo das patologias associadas ao climatério. Além disso, a segmentação do ciclo vital tem sido criticada por comprometer a visão de integralidade dos fenômenos da saúde-doença influenciando - inclusive de forma negativa - a organização dos serviços de saúde (Graham \& Campbell, 1991).

Outro aspecto controverso quanto à definição de morbidade reprodutiva diz respeito à sua relação com a 'morbidade materna' (decorrente direta ou indiretamente de gravidez), a qual pode ser tratada como um componente da primeira ou não. No caso de exclusão, a morbidade reprodutiva é, então, reconhecida por sua ocorrência no período reprodutivo, fora dos intervalos obstétricos. Dessa forma, a saúde da mulher englobaria os dois componentes: a 'saúde reprodutiva' e a 'saúde materna' (Graham \& Campbell, 1991), o que restringe muito a abrangência do primeiro componente.

De qualquer modo, a saúde/morbidade materna é referida à ausência/presença de agravos ou doenças ocorridas em um intervalo de tempo delimitado entre a contracepção e o término da gestação, independentemente de sua duração, em uma aproximação ao conceito de 'mortalidade materna'. Apesar de este último ser largamente consagrado e utilizado, no que diz respeito ao período de tempo a ser considerado, há controvérsias entre os autores (Fortney, 1995; Campbell \& Graham, 1990). Em grande parte da literatura, o seu término coincide com o do puerpério, ou seja, 42 dias após o final da gestação, e é desse modo que a 93 Revisão da Classificação Internacional de Doenças (CID) o define (OMS, 1978). Todavia, o reconhecimento de que um número expressivo desses óbitos, agravos ou doenças poderiam ocorrer após o tempo estabelecido (Walker et al., 1986; Turnbull et al., 1986), levou à proposição de um prolongamento do período a ser considerado. Em conseqüência, a CID, em sua $10^{\mathrm{a}}$ revisão, embora mantendo o limite de 42 dias após a gestação, incorporou uma nova categoria: a 'morbidade/mortalidade materna tardia', que çorresponderia àquela ocorrida no intervalo de tempo entre 42 dias e um ano após o fim da gravidez (Laurenti, 1994).

Quanto à 'morbidade reprodutiva', caberia ainda discutir a natureza dos problemas de saúde a serem considerados. O conceito diz respeito a todos os agravos à saúde da mulher no período reprodutivo, ou apenas às patologias e agravos direta ou indiretamente relacionados à função reprodutiva? A inclusão de todos os eventos mórbidos ocorridos no período reprodutivo traria dificuldade em estabelecer limites entre os conceitos de 'morbidade reprodutiva' e 'morbidade da mulher', nessa etapa da vida, em contrapartida, excluindo os problemas relacionados à re- 
produçãoem outras fases. A demarcação do que considerar como morbidade reprodutiva não é clara. Considerá-la como "doenças que afetam o sistema reprodutivo, mesmo não se constituindo necessariamente uma conscqüência da reprodução" (Fortney, 1995:3) sugere limites restritos à sua conceituação. Tornaria difícil reconhecer, como parte do grupo, os agravos à saúde decorrentes da reprodução, cuja repercussão darse-ia em outros órgãos e sistemas, a exemplo de algumas doenças cardiovasculares, para as quais o uso de contraceptivo hormonal constitui-se um dos fatores de risco. Este problema poderia ser contornado, adotando-se a definição proposta pela OMS (1989:2) que abrange:

qualquer morbidade ou disfunção do trato reprodutivo, ou qualquer morbidade conseqüente ao comportamento reprodutivo, incluindo gravidez, aborto, parto ou comportamento sexual, podendo incluir aquelas de natureza psicológica.

No entanto, persistiria nessa, assim como na anterior, a impossibilidade de tratar de casos de violência - englobando homicídios, agressões e suicídios em mulheres grávidas-ou envolvendo questões relacionadas à sexualidade e à reprodução. Esse último ponto tem sido posto em discussão no contexto da definição de morte materna a partir de cstudos que documentam a ocorrência de casos concretos, ainda que ressaltando as dificuldades envolvidas no estabelecimento de nexos causais entre a situação de violência e a gravidez (Fauveau \& Blanchet, 1989; Compte, 1996).

No sentido de superar as dificuldades discutidas anteriormente, tendo como referência a proposta do grupo técnico reunido pela OMS (WHO, 1989), Fortney (1995) apresentou um sistema de classificação a partir do qual a morbidade reprodutiva é categorizada em três grandes grupos:

- Morbidade Obstétrica (ou materna): consistc na conseqüente à gravidez ou ao parto ou, ainda, a resultante de tratamento recebido no decorrer da gravidez ou do parto (Fortney, 1995). Em uma dimensão aparentemente conflitante, a morbidade obstétrica é tempo definida, referindo-se às condições que ocorrem até 42 dias ou 12 meses após o parto (respectivamente, como na $9 \mathrm{a}$ e na $10^{\mathrm{a}}$ Revisão da CID). Todavia, inclui problemas que ultrapassam o pucrpério, como o prolapso uterino pós-parto prolongado. Tradicionalmente, é subdividida em quatro categorias:

- Morbidade Obstétrica Direta: surgida em conseqüência à gravidez ou ao parto; que não ocorreria se a mulher não estivesse grávida. Citam-se como exemplos hemorragias, septicemias puerperais, desordens hipertensivas da gravidez, partos distócicos e conseqüências do aborto, incluindo-se, também, condiçõcs resultantes do tratamento de problemas obstétricos, como infecção pós-cesárea;

- Morbidade Obstétrica Indireta: não resultante de gravidez, mas agravada a partir de sua ocorrência (malária, tuberculose, hipertensão crônica, hepatite, doença rcumática do coração, câncer de mama); 
- Distúrbios Psicológicos: associados ao resultado de gravidez ou a alterações hormonais conseqüentes à gestação (como depressão, psicose puerperal).

Morbidade Não-Obstétrica: agravos acidentais ou incidentais (suicídios e violência) ocorridos durante a gravidez, o parto ou o puerpério.

- Morbidade Ginecológica: problemas do sistema reprodutivo não resultantes de gravidez ou parto, ou em conseqüências destes problemas ou de seu tratamento. A categoria abrange três subgrupos:

- Morbidade Ginecológica Direta: inclui doenças sexualmente transmissíveis (DST) e outras infecções do trato reprodutivo e suas seqüelas; neoplasias do sistema reprodutivo; distúrbios endócrinos associados à disfunção menstrual e à infertilidade; malformações congênitas ou danos da genitália feminina (decorrentes de violência sexual ou de trauma acidental); disfunções sexuais; distúrbios associados à menopausa; infertilidade primária ou secundária; outros problemas ginecológicos (endometriose, processos inflamatórios pélvicos não decorrentes de DST);

- Morbidade Ginecológica Indireta: refere-se a problemas resultantes de práticas terapêuticas modernas ou tradicionais, tais como fístulas conseqüentes à terapia por radioterapia do câncer de colo uterino ou mutilação da genitália feminina conseqüente a preceitos religiosos ou culturais;

- Distúrbios Psicológicos: resultantes de trauma ginecológico ou sexual e de alterações hormonais (dispareunia, depressão associada à infertilidade, DST ou AiDs).

- Morbidade Contraceptiva: compreende os danos à saúde decorrentes do uso de contraceptivos, incluindo efeitos locais (irritações, reações alérgicas, sangramentos e infecções) e sistêmicos (entre outros, a carcinogenicidade e os impactos sobre os sistemas cardiovascular e hormonal).

Segundo a tipologia de Fortney (1995), haveria, ainda, a possibilidade da inclusão de um quarto grupo: o de Morbidade Sexual, o qual, rigorosamente, superpõe-se ao de morbidade ginecológica.

Essa proposta reflete o esforço de ampliação e percepção da morbidade reprodutiva, podendo abranger aspectos referentes à saúde mental è̀ sexualidade, entre outros, ainda que persista o enfoque exclusivo na mulher. Contudo, as contradições presentes em outras definições são, novamente, evidenciadas quando se comparam o conceito e o sistema de classificação propostos, este último apresentando limites bem mais abrangentes do que o primeiro (Fortney, 1995).

Em estudos epidemiológicos, a produção de informação pressupõe a sumarização de dados sob a forma de indicadores, os quais estão estritamente condicionados pelo conceito de saúde/morbidade reprodutiva adotado. Exemplificando: no manual da OMS (Wingo et al., 1996), os indicadores propostos referem-se, exclusivamente, à fecundidade, à mortalidade materna e à mortalidade infantil, refletindo o enfoque materno-infantil 
e o caráter restrito do conceito adotado. Em contrapartida, a constituição de medidas a partir do sistema de classificação proposto por Fortney (1995), pela maior abrangência conceitual implícita, resultará em uma maior diversidade dos indicadores, ainda que limitados à morbidade e não à saúde reprodutiva.

Entretanto, além dos condicionantes de ordem conceitual, a operacionalização de indicadores de saúde/morbidade reprodutiva, para uma análise epidemiológica a partir de dados rotineiros, depende, também, do tipo de dado disponível, sendo importante, portanto, conhecer as fontes de informação existentes no País quanto à abrangência, à periodicidade, à disponibilidade de acesso, em suma, quanto aos seus limites e suas potencialidades.

\section{Bases de dados de interesse em saúde reprodutiva}

No Brasil, encontram-se disponíveis grandes bases de dados de abrangência nacional. As de interesse mais imediato em saúde reprodutiva, sistematizadas nos quadros 1 e 2, podem ser apresentadas em dois subconjuntos.

O primeiro refere-se àquelas de caráter demográfico (Quadro 1), relativas à dinâmica populacional, cujos dados são produzidos pelo IBGE por intermédio de Ccnsos demográficos decenais e da Pesquisa Nacional por Amostra de Domicílios (PNAD), de realização anual, nos períodos intercensitários. Além de um questionário básico com perguntas sobre características demográficas, as relativas a habitação, mão-deobra, rendimento e instrução, a PNAD inclui, com periodicidade variável, outros temas, como a saúde - que constituiu bloco suplementar em 1981 e em 1986 . O primeiro, embora mais abrangente, teve problemas metodológicos sérios, ocasionando um alto grau de subestimação das taxas de prevalência de problemas e de utilização de serviços de saúde (Aquino et al., 1992). Além dessas duas fontes regulares, destaca-se a realização, em 1989, da Pesquisa Nacional sobre Saúde e Nutrição e, em 1996, da Pesquisa Nacional sobre Demografia e Saúde (PNDS), esta de particular interesse para a Saúde Reprodutiva.

O segundo conjunto de bases de dados nacionais integra o sistema de informação do Sistema Único de Saúde (SUS), que tem cobertura de cerca de $75 \%$ da população (Mendes, 1995), sendo de particular interesse o Subsistema de Informação de Mortalidade (SIM), o Subsistema de Informação de Nascidos-Vivos (SiNASC), os Subsistemas de Informações Hospitalares (SIH-SUS) e Ambulatoriais (SIA-SUS) (quadro 2). 


\section{Quadro 1 - Fontes de dados nacionais segundo características principais (IBGE)}

\begin{tabular}{|c|c|c|c|c|c|}
\hline $\begin{array}{c}\text { Fonte Origem } \\
\text { de dados }\end{array}$ & & Período & Abrangéncia & Atualização & Variáveis \\
\hline $\begin{array}{c}\text { Censo } \\
\text { Demográfico } \\
\text { (Demo) }\end{array}$ & $\begin{array}{c}\text { Questionário } \\
\text { básico e } \\
\text { ampliado }\end{array}$ & $\begin{array}{r}\text { A partir } \\
\text { de } 1940\end{array}$ & \begin{tabular}{|c|} 
Brasil \\
UF \\
Regiōes \\
Municipios \\
Microrregiōes \\
Distritos \\
\end{tabular} & $\begin{array}{l}\text { Decenal } \\
\text { (0 Censo } \\
\text { de } 1990 \text { toi } \\
\text { realizado } \\
\text { em 1991) }\end{array}$ & $\begin{array}{l}\text { Domiciliares (localização, tipo, estrutura, material, } \\
\text { ne cómodos e dormiţrios, condição de ocupação, } \\
\text { água, esgoto, lixo, luz e bens duráveis); individuais } \\
\text { (sexo, idade, religião, cor, raça, nacionalidade, na- } \\
\text { turalidade); famillias (composição e parentesco); } \\
\text { educacionais (alfabetizaçăo, escolaridade, nivel e } \\
\text { cursos); mão de obra (ocupação, posiçăo na ocu- } \\
\text { pação, ramo de atividade, vínculo empregaticio, } \\
\text { horas trabalhadas, rendimento, situaçãao } \\
\text { previdenciária, procura de trabalho e trabalho ante- } \\
\text { rior); mortalidade, fecundidade e migração. }\end{array}$ \\
\hline $\begin{array}{l}\text { Pesquisa } \\
\text { Assisténcia } \\
\text { Médico- } \\
\text { Sanitária } \\
\text { (AMS) }\end{array}$ & $\begin{array}{r}\text { Questionário } \\
\text { especifico }\end{array}$ & $\begin{array}{c}\text { A partir } \\
\text { de 1976 } \\
\text { (desde } \\
\text { 1993, no } \\
\text { Sistema } \\
\text { Único de } \\
\text { Cadas- } \\
\text { tramento } \\
\text { de Estab } \\
\text { Saúde- } \\
\text { SucEs, } \\
\text { como } \\
\text { módulo } \\
\text { básico) }\end{array}$ & $\begin{array}{l}\text { Brasil } \\
\text { UF } \\
\text { Regiōes } \\
\text { Municipios } \\
\text { Distrito } \\
\text { Bairro } \\
\end{array}$ & Anual & $\begin{array}{l}\text { Identificação (localização, início de atividade, cons- } \\
\text { tituição jurídica, entidade mantenedora); funcio- } \\
\text { namento (situação atual, motivo da desativação, } \\
\text { tipo, categoria, especialidades, classe de atendi- } \\
\text { mento, regime de atendimento, contratos e con- } \\
\text { vénios assistenciais, atendimentos a pacientes } \\
\text { externos, movimento geral do estabelecimento } \\
\text { com internação, recursos humanos). Desde 1992, } \\
\text { inclúda a internação por aborto. }\end{array}$ \\
\hline $\begin{array}{c}\text { Pesquisa } \\
\text { Nacional por } \\
\text { Amostra de } \\
\text { Domicilios' } \\
\text { Suplem. } \\
\text { Especiais } \\
\text { (PNAD) }\end{array}$ & $\begin{array}{c}\text { Questionário } \\
\text { específico }\end{array}$ & $\begin{array}{l}\text { A partir } \\
\text { de } 1981\end{array}$ & $\begin{array}{c}\text { Brasil } \\
\text { (exceto a } \\
\text { area rural da } \\
\text { RegiäoNorte) } \\
\text { Regiōes } \\
\text { Metropolitanas }\end{array}$ & \begin{tabular}{|} 
Anual, \\
com \\
apenas 2 \\
suplemen- \\
tos sobre \\
saúde
\end{tabular} & $\begin{array}{l}\text { (1981) saúde; (1982) educação; (1983) previdéncia e } \\
\text { mão de obra; (1984) fecundidade; (1985) situação do } \\
\text { menor; (1986) acesso a serviços de saúde, } \\
\text { suplementação alimentar, associativismo e } \\
\text { anticonceppão; (1988) participação pollico-social e es- } \\
\text { toque de aparelhos que utilizamenergia; (1989) trabalho. }\end{array}$ \\
\hline $\begin{array}{c}\text { Peril Estatistiod } \\
\text { de Crianças e } \\
\text { Mães }\end{array}$ & \begin{tabular}{|} 
Tabulaçбes \\
especiais \\
do Censo e \\
PNAD
\end{tabular} & $\begin{array}{r}\text { A partir } \\
\text { de } 1980\end{array}$ & $\begin{array}{l}\text { Brasil } \\
\text { Grandes } \\
\text { Regiōes }\end{array}$ & Anual & $\begin{array}{l}\text { Situação de domicílio; condição da família; fre-- } \\
\text { quéncia a escola; rendimento mensal familiar per } \\
\text { capita; condição e ramos de atividade; posição na } \\
\text { ocupaçăo, ocupação e horas trabalhadas }\end{array}$ \\
\hline $\begin{array}{l}\text { Pesquisa } \\
\text { Nacional } \\
\text { sobre } \\
\text { Saúde e } \\
\text { Nutrição } \\
\text { (PNSN) }\end{array}$ & $\begin{array}{c}\text { Questionário } \\
\text { especifico }\end{array}$ & 1989 & $\begin{array}{l}\text { Brasil } \\
\text { (exceto } \\
\text { a área } \\
\text { rural da } \\
\text { região } \\
\text { Norte) }\end{array}$ & $\begin{array}{c}\text { Sem } \\
\text { previsão }\end{array}$ & $\begin{array}{l}\text { Saúde Nutrição (aleitamento, parto, idade, peso ao } \\
\text { nascer, creche); de } 4 \text { a } 20 \text { anos: alimentação (con- } \\
\text { sumo de leite), freqüência escolar, merenda; mulhe- } \\
\text { res de } 10 \text { a } 54 \text { anos: menstruaçăo, gravidez, alimen- } \\
\text { tação para gestante, filho nascido vivo ou morto; } \\
\text { outras: doenças, perfodo de doenças, bebida e fumo. }\end{array}$ \\
\hline $\begin{array}{c}\text { Pesquisa } \\
\text { Nacional } \\
\text { sobre } \\
\text { Demografia e } \\
\text { Saúde (PNDS), } \\
\text { coordenado } \\
\text { pela BENFAM } \\
\text { DHS, em } \\
\text { parceria com } \\
\text { O IBGE, UsAD, } \\
\text { FUNUAP, MS e } \\
\text { UNICEF. }\end{array}$ & $\begin{array}{l}\text { Questionário } \\
\text { especifico } \\
\\
\end{array}$ & 1996 & Brasil & $\begin{array}{c}\text { Sern } \\
\text { previsão }\end{array}$ & 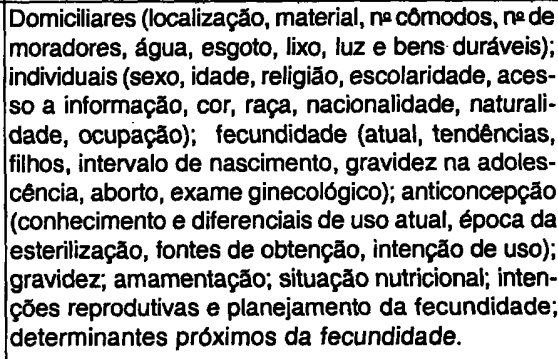 \\
\hline
\end{tabular}




\section{Quadro 2-Fontes de dados nacionais segundo características principais (Ministério da Saúde)}

\begin{tabular}{|c|c|c|c|c|c|}
\hline Fonte de dados & Origem & Período A & Abrangéncia & Atualizaçăo & Variáveis \\
\hline $\begin{array}{l}\text { Sistema de } \\
\text { Intormaçăo de } \\
\text { Nascidos-Vivos } \\
\text { (SinAsC/ FNS/ } \\
\text { CENEPI) }\end{array}$ & $\begin{array}{c}\text { Declaração de } \\
\text { nascido-vivo } \\
\text { (preenchidas } \\
\text { nos serviços } \\
\text { de saúde) }\end{array}$ & $\begin{array}{c}\text { A partir de } \\
1991\end{array}$ & $\begin{array}{c}\text { Brasil } \\
\text { UF } \\
\text { Municípios }\end{array}$ & Anual & $\begin{array}{l}\text { Local de nascimento; informaçōes dos } \\
\text { recém-nascidos: sexo, peso aos nascer, } \\
\text { Indice APGAR; tipo e duração de gesta- } \\
\text { ção e tipo de parto; informaç̋̃es da mãe: } \\
\text { escolaridade, residéncia e filhos tidos. }\end{array}$ \\
\hline $\begin{array}{l}\text { Sistema de } \\
\text { Informação de } \\
\text { Mortalidade } \\
\text { (SIM/FNS/ } \\
\text { CENEPI) }\end{array}$ & $\begin{array}{c}\text { Declaração } \\
\text { de Óbito da } \\
\text { Secretaria } \\
\text { Estadual de } \\
\text { Saúde, } \\
\text { complementa- } \\
\text { da por } \\
\text { dados de } \\
\text { cartórios, } \\
\text { hospitais, } \\
\text { cemitérios, } \\
\text { unidades de } \\
\text { saúde, IML }\end{array}$ & $\begin{array}{c}\text { A partir de } \\
1979\end{array}$ & $\begin{array}{c}\text { Brasil } \\
\text { UF } \\
\text { Municípios }\end{array}$ & $\begin{array}{c}\text { Brasil: } \\
\text { bianual } \\
\text { UF: anual } \\
\text { Município: } \\
\text { mensal }\end{array}$ & $\begin{array}{l}\text { Tipo de óbito (fetal ou não); óbito fetal e } \\
\text { de menores de umano (ocupação habitu- } \\
\text { al e grau de instrução dos pais, idade da } \\
\text { mãe e ñ filhos nascidos vivos e mortos, } \\
\text { duração da gestação, tipo de gravidez, } \\
\text { tipo de parto, peso ao nascer); outros } \\
\text { óbitos (nome, estado civil, sexo, idade, } \\
\text { ocupação habitual, naturalidade, grau de } \\
\text { instrução, local de residéncia e filiaçãa); } \\
\text { atestado médico (assisténcia médica, } \\
\text { confirmação diagnóstica, óbito feminino } \\
\text { em idade fértil, causa da morte imediata, } \\
\text { antecedentes, incluindo a causa básica e } \\
\text { outras); causas externas (tipo, local, aci- } \\
\text { dente de trabalho). }\end{array}$ \\
\hline $\begin{array}{l}\text { Sistema de } \\
\text { Informação } \\
\text { de Agravos } \\
\text { de Notificacăa } \\
\text { (SinAscl } \\
\text { FNS/ } \\
\text { CENEPI) }\end{array}$ & $\begin{array}{c}\text { Ficha de } \\
\text { notificação }\end{array}$ & $\begin{array}{c}\text { Em } \\
\text { implantaçăo }\end{array}$ & \begin{tabular}{|} 
Brasil \\
UF \\
Municípios \\
Distritos \\
Sanitários
\end{tabular} & Semanal & $\begin{array}{l}\text { Ne semanal de casos; ne de casos por } \\
\text { faixa etária, sexo, grau de instrução, lo- } \\
\text { cal de residéncia (UF, Regional de Saú- } \\
\text { de, Município, Distrito e Bairro) e local de } \\
\text { notificacăo (UF, Regional de Saúde, Mu- } \\
\text { nicípio); informaçסes especlficas para } \\
\text { cada tipo de agravo provenientes das fi- } \\
\text { chas de investigação. }\end{array}$ \\
\hline $\begin{array}{l}\text { Sistema de } \\
\text { Informaçס̃es } \\
\text { Hospitalares } \\
\text { do SUS } \\
\text { (SIH-SUSI } \\
\text { FNS/DATASUS) }\end{array}$ & $\begin{array}{c}\text { Autorizaçăo } \\
\text { de Internação } \\
\text { Hospitalar } \\
\text { (AlH) }\end{array}$ & $\begin{array}{c}\text { A partir de } \\
1992\end{array}$ & $\begin{array}{c}\text { Brasil } \\
\text { UF } \\
\text { Municípios }\end{array}$ & Mensal & $\begin{array}{l}\text { № de AlH apresentadas e valores efetiva- } \\
\text { mente pagos, por competência, por hospi- } \\
\text { talidade e especialidade, incluindo procedi- } \\
\text { mentos médicos; cadastro de hospitais e } \\
\text { de terceiros; custo médio, custo dia, tempo } \\
\text { médio de permanéncia; Taxa de Mortalida- } \\
\text { de Geral; Taxa de Internaçắo e de Ocupa- } \\
\text { çăo; Causa da Internação; qualificaçăo } \\
\text { hospitalar; qualificação dos profissionais. }\end{array}$ \\
\hline $\begin{array}{c}\text { Sistema de } \\
\text { Informaçōes } \\
\text { Ambulatoriais do } \\
\text { SUS (SIA-SUS/ } \\
\text { FNS/DatASUS) }\end{array}$ & $\begin{array}{l}\text { Boletim de } \\
\text { Produção } \\
\text { Ambulatorial } \\
\text { (BPA) }\end{array}$ & $\begin{array}{c}\text { A partir de } \\
1993\end{array}$ & \begin{tabular}{|c} 
Brasil \\
UF \\
Municípios
\end{tabular} & Mensal & $\begin{array}{l}\text { Unidades Prestadoras de Serviço: dados } \\
\text { cadastrais; capacidade instalada; ne pro- } \\
\text { fissionais; programação fisico-orçamentá- } \\
\text { ria; produçăo ambulatorial por procedimento; } \\
\text { produçąo ambulatorial por especialidade. }\end{array}$ \\
\hline $\begin{array}{c}\text { Registros de } \\
\text { Câncer de } \\
\text { Base } \\
\text { Populacional } \\
\text { (NCNPRO-ONCO) }\end{array}$ & $\begin{array}{l}\text { busca } \\
\text { ativa de } \\
\text { casos } \\
\text { incidentes }\end{array}$ & $\begin{array}{c}\text { Desde os } \\
60 ; \\
\text { abrangén- } \\
\text { cia variada } \\
\text { nos distin- } \\
\text { tos munici- } \\
\text { pios }\end{array}$ & \begin{tabular}{|} 
São Paulo, \\
Recife, \\
Porto Alegre, \\
Fortaleza, \\
Goiania, \\
Belém e \\
Campinas
\end{tabular} & Anual & $\begin{array}{l}\text { Caracteristicas sócio-demográticas } \\
\text { (sexo, idade, cor, ocupaçáa); dados clíni- } \\
\text { cos e laboratoriais (diagnóstico, cirurgia, } \\
\text { exames histopatológico, radiológico etc.) } \\
\text { Fornece taxas de incidéncia de neoplasias } \\
\text { malignas. }\end{array}$ \\
\hline $\begin{array}{c}\text { Registro Nacio- } \\
\text { nal de Patologia } \\
\text { Tumoral (INCA } \\
\text { PRO-ONCO) }\end{array}$ & $\begin{array}{c}\text { Ficha de } \\
\text { notificaçăo }\end{array}$ & $\begin{array}{c}\text { A partir de } \\
1976\end{array}$ & $\begin{array}{c}\text { Brasil } \\
\text { Grandes } \\
\text { Regiסes } \\
\text { UF }\end{array}$ & Anual & $\begin{array}{l}\text { Distribuição relativa de resultados de exa- } \\
\text { mes cito e histopatológicos (neoplasias } \\
\text { malignas/lesర̃es "pré-cancerosas"). Não } \\
\text { permite o cálculo de incidência. }\end{array}$ \\
\hline
\end{tabular}


Os dados de mortalidade, que referem-se a um evento único e inequívoco, além disso, são originados a partir da declaração de óbito, cujo caráter legal de registro possibilitaria uma ampla cobertura e uma maior confiabilidade da informação. Entretanto, estima-se que, em todo o País, exista elevado nível de sub-registro, ainda que não se disponha de uma adequada avaliação sobre a magnitude do problema (CENEP//FNS, 1997). Segundo o Ministério da Saúde, uma proporção grande de municípios não conta com informação regular sobre mortalidade e, exceto nas regiões Sul e Sudeste do País, o SIM apresenta um alto percentual de óbitos sem causa definida, particularmente no Nortee no Nordeste (Tabela 1), o que limita a comparabilidade dos indicadores. Isso tem levado à recomendação de que o cálculo de taxas de mortalidade restrinja-se às capitais, onde o sub-registro é pouco expressivo e a proporção de causas mal definidas não ultrapassa $5 \%$ do total de óbitos (Paula et al., 1994). Para os demais locais, deve-se priorizar a utilização de proporções, para contornar os problemas intrínsecos à construção de taxas com dados de qualidade duvidosa ou sabidamente ruim.

Cabe destacar que os problemas mencionados afetam diferentemente os grupos de causas de óbitos, sendo particularmente relevantes entre as complicações da gravidez, do parto e do puerpério. Segundo vários estudos nacionais e internacionais (Puffer \& Griffith, 1968; Högberg, 1986; Ferreira \& Ceneviva, 1986; Viana, 1992), as causas maternas são as mais mal declaradas nos atestados de óbito, mesmo nas regiões que possuem boa qualidade das estatísticas vitais.

\section{Tabela 1 - Fidedignidade da informação sobre mortalidade. Brasil e Grandes Regióes - 1994}

\begin{tabular}{|c|c|c|c|}
\hline \multirow[t]{2}{*}{ Regiões } & \multicolumn{2}{|c|}{ Municípios com informações } & \multirow{2}{*}{$\frac{\text { Causas mal dèfinidas }}{\text { Capitais (\%) }}$} \\
\hline & regionais (\%) & Estados (\%) & \\
\hline $\begin{array}{l}\text { Norte } \\
\text { Nordeste } \\
\text { Sudeste } \\
\text { Sul } \\
\text { Centro-Oeste } \\
\text { Brasil }\end{array}$ & \begin{tabular}{r|}
3,77 \\
27,85 \\
69,34 \\
62,57 \\
29,74 \\
57,74
\end{tabular} & $\begin{array}{r}28,33 \\
37,01 \\
9,77 \\
9,51 \\
12,85 \\
17,04\end{array}$ & $\begin{array}{l}6,61 \\
2,17 \\
1,53 \\
0,21 \\
2,71 \\
1,76\end{array}$ \\
\hline
\end{tabular}

Fonte: CENEP/FNS, 1997.

A morbidade tem abordagem ainda mais complexa do que a mortalidade, em decorrência de dificuldades intrínsecas à análise de eventos que podem ocorrer várias vezes em um mesmo indivíduo, apresentando distintos graus de severidade. Além disso, os bancos de dados existentes no SUS derivam da utilização de serviços de saúde, apresentando cobertura populacional mais restrita, porque nem todos os problemas de saúde 
resultam na procura de assistência, e nem toda demanda é satisfeita em condições de dificuldades de acesso aos serviços de saúde; e limita-se aos quadros de maior gravidade, expressos pelas causas de internação hospitalar (SIH-SUS), já que, de fato, o sistema de informações ambulatoriais (SIA-SUS) não engloba o registro da enfermidade, que motivou a busca do serviço de saúde, mas apenas os procedimentos realizados.

É importante ressaltar que a enfermidade hospitalar reflete, ainda, a definição de prioridades quanto à alocação de recursos (que se traduz no números de leitos hospitalares), tanto no que diz respeito aos problemas de saúde, quanto às especialidades médicas. Essas peculiaridades devem ser consideradas ao se elaborar perfis de morbidade, especialmente com a realização de estudos comparativos.

Para o estudo de enfermidades específicas, dispõe-se, também, dos produzidos pelo Subsistema de Agravos de Notificação (Sinam), destacando-se neste caso as doenças sexualmente transmissíveis e a AIDs. Historicamente, essa base de dados tem sido criticada quanto à subnotificação dos casos, especialmente considerandose problemas de saúde amplamente estigmatizados.

Também podem ser mencionados o Rcgistro Nacional de Patologia Tumoral, de base laboratorial, e os Registros de Câncer de Base Populacional. Estes últimos permitem o cálculo de taxas de incidência, mas limitam-se a alguns municípios do País - entre os quais alguns têm sofrido grande descontinuidade de sua ação. Além de publicações específicas ' , o Instituto Nacional do Câncer (INCa/MS), lançou, em 1997, "Estimativas da Incidência e Mortalidade por Câncer no Brasil", disponível também em CD-ROM.

Merece ser comentado que as bases de dados nacionais ainda apresentam problemas de compatibilização, existindo mais dificuldade quanto maior o nivel de desagregação geográfica. De todo modo, são fontes de informação valiosas e ainda pouco exploradas, especialmente quanto ao tema em questão.

\section{Saúde reprodutiva e o movimento de mulheres: notas finais}

Nas duas últimas décadas, a noção de saúde reprodutiva desenvolveu-se de modo amplo em espaços institucionais, que envolveram fundamentalmente a OMS e setores ligados ao sistema internacional de planejamento familiar (Corrêa, 1996).

Em fóruns internacionais da década de 90, particularmente na Conferência Internacional de População e Desenvolvimento (CIPD), de 1994, no Cairo, e na IV Conferência Mundial sobre a Mulher, Desenvolvimento e Paz (em 1995, em Beijing), a noção de saúde reprodutiva esteve na base das negociações que propiciaram a construção de um consenso entre a vertente institucional es movimentos sociais, destacando-se o movimento de

' Citam-se, entre outras, Brumins, 1982; Ministério da Saúde, 1991a e $1991 \mathrm{~b}$. 
mulheres. Um dos principais resultados desse processo foi a inflexão nos debates em tomo da reprodução humana de sua perspectiva de controle demográfico para o reconhecimento, como direitos humanos inalienáveis, dos direitos sexuais e reprodutivos, os quais, até então, encontravam-se abrigados na saúde reprodutiva (Corrêa, 1996).

Embora apresentando distintos potenciais de legitimação, esses termos têm sido usados freqüentemente de modo intercambiável, como ficou ilustrado anteriormente nas definições adotadas por diferentes autores (Fatalla, 1988; Germain, 1987 apud Graham \& Campbell, 1991). Além das imprecisões semânticas, nos debates atuais, persiste até mesmo a dúvida se a saúde reprodutiva é um conceito, um campo ou apenas um recorte de investigação. Mais do que uma questão acadêmica, como bem afirma Corrêa (1996:2):

é (...) crucial precisar o conteúdo e o sentido dessas novas definições, senão por outra razão porque podem ocorrer simplificações e distorções no contexto de sua aplicação nas políticas públicas e legislações.

Fica clara, portanto, a necessidade de se explicitar essas dificuldades, para superá-las. O conceito de saúde reprodutiva que emergiu da Conferência do Cairo a define como:

o estado de completo bem-estar fisico, mental e social, e não meramente a ausência de doença e enfermidade, em todas as questões relativas ao sistema reprodutivo e às suas funçōes e processos. (Themis, 1997:23)

A definição inspira-se no conceito de saúde da OMS (1981), que traduziu a preocupação de projetar o reconhecimento do estado de saúde e seus determinantes para além dos processos biológicos e de alcançar um grau de generalidade que pudesse englobar diferentes contextos culturais, socioeconômicos e políticos. No entanto, a forma genérica como é estabelecido o que poderia ser um estado perfeito de saúde imprime ao conceito um nível de abstração que o torna quase metafísico, difícil de operacionalizar ou, ainda, de ser atingido, tanto individualmente quanto por coletivos humanos.

Em outra perspectiva crítica à definição de saúde da OMS, Camargo Jr. (1995) questiona a mera justaposição de discursos (da biologia, da psicologia e da sociologia) como possibilidade de superar a fragmentação inerente ao desenvolvimento disciplinar moderno. Além disso, ressalta-se o fato de que, na perspectiva hegemônica, os termos 'psico' e 'social' não passam de referências genéricas subordinadas ao primado do discurso biológico.

Prosseguindo a análise de seu sucedâneo, as dificuldades identificadas na primeira parte do conceito não são contomadas pela especificação pretendida a partir da referência ao processo de reprodução. Ao contrário, ocorre seu confinamento nos limites dos processos biológicos, ao qualificar o estado de bem-estar "em todas as questões relativas ao sistema reprodutivo e a suas funções e processos". 
Embora reconhecendo a importância das declarações do Cairo e de Beijing (Themis, 1997) como instrumentos políticos nas lutas das mulheres, no plano internacional o conteúdo de suas definições deve ser retraduzido à luz das especificidades locais e conjunturais, especialmente considerando-se sua aplicação em distintos setores das políticas públicas.

No âmbito da saúde, odiscurso hegêmonico trata a reproduçãoe a sexualidade exclusivamente em sua dimensão biológica, naturalizando as diferenças entre homens e mulheres e reiterando o essencialismo na figura da mulher mãe, reprodutora biológica e provedora de cuidados à prole e à família. O saber médico contemporâneo classifica comodoenças eventos fisiológicos, como a menstruação e o climatério; como desvios, as escolhas sexuais distintas da união heterossexual para a procriação; como objetos de medidas de prevenção, a gravidez 'precoce' e a 'tardia', em um fenômeno de biologização do social (Ávila, 1996). Em conseqüência, nesse campo em particular, a utilização de termos como 'sexual' e 'reprodutivo' vem carregada de valores intrinsecamente conservadores, 'biologizando' outros termos aos quais estejam agregados, como 'saúde sexual' e 'saúde reprodutiva'.

Esta reflexão é particularmente relevante ao se tratar da formulação e operacionalização de propostas de políticas e programas de atenção à saúde, pois correse o risco de aprisionar o debate sobre saúde e direitos reprodutivos nos marcos estritos da ginecologia e obstetrícia, tendo os médicos como principais interlocutores.

A saúde tem ocupado lugar central nas lutas das mulheres brasileiras nos últimos vinte anos. Durante a década de 80 , ocorreram inúmeros encontros sobre o tema promovidos pelo movimento feminista, cujas proposições tiveram contribuição inegável na definição de políticas sociais do interesse das mulheres, destacando-se a formulação do Programa de Assistência Integral à Saúde da Mulher (PASM), em 1983. Isto se deu em meio ao processo mais amplo de redemocratização do País e, particularmente, de democratização da saúde, consubstanciado no artigo 196 da Constituição Federal de 1988, que define saúde como direito de cidadania e dever do Estado.

Embora não seja pretensão deste artigo aprofundar essa questão, entre as reflexões finais, cabe ser apontada a necessidade de retomada de uma articulação das lutas das mulheres pela saúde com os demais movimentos sociais que, atualmente, buscam defender as conquistas formais obtidas e implementar políticas públicas de saúde com características de eqüidade, universalidade e justiça social.

As contribuições do feminismo no campo da saúde não se esgotam nas reflexões sobre o corpo, a reprodução e a sexualidade. As teorias de gênero podem ampliar o debate sobre eqüidade, enriquecendo as conceituações de saúde e a própria compreen-

\footnotetext{
2 Entre outros, o $1^{2}$ Encontro Nacional sobre Saúde, Sexualidade e Aborto (1983), no Rio de Janeiro; o $1^{\circ}$ Encontro Nacional de Saúde das Mulheres (1984), em Itapecirica da Serra; I Conferência Nacional de Saúde e Direitos Reprodutivos (1986); Encontro Nacional Saúde da Mulher: um direito a ser conquistado (1989), em Brasília.
} 
são sobre o processo saúde e doença. Aplicá-las nesse campo implica desnaturalizar diferenças entre homens e mulheres, entre homens e homens, entre mulheres e mulheres; e evidenciar hierarquias e subordinações, buscando entender como estas se produzem e se reproduzem, e, particularmente, como se articulam com as iniqüidades em saúde.

No Brasil, os elementos que compõem a reflexão e a luta das mulheres pela saúde têm incluído

o questionamento acerca do saber e do poder médico; a emergência do discurso das mulheres sobre suas experiências corporais; uma crítica contundente à situação atual do serviço de saúde; além do empenho em exigir do Estado uma maior eficácia no que se refere ao funcionamento do sistema de saúde. (Ávila, 1993)

No momento atual, construindo-se uma agenda para a virada do século, duas questões parecem especialmente estratégicas: a incorporação de gênero à saúde reprodutiva, desconstruindo a imagem da mulher como reprodutora e o seu reverso de que reprodução nada tem a ver com os homens; e a repolitização das necessidades de saúde, com a retomada da ênfase na noção de integralidade da assistência, com base em uma concepção holística de saúde.

\section{Referências Bibliográficas}

Aquino, E. M. L; Menezes, G. M. S. \& Amoedo, M. B. Gênero e Saúde no Brasil: contribuições a partir da Pesquisa Nacional por Amostra de Domicílios. Revista de Saúde Pública, São Paulo: 26(3):195-202, 1992.

Aquino, E. M. L et al. Gênero e Saúde: estado atual da produção do conhecimento epidemiológico no Brasil (Documento básico para Oficina de Trabalho) Epidemiologia: III Congresso Brasileiro, II Congresso Iberoamericano e I Congresso Latinoamericano.

AlAN GUTTMACHER InSTIUTIE. Aborto Clandestino: uma realidadelatino-americana. Nova Iorque: AGI, 1994. Áviц, M. B. Modernidade eCidadania reprodutiva. Revista Estudos Feministas 2(1):382-393, 1993. ÁvILA, M. B. \& Gouvea, T. Notas sobre direitos reprodutivos e sexuais. In: PARKER, R. \& BARBOSA, R. M. (Org.) Sexualidades Brasileiras. Rio de Janeiro: Relume-Dumará: Abia: IMS/Uerr, 160-172, 1996.

BARBOSA, R.H.S. AIDS, gênero e reprodução. Revista Estudos Feministas, 1 (2): 41 8-23, 1993.

Benfam/Dhs. Pesquisa Nacional sobre Demografiae Saúde, 1996. Rio de Janeiro: Benfam/ DHS / IBGE / USAD / MS / FNUAP/UNICEF, 1997.

BERQuó, E., 1993. Brasil, um caso exemplar: anticoncepção e partos cirúrgicos - à espera de uma ação exemplar. Revista Estudos Feministas 1 (2): 366-381. 
Brastr. Ministério da Saúde. Instituto Nacional de Câncer. Pró-Onco. Câncerno Brasil: Dados de Registros de Base Populacional. Rio de Janciro: MS/INCa/Pro-Onco, 1991 a. 35p.

Brasil. Ministério da Saúde. Instituto Nacional de Câncer. Pro-Onco. Registro Nacional de Patologia Tumoral. Diagnósticos de Câncer: Brasil, 1981-1985. Rio de Janeiro: MS/INCa/Pro-Onco, $1991 \mathrm{~b}$.

Brasil. Ministério da Saúde. Secretaria Nacional de Saúde. Programa Nacional de DST/ AIDs. Relatónio de trabalho do Grupo Assessor para a elaboração de diretrizes e políticas de Prevenção e Controle das DST/AIDS entre mutheres. Documento Preliminar. Março, 1997. 14 p.

Brasil. Ministério da Saúde. Secretaria Nacional de Programas Especiais de Saúde. Divisão Nacional de Saúde Materno Infantil. Programa de Saúde do Adolescente. Brasília, 1989.

BRUMINI, R. (Ed.). Câncerno Brasil: dados histopatológicos. 1976-80. Rio de Janeiro: Ministério da Saúde/Campanha Nacional de Combate ao Câncer, 1982. 480 p.

CAMARGO Jr, K. R., 1995. Racionalidades médicas: a medicina ocidental contemporânea. Cadernos de Sociologia 7: 129-150, 1995.

CAmpBeLL, O. M. R \& GrahaM, W. J. Measuring Maternal Mortality and Morbidity: levels and trends. London: London School oh Higyene and Tropical Medicine, Maternal and Child Epidemiology Unit, 1990.

Castll.ho, E. A.; Chequer, P. \& Struchiner, C. I. Aids no Brasil. Informe EpidemiológicoSUS 1 (3): 117 $124,1992$.

Centro Nacional de EptDemiologia/FNS Mortalidade Brasil, 1994. Brasília: Cenepi / Fundação Nacional de Saúde, 1997.520 p.

Compre, G. 1996. Mortalidade materna em Salvador, 1993, 1996. Dissertação de Mestrado em Saúde Comunitária. Salvador: Instituto de Saúde Coletiva, UFBa.

CORRÊA, S. Saúde reprodutiva, gênero e sexualidade: legitimação e novas interrogações. Apresentado no Seminário Internacional do Programa de Saúde Reprodutiva e Sociedade. Colégio do México, Novembro, 1996. 26 p. (Mimeo)

Fauveau, V. \& Blanchet, T. Deaths from injuries and induced abortion among rural Bangladesh women. Social. Science \&Medicine. 29 (9): 121-127, 1989.

FERREIRA, C. E. \& CENEVIVA, P. V.Análise da mortalidade materna através das estatísticas vitais: dificuldades e perspectivas. In: Seminário Latinoamericano sobre População e Saúde. Anais. Campinas: Unicamp, 1986.

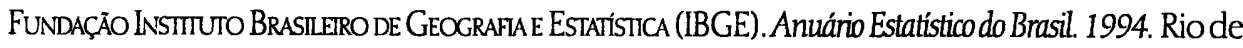
Janeiro: IBGE. v. 54: 1-1; 8-32, 1994. 
FORTNEY, J. A. Reproductive morbidity: a conceptual framework. Family Health Inlemational Working Papers, 1995.

GRAHAM,WJ. \& CAMPBELL, O.M.R. Measuring matemal heallh. defining issues. London: London School of Hygiene and Tropical Medicine, Maternal and Child Epidemiology Unit, 1991.

HöGBERG, U. Maternal Death in Sweden, 1971-1980. Acta Obstetricia et Gynecologica Scandinavica, 65: 161-167, 1986.

LAURENTI, R. A $10^{\mathrm{a}}$ Revisão da Classificação Internacional de Doenças: características e análise crítica. Apresentado no IV Congresso Brasileiro de Saúde Coletiva. Recife: 2024 de junho, 1994. 12 p. (Mimeo.)

MENDES, E. V. As políticas de saúde no Brasil nos anos 80: a conformação da Reforma sanitária e a construção da hegemonia do projeto neoliberal. In: MENDES, E. V. (Org.) Distrito Sanitário: o processo social de mudança das práticas sanitárias do Sistema Único de Saúde. São Paulo-Rio de Janeiro: Hucitec-ABRASCO, 1991.p. 19-91.

MORAES, H.S. et al. Utilização de Grandes Bancos de Dados Nacionais. In: Lima, E. Costa, M. F. F. \& SousA, R. P. (Org.) Qualidade de Vida: compromisso histórico da Epidemiologia. Belo Horizonte: COOPMED Editora/ Abrasco, 1994. p. 285-290.

OrGanizaçÃo Mundial da Saúde. Manual da Classificação Estatística Intemacional de Doenças, Lesõese Causas de Óbito, $9^{\circledR}$ Revisão, 1975. São Paulo: Centro da OMS para Classificação de Doenças em Português - USP. v. 1, 1978.

Organização Mundial da Saúde. Documentos Básicos. $31^{a}$ ed. Genebra: OMS, 1981. 167p.

Pauta, A. M. C. et al. Avaliação dos dados de mortalidade no Brasil - 1979 a 1989. Informe Epidemiológico SUS. 3(1): 21-41, 1994.

PUfFer, R. R. \& GRIFFITH, R. Paterns of Urban Morbility. Washington: Pan American Health Organization (PAHO)-World Health Organization-(WHO). Scientific Publication № $151,1968$.

SIMÕES, C. C. S. \& OLveIRA, L. A. P. Perfil Estatístico das Crianças e Mães no Brasil: a siluação de fecundidade; determinantes gerais e caracterislicas da transição recente. Rio de Janeiro: IBGE/ Departamento de Estatísticas e Indicadores Sociais, 1988. 64 p.

THEmIs. Direitos Sexuaise Reprodutivos: Instrumentos Internacionais de Proteção. Porto Alegre: Themis, Assessoria Jurídica e Estudos de Gênero, 1997. 141 p.

TURnBull, A. et al. Confidential Enquiries into Maternal Death in England and Wales, 1982-1984. Report on Health and Social Subjects n³4, 1989. p.166.

Vianna, L. A. C. Fidedignidade da Mortalidade Materna. In: VIII Encontro Nacional Estudos População, 1992. Anais. São Paulo: Associação Brasileira Estudos de População (ABEP), v.2, p.471-483. 
WALKER, G. J. A. et al. Maternal mortality in Jamaica. Lancet l (8479): 486-488, 1986.

Wingo, P. A. et al. (Eds.) Epidemiología Aplicada a la Salud Reproductiva. Atlanta: Centers for Disease Control; North Carolina: Family Health International; Ginebra: Organización Mundial de la Salud. WHO/HRP/EPID/96.1, 1996. 478 p.

World HeAlth OrGanizamon (WHO). Measuring Reproductive Morbidity. Report of a technical Working group. Geneva, 30 August-September. Document WHO/MCH, 1990. Geneva: WHO, 1989. 


\section{A Mortalidade Materna no Brasil}

\section{no Período de 1980 a 1993}

Kátia Silveira da Silva, Catherine M. Lowndes, Eleonora D'Orsi \& Ana Cristina. C. Vaz Reis

\section{Introdução}

O óbito de uma mulher em decorrência de causa associada à maternidade é hoje um fato considerado inaceitável, principalmente se levarmos em conta que, com o conhecimento médico disponível, a grande maioria destas mortes poderia ser evitada. A sua ocorrência representa o final da linha de uma rede complexa de eventos - que abrangem desde determinantes mais gerais, como o nível de concentração de renda e o desenvolvimento de políticas sociais, até os mais específicos, como a percepção da mulher de sua própria saúde e o acesso aos serviços de assistência médica de qualidade tanto para as grávidas e puérperas quanto para aquelas mulheres que desejam o controle de sua fecundidade.

Em estimativas mais recentes, a Organização Mundial de Saúde (OMS) avalia que ocorram aproximadamente 585 mil óbitos maternos por ano no mundo-99\% localizados em países do Terceiro Mundo (Weekly Epidemiological Record, 1996). Considera-se que, no passado, o nível da mortalidade materna estava subestimado-sem, contudo, ter havido mudanças na distribuição geográfica dos óbitos. Embora as medidas para redução da . mortalidade materna já sejam conhecidas, pode-se dizer que não houve avanços nos últimos anos (Abouzahr, 1996).

Na comparação de taxas de mortalidade materna entre diferentes países, constata-se que, nos países em desenvolvimento, as mulheres no ciclo gravídico-puerperal apresentam risco de morrer por causa materna até 25 vezes maior do que nos países desenvolvidos (Armstrong \& Royston, 1989), (Tabela 1). 


\section{Tabela 1- Razão de mortalidade materna - 1991-1993}

\begin{tabular}{lcc}
\hline País & Razão & No Óbito Materno \\
\hline EUA & 7,8 & 323 \\
Dinamarca & 7,4 & 5 \\
Japão & 6,9 & 82 \\
Canadá & 4,7 & 19 \\
Argentina & 40,9 & 334 \\
China & 64,5 & 439 \\
Tanzânia* & 297 & 62 \\
\hline
\end{tabular}

Fonte: World Health Statistic Annual, 1994.

Nota: * WALRAVE, 1994

As diferenças existentes entre níveis de mortalidade materna dos países são reflexo das grandes desigualdades nas condições políticas, econômicas e sociais. Estas desigualdades se reproduzem dentro dos próprios países. Sabe-se que o Brasil apresenta no seu interior situações bastantes diferenciadas: enquanto uma parcela pequena da população usufrui de elevado padrão de vida, existem bolsões de pobreza semelhantes aos dos países da África e Ásia. Duchiade (1995) identificou, no artigo "População Brasileira: retrato em movimento", a cxistência de múltiplas realidades que compõem os vários brasis. Apresentar este quadro sobre o aspecto específico da mortalidade materna é uma contribuição para o conhecimento do nosso país.

O objetivo deste capitulo é descrever a tendência e as causas específicas da mortalidade materna no Brasil, em suas regiões e estados, de 1980 a 1993. Este estudo permite conhecer, em parte, que etapas do processo reprodutivo feminino podem ser modificadas, definindo áreas prioritárias nos Programas de Saúde, reduzindo o nível das taxas de mortalidade materna e repercutindo positivamente no quadro de saúde da mulher.

No Plano de Ação para Redução da Mortalidade Materna (1995), o Ministério da Saúde (MS) refere que o Brasil é o quinto país de maior Razão de mortalidade materna na América Latina, estimada em 134.7 óbitos para 100.000 nascidos-vivos para o ano de 1988. Odocumento afirma que: "98\% destas mortes seriam evitadas se as mulheres tivessem condições dignas de vida e atenção à saúde, especialmente prénatal realizado com qualidade, assim como bom serviço de parto e pós-parto" (Brasil. Ministério da Saúde, 1995).

Será adotado o conceito de óbito materno recomendado pela OMS, que considera como morte materna (OMS, 1978):

a morte de uma mulher durante a gestação ou dentro de um período de 42 dias após o término da gravidez, independente da duração ou localização da gravidez, devido a qualquer causa relacionada com, ou agravada pela gravidez, porém não devido a causas acidentais ou incidentais. 
Esta definição corresponde às causas de óbito descritas no capítulo XI da Classificação Internacional de Doenças (IX Revisão): complicações da gravidez, do parto e do puerpério.

Os principais aspectos a serem analisados são: estimativas do indicador de mortalidade materna para o Brasil e macrorregiões para o ano de 1992; a evolução da Razão de mortalidade materna no Brasil e regiões e estados durante o período de 1979 a 1993; e a Razão de mortalidade específica no Brasil para os principais grupos de causas maternas no período de 1979 a 1993.

\section{Metodologia}

A medida mais usual nos estudos sobre o tema é a Razão de mortalidade materna, obtida a partir do seguinte cálculo:

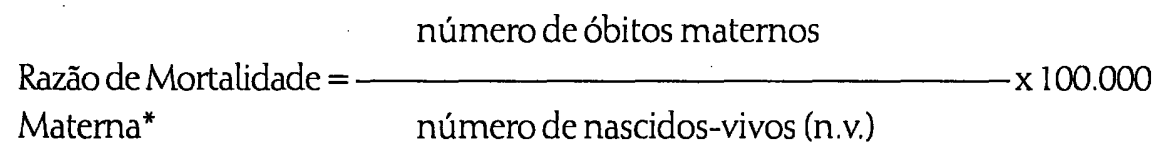

("para um dado periodo e região geográfica)

Como um indicador de saúde, possibilita avaliar a qualidade da assistência médica prestada às mulheres durante a gravidez, o parto e o puerpério. Porém, a sua análise em diferentes períodos e lugares permite afirmar que ele ultrapassa os limites de um simples indicador de saúde, tornando-se uma medida das condições socioeconômicas.

\section{Fonte de dados}

As informações sobre o número de óbitos maternos e de nascidos-vivos são a base para construção do indicador Razão de mortalidade materna.

- Os óbitos

Os dados referentes ao período 1979 a 1993 foram obtidos junto ao Subsistema Nacional de Mortalidade - MS (SIM), que nos permitiu ter acesso às informações sobre a causa básica de morte, município de residência e idade.

- Os nascidos-vivos

As estimativas do número de nascidos-vivos para o Brasil, regiões geográficas, estados e capitais foram obtidas junto à Fundação Instituto Brasileiro de Geografia e Estatística (IBGE). Em relação ao número de nascidos-vivos, o IBGE fornece publicações anualmente sob o título "Estatísticas do Registro Civil" com os dados coletados diretamente no registro civil. No entanto, existe uma série de entraves na legislação 
pertinente, como a não-gratuidade do registro, que contribuem para o sub-registro existente. Ainda que estas restrições existam, o Registro Civil é a única fonte de nascimentos que permite a construção de séries históricas.

Neste trabalho, foi utilizado o número de nascidos-vivos corrigidos para o registro atrasado em até oito anos, fornecido pclo Departamento de População e Indicadores Sociais (DEPIS) da IBGE. A partir desta metodologia, foi construída a série de registros tardios, entre 1974 e 1994. Para obtenção do número de nascidos-vivos corrigido para as regiões metropolitanas foram utilizados os fatores de correção multiplicados pelo total de nascidos-vivos e registrados no ano, disponíveis nas estatísticas do Registro Civil. Para o cálculo do número de nascidos-vivos corrigido segundo idade da mãe, a distribuição etária proporcional dos nascidos e registrados no ano do Registro Civil foi aplicada ao total de nascidos-vivos corrigido, assumindo-se não haver sub-registro diferenciado por idade materna.

- Razão de mortalidade materna

A morte materna é um evento relativamente raro. Por isto, a sua razão fica sujeita a grandes oscilações, quando estratificamos em áreas menores ou em causas matemas específicas. Optamos, portanto, por calcular a média móvel de cinco anos, somando os óbitos maternos de dois anos anteriores com os do ano de interesse e os de dois anos posteriores, dividindo pela soma dos seus respectivos nascidos-vivos, para suavizar esta instabilidade do indicador (Neter; Wasserman \& Whithmore, 1993).

A taxa de variação anual dos níveis de mortalidade materna foi calculada através de regressão linear simples para uma análise inicial da tendência do indicador no período estudado para se identificar uma variação média - embora se saiba que esta tendência se modifica ao longo do período estudado (Morettin \& Toloi, 1987).

- Aqualidade dos dados

É bastante discutida a qualidade das informações relacionadas aos óbitos matemos e aos nascidos-vivos. Daí decorre a preocupação de que os resultados possam estar distorcidos por algum viés, comprometendo a validade dos resultados do estudo. A principal distorção se atribui ao número de óbitos - porém, mesmo que estas razões estejam subestimadas, já refletem uma realidade bastante dramática.

$\mathrm{Na}$ análise da mortalidade materna, deve-se considerar que, além deste sub-registro de óbitos que atinge todas as causas, existe uma subenumeração específica da causa materna, já evidenciada em estudos nacionais e internacionais.

Tendo conhecimento do sub-registro geral dos óbitos e subenumeração de óbitos maternos, optamos por estimar Razão de mortalidade materna esperada no ano de 1992, para que se pudesse ter uma dimensão da real magnitude do problema. O cálculo para esta estimativa seguiu a metodologia proposta por Becker e aplicada por Siqueira et al. (1984) para o ano de 1980. A metodologia consiste em, para cada região, 
estimar o número de óbitos, caso todos os municípios informassem regularmente. Deste total estimado, calcula-se o número de óbitos maternos esperados, considerando a proporção destes em relação ao total de causas definidas.

Além disso, para melhor compreensão do perfil das causas maternas, considerou-se importante detalhar, em alguns anos da série estudada, a estrutura destes grupos mais gerais: aborto, hemorragias, toxemias, complicações puerperais e outras causas obstétricas diretas e indiretas.

\section{Quadro 1 - Conversão das causas de morte do XI capítulo do Código Internacional de Doenças}

\begin{tabular}{|lcc|}
\hline Causas & 9a Revisão & CID \\
\hline Causa materna & XI comp.grav. parto puerp. & $630-676$ \\
\hline $\begin{array}{l}\text { Aborto 630.0-639.9 } \\
\text { (Mola hidatiforme, abortos } \\
\text { gravidez ectópica) }\end{array}$ & $\begin{array}{c}\text { Compl. puerperais } \\
\text { (Infeç̧ōes e Embolia) }\end{array}$ & $670-676$ \\
\hline $\begin{array}{l}\text { Hemorragia 640 641 666 } \\
\text { (Hemorragia do início da } \\
\text { gravidez, DDP e PP*, Hemorragia } \\
\text { pós-parto) }\end{array}$ & Outras causas diretas & $6420-6423$ \\
\hline \multicolumn{1}{|c|}{642.4} & & $650-651$ \\
Toxemias 642.6-642.9 & & $651-665$ \\
643 & & $667-669$ \\
(Eclâmpsia, Pré-eclâmpsia, & Causas indiretas & $647-648$ \\
Hipertensão arterial) & (Patologias preexistentes) & \\
\hline
\end{tabular}

Fonte: CID. 9a Revisão; 1993, OPS.

* DPP - Descolamento prematuro de placenta, PP- Placenta prévia.

\section{Resultados}

- A qualidade do sistema de informação de óbitos

No trabalho "Mortalidade Materna no Brasil-1980", segundo dados oficiais, a Razão de mortalidade associada ao ciclo gravídico-puerperal foi de 70 óbitos para 100.000 n.v. No entanto, ao se levar em conta o sub-registro de óbitos, esta Razão aumentaria para $154.3 / 100.000$ (Siqueira, 1984). 
Para o ano de 1992, oSIM refere que ocorreram no Brasil 1.528 óbitos femininos por "complicações da gravidez, do parto e do puerpério". Ao considerarmos os diferentes níveis de sub-registro de óbitos para as regiões geográficas - estimando um total de mortes como se todos os municípios informassem regularmente e não houvesse causas mal definidas - teríamos um registro de 2.577 mortes maternas (Tabela 2).

\section{Tabela 2 - Sub-registro de óbitos (\%), número de óbitos maternos observados e esperados no Brasil e Regióes - 1992}

\begin{tabular}{|c|c|c|c|c|c|}
\hline \multirow[t]{2}{*}{ Região } & \multirow[t]{2}{*}{ Sub-registro (\%) } & \multirow{2}{*}{$\begin{array}{l}N^{9} \text { óbitos } \\
\text { observados }\end{array}$} & \multirow{2}{*}{$\begin{array}{c}\text { № óbitos } \\
\text { esperados* }\end{array}$} & \multicolumn{2}{|c|}{ Razão da mortalidade materna } \\
\hline & & & & Oficial & $A^{*}$ \\
\hline $\begin{array}{l}\text { Norte } \\
\text { Nordeste } \\
\text { Sudeste } \\
\text { Sul } \\
\text { Centro-Oeste } \\
\text { Brasil }\end{array}$ & $\begin{array}{r}45,0 \\
33,0 \\
26,0 \\
4,0 \\
10,0 \\
29,0\end{array}$ & $\begin{array}{r}118 \\
417 \\
604 \\
291 \\
98 \\
1.528\end{array}$ & $\begin{array}{r}255 \\
1.028 \\
853 \\
331 \\
110 \\
2.577\end{array}$ & $\begin{array}{l}48,3 \\
37,1 \\
48,9 \\
58,6 \\
39,5 \\
45,9\end{array}$ & $\begin{array}{l}98,0 \\
95,5 \\
64,8 \\
69,8 \\
47,8 \\
77,5\end{array}$ \\
\hline
\end{tabular}

Fonte: Estatística de Mortalidade, 1992, MS.

Nota: * Considerando apenas o sub-registro de óbitos e o percentual sobre as causas mal definidas, porém sem levar em conta a subenumeração do óbito materno.

A Razão de mortalidade materna - que inicialmente era de 46 óbitos maternos cresceria para 77.5 óbitos maternos para cada 100.000 crianças que nascem vivas. Ao compararmos estas taxas estimadas para o ano de 1980 e 1992, observamos uma redução de $50 \%$ da mortalidade materna.

Esta discussão sobre a qualidade do sistema de informaçãoéfundamental para uma visão crítica dos dados que serão analisados a seguir.

A Razão de mortalidade materna duplicaria, atingindo níveis muito elevados (próximos a 174 óbitos maternos por 100.000) se, além do sub-registro, fosse também corrigida a subenumeração com os fatores diferenciados de correção sugeridos pelo Ministério da Saúde: 2,04 vezes (região Sul); 2,24 vezes (Sudeste); e 3 vezes para demais regiões (Brasil, Ministério da Saúde, 1995). Com base nisto, podemos ter uma aproximação maior do risco a que efetivamente se expõem as mulheres nas diferentes regiões. Com estes fatores de correção, este indicador se toma mais coerente com outros indicadores existentes sobre condições de vida e de assistência médica. Desta forma, as regiões Sul e Sudeste passam a ser aquelas de menor mortalidade materna; e Norte e Nordeste ocupam o lugar de maior risco, com uma magnitude que corresponde a um óbito materno para cada 340 crianças que nascem vivas. 
Embora estas correções pareçam um artifício matemático, elas decorrem da experiência acumulada nesta área por meio de estudos que comparam diversas fontes de informações (realizados por profissionais que buscam a melhoria da qualidade dos dados e a redução da mortalidade materna).

- A tendência da mortalidade materna no Brasil

A análise da Razão oficial de mortalidade materna no Brasil revela uma redução do risco (com a ocorrência de -1,2 óbitos maternos por ano), mas os níveis se mantêm elevados durante todo o período compreendido entre os anos de 1980 e 1993. Seria possivel identificar uma tendência de redução contínua desta Razão apenas entre os anos de 1980 e 1986, quando a mortalidade materna variou entre 66,04 e 50,05 por 100.000 crianças nascidas vivas. Porém, a partir de 1987, percebe-se uma mudança nesta tendência, com a Razão se mantendo estável em torno de 47 mortes maternas por 100.000 n.v. (Tabela 3).

\section{Tabela 3 - Taxa de mortalidade materna e média móvel (Mm) de 5/5 anos, Brasil - 1979 a 1993}

\begin{tabular}{ccccc}
\hline Ano & Óbitos maternos & Nascidos-vivos & Taxa & Mm 5/5 anos \\
\hline 1979 & 2.609 & 3.798 .802 & 68,68 & 66,04 \\
1980 & 2.551 & 3.860 .526 & 66,08 & 63,69 \\
1981 & 2.540 & 4.000 .537 & 63,49 & 62,03 \\
1982 & 2.293 & 4.031 .356 & 56,88 & 59,04 \\
1983 & 2.118 & 3.832 .389 & 55,27 & 55,86 \\
1984 & 1.962 & 3.693 .040 & 53,13 & 52,76 \\
1985 & 1.892 & 3.786 .311 & 49,97 & 51,64 \\
1986 & 1.814 & 3.761 .997 & 48,22 & 50,05 \\
1987 & 1.912 & 3.706 .827 & 51,58 & 48,79 \\
1988 & 1.759 & 3.712 .164 & 47,38 & 48,48 \\
1989 & 1.670 & 3.577 .158 & 46,69 & 47,90 \\
1990 & 1.633 & 3.370 .056 & 48,46 & 46,75 \\
1991 & 1.521 & 3.368 .333 & 45,16 & 46,91 \\
1992 & 1.528 & 3.323 .738 & 45,97 & 46,97 \\
1993 & 1.643 & 3.402 .568 & 48,29 & 46,48 \\
\hline
\end{tabular}

Fonte: MS/FIBGE. 
Inicialmente buscaremos identificar como se apresentam as regiões do País em relação aos níveis de mortalidade materna (Gráfico 1).

\section{Gráfico 1 - Razão de mortalidade materna (média móvel de 5 anos) para as regióes do Brasil - 1979-1993}

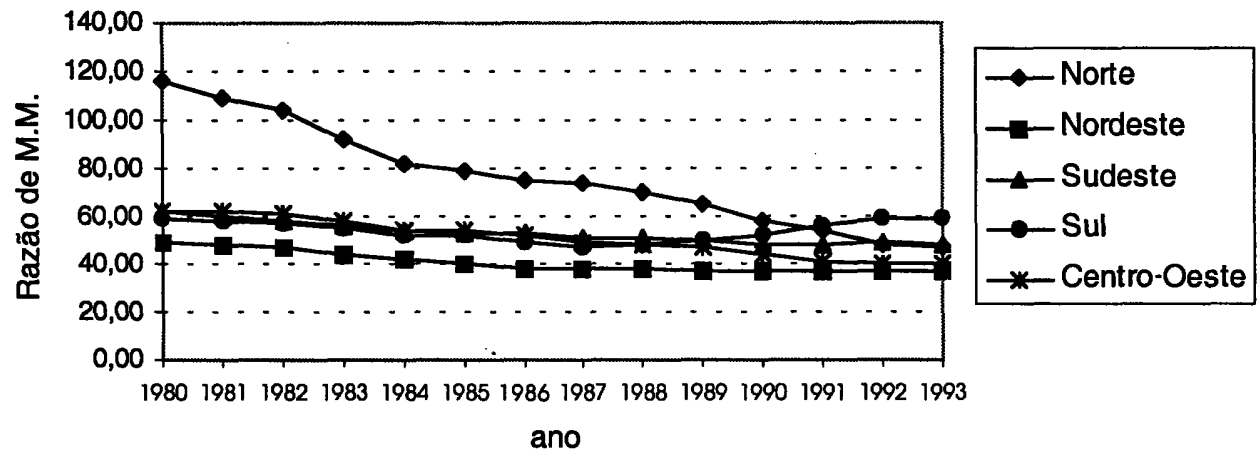

A região Norte se destaca nesta análise por possuir características bastante particulares em relação à tendência do indicador. Em primeiro lugar, é a única região onde se observam, segundo os critérios descritos por Laurenti (1995), níveis muito altos do indicador (116,17 óbitos maternos por 100.000 n.v.). Este fato se deu no início da década de 80 . Além disso, apresenta também a maior variação média do indicador de mortalidade materna do País, com redução anual de cinco óbitos maternos.

Em 1993, contrariando o esperado, constatou-se no Norte um nível médio de mortalidade materna (47 óbitos por 100.000 n.v.) inferior ao das regiões Sudeste e Sul, mais desenvolvidas. Quando se faz a análise dos estados que a compõem, constata-se uma redução das taxas de mortalidade materna - principalmente em Roraima e no Pará, que possuíam os níveis mais elevados do País: 163,84 e 138,59, respectivamente.

Também cabe chamar atenção para o aspecto de a região Nordeste, uma das áreas mais carentes do Brasil, ser aquela de menores taxas de mortalidade materna (próximo a 40 óbitos por 100.000 n.v.) ao longo de todo o período estudado, com uma razão de crescimento anual de -0,9 óbitos maternos. Porém, nos estados da Bahia, Ceará e Sergipe, há registro de aumento da Razão a partir de 1989. No Rio Grande do Norte, a situação da mortalidade materna permanece praticamente inalterada nestes 15 anos. Surpreendeo fato de este indicador na Paraíba se encontrar em um nível considerado baixo, semethante ao de países desenvolvidos, o que deve ser explicado pelo desconhecimento do total de óbitos maternos que efetivamente ocorrem. 
Na região Sudeste, embora tenha havido uma tendência de queda da Razão de mortalidade materna, com uma diminuição de um óbito materno ao ano durante o período, este declínio se concentrou nos primeiros anos: em 1980, estima-se que tenham ocorrido 61.8 óbitos maternos; em 1988, para cada 100.000 nascidos-vivos, morriam 50 mães. Contudo, nos anos 90 , não houve alteração significativa para as mulheres em relação ao risco de morte materna. Se estratificamos este dados por estados, evidenciamos situações diferenciadas. Enquanto no Rio de Janeiro este risco vem aumentando, no Espírito Santo e Minas Gerais a Razão vem diminuindo e, em São Paulo, se mantém relativamente constante.

Na região Sul, ao analisarmos o período completo (apesar de o Rio Grande do Sul e o Paraná apresentarem uma tendência de aumento das razões de mortalidade materna), ainda prevalece uma Razão de crescimento negativo de 0,1 óbitos por 100.000 n.v. por ano. Diferentemente das demais regiões, esta apresenta, no período 1988 a 1993, um aumento contínuo da Razão de mortalidade materna, atingindo neste último ano os níveis de 13 anos atrás, colocando o Sul como a região de maiores índices - aproximadamente 59 mortes maternas por 100.000 n.v.

Na região Centro-Oeste, a redução foi mais acentuada (-1,9 mortes maternas/ano), destacando-se o período pós-1988. A Razão variou entre 62 e 39,6 óbitos maternos por $100.000 \mathrm{n} . \mathrm{v}$. nos anos estudados. Dentro da região, todos os estados tiveram reduzidas suas taxas, destacando-se Goiás, com Razão de 19,75 óbitos maternos por 100.000 n.v. em 1990.

Portanto, poderíamos sugerir que a estabilidade alcançada pelo indicador em termos nacionais, na década de 90, é fruto da diminuição da Razão de mortalidade materna nas regiões Norte e Centro-Oeste; da elevação da Razão na região Sul; e da reduzida alteração ocorrida nos níveis do Sudeste e Nordeste.

Em 1993, os maiores riscos para as mulheres situam-se em primeiro lugar no Sul, seguido do Sudeste-o que seria um paradoxo, se não fosse considerado o trabalho que vem sendo realizado nestas áreas para melhorar a qualidade da informação sobre o óbito materno.

Se estratificarmos os nossos dados pelos estados e analisarmos a variação percentual ocorrida entre 1980 e 1993, as áreas com maiores descensos foram Goiás e Rondônia (Tabela 4). 
Tabela 4 - Variação percentual da razão de mortalidade materna entre os anos de 1980 a 1993

\begin{tabular}{lrrr}
\hline Estados & 1980 & 1993 & Variação(\%) \\
\hline PB & 44,03 & 18,89 & $-57,09$ \\
GO & 74,25 & 19,75 & $-73,39$ \\
BA & 35,29 & 23,84 & $-32,47$ \\
CE & 28,29 & 27,27 & $-3,61$ \\
DF & 45,41 & 29,82 & $-34,33$ \\
AC & 83,48 & 31,24 & $-62,58$ \\
MG & 75,57 & 32,01 & $-57,64$ \\
AP & 91,52 & 33,24 & $-63,68$ \\
SC & 32,16 & 35,50 & 10,39 \\
RS & 59,35 & 39,94 & $-32,70$ \\
AL & 69,33 & 41,58 & $-40,02$ \\
RN & 30,76 & 42,36 & 37,74 \\
ES & 64,35 & 43,43 & $-32,51$ \\
R & 56,24 & 43,96 & $-21,84$ \\
PA & 138,59 & 45,50 & $-67,17$ \\
SP & 53,43 & 45,96 & $-13,97$ \\
MT & 26,88 & 46,62 & 73,44 \\
RR & 95,79 & 47,92 & $-49,98$ \\
MA & 52,95 & 48,29 & $-8,79$ \\
FE & 82,09 & 49,59 & $-39,59$ \\
AM & 88,71 & 50,16 & $-43,46$ \\
MS & 86,21 & 50,57 & $-41,35$ \\
RO & 163,84 & 50,83 & $-68,97$ \\
SE & 89,04 & 51,78 & $-41,84$ \\
RJ & 81,09 & 73,10 & $-9,86$ \\
PR & 79,48 & 89,32 & 12,37 \\
\hline
\end{tabular}

Fonte: MS/RBE.

Com exceção de alguns estados, identifica-se uma tendência generalizada de redução do nível de mortalidade materna, embora tenha sido observada alguma elevação a partir de certo momento da série estudada, principalmente após o ano de 1988. Além de evidenciarem índices bastantes altos, algumas áreas indicam uma tendência de elevação das taxas a partir da segunda metade da década de 80; e os estados do Paraná e Rio de Janeiro aparecem com os maiores riscos (Gráfico 2). 


\section{Gráfico 2- Taxa de mortalidade materna segundo estado de residência - 1993}

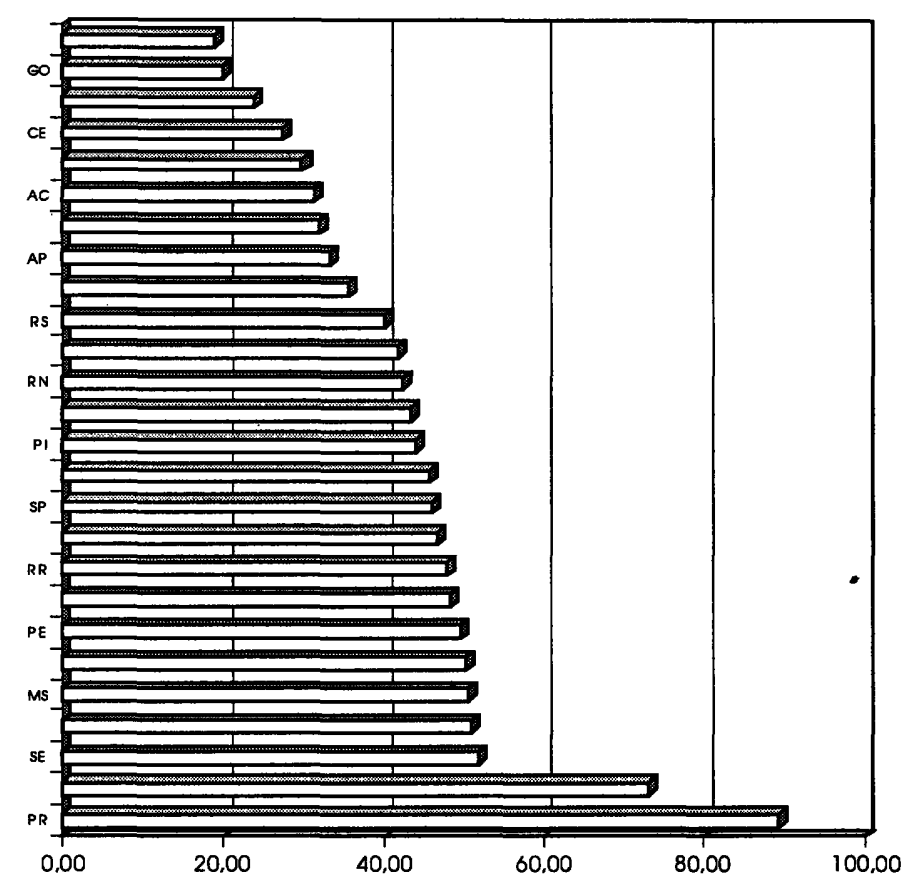

Laurenti (1994) também refere um aumento de 6\% da mortalidade na cidade de São Paulo neste mesmo período. Entre os Estados com pior desempenho estavam Paraná, Santa Catarina, Rio Grande do Sul e Mato Grosso.

- Análise das causas específicas de mortalidade materna

$\mathrm{Na}$ análise das causas específicas de mortalidade materna constata-se que, embora tenha havido um declínio das taxas, durante estes anos não houve alterações significativas no padrão de causas de mortalidade materna, quando se estuda os dados agregados nacionalmente (Gráfico 3). 
Gráfico 3 - Média móvel de 5 em 5 anos da taxa de mortalidade materna por subgrupos de causas. Brasil - 1979-1993
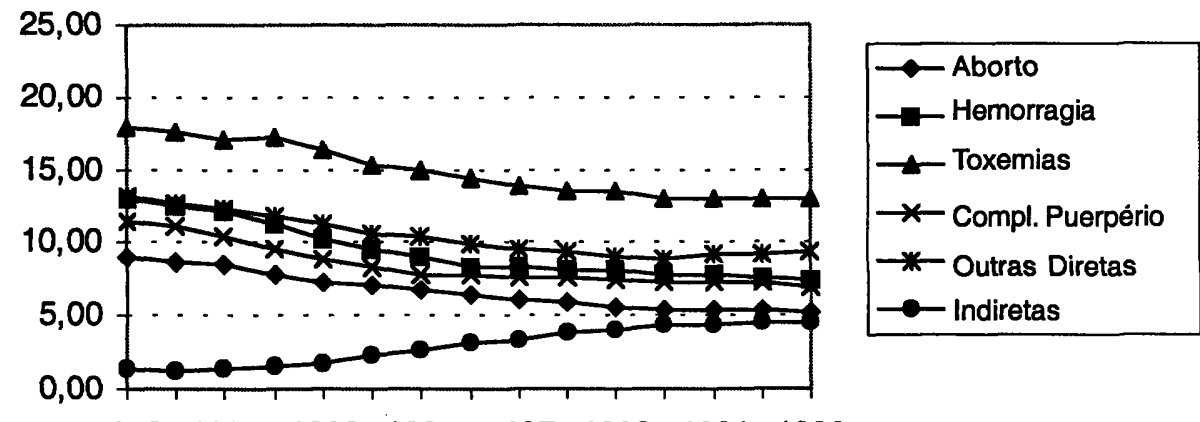

$\begin{array}{llllllll}1979 & 1981 & 1983 & 1985 & 1987 & 1989 & 1991 & 1993\end{array}$

Observa-se que as maiores taxas são atribuídas às toxemias, seguidas das outras causas diretas, hemorragias, complicações do puerpério, abortos e das causas indiretas. Chamam atenção o aumento gradativo das taxas de mortalidade materna pelas causas indiretas e o risco de uma mulher gestante ou puérpera vir a morrer por esta causa, atualmente três vezes maior do que nos anos iniciais.

As toxemias foram as principais causas em todos os anos descritos (Gráfico 4).

Gráfico 4-Mortalidade proporcional por subgrupos de causas maternas - Brasil - 1993

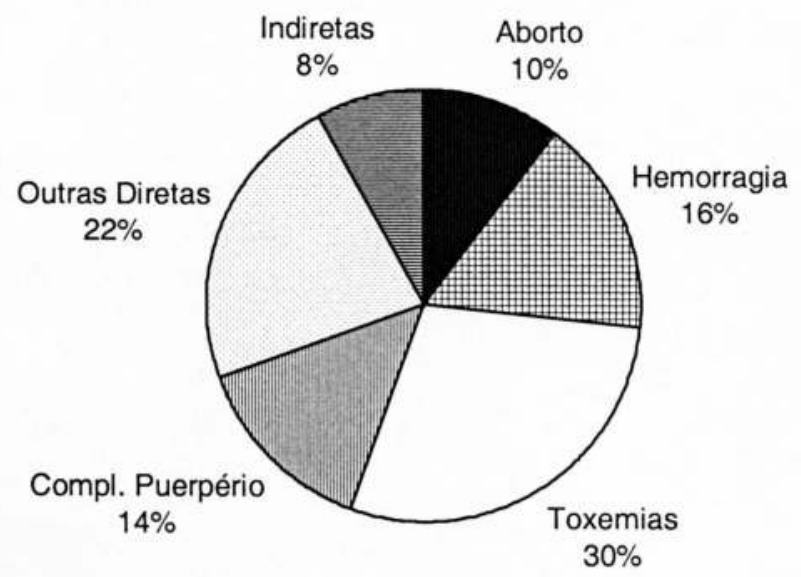


Apesar do declínio ocorrido na Razão específica de mortalidade por toxemias - de 17,84 mortes para 13,02 mortes por 100.000 crianças que nascem vivas -, quando calculamos a Razão das taxas de mortalidade materna entre 1980 e 1993 identificamos que, passados 15 anos, o risco de morte materna por esta causa em 1980 é apenas 1,35 vezes maior do que no ano mais recente da série. Além disso, mais da metade destes casos são atribuídos a eclâmpsia e esta realidade se repete ainda hoje. Em termos proporcionais, observa-se também pouca mudança na sua importância em relação às outras causas de óbito materno, mantendo um percentual de aproximadamente $28 \%$ no período.

A segunda principal causa de morte materna foi a denominada "outras causas diretas", com uma Razão de 9,35 óbitos para cada 100.000 n.v. (1993). Destas, 29\% correspondem às complicações do trabalho de parto; e 22\% são ocasionadas pelo trabalho de parto obstruído. Embora o risco de morrer por esta causa já tenha sido maior $(12,61$ em 1980), houve um redução bastante limitada (1,3 vezes).

Neste período, as hemorragias constituíram a terceira causa de morte, com uma Razão de 7,47/100.000 n.v. (1993). Deste grupo, as hemorragias pré-parto apresentaram um percentual de $64 \%$ e as pós-parto de $36 \%$.

No ano de 1993, a quarta causa de morte foram as complicações puerperais, com uma Razão de 7,02 óbitos maternos para 100.000 n.ve um percentual de 14\%do total de mortes maternas. Destacaram-se, neste caso, as infecções puerperais, que atingiram metade das mulheres que tiveram um pós-parto complicado.

Ressalta-se que o grupo de causas especíicas denominado "aborto" inclui a mola hidatiforme, a gravidez ectópica, os abortos espontâneos e induzidos e os não-especificados. O aborto representa a quinta causa mais freqüente de morte materna no País, com uma Razão que variou de 8.73 (1980) a 5.18(1993) óbitos para cada 100.000 crianças nascidas vivas. Em 1993, os abortos induzido e não-especificado corresponderam à metade das mortes deste grupo.

De todas as causas maternas, estas duas últimas - aborto e hemorragia, com uma razão de taxas igual a 1,7-, e as Complicações Puerperais, com uma razão de 1,6, se destacaram por apresentaros maiores declínios quando se relacionam os anos de 1980 e 1993. Portanto, concluímos que a redução ocorrida nestas três causas deram a maior contribuição para a diminuição da Razão de mortalidade materna ocorrida no Brasil ao longodestes anos.

- Adistribuição etária dos óbitos maternos

Os riscos relacionados às várias faixas etárias no Brasil são descritos por uma curva tipo J e são comuns às diversas áreas geográficas analisadas, apesar de corresponderem a magnitudes diferenciadas (Gráfico 5). 


\section{Gráfico 5 - Taxas de mortalidade materna segundo faixas etárias da mãe. Brasil - médias de 79, 80, 81 e 91, 92, 93}

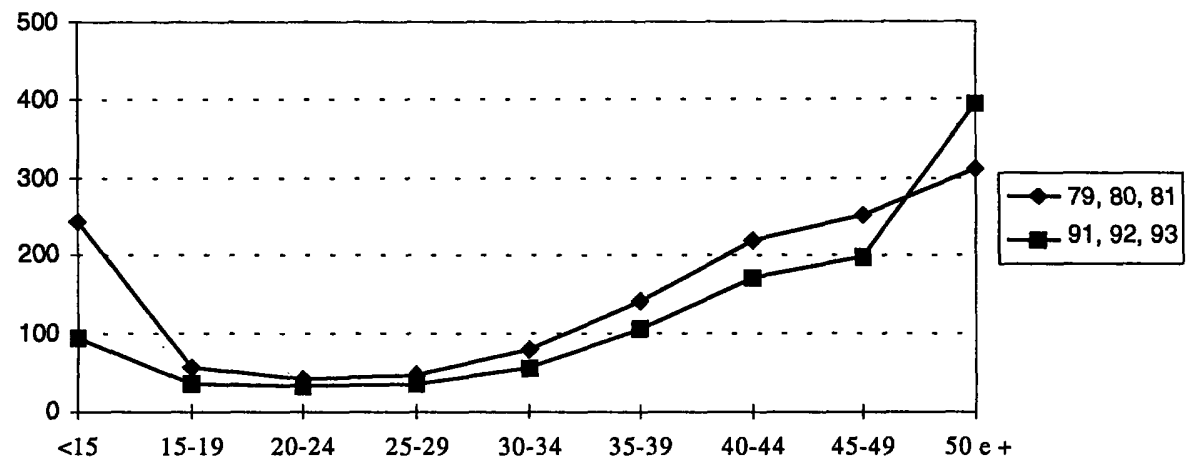

Observa-se maior mortalidade nas idades extremas, isto é, abaixo de 15 anos e acima de 35 anos - o risco vai aumentando gradativamente, à medida que aumenta a idade. Duas características se destacam: um grande número de estados com óbitos maternos acima de 50 anos (com niveis de mortalidade que atingem até 1.700 e 2.200 por 100.000 n.v.) - como em Mato Grosso no segundo e primeiro triênios estudados; $\mathrm{e}$ um aumento da mortalidade materna na faixa etária entre 10-15 anos em todos os estados da região Sudeste, com exceção do Rio de Janeiro (embora, neste grupo, a Razão de mortalidade materna do Rio de Janeiro seja uma das mais elevadas da região, com 200 óbitos para cada 100.000 crianças que nascem vivas).

\section{Discussão}

A qualidade dos dados do Subsistema de Informação de Mortalidade compromete uma análise mais aprofundada da tendência da Razão de mortalidade materna no Brasil no período de 1979 a 1993. Estudos de investigação de óbitos de mulheres em idade fértil realizados em São Paulo, Paraná e Recife demonstraram uma subenumeração que variou entre 50 e 56\% (Albuquerque, 1997; Braga, 1992; Laurenti, 1990). Este fenômeno tambémé observado nos países do Primeiro Mundo. Atrash (1995) identificou que havia algum nível de subenumeração na maioria dos países desenvolvidos. Na Holanda, havia um desconhecimento de $26 \%$ das mortes maternas (Schuitemaker, 1997), ao passo que nos Estados Unidos estima-se que, apesar do esforço de valorizar as várias fontes de informação, este percentual esteja próximo de 50\% (Berg, 1995). 
Isto acontece porque parte dos óbitos femininos decorrentes de causas relacionadas à gravidez, ao parto e ao puerpério permanece desconhecida das estatísticas oficiais, porser registrada tendo como causa básica afecções pertencentes a outros capítulos da CID: doenças do aparelho circulatório, septicemia, pelviperitonite, anemia e coagulação intravascular disseminada (Schuitemaker, 1997; Albuquerque, 1997). Acredita-se que, quanto mais grave a situação, maioro nível de subenumeração (Allen, 1991; Bouvier-Colle, 1991).

Os dados oficiais, ainda que subestimados, demonstram que o nível da mortalidade materna no Brasil se aproxime do nível de países desenvolvidos registrados há 40 anos (Hogberg \& Wall, 1986).

Embora tenha havido importantes mudanças no padrão reprodutivo na última década, com aumento do número de mulheres esterilizadas; maior proporção de uso de práticas contraceptivas; declínio da fecundidade-principalmente no Nordeste e áreas mais pobres, onde provavelmente as mulheres apresentam um risco maior para a mortalidade materna (BEMFAM, 1997) -, o impacto destes fatores não pode ser considerado significativo.

A partir de 1988, foram realizados no País seminários regionais, promovidos pelo Ministério da Saúde, para aprofundar o conhecimento sobre a mortalidade materna e incentivar a criação dos comitês de prevenção entre os profissionais da saúde ligados a esta área. O principal saldo desta mobilização nacional foi certamente o surgimento dos comitês de Prevenção da Mortalidade Materna em São Paulo e Rio de Janeiro (1988), Paraná (1989), Ceará (1992) e Distrito Federal (1993).

É provável que estes trabalhos estejam causando, principalmente, um impacto sobre a qualidade da informação, descobrindo novos óbitos a partir de investigação. Isto explica, em parte, a tendência de aumento da mortalidade matema para áreas como Rio de Janeiro, São Paulo e Paraná, e o fato de termos as regiões Sul e Sudeste com os mais elevados níveis de mortalidade do País. Também se sabe que a década de 80 se caracteriza pelo empobrecimento da população brasileira, principalmente da urbana (CEPAL, 1990). Além disso, houve redução dos gastos públicos federais em áreas sociais, particularmente na saúde.

É reconhecida, por diversos autores nacionais e internacionais, a relação existente entre a pobreza e as altas taxas de mortalidade, proporcionando grandes diferenciais entre os países desenvolvidos e subdesenvolvidos (Qzumba, 1988; Royston \& Armstrong, 1991, Starrs, 1987; Pinto \& Ribeiro, 1991). Por isto, acreditamos que, ao corrigir o subregistro, aplicando os fatores de correção propostos pelo Ministério da Saúde, nossas estimativas nos permitem uma aproximação do risco efetivo de mortalidade materna nas diferentes regiões do País.

Segundo dados do documento "Síntese de indicadores de pesquisa básica PNAD (Pesquisa Nacional de Amostra por Domicílios) de 1981 a 1989-IBGE", a região Nordeste tem cerca de 58\% de sua população economicamente ativa recebendo, no máximo, um 
salário mínimo. Ao relacionarmos as rendas médias feminina e masculina em algumas regiões metropolitanas, entre 1976-1986, observamos que a mulher recebe, em média, aproximadamente metade do salário do homem (FLACSO, 1993). Diante destes fatos, fica dificil admitir que a Razão de mortalidade das regiões Norte e Nordeste seja tão baixa como por exemplo na Paraíba, com a menor mortalidade (dados oficiais), colocando-se em um nível próximo ao de alguns países desenvolvidos.

Quanto ao perfil de causas de mortalidade materna, o Brasil se caracteriza por elevadas taxas de toxemias, outras causas diretas, hemorragias, complicação puerperal e abortos. Este perfil é bastante diferenciado do encontrado em países desenvolvidos. Ao longo do tempo, estas causas foram reduzidas e hoje predominam a embolia obstétrica e as causas indiretas, consideradas mais difíceis de serem evitadas (Sachs, 1986; Rochat, 1988). Quando são desenvolvidas estratégias para se identificarem as causas maternas, seja por investigação de óbitos e de prontuários hospitalares, seja por utilização de informações a partir dos nascimentos, percebese que a subenumeração dos óbitos varia de acordo com a causa de morte, sendo maior para o aborto e as causas indiretas (Albuquerque, 1997; Bouvier-Colle, 1991). Laguardia (1990) revela, em levantamento hospitalar realizado no Rio de Janeiro, uma tendência de aumento da mortalidade materna por aborto entre 1978 e 1987. Compte (1995) realizou estudo a partir de óbitos femininos ocorridos em 1993 em Salvadore encontrou como causa principal de morte materna o aborto (26\%). Outros estudos nacionais (Paraná e São Paulo), embora tenham apontado para um importante sub-registro desta causa, ainda tiveram as toxemias como a causa mais importante de morte materna.

É importante salientar o surgimento da AiDs como uma causa indireta de morte materna, na medida em que sua incidência tem sido cada vez maior em mulheres de idade fértil (Berg, 1996).

O conhecimento médico necessário para prevenir o óbito materno já se encontra desenvolvido: medicamentos para controle dos níveis tensionais; antibióticos para controle de infecção; transfusão sangüínea para o controle das hemorragias; técnicas cirúrgicas seguras para a cesariana; terapia intensiva no tratamento de choque; e métodos contraceptivos para aquelas mulheres que não desejam ou não podem engravidar.

Para análise destas causas específicas, também devemos levar em conta o acesso aos serviços de saúde e a qualidade de assistência médica oferecida.

Caberia discutir se estas mulheres têm acesso ao serviços de saúde. Segundo dados da Pesquisa Nacional sobre Demografia e Saúde (PNDS)/1996, a cobertura do pré-natal em âmbito nacional era de $74 \% \mathrm{em} 1986$ e, em 1996, de $85 \%$ do total de gestantes. Refere que destes nascimentos, nos últimos cinco anos, $48 \%$ tiveram mais de sete consultas e $66 \%$ das gestantes procuraram assistência no primeiro trimestre da gravidez. Na região 
Nordeste ainda existe uma parcela importante da população (aproximadamente 25\%) que não usufrui dos benefícios que poderiam ter da assistência pré-natal - na região Sul, este percentual não chega a $10 \%$.

O momento da consulta pré-natal é um espaço privilegiado para prevenção e controle da hipertensão arterial associada à gravidez, que se caracteriza por ser fator de risco para eclâmpsia e outras complicações. Se é fato que a cobertura se encontra tão alta, é pertinente questionar a qualidade da assistência prestada a estas mulheres e afirmar que este pré-natal realizado está longe de cumprir o seu papel na saúde pública. Caso isto ocorresse, poderia registrar um impacto significativo na tendência de mortalidade, principalmente por toxemias e, desta forma, evitar milhares de mortes femininas.

Ao se considerarem as condições de assistência ao parto no Brasil, identifica-se também um aumento da proporção de partos hospitalares quando são comparados os resultados da PNDS-1996 aos encontrados em 1986. Constata-se que 95\% dos nascimentos vivos da população urbana ocorrem em ambiente hospitalar e este percentual diminui para 78\% quando se trata de população rural (BEMFAM, 1996).

As complicações do trabalho de parto e do parto e o trabalho de parto obstruído foram, para o ano de 1993, as principais causas entre as outras causas diretas. Estes fatos não parecem compatíveis com o índice de parto hospitalar e de cesarianas (36\%) realizadas no Brasil nas últimas décadas.

Parte destas cesáreas surge para atender a demanda de um grande número de ligações tubárias que visam a esterilização definitiva. A esterilização feminina, ao ter como via de acesso preferencial o parto cesáreo, contribuiu para que um grande número de cirurgias fosse realizado sem indicação obstétrica precisa. Este procedimento certamente contribui para a elevação do risco de morte materna devido a complicações como infecção e hemorragias. Ao mesmo tempo, se convive com situações em que a realização da cesariana seria indicada, mas a escolha acaba recaindo sobre o parto normal (Carvalho, 1993).

Cecatti \& Faúndes (1991) alertam sobre o risco maior de infecção puerperal após a cesárea quando comparado com o parto normal e para a importância das condições de assepsia e antissepsia durante o parto. Este aspecto deve ser enfatizado quando se discute a qualidade da assistência hospitalar ao parto em todo o País.

As hemorragias se sobressaíram como terceira causa de mortalidade materna no Brasil, apresentando uma tendência de declínio de suas taxas no período de 1979 a 1990, embora muitas maternidades não tenham disponibilidade de transfusão sangüínea.

Neste estudo da mortalidade materna no País, ficou evidenciada a importância do grupo denominado aborto, apontando para a necessidade de um estudo específico sobre o aborto induzido e o não-especificado (considerando-se que este procedimento é ilegal e, portanto, de maior subenumeração, tornando mais dramático este quadro). 
Esta situação pode estar revelando condições de vida muito adversas para estas mulheres. Entretanto, quando analisada a tendência da mortalidade materna por aborto em âmbito nacional, observa-se uma redução de suas taxas.

Durante muito tempo pouca atenção foi dada à morte materna, talvez porque, pensando-se em termos de números absolutos, torna-se difícil dimensionar a extensão do problema. Mas a partir do momento em que se realizaram estudos sobre a epidemiologia da mortalidade materna e as suas repercussões sociais, pode-se reconhecer a existência de uma situação dramática, até então silenciosa.

\section{Conclusão}

Os estudos de mortalidade materna com base em estatísticas oficiais, principalmente os de âmbito nacional, são limitados por uma série de aspectos metodológicos e trazem uma importante questão: até que ponto é válida a utilização destas informações de qualidade discutível?

O caminho para dar validade aos sistemas de informação existentes - sejam eles de mortalidade ou de nascimento - é analisar os dados e criticá-los, contribuindo para o seu aprimoramento.

Para análise da mortalidade materna foi necessário sistematizar um conjunto de dados de óbitos e de estimativas de nascidos-vivos, o que pode ter gerado diferentes tipos de erros. Porém, estes erros, de uma maneira geral, tendem a subestimaro número real de mortes maternas, o que torna de maior gravidade o quadro da saúde feminina.

Consideramos que estes dados, após terem sido trabalhados a partir dos indicadores para séries temporais e para diferentes áreas geográficas, tenham contribuído para revelar um diagnóstico de saúde consistente e sugerir medidas para melhorar o quadro de saúde da população.

Concluímos, também, que a situação da mortalidade materna é pouco estudada; e enfatizamos a necessidade da realização de investigações dos óbitos de mulheres em idade fértil para um conhecimento mais apurado da magnitude, distribuição das causas específicas e dos fatores de risco da morte materna, assim como o desenvolvimento de estudos localizados em hospitais e maternidades. Desta forma, poderemos analisar mais profundamente o efeito de variáveis como renda, educação, paridade, tipo de parto e qualidade da assistência na mortalidade matema. Salientamos que por trás desta mortalidade existe uma morbidade que não vem sendo analisada.

Também acreditamos ser de suma importância a criação de comitês de Prevenção da Mortalidade Materna. A partir daí, será possível identificar melhor as "causas maternas tardias" (que ocorrem entre 43 dias e um ano após o parto), como sugere a $10^{a}$ Revisão da CID. 
Apesar de compreender a existência do óbito materno dentro de um contexto complexo, em que se interrelacionam fatores políticos, econômicos, sociais ebiológicos, vale afirmar que, quando falamos deste óbito, estamos fazendo referência a um grupo específico de mulheres: o de baixa renda. Assim, consideramos que a maioria destas mortes poderia ter sido prevenida basicamente com uma assistência adequada ao pré-natal, ao parto e ao puerpério, como apontam os estudos em que a evitabilidade é analisada.

\section{Referências Bibliográficas}

ABOUZAHR, C. et al. Maternal mortality. World Heallh Stat Quarterly, 49(2):77-87, 1996.

ALBUQUERQUE, R. M. et al. Mortalidade materna em Recife. Avaliação da subenumeração de estatísticas oficiais. Cademos de Saúde Pública, 13(1):59-65, 1997.

AшEN, H. M.; ChaVkIN, W. \& MARINOFF, J. Ascertainment of maternal deaths in New York City. American Joumal of Public Health, 81(3):380-383, 1991.

ARMSTRONG, S. \& RoYston, E. Preventing Matemal Deaths. Genebra: World Health Organization, 1989.

ARRASH, H. K et al. Maternal mortality in the United States, 1979-1986. Obstetric \& Gynecology, 76 (6):1055-1060, 1990.

ATRASH, H. K; AleXANDER, S. \& BERG, C. J. Maternal mortality in developed countries: not just a concern of the past. Obstetric \& Gynecology, 86(4):700-705, Oct. 1995.

BarRos, F. C.; VAughan, P.V. \& Victora, C. G. Why so many caesarea sections? The need for a futher policy change in Brasil. Heallh Policy and Planning, 1(1):19-29, 1986.

Bemfam. Pesquisa Nacional Sobre Demografiae Saúde. Rio de Janeiro: 1997.

BerG, C. J.; ATRASH, H. K. \& KoONIn, L. M. Pregnancy - related mortality in the United States, 1987-1990. Obstetric \& Gynecology 88(2):161-167, Aug.1996.

Brasil. Ministério da Saúde. Plano de Ação para redução da Mortalidade Matema. Secretaria de Assistência à Saúde: Coordenação materno-infantil. Brasília: MS, 1995 .

BOUVER-COLLE, M. .H. et al. Reasons for underreporting of maternal mortality in France as indicated by a survey of all deaths among woman of childbearing age. Intemational Journal of Epidemiology, 20 (3): 717-721, 1991.

CarvalHo, M. L. Mortalidade Neonatal e Aspectos da Qualidade da Atençãoà Saúde Neonatal na Região Metropolitana de Rio de Janeiro em 1986/1987, 1993. Dissertação de Mestrado. Rio de Janeiro: Ensp/Fiocruz.

COMISIÓN ECONÓMICA PARA AMÉRICA LATINA Y EL CARIBE. Magnitud de la Pobrza en la America Latina en los años ochenta, Santiago do Chile: 1990. 
Compte, G. Mortalidade materna em Salvador, Bahia-1993. In: Resumos III Congresso Brasileirode Epidemiologia. Bahia, Brasil, 1995.

Cortes-MAOO, M. et al. Análisis epidemiológico del papel de la fecundidad en el descenso la mortalidad materna en las comunidades autónomas españolas a lo largo del siglo XX. Revista San Higiene Pública, 64(4): 425-438, 1990.

DuCHIADE, M. P. População Brasileira: um retrato em movimento. In: MinAYO, M. C. S. (Org.). Os Muitos Brasis: saúdee população na década de 80. São Paulo/Rio de Janeiro: Hucitec-Abrasco, 1995.

DutriE, S. J. \& GHOSH, H. K. Maternal mortality. British Joumal of Obstetrics and Gynaecology. 96(1):4-8, 1989.

FAÚNDES, A. \& CECATn, J.G. A Operação cesareana no Brasil. Incidência, tendência, causas, conseqüências e propostas de ação. Cademos de Saúde Pública, 7(2):150-173, 1991.

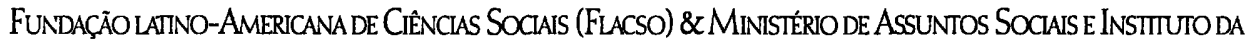
Murher Da EspanHa. Mulheres Latinoamericanas em Dados. Brasil. Santiago doChile: Flacso (Chile) \& Instituto da Mulher (Espanha), 1993.

HOGBERG, U. \& WAL, S. Secular trends in maternal mortality in Sweden from 1750 to 1980 , Bulletin of the World Health Organization, 64 (1):79-84, 1986.

HOGBERG, U; INNALA, E. \& SANDSTROM, A. Maternal mortality in Sweden, 1980-1988. Obstetrics \& Gynecology, 84 (2):240-244, Aug. 1994.

LAGUARDIA, K. D.; RothOLZ, M. V. \& Belfort, P. A. 10-years review of maternal mortality in a municipal hospital in Rio de Janeiro: a cause for concern. Obstetrics \& Gynecology, 75(1):2732,Jan.1990.

LAURENT, R. et al. Mortalidade de mulheres em idade fértil no município de São Paulo (Brasil). II - mortes por causas maternas. Revista Saúde Pública, 24(3):468-472. São Paulo, 1990.

LAURENT, R. Matemal mortality in Latin American urban areas: the case of São Paulo,Brazil. Bull Pan American Health Organ, 27(23): 205-214, 1993.

LaURent, R. Perfil da Mortalidad Materna. In: MinaYo, M. C. S. (Org.). OsMuitos Brasis: saúdee população na década de 80. São Paulo/Rio de Janeiro: Hucitec-Abrasco, 1995.

MORETTIN, P. \& ToloI, C. M. Séries Temporais (Métodos Quantitativos). $2^{\text {a }}$ edição. São Paulo: Atual Editora Ltda., 1987.

Neter, J; Wasserman, W. \& Hithmore, G. A. Applied Statistic, 4th edition. Boston: Ally and Bacon, 1993.

OrGanIZAÇÃo Mundial de SAÚdE. Manual de Classificaşão Estatística Intemacional de Doenças, Lesõese Causas deóbito, 9a Revisão, v.1. São Paulo: OMS, 1978. 
OrGanzação Panamericana de Saúde. La mortalidad materna en las Américas. Boletin Epidemiológico, 14(1): 1-8,1993.

PINTO, C. S. \& Ribeiro, A. F. Mortalidade Materna - dimensões de uma perda evitável. In: FAÚNDESA. \& CECATn, J. G. (Orgs.) Morte Materna: uma tragédia evitável. Campinas: Editora da Unicamp, 1991.

RocHAт, R. W. et al. Maternal Mortality in United States: report from the Maternal Mortality Collaborative. Obstetrics \& Ginecology, 72(1): 91-97, 1988.

SACHS, B.P. et al. Hemorrage, infection, toxemia and cardiac disease 1954 - 85: causes for theird eclining role in maternal mortality. American Joumal of Public Health, 78(6): 671$675,1988$.

SCHUTEMAKER, N. et al. Underreporting (of maternal mortality in The Netherlands) Obstetrics \&Gynecology, 90(1):78-82, Jul.1997.

Siqueira, A. A. F. et al. Mortalidade materna no Brasil, 1980. Revista de Saúde Pública (18):448465, São Paulo: 1984.

TUCKER BRAGA, L. F. C. O. et al. Relatório do comitê de mortalidade materna do Paraná-1991. Informe Epidemiológico do SUS, 1(7): 31-49, 1992.

WEEKYY EPIDEMIOLOGICAL RECORD. New estimates of maternal mortality, 71(13):97-100, 1996. 



\section{Incidência e Mortalidade por Câncer em Mulheres Adultas no Brasil"}

\section{Sergio Koifman \& Rosalina Jorge Koifman}

\section{Introdução}

O câncer se caracteriza como um processo no qual desaparece progressivamente a relação entre forma e função das células e, conseqüentemente, a viabilidade metabólica dos tecidos, necessária à preservação da vida. Embora verificado em outros seres vivos e registrado de diversas maneiras na história humana, o câncer como fenômeno de saúde pública - atingindo contigentes populacionais cada vez maiores - é relativamente recente. Com as modificações ambientais originadas e aceleradas desde a Revolução Industrial, diversificaram-se as oportunidades de exposição contínua a diversos agentes químicos, físicos e biológicos (pesticidas, solventes, asbestos, radiação ionizante, aflatoxina, vírus diversos etc.) associados ao desenvolvimento tumoral.

Do ponto de vista comportamental, as modificações na esfera da vida reprodutiva (número de gestações, idade de ínicio da vida reprodutiva, duração do aleitamento materno, prática de abortamento, ampliação do número de parceiros sexuais, entre outros) decorrentes tanto da inserção da mulher na esfera do trabalho produtivo como da introdução de consumo de medicamentos de natureza hormonal (entre os quais a pílula anticoncepcional se destaca) vêm acarretando transformações biológicas direta ou indiretamente associadas ao desenvolvimento de tumores em mulheres adultas.

"Os autores agradecem a Catherine M. Lowndes pela revisão do texto e sugestôes; a Ana Cristina Gonçalves Vaz e Elconora d'Orsi pela organização dos dados de mortalidade no Brasil, e consulta ao SIA-SUS; e a Fundação Ford, que financiou o projeto 950-0546 de análise de dados sobre condições de saúde da mulher no Brasil. 
Este fenômeno é particularmente notável no caso da pílula anticoncepcional: em uma análise objetiva, sem qualquer tentativa de introduzir juízo de valor, acredita-se que, embora a pílula não esteja associada diretamente à maioria dos tumores reprodutivos, seu consumo permitiu a ampliação da vida sexual da mulher, e com esta, as oportunidades de infecção por agentes virais (herpesvírus, papillomavírus) associados ao câncer de colo uterino e outros (vírus da hepatite B e câncer de fígado).

No caso do câncer de mama, provavelmente o maior problema de saúde pública associado ao câncer em mulheres no Brasil e em diversos outros países industrializados, acredita-se que as modificações associadas a mudanças na duração da vida reprodutiva da mulher (menarca precoce, menopausa tardia, maior freqüência de ciclos hormonais decorrentes do menor número de gestações) vêm tendo um importante papel contributório no desenvolvimento deste tipo de câncer.

Acreditamos que ambos os exemplos revelam a dimensão de obstáculos inerentes à resolução do problema do câncer na mulher adulta na atualidade. Além de dependentes de avanços no conhecimento científico contemporâneo, estes estão diretamente relacionados a um processo social mais amplo nas relações produtivas que vem modificando a longo prazoo padrão de vida reprodutiva da mulher; e a características associadas, no plano individual, à esfera comportamental, freqüentemente determinadas pela primeira condição.

Procuramos apresentar algumas das características da distribuição de algumas localizações tumorais em mulheres adultas no Brasil, especificamente, câncer de mama, de colo uterino, de outras localizações uterinas e câncer de ovário. Outras localizações tumorais em mulheres adultas não foram analisadas, uma vez que o interesse primário residia em caracterizar o problema do câncer na esfera da vida reprodutiva. Os padrões de distribuição da doença encontrados foram comparados entre algumas capitais no Brasil e com a realidade observada em países selecionados e, quando possível, buscouse delimitar cenários futuros para sua ocorrência e controle no País.

\section{Metodologia}

Realizou-se o levantamento e posterior comparação dos coeficientes de incidência e de mortalidade por tumores reprodutivos em cidades brasileiras e países selecionados: câncer feminino de mama ( $9^{\mathrm{a}} \mathrm{CID} 174$ ), câncer de colo uterino (9a CID 180-0), corpo uterino (9 $\mathrm{CID} 182$ ), útero não especificado ( $9^{\circ} \mathrm{CID} 179$ ) e ovário e anexos ( $9^{\circ} \mathrm{CID} 183$ ), além da incidência de câncer em todas as localizações em mulheres (9 CID 140-239).

Os coeficientes médios de incidência por idade em mulheres adultas foram obtidos a partir dos relatórios dos Registros Brasileiros de Câncer de Base Populacional cxistentes nas cidades de Porto Alegre (1990-91), Campinas (1991-92), Goiânia (1990-91), 
Belém (1988-89) e Fortaleza (dados disponíveis apenas para 1985), compilados pela Coordenação do Programa de Políticas de Controle do Câncer (Pro-Onco) do Instituto Nacional do Câncer (Ministério da Saúde, 1995). Dados similares foram obtidos para Cali, Colômbia (1982-86); mulheres brancas de Atlanta, Estados Unidos (1983-87); mulheres nativas no Havaí (183-87); Miyagi, no Japão (1983-87); Suécia (1983-87); e população de imigrantes askhenazi (originária dos Estados Unidos e Europa Oriental) em Israel (1983-87) (Parkin et al., 1992). Estes coeficientes (incidência média no período) foram analisados por faixas etárias mediante ajustamento por idade com a população mundial (Segi, 1960) conforme procedimento rotineiro em estudos descritivos de câncer. Nas comparações com diferentes países, adotou se o procedimento de incluir as cidades brasileiras apresentando os coeficientes de maior e menor magnitude para a distribuição epidemiológica analisada.

Os registros de câncer de base populacional no País acompanham o surgimento de casos novos de câncer em sua região de cobertura por intermédio da confirmação da residência do caso. Todos os casos de neoplasia maligna, incluindo carcinoma in situ, são registrados, agrupando-se desta maneira o conjunto de casos de câncer com diagnóstico confirmado. As informações são coletadas por busca ativa de casos em hospitais da rede pública e privada, de centros de referência para o tratamento de câncer, serviços de diagnóstico e por intermédio dos dados do sistema de mortalidade dos estados e municípios no país (Ministério da Saúde, 1985).

Um dos obstáculos para a realização de comparações entre indicadores de saúde como aquelas aqui realizadas reside na qualidade existente no processo de obtenção dos dados necessários para a determinação dos coeficientes. Esta avaliação, também adotada pelos Registros de Câncer de Base Populacional no Brasil, está baseada na construção de indicadores de cobertura e de precisão das informações coletadas.

São adotados como indicadores de cobertura o percentual de casos de câncer identificados exclusivamente pelo atestado de óbito (quanto menor for este percentual, melhor a qualidade do registro) e a razão mortalidade/incidência de tumores em um dado período de tempo (sendo esperada que a mortalidade apresente magnitude inferior a incidência na maioria das localizações tumorais). Os indicadores de precisão adotados são o percentual de casos de câncer com verificação histológica (sendo desejável que este seja superior a 75\%) e o percentual reduzido de casos com idade ignorada (Ministério da Saúde, 1995). Na Tabela 1, apresentase a magnitude de alguns destes indicadores observados nos registros de câncer de base populacional no Brasil. 


\section{Tabela 1 - Indicadores da qualidade dos dados dos registros de câncer de base populacional no Brasil (1985-92)}

\begin{tabular}{lccc}
\hline Registro câncer & $\begin{array}{c}\text { Confirmação } \\
\text { histológica (\%) }\end{array}$ & $\begin{array}{c}\text { Confirmação } \\
\text { Atestado óbito (\%) }\end{array}$ & $\begin{array}{c}\text { Idade } \\
\text { ignorada (\%) }\end{array}$ \\
\hline Belém (1988-89) & 79,0 & 11,0 & 6,0 \\
Goiânia (1990-91) & 80,0 & 11,0 & 0,4 \\
Campinas (1991-92) & 92,0 & 1,9 & 0,4 \\
P.Alegre (1990-91) & 83,8 & 16,2 & 6,8 \\
Fortaleza (1985) & 59,0 & 34,0 & 1,3 \\
\hline
\end{tabular}

Fonte: Ministério da Saúde, 1995.

Com base nestes indicadores, a Agência Internacional de Pesquisa de Câncer da Organização Mundial de Saúde (IARC/WHO) realiza avaliações periódicas sobre a qualidade dos registros de câncer de base populacional existentes nos diferentes países. Em sua última publicação (WHO, 1992), apenas os registros de Porto Alegre e Goiânia foram incluídos como atendendo aos critérios de avaliação da entidade. Os dados dos demais centros foram, no entando, mantidos neste trabalho para ilustrarem a diversidade regional da distribuição de câncer em mulheres adultas no País, mesmo considerando-se a reserva necessária na elaboração de conclusões.

Os coeficientes de mortalidade por câncer em mulheres segundo faixa etária nas localizações anteriormente mencionadas foram determinados a partir do Sistema Nacional de Mortalidade do Ministério da Saúde para as cidades (regiões metropolitanas não incluídas) de Porto Alegre, Curitiba, São Paulo, Rio de Janeiro, Belo Horizonte, Salvador, Recife, Fortaleza e Belém. Coeficientes similares de mortalidade por câncer foram obtidos para o México, Estados Unidos, Suécia, Israel e Japão (WHO, 1993). No caso das capitais brasileiras, realizaram-se, ainda, comparações das distribuições etárias entre os coeficientes médios de mortalidade nos períodos 1980-82 e 1992-93, para descrever suas modificações ao longo deste período.

Em relação à confiabilidade dos indicadores de mortalidade, existem evidências de que a mesma seja elevada. Durante a estruturação da Classificação Internacional de Doenças (CID), a Organização Mundial de Saúde (OMS) criou um subcomitê de Oncologia com o objetivo de elaborar normas mais explícitas de notificação das declarações de óbito por câncer. Posteriormente foi realizado um teste com codificadores de diferentes países, tendo-se observado uma concordância de $75 \%$ na codificação de um conjunto de declarações de óbito por neoplasias com o emprego das novas regras (Percy \& Dollman, 1978). Conforme mencionado por Monteiro (1995), o mesmo con- 
junto de declarações de óbito foi retestado na preparação da $10^{\mathrm{a}} \mathrm{CID}$, tendo os codificadores brasileiros apresentado um nível de discordância do padrão escolhido (norte-americano) da ordem de 8,6\%, considerado reduzido em comparação com os níveis de discordância verificados em outros países, variando de 6 a 16\% (Percy, 1989; Percy \& Muir, 1989): Mais recentemente, estudo realizado no Rio de Janeiro confirmou a observação anterior sobre a qualidade dos registros de mortalidade por câncer naquela cidade, observando-se um nível de concordância de 90\% (kappa de 0.89) entre as codificações independentes de uma amostra de 394 declarações de óbito por neoplasias (Monteiro, 1995).

Desta maneira, acreditamos que, pelas características de evolução clínica dos casos de câncer, sobretudo as neoplasias da esfera reprodutiva da mulher, é elevada a probabilidade que a mesma seja diagnosticada como tal, já que a paciente vivendo em capitais de Estados no País seria eventualmente hospitalizada pelo menos em uma oportunidade durante sua evolução. Assim, tomando em conta as devidas cautelas inerentes à utilização destes indicadores (sobretudo quanto a subnotificação e qualidade do diagnóstico dos dados coletados), consideramos também aceitável a utilização dos coeficientes de mortalidade para a realização de comparações nos diferentes grandes centros urbanos analisados.

\section{Resultados}

- Câncer em todas as localizações

A magnitude da incidência de câncer em mulheres para todas as localizações, uma vez controladas as diferenças na distribuição por idade de diferentes localidades (taxas de incidência ajustados por idade), permite-nos avaliar a magnitude alcançada por este conjunto de doenças em distintas sociedades. No Brasil este indicador é desigual entre as cidades analisadas, sendo a menor aquela observada em Belém (taxa ajustada por idade de 156,5/100.000 mulheres) e a mais elevada aquela verificada em Porto Alegre236,3/100.000 (Gráfico 1). Comparativamente com coeficientes similares de outras localidades, Porto Alegre aproxima-se de países com taxas de incidência de câncer muito elevadas, Belém com aqueles apresentando taxas reduzidas, e as demais cidades posicionadas em um patamar intermediário (Gráfico 2). Este padrão de distribuição é também constatado ao analisarmos a distribuição dos coeficientes de incidência de neoplasias desagrupados por faixas etárias. Quando comparadas as taxas de incidência de câncer na faixa etária de 35 a 64 anos entre diversos registros nacionais da doença, Porto Alegre apresenta, na verdade, um dos coeficientes mais elevados do mundo: 484,7/ 100.000 (Parkin et al., 1992). 
Gráfico 1 -Incidência de câncer em mulheres ajustada por idade, todas localizaçóes - Brasil - 1988-1992

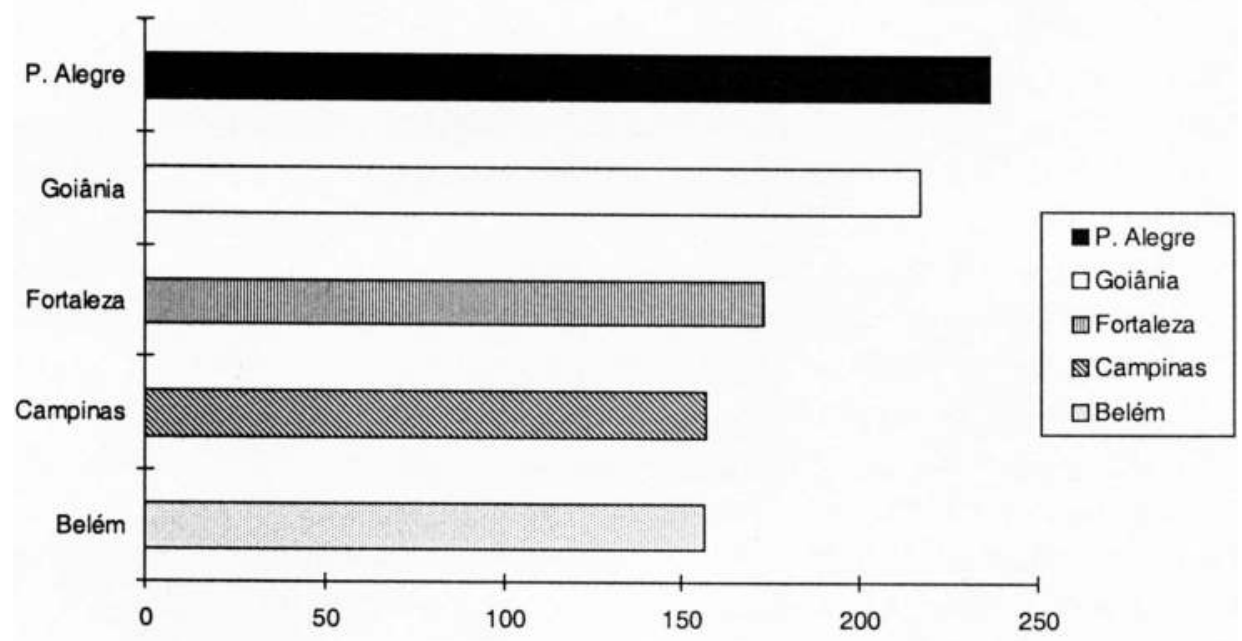

Gráfico 2-Incidência de câncer em mulheres ajustada por idade, todas localizaçóes - 1988-1992

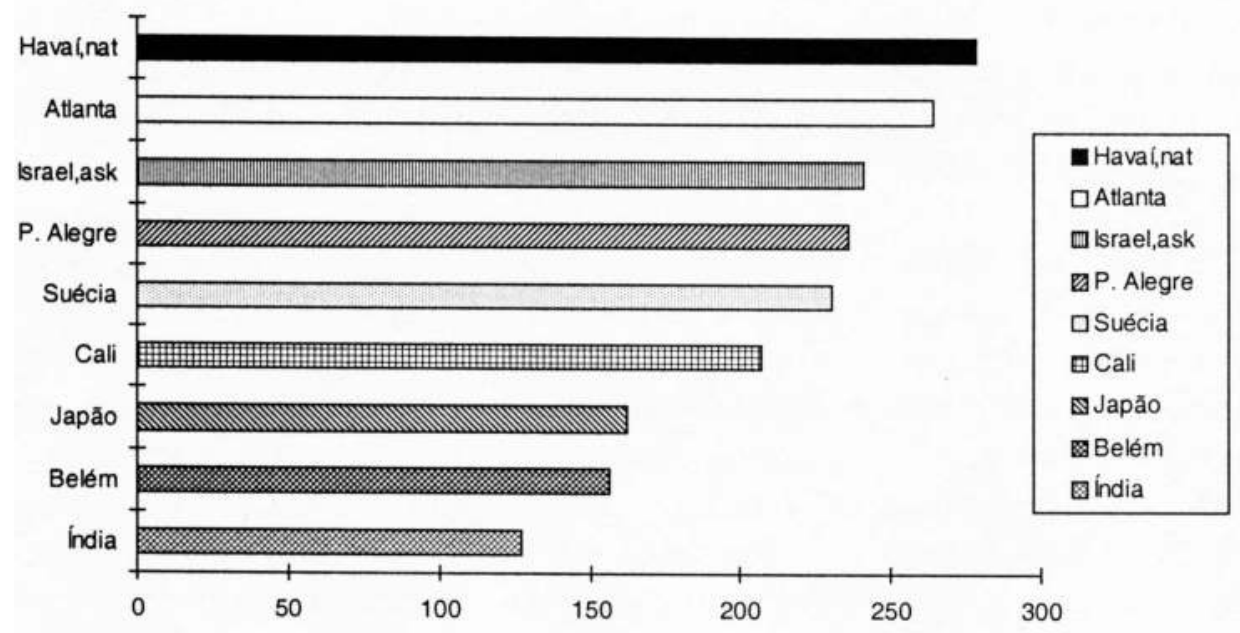


- Câncer de mama

O câncer de mama é atualmente a localização tumoral de maior incidência em mulheres vivendo nas regiões Sul e Sudeste do País, ocupando o segundo lugar, após o câncer de colo uterino, nas regiões Centro-Oeste, Norte e Nordeste. Mesmo entre estas, se observa um processo de transição como em Fortaleza, onde o câncer de mama já ocupava em 1985 o primeiro lugar de incidência. Em 1991-92, ele representou 19\% dos casos novos de câncer em mulheres nas cidades de Porto Alegre e Campinas (Ministério da Saúde, 1995), sendo estimada a ocorrência de 32.695 casos novos de câncer feminino de mama no Brasil em 1998, equivalentes a 23,3\% de todos os casos novos de câncer esperados em mulheres no País durante este mesmo ano (Ministério da Saúde, 1998).

Este processo de elevação acelerada da incidência do câncer de mama torna o Brasil, assim como outros países latino-americanos e asiáticos vivenciando processo similar, locais privilegiados de estudo da dinâmica desta doença por não terem ainda alcançado os níveis elevados de incidência observados na Europa e América do Norte (Kelsey, 1993). No Gráfico 3, apresenta-se a magnitude de nossos coeficientes de incidência comparados com aqueles de outros países, podendo se observar que Porto Alegre apresenta o maior dos coeficientes de incidência ajustados por idade observados em cidades brasileiras, e similar ao verificado na Suécia e entre os imigrantes ashkenazi em Israel. Já em Belém, o coeficiente padronizado de incidência aproxima-se daquele observado em países de baixa incidência como o Japão. Quando se analisam os coeficientes de incidência por idade nas diferentes cidades brasileiras, este padrão de hetereogeneidade regional (Porto Alegre com incidência relativamente elevada de câncer de mama, Belém com incidência reduzida e Fortaleza, Campinas e Goiânia com coeficientes intermediários) é também verificado (Gráfico 4), sendo ressaltado por intermédio de comparações com outros países (Gráfico 5).

\section{Gráfico 3 - Incidência de câncer de mama ajustada por ida- de, população mundial - 1988-1992}

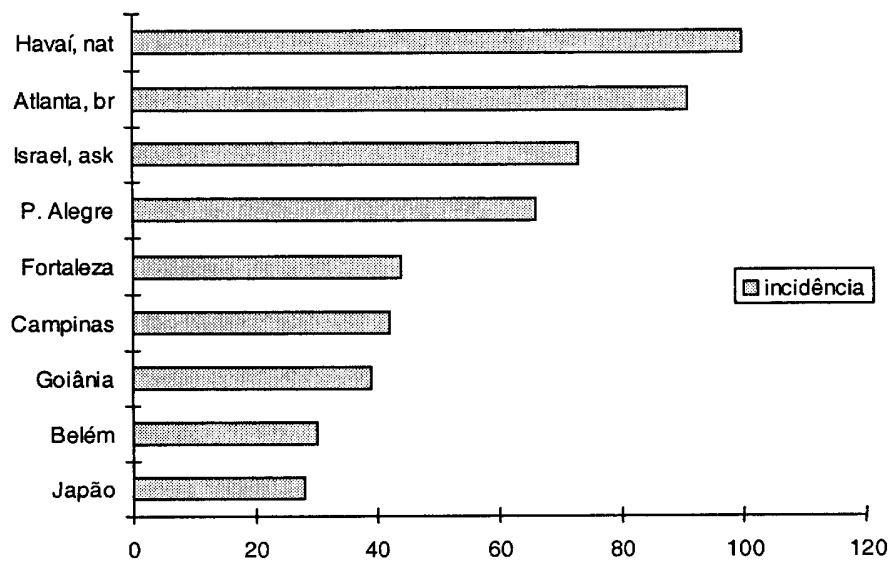




\section{Gráfico 4-Incidência de câncer de mama segundo idade. Brasil - 1988-1992}

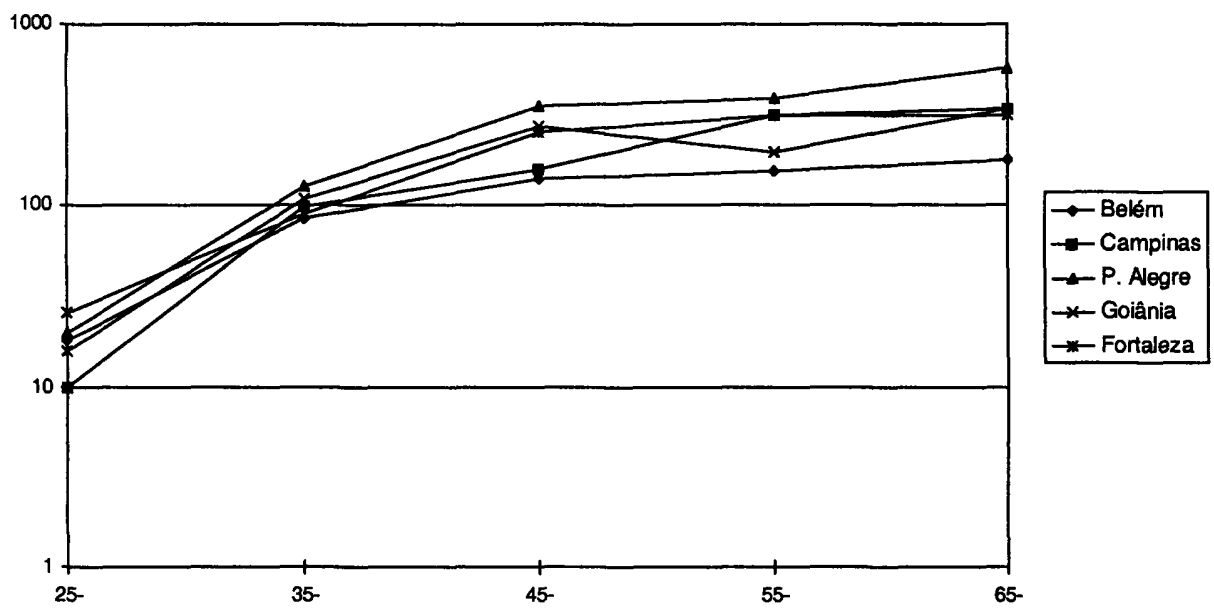

\section{Gráfico 5-Incidência de câncer de mama por idade. Países selecionados - 1988-1992}

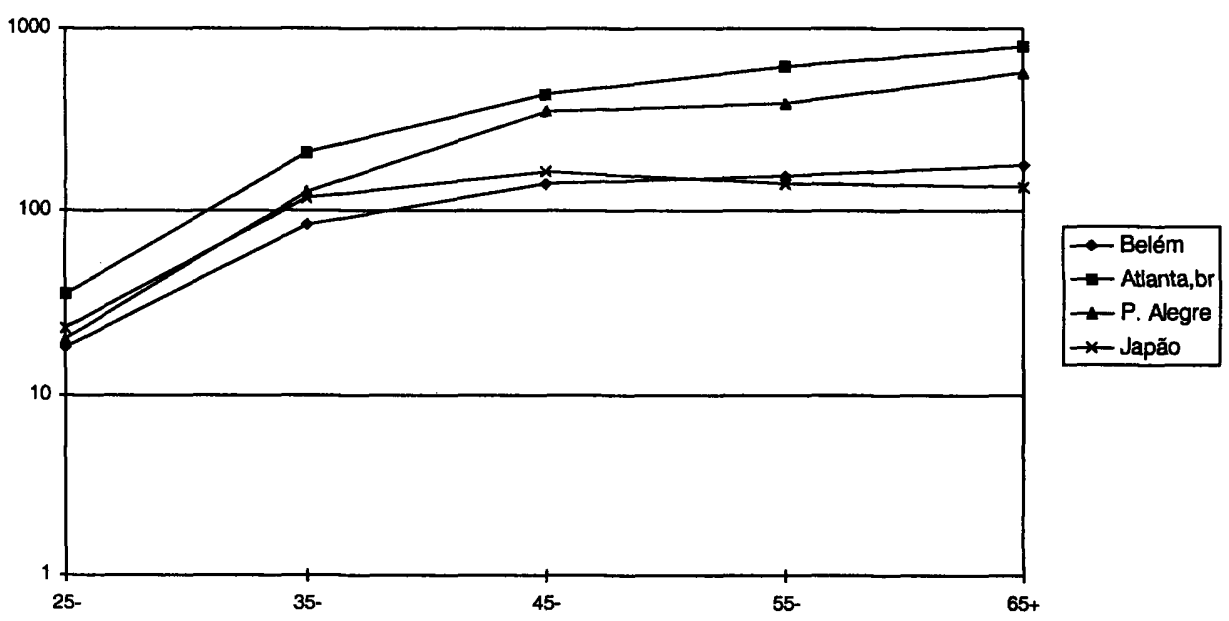

Apesarda menor incidência de câncer de mama no Brasil que aquela observada em países europeus e na América do Norte, a mortalidade por este tumor é mais elevada em nosso meio. Assim, Porto Alegre apresenta coeficientes de mortalidade por idade mais elevados do que naqueles países (Gráfico 6), situação esta que se repete para outras capitais. Este fatoé preocupante, pois uma análise sobre a dinâmica dos coeficientes de mortalidade porcâncer de mama ao longo de década de 80, tanto no período précomo no pós-menopausa, revela que estes tem se mantido relativamente estáveis, ou mesmo aumentado (Gráficos 7e 8). 
Gráfico 6-Mortalidade por câncer de mama segundo idade. Brasil e outros países - 1988-1992

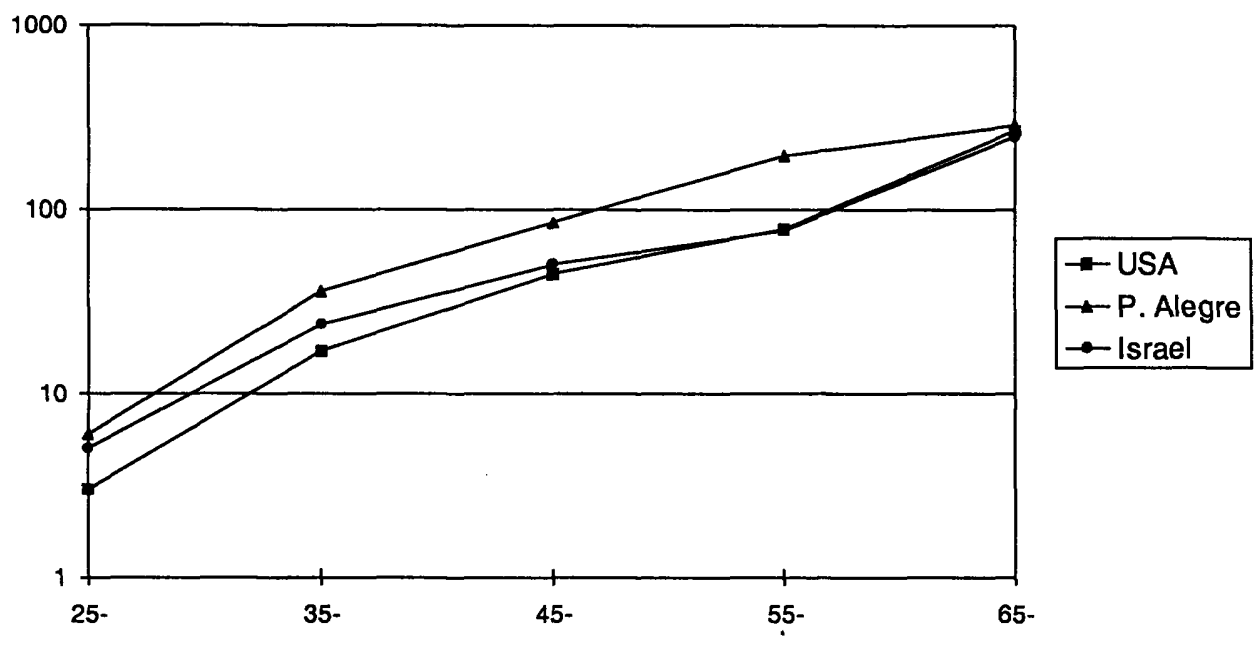

Gráfico 7-Mortalidade por câncer de mama, mulheres 3549 anos. Brasil - 1988-1992

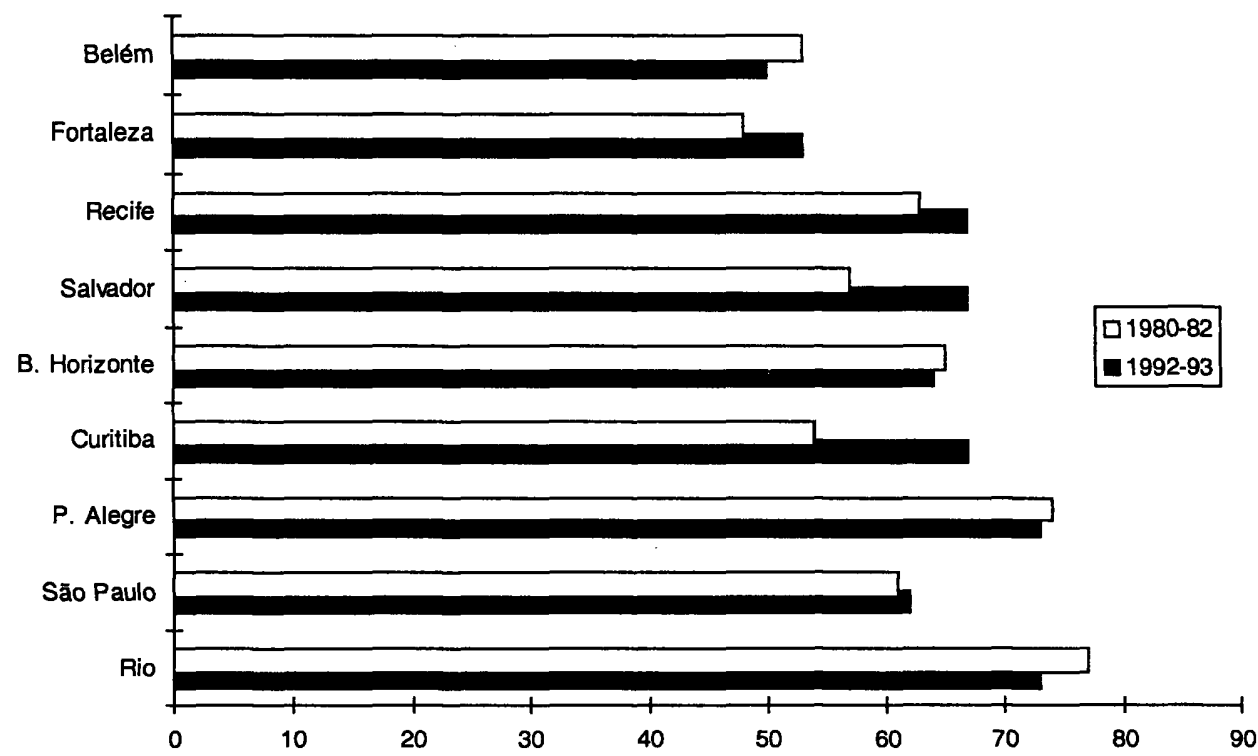




\section{Gráfico 8-Mortalidade por câncer de mama, mulherès 50- 64 anos. Brasil - 1988-1992}

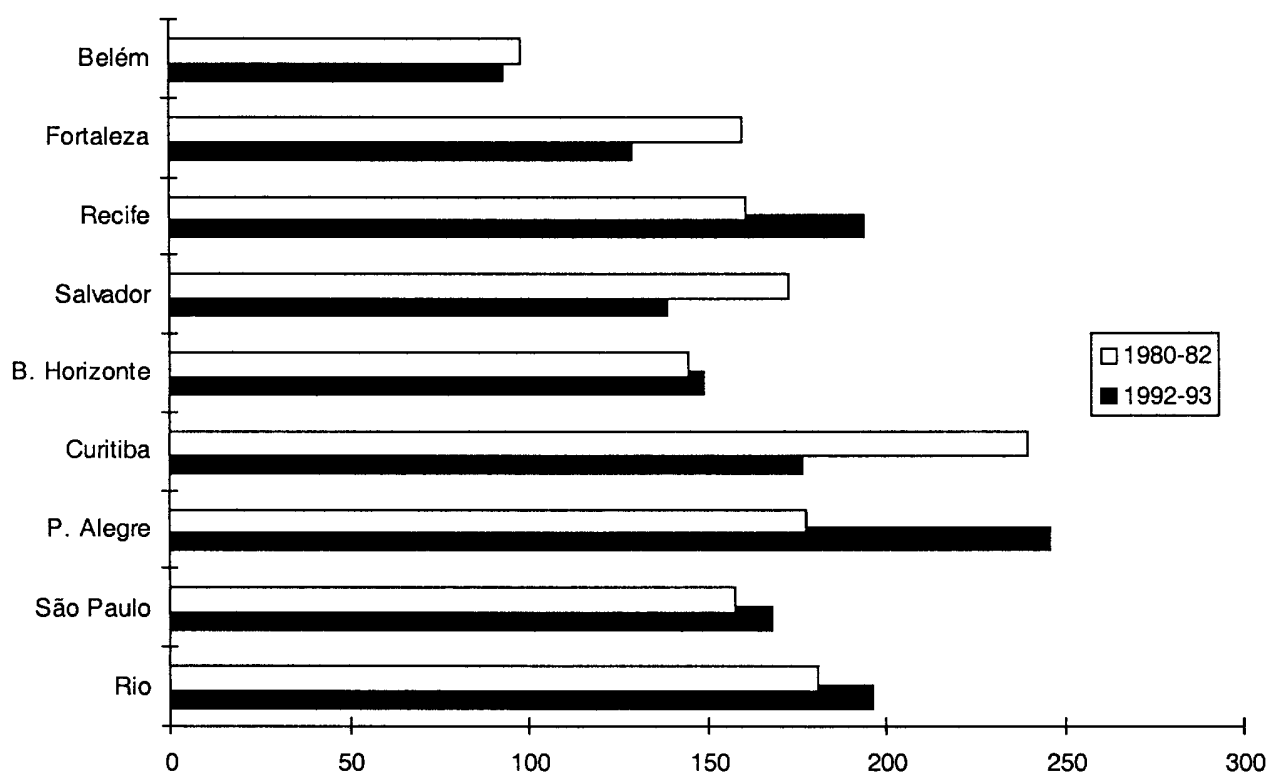

Desta maneira, frente a uma conjuntura de transição para a elevação da incidência de câncer de mama no País (Koifman, 1995), a manutenção de coeficientes elevados de mortalidade pode estar revelando as dificuldades assistenciais atuais para exercer o controle sobre o tratamento precoce da doença, e consequentemente, sobre a qualidade de vida e sobrevida das pacientes. Tais atividades voltadas para o diagnóstico em fases iniciais da doença, como mediante a realização do auto-exame, de mamografias periódicas e do controle de famílias de alto risco para câncer de mama e ovário (Howard, 1987; McWhorter \& Eyre, 1990) são ainda precariamente desenvolvidas no País. A título de exemplo, foi autorizada pelo Sistema Único de Saúde (SUS) a realização média mensal de aproximadamente 4 mil mamografias na cidade do Rio de Janeiro em 1994 (SIA-SUS), o que representaria uma cobertura ao redor de 10\% da oferta necessária para cobrir a população de mulheres de 50 a 69 anos naquele município com a realização de uma mamografia anual, conforme recomendação da American Cancer Society (Henderson, 1995). Diante da impossibilidade de prevenção do câncer de mama à luz dos conhecimentos científicos atuais, a deteç̧ão precoce consiste na única possibilidade de se exercer alguma intervenção eficaz sobre as mulheres afetadas (Seidman et al., 1987; Miller, 1993). Mesmo assim, os tumores mamários detectados pelo auto-exame geralmente já apresentam diâmetros da ordem de $2 \mathrm{~cm}$, sendo desejável sua identifica- 
ção em estágios preliminares, o que só é alcançável atualmente por intermédio dos exames de radioimagem específicos. Nestas condições de diagnóstico precoce, a sobrevida de cinco anos após a identificação de lesões iniciais em mulheres com câncer de mama pode alcançar a magnitude de 91\% (Garfinkel, 1995).

No Brasil, entretanto, a realidade é preocupante na medida em que múltiplas condições de risco associadas com o desenvolvimento do câncer de mama estão sendo crescentemente introduzidas em nossa sociedade. A acentuada queda da natalidade, a redução da idade da menarca decorrente da melhoria do estado nutricional da população, o retardo na idade de início da primeira gestação, a ampliação da prevalência de nulíparas bem como de gestantes engravidando após os 35 anos de idade, a utilização de anticoncepcionais orais durante longos períodos de tempo antes da primeira gestação, o encurtamento ou mesmo abolição do aleitamento materno são, todas elas, condições da vida reprodutiva da mulher possivelmente implicadas na gênese desta neoplasia (White, 1987; Stadel et al., 1988; Miller et al., 1989).

Se a estas condições acrescentamos a presença crescente de gordura de origem animal na dieta de crianças e adolescentes, a exposição desnecessária a radiação ionizante nas mesmas faixas etárias - como por exemplo, em decorrência da realização dispensável de fluoroscopias (abreugrafias) por motivos diversos -, a elevação do consumo de bebidas alcóolicas em adolescentes e mulheres adultas, bem como a exposição crescente a substâncias químicas em nossa sociedade, tais como pesticidas e tinturas de cabelo, veremos que coexistem oportunidades de exposição a diversos agentes também supostamente envolvidos na estimulação do processo de desenvolvimento do câncer de mama (Willet, 1989; Gammon \& John, 1993; Kelsey \& Horn, 1993).

Neste contexto, a adoção de programas de divulgação das características de evolução da doença, de deteç̧ão precoce bem como acompanhamento clínico e radiológico periódico dos grupos de risco (mulheres com antecedentes familiares de casos múltiplos de câncer de mama e ovário, além das mulheres com mais de 50 anos na população geral) se torna necessária para enfrentar a dinâmica atual do câncer de mama como problema crescente de saúde pública em nossa sociedade.

\section{- Câncer de colo uterino}

Acredita-se que o câncer de colo uterino se desenvolve a partir de processos irritativos de ação contínua sobre aquele órgão, como aqueles desencadeados por certos agentes virais como o papillomavírus, facilitados pela ação hormonal dos anticonceptivos orais e do fumo. Desta maneira, a precocidade no início da vida sexual da mulher, assim como o número de parceiros e a paridade elevada, parecem atuar como indicadores de grupos de risco mais elevado para o desenvolvimento do câncer de colo uterino. Por outro lado, é um tumor raramente observado em mulheres nulíparas ou sexualmente inativas (Morrow \& Townsend, 1987; Syrjanen 1987; Averette \& Nguyen, 1995). 
Embora o conjunto de mecanismos envolvidos no processo de evolução da doença não seja ainda conhecido em detalhe, algumas etapas antecedentes o são. Assim, mediante a realização de um exame laboratorial pouco custoso (teste de Papanicolau), são obtidas amostras de células da região do colo, o que permite a identificação quer de displasias, quer do chamado carcinoma in silu, ou seja, o câncer em sua forma localizada e restrita ao colo do útero, quando é possível sua extirpação cirúrgica e a cura. Caso tal não ocorra, o tumor se expande para o estágio de carcinoma invasivo c não-controlável. Como a incidência do carcinoma in situ é predominante em mulheres menores de 35 anos, e o câncer invasivo em mulheres de maior idade, se acredita que haja uma lento processo de evolução para os estágios mais avançados da doença. Desta maneira, do ponto de vista científico, o controle do câncer de colo uterino invasivo é factível em termos populacionais por intermédio do rastreamento periódico de alterações citopatológicas realizadas com o teste de Papanicolau em mulheres em idade reprodutiva. Assim, a sobrevida após cinco anos do diagnóstico do carcinoma de colo uterino in situ pode alcançar a cifra ao redor de $100 \%$ dos casos (Garfinkel, 1995).

No Brasil, entretanto, a distribuição epidemiológica deste tumor, tanto quanto a sua incidência e mortalidade, revela níveis de ambos indicadores considerados dos mais elevados no mundo, tendo contribuído com $17 \%$ de todos os óbitos por câncer em mulheres de Belém (1989); 13\% em Fortaleza (1985); 12,5\% em Goiânia (1991); 10\% em Campinas (1992); e 7\% cm Porto Alegre durante 1991 (Ministério da Saúde, 1995). Estimava-se, para 1998, o surgimento de 21.725 casos novos de câncer de colo uterino no Brasil, representando 15,4\% da totalidade de casos novos de neoplasias em mulheres no País (Ministério da Saúde, 1998). A análise da distribuição dos coeficientes de incidência de câncer de colo uterino ajustados por idade em cidades brasileiras e outras localidades (Gráfico 9) revela que Belém c Goiânia apresentam coeficientes oito a dez vezes mais elevados do que aquele verificado nos imigrantes ashkenazi em Israel. A comparação dos coeficientes de incidência por faixa etária em cidades brașileiras (Gráfico 10) revela diferenças de pequena magnitude, sendo Campinas e Porto Alegre aquelas que apresentam menor incidência da doença a partir dos 30 anos. Este fato é realçado com as comparações de curvas similares com outras Regiões (Gráfico 11), verificando-se uma certa tendência à polarização das curvas, com Atlanta, Japão e Israel em um grupo, e as de Cali, Campinas e Belém em outro de níveis mais elevados. 
Gráfico 9-Incidência de câncer de colo de útero ajustada por idade pela população mundial - 1988-1992

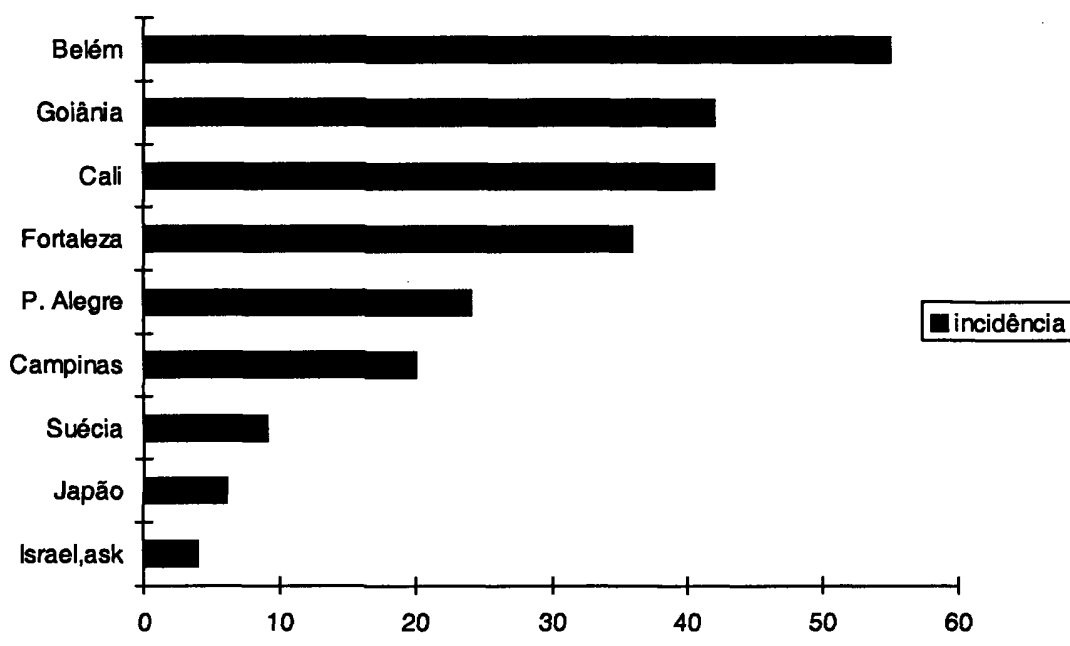

Gráfico 10-Incidência de câncer de colo uterino por idade, Brasil - 1988-1992

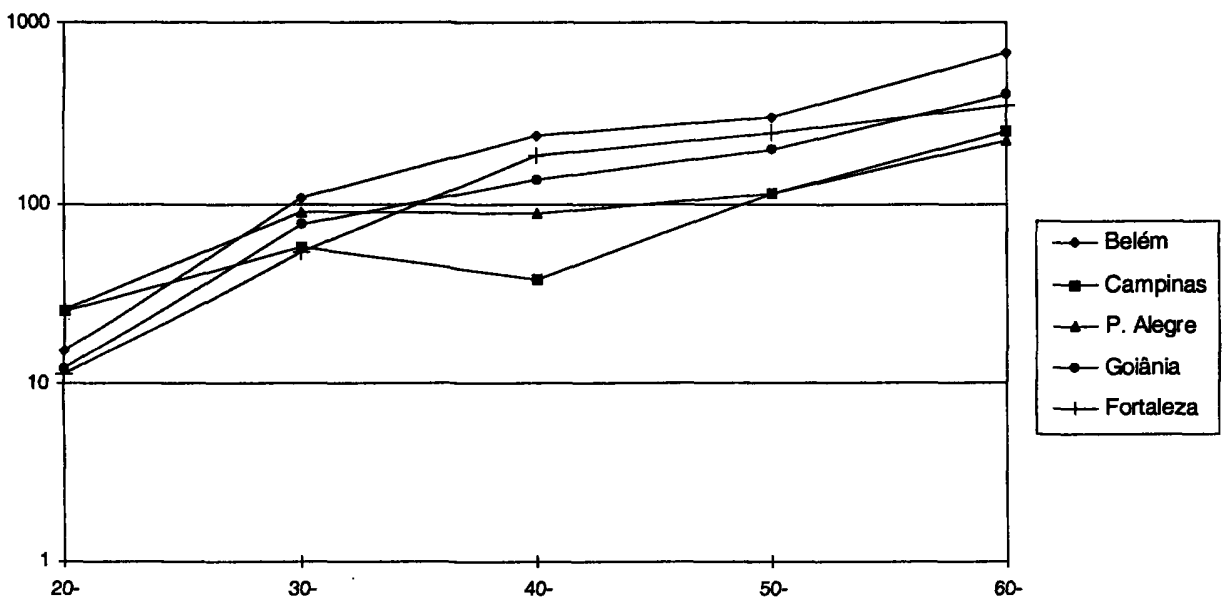


Gráfico11 -Incidência de câncer de colo uterino por idade, 1988-1992

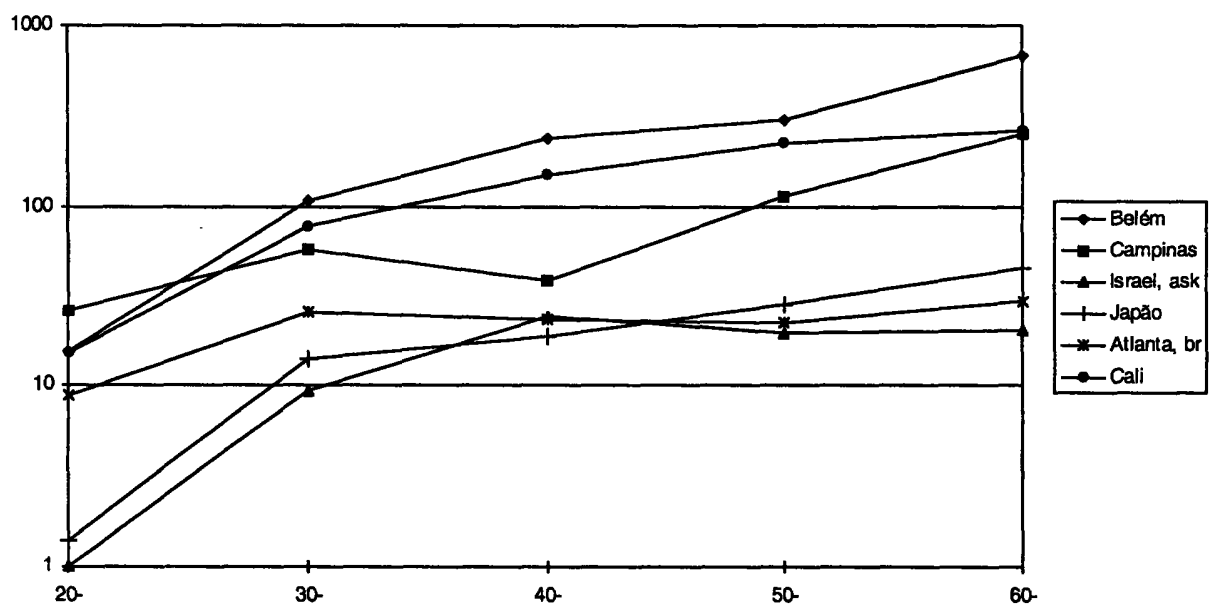

A análise dos dados de mortalidade por câncer de colo uterino reiteram estas observações quanto à similaridade das curvas de mortalidade em cidades brasileiras (Gráfico 12), e seu distanciamento em relação às curvas de magnitude mais reduzida encontradas em países desenvolvidos (Gráfico 13). A evolução da mortalidade por câncer de colo uterino ao longo da década de 80 na faixa de 20-34 anos corrobora a gravidade da distribuição desta doença, quer pela manutenção de níveis ainda muito elevados de mortalidade nas cidades nordestinas, quer por sua elevação em capitais das Regiões Sul-Sudeste (Gráfico 14).

\section{Gráfico 12-Mortalidade por câncer de colo uterino segundo idade. Brasil - 1988-1992}

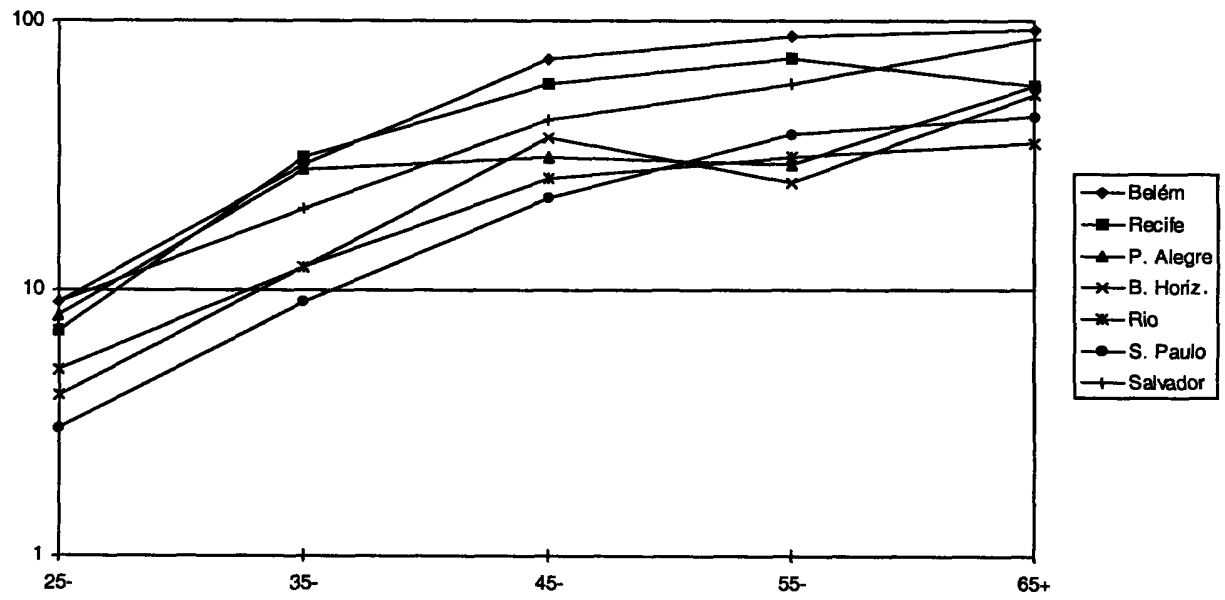


Gráfico 13-Mortalidade por câncer de colo uterino segundo idade. Brasil e outros países - 1988-1992

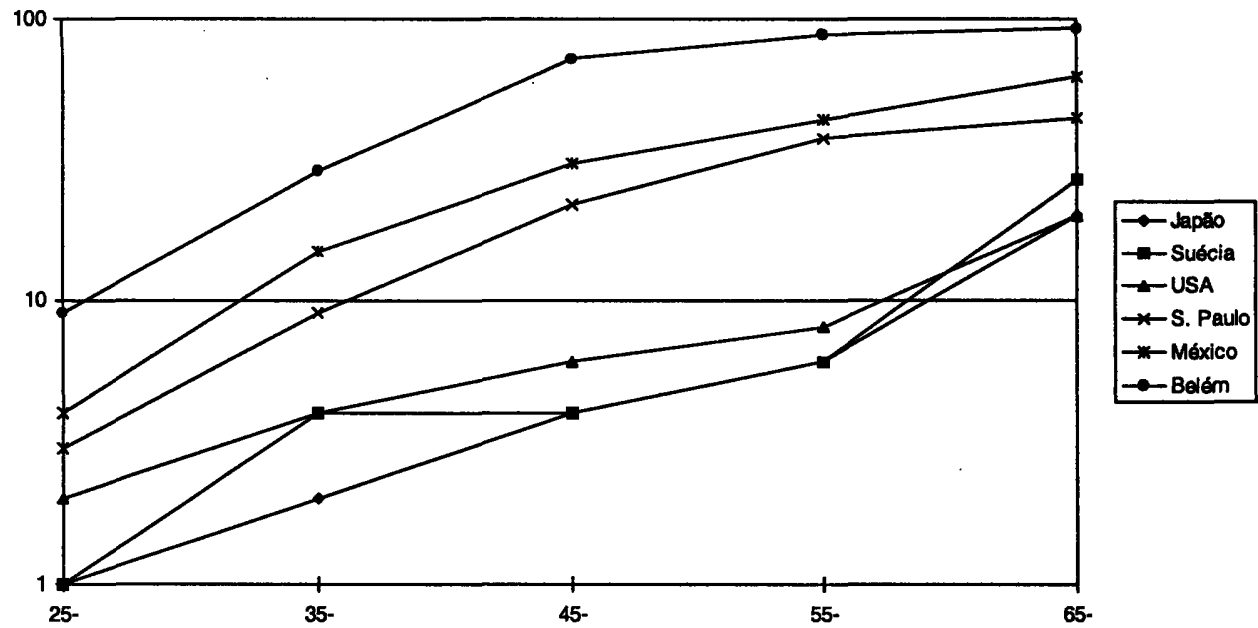

Gráfico 14-Mortalidade por câncer de colo uterino, mulheres 20-34 anos. Brasil - 1988-1992

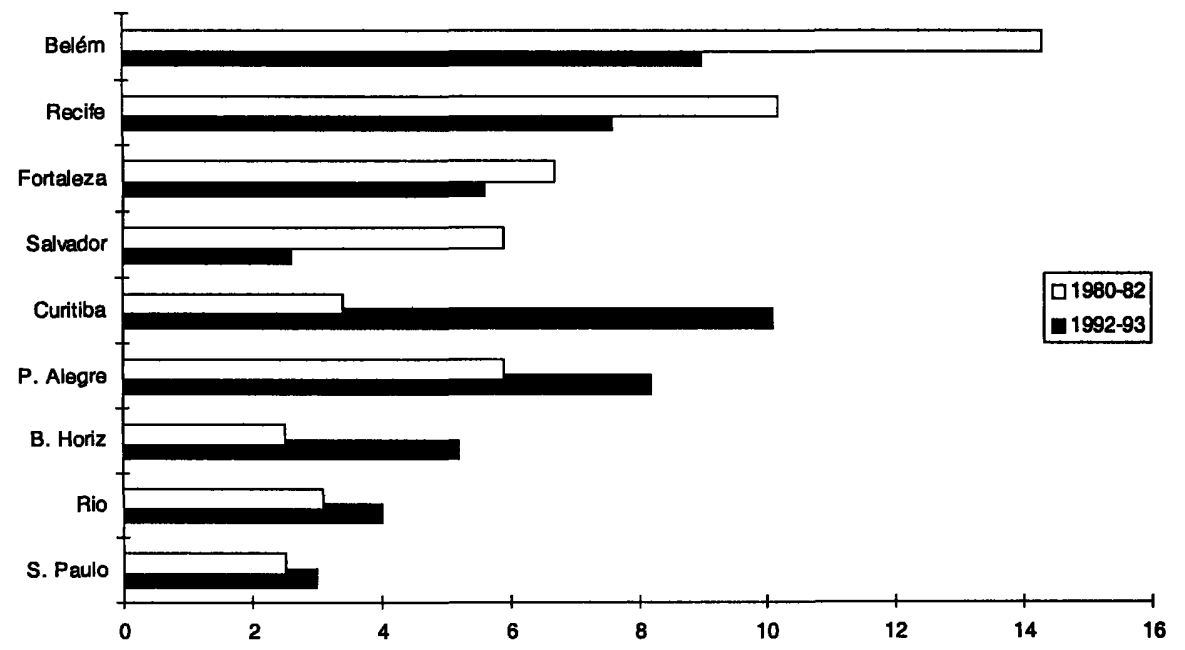


Em seu conjunto, estes dados podem serconsiderados preocupantes uma vezque, ao contrário do câncer de mama, para o qual a ciência não conta ainda com tecnologia disponível para prevenção, as lesões que antecedem o pleno desenvolvimento do câncer de colo uterino são, na grande maioria dos casos, plausíveis de serem detectadas preliminarmente ao surgimento da doença por intermédio de uma técnica de custos reduzidos e com eficácia internacionalmente constatada. Desta maneira, os obstáculos para a superação do problema docâncer de colo uterino no Brasil são, na perspectiva da saúde pública, um problema gerencial quanto à organização dos serviços de saúde e não uma questão de obstáculos científicos.

\section{- Câncer de ovário}

Ao contrário do observado nos Estados Unidos em outros países industrializados onde ocâncer de ovário ocupa a segunda maior causa de freqüência de tumores ginecológicos, ele tem representado ao redor de 3 a 5\% dos casos novos de câncerem mulheres no Brasil, seguindo em ordem decrescente de incidência aos tumores de mama e colo uterino. Nos Estados Unidos, a sobrevida após cinco anos de diagnóstico se situa ao redor de $41 \%$ dos casos, alcançando a cifra de $88 \%$ daqueles diagnosticados precocemente, o que mesmo naquele país somente ocorre com 23\% dos diagnósticos desta neoplasia (Garfinkel, 1995).

Embora os mecanismos relacionados à etiologia desta neoplasia sigam pouco identificados, acredita-se que os hormônios femininos possam ter um papel importante na etiologia da doença. Esta hipótese é reforçada pela observação de um efeito protetor para o desenvolvimento deste tumor proporcionado pela ocorrência de gestações múltiplas. Mulheres expostas intensamente à radiação ionizante - como as sobreviventes da bomba atômica-também apresentaram riscos até duas vezes mais elevados de desenvolverem câncer de ovário. Os principais fatores de risco para o câncer de ovário são, contudo, a história familiar desta neoplasia, com risco relativo superior a 17, e a nuliparidade, com risco relativo de 4 (Morrow \& Townsend, 1987).

A descrição na literatura científica de famílias com grande número de casos de câncer de mama e/ou ovário encontrou recentemente um substrato no conhecimento mediante a identificação de algumas mutações no gene BRCAl, localizado no cromossoma 17 (Hall et al., 1990). Uma desta mutações, a 185 delAG, tem sido observada em freqüência oito vezes maior em mulheres judias ashkenazi do que na população geral, supondose ser potencialmente capaz de explicar a agregação familiar de câncer de mama e ovário encontrada em algumas famílias daquela comunidade (Fitzgerald et al., 1995).

A análise dos dados de incidência de câncer de ovário ajustados por idade revela coeficientes reduzidos nas cidades brasileiras estudadas, com exceção de Porto Alegre: esta capital apresenta taxa aproximadamente duas vezes maior do que a de Campinas e Belém, e relativamente similar àquelas de Atlanta e à de imigrantes askhenazi em Israel (Gráfico 15). Este padrão é novamente observado na comparação das curvas de incidência por faixa etária entre cidades brasileiras e naquelas em outros países (Gráfico 16). 
Gráfico 15-Incidência de câncer de ovário ajustada por idade pela população mundial, 1988-1992

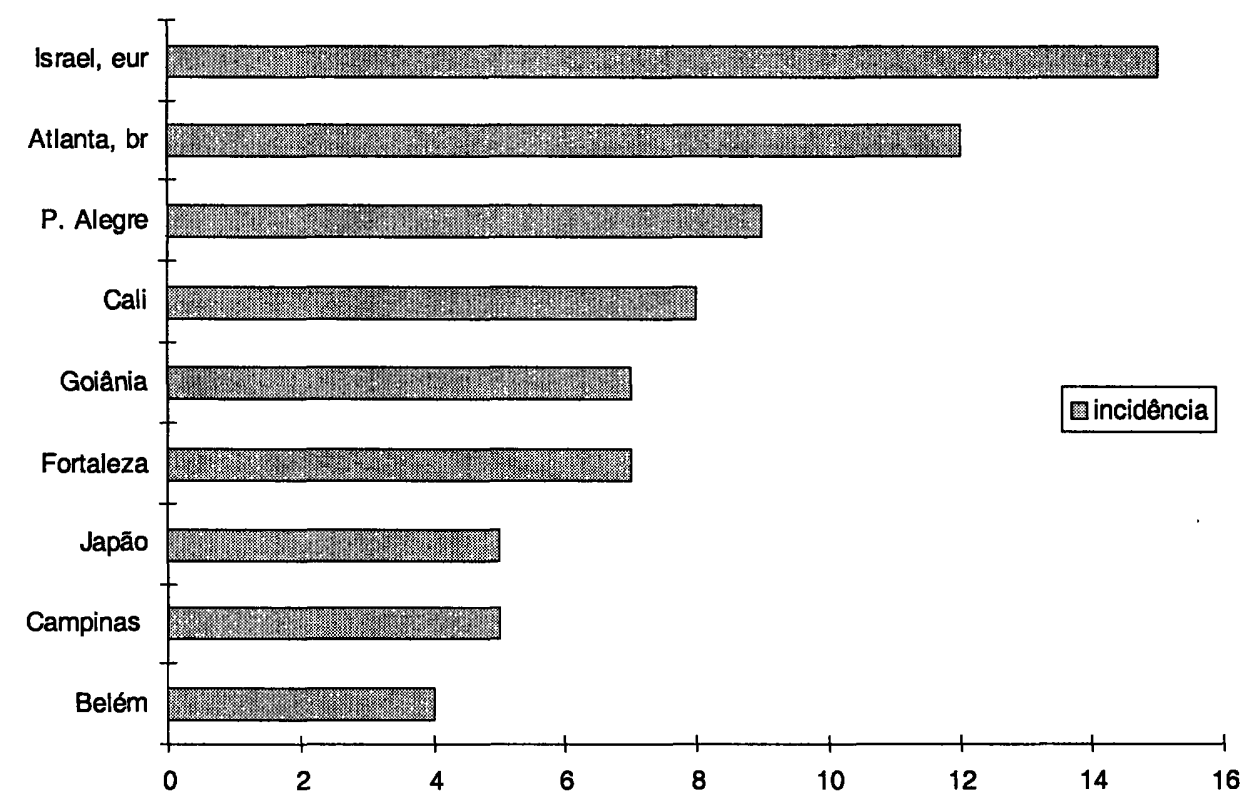

Gráfico 16-Incidência de câncer de ovário por idade, 19881992

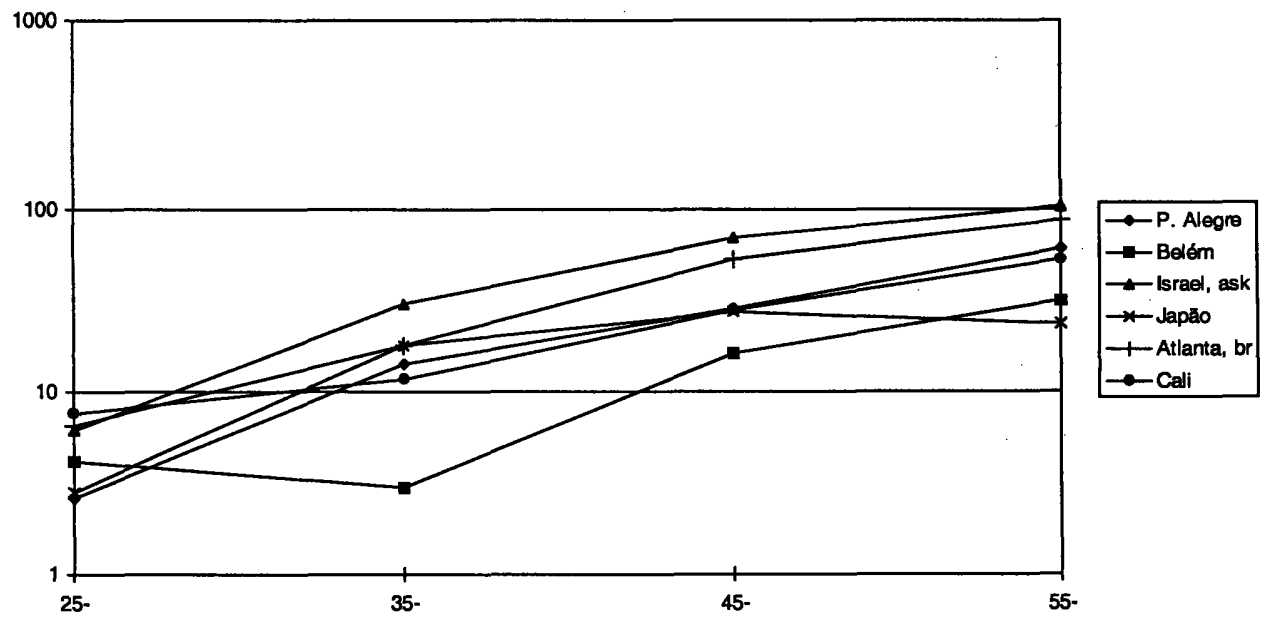


A mortalidade porcâncer de ovário segundo faixa etária em diferentes cidades brasileiras revela um padrão homogêneo, sobretudo a partirdos 45 anos, ecrescente com a idade (Gráfico 17). Aolongo da década de 80, as taxas de mortalidade em capitais brasileiras se mantiveram relativamente estáveis eelevadas (Gráfico 18), dada a alta letalidade destetumor mesmo em países desenvolvidos, nãose dispondoatualmente de medidas para sua prevenção.

\section{Gráfico 17-Mortalidade por câncer de ovário segundo idade. Brasil - 1988-1992}

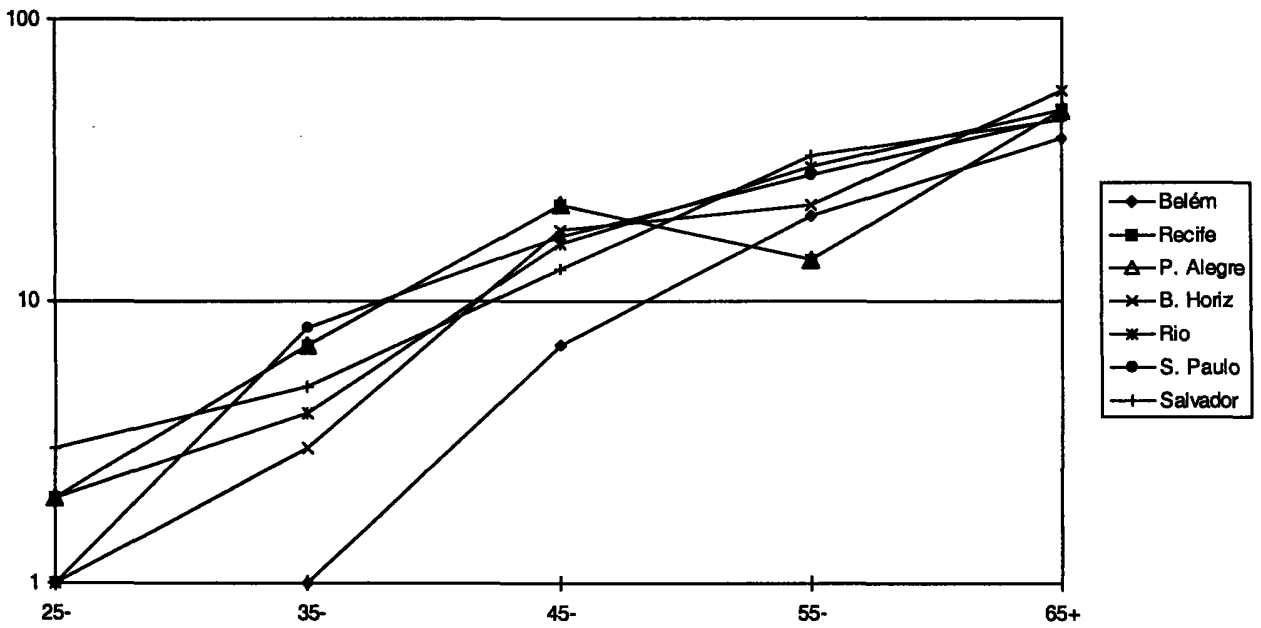

Gráfico 18-Mortalidade por câncer de ovário, mulheres 5064 anos, Brasil, 1988-1992.

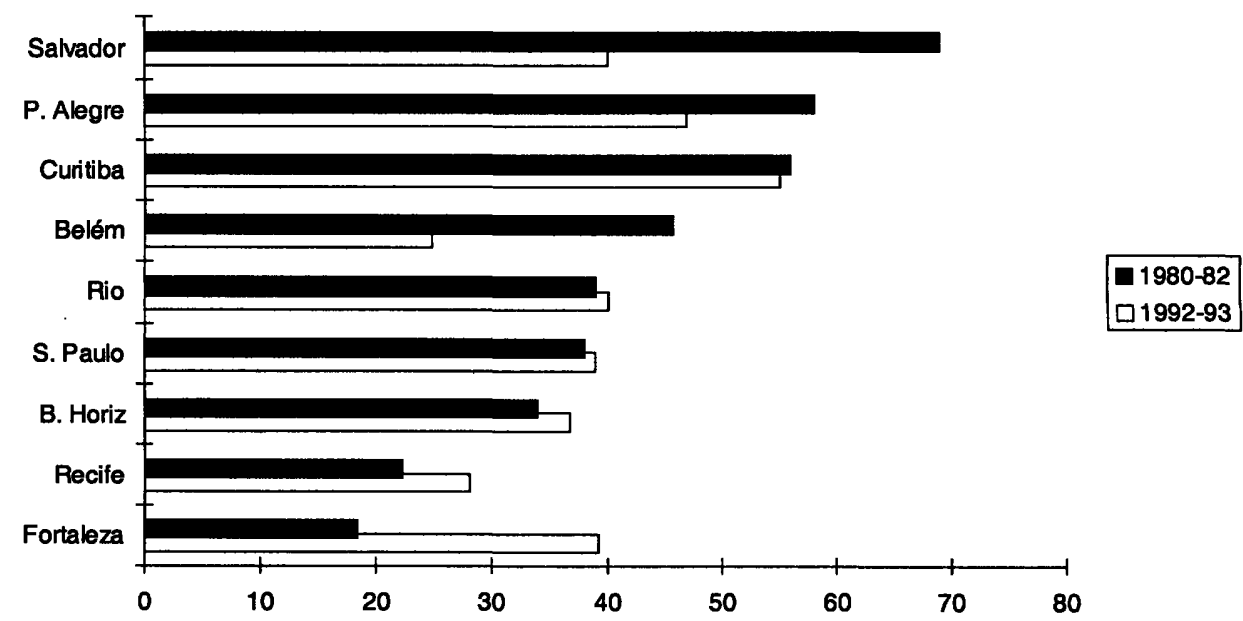


- Câncer de corpo e outras localizações uterinas não-especificadas

A maior parte dos tumores do corpo uterino é originada a partir do endométrio, a camada interna com características proliferativas durante os períodos entre ciclos menstruais. Estes tumores são mais freqüentemente observados após a menopausa, estando relacionados a vários dos mesmos fatores de risco associados ao câncer de mama (paridade reduzida, obesidade, menarca precoce, menopausa tardia), todos relacionados a metabolismo de hormônios estrógenos no organismo. Outros fatores de risco mencionados na literatura são hipertensão arterial, diabetes, ciclos menstruais irregulares, anovulação crônica e exposição pélvica à radiação ionizante (Parazzini et al., 1991; Park et al., 1992). A associação entre tumores de endométrio e a prática de reposição hormonal após a menopausa vem sendo estudada há duas décadas, sendo sua adoção atualmente decidida em função de uma análise individualizada de benefícios (proteção contra a doença isquêmica do coração, doença de Alzheimer e a osteoporose no período pós-menopausa) versus desvantagens, sobretudo, em relação ao câncer de endométrio. A sobrevida de cinco anos após o diagnóstico é de $83 \%$ para o conjunto de casos, elevando-se para $94 \%$ nos casos localizados do tumor (Garfinkel, 1995).

O diagnóstico de 5.685 casos novos de câncer do corpo uterino é esperado no Brasil em 1998, representando 4,0\% do total de casos novos de câncer previstos de virem a ser diagnosticados em mulheres durante o mesmo ano (Ministério da Saúde, 1998). Comparativamente com outros países, as taxas de incidência de câncer do corpo uterino ajustadas por idade no Brasil são mais reduzidas, estando Belém e Porto Alegre com coeficientes aproximadamente três vezes menores do que aqueles observados em Atlanta e no Havaí (Gráfico 19). A mesma observação pode ser constatada na análise das curvas de incidência de câncer de corpo uterino segundo idade entre diferentes localidades (Gráfico 20), sendo os coeficientes de incidência da doença no Brasil muito similares (Gráfico 21). A mortalidade por câncer de corpo uterino no período pós-menopausa tem se mantido relativamente estável no Brasil durante a década de 80, com exceção de Curitiba, Recife e Porto Alegre, onde importantes reduções foram observadas (Gráfico 22). Entretanto, a magnitude dos coeficientes de mortalidade por este tumor segundo idade se mantém em níveis mais elevados do que aqueles verificados em outros países industrializados (Gráfico 23). 
Gráfico 19-Incidência de câncer do corpo uterino ajustada por idade pela população mundial, 1988-1992

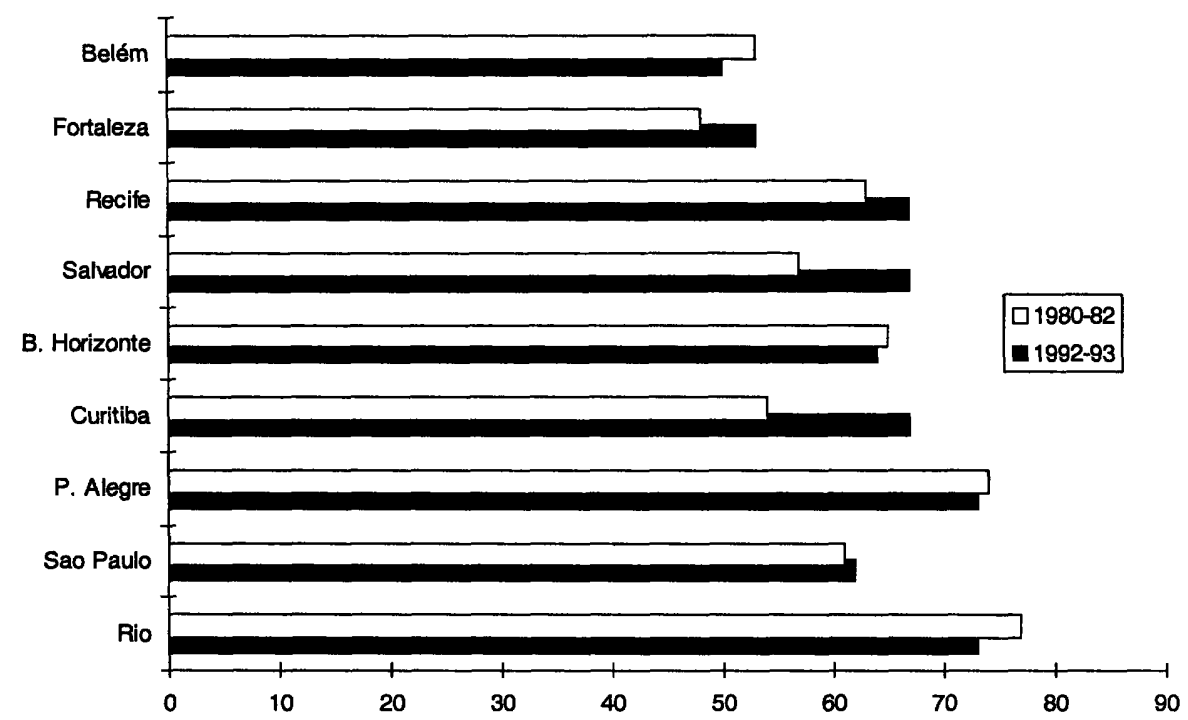

Gráfico 20-Incidência de câncer de corpo uterino por idade, 1988-1992

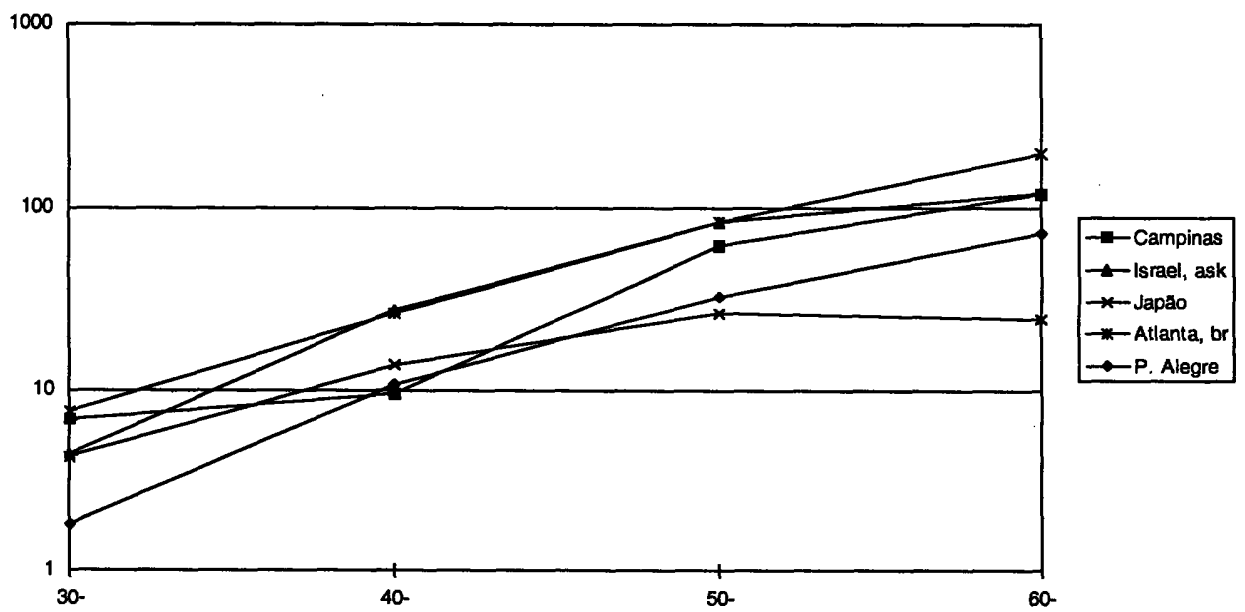


Gráfico 21 -Incidência de câncer do corpo uterino por idade. Brasil - 1988-1992

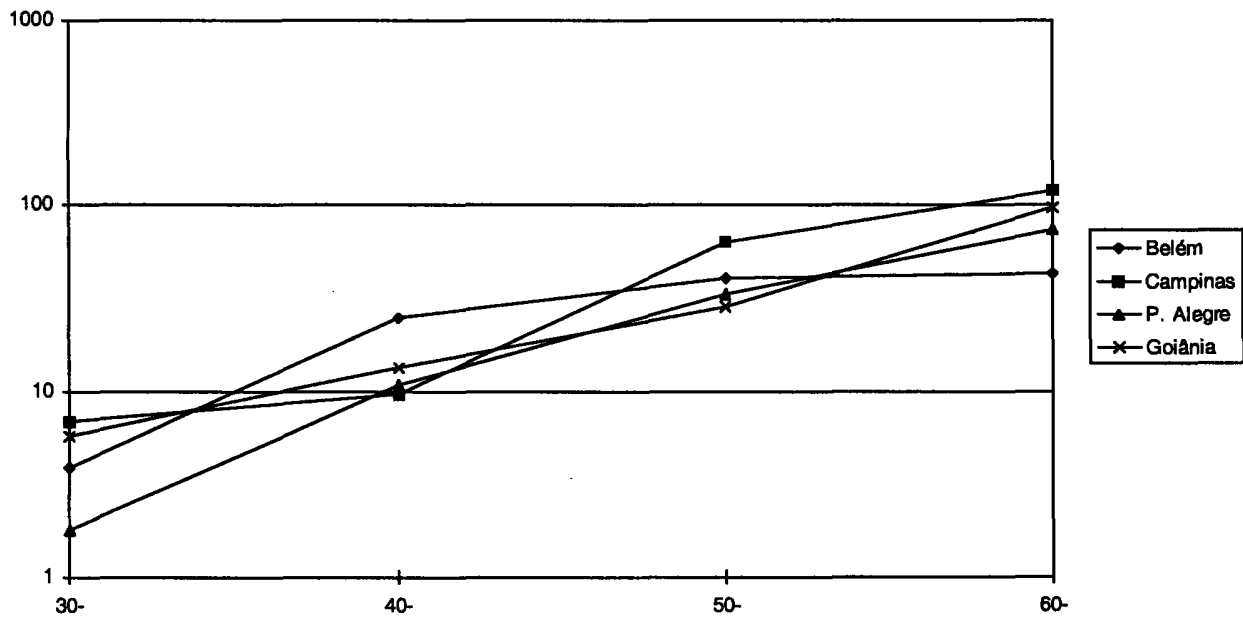

Gráfico 22-Mortalidade por câncer do corpo uterino, mulheres 50-64 anos. Brasil - 1988-1992

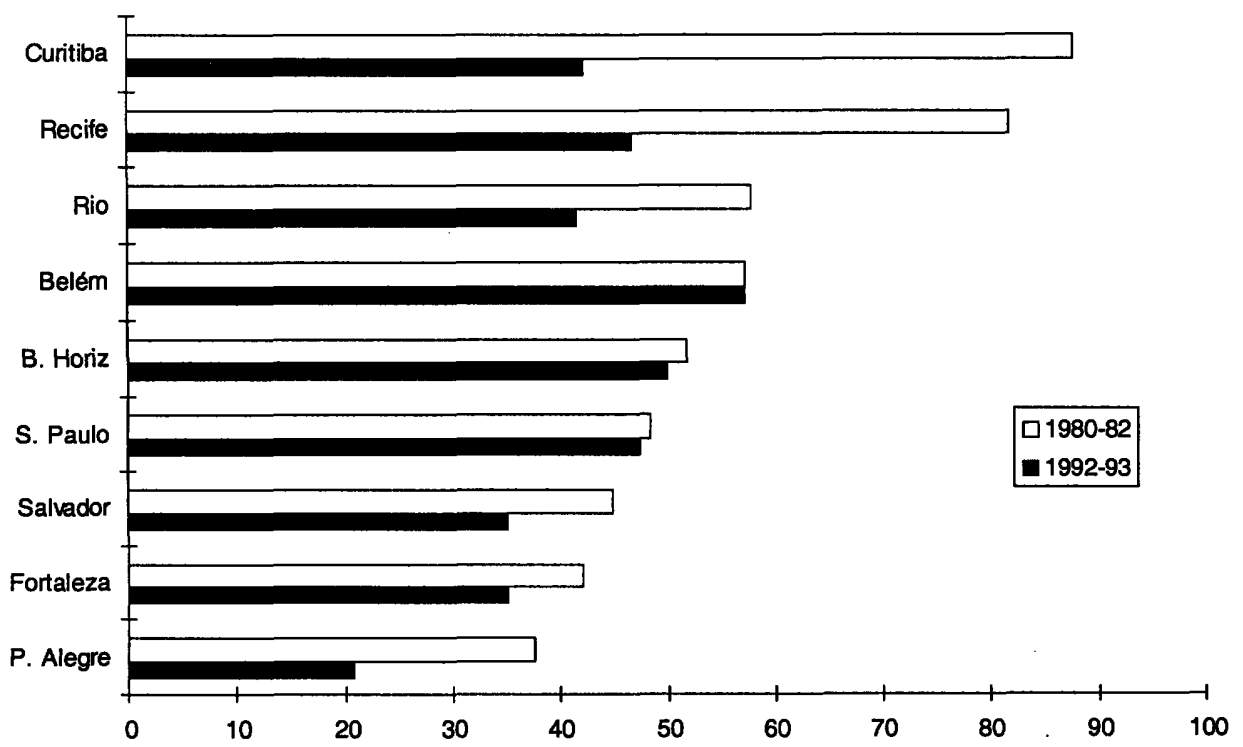




\section{Gráfico 23-Mortalidade por câncer de corpo uterino segundo idade. Brasil e outros países - 1988-1992}

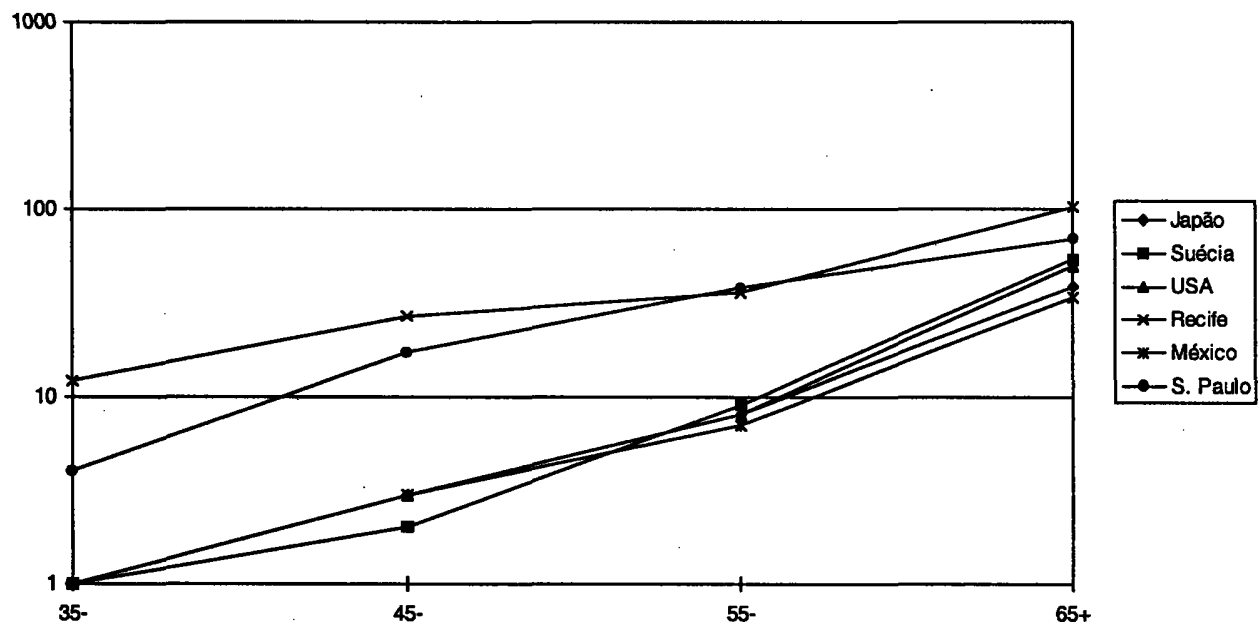

\section{Conclusōes}

Do ponto de vista de saúde pública, a ocorrência de neoplasias em mulheres durante a vida adulta no Brasil apresenta hoje três grandes desafios, com características de distribuição e obstáculos distintos a serem superados.

Em função da velocidade de sua crescente expansão em períodos recentes, o câncer de mama é, na atualidade, motivo de forte preocupação, para o qual as medidas disponíveis de controle se limitam ao diagnóstico precoce, e não à prevenção. Na realidade nacional, a maior parte dos casos se apresenta aos serviços de saúde em estágio avançado da doença, quando as medidas adotadas são pouco eficazes. A divulgação das características de desenvolvimento da doença e a ampliação da cobertura dos serviços, realizando mamografias - usualmente não operando em sua plena capacidade conforme internacionalmente recomendado, o que barateia custos e eleva a qualidade técnica do diagnóstico-são as respostas hoje possíveis para a detecção precoce da doença, e com esta, aumentar as chances de cura, elevação da sobrevida e melhora da qualidade de vida das mulheres afetadas.

O segundo desafio consiste no monitoramento da distribuição do câncer de colo uterino, tumor para o qual não existem obstáculos científicos para a prevenção da maioria dos casos, e subseqüente controle da doença. Programas de rastreamento periódico da doença em mulheres adultas por intermédio da citopatologia (Papanicolau) vêm sendo adotados de forma eficaz em vários países, dado seus baixos 
custos e elevada resolutividade. O Brasil detém atualmente as maiores taxas de incidência da doença, e a reversão deste quadro baseia-se na reorganização de serviços de saúde no País.

Finalmente, embora não abordado ao longo deste trabalho, não deve ser esquecida a crescente exposição a agentes cancerígenos, sobretudo de natureza química (como pesticidas, asbestos, cloreto de vinila, entre outros), mas também físicos (radiação ionizante e não-ionizante) e biológicos, decorrentes da inserção da mulher na atividade produtiva. Tal como já observado em outros países, este fenômeno é responsável pela introdução de um novo perfil de câncer ocupacional em mulheres adultas (decorrente da exposição direta a agentes carcinogênicos) bem como de natureza ambiental -este afetando a população geral em conjunto. Ambos poderão ser, entretanto, atenuados de forma consideravel graças à limitação da exposição a tais fatores de risco, evitando, desta maneira, a reprodução do mesmo fenômeno já ocorrido com as populações de outros países industrializados.

\section{Referências Bibliográficas}

Averette, H. E. \& NGUYEN, H. Gynecologic Cancer. In: MURPHY, G. P.; LAWRENCE W. Jr; LENHARD, R.E. Jr. The American Cancer Society Texbbook of Clinical Oncology, 2nd ed., Atlanta,GA: American Cancer Society, 1995. p. 552-579.

Brasil. Ministério da Saúde.Secretaria Nacional de Assistência à Saúde. Instituto Nacional do Câncer. Coordenação de Programas de Controle de Câncer-Pro-Onco.(1995). Câncerno Brasil-dados dos registros de base populacional, v. II, Rio de Janeiro: MS/INCa/Pro-Onco, 1995.

BraSIL. Ministério da Saúde.Secretaria Nacional de Assistência à Saúde. Instituto Nacional do Câncer. Coordenação de Programas de Controle de Câncer-Pro-Onco. Estimativa da incidência e mortalidade por câncerno Brasil, Rio de Janeiro: MS/INCa/Pro-Onco, 1998.

FTrZGERALD, M. G. et al. Germ-line BRCAl mutations in jewish and non-jewish women with early-onset breast cancer. New England Journal of Medicine, 334: 143-149, 1995.

GAMmON, M. \& JOHN, E. Recent etiologic hypothesis concerning breast cancer. Epidemiologic Reviews, 15:163-168, 1993.

GARFINKEL, L. Cancer statistics and trends. In Murphy G.P.; Lawrence W. Jr; Lenhard R.E. Jr. The American Cancer Society Textbook of Clinical Oncology, 2nd ed., Atlanta, GA: American Cancer Society, 1995. p.1-9.

HALL, J. M. et al. Linkage of early-onset breast cancer to chromosome 17q21. Science, 250: 1684-1689, 1990. 
HendeRSON, I. C. Breast Cancer. In: MURPHY, G. P.; LAWRENCEW.Jr; LENHARD, R.E. Jr. The American Cancer Society Textbook of Clinical Oncology, 2nd ed., Atlanta,GA: American Cancer Society, 1995. p.198-219.

HOWARD, J. Using mammography for cancer control: an unrealized potential. CA: A Cancer Joumal for Clinicians, 37:33-48, 1987.

KeLSEY, J. L. \& RoRN-Ross, P. L. Breast cancer: magnitude of the problem and descriptive epidemiology. Epidemiologic Reviews, 15: 7-16, 1993.

KELSEY, J. L. Breast cancer epidemiology:summary and future directions. Epidemiologic Reviews, 15:256-63, 1993.

Korfman, S. Incidência de Câncer no Brasil. In: MinaYo, M. C. S. Os Muitos Brasis: saúde epopulação na década de 80. São Paulo-Rio de Janeiro: Ed Hucitec-Abrasco, 1995.

MCWHORTER, W. P. \& EYRE, H. J. Impact of mammography screening on breast cancer diagnosis. Joumal of the National CancerInstitule, 82:153-154, 1990.

MILLER, D. R. et al. Breast cancer before age 45 and oral contraceptive use: new findings. American Joumal of Epidemiology, 129:269-280, 1989.

MILER, B. A.; FEUER, E. J. \& HANKEY, B. F. Recent incidence trends for breast cancer in women and the relevance of early detection: an update. CA: A Cancer Joumal for Clinicians, 43:27$41,1993$.

MonteIro, G. T. R. Confiabilidade e Validade das Declarações de Óbilo por Neoplasias no Municipio do Riode Janeiro, 1995. Dissertação de Mestrado. Rio de Janeiro: ENSP/Fiocruz.

MORROW, C. P. \& TOWNSEND, D. E. Tumors of the ovary: general considerations, classification, the adnexal mass. In: MorRow, C. P. \& TowNSEND, D. E. (Eds.) Synopsis of Gynecologic Oncology, erd ed., New York: John Wiley Sons Inc, 1987. p.233.

PARAZZINI, F. et al. Review: the epidemiology of endometrial cancer. Gynecologic Oncology 41:116, 1991.

PARK, R. C. et al. Corpus: epithelial tumors. In: Hoskins, W. J.; Perez, C. A. \& Young, R. C. (Eds.) Principles and Practice of Gynecologic Oncology. Philadelphia, Pa: JB Lippincott, 1992. p. 664.

PARKIN, D. M. et al. Cancer Incidence in Five Continents. International Agency for Research on Cancer, IARC. Scientific Publications N 120, Oxford: Oxford University Press, U.K, 1992.

PERCY, C. International comparability of coding cancer data: present state and possible improvement by ICD 10. Recents Results in Cancer Research 114: 240-252, 1989.

PERCY, C. \& MUIR, C. The international comparability of cancer mortality data. Results of an international death certificate study. American Joumal of Epidemiology, 129(5):934-946, 1989. 
PUFFER, R. R. \& GRIFrThH, G.W. Caracteristicas de la mortalidad urbana. Publicação. Cientifica OPS N ${ }^{0}$ 151, Washington D.C, 1968.

Seidman, H.; Gelb, S. K. \& Siliverberg, E. Survival experience in the Breast Cancer Detection Demonstration Project. CA: A Cancer Joumal for Clinicians, 37:258-290, 1987.

SEGI, M. Cancer Mortality for Selected Sites in 24 Countries (1950-57). Senday: Tohoku University School of Medicine, 1960.

SYRJANEN, K. et al. Evolution of human papillomavirus infections in the uterine cervix during a long-term prospective follow-up. Applied Palhology 5: 12 1-135, 1987.

StADEL, B. V. et al. Oral contraceptives and premenopausal breast cancer in nulliparous women. Contraception, 38(3):287-299, 1988.

WiuET, W.C. The search for the causes of breast and colon cancer. Nature, 338:389-394, 1989.

WHITE, E. Projected changes in breast cancer incidence due to the trend toward delayed child-bearing. American Joumal of Public Health, 77:495-497, 1987.

Wordd HeatTh Organization. World Health Statistics Annual. Genebra: WHO, 1993. 



\section{4}

\section{Doenças Sexualmente Transmissivieis na Mulher'}

Catherine M. Lowndes

\section{Introdução}

As doenças sexualmente transmissíveis (DST), antigamente conhecidas como doenças venéreas, são infecções extremamente comuns que, a curto prazo, causam dor e sofrimento. Podem ter conseqüências secundárias severas, muitas vezes irreversíveis, que prejudicam de uma forma desproporcionada a saúde reprodutiva e o bem-estar da mulher. Em países em desenvolvimento, as DST constituem a segunda causa da perda de anos de vida saudável em mulheres em idade reprodutiva, após a morbidade e mortalidade maternas (World Development Report, 1993).

A prevenção e o controle destas infeç̧ões, freqüentemente curáveis, representam oportunidades únicas de melhorar a saúde reprodutiva da mulher. Entretanto, no Brasil e em muitos outros países, é somente com o advento do vírus da imunodeficiência humana (HIV) e da AIDs (a síndrome de imunodeficiência adquirida) que o controle das DST tem sido considerado prioritário.

Descreveremos as variedades e as características clínicas das DST, além de suas conseqüências para a saúde reprodutiva da mulher e para a saúde do feto e do recémnascido. Em seguida, são apresentados dados epidemiológicos sobre a magnitude do problema no Brasil e no mundo. Por último, apresentamos uma discussão sobre a prevenção e o controle destas infecções, que ressalta áreas prioritárias para programas

\footnotetext{
* Agradeço a Francisco Inácio Bastos (CICT/Fıocruz) e Fábio Moherdaui (MS, CN-DST/Aıds) pela leitura crítica do texto e pelas correções lingüísticas e sugestões úteis quanto ao seu conteúdo; e a Fábio Moherdaui pela provisão dos fluxogramas nacionais para o manejo sindrômico das DST no Brasil.
} 
de prevenção das DST na mulher. As DST assintomáticas são enfatizadas por constituírem uma área prioritánia em termos do controle das DST na mulher. Concentraremos nossa atenção mais especificamente nas DST que não a Aids (tema já abordado especificamente neste livro). Entretanto, sobretudo no contexto da saúde pública, existem inter-relações, como a interação entre as DST e a Aids e a prevenção das DST/ AIDS, que serão abordadas aqui.

\section{O que são as DST?}

São infecções transmitidas obrigatória, freqücnte ou eventualmente pelo contato sexual. Elas compreendem uma variedade de infecções bacterianas, viróticas e protozoárias (Quadro 1).

\section{Infecçóes do trato reprodutivo inferior}

Geralmente, uma infecção por uma DST começa pela colonização do trato reprodutivo inferior (genitália externa, vagina e colo uterino). As DST causadas por bactérias e protozoários geralmente produzem úlceras e outras lesões genitais, infecções vaginais (vulvovaginite), ou infecções do colo uterino (cervicite) (Quadro 1). Os sintomas das infecções vaginais e cervicais são parcialmente coincidentes e incluem secreções anormais vaginais (malcheirosas ou não) e/ou cervicais (cervicite mucopurulenta), acompanhadas por inflamação, dor e irritação dos órgãos genitais, ardor durante a micção, dor durante o ato sexual e dor pélvica. Apesar de curáveis de modo geral, estas infecções são freqüentemente assintomáticas (sobretudo as cervicais), ou têm fases assintomáticas (como a sífilis), o que pode dificultar sua detecção.

As DST virais incluem o HSV-2 (úlceras e vesículas dolorosas) e o HPV (verrugas genitais) (Quadro 1). Geralmente, não são curáveis, mas os sintomas das infecções pelo HPV e HSV-2 são, ao menos, controláveis. Em geral, tendem a produzir sintomas mais complexos do que as demais DST, incluindo uma variedade de efeitos sistêmicos.

A maioria das infecções do trato reprodutivo (ITRs) são DST, mas incluem também as infecções endógenas causadas pelo crescimento exagerado de microorganismos normalmente presentes no trato reprodutivo inferior (por exemplo, a vaginose bacteriana e a candidíase vulvovaginal). Entretanto, uma vez que estas infecções se estabelecem, podem, em um momento subseqüente, ser transmitidas sexualmente. Existem evidências de que estas infecções sejam também associadas com morbidade secundária (Quadro 1).

Além de causar ITRs, os agentes sexualmente transmitidos também podem causar doenças sistêmicas, como sífilis, AIDs, hepatite, e mesmo a morte (Wasserheit, 1989; Grimes, 1986). Muitas DST também afetam a boca, o reto e o trato urinário. As infecções por DST podem se tornar latentes, ou seja, a infecção permanece no corpo, mas sem manifestações óbvias. 
Doenças Sexualmente Transmissíveis na Mulher

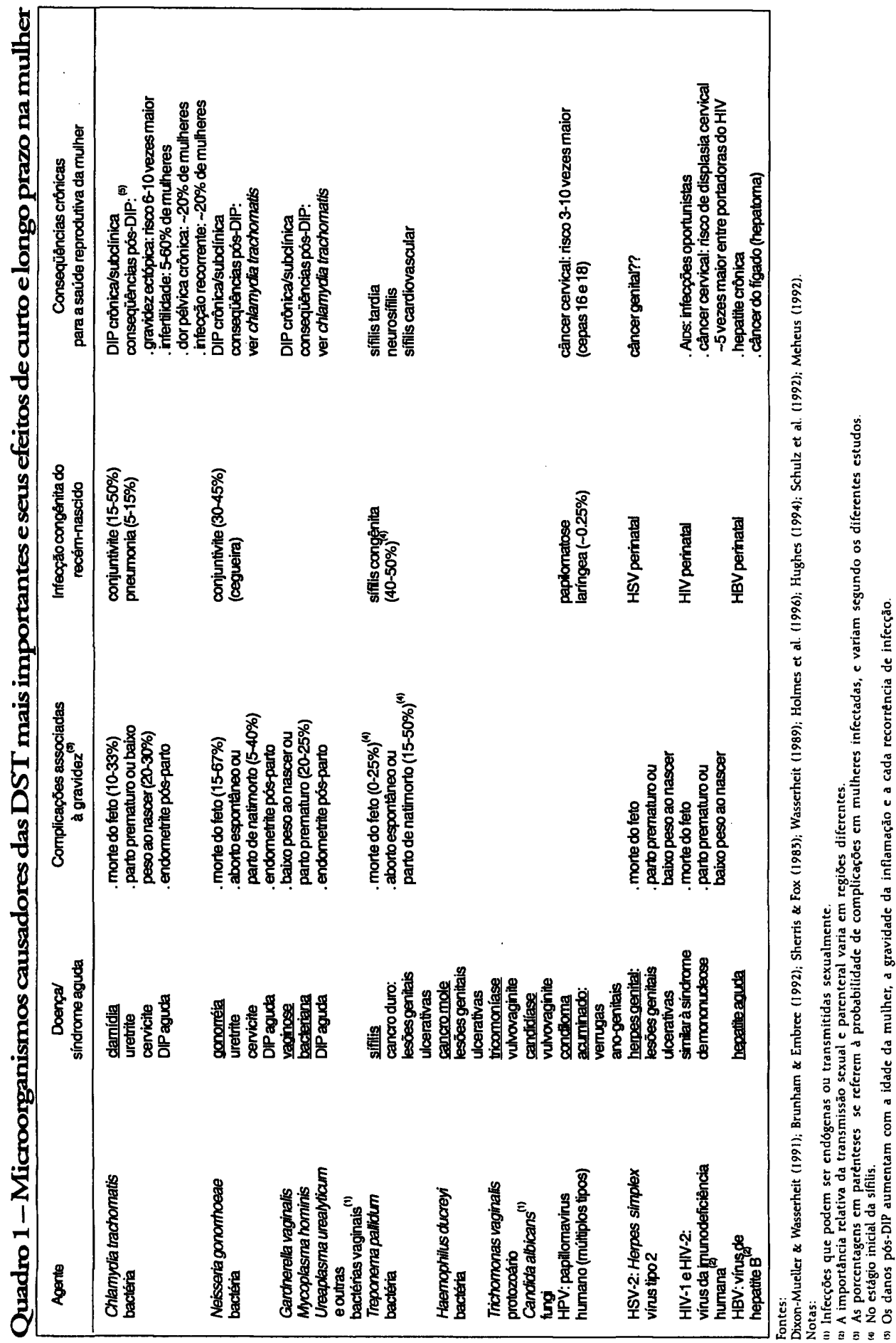




\section{Infecçōes do trato reprodutivo superior}

$\mathrm{Na}$ ausência de detecção precoce e tratamento apropriado durante a fase inicial, algumas infecções do trato reprodutivo inferior podem se espalhar para o trato reprodutivo superior, podendo causar doença inflamatória pélvica (DIP), ou seja, infccção do útero, das trompas de Falópio e/ou dos ovários. Em países desenvolvidos, aproximadamente $10 \%$ de mulheres com infecção cervical por Chlamydia e $10-20 \%$ com infecção cervical por Neisseria desenvolvem infecções ascendentes (Wasserheit, 1989). Este processo pode ocorrer espontaneamente, mas o risco de ele acontecer se amplia durante procedimentos transcervicais como o parto, o aborto e a inserção do DIU (dispositivo intra-uterino).

Os microorganismos que mais freqüentemente causam a DIP são a Chlamydia trachomatis e a Neisseria gononhoeae (Quadro 1). As bactérias associadas à vaginose bacteriana provavelmente agem como co-fatores na infecção do trato reprodutivo superior, facilitando o processo de disseminação das bactérias Chlamydia e Neisseria para o trato reprodutivo superior. Os sintomas da DIP são dor abdominal, febre, corrimento vaginal anormal e sangramento irregular. Casos de DIP aguda não infreqüentemente requerem internação hospitalar. Entretanto, especialmente quando causada por Chlamydia, a DIP pode ser assintomática. Devido à resposta imunológica à infecção, a DIP não-tratada, ou tratada inadequadamente, seja ela sintomática ou assintomática, pode causar processos inflamatórios e cicatriciais severos das trompas de Falópio e dos ovários.

\section{Conseqüências secundárias (de longo prazo) das DST na mulher}

\section{Complicaçōes da DIP}

As complicações freqüentes e geralmente irreversíveis da DIP estão entre os mais sérios problemas de saúde reprodutiva da mulher. Devido à cicatrização pós-inflamatória progressiva causada pela infecção pélvica, resultando em obstrução total ou parcial das trompas de Falópio, a DIP pode resultar em dor abdominal crônica, infertilidade, gravidez ectópica e infecção recorrente (Quadro 1).

\section{Complicaçōes durante a gravidez e para o recém-nascido}

As infecções por certas DST durante a gravidez podem ter efeitos adversos sobre o desenvolvimento do feto, incluindo baixo peso ao nascer, prematuridade, aborto espontâneo e morte fetal (Quadro 1). Na mãe, podem causar endometrite pós-parto. Além dos efeitos sobre o desenvolvimento do feto, as infecções congênitas por DST podem também ser transmitidas diretamente ao feto durante o parto (Quadro 1). Várias DST, incluindo a sífilis, a herpes genital e o HIV, podem, também, causar morte neonatal/infantil. 


\section{Câncer cervical}

O câncer do colo do útero é um problema relevante de saúde pública no mundo inteiro, sendo este neoplasma o segundo mais comum entre as mulheres dos países desenvolvidos e o mais comum em muitos países em desenvolvimento. Pelo menos 500 mil casos ocorrem por ano - 75\% em países em desenvolvimento (Meheus, 1992), onde o câncer cervical é, freqüentemente, a primeira causa de morte feminina por câncer (ver Koifman \& Koifman)' . Evidências epidemiológicas e biológicas sugerem que o câncer do colo do útero geralmente resulta de uma infecção sexualmente transmitida, e indicam que a infecção por alguns subtipos de HPV (sobretudo as cepas 16 e 18) está fortemente associada ao desenvolvimento do câncer cervical (Meheus, 1992). Se a prevalência de infecções assintomáticas por HPV é alta (17\% em mulheres no Brasil - Muñoz et al., 1996), somente uma pequena proporção das mulheres infectadas por HPV desenvolve câncer cervical.

\section{As DST e o uso de anticoncepcionais}

Além de seus efeitos contraceptivos, alguns métodos anticoncepcionais reduzem a probabilidade de se contrair DST, ao passo que outros podem aumentá-la.

O preservativo masculino de látex (camisinha, condom) é, atualmente, o único método que comprovadamente oferece um alto grau de proteção contra a infecção pelo HIV e outras DST (Lamptey e Goodridge, 1996). Os espermicidas (como o nonoxynol-9) oferecem a melhor perspectiva em termos de um método eficaz de proteção contra a infecção pelo HIV e demais DST controlado pela mulher. O desenvolvimento e a disponibilização de um método de proteção seguro e eficaz, que possa ser utilizado pela mulher sem a colaboração nem o conhecimento do parceiro, é da maior urgência (Elias $\&$ Heise, 1994). Embora os estudos clínicos demostrem que os espermicidas oferecem proteção contra a infecção por certas DST (Niruthisard, Roddy \& Chutivongse, 1992), ainda não está bem estabelecido se existe ou não um efeito protetor contra a infecção pelo HIV (Roddy et al., 1998; Hira et al., 1997). O preservativo feminino (Musaba et al., 1998; Bounds, 1997) é uma outra opção controlada pela mulher que vem ganhando popularidade, embora as evidências quanto à sua eficácia protetora com relação às infecções pelas DST e pelo HIV in vivo sejam ainda limitadas.

O uso do DIU aumenta o risco de desenvolvimento de DIP. Este risco adicional de DIP parece se dever, pelo menos em parte, às DST. De forma global, as usuárias do DIU têm um risco aproximadamente 2-4 vezes maior de desenvolver DIP, se comparadas às mulheres que não utilizam métodos anticoncepcionais (Trieman et al., 1995). Este

\footnotetext{
' Capítulo 13 deste livro.
} 
risco se concentra em grande parte no primeiro mês após a inserção do DIU (Farley et al., 1992), e se deve à transferência de microorganismos causadores de DST (especificamente Chlamydia, Neisseria e bactérias associadas à vaginose bacteriana) presentes na vagina e/ou no colo do útero para a cavidade uterina, durante o processo de inserção do DIU. Em momentos posteriores, somente as mulheres expostas às DST após a inserção do DIU têm um risco persistentemente ampliado de desenvolver a DIP (Trieman et al., 1995). Devido ao risco aumentado de desenvolver a DIP logo após o processo de inserção do DIU, é extremamente importante detectar e tratar DST como a clamídia e a gonorréia antes de inseri-lo.

\section{O tamanho do problema: epidemiologia das DST}

As DST estão entre os agravos à saúde mais comuns. O número de patógenos microbianos identificados como causadores destas infecções e a morbidade atribuível às DST, se comparada à causada por outras doenças infecciosas, têm aumentado de uma forma contínua ao longo do século XX. Análises recentes mostram que as DST, consideradas como um conjunto, estão entre as cinco principais causas de anos de vida saudável perdidos nos países em desenvolvimento. O impacto é maior nas mulheres e nas crianças: em mulheres em idade reprodutiva (15-45 anos), a morbidade e a mortalidade secundárias às DST (não incluindo o HIV) são menores apenas do que as devidas às causas maternas (World Development Report, 1993).

\section{Epidemiologia global}

Atualmente, as DST são o grupo mais comum de doenças infecciosas notificadas na maioria dos países no mundo (De Schryver \& Meheus, 1990). Além da persistência das DST bacterianas clássicas (sifilis, gonorréia, e cancro mole), durante as décadas recentes houve um aumento na incidência das DST 'de segunda geração', incluindo a clamídia e as DST virais como o HSV e o HPV. Em grande parte dos países industrializados, essas 'novas' DST se tornaram mais importantes do que as DST bacterianas clássicas; nos países em desenvolvimento, os dois grupos representam problemas de saúde pública igualmente sérios (De Schryver \& Meheus, 1990). Entretanto, nos Estados Unidos, a prevalência de sífilis e gonorréia tem aumentado dramaticamente entre certos grupos populacionais em anos recentes, provavelmente em função da pobreza e do consumo de drogas (Aral e Holmes, 1991). O aumento na incidência das DST que vem ocorrendo em um grande número de países é atribuído a fatores como mudanças no comportamento sexual; ausência de educação em saúde; aumento da mobilidade gcográfica; existência de tabus sociais referentes às DST; fálta de reconhecimento do fato de que a maioria destas doenças são tratáveis; e o desenvolvimento de resistência gênica aos antibióticos por microorganismos causadores das DST (Passos \& Fonseca, 1990). 
A Organização Mundial da Saúde (OMS) estimou que, em 1995, teriam ocorrido 333 milhões de casos de DST curáveis no mundo (Tabela 1), dos quais 36 milhões na América Latina (WHO, 1995). Dois terços de todos os casos de DST ocorrem em pessoas com idade inferior a 25 anos. Os dados de países menos desenvolvidos são escassos, mas as informações disponíveis sugerem que, em geral, as DST são mais comuns e mais graves em países em desenvolvimento (De Schryver \& Meheus, 1990; Rowe, 1992), em decorrência da estrutura etária jovem; da pobreza; das más condições de saneamento; da falta e/ou má qualidade dos serviços de saúde pública, e da prática de automedicação com antibióticos. Freqüentemente ineficaz devido à prescrição errada, a automedicação também contribui para aumentar a taxa de resistência gênica dos microorganismos causadores destas infecções aos antibióticos (Gir et al., 1991; Magalhães, 1987).

\section{Tabela 1 - Incidência global das DST}

\begin{tabular}{lcc}
\hline & \multicolumn{2}{c}{ Estimativas do número de novos casos anuais } \\
\cline { 2 - 3 } DST & 1991 & 1995 \\
& & (DST somente curáveis) \\
\hline Tricomoníase & 120 milhões & 179 milhões \\
Infecções por Chlamydia & 50 milhões & 89 milhões \\
Papillomavírus humano (HPV) & 30 milhões & 62 milhões \\
Gonorréia & 25 milhōes & 12 milhões \\
Herpes Simplex Virus (HSV) & 20 milhões & \\
Sífilis & 3,5 milhões & \\
Cancro mole & 2 milhōes & \\
\hline
\end{tabular}

Fontes: Rowe (1992); WHO(1995).

\section{Epidemiologia das DST no Brasil}

No Brasil, existem poucas informações concretas sobre a magnitude do problema das DST. Segundo publicação do Ministério de Saúde (MS), tanto a inexistência de informações confiáveis sobre a extensão do problema quanto a falta de uma política nacional de controle impossibilitavam uma avaliação epidemiológica dessas doenças (MS, 1993). O sistema oficial de notificação de casos de DST do Ministério da Saúde recebeu, entre 1987 e 1996, registro de 474.862 casos (MS, 1996). Estima-se que o número real de episódios de DST estaria entre 3.5 e 4 milhões por ano no Brasil (Moherdaui et al, 1997). Além da falta de priorização das DST como um problema relevante de saúde pública, outros fatores contribuem para o problema de baixa notificação de casos de DST no País. Entre eles incluem-se a alta incidência de DST assintomáticas na mulher, a prática freqüente de automedicação com relação às DST (Gir et al., 1991) e a ausência de um sistema de notificação que compreenda o sistema de saúde privado. 
Na ausência de dados nacionais confiáveis sobre a incidência (taxa/número de casos novos) de DST, uma outra fonte de informações - que permite ao menos uma caracterização parcial da situação das DST no Brasil - são os estudos de prevalência (taxa/número de pessoas infectadas) em grupos específicos da população. Uma publicação recente apresentou um resumo de estudos desta natureza, realizados em clientes que procuram assistência em clinícas especializadas ou em grupos específicos da população (Faúndes \& Tanaka, 1992). É difícil interpretar os resultados da maioria dos estudos desta natureza no Brasil, devido a problemas metodológicos como a má definição das populações sob estudo e o uso de métodos diagnósticos inadequados (especialmente para a clamídia), além do tamanho muito reduzido das amostras.

Outra fonte de informações são os dados referentes a casos de DST tratados em serviços de dermatologia sanitária. Eles fornecem informações sobre a ocorrência proporcional de DST sintomáticas e sugerem que condiloma, sífilis, uretrite gonocócica e uretrite não-gonocócica são as DST mais importantes entre os homens (Boletín Informativo de la Unión, 1995). A faixa etária mais atingida pelas DST no Brasil é a de 15-30 anos (Passos \& Fonseca, 1990).

Na Tabela 2, apresentam-se alguns estudos selecionados de prevalência das DST em mulheres brasileiras. Estes dados indicam que:

- a prevalência de infecções por DST é alta no Brasil, mesmo em populações assintomáticas e indivíduos de baixo risco;

- as taxas são mais altas em populações de alto risco (por exemplo, prostitutas e pacientes que procuram atendimento em clínicas de DST);

- as taxas de sorologia positiva para a sífilis são elevadas. Apesar de a sífilis ser uma condição de prevenção fácil e barata, a falta de detecção e tratamento de um número grande de casos de sífilis em gestantes continua no Brasil, resultando em uma taxa inaceitável de sífilis congênita (Gomes et al., 1996);

- infecções cervicais assintomáticas na mulher (clamídia e gonorréia) são muito freqüentes no Brasil. 


\section{Tabela 2-Prevalência de algumas DST/ITRS em mulheres no Brasil}

\begin{tabular}{|c|c|c|c|c|c|}
\hline DST/ITR & População estudada & $\begin{array}{l}\text { Número } \\
\text { estudado }\end{array}$ & Ano & $\begin{array}{c}\text { Porcentagem } \\
\text { infectada }\end{array}$ & UF \\
\hline Clamídia & $\begin{array}{l}\text { gestantes } \\
\text { ambulatório de ginecologia*(1) } \\
\text { ambulatório de ginecologia \#(2) } \\
\text { gestantes } \\
\text { mulheres com cervicite }^{(14)}\end{array}$ & $\begin{array}{r}151 \\
716 \\
70 \\
122 \\
50\end{array}$ & $\begin{array}{l}1995 \\
1995 \\
1993 \\
1995 \\
1998\end{array}$ & $\begin{array}{r}12,6 \\
7,3 \\
22,6 \\
9,0 \\
56,0\end{array}$ & $\begin{array}{l}R J \\
R J \\
S P \\
S P \\
* *\end{array}$ \\
\hline Gonorréia & $\begin{array}{l}\text { gestantes }^{(3)} \\
\text { ambulatório de ginecologia } \\
\text { mulheres com corrimento vaginal(16) } \\
\text { mulheres com cervicite }\end{array}$ & $\begin{array}{r}142 \\
624 \\
10.559 \\
50\end{array}$ & $\begin{array}{l}1995 \\
1995 \\
1984 \\
1998\end{array}$ & $\begin{array}{r}1,4 \\
1,0 \\
2,9 \\
48,0\end{array}$ & $\begin{array}{l}\text { RJ } \\
\mathbf{R J} \\
\mathbf{S P} \\
* *\end{array}$ \\
\hline $\begin{array}{l}\text { Sífilis } \\
\text { (prova } \\
\text { sorológica) }\end{array}$ & $\begin{array}{l}\text { gestantes }^{(4)} \\
\text { gestantes }^{(5)} \\
\text { gestantes } \\
\text { doadores de sangue } \\
\text { recém-nascidos }^{(7)} \\
\text { presidiárias }^{(8)} \\
\text { prostitutas }^{(15)}\end{array}$ & $\begin{array}{r}481 \\
2.909 \\
3.859 \\
62.814 \\
3.664 \\
57 \\
600\end{array}$ & $\begin{array}{l}1990 \\
1983 \\
1983 \\
1989 \\
1993 \\
1996 \\
1995\end{array}$ & $\begin{array}{r}5,2 \\
3,0 \\
9,4 \\
4,1 \\
5,6 \\
14,0 \\
45,0\end{array}$ & $\begin{array}{l}\text { SP } \\
\text { SP } \\
\text { SP } \\
\text { GO } \\
\text { SP } \\
\text { SP } \\
\text { SP }\end{array}$ \\
\hline Tricomoniase & $\begin{array}{l}\text { gestantes }^{(9)} \\
\text { ambulatório de ginecologia(12) } \\
\text { mulheres com vaginite } \\
\end{array}$ & $\begin{array}{r}74 \\
485 \\
156\end{array}$ & $\begin{array}{l}1988 \\
1984 \\
1998\end{array}$ & $\begin{array}{l}19,0 \\
24,0 \\
38,5\end{array}$ & SP \\
\hline $\begin{array}{l}\text { Gardnerella } \\
\text { vaginalis } \\
\text { (vaginose } \\
\text { bacteriana) }\end{array}$ & $\begin{array}{l}\text { pacientes sintomáticas para DST(10) } \\
\text { serviço de planejamento familiar(11) } \\
\text { mulheres com vaginite } \\
\text { (14) }\end{array}$ & $\begin{array}{r}97 \\
49 \\
156\end{array}$ & $\begin{array}{l}1987 \\
1994 \\
1998\end{array}$ & $\begin{array}{l}48,4 \\
53,0 \\
32,1\end{array}$ & $\begin{array}{l}\text { SP } \\
\text { MG } \\
\star \star\end{array}$ \\
\hline
\end{tabular}

Fontes:

(1) Lowndes et al. (1996); (2)Raddi et al. (1993); (3) Lowndes (1995); ; ${ }^{(4)}$ Vaz et al. (1990); ${ }^{(5)}$ Cunha et al. (1983); ${ }^{(6)}$ de Andrade et al. (1989); ${ }^{(7)}$ Guinsberg et al. (1993); ${ }^{\left({ }^{(8)}\right.}$ Tellini et al. (1996); ${ }^{(9)}$ Cunha et al. (1988); ${ }^{(10)}$ Guerreiro et al. (1987); ${ }^{(11)}$ Aleixo Neto et al. (1994); ${ }^{(12)}$ Brum \& Brum (1984); ${ }^{(13)}$ Amaral et al. (1995); ${ }^{(14)}$ Moherdaui et al. (1998); ${ }^{(15)}$ Lurie et al. (1995); ${ }^{(15)}$ Gonçalves et al. (1984).

Notas:

*mulheres que fizeram o preventivo.

**Estudo multicêntrico em cinco centros de atendimento de casos de DST.

\#mulheres com indicação clínica.

\section{Chlamydia trachomatis e infecçōes cervicais assintomáticas}

A clamídia é a DST bacteriana mais comum em países desenvolvidos. Nos Estados Unidos, estima-se que 3-5 milhões de casos novos de clamídia ocorram anualmente (McGregor, 1989; Weinstock, Dean \& Bolan, 1994) e que a prevalência de infecção é de 5-10\% em mulheres de idade fértil. Além do sofrimento, da dor e da morbi-mortalidade 
causados pela infecção, o custo econômico da clamídia é enorme, sendo estimado em U $\$ 3,5$ bilhões por ano no país, a maioria destes custos resultantes de efeitos secundários de infecções não-tratadas em sua fase inicial (Washington et al., 1986).

A natureza freqüentemente assintomática das infecções primárias (colonização do trato reprodutivo inferior) por Chlamydia e Neisseria dificulta sua detecção, já que a maioria das mulheres infectadas não apresenta sintomas. A única maneira de detecção destas infecções é portanto por meio de screening de mulheres assintomáticas, usandose testes diagnósticos específicos. Estudos recentes comprovam que a identificação e o tratamento de infecções por Chlamydia em mulheres sob risco para esta infecção podem reduzir a incidência de DIP (Scholes et al., 1996). Entretanto, os testes diagnósticos atualmente disponíveis para Chlamydia são tecnicamente difíceis e/ou muito caros - apesar de o tratamento ser fácil e barato.

Os poucos estudos disponíveis no Brasil indicam uma prevalência elevada de infeç̧ão por Chlamydia em mulheres (Tabela 2). De acordo com estudos realizados em outros países, a prevalência de clamídia é especialmente alta em mulheres jovens: em um estudo realizado no Rio de Janeiro, a taxa de infecção na faixa etária de 14-24 anos foi $11.2 \%$ em mulheres não-grávidas e $16.8 \%$ em grávidas (Lowndes, Domingues \& Cintra, 1996). O fato de até $80 \%$ de casos de clamídia serem assintomáticos em mulheres (Weinstock, Dean \& Bolan, 1994), em combinação com o custo elevado e a conseqüente ausência de metodos diagnósticos laboratoriais adequados nos serviços de saúde pública indica que muitas infecções por Chlamydia não vêm sendo detectadas atualmente no País. Neste contexto, é importante ressaltar que o 'preventivo' (teste utilizado para detectar a displasia cervical em esfregaços corados pelo método de Papanicolaou) - único teste laboratorial hoje disponível na maioria dos centros de saúde públicos para diagnóstico de DST - é ineficaz na detecção das infecções por Chlamydia (Arroyo et al., 1989).

Esta situação tem implicações sérias para a saúde reprodutiva da mulher, dados os efeitos secundários das infecções por Chlamydia não-tratadas (Quadro 1). O risco de ocorrência desses efeitos secundários seria mais elevado no Brasil em conseqüência da alta freqüência de abortos ilegais (em sua maioria de baixa qualidade), e da prática de inserção do DIU sem acesso ao diagnóstico laboratorial para clamídia. O mesmo problema existe em termos de infecções por Neisseria na mulher: a prevalência desta infecção é mais baixa, embora também importante no País (Tabela 2). Os métodos eficazes para o diagnóstico desta infecção em mulheres assintomáticas não estão igualmente disponíveis nos serviços de saúde. 


\section{A interação das DST com o HIV}

A presença de infecções por outras DST aumenta o risco de transmissão e de infecção pelo HIV. Estudos epidemiológicos na África, Europa e nos Estados Unidos sugerem que há um risco aproximadamente quatro vezes maior de infecção pelo HIV na presença de úlceras genitais, como as causadas pela sífilis e pelo cancro mole; e um risco significativamente aumentado, porém menor, quando da presença de DST como gonorréia, clamídia e tricomoníase, que provocam acumulações locais de linfócitos e macrófagos no trato genital (Wasserheit, 1992; WHO, 1995). Fatores biológicos responsáveis pelo aumento do risco de transmissão de HIV na presença de DST incluem a ruptura da barreira epitelial normal por ulceração ou microulceração genital e a acumulação de células suscetíveis ao, ou infectadas pelo HIV em secreções vaginais e sêmen (WHO, 1995; Kreiss et al., 1994).

Recentemente, um estudo comunitário randomizado na África demionstrou que o diagnóstico e o tratamento rápidos e adequados de pessoas com sintomas de DST, baseadọs na abordagem sindrômica, se mostrarem associados a uma redução de $42 \%$ na incidência de novas infecções pelo HIV (Grosskurth et al., 1995). Esta redução ocorreu sem mudanças concorrentes do comportamento sexual, como o uso do preservativo. Estes resultados indicam que o controle clínico das DST, especialmente em situações onde as mudanças comportamentais podem ser de difícil obtenção, constitui uma das maneiras mais eficazes de reduzir a incidência de HIV a curto prazo.

\section{Aspectos de saúde pública: prevenção e controle das DST na mulher}

\section{Prevenção e controle das DST: o desafio}

Todas as DST são preveníveis e muitas são, também, curáveis. A prevenção e o controle das DST são prioridades por duas razões:

- representam uma oportunidade única para melhorar a saúde reprodutiva da mulher, reduzindo as conseqüências sérias e freqüentemente irreversíveis das DST, reduzindo, também, os altos custos hospitalares de tratamento da DIP e outros efeitos secundários das DST;

- as DST aumentam o risco de transmissão de infecção pelo HIV. Já foi demonstrado que programas de controle das DST podem contribuir para uma diminuição na incidência de novas infecções pelo vírus. 
Apesar da falta de informações sobre a magnitude do problema de DST na população brasileira, os dados apresentados anteriormente neste capítulo indicam que as DST são extremamente comuns no Brasil, mesmo em populações assintomáticas e mulheres de baixo risco. As informações disponíveis indicam a necessidade urgente de uma melhoria dos programas de controle de DST no País.

\section{DST e gênero: o contexto}

Fatores biológicos, socioculturais e assistenciais, além do efeito combinado deles, fazem com que a mulher seja mais vulnerável do que o homem quanto à possibilidade de contrair DST e sofrer seus efeitos secundários, biológicos e sociais (Quadro 2).

Biologicamente, as mulheres são mais suscetíveis à infecção pelas DST, pelo maior risco biológico de transmissão (por ato sexual) das DST (inclusive do HIV) do homem para a mulher (Dixon-Mueller \& Wasserheit, 1991). Além disso, sendo as DST na mulher em grande medida assintomáticas, elas têm menor probabilidade de procurar assistência médica e de ter uma infecção diagnosticada. Isso faz com que corram mais risco de sofrer conseqüências biológicas de DST, igualmente mais graves nas mulheres.

Estes riscos biológicos são agravados por uma série de fatores socioculturais e fatores associados aos serviços de saúde e à assistência médica (Quadro 2). A subordinação econômica, sociocultural, física e sexual da mulher faz com que elas tenham poucos recursos para controlar sua exposição às DST/HIV, devido à falta de poder de barganha nas relações sexuais e à conseqüente dificuldade de exigir um comportamento sexual responsávcl e seguro do seu parceiro (Lowndes \& Giffin, 1995; World Development Report 1993; Dixon-Mueller \& Wasserheit, 1991). Ao mesmo tempo, elas não têm como recorrer a métodos de prevenção de infecção sobre os quais tenham controle.

Uma série de outros fatores diminui a probabilidade da mulher procurar tratamento para DST, incluindo a aceitação de sintomas de DST (corrimento vaginal, dor no baixo ventre etc.) como normais à condição feminina (Faúndes \& Tanaka, 1992); o estigma social que associa as DST à promiscuidade e à prostituição na mulher; $\mathrm{e} \mathrm{a}$ prática comum de automedicação das DST pelo homem.

No âmbito dos serviços de saúde, as longas demoras para consultas e obtenção de resultados de testes laboratoriais (quando realizados), combinadas à falta de medicamentos e de insumos, dificultam a obtenção de atendimento e tratamento adequados para as DST. Além disso, a falta de métodos diagnósticos apropriados para as DST - sobretudo para as assintomáticas -, associada à falta de consciência quanto à alta prevalência e ao risco de efeitos secundários das DST assintomáticas, reduz ainda mais a possibilidade de a mulher ser diagnosticada e tratada adequadamente. 
Mesmo conseguindo atendimento, as mulheres com DST ou seus sintomas freqüentemente não recebem informações claras e apoio prático ou emocional por parte dos profissionais da saúde. Isto parece resultar, pelo menos em parte, da situação sensível em que o médico se encontra perante as normas sociais quanto à sexualidade e à infidelidade masculina no Brasil (Giffin \& Lowndes, 1999). Isto gera uma conseqüente dificuldade para o profissional da saúde em termos de dizer claramente à mulher que ela tem uma infecção transmitida sexualmente. O uso comum de termos como 'inflamação' e 'ferida no útero' permite que o médico e a mulher possam falar da sua condição clínica sem mencionar as palavras DST. O médico, em uma tentativa de proteger tanto a mulher quanto a ele mesmo de situações emocionais e sociais dificeis, acaba por não explicar claramente à paciente que ela possa ter uma DST. Isto em uma situação em que a mulher freqüentemente possui poucas - se algumas - informações corretas sobre as causas e as conseqüências das DST. O fato de nem todas as ITRs serem DST na mulher, tendo o corrimento vaginal, por vezes, causas não-infecciosas, em combinação com o uso de métodos diagnósticos inespecíficos para as DST, torna a situação ainda menos clara e mais confusa para a mulher.

Ao mesmo tempo, nos casos em que há medicamentos disponíveis nos serviços, e quando este tratamento é oferecido, a conduta mais freqüente parece ser mandar um remédio para o parceiro pela mulher. A falta de um apoio médico nesta situação a deixa vulnerável à possibilidade de ser culpada pela infecção e, conseqüentemente, enfrentar rejeição, vergonha e culpa. Mesmo nos casos em que a mulher desconfia da infidelidade do marido e acredita que foi infectada por ele, ela sai da consulta médica sem elementos que a apóiem. Nesta situação, a probabilidade de o parceiro tomar tratamento é reduzida.

O feito combinado destes fatores biológicos e socioculturais e de fatores associados à assistência médica determina, muito provavelmente, a não-resolução de muitos casos de DST na mulher, deixando-a sob risco de desenvolver efeitos secundários sérios e sem meios de se proteger contra a reinfecção e as infecções futuras.

A discussão precedente demostra as dificuldades com que a mulher se depara em termos de se proteger contra a exposição às DST/HIV. Freqüentemente, ela não pode reduzir o número de parceiros sexuais, porque sua exposição depende, de fato, do número de parceiros sexuais do seu parceiro. Além disso, ela não tem o poder de negociar o uso do preservativo masculino, nem o acesso a métodos de prevenção de infecção controlados por ela. A mulheré, então, simultaneamente, vulnerável à infecção e impedida de se proteger. Finalmente, nos serviços de saúde, ela não recebe nem um manejo adequado das DST, nem apoio prático ou emocional quanto à informação e ao tratamento de seu parceiro ou à proteção contra futuras infecções. Nesta situação, o risco de contrair uma infecção por HIV seria ampliado, tanto em termos do comportamento sexual do seu parceiro, quanto da associação biológica das DST com a infecção pelo HIV. 


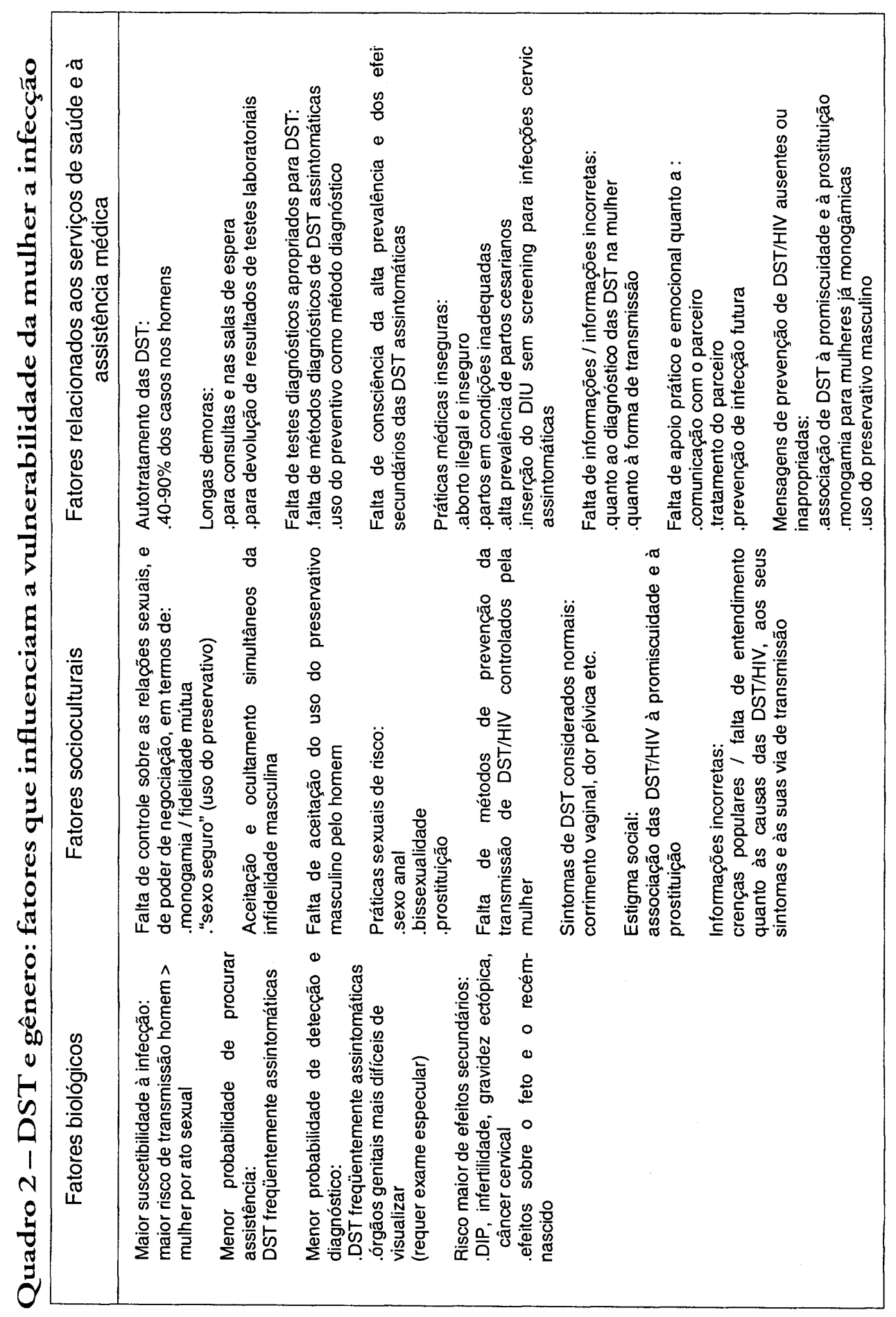




\section{Diagnóstico sindrômico: a soluçāo?}

Estimulado pela necessidade de melhorar o manejo das DST no Brasil, e em um esforço de reduzir a incidência de infecções pelo HIV no País, o Ministério de Saúde recentemente introduziu, em alguns centros de saúde do Brasil, a Terapêutica Padronizada Combinada, também denominada abordagem sindrômica ou diagnóstico sindrômico das DST (WHO, 1993; Vuylsteke \& Meheus, 1996). O seu objetivo é, em uma única consulta, prover avaliação terapêutica das DST e aconselhamento adequado ao paciente (MS, 1993a). A abordagem sindrômica é baseada na deteç̧ão de uma síndrome composta de sintomas e sinais associados a um número de agentes etiológicos de DST bem-definidos. A abordagem utiliza fluxogramas clínicos (Figura 1)-normas simples e padronizadas, adaptadas às condições locais, para guiar o processo de decisão médicapara as síndromes mais comuns de corrimento uretral, úlcera genital e corrimento vaginal/dor pélvica (Moherdaui et al., 1998). O tratamento preconizado para cada uma das síndromes visa a agir contra todos os possíveis agentes etiológicos que possam causá-las (por exemplo, o corrimento uretral no homem é tratado com medicamentos contra Neisseria e Chlamydia). Os fluxogramas podem ter vários níveis de sofisticação, dependendo dos recursos disponíveis em cada situação. Em caso de corrimento vaginal, o tratamento pode visar todas as possíveis causas (tricomoníase, candidíase e vaginose bacteriana), sem que seja necessária investigação. Ou, estando disponível um espéculo .e/ou um microscópio, algum grau de diagnóstico mais específico pode ser obtido. Distinguindo-se o corrimento vaginal causado por tricomoníase daquele causado por candidíase, possibilita-se um tratamento mais específico (Figura 1). Apesar de resultar na prescrição de medicamentos desnecessários, a abordagem sindrômica pode ser eficaz em uma situação em que há poucos recursos disponíveis, e em que seja impossível identificar as etiologias específicas de sintomas das DST. Além disso, já que o diagnóstico e tratamento são feitos a partir de sintomas e sinais, o atendimento ao paciente e a prescrição de medicamentos para ele e para todos seus contatos sexuais podem ser realizados em uma única consulta. Isto é extremamente importante para a interrupção da cadeia de transmissão das DST.

As avaliações de um modo geral mostram que a abordagem sindrômica detecta e trata corretamente aproximadamente 75\% de DST sintomáticas. Estudo do Ministério da Saúde realizado em cinco clínicas de DST no Brasil concluiu que a abordagem sindrômica resulta no tratamento adequado de um número consideravelmente maior de pacientes do que tratamento baseado somente na impressão clínica do médico (Moherdaui et al., 1998). Entretanto, apesar do objetivo da introdução da abordagem sindrômica ser a melhoria de atendimento às DST de uma forma global - incluindo educação para a prevenção futura e notificação/tratamento de parceiros-, uma avaliação recente do manejo de casos de DST em São Paulo e Rio de Janeiro indica que, mesmo com a introdução de métodos de detecção e tratamento de DST mais eficazes, 
outros problemas estruturais, tais como aqueles detalhados anteriormente neste capítulo, ainda persistem (D'Angelo et al., 1996). Nesta avaliação de 162 pacientes entrevistados após atendimento para sintomas de DST, o tratamento sindrômico preconizado foi feito em $50 \%$ dos homens e $2,6 \%$ das mulheres; as informações sobre a necessidade de tratamento dos parceiros foram relatadas por $90 \%$ dos homens e 34\% das mulheres; a orientação sobre o beneficio do uso de preservativos foi descrita por $80 \%$ dos homens e $28 \%$ das mulheres e apenas $10 \%$ das mulheres receberam orientação quanto ao uso do preservativo. Este estudo mostra diferenças grandes entre o tratamento e a orientação preventiva oferecidos a homens e mulheres: a maioria absoluta delas não compreendeu o diagnóstico do médico, não foi medicada adequadamente, não foi orientada em termos de informação e tratamento do parceiro, não levou medicamentos para o parceiro e não recebeu orientação quanto ao uso de preservativo.

A introdução de métodos mais eficazes de abordagem clínica de DST não será em si eficaz no controle das DST nas mulheres caso elas continuem sem acesso a informações, medicamentos e apoio prático e emocional necessários para informar e tratar seu(s) parceiro(s) e para se proteger da reinfecção. Além disso, mesmo com a existência de serviços de saúde para DST mais eficazes, a facilidade com que os antibióticos são adquiridos em farmácias possibilita que homens com DST ainda possam obter tratamento desta maneira. A disponibilidade desta alternativa para o homem significa que a mulher, freqüentemente assintomática ou com sintomas considerados normais, fica sem diagnóstico e tratamento. 


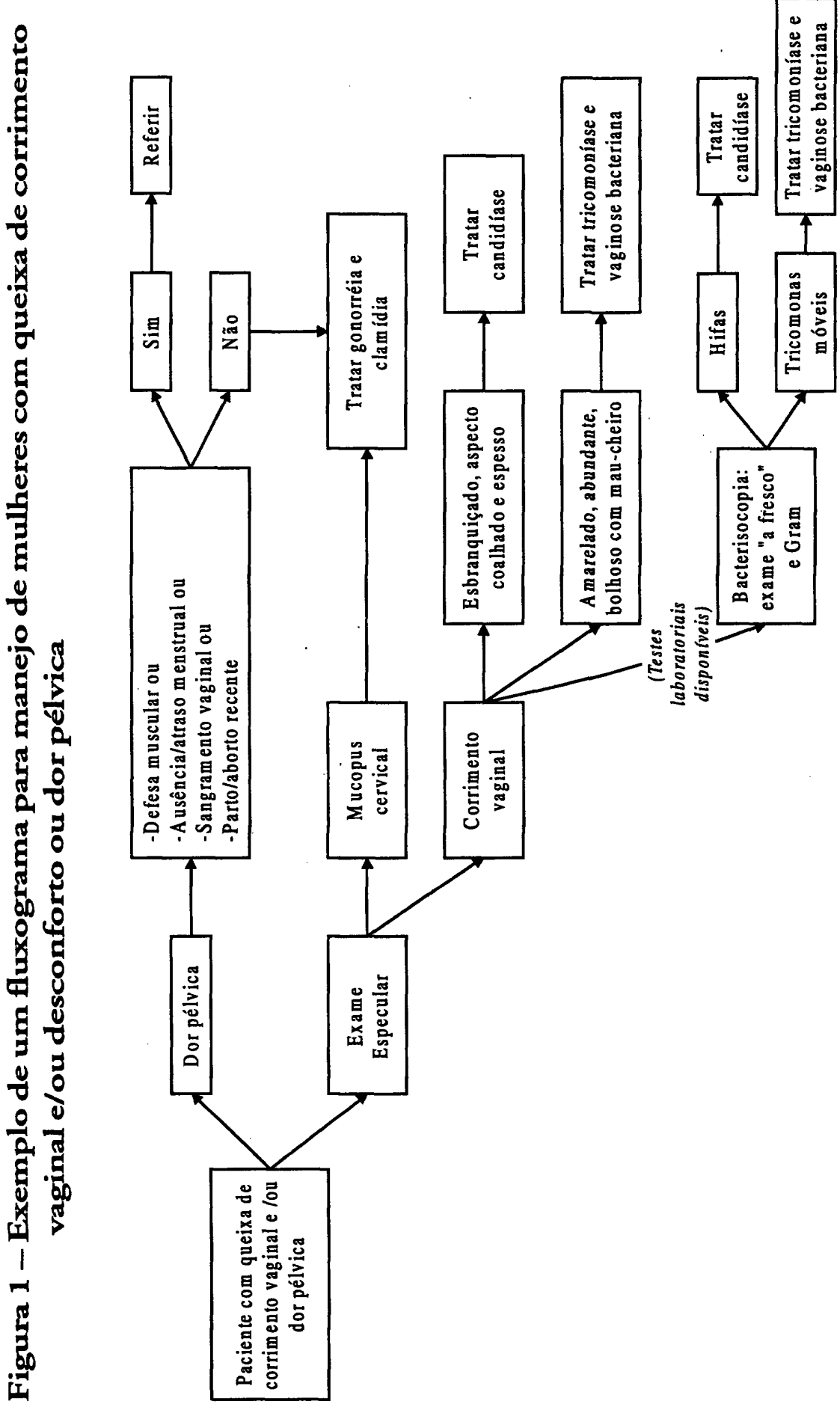

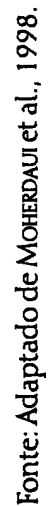


Questões da Saúde Reprodutiva
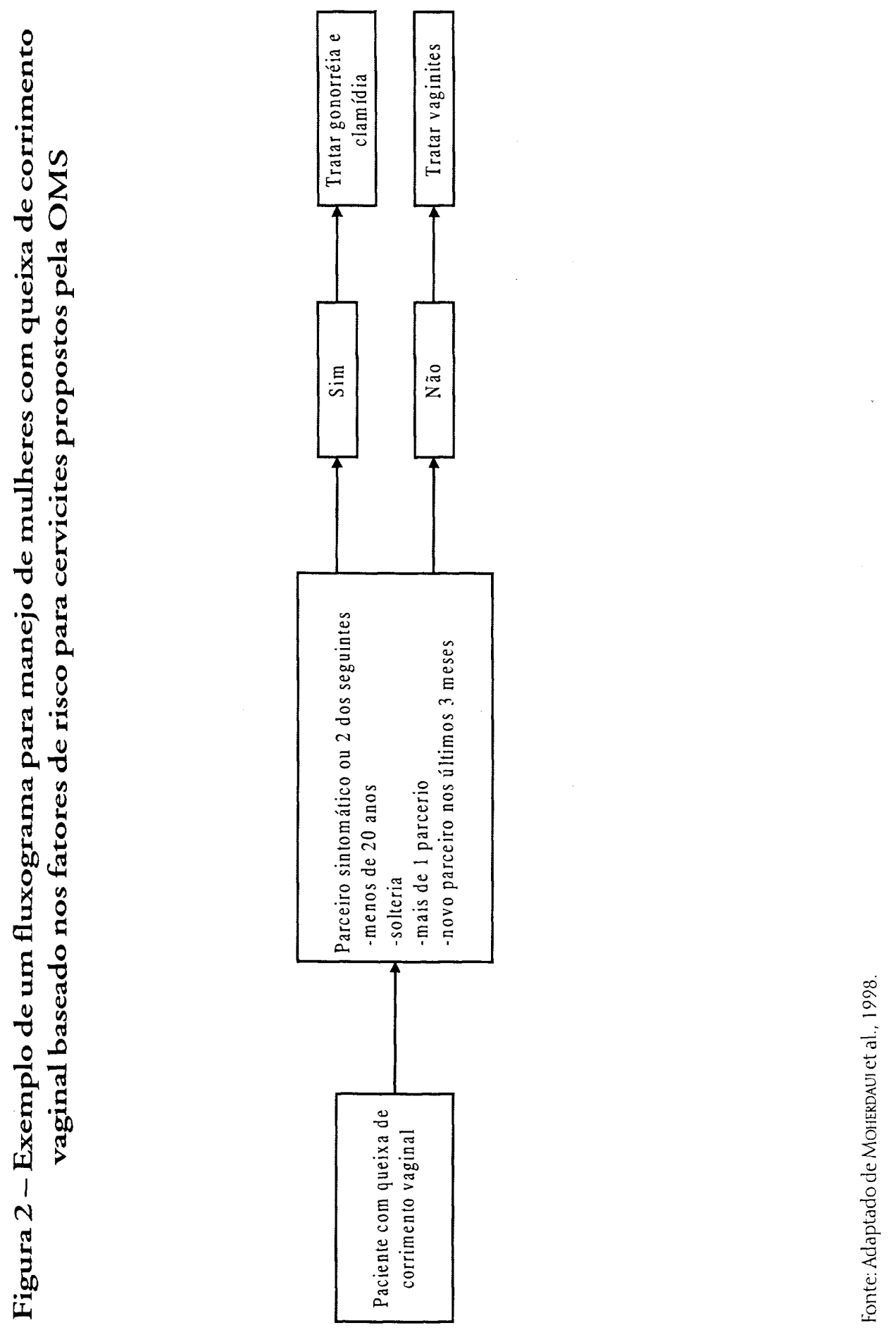


\section{Diagnóstico sindrômico e DST assintomáticas na mulher}

A introdução da abordagem sindrômica é justificada como uma medida de controle de DST sintomáticas. Se bem implementada, com a disponibilização de medicamentos e de apoio prático e emocional adequado, é possível que ela represente um avanço no manejo clínico das DST sintomáticas no Brasil. Muitas mulheres, entretanto, com infecções por DST como sífilis, herpes e HPV não apresentam quaisquer sintomas. Ressalta-se que a grande maioria de infecções cervicais (até $80 \%$ das infecções por Chlamydia, e 50\% das infecções por Neisseria) é assintomática na mulher. Estas infecções cervicais estão entre as mais sérias DST em termos de efeitos secundários. Os dados disponíveis indicam que a prevalência das infecções por Chlamydia na mulher é elevada no País, mesmo em populações consideradas de baixo risco (Tabela 2). A abordagem sindrômica, que é, por definição, desenhada para a deteç̧ão c o tratamento de DST em pessoas que apresentam sintomas, não pode ser eficaz nos muitos casos em que, devido à ausência de sintomas, a mulher não chega a procurar assistência médica.

Devido a esta situação, e ao fato de que o alto custo de testes diagnósticos para infecções cervicais impossibilita sua realização em países com poucos recursos, vários estudos foram realizados em uma tentativa de se definir "marcadores de risco", por exemplo, idade e comportamento sexual, que estariam associados a infecções por Chlamydia e Neisseria (WHO, 1995a; Vuylsteke \& Meheus, 1996). Em um contexto em que não há recursos para realizar testes diagnósticos específicos, estes marcadores de risco poderiam ser utilizados para identificar mulheres que têm uma probabilidade ampliada de apresentarem uma infecção cervical assintomática. Estas mulheres poderiam, então, ser selecionadas para a realização de testes laboratoriais especifícos (se existirem recursos) ou tratadas para as infecções cervicais de uma maneira profilática.

Há duas situações em que este tipo de abordagem pode ser aplicado: em mulheres que procuram atendimento por causa de sintomas de infecções vaginais (corrimento vaginal etc.), e que não apresentam sintomas óbvios de infeç̧ão cervical (Figura 2); e em mulheres assintomáticas, por exemplo, aquelas que procuram atendimento ginecológico ou pré-natal. Quanto às que apresentam sintomas de infecções vaginais, estudos no Brasil e em outros países mostram que a eficiência de detecção de infecções cervicais nestas mulheres é aumentada adicionando-se ao fluxograma este tipo de avaliação de risco (Figura 2; Moherdaui et al., 1998). Análises em outros países mostram, igualmente, que a avaliação de risco pode, também, detectar certa proporção de infecções cervicais em mulheres assintomáticas (Braddick et al., 1990; Vuylsteke et al., 1993). Entretanto, a especificidade de uma abordagem desta natureza é geralmente baixa, resultando no tratamento desnecessário de muitas mulheres que têm os marcadores de risco, mas que, de fato, não têm infecções cervicais (Ryan \& Holmes, 1995). Naquelas com infecções vaginais sintomáticas, que receberiam tratamento para as DST de qualquer forma, 
esta abordagem se justifica na ausência de recursos para os testes diagnósticos laboratoriais. Entretanto, dada a baixa especificidade da avaliação de risco, o tratamento profilático das infecções cervicais com base nesta abordagem em mulheres que não têm sintomas de DST é bastante mais complicado, uma vez que os medicamentos deveriam também ser tomados pelo parceiro, o que poderia causar problemas emocionais e sociais sérios para o casal.

Evidentemente, há uma necessidade urgente de desenvolvimento de testes diagnósticos simples e baratos para as infecções cervicais assintomáticas. Cabe observar que, hoje, no Brasil, não existe uma política definida quanto à detecção de infecções cervicais assintomáticas na mulher, apesar de sua alta prevalência e de seus graves efeitos secundários sobre sua saúde reprodutiva. Isto, além do risco aumentado de transmissão de HIV associado às DST, mesmo assintomáticas.

\section{A importância de serviços integrados de saúde reprodutiva}

A discussão anterior ressalta duas áreas prioritárias para o aprimoramento do manejo das DST na mulher: a necessidade de meios eficazes de deteç̧ão das infecções cervicais em mulheres assintomáticas; e a abordagem dos problemas mais globais relacionados ao contexto sociocultural da mulher e DST.

Neste contexto, a necessidade de integração do atendimento às DST nos serviços de ginecologia, planejamento familiar, pré-natal e saúde materno-infantilé clara. Serviços de diagnóstico e tratamento das DST estão logicamente relacionados a atendimentos desta natureza: ambos têm acesso à mesma clientela - mulheres sexualmente ativas -e requerem profissionais da saúde com habilidades similares, incluindo a de comunicar sobre questões sensíveis de sexualidade. Salienta-se que as mulheres grávidas são alvos especialmente importantes para os programas de controle de DST, diante da alta prevalência de DST nesta população, incluindo a clamídia e a sífilis; e dos graves efeitos de DST sobre a saúde do feto e do recém-nascido.

As mulheres que demandam este tipo de atendimento são alvos ideais para a introdução de programas de controle de DST mais globais, sendo estes a única maneira prática de se alcançare sensibilizar mulheres assintomáticas, ou que não percebem que os sintomas que elas têm possam estar relacionados a uma DST. Clínicas desta natureza são também lugares ideais para campanhas de educação e sensibilização em termos de DST/HIV em geral.

Existem hoje alguns exemplos de serviços mais integrados e centrados na mulher, incluindo o Coletivo Feminista Sexualidade Saúde, em São Paulo (ver Diniz ${ }^{2}$ ), e a Associação Brasileira de Bem-Estar Familiar no Brasil (BEMFAM). Esta última vem introduzindo

\footnotetext{
${ }^{2}$ Ver capítulo 20.
} 
os conceitos de abordagem sindrômica das DST na mulher em suas clínicas de planejamento familiar, no contexto da sensibilização dos profissionais da saúde quanto aos problemas de DST do ponto de vista emocional e social, e da introdução de sessões de aconselhamento individual e de grupo, incluindo, quando possivel, a participação dos parceiros (Badiani et al., 1996; Costa e Petti, 1997). Tais programas indicam a possibilidade da introdução de serviços para as DST mais efetivos, que visam a protegera mulherde infecção na globalidade da sua vida, e não somente em termos de casos individuais de DST.

Nestas situações, além da introdução da abordagem sindrômica para as DST, algumas outras medidas de controle das DST assintomáticas e seus efeitos secundários poderiam ser facilmente introduzidas desde já, e são justificáveis diante das indicações existentes de uma elevada prevalência de DST assintomáticas nesta população:

- tratamento profilático das infecções cervicais (clamídia e gonorréia) antes da inserção do DIU. A administração de tratamento profilático antibacteriano imediatamente antes da inserção do DIU pode diminuir o risco de desenvolver uma DIP subseqüente;

- recomendações a mulheres que praticam o aborto induzido de procederem ao tratamento profilático (enfatizando a necessidade do autocuidado, além dos procedimentos realizados pelos profissionais da saúde) para as infecções cervicais antes da realização do aborto;

- a introdução de 'avaliação de risco' para as infecções cervicais em mulheres com corrimento vaginal (conforme recomendado pelas normas do MS, Moherdaui et al., 1998).

Entretanto, estas soluções são parciais e imperfeitas. Sobretudo é necessário se ter em mente que a abordagem sindrômica não é adequada para a deteç̧ão e o manejo das DST assintomáticas na mulher. Conseqüentemente, é necessária a introdução de uma política de deteç̧ão e tratamento destas DST, para diminuir a incidência de efeitos secundários e o risco aumentado de infecção pelo HIV. Isto requer o investimento de recursos no screening de mulheres assintomáticas, especialmente jovens e grávidas, que se encontram sob maior risco de ter infecções cervicais e de sofrer seus efeitos secundários.

\section{Conclusóes}

A existência da AIDs estimulou a introdução de programas de controle e prevenção das DST mais eficazes. Embora a introdução da abordagem sindrômica e do manejo mais eficaz de DST sintomáticas possam contribuir para o controle de DST, e, possivelmente, para a diminuição da incidência de infecções pelo HIV no Brasil, é importante ressaltar que isto não representa uma solução em termos da saúde reprodutiva da mulher. Uma abordagem diferenciada se faz necessária, de modo a diminuir a incidência e os efeitos secundários das DST na mulher, sobretudo naquelas consideradas de 
baixo risco para as DST. Isto requer a introdução de uma política quanto à deteç̧ão de infecções cervicais em mulheres assintomáticas, dentro de uma abordagem mais global dos problemas relacionados ao contexto sociocultural da mulher e das DST.

De forma global, existem duas necessidades urgentes em termos de desenvolvimento de meios eficazes de controle das DST/HIV na mulher: o desenvolvimento de testes diagnósticos simples e baratos para a detecção de infecções cervicais assintomáticas, e, sobretudo, o desenvolvimento de um método seguro, controlado pela mulher, que ofereça proteção contra a infecção por HIV e outras DST. O baixo nível de investimento nestas áreas e a conseqüente demora na disponibilização de meios eficazes refletem a falta de priorização da saúde da mulher, não somente no Brasil, mas em todo o mundo.

\section{Referências Bibliográficas}

Aleixo Neto, A. et al. Avaliação de um esquema diagnóstico prático para a vaginose bacteriana. Jomal Brasileiro de Ginecologia, 104(7):209-2 12, 1994.

AmARAL, M.G. et al.Chlamydia trachomatis infection and risk factors in pregnant women. Revista da Associação Brasileira de Medicina, 41:193-196, 1995.

ARAL, S. O. \& Holmes, K. K. Sexually transmitted diseases in the AIDS era. Scienlific American, 264(2):18-25, 1991.

ARROIO, G.; LNNEMAN, C. \&WESSLER, T. Role of the Papanicolaou smear in diagnosis of chlamydial infections. Sexually Transmited Diseases 16:11-14, 1989.

BaDIAN, R. et al. Avaliação Qualitativa: Projeto Mulher-Ams-Prevenção. Rio de Janeiro: Bemfam (Sociedade Civil de Bem-Estar Familiar no Brasil), 1996.

BoletTn INFORMativo De La Unón. Distribuição dos diagnósticos de DST realizados no Serviço de Dermatologia Sanitária da Faculdade de Saúde Pública da Universidade de São Paulo. Boletin Informativo de la Unión, 20(80):3, 1995.

Bounds, W. Female condoms. European Journal of Contraception and Reproductive Health Care 2(2):113-116, 1997.

BraDDICK, M. R. et al. Towards developing a diagnostic algorithm for Chlamydia trachomatis and Neisseria gonorhoeae cervicitis in pregnancy. Genilourinary Medicine 66:62-65, 1990.

Brasil. Ministério da Saúde. Programa Nacional de Controle de DST/Aids. Boletim Epidemiológico de DST, Ano III, № 01, março a agosto, 1996.

Brasiz. Ministe̊rio da Saúde. Programa Nacional de Controle de DST/AIDs: Centros de Referência Nacional em DST/AIDS, 1993. 
Brasil. Ministério da Saúde. Programa Nacional de Controle de DST/Aids: Abordagem Sindrômica das Doenças Sexualmente Transmissíveis, 1993a.

BRUM, V. M. A. \& BRUM, J. G. W. Trichomonas vaginalis em pacientes de ambulatório. Revista da Associação Médica do Rio Grande do Sul (Amrigs) 28(4):360-362, 1984.

BRUNHAM, R. C. \& EMBREE, J. E. Sexually Transmitted Discases: Current and Future Dimensions of the Problem in the Third World. In: Reproductive Tract Infections. Global Impact and Prionities for Women's Reproductive Health (A. Germain, K. K. Holmes, P. Piot \& J. N. Wasserheit, orgs.). New York: Plenum Press, 1992, p. 35-60.

COSTA, N. F. P., Fontes, R. D. \& PETT, V. L. B. Prolocolode atenção às doenças sexualmentetransmissiveis. Rio de Janeiro: Bemfam, 1997.

Cunha, V. F., CaRvalHo, J. P. P. \& Belda, W. Aspectos do problema da sífilis em duas unidades de atenção a gestantes na capital de São Paulo. Anais Brasileiros de Dermatologia 58(2):62-66, 1983.

DaCunha, R. A. F., Takmoto, S. \& CURY, M. Pesquisa de Ureaplasma urealyticum em gestantes e sua correlação com a presença de Trichomonas sp. Revista Farmacêulica e Bioquímica da Universidade de São Paulo 24(1):71-75, 1988.

DE ANDRADE, A. L. S. S. et al. Rastreamento sorológico para doenças infecciosas em banco de sangue como indicador de morbidade populacional. Revista de Saúde Pública, São Paulo, 23(1):20-25, 1989.

De SCHRYVER, A. \& MeHeus, A. Epidemiology of sexually transmitted diseases: the global picture. World Healh Organization (WHO) Bulletin, 68:639, 1990.

DIXON-MUELLER, R. \& WASSERHET, J. A cullura do silêncio. As infeç̧ões do trato reprodutivo nas mulheres do terceiro mundo. New York: International Women's Health Coalition / São Paulo: Coletivo Feminista Sexualidade Saúde, 1991.

D'ANGELO, L. A., et al. Avaliação do manejo de casos de DST utilizando indicador proposto pela OMS (Pl6 e PI7). In: I Congresso Brasileiro de Prevenção das DST/AIDS, Salvador, Bahia, Dez. 1996.

ELIAS, C. J. \& HeIse, L. L. Challenges for the development of female-controlled vaginal microbicides. AIDS 8:1-9, 1994.

FARLEY, TM.M., ct al. Intrauterine devices and pelvic inflammatory disease: an international perspective. Lancet 339: 785-788, 1992.

FAÚNDES, A. \& TANAKA, A. C. Reproductive tract infections in Brazil: solutions in a difficult economic climate. In: GerMAIN, A. et al.. (orgs.). Reproductive Tract Infections. Global Impact and Priorilies for Women's Reproductive Heallh. New York: Plenum Press, 1992, p.253-274. 
GrFFrn, K \& Lowndes, C. M. Gender, sexuality and the prevention of sexually transmissible diseases: a Brazilian study of clinical practice. Social Science and Medicine, 48:283-292, 1999.

GrR, E. et al. Estudo das condutas adotadas por balconistas de farmácias frente a casos relatados de gonorréia. Medicina, Ribeirão Preto, 24:15-25, 1991.

GOMES, F. B. et al. Evaluation of the national congenital syphilis surveillance system in Brazil, 1993 to 1995. XI International Conference on AIDS, Vancouver, Canada, 1996.

Gonçalves, A., PAes E Alcântara, M.F.L. \& DA Silva, L.A. Incidência de gonorréia em população previdenciária da Baixada Santista. Revista Brasileira de Patologia Clínica 20:47-52, 1984.

GrimES, D. A. Deaths due to sexually transmitted diseases. The forgotten component of reproductive mortality. Journal of the American Medical Association, 255:1727-1729, 1986.

GROSSKURTH, H. et al. Impact of improved treatment of STD on HIV infection in rural Tanzania: randomised controlled trial. The Lancet, 346:530-536, 1995.

Guerreiro, H. M. N. et al. Vaginite por Gardnerella vaginalis - prevalência e avaliação de metodologia para seu diagnóstico. Revista de Microbiologia, 18(4):305-310, 1987.

GUINSBURG, R., et al. Sorologia positiva para sífilis no período neonatal: prevalência em maternidade de nível secundário. Associação com fatores de risco maternos e com sorologia positiva para HIV-1. Revista da Associação de Medicina Brasileira, 39 (2):100-104, 1993.

HATChER, R. A. et al. Contraceptive Technology: International Edition 91-121, 1989.

HIRA S.K., et al. Condom and nonoxynol-9 use and the incidence of HIV infection in serodiscordant couples in Zambia. Intermational Joumal of STD and AIDS, 8: 243-50, 1997.

Holmes, K. K, Delay, P. R. \& Cohen, M. S. STD control: A public health priority. In: DALLABetA, G. A.; LAGA, M. \& LAmpteY, P. R. (orgs).Control of Sexually Transmilled Diseases. A Handbookfor the Design and Management of Programs. Arlington, Virginia: The AIDS Control and Prevention (ArDSCAP) Project/Family Health International, 1996, p. V.

Hughes, V. HIV and cervical cancer, 1994. Monografia de mestrado. Berkeley: Epidemiology Program, University of California.

KREISS, J., et al. Association between cervical inflammation and cervical shedding of human ...... immunodeficiency virus DNA. Joumal of Infectious Diseases, 170:1597-1601, 1994.

LAMPTEY, P.R. \& GoOdRIDGe, G. Condoms. In: Dallabetta, G. A.; LAGA, M. \& LAMPTEY, P. R. (orgs). Control of Sexually Transmitted Diseases. A Handbook for the Design and Management of Programs. Arlington, Virginia: The AIDS Control and Prevention (AIDSCAP) Project/Family Health International, 1996, p.73-103. 
LOWNDEs, C. M. Um estudo da prêvalencia e características epidemiológicas de infecções por Chlamydia trachomatis e Neisseria gonorhoeae em mulheres de baixa renda no município do Rio de Janeiro. In: Relatório final de pesquisa: Gênero, Sexualidadee Saúde: Vertentes (K.Giffin, ed.); Fundação Ford (doação 925-1330); Rio de Janeiro, 1995.

LoWndes, C. M. \& Gifrn, K. Gênero e Doenças Sexualmente Transmissíveis. Ação Anti-AIDs (Boletim Intemacional sobre Prevenção e Controle de AIDs), 26:3-4, 1995.

LOWNDES, C. M.; Domingues, A. L. S. \& CINTRA, A. F. U. Infecção porChlamydia trachomatis em mulheres no município do Rio de Janeiro. In: VI Congresso Brasileiro de DST/AIDS, Porto Alegre/RS, 9-12 Outubro, 1996.

LURE, P. et al. Socioeconomic status and risk of HIV-1, syphilis and hepatitis B infection among sex workers in São Paulo State, Brazil. AIDS 9 Suppl.1:S31-7.

MAGALHÃES, M. Resistência cromossômica à penicilina em Neisseria gonorrhoeae. Revista de Microbiologia, São Paulo, 18(3):219-223, 1987.

MCGREGOR, J. A. Chlamydial infections in women. Obstetricsand Gynecology Clinics of North America, 16:467-478, 1989.

Meneus, A. Women's Health: Importance of Reproductive Tract Infections, Pelvic Inflammatory Disease and Cervical Cancer. In: GERMAN, A et al.. (orgs.) Reproductive Tract Infections. Global Impact and Prionities for Women's Reproductive Health New York: Plenum Press, 1992, p. 61-92.

MoнERDAUI, F., et al. Validation of national algorithms for the diagnosis of sexually transmitted diseases in Brazil: results from a multicentre study. Sexually Transmitted Diseases, 74 (Suppl. 1): S38-S43.

MUÑOZ, N. et al. Risk factors for HPV DNA detection in middle-aged women. Sexually Transmitted Diseases, 23:504-510, 1996.

MUSABA, E. et al. Long-term use of the female condom among couples at high risk of human immunodeficiency virus infection in Zambia. Sexually Transmitted Diseases 25(5):260-264, 1998.

NIRUTHISARD, S.; RODDY, R.E. \& CHUTIVONGSE, S. Use of nonoxynol-9 and reduction in rate of gonococcal and chlamydial infections. Lancet 339:1371-75, 1992.

Passos, M. R. L. \& FonSECA, C.G. Epidemiologia das DST. Jomal Brasileiro de Doenças Sexualmenté Transmissiveis (DST), 2:37-47, 1990.

RADDI, M. S. G. et al. Etiologia das infecções cérvico-vaginais em pacientes com indicação clínica. Revista Brasileira de Análises Clínicas 25:17-22, 1993. 
RoDDY, R. E. et al. A controlled trial of nonoxynol 9 film to reduce male-to-female transmission of sexually transmitted diseases. New England Joumal of Medicine 339: 504510, 1998.

RowE, P. J. Global Epidemiology of STD. International Symposium on the Impact of Infection on Reproductive Health, Ujung Pandang, Indonesia, October 1992.

Ryan, C. A. \& Holmes, K. K. How should clinical algorithms be used for syndromic management of cervical and vaginal infections? (Editorial). Clinical Infectious Diseases, 21:1456-1458, 1995.

Scholes, D. et al. Prevention of pelvic inflammatory disease by screening for cervical chlamydial infection. New England Joumal of Medicine, 334:1362-1366, 1996.

Schurz, K. F.; Schurte, J. M. \& BeRMAN, S. M. Maternal Health and Child Survival:Opportunities to Protect both Women and Children from the Adverse Consequences of Reproductive Tract Infections. In: GeRMAin, A. et al. (orgs.). Reproductive Tract Infections. Global Impact and Priorities for Women's Reproductive Health. New York: Plenum Press, 1992, p. 145-184.

SHERrIS, J. D. \& Fox, G. Infertility and Scxually Transmitted Disease: A Public Health Challenge. Population Reports, Série L, № 4:12 1-126; Baltimore, Johns Hopkins School of Public Health, Population Information Program, 1983.

TELNI, R. M. C. et al. STD survey among female inmates in the city of Santos, Brazil. In: XI International Conference on Aids, Vancouver, Canada, 1996.

Trieman, K et al. IUDs - An Update. Population Reports, Série B, № 6. Baltimore, Johns Hopkins School of Public Health, Population Information Program, 1995.

VAZ, A. J. et al. Sorologia positiva para síflis, toxoplasmose e doença de chagas em gestantes de primeira consulta em centros de saúde de área metropolitana, Brasil. Revista de Saúde Pública, São Paulo, 24(5):373-379, 1990.

VUYLSTEKE, B. et al. Clinical algorithms for the screening of women for gonococcal and chlamydial infection: Evaluation of pregnant women and prostitutes in Zaire. Clinical Infectious Diseases, 17:82-88, 1993.

VUYLSTEKE, B. \& MEHEUS, A. STD syndrome management. In: Control of Sexually Transmitted Diseases. A Handbook for the Design and Management of Programs DALABETTA, M. L. \& LAMPTEY P. R., (orgs.), pp. 149-168, Arlington, Virginia: The AIDS Control and Prevention (AIDSCAP) Project/ Family Health International, 1996.

WASHINGTON, A. E.; ARNO, P. S. \& BROOKS, M. A. The economic cost of pelvic inflammatory disease. Joumal of the American Medical Association, 255(13):1735-1738, 1986.

WASSERHET, J.N. The Significance and Scope of Reproductive Tract Infections Among Third World Women. International Journal of Cynecology and Obstetrics, Suplemento 3:146-149, 1989. 
WASSERHET, J. N. Epidemiologic synergy: interrelationships between HIV and other STDs. Sexually Transmilted Diseases, 19:61-77, 1992.

WeINSTOCK, H.; DeAN, D. \& Bolan, G. Chlamydia trachomatis infections. Infectious Disease Clinics of North America, 8(4):797-819, 1994.

World Development RePORT 1993. Investing in health. The World Bank. New York: Oxford University Press, 1993.

WORLD HEALTH ORGANZATION. Recommendations for the management of sexually transmitted diseases. WHO Advisory Group Meeting on Sexually Transmitted Diseases Treatments, 1993.

Worid Health Organization. Global Programme on Aids. An Overview of Selected Curable Sexually Transmitted Diseases, 1995.

World Headth Organizanon. Global Programme on Aids. WHO/ AidsCAP Co-sponsored satellite meeting on STD syndromic case management. Report. IUVDT World STD/ AIDS Congress, Singapore, 1995a. 



\section{5}

\section{Alds e Saúde Reprodutiva: novos desafios}

Regina Helena Simóes Barbosa

Às vezes eu tenho que transar pra satisfazer a ele porque... tendo mulher dentro de casa... se cu não procurar satisfazer ele, ele vai procurar mulher na ma e a coisa que eu tenho o maior medo é dessa doença, da Ams.

Não, quando eu toco [no assunto Arvs], ele desconversa. Diz: 'mulher boba, essa mulher só pensa em morrer, só pensa em doensa'...

Esse problema que eu tô de infeçãona urina é dele e ele passa pra mim. É por isso que eu às vezes falo pra ele: usa camisinha. Mas ele não accita.

Eu não converso [com o marido sobre sexo]. Às vezes eu procuro conversar mas ele...'ah, vou sair um pouquinho...' sempre fugindo. Enttão, agora, desisti.

Sem camisinha, não tem. Hoje em dia eu jamais teria qualquer relaşão com qualquer outra pessoa sem camisinha. I...I E agora a Ars, que não tem cura? E eu sempre pensei muito: eu tenho meu fitho, eu amo meu filhoe eu amo a mim. Então, eu não vou morrer por causa de amor...

Essa falas são de mulheres pobres, casadas, com filhos, moradoras de uma comunidade favelada da zona urbana do Rio de Janeiro (Simões Barbosa, 1993a). Elas expressam a angústia, a perplexidade, o medo e a impotência, mas também sua garra e coragem no enfrentamento de um duro cotidiano de vida em que as dificuldades de sobrevivência são muitas; as realizações pessoais, poucas. AAIDs entra em suas vidas como mais uma preocupação, como mais um 'risco' que se acrescenta a tantos outros, alguns mais imediatos e ameaçadores. Estes depoimentos revelam desde o conformismo com um destino que parece previamente traçado para as mulheres, suas contradições e conflitos ao buscarem caminhos para lidar com temas tão complexos quanto o amor, a 
dependência, a auto-estima, a fidelidade e o companheirismo - tão arraigadas na cultura de gênero-até uma consciente (e conquistada!) auto-estima, que não abre espaço para riscos que podem ser evitados, como é o caso do último.

Fica claro que não se podc discutir a Aids e seu cnfrentamento sem compreender os papéis de gênero e todas as implicações que esses têm nas relações entre homens e mulheres. A adoção de medidas preventivas, como é o caso do preservativo, esbarra em assuntos profundamente arraigados e sobre os quais ainda é difícil dialogar, romper barreiras (especialmente as emocionais), vencer medos, enfim, enfrentar abertamente uma ameaça real à vida de milhares, senão milhões, de homens, mulheres e crianças em todo o mundo. Porém, é importante ter clarcza que a vulnerabilidade-tanto individual quanto coletiva-ao vírus HIV é variável e depende de inúmeros determinantes sociais, econômicos, biológicos e culturais. Desta forma, a vulnerabilidade feminina ao HIV necessariamente remete às formas como homens e mulheres se relacionam em nossa socicdade, a dinâmica de poder que perpassa tais relações e o imaginário colctivo em relação aos papéis de gênero-que, certamente, constituem importantes variáveis na conformação do atual perfil da epidemia (Pitanguy, 1995).

\section{As abordagens teóricas da AIDs e o dilema biológico X social}

No campo das ciências da saúde, a AIDS tem se mostrado um campo fértil para o (re)desvelamento das complexas relações entre o biológico e o social.

Para além das interações reconhecidamente produtivas e legitimadas entre as ciências sociais e a medicina, coloca-se, mais do que nunca, a necessidade de secompreender a doença também a partir de seu referencial social, cultural e político.

O enfrentamento da pandemia de Aids e os conseqüentes enfoques teóricometodológicos devem considerar que a distribuição de poder nas relações entre homens e mulheres na maioria das sociedades e, particularmente, os aspectos vinculados às decisões sobre os encontros sexuais entre uns e outras - além da aparente maior suscetibilidade das mulheres para adquirir a infecção heterossexualmente - constituem uma dimensão complexa que provavelmente continuará tendo efeitos decisivos na evolução da epidemia em todas as nações e grupos sociais (Cáceres, 1995).

Neste campo, destaca-se a contribuição que a análise de 'gênero' trouxe para a discussão da sexualidade nas últimas décadas, causando, segundo alguns(as) autores(as), um impacto revolucionário, por meio da discussão e da crítica ao determinismo biológico e às conexões históricas entre a dominação masculina, a ideologia científica e o desenvolvimento ocidental da ciência e, em particular, da medicina (Vance, 1991). 
Historicamente, a identidade feminina e a condição social da mulher estiveram referidas a fatores biológicos, caracterizando, com a ajuda da ciência, a chamada "inferioridade biológica da mulher" (Giffin, 1991). Com o surgimento da análise feminista, posteriormente incorporada à discussão teórica e acadêmica pelo conceito de 'gênero', a hegemonia das explicações biológicas foram sendo substituídas pela ênfase na 'construção social da identidade feminina'. Dentro desta discussão, é explicitado o papel ideológico da ciência que, via de regra, relegou a questão da mulher à esfera do natural. Como bem sintetiza Giffin (1991),

a tese 'mulher é uma categoria biológica' foi substituída pela antítese 'mulher é uma construção social' $\mathrm{e}$, finalmente, pela síntese 'os fatos biológicos foram processados no nivel do social, que inclui as atividades cientificas que, por sua vez, reforçaram os estereótipos tradicionais que enfatizam os fatores biológicos'.

As tentativas de se historicizar a sexualidade produziram um corpo de trabalho inovador para historiadores, antropólogos, sociólogos e psicólogos, que passaram a desenvolver conversações interdisciplinares incomuns até então. O pressuposto de que a realidade é uma construção social parte do princípio de que atos físicos podem ter diferentes significados sociais e subjetivos, dependendo de como são definidos e compreendidos em diferentes culturas e períodos históricos. Assim, as construções sociais não só influenciam a subjetividade individual como organizam e conferem sentido à experiência sexual coletiva por meio do impacto das identidades sexuais, ideologias e regulações (Vance, 1991).

Com o surgimento da epidemia de AIDs, antigos dicotomias/dualismos ressurgem e, com eles, as tentativas de se retomarem análises reducionistas, biologicistas e/ou comportamentalistas. Muito do conhecimento produzido sobre a Aiss compreende a sexualidade como uma função fisiológica derivada de um corpo supostamente universal, ignorando seus aspectos culturais, políticos e históricos. Resultam desta abordagem pesquisas mais preocupadas em quantificar comportamentos do que em explorar significados, confundindo ato sexual com identidade sexual e tratando categorias como 'heterossexualidade' como não-problemáticas. Além do perigo de se repatologizar o sexo, como no século XIX e início do XX, quando a discussão pública do sexo era motivada e circunscrita pelos discursos das doenças venéreas, da prostituição e masturbação, o que abriu as portas para uma crescente intervenção governamental a partir da medicina e dos serviços de saúde (Vance, 1991).

Apesar dessas tendências, o cenário da Ains permanece complexo e contraditório: muitas investigações esbarram na discrepância entre as ideologias sobre a sexualidade e as experiências concretas, o que obriga os cientistas a reverem seus modelos:

Muito embora o movimento organizado das mulheres, no Brasil, tenha resistido a incorporar a temática da Ains à sua agenda (Barbosa, 1996), mais recentemente a categoria 'gênero' vem sendo gradativamente reconhecida e incorporada nos estudos sobre AIDS, oque (re)abre novas e promissoras abordagens teórico-metodológicas (Simões Barbosa, 1995). 
As ciências sociais, por intermédio das suas categorias explicativas da complexidade do social, aliadas ao conceito de gênero, têm - e continuarão tendo - um papel fundamental na explicitação de todas as questões apontadas, cruciais para determos essa epidemia que coloca em risco gerações inteiras de vidas humanas jovens.

\section{As representaçóes de gênero no contexto da epidemia de AIDs: 'a doença deles é nossa!!!'}

Nos últimos anos, os meios de comunicação vêm anunciando, de forma alarmista, a crescente infecção de mulheres pelo vírus HIV. Mais precisamente em 1992, durante a VIII Conferência Internacional de AIDS, realizada em Amsterdam, o mundo tomou conhecimento do risco que as mulheres corriam: "mulheres estão em risco para a Aids!, alertam cientistas" (Jomal do Brasil, 19/07/92). De lá para cá, a situação se agravou.

Recentemente, o último relatório do Programa das Nações Unidas para a Aids novamente alertou para o explosivo agravamento da infecção em mulheres e crianças, especialmente na América Latina e Caribe. Em São Paulo, entre 1993 e 1994, o número de casos se estabilizou entre homens e se multiplicou por cinco entre as mulheres (Jomal do Brasil, 29/11/96). Mais recentemente, as autoridades de saúde brasileiras fizeram um novo alerta: "Ministério alerta mulheres sobre AiDs", chamando a atenção para o fato de que crescem os casos de mulheres infectadas nas relações heterossexuais (Jomal do Brasil, 8/3/97).

Pesquisas recentes mostram que, ao contrário do que preconceituosamente se supunha, são principalmente as mulheres casadas ou com um único parceiro as que mais estão sendo atingidas pela ArDs. Esse perfil feminino da síndrome revela claramente que as questões de gênero estão presentes desde o início na determinação e na representação da epidemia, mas somente agora se tornam explícitas.

O que houve com uma epidemia que, desde o aparecimento dos primeiros casos, no início dos anos 80 , foi associada a homens homossexuais e chamada de 'peste gay'? A construção social e científica da ArDs, fortemente marcada por representações de classe, raça e gênero, deu margem a interpretações preconceituosas e equivocadas, que muito dificultaram-e dificultam - as estratégias de enfrentamento. Inclusive, e principalmente, a falsa sensação de que, desta vez, as mulheres estavam excluídas. Como afirma Ramos (1992),

preconceitos, estigmas e discriminações podem aumentar quando massacres lingüisticos do tipo 'a AIDS não discrimina sexo, raça ou cor' são acionados ali onde negros, hispânicos e mulheres estão sendo massacrados pelo vírus. 
Ao se refletir sobre o impacto a gravidade do vírus HIV para a população feminina, deve-se, necessariamente, considerar os determinantes sociais, econômicos, culturais e de saúde que agravam a 'vulnerabilidade' ${ }^{1}$ das mulheres, especialmente no atual contexto mundial, em que as desigualdades econômicas e sociais se aprofundam. Nos países pobres, porém, a situaçãoé mais grave, na medida em que a insuficiência, ou mesmo ausência de políticas sociais compensatórias, agravam a situação de vida das parcelas da população que já vivem no limiar da pobreza. Nesse contexto, a situação da população feminina édesvantajosa. Alguns dados ajudam a comporum quadro dessa situação.

Nos Estados Unidos, um dos países mais prósperos do mundo, dois em cada três adultos que viviam abaixo do nível de pobreza em 1983 eram mulheres. Esse fenômeno - chamado de 'feminização da pobreza' - ocorre tanto nos países ricos quanto nos pobres, especialmente na última década, quando o desemprego aumentou consideravelmente em quase todo o mundo (Panos, 1993). No cenário da Aids, assiste-se não só à 'pauperização' da epidemia, como à sua 'feminização', pois o vírus HIV, como se sabe, se dissemina mais rapidamente entre os setores sociais de menor poder na sociedade.

Com relação à questão reprodutiva, os dados são dramáticos e revelam uma situação preocupante para as mulheres. No Brasil, a idade média das mulheres esterilizadas caiu de 34 para 29 anos (pesquisa realizada pelo IPEA BENEAM, publicada parcialmente no Jomal do Brasil, 29/1 1/96). Entre as mulheres casadas, $40 \%$ estão esterilizadas; entre todas as mulheres que usam métodos anticonceptivos, apenas $4,4 \%$ adotam o preservativo, 0 que mostra a pouca tradição de seu uso na cultura brasileira. A opção pela esterilização, especialmente em idade tão precoce, pode ser um indicador das dificuldades que as mulheres têm na negociação de métodos anticonceptivos que pressupõem uma maior participação masculina (Goldstein, 1992). Além disso, 51\% das jovens entre 15 e 19 anos que não freqüentam a escola já têm filhos. Esse alarmante índice revela a ausência de educação sexual para os jovens e a falta de acesso de significativas parcelas da população às informações contraceptivas e serviços de planejamento familiar.

A vida reprodutiva das mulheres retrata a história de sua opressão. As pílulas de vinte anos atrás foram, inicialmente, libertadoras da sexualidade feminina. Alguns anos depois, tornaram-se problemáticas: além das conseqüências adversas para a saúde das mulheres, os homens afastaram-se definitivamente da responsabilidade pela anticoncepção. Hoje, alguns anos depois das primeiras laqueaduras, já circula uma fala que desmonta a magia deste método radical e irreversível: o arrependimento, a melancolia pela gestação que não pode mais ocorrer, queixas vagas que retornam aos consultórios e estudos que revelam novos dados sobre efeitos colaterais.

\footnotetext{
' Vulnerabilidade é aqui compreendida como um conceito que avalia o risco de infecção para o HIV, levando em conta o contexto socioeconômico e cultural dos indivíduos e suas coletividades (ManN et al., 1993). Tal conceito é muito mais abrangente do que os anteriores - grupo de risco e, posteriormente, comportamento de risco - pois considera que o risco que uma pessoa tem de se expor ao HIV é, além de individual, coletivo e, além de biológico ou comportamental, cultural e político.
} 
Com o passar do tempo, as mulheres constatam que os 'novos' métodos não alteram seu status como cidadãs e trabalhadoras $\mathrm{c}$ trazem complicações para sua saúde. Além disso, o preservativo, o coito interrompido e a tabela - métodos que pressupõem a participação masculina - foram isolados. Com o surgimento da AIDS, as conseqüências são visíveis: os homens distantes das decisões anticonceptivas; as mulheres, 'convencidas' sobre os benefícios dos novos métodos.

Apesar de o preservativo feminino já estar sendo testado em vários países do mundoe geralmente com boa aceitação pelas mulheres e seus parceiros, sabe-seque seu (alto) custo será problemático para os países pobres. Além disso, pesquisas recentes revelam que, mesmo não interferindo no prazer sexual das mulheres, a maioria dos motivos que estas apontaram para gostardo prescrvativo feminino foram centrados na perspectiva masculina (Ray et al., 1995).

Atualmente, a alarmante opção das mulheres, especialmente as pobres, pela laqueadura e outros métodos irreversíveis parece indicar que estas, num contexto de opções limitadas, conforme Xavier et al., 1989: "pagam o preço das decisões tomadas no terreno da realidade objetiva: as precárias condições de vida, a oferta limitada de métodos reversíveis, a falta de assistência adequada c a ausência de solidariedade dos companheiros."

Os questionamentos que hoje são apresentados - e que representam um desafio urgente não só para os 'especialistas', mas para toda a sociedade são: como reintroduzir o preservativo na vida sexual de homens e mulheres? Como superar e mudar uma história que, como se viu, tenta impor às mulheres um discurso e um conhecimento que não levam em conta suas reais necessidades, tanto biológicas quanto afetivas e sociais? Como trazer os homens para essa discussão de forma que estes assumam uma participação responsável e solidária no campo das decisões sexuais?

\section{A epidemiologia da AIDs e as mulheres}

As estimativas da Organização Mundial de Saúde (OMS) indicam que dos 10 a 14 milhões de pessoas infectadas pelo HIV no mundo um terçoé de mulheres (OPS, 1990) que contraíram o vírus em relações sexuais. A OMS prevê que, até o ano 2000, 75 a 80\% das infecções pelo HIV terão ocorrido pela via das relações heterossexuais e que 13 milhões de mulheres estarão infectadas. Destas, 4 milhões deverão estar mortas (Panos, 1993).

No Brasil, a relação homem/mulhervem mudando drasticamente nos últimos anos. Em 1985, era de 35:1; em 92, 4:1; e, em 96, 3:1 (MS, 1996). A transmissão heterossexual vem assumindo importância cada vez maior para a população feminina, sendo responsável, no período 1993/1994, por 54,2\% dos casos notificados (Barbosa et al., 1996).

AArss já é a principal causa de morte entre mulheres de 20 a 34 anos em São Paulo. Segundo estimativas, existiam, em 1994, aproximadamente 420 mil pessoas infectadas 
pelo HIV, sendo 60 mil mulheres (Barbosa et al., 1996). Se levarmos em conta que o índice de subnotificações no Brasil é clevado, é possível que o quadro seja mais grave do que se pensa e conhece.

Em São Paulo, 45\% das infectadas têm um único parceiro. O perfil ocupacional das mulheres infectadas, tanto em São Paulo quanto no Rio de Janeiro, revela que são as donas de casa e as empregadas domésticas as que mais vêm sendo atingidas pelo vírus HIV (Barbosa et al., 1996; Matida, 1994). Além disso, registra-se uma acentuada queda no número de casos entre mulheres com nível superior de escolaridade e, inversamente, ascensão dos casos entre as de baixa. Longe de ser uma doença de mulheres 'promíscuas', ou das trabalhadoras sexuais, a AIDs, hoje, se configura como um problema da população feminina em geral e, particularmente, das mulheres mais pobres, com menor acesso às informações e serviços e menor poder para tomar decisões, especialmente as relacionadas ao sexo.

Mesmo com as evidências acumuladas de que a transmissão do HIV podia ser heterossexual - sempre foi esse o padrão de transmissão no continente africano- os discursos científico e social continuaram, até o final da década de 80 , a representar as mulheres como excluídas da epidemia. Quando as evidências da Ains em mulheres aumentaram (ironicamente, 'descobriu-se' o grande contingente de mulheres notificadas na rubrica 'outros'), as especulações as associaram às prostitutas, usuárias de drogas injetáveis e mulheres do Terceiro Mundo. As prostitutas seriam os 'reservatórios de HIV' que ameaçariam a sociedade e, paradoxalmente, as mulheres com um único parceiro, monogâmicas e em idade reprodutiva, foram excluídas do risco. Com a constataçãotardia - de que este contingente de mulheres estava sendo crescentemente atingido, passaram a representar uma ameaça para as crianças, que poderiam nascer infectadas. Como aponta Carovano (1991),

Tanto 'mães' como 'putas' são definiçōes baseadas em seus relacionamentos com outros, o que reflete as necessidades de homens e crianças, deixando margem para que as mulheres sejam tratadas ou como uma 'preocupação' ou como uma 'ameaça' para os outros.

A construção científica de um modelo de epidemia que ignorou desde o princípio seus determinantes sociais e culturais tevc e tem sérias conseqüências nas estratégias de enfrentamento. Até hoje, pouca atenção e recursos têm sido destinados à prevenção, pesquisa e tratamentos voltados para as mulheres. Os cientistas constatam que elas estão morrendo cada vez mais, apesar dos avanços no tratamento da doença. O tempo de sobrevivência das mulheres com Arps é menor do que o dos homens; nelas, a doença é mais letal. Uma das hipóteses trazidas à tona é a demora na procura de serviços médicos Uornal do Brasil, 8/5/97). A situação das mulheres, especialmente no Terceiro Mundo, é grave, pois, como afirma Panos (1993). 
ainda hoje, no início dos anos 90 , as opções das mulheres - sobretudo aquelas relacionadas às posturas sexuais - estão sujeitas a coerções poderosas e profundamente enraizadas. A consciência do perigo que o vírus representa para a sociedade como um todo leva agora o foco das atenções para as limitações sofridas pelas mulheres no espaço de suas relações sociais.

\section{A vulnerabilidade feminina diante do HIV}

A vulnerabilidade feminina ao HIV/AIDs envolve fatores biológicos - que adquirem especificidades no corpo feminino - e relações sociais, que determinam, em última instância, o poder das mulheres não só para se proteger da infecção como para influir nas decisões políticas que envolvem a destinação de recursos para pesquisas relacionadas a sintomas, tratamentos e vacinas. Como bem apontam Galvão \& Parker (1996):

A vulnerabilidade das mulheres frente ao HIV/ AlDs e o impacto da epidemia nas suas vidas têm sido colocados como uma questão secundária - cercada, quase sempre, pelo silêncio e descaso tradicionalmente associados com a sexualidade e a saúde femininas.

Biologicamente, as mulheres estão sujeitas a doenças específicas de órgãos genitais, como doença pélvica, endometriose, tumor uterino, câncer cervical; outras, a uma incidência maior de algumas doenças (infecção do trato urinário, câncer de mama e infecção por papilomavírus) e o sofrimento de sérias conseqüências decorrentes de problemas comuns, como gonorréia e clamydia, por exemplo. As mulheres, de uma forma geral, morrem muito de complicações associadas à gravidez e doenças dos órgãos reprodutivos. Se, no campo das Doenças Sexualmente Transmissíveis (DST), sabe-se que existem especificidades entre homens e mulheres, inclusive na apresentação de sintomas, verifica-se, ainda, que as informações sobre a infeccção pelo HIV nas mulheres não são suficientes. Pode-se supor também que o aborto, prática criminalizada e clandestina e que é um indicador de insegurança no controle da fecundidade, aumenta as chances de infecção pelo HIV das mulheres, tendo em vista as condições precárias em que são realizados nos países latino-americanos.

Além disso, as queixas freqüentemente relacionadas ao HIV-como cansaço, perda de peso, apetite e outras - são interpretadas, pelos médicos e pelas próprias mulheres, como de origem psicossomática e/ou relacionadas ao stress, e não ao HIV (Denenberg, 1990).

Os poucos estudos realizados com mulheres apontam que o risco de se infectarem em relações sexuais desprotegidas é maior que do que o dos homens, provavelmente em função da conformação anatômica de seu aparelho genital (Panos, 1993).

No campo das pesquisas relacionadas a tratamentos e drogas, as mulheres têm sido discriminadas. Em 1989, o Laboratório Burrougs-Wellcome admitiu que o AZT causava câncer nos órgãos genitais de ratas (Banzhaf et al., 1990). Além disso, as mulheres foram 
mantidas à parte de muitas pesquisas com drogas terapêuticas, devido aos elevados custos financeiros envolvidos no potencial risco fetal de muitas drogas. Isto impede melhores estudos - não só os relacionados com os cânceres ginecológicos próprios da infecção pelo HIV, como das funções endocrinológicas, do ciclo menstrual, dos métodos anticonceptivos e outros.

Portanto, a rápida disseminação da epidemia de HIV/ArDs entre as mulheres brasileiras não pode ser dissociada da falta de responsabilidade que perpassa o desenvolvimento de programas integrados de atenção à saúde da mulher no Brasil.

A luta empreendida pelas mulheres organizadas, nas últimas décadas, para a implantação de serviços de saúde integrados e que abranjam a integralidade de sua saúde, especialmente as questões relacionadas à saúde reprodutiva (de maneira a atender de forma mais efetiva os problemas associados à desigualdade social e econômica e à generalizada negação dos direitos reprodutivos e sexuais), resultou, em 1983, na criação do PAISM. Porém, como atesta Costa (1992), a qualidade dos serviços de saúde disponíveis para as mulheres no Brasil, no sistema de saúde pública, vem decaindo com o passar dos anoscomo ocorre com a qualidade dos serviços de saúde pública em geral. Além disso, uma necessária integração entre as atividades de prevenção da Aibs e os serviços de saúde da mulher tem sido permanentemente sacrificada, na medida em que os programas de saúde da mulher que de fato existem vêm deixando de incorporar a Ains como ponto significante, ao passo que os programas de prevenção de Aibs continuam a se voltar predominantemente para a sexualidade masculina ou para as prostitutas.

Enfim, toda a discussão que envolve a 'vulnerabilidade' das mulheres à infecção pelo HIV implica na compreensão das relações de poder entre os sexos, que levam as mulheres a aceitarem, nem sempre passivamente, o destino para elas traçado.

\section{A prevenção e o sexo seguro para as mulheres: seguro?}

O que podem fazer as mulheres para se proteger da infecção pelo HIV, se nossa cultura confere aos homens o poder - quase absoluto - sobre as decisões sexuais? Podem as mulheres impor aos homens o uso do preservativo? Será realista esperar que os homens venham a assumir suas reponsabilidades e se disponham a experimentar práticas que lhes pareçam contrárias ao seu prazer è sua própria 'natureza', como é o sexo não-penetrativo? Poderá a fidelidade conjugal deixar de ser um preceito religioso e jurídico em culturas em que a representação da masculinidade pressupõe inúmeras parcerias?

Quanto menos poder de barganha tem a mulher, mais difícil é, para ela, evitar os riscos. Ao insistir no uso da camisinha, ou apenas pedir aos seus parceiros que a usem, muitas receiam estarem colocando em risco sua relação - o que pode signi- 
ficar não só a perda de stalus e segurança emocional, mas, principalmente, o suporte econômico necessário à sua sobrevivência. Muitas mulheres com filhos dependentes estão em situação ainda mais vulnerável. Como afirma Panos (1993),

o comportamento humano está enraizado nos fatores sociais e econômicos da vida de um indivíduo. Ainda hoje, no início dos anos 90, as opções das mulheres - sobretudo aquelas relacionadas a posturas sexuais - estão sujeitas a coerções poderosas e profundamente enraizadas.

A maior parte dos homens, em diversas culturas ocidentais, considera o sexo com preservativo desagradável e desnecessário, c tenta, de todas as maneiras, evitá-lo. Para muitas mulheres, o medo da infecção pelo HIV é menor do que o medo de sugerirem aos seus parceiros o uso de preservativos (Pearl, 1990). Além disso, "as mulheres que tentam introduziro condom na relação são, freqüentemente, percebidas como'preparadas demais' para o sexo, desconfiadas da infidelidade do parceiro, infiéis ou mesmo infectadas peloHIV" (Carovano, 1991).

A maioria dos programas preventivos destinados às mulheres sãodirigidos às trabalhadoras sexuais, vistas, conforme referido anteriormente, como "reservatórios de HIV que ameaçam a humanidade". Mais recentemente, novos programas têm sido criados para as mulheres grávidas, o que reflete a preocupação com o crescente número de crianças infectadas.

As mulheres em idade reprodutiva são as mais negligenciadas: apesar de serem relativamente mais bem informadas sobre sexualidade e planejamento familiar, e talvez mais capazes de fazer escolhas mais maduras sobre seus comportamentos sexuais, estão em risco crescente para a Aibs. Este é o grupo que menos tem recebido atenção: são as 'boas moças', representadas como assexuadas e que, só quando grávidas, são defrontadas com os riscos potenciais de estarem infectadas.

Ironicamente, apesar de serem mulheres em idade reprodutiva, o único conselho dado a elas é que, ao se perceberem em risco, usem métodos que evitam a concepção, o que expõe a contradição entre a prevenção da doença e o papel reprodutivo da mulher. Assim, as medidas de prevenção que negam o papel reprodutivo da mulher vão ter um impacto limitado, bem como os métodos que contradigam as normas de fertilidade das sociedades. De acordo com Panos (1993):

O processo de tomada de decisões sobre o uso do preservativo (e outros contraceptivos) está relacionado a um conjunto de influências sociais, econômicas e culturais que, além de muito complexo, é sempre voltado para um reforço do perfil materno das mulheres.

Os programas de prevenção à Airs dirigidos às mulheres devem ser desenvolvidos em um contexto de compreensão das barreiras sociais e cconômicas que resultam na falta de poder que caracteriza as mulheres afetadas pela Aids. Além disso, devem contar com a participação das mulheres-alvo na definição de todos os estágios das políticas e programas que estão sendo desenvolvidos pois, como adverte Berer (Panos, 1993), 
as escolhas e prioridades das mulheres precisam encontrar eco junto aos responsáveis pelas políticas públicas. Se as mulheres não falam nem agem no sentido de se fortalecerem(...) nossos interesses serão esquecidos ou serão submetidos aos interesses do homens.

Por fim, resta questionar c re-pensar o modelo de 'sexo seguro', surgido dos grupos homossexuais americanos e que tem sido amplamente utilizado nas campanhas educativas em AIDS, com forte apelo à proteção do corpo e à responsabilidade mútua, além da tentativa de erotizá-lo. Porém, serão essa estratégia e esse discurso adequados para as mulheres? O que ć 'sexo seguro' para elas? A história da sexualidade feminina sempre remeteu para o 'sexo inseguro': o medo da gravidez indesejada, do aborto, do estupro, do parto inseguro e em precárias condições etc. Além disso, a temática das DST nunca esteve presente como uma preocupação, a não ser com as prostitutas. Os homens, nos seus papéis sociais de 'protetores' da família e da prole, não se admitem como 'trasmissores de doenças' para a esposa/mãe.

Como, então, se coloca a discussão do sexo scguro-que pressupõe diálogo e confiança mútuos-em uma cultura que não discute sexualidade, afeto e prazer; e em que o sexoé circunscrito ao mundo privado? Será, além disso, que o leitmotiv do sexo seguro- uso do preservativo em todos os encontros sexuais, independentemente do número de parcerias (e que supõe um acordo tácito e silencioso sobre as inúmeras parcerias) -é o que desejam as mulheres nas suas relações afetivas/sexuais? Cremos que não. Em nossa pesquisa com mulheres de baixa renda (Simões Barbosa, 1993a), constatamos que as entrevistadas, embora associem em sua maioria o sexo seguro à prevenção de doenças, especialmente a AIDS, o atribuem à fidelidade do companheiro. Porém, quase nenhuma confia nessa fidelidade: "homemé assim, impulsivo, não secontrola". Poucas conseguem discutircom ocompanheiro. Asaída, para àlgumas mais temerosas, éaconselharo parceiroa usara camisinha com as 'outras'. Porém, isso tem um custoemocional alto para as mulheres, como ilustra o seguinte depoimento accrca da infidelidade do marido: "Eu preferia não saber. Eu não quero, porque a verdade dói e eu tenho medo, então. Eu não tenho estrutura suficiente pra suportarcertascoisas."

Será, então, que devemos insistir no sexo seguro tal como está colocado? Não seria esse o momento de se investir em uma transformação mais profunda das relações entre os sexos? Devemos optar por uma linha mais 'pragmática' de ação, ou investir nossos esforços em transformações e utopias? O discurso feminino aponta, nos parece, para o segundo caminho. As mulheres continuam a descjar o amor-companheirismo, a despeito de todas as transformações ocorridas em seu mundo produtivo-reprodutivo.

Todas essas indagações nos apresentam o desafio de re-pensar não só as estratégias preventivas, mas também a produção de conhecimentos sobre o mundo reprodutivoamoroso das mulheres que lhes proporcione maior visibilidade social.

Mais recentemente, vem-se colocando a necessidade - urgente e inadiável-de inclusão dos homens heterossexuais nas agendas de pesquisa e programas preventivos. 
Como aponta uma pesquisadora (Panos, 1993),

Para as mulheres, as mensagens atingem apenas uma metade do casal. Qualquer proposta com o objetivo de prevenir a transmissão heterossexual do HIV deve dirigir-se aos homens e às mulheres. Mas, na maioria das vezes, os homens heterossexuais não têm sido considerados público-alvo. Eles podem estar sendo contemplados por tabela, pelo fato de serem parte de um casal, ou, quem sabe, porque transam com prostitutas, mas são poucas as iniciativas que tentam atingir os homens de uma forma mais geral (...).

Constata-se, hoje, uma crescente preocupação de pesquisadores e profissionais da saúde que atuam no campo da saúde reprodutiva com essa temática. E, também, uma demanda aos serviços de saúde - ainda incipiente e desorganizada - de homens interessados em discutir assuntos referentes a saúde e papćis sexuais. Alguns autores apontam para uma 'crise da masculinidade' (Nolasco, 1993). É possível suporque sim, na medida em que o próprio processo de transformações econômicas e produtivas em curso está gerando profunda insegurança, especialmente no que sc refere à vinculação ao emprego. Isto, certamentc, está tendo - e terá - repercussões no histórico papel masculino do 'provedor familiar' (Giffin, 1994). Cabe, portanto, um investimento em pesquisas e programas que potencializem e transformem essas questões na direção de mudanças qualitativas nas relações entre os sexos.

\section{As mulheres e a luta pelos direitos reprodutivos no contexto da epidemia de AIDs}

A epidemia de AiDs recoloca em pauta a longa e histórica luta das mulheres por seus direitos reprodutivos. Afinal, quanto mais mulheres em idade reprodutiva ficarem infectadas e mais crianças desenvolverem AIDS, a procriação pode ficar sob um controle estatal ainda maior. Se todos praticarem o 'sexo seguro', não nascerão mais bebĉs. Então, as mulheres podem ser o próximo - mas não o primeiro - grupo testado compulsoriamente para o HIV, com a presumível separação entre as infectadas e nãoinfectadas (Simões Barbosa, 1993b).

No Brasil, como em outros países, a maioria das mulheres está sendo diagnosticadamuitas vezes compulsoriamente- para o HIV quando grávidas, ao procurarem assistência pré-natal. Como o teste anti-HIV vem sendo introduzido como rotina de pré-natal cm grande parte dos serviços públicos de saúde, ao menos nos grandes centros urbanos, a maioria recebe a notícia no meio de uma gravidez. Segundo pesquisa realizada em duas maternidades públicas do Rio de Janeiro, o número de gestantes que não sabiam que estavam contaminadas cresceu 200\% em três anos (entre 1992 e 1995). Além disso, o percentual de gestantes infectadas passou de $0,9 \%$ para $2,7 \%$ no mesmo período Vomal do 
Brasil, 06/10/96). A maior parte dessas gestantes confirma o atual perfil de mulheres infectadas: são mulheres casadas, monogâmicas e sem noção de seu risco e de como se contaminaram.

No País, já se 'ouviram' falas neste sentido. Em 1993, o Ministério da Saúde anunciou campanha para a 'prevenção' da gravidez em mulheres infectadas. Posteriormente, um renomado médico obstetra carioca, professor universitário, se posicionou publicamente favorável ao aborto obrigatório para mulheres soropositivas. Posições como essas, que podem parecer isoladas ou pessoais, expressam a visão de importantes segmentos sociais, inclusive de formuladores de políticas públicas.

Em relação ao sexo seguro, é fundamental lembrar que gravidez e esterilização não protegem as mulheres de nenhum tipo de infecção: esses eventos importantes na vida das mulheres sinalizam mudanças que requerem diferentes tipos de proteção e novas maneiras de se pensar a segurança no sexo. A gravidez é um momento especialmente vulnerável para as mulheres: há um futuro bebê a proteger, assim como a própria mulher. A amamentação, por sua vez, tanto para as mulheres soropositivas como para as que suspeitam ter o vírus (especialmente quando a mortalidade infantil é elevada), torna-se questão extremamente problemática (Berer et al., 1995).

Muitas mulheres não se incluem na categoria das que procuram um serviço de planejamento familiar ou materno-infantil: são as esterilizadas; as quejá passaram a menopausa; ou as que não têm filhos. Os serviços de prevenção de câncer uterino poderiam sero espaço para se abordar essas mulheres, mas são insuficientes na maioria dos países pobres, sem falar nas dificuldades de acesso aos serviços, mesmo nos grandes centros urbanos.

Estas teses, relativamentc pouco discutidas, somentc emergirão se as DST, o HIV e a AiDS forem inseridos na discussão da gravidez e da anticoncepção: para as mulheres - mas não somente para elas-o conceito de segurança em relação às DST eà ADs, que significa a prevenção de doenças que ameaçam a vida, étambém relevante para a gravideze a anticoncepção.

Somente quando todas essas questões estiverem juntas será possível começar a compreender o significado de suas interconexões e o que deveria ser uma 'abordagem integrada da sexualidade e da saúde c os direitos reprodutivos'. Desta maneira, crescentemente, as definições de sexo seguro se associam aos direitos, o que significa colocar o debate no campo das lutas jurídica e política.

Mas não só. Praticar o sexo seguro, não por um mês ou um ano, mas por toda a vida, é muito mais difícil do que muita gente julga querer ou poder. Aí reside a complexidade da questão que nos coloca o desafio de compreender como essas teses se configuram no âmbito das subjetividades e das culturas. Há que se ressaltar que homens e mulheres, ao longo de sua trajetória histórica, sempre aceitaram conviver com riscos, conscientemente ou não. Entre as mulheres na luta pelos direitos reprodutivos, houve um entendimento, nas últimas décadas, de que, quando elas controlarem sua fertilidade, terão mais poder e direitos nos seus relacionamentos afetivos e sexuais. Hoje, constatamos 
que o "buraco é mais embaixo". O uso de conhecimentos sobre a anticoncepção certamente permite maior controle sobre a fertilidade, mas isso não significa, necessariamente, que as mulheres tenham controle sobre sua fertilidade ou sobre os outros aspectos de suas relações (Bereret al, 1995). Porém, é indiscutívcl que, quando o controle da fertilidade é reduzido a informações técnicas e uso de métodos, sem se discutirem a sexualidade e as relações de gêncro, as mudanças são mais limitadas, e o poder é menos ameaçado ou, até, nãoameaçado. Falar sobre sexoć ameaçador. Educarosjovens para o sexoé vistocomo ameaçador. Mudar as práticas sexuais c torná-las mais seguras é percebido como ameaçador. É ameaçador para a autoridade masculina, parental, religiosa, enfim, para todos aqueles que decidiram o que é certo e o que é crrado para a sociedadecomoum todo.

Ainda há muito que avançar. Tem havido sucessos, sem dúvida, mas ainda há muitos problemas e dificuldades. Quinze anos de epidemia é um tempo curto e valores e crenças são muito profundos. Afinal,

Essas doenças (sexualmente transmissíveis) sempre foram vistas como resultado de uma sexualidade socialmente inaceitável, de uma falência moral do controle do indivíduo sobre seus impulsos e como uma punição pela transgressão de normas societais. (Gostin et al, 1995)

Enfim, a epidemia de AiDs toca em aspectos essenciais da vida humana: a sexualidade, a moral, as relações de gênero, as relações de poder, as relações com a vida e com a morte. Sem que se trabalhem todas essas temáticas será impossivel sensibilizar para as mudanças que o controle da epidemia exige.

Se nós, mulheres, fomos capazes de enfrentar e criar alternativas para a prevenção do câncer, para a contracepção, para a gravidez e o aborto, também podemos e devemos nos tornar conhecedoras dos problemas que a Aids está - e estará cada vez mais - trazendo. Somente assim se poderá enfrentá-la e criar as respostas necessárias à nossa autoproteção. Esse é mais um desafio que temos de enfrentar. Possivelmente não o último. Certamente, um dos mais graves à nossa saúde e nossas vidas.

\section{Referências Bibliográficas}

BANZHAF, M. Reproductive Rights and AIDS: the connections. In: THE ACT UP/New York. Women, Arss and Activism. Boston: South End Press, 1990.

Barbosa, R.M. Feminismo e Aids. In: Galvão, J. \& PARKER, R. (Orgs.). Quebrando o Silêncio: mulherese AIDs no Brasil. Rio de Janeiro: Ed. AbiNIMS-Uer/Relume-Dumará, 1996.

Barbosa, R.M. \& Villela, W.V. A Trajetória Feminina da Ams. In: Galvão, J. \& Parker, R. (Orgs.). Quebrando o Silêncio: mulheres e Ards no Brasil. Rio de Janeiro: Ed. ABI/IMS-UER /RelumeDumará, 1996. 
BERER, M. E RAVDRAN, TK. S. (Org.). Reproductive HealthMalters, London:(5), 1995.

BRaSIL. Ministério da Saúde. Boletim Epidemiológico de AIIS, set/nov, 1996.

CÁCERES, C. F. Aids: um desafio para as Ciências Sociais e a Medicina: La Construcción Epidemiológica. In: HARDY, E.; OsIS, M.J.D. \& CRESPO, E.R.(Ongs.). Ciências Sociais e Medicina. Atualidades e Perspectivas Latino-americanas. Campinas/SP: CEMICAMP, 1995.

Carovano, K. More than Mothers and Whores: redefining the Aids Prevention Needs of women. International Joumal of Heallh Services, I(1):131-142, 1991.

Costa, A.M. PAism: uma Política de Assistência Integral à Saúde da Mulher a ser Resgatada. São Paulo: Comissão de Cidadania e Reprodução, 1992 (Mimeo.)

DENENBERG, R. Unique Aspects of HIV Infection in Women. In: The Act Up/New York. Women, Aiss and Activism. Boston: South End Press, 1990.

GALVÀO, J. \& PARKER, R. (Orgs.). Quebrando o Silêncio: mulherese AIDs no Brasil. Rio de Janeiro: Ed. ABIN IMS-UER/Relume-Dumará, 1996.

GifFin, K. M. Nosso corpo nos pertence: a dialética do biológico e do social In: GrFin, K. M. (Org.). Cademos de Saúde Pública,VII(2), abr/jun:190-200,1991.

GIFFIN, K.M. Esfera de reprodução cm uma visão masculina: considerações sobre a articulação da produção e da reprodução, de classe e de gênero. Physis-Revista de Saúde Coletiva, 4(1):23-40, 1994.

GOLDSTEIN, D. Olugar da mulher no discurso sobre a AIDs no Brasil. In: Seminário Mutherese Ams - IMS/ Uers. Rio de Janeiro, 1992. (Mimeo.)

Mann, J.; Tarantola, D.J.M \& Netter, T.W. (Orgs.) A Airs no Mundo. Rio de Janeiro, Ed. Abia/MSUER/Relume-Dumará, 1993.

MATIDA, A. AIDS no Município do Rio de Janeiro: a vulnerabilidade da mulher à epidemia. Rio de Janeiro, 1994. (Mimeo.)

MarTin, E. The Woman in the Body. Boston: Beacon Press, 1984.

Nolasco, S. OMito da Masculinidade. Rio de Janeiro: Ed. Rocco, 1993.

Organización Panamericana de la Salud (OPS). Bolelín Epidemiológico. v.13, 1990.

Pavos, Dosstê. A Tripla Ameasa: mulherese Ams (Org. brasileira ABIA e SOS Corpo/Recife). London: Panos Institute Ltda., 1993.

PeArt, M. Heterosexual Women and Aids. In: The Act Up/New York. Women, Aids and Activism. Boston: South End Press, 1990. 
Pitanguy, J. Saúde e Cidadania: Ciências Sociais e Medicina. In: Hardy, E.; Osis, M.J.D. \& CRESPO, E.R. (Orgs.) Ciências Sociais eMedicina. Atualidades e Perspectivas Latino-americanas. Campinas/SP, CEMICAMP, 1995.

RAmOs, S. A Heterossexualização da ArDs nos anos 90: o papel das representações de gênero na construção de representações da Aids. (Mimeo). Rio de Janeiro. 1992.

SIMÕES BARBOSA, R.H. Aldse Gênero: as mulheres de uma comunidade favelada, 1993a. Dissertação de Mestrado. Rio de Janeiro: Ensp/Fiocruz (Mimeo).

SIMÕES BARBOSA, R.H. AIDS, gênero e reprodução. Revista Estudos Feministas I (2): 418-423, 19936.

SimŌEs BARBOSA, R.H. As mulheres, a Aids e a questão metodológica: desafios. In: CZERESNIA, D. et al. (Orgs.). Ards: Pesquisa Social e Educação. São Paulo/Rio de Janeiro: Hucitec/Abrasco, 1995.

The Act Up/New York. Women, Ards and Activism. Boston: South End Press, 1990.

TREICHLER, P. AIDS, Gender and Biomedical Discourse: current contests of meaning. In: FeE, E. \& Fox, D. (Orgs.) Ains: the Burdens of History. Berkeley: University of California Press, 1988.

VANCE, C.S. Anthropology Rediscovers Sexuality: a theoretical comment. In: Social Sciences and Medicine, 33(8):875-884, 1991.

XAVIER, D., ÁviLA, M.B. \& CoRReA, S. Questões feministas para a ordem médica: o feminismo e o conceito de saúde integral. In: LABRA, M.E. (Org.). Mulher, Saúdee Sociedade no Brasil. Rio de Janeiro: Vozes. 



\section{Direito à Saúde ou Medicalização da Mulher? Implicações para a avaliação dos serviços de saúde para mulheres}

Lynn D. Silver

\section{Introdução}

Existem duas grandes vertentes de preocupações ético-políticas na construção da saúde pública hoje em dia. A primeira visa a aumentar a eqüidade e qualidade de vida, garantindo o direito de todo cidadão à saúde e implica tanto na construção de condições de vida que promovam a saúde como na universalização do acesso a serviços de saúde de boa qualidade (Brasil, 1988). A segunda vertente chama a atenção para os perigos de tornar a saúde um mero objeto de consumo, que comercializa e medicaliza a vida e a sexualidade das pessoas, expondo-as a riscos e custos desnecessários e diminuindo sua autonomia e integridade (lllich, 1976; Barros, 1991).

Pese a estas preocupações as tendências recentes de organização dos sistemas de saúde e as políticas fomentadas em diversos países, de promover a privatização-com fins lucrativos - dos sistemas de saúde, contexto no qual tende a florescer a mercantilização da saúde. Esta tendência persiste, pese as pesquisas que demostram a maior eficiência de sistemas públicos ou gerenciados no interesse público, ainda quando se prestam serviços por meio de organizações de direito privado. Ainda há uma longa história de políticas que tornam a saúde e a vida reprodutiva objetos de metas demográficas e econômicas aos quais os direitos individuais são subordinados.

Talvez seja no campo da saúde da mulher que estas preocupações potencialmente contraditórias têm sido expressas com mais nitidez. Neste trabalho, refletimos sobre as implicações destas inquietudes para a avaliação dos serviços e tecnologias de saúde que se denominam 'para mulheres'. 


\section{A 'saúde da mulher' e o conceito de integralidade}

Um desafio inicial para a avaliação dos serviços de saúde 'para mulheres' é ter clareza sobre o objeto do qual estamos falando. Tradicionalmente, os serviços de saúde 'da mulher' têm sido entendidos como aqueles que atendem às necessidades de saúde relacionadas à reprodução humana - atendimento pré-natal, ao parto e puerpério, anticoncepção e, quando muito, detecção precoce de câncer nos órgãos reprodutivos ou tratamento de infertilidade. Esta abordagem, se ajudou a aumentar o acesso a estes serviços essenciais, também propiciou uma fragmentação no atendimento à mulher, cujos problemas de saúde não se limitam aos órgãos reprodutivos. A maioria dos contatos das mulheres com o sistema de saúde acontece por problemas agudos ou crônicos dc ordem não-reprodutiva. Esses contatos, geralmente, são 'oportunidades perdidas' para o atendimento às necessidades reprodutivas. Por outro lado, os serviços de saúde 'da mulher' mantêm-se igualmente cegos quando deixam de apreciar as outras necessidades da mulher como pessoa - problemas como hipertensão arterial, violência doméstica ou o câncer. Pode-se argumentar que cste problema não é limitado a clas: a organização do sistema de saúde como um todo sofre de falta de integralidade tanto no atendimento aos homens como às mulheres. No entanto, é no atendimento a elas que os serviços de saúde estabelecem estruturas c mecanismos específicos de parcialização do cuidado, tornando esta falta de integralidade mais patente e suscetível de críticas.

Quando se analisa o quadro de saúdc, detecta-se que, com a transição demográfica e epidemiológica, há uma crescente carga de morbidade e mortalidade entre as mulheres não relacionada à reprodução (Figura 1). O Banco Mundial (1993) estimou que a porcentagem de anos de vida perdidos ajustados por incapacidade (DalYs), devido aos problemas de saúde reprodutiva em mulheres de 15-44 anos, era de apenas 32\% na América Latina (11\% DST, 7\% HIV e 14\% materna) e 28\% na Ásia, comparada com 60\% na África.

\section{Figura 1 - Distribuição da carga de doença em mulheres de 15-44 anos, ajustados por incapacidade (DALYs), em países demograficamente em desenvolvimento $-1990$}

Fonte: Banco Mundial, 1993.

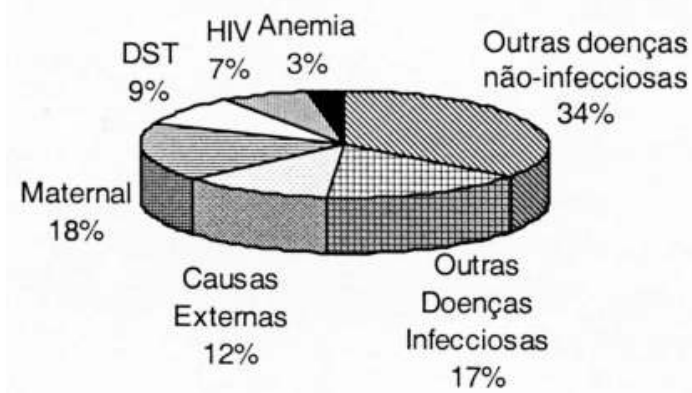


No Brasil, os padrões de mortalidade indicam claramente novos desafios para o atendimento à mulher, embora a atenção ao ciclo gravídico puerpcral ainda seja a primeira causa de internação hospitalar (Tabela 1). O quadro de mortalidade anteriormente apresentado demonstra o quanto estão-se modificando as necessidades de saúde da mulher brasileira. Em 1992, as doenças cardiovasculares mataram 70 vezes mais do que a gravidez e o parto. As chamadas 'causas externas'-que incluem acidentes $\mathrm{C}$ violência - nove vezes mais. Ou seja, embora as taxas de mortalidade materna no Brasil permaneçam escandalosamente altas, há problemas ainda muito mais graves que precisam ser resolvidos.

O programa de Atenção Integral à Saúde da Mulher (PAISM) adotou uma atitude revolucionária ao enfocar a saúde da mulher de forma integral, fugindo da tradicional abordagem limitada à saúde reprodutiva. No entanto, têm-se enfrentado enormes dificuldades para implantar, efetivamente, a integralidade dentro de um sistema de saúde que tende a seguir um modelo de especialização na clínica e verticalidade dos programas. Além disso, sua organização c financiamento precários não têm permitido um desempenho satisfatório tanto no atendimento às necessidades básicas no ciclo gravídico-puerperal, quanto no atendimento a outros problemas de saúde.

Portanto, o primeiro desafio para a avaliação de serviços de saúde para mulheres - e usamos o termo 'para' mulheres, incluindo o conjunto de serviços prestados à mulher, sejam ou não assim rotulados - consiste em apreciar se estão atendendo, nas ações de promoção, prevenção e recuperação, todo o elenco de problemas de saúde que afetam a mulher e se conseguem integrar essa oferta ao âmbito de atendimento individual ao ser humano.

Quanto à avaliação do conteúdo dos serviços em si, a tradicional trilogia proposta porAvedis Donabediam como objeto de análise para apreciar serviços de saúde mantém sua relevância. Consiste em estudar as "estruturas" - físicas e de recursos humanos e materiais, que possam permitir a prestação de serviços; os "processos" - interações que efetivamente acontecem entre prestadores c usuários, em relação a algum modelo normativo, seja do campo das ciências médicas ou no da ética; e, por último, os "resultados" - mudanças no estado de saúde atribuíveis a assistência recebida, sejam elas de ordem física, fisiológica ou psicológica. 


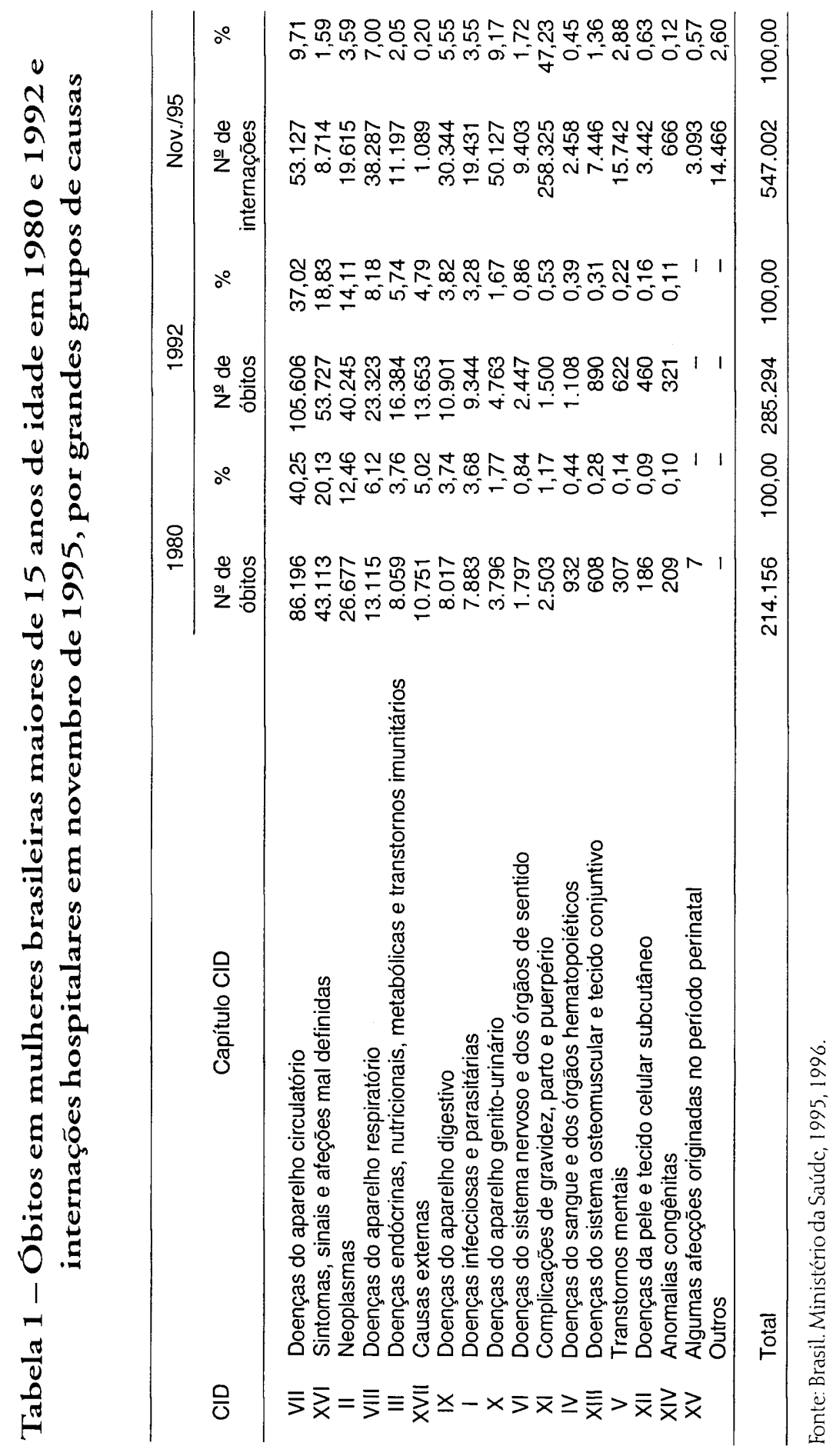




\section{O acesso da mulher aos serviços de saúde}

A expansão do acesso aos serviços de saúde, nos níveis primário c hospitalar, tem sido um dos principais objetivos das reformas sanitárias das últimas décadas no Brasil e no mundo. Coerentemente com este objetivo, os indicadores de avaliação mais utilizados diziam respeito à existência de infra-estrutura física e humana e à freqüência de utilização ou cobertura dos mesmos. Os dados de sucessivos inquéritos populacionais demonstram importante progresso na cobertura de serviços básicos de saúde reprodutiva e no número de contatos da população com o sistema de saúde. Em 1992, foram realizadas 13 milhões de internações hospitalares pelo Sistema Único de Saúde (SUS) - mais de nove para cada 100 habitantes (Barros; Piola \& Vianna, 1996). Ressalte-se que os serviços ambulatoriais são amplamente utilizados pela população, embora o número médio de consultas por habitante ainda seja baixo. As mulheres são os usuários mais freqüentes dos ambulatórios. Pesquisa de demografia e saúde, realizada em 1996 (Bemfam, 1997), documenta essas tendências para a gravidez e parto.

\section{Tabela 2 - Distribuição dos nascidos-vivos nos últimos cinco anos por cobertura de serviços durante a gravi- dez. Brasil - 1996}

Tipo de Serviço

Alguma atenção pré-natal

Média de consultas pré-natais

Inicio de pré-natal no $1^{\ell}$ trimestre

Pré-nätal realizado por médico

Nenhuma vacina antitetânica na gravidez

Com cartão do pré-natal

Parto hospitalar

Parto assistido por médico

Parto cesariana
Cobertura

$85,7 \%$

$7,4 \%$

$66,0 \%$

$81,4 \%$

$36,5 \%$

$51,1 \%$

$91,5 \%$

$77,6 \%$

$36,4 \%$

Fonte: BEMFAM, 1997.

No campo de acesso ao planejamento familiar, a mesma pesquisa considerou que a necessidade insatisfcita de anticoncepção-definida como o número de mulheres sexualmente ativas que não fazem uso de contraceptivos e não desejam ter mais filhos - era de apenas 5,3\%. A fonte mais comum de métodos modernos de anticoncepção é a farmácia, que atende a 35,7\% das usuárias (que inclui o abastecimento de $88 \%$ das usuárias de pílula e $94 \%$ das de injeções). Em seguida, surgem o hospital público, com $27,5 \%$, e o conveniado, com $12,4 \%$. Os centros e postos de saúde públicos eram a fonte de anticoncepção para apenas 3,1\%. OSUS não pode se eximir de responsabilidade no uso excessivo de esterilização feminina, porque o índice de cirurgias reali- 
zadas por ele era de $70,9 \%-48,9 \%$ em hospitais públicos e $22 \%$ em hospitais conveniados.

Ou seja, tanto em planejamento familiar quanto no atendimento à gravidez e ao parto, a cobertura maior é positiva, embora métodos e procedimentos importantes para a qualidade das ações sejam esquecidos. Mas, em contrapartida, o aumento da cobertura de procedimentos como a cesariana indica principalmente maior medicalização do parto normal e risco de iatrogênese. A opção pela esterilização reflete em parte a falta de acesso a outros métodos contraceptivos.

De modo geral, quase toda a população feminina faz algum uso de intemação hospitalar e contatos ambulatoriais, com atendimento predominantemente realizado por médicos-embora, dependendo da região do País, ainda haja graves problemas de acesso (arquetipicamente representados pela peregrinação das grávidas à procura de uma vaga para darà luz, ou pelas filas nos ambulatórios e hospitais).

Estes indicadores sugerem que, embora os problemas de acesso persistam, o enfoque futuro de avaliação precisa incorporar, cada vez mais, os aspectos da qualidade no processo de assistência. Precisamos indagar se esse ato de assistência contabilizado e pago com os parcos recursos da saúde de fato contribuiu para a saúde da mulher usuária do sistema, ou representou apenas o que poderíamos chamar de um ato de 'consumo simbólico' - consultas e internações desnecessárias, ou de qualidade tão precária que em pouco ou nada contribuem para a saúde. Diversas pesquisas realizadas nos últimos anos no Brasil tendem a apoiar a segunda hipótese.

\section{Do processo de atendimento}

É no interior desse atendimento que se constatam graves problemas de qualidade. Scochi (1996), avaliando a expansão da rede básica em Maringá, Paraná (uma das áreas relativamente prósperas do País), entre 1983-1993, documentou graves distorções no conteúdo do atendimento, pese a existência de uma boa infra-cstrutura sanitária. Entre 76 parturientes entrevistadas, 64 (84\%) fizeram parto cesárea, 38 marcados com antecedência - uma prática que aumenta o risco de prematuridade iatrogênica. Destas, 20 ( 15 delas com idade inferior a 30 anos) realizaram laqueadura tubária durante a cesárea. Embora todas tenham feito pré-natal, apenas 36 foram vacinadas contra o tétano. Quarenta e oito tiveram o tipo sangüíneo e fator RL registrados no prontuário hospitalar; nove, o registro da sorologia de lucs. Trinta e três por cento das parturientes relataram nunca ter feito um exame de Papanicolau (preventivo) para diagnóstico de câncer do colo uterino. Um único nascido morto era uma criança com Síndrome de Down, filho de mãe com 43 anos. Ela só não fez laqueadura no parto-uma cesariana-porque não dispunha dos $\mathrm{R} \$ 400,00$ cobrados 'por fora' para o procedimento no hospital privado. 
Carvalho (1993), analisando o atendimento perinatal dispensado antes de 519 óbitos neonatais e a 388 crianças sobreviventes, no Rio de Janeiro em 1986 e 1987, detectou padrões semelhantes de falhas. Em apenas metade dos casos o hospital registrava os exames de pré-natal. Houve um elevado índice de cesáreas para laqueadura tubária $23 \%$ dos óbitos e $33 \%$ dos sobreviventes, com $31 \%$ das cesáreas marcadas com antecedência para os óbitos e $53 \%$ para os sobreviventes. Identificaram-se nascimentos prematuros iatrogênicos por esta causa, cinco dos quais levaram ao óbito. Coexistindo com o uso excessivo da cesárea, documentaram-se casos de óbitos neonatais, em que a cirurgia era indicada e não foi realizada, ou demorou demais. Em 40\% dos nascimentos estudados não foi registrado monitoramento dos batimentos cardíacos fetais.

A taxa de cesáreas nacional é de 36\% (BEMFam, 1997), a mais alta do mundo. Nos partos financiados pelo setor público, este índice cai ligeiramente para $32 \%$, sendo que existem mais de trezentos hospitais com taxas de cesáreas que superam $68 \%$. As taxas dos estados brasileiros variam entre 50\% (Mato Grosso do Sul) e 9\% no Amapá (Silver \& Holanda, 1996).

O tratamento das doenças crônicas no estudo em Maringá foi um pouco melhor, embora a tendência da amostra fosse de captar pacientes com problemas mais graves. Scochi entrevistou 59 pessoas hospitalizadas (64\% eram mulheres). Quase todas estavam em tratamento medicamentoso antes da internação. A maioria relatou ter recebido orientação sobre dieta, mas não sobre exercícios físicos. As dificuldades de acesso aos medicamentos eram claras - mais da metade os obteve em farmácias particulares. A avaliação dos prontuários ambulatoriais demostrou que grande parte estava sem registros básicos: dos 29 prontuários recuperados, 17 tinham um diagnóstico; 13, um exame físico; 10, uma história clínica; 12, registro de peso; 4, registro de altura; e 23, de pressão arterial. Apesar disso, a freqüência de utilização dos serviços ambulatoriais era muito alta: dos 59 pacientes, 29 compareceram até cinco vezes ao ano; 8 receberam entre seis e dez consultas; e 15 confirmaram freqüência superior a duas por mês. Uma paciente teve nada menos do que 50 consultas médicas no curso de 1995. Daí concluir-se que o aparato assistencial medicaliza a vida do paciente, fazendo-o passar parte significativa do seu tempo em estabelecimentos de saúde. No entanto, não lhe proporciona os elementos que possam oferecer-lhe maior autonomia, como garantia de medicamentos e orientação para atividade física. Ao mesmo tempo, essa excessiva concentração em torno de poucos usuários torna os serviços menos acessíveis aos demais.

Esta situação em Maringá parece caracterizar as distorções que podem surgir no contexto da expansão do direito à saúde dentro do um sistema que faz um uso iatrogênico e inapropriado das tecnologias médicas disponíveis. Houve, sem dúvida, um aumento da disponibilidade de serviços médicos. No entanto, os procedimentos básicos e custo-efetivos, tais como detecção de sífilis congênita ou sensibilização a Rh, ou orientação de hipertensos para exercício físico, não estão sendo postos em prática, 
ao mesmo tempo em que procedimentos agressivos e geradores de iatrogenese, como cesarianas sem indicação médica e esterilização em mulheres jovens, são empregados em escala maciça. Na medida em que o atendimento à saúde da mulher olha cada vez mais para as doenças crônicas que hoje lhe acometem, qual será o modelo de atenção adotado? Uma escravização de poucas aos serviços de saúde acompanhada da exclusão de muitas? Ou uma busca para manter as mulheres autônomas e ativas, pelo uso da educação e de tecnologias apropriadas?

\section{Medindo os resultados da assistência à mulher}

Donabedian (1984) define resultados da atenção médica como mudanças no estado de saúde atual e futuro atribuíveis à assistência anterior. O estudo da evolução dos indicadores de saúde da mulher no Brasil leva a uma mistura de satisfação e amargura. Satisfação, porque, sem dúvida, constatam-se tendências históricas de declínio de mortalidade materna e outras causas evitáveis. Amargura, porque os níveis atuais ainda estão muito aquém daqueles de outros países com graus de desenvolvimento socioeconômico semelhantes - demostrando, mais uma vez, que o preço das enormes ineqüidades da sociedade brasileira é pago anualmente em vidas humanas. Ainda existe muita dúvida sobre que parcela dessa melhoria pode ser atribuída à assistência médica. A acentuada redução da prevalência de má nutrição materna (BEMFAM, 1997), a elevação paulatina do nível de educação e do acesso a água, esgoto e moradia, além da redução da fertilidade sem dúvida contribuíram de forma importante para o aumento da expectativa de vida feminina e para a redução da mortalidade materna constatada nos últimos anos. A existência de altos índices de morte por doenças consideradas 'sentinelas' (Rutstein et al., 1976) como câncer do colo uterino, morte materna e hipertensão sugerem a existência de graves falhas de resolutividade na rede de serviços de saúde (Scochi, 1996). Mesmo a expansão da rede de serviços municipais e da oferta de profissionais não vem garantindo um melhor resultado para as mulheres e seus filhos. A pesquisa de Scochi em Maringá documentou flutuações e até aumentos na freqüência de mortalidade materna e sífilis congênita entre 1983 e 1993, ao mesmo tempo em que verificou o aumento considerável da infra-estrutura sanitária pública e privada no município.

Com a mudança do enfoque controlista para um foco centrado nos direitos reprodutivos e sexuais, vêm surgindo novas propostas de indicadores de resultados para o atendimento à saúde reprodutiva. Um exemplo interessante é a proposta de se trocarem os antigos indicadores do sucesso ou fracasso de programas de população (como queda de fertilidade e aceitação de uso de anticoncepcionais) pelo chamado 'índice de HaRI' (Helping Individuals to Achieve their Reproductive Intentions - em português, Apoiando os Indivíduos para Alcançar suas Intenções Reprodutivas). Este 
índice mede a proporção de usuárias que alcançam suas intenções reprodutivas no pcríodo de observação, seja a de ter filhos, a de evitar, ou a de espaçar nascimentos. Uma proposta de índice modificada incorpora, ainda, a medição da proporção de mulheres que sofrem de morbidade na tentativa de alcançar suas intenções reprodutivas. Exemplificando: o índice modificado de HaRı seria de 100 menos a proporção de mulheres que têm uma gravidez não-planejada ou não-desejada, ou que padecem de morbidade significativa relacionada à reprodução durante o período de observação. Desta forma, o indicador muda uma perspectiva centrada em metas externas para um centrado nos desejos do cliente. O modelo atual ainda não incorpora o problema da infertilidade adequadamente (Jain \& Bruce, 1994).

Com o aumento do enfoque no cliente, a realização de pesquisa sobre a salisfação da população também vem sendo trabalhada com maior freqüência, embora ainda pouco em relação específica com a saúde da mulher. Sousa (1996), estudando um município do interior de Minas Gerais em processo de consolidação da rede pública - em um dos poucos estudos de satisfação com base populacional-demonstrou que as mulheres são usuárias mais exigentes, além de mais freqüentes. Embora o nível geral de satisfação fosse alto, $75 \%$ das mulheres versus $60 \%$ dos homens manifestaram insatisfação com algum elemento do atendimento e apontaram numerosas áreas para melhoria. Moura (1997), estudando a satisfação de usuárias de uma maternidade do Rio de Janciro, documentou tanto os sentimentos de satisfação e gratidão pelo bom atendimento como a revolta com as dificuldades de acesso, demora, ou atendimento inadequado em outros momentos e serviços. Os estudos de satisfação e visão do usuário demonstram-se mais interessantes e úteis para melhoria de qualidade na medida em que fogem de medidas únicas e sintéticas de satisfação para captar qualitativamente (ou por meio de observações mais complexas) as percepções da população.

\section{Avaliação como ferramenta para transformação}

A grande limitação da abordagem donabediana de avaliação de serviços de saúde é que ela se limita a isso mesmo - a avaliar. No entanto, o ato de avaliar é idealmente inserido dentro de um processo de gestão que visa a transformar os serviços, melhorando sua qualidade. Para isso acontecer, a forma como se realiza uma avaliação é da maior importância. Nas últimas décadas, tem surgido uma série de propostas, desenvolvidas por Deming (1990), Juran \& Gryna (1991) e Ishikawa (1993), entre outros, geralmente reunidas sob as denominações de 'gestão' ou 'controle de qualidade total', cuja idéiaforça é a de uma gestão centrada no aperfeiçoamento contínuo do atendimento às necessidades do cliente. Estas propostas não serão discutidas aqui, mas constituem referências obrigatórias para quem trabalha com avaliação. 
A necessidade de introduzir o que Nogueira (1994) chama de "problematização pedagógica da qualidade" na equipe de saúde aparece claramente no campo do atendimento à saúde da mulher. Ratto (1997) avaliou o esforço de três anos para 'humanizar' o atendimento obstétrico e conseguir que a equipe de uma maternidade pública do Rio de Janeiro despertasse para resolver os problemas de qualidade. Ela documenta com sensibilidade o modesto progresso alcançado c as enormes dificuldades para transformar a visão dos profissionais da saúde sobre o que constitui a qualidade do atendimento à mulher e modificar os comportamentos adquiridos ao longo da vida particulare profissional. Embora tenha identificado avanços, como a aceitação do acompanhante na rotina do serviço, a pesquisa detectou a permanência de práticas obstétricas proscritas e agressivas, como manobras de Kristeller e atitudes agressivas com as parturientes entre muitos profissionais. Demonstrou, também, a necessidade de uma orientação contínua e de envolvimento maior da equipe com o projeto institucional; de condiçõcs de infra-estrutura mais adequadas; e de liderança constante para efetivar as almejadas transformações.

Ou seja, a experiência demonstra que é necessário não apenas ter boas intenções e um programa normativamente correto para atender bem a mulher. É preciso desenvolver, cada vez mais, a capacidade de gerenciar os serviços e de formar profissionais da saúde orientadas a uma assistência integral e humana, com eqüidade, e sem o uso abusivo de tecnologias médicas. Nesse contexto, a avaliação se torna uma entre as várias ferramentas indispensáveis para alcançar esta transformação.

Além de ser um subsídio para a gerência, a avaliação fornece uma base de informação indispensável para o exercício efetivo do controle social sobre o sistema de saúde. Sem acesso às informações, o controle social tende a se converter em um exercício estéril. O movimento de gênero precisa utilizar cada vez mais as informações disponíveis de pesquisas e dos próprios registros do sistema de saúde para lutar pela melhoria do atendimento à mulher. Hoje em dia, por exemplo, existem dados facilmente disponíveis sobre o atendimento de quase todos os hospitais do País, que retratam, com clareza cristalina, sucessos e desvios no atendimento à mulher. No entanto, estas informações são pouco utilizadas, seja pelos gestores do sistema, seja para o controle social.

\section{Tecnologias e consumo}

Alguns entendem que aplicação do termo 'consumo' ao campo da saúde representa, em si, uma mercantilização das relações. Em contraposição, receber serviços de saúde ou tecnologias é, sem dúvida, um ato de 'consumo', sem se constituir esse fato um comentário sobre sua natureza econômica. A produção e consumo desses serviços ou tecnologias podem estar regidos, em maior ou menor grau, pelas regras de mercado ou 
pelos interesses sanitários. No Brasil, embora existam numerosas tecnologias de extraordinária importância e benefício social - que possibilitaram a melhoria da saúde da mulher e a possibilidade de planejar a vida reprodutiva - a oferta e utilização de tecnologias médicas é muito mais regida pelos interesses de mercado do que por qualquer visão de interesse sanitário. Contribuem para esta situação a fraca capacidade de regulamentação do Estado; a organização ainda insuficiente da sociedade civil para se contrapor à hegemonia de fabricantes e prestadores de serviços; e os vícios da formação de profissionais de saúde, que, na maioria das faculdades, produzem, anualmente, novas gerações de profissionais com uma baixa capacidade crítica para a incorporação e uso de tecnologias em saúde.

Falando das 'sociedades de consumo' e da ânsia de produzir que as caracteriza, Galbraith (1968), citado por Rios (1997) observa:

O indivíduo serve ao sistema industrial, não para abastecê-lo com a poupança e o capital deles resultante; ele o serve pelo consumo de seus produtos. Em nenhum outro assunto, religioso, político ou moral, está a comunidade tão elaborada, perita e dispendiosamente instruida. Especificamente, de modo paralelo à produção de bens, são feitos esforços enérgicos e não menos importantes para garantir seu uso. Estes esforços enfatizam a saúde, a beleza, a aceitação social, o sucesso sexual - a felicidade em resumo - que resultarão da posse e do uso de um determinado produto (...) . Por sua vez, inevitavelmente, este fato afeta os valores sociais (...).

Rios (1997) complementa, citando novamente Galbraith (1972:159) e outros autores:

Se essa construção observa valores humanísțicos e éticos, como a não 'coisificação' do homem, a não violação de valores ambientais, a não discriminação social pelos "estilos de vida" que são criados, ou a não fomentação do desperdício e do descartável, é outra história, ou não se põe em questão. (...) E se produzir é preciso, a absorção de toda a produção pelo consumo constitui necessidade imperiosa para este sistema produtivo. Enem importa muito o que seja produzida, se "gomma, whiskey, carne infetta, amori carnali ou tabaco," como lembrado por Guido Alpa (1977). O sistema fabricará as necessidades dos seres humanos a que chamamos consumidores. Afinal, desde quando 'uma sociedade se torna cada vez mais afluente, as necessidades são cada vez mais criadas pelo processo em que são satisfeitas'.

A análise do perfil de algumas tecnologias para saúde reprodutiva no Brasil tende a confirmar essa visão da relação de forças. Iniciando-se antes do nascimento e estendendo-sc até a velhice e a morte, a mulher é objeto permanente de promoção de consumo de bens e serviços que afirmam visar a promoção da sua saúde, beleza, sexualidade e felicidade geral (Barros, 1991). Quando analisamos essa oferta utilizando os instrumentos do campo da avaliação tecnológica, percebemos que, além de um conjunto de tecnologias verdadeiramente úteis, a mulher ć, também, alvo predileto da venda do equivalente moderno da came infetta a que Guido Alpa se refere. 
Existem várias situações. A primeira é dos produtos e serviços técnica e moralmente podres, para os quais não há evidência de eficácia e segurança, e que oferecem riscos às mulheres sem oferecer os benefícios correspondentes. O segundo grupo é composto pelos produtos ou serviços que, cmbora ofereçam benefícios reais para algum grupo de mulheres, são promovidos de forma a expor grande número de usuárias a riscos desnecessários. O terceiro grupo é formado pelos produtos ou serviços que, embora seguros e eficazes quando produzidos de forma apropriada, são oferecidos no mercado com um nível de qualidade tão precário que sua utilidade hipotética é convertida em novos riscos.

No primeiro grupo, há inúmeros cxemplos no mercado brasileiro. Recentemente, a Sociedade Brasileira de Vigilância de Medicamentos e o Instituto Brasileiro de Defesa do Consumidor (IDEC) analisaram 101 anti-infectivos ginecológicos disponíveis no mercado brasileiro para atender ao grave problema das doenças sexualmente transmitidas e outras infeções vaginais. Destes, 49 foram considerados associações medicamentosas irracionais, em flagrante violação da normatização técnica existente no País (Silver \& Pizzo, 1996). Em alguns, utilizavam-se substâncias cujo uso interno ć desaconselhado mundialmente. O uso maciço destes produtos oferece riscos desnecessários e, em muitos casos, deixa a mulher sem adequado tratamento do seu problema.

No segundo grupo, encontramos tratamentos como a reposição hormonal na menopausa, ou os novos medicamentos para osteoporose (que embora eficazes em determinados grupos de mulheres de alto risco de fraturas por osteoporose, estão scndo promovidos de forma maciça para uso no período após a menopausa em mulheres saudáveis). A menopausa e a anticoncepção oral são particularmente visadas, pois podem levar ao consumo de produtos medicamentosos durante décadas. Métodos mecânicos como diafragmas, dispositivos intra-uterinos ou capuz cervical, que oferecem pouco lucro, são pouco utilizados no Brasil. No campo dos produtos hormonais, constatamos, por exemplo, que entre os anticoncepcionais orais mais vendidos no Brasil encontram-se os à base de desogestrel ou gestodene-produtos cujo uso é associado a uma elevada incidência de problemas trombóticos identificados em pesquisas da Organização Mundial da Saúde (OMS) e que sofreram restrições pelos governos da Alemanha e Noruega (OMS, 1995a/b; Carnall et al., 1995). O gestodene, por exemplo, nunca foi registrado pelo governo americano. Ainda está sendo pesquisado se estcs produtos têm outros benefícios cardiovasculares que justifiquem o maior risco a eventos trombóticos. Estes produtos, no entanto, são promovidos como tendo menor risco cardiovascular, e não alertam quanto ao problema de trombose.

Esta tentativa de medicalizar a vida da mulher é altamente lucrativa e gerou uma literatura científica importante e enviesada, que precisa ser avaliada com olhos críticos. Segundo a publicação do mercado farmacêutico INPHARMA (1997): 
Com um valor de US $\$ 8,5$ bilhões, o mercado de produtos endócrinos compreende $6 \%$ do mercado farmacêutico mundial. Vendas são maiores para os agentes endócrinos utilizados para tratar condições crônicas como diabetes e menopausa. (...) O produto de reposição hormonal pós-menopausa, Premarina ( $\mathrm{Rm}$ )(American Home Products), atingiu vendas mundiais de US $\$ 749$ milhões em 1993; foi o produto endócrino mais prescrito nos USA em termos de volume. As vendas previstas para o ano 2002 (...) de Premarin (...) são de US $\$ 1250$ milhões (...). O crescimento do mercado de osteoporose deve acontecer seguindo a aprovação de bifosfonatos para esta condição em mercados maiores (...). O mercado de reposição hormonal deve aumentar até o ano 2000, motivado pelas mudanças na percepção da menopausa.

Novamente, o caso mais flagrante, citado no Brasil há mais de 25 anos (Mello, 1971), é do uso excessivo do parto cesariana. Este procedimento, tão necessário nas verdadeiras emergências obstétricas, tornou-se objeto de lucro ou de conveniência para hospitais e médicos e símbolo de status social pela população feminina, pese a evidência dos seus riscos maiores quando utilizado sem indicação obstétrica real. Enquanto um médico jamais pensaria em fazer uma apendicectomia apenas por solicitação (e qualquer conselho de ética condenaria tal prática invasiva e arriscada), no Brasil é considerado normal que a paciente ou o mćdico escolham um parto cesariana sem nenhuma indicação. Seu uso como principal via de acesso a esterilização cirúrgica, quando há outros métodos tanto de anticoncepção como de esterilização mais seguros, é outro exemplo no qual o sistema da atenção a saúde não se importa em expor as mulheres desnecessariamente ao risco de morte, infecção ou outras complicações. No campo cirúrgico ginecológico, histerectomias e perineoplastias são outros exemplos de tecnologias que fugiram a qualquer controle.

Em um outro exemplo tragicômico, não fosse verdade, uma clínica do Rio de Janeiro faz, sem querer, uma verdadeira caricatura da promoção da saúde, promovendo sua proposta para o atendimento preventivo à mulher. A proposta envolve o uso periódico de uma imensa lista de testes desde ultra-som abdominal e cervical a exames dermatológicos completos. Embora cada teste tenha algum uso real na medicina, o uso indiscriminado em mulheres saudáveis levaria, sem dúvida, a um custo elevado desnecessário, além de inúmeros resultados falso-positivos e subseqüentes avaliações com tecnologias e cirurgias igualmente desnecessárias para desmentir os falso-positivos gerados. Esta comercialização da pscudo-promoção da saúde da mulher exemplificou a natureza mercantilizada do uso da tecnologia médica e a perversidade do acesso ao seu consumo. Em uma cidade como o Rio de Janeiro, na qual milhares de mulheres com câncer de mama não conseguem deteç̧ão e tratamento adequados, promove-se a mamografia para mulheres abastadas jovens. Demonstra também a falta de preparação da classe médica e da população feminina para utilizar estas tecnologias de forma apropriada. 
No último grupo, encontramos os produtos e serviços que, embora sejam necessários e teoricamente eficazes, chegam à usuária de tal forma que sua utilidade real esvanece. Por exemplo, em 1996 o IDEC, em conjunto com a Fundação Oswaldo Cruz (FIOCRUz) avaliou 16 marcas de testes de gravidez para uso em urina, uma tecnologia simples de utilidade óbvia. No entanto, a maioria se mostrou tecnologicamente obsoleta, deixando de detectar a gravidez a partir do primeiro dia de atraso menstrual. Sete produtos deixaram de cumprir com a sensibilidade que eles mesmos declaravam. Outros produtos, vendidos por preços semelhantes, eram de boa qualidade. Havia testes de boa e de má qualidade tanto para uso pela mulher em casa como para uso laboratorial. Uma das marcas dava resultados falso-positivos. Esta falta de qualidade tem conseqüências óbvias. Das 25 mulheres entrevistadas, 11 tinham tido resultados falsos negativos de testes de gravidez, atrasando seus cuidados pré-natais e potencialmente expondo o feto a riscos. Em outros casos, exames falso-positivos podem levar mulheres a tentativas de aborto sem sequer estarem grávidas. A falta de confiança nestes produtos leva mulheres e médicos a procurar testes de sangue mais caros e invasivos (Silver et al., 1996a).

Outro exemplo deste último grupo são os preservativos masculinos, que hoje representam (talvez junto com suas novas versões para uso feminino) o método mais seguro para prevenção de transmissão do vírus da Aids e outras doenças sexualmente transmissiveis. Tendo em vista esse papel essencial, o produto teria de chegar ao usuário com uma qualidade impecável. No entanto, em 1996, o IDEC e a FIOCRUz também avaliaram 20 marcas de preservativos masculinos no mercado brasileiro. Oito apresentaram falhas nos ensaios relacionados à segurança. O preço do produto (elevadíssimo no Brasil, entre 40 e 80 centavos por unidade) e o fato de ser distribuido nas farmácias ou pelo sistema público não guardava relação com a qualidade (Silver et al., 1996b). Simultaneamente, com a finalidade de facilitaro comércio entre países, estava a ponto de ser oficializada uma nova norma para o Mercosul que reduzia as exigências para o produto. Estes resultados estão levando a uma rediscussão das normas vigentes e um aprimoramento do sistema de certificação de qualidade no Brasil, e mais recentemente, da norma internacional da ISO. Ainda houve os casos recentes dos anticoncepcionais Ciclo-2 1 e Microvlar, cujo uso foi associado à gravidez e outros efeitos colaterais. No caso do Ciclo-21, somente após um longo período de denúncias e investigações alguns lotes do produto finalmente foram retirados de circulação.

Estas situações, como tantas outras, caracterizam novamente o que poderíamos denominar o 'consumo simbólico ou fictício de tecnologia médica'. A fábrica produz o produto, ou o profissional, o serviço. O médico prescreve. A consumidora o adquire, por prescrição ou por automedicação. Gastam-se recursos. A utilização traz algum resultado. Só que o resultado nãoé aquilo que se esperava-muitas vezes implicando danos à saúde e/ou gasto de recursos adicionais. $O$ atual sistema de registro, inspeção e controle de qualidade de produtos no País, bem como da qualidade da assistência médica têm se 
demonstrado completamente ineficientes para efetivamente proteger contra este tipo de problema. Com a integração econômica regional e o conseqüente aumento do fluxo de produtos entre países, bem como o explosivo e desregulado crescimento do setor de serviços de saúde com fins lucrativos, esta situação deve se agravar nos próximos anos.

A avaliação de tecnologias e de sua incorporação e uso pelo sistema de saúde e pela população feminina constitui sem dúvida outro dos principais desafios para a avaliação da atenção à saúde da mulher.

\section{Dos critérios éticos para avaliação de serviços e tecnologias}

Tradicionalmente, na medicina e na avaliação de tecnologias, algumas características vêm sendo procuradas para identificar aquilo que constitui "boa qualidade" em saúde. Donabedian (1990), sinteticamcnte, descreveu estas características como os "sete pilares da qualidade". Estes incluem a eficácia (e a efetividade), a eficiência, a eqüidade, a aceitabilidade ao usuário, a otimização do uso de recursos sociais e a legitimidade frente aos valores sociais.

Corrêa \& Petchesky (1994), em uma reflexão sobre as propostas de direitos reprodutivos e sexuais, propõem quatro princípios para constituir as bases éticas dos mesmos. O primeiro é o respeito à integridade corporal, entendido como o direito de segurança e controle sobre seu próprio corpo. Integridade corporal inclui tanto

o direito da mulher de não ser alienada de sua capacidade sexual e reprodutiva (por exemplo, pelo sexo ou casamento forçado, (...) negação de acesso a anticoncep̧̧ão, esterilização sem consentimento informado (...) como também da integridade de sua pessoa fisica (por exemplo, liberdade de violência sexual, do encarceramento doméstico, de métodos anticoncepcionais inseguros, de gravidez indesejada, ou fertilidade forçada, e de intervenções médica indesejadas). Esta integridade implica não somente na proteção contra abusos negativos, como nos direitos afirmativos de desfrutar o pleno potencial do seu corpo para saúde, procriação e sexualidade.

Para estas autoras, a integridade "implica também na integralidade, em tratar o corpo e suas necessidades como uma unidade, e não como colcha de retalhos de funções mecânicas ou fragmentadas".

O segundo princípio ético por elas citado é de respeito à pessoa:

Escutar a mulher é a chave para honrar sua personalidade moral e jurídica-ou seja, seu direito à autodeterminação. Isso implica em tratá-las como atores principais e tomadores de decisão em assuntos de reprodução e sexualidade. (...) Respeito à pessoa significa que prestadores devem 'levar a sério' os desejos e experiências da mulher. (...) No caso de anticoncepção significa 'levar a sério' reclamações sobre efeitos colaterais (...) e em oferecer um leque completo de opções (...). (Corrêd \& Petchesky, 1994) 
No âmbito do desenvolvimento de políticas, tratar as mulheres como pessoas significa, também, garantir a representação e participação de entidades de mulheres nos foros decisórios.

O terceiro princípio colocado pelas autoras é o da igualdade, aplicando-se tanto na área de igualdade nas relações entre homens e mulheres (divisões de gênero) como entre mulheres, por condições como classe social, idade, nacionalidade ou ctnicidade que as dividem. Neste sentido, difere pouco do princípio da eqüidade tradicionalmente empregado na avaliação dos serviços de saúde. O quarto princípio das autoras é de respeito à diversidade - às diferenças entre as mulheres em valores, culturas, desejos reprodutivos, religião, orientação sexual, condição familiar ou médica. Defendem a aplicação universal dos direitos reprodutivos, mas reconhecem que o significado desses direitos variam em diferentes contextos sociais.

Estes princípios propostos para direitos reprodutivos e sexuais têm uma clara aplicabilidade mais ampla para saúde da mulher em geral. O respeito à integridade corporal, à pessoa e à diversidade, bem como à eqüidade, são princípios tão relevantes para os problemas não- reprodutivos como para os reprodutivos e sociais. Eles ainda são estreitamente relacionados com os princípios mais gerais da bioética de autonomia e de beneficência. Existem, de certa forma, duas interpretações da palavra autonomia. A mais comum na bioética advém da sua raiz grega: a capacidade de governar a si mesmo, scgundo Pellegrino (1990):

Emana da capacidade dos seres humanos de pensar, sentir, e emitir juízos sobre aquilo que consideram bom. (...) Entretanto, o processo decisório autônomo pode ser obstaculizado por fatos externos como a coerção, o engano físico ou emocional ou a privação de informação indispensável.

Já nos escritos de Ivan Illich (1976), o conceito de autonomia não se limita a escolha informada, mas é intimamente relacionado à capacidade de auto-cuidado do indivíduo e da comunidade:

A idéia de saúde-como-liberdade deve restringir a produção total de serviços de saúde dentre limites sub-iatrogênicos que maximizam a sinergia entre modos autonômos e heteronômos de produção de saúde. Em sociedades democráticos tais limitações provavelmente são inatingiveis sem garantias de eqüidade (...). Crescente e irreparável dano acompanha a expansão industrial em todos os setores. Na Medicina aparece como iatrogênese. latrogênese é clínica quando dor, doença e morte resultam da atenção médica; é social quando politicas de saúde reforçam uma organização industrial que gera a ausência de saúde; é cultural e simbólica quando comportamentos medicamente promovidos e delusôes restringem a autonomia vital das pessoas, minando sua capacidade de crescer, cuidar uns aos outros e envelhecer, ou quando a intervenção médica paralisa as respostas pessoais a dor, incapacidade, angústia ou morte. 
Como será a apreciação da legitimidade social que Donabedian (1990) propaga como característica da qualidade da atenção? Ela depende da incorporação de um ou outro conjunto de valores éticos e sociais referentes à medicina - entre eles os que constituem autonomia e beneficência. Hoje, na sociedade brasileira, existem defensores de valores muito distintos. Alguns valorizam o acesso universal à saúde, mas não querem nenhuma restrição ao poder da corporação médica ou do complexo médico-industrial de definir o que é bom para a população. Já outras defendem a eqüidade e o acesso universal à saúde, mas qualificam esse acesso buscando limitar o iatrogênese e procurando formas de atenção que mantenham a integridade e autonomia das pessoas. Ou seja, procuram efetivar o direito à saúde scm estabelecer o acesso universal à iatrogênese. Um terceiro grupo descarta de vez os princípios de eqüidade tão valorizados na carta constitucional e declara o Sistema Único de Saúde um fracasso, visando a estabelecer um livre mercado da saúde - o usuário que se cuide. A construção (e conseqüente avaliação da atenção à saúde da mulher) inevitavelmente precisará se pautar, além de nos critérios técnicos tradicionais, em uma escolha de princípios e valores orientadores.

\section{Referências Bibliográficas}

ALPA, G. Tutela del Consumatoree Controlli Sullímpresa. Bologna: Societá Editrice il Mulino, 1977.

BARROS, J. A. C. A medicalização da mulher no Brasil. In: WolfFers, I.; HARDON, A. \& JANSSEN, J. OMarkeling da Fertilidade. São Paulo: Hucitec, 1991.

BarRos, M. E.; Piola, S. F. \&Vianna, S.M. Bblitica de Saúdeno Brasil: diagnóstico e perspectivas. Instituto de Pesquisa Econômica Aplicada (Ipea). Texto para Discussão n² 401, Brasília, 1996.

Bemfam e MaCro InTERnational, Inc. Brasil: Pesquisa Nacional Sobre Demografia e Saúde 1996. Rio de Janeiro: Bemfam, 1997.

BraSil. MINISTÉRIO DA SAÚdE/Fundação Nacional de Saúde. Movimento de Autorização de Intermação Hospitalar Novembro 1995. Brasília: MS/FNS, 1995 (CD-ROM).

BraSIL. Ministério da Saúde/Fundação Nacional de Saúde. Sistema de Informação sobre Mortalidade 1979-1995, Dados de Declaração de Óbilo. Brasília: MS/FNS, 1996 (CD-ROM).

CARNALL, D. et al. Third generation oral contraceptives - the controversy. British Medical Joumal, 311:1589-1590, 1995.

CARVALHO, M. L. Mortalidade Neonatal e Aspectos da Qualidade da Atençãoà Saúdena Região Metropolitana do Rio de Janeiro em 1986-7, 1993. Tese de Mestrado. Rio de Janeiro: Ensp/Fiocruz. 
CORREA, S. \& PETCHESKY, R. Reproductive and sexual rights: a feminist perspective. In: Sen, G.; Germain, A. \& ChEN, L. C. Population Policies Reconsidered: health empowerment and rights. Boston: Harvard University Press, 1994.

DEMING, W. E. Qualidade - a revoluçãona administração. Rio de Janeiro: Marques Saraiva, 1990.

DONABEDiAv, A. La calidad dela atención médica: definición y método de evaluación. México, DF: La Prensa Médica Mexicana, 1984.

DONABEDiAn, A. The seven pillars of quality. Archives of Pathology \& Laboratory Medicine, 114:11 15 $1118,1990$.

Galbratth, J. K. O Novo Estado Industrial. Tradução de A. Cabral. Rio de Janeiro: Civilização Brasileira, 1968.

GalbRatrH, J. K. A Sociedade Afluente. Rio de Janeiro: Expressão e Cultura, 1972.

IucH, I. Medical Nemesis: the expropriation of health. New York: Pantheon Books, 1976.

INPHARMa. Market News. A Look al Ihe World Endocrinology Markel. ADIS International Lid. Inpharma Vol. 92. Acession Number X800325879. 11/1 1/94. CD-ROM 1997.

IsHiKAWA, K. Controle de Qualidade Total à Maneira Japonesa. Rio de Janeiro: Ed. Campus, 1993.

JAIN, A. \& BRUCE, J. A Reproductive Health Approach to the Objectives and Assesment of Family Planning Programs. In: Sen, G.; Germain, A. \& Chen, L. C. Population Policies Reconsidered: heallh empowerment and rights. Boston: Harvard University Press, 1994.

Juran, J. M. \& Grina, F. M. Controle da Qualidade, Conceitos, Politicase Filosofia da Qualidade. Volume 1. São Paulo: McGraw-Hill, 1991.

Mello, C. G. A epidemiologia da cesariana. Revisla Paulista de Hospitais 19(3):29-33, 1971.

Moura, M. A. V.A Qualidadena Assistência à Saúdeda Muther-Gestante: possibilidades elimites, 1997. Tese de Doutorado, Rio de Janeiro: Escola de Enfermagem Anna Nery, Universidade Federal do Rio de Janeiro.

NoguetrA, R. P. Perspectivas da Qualidade em Saúde. Rio de Janeiro: Qualitymark, 1994.

Ouveira J. (Org.). Constituição da República Federativa do Brasil. São Paulo: Editora Saraiva, 1996.

Pellegrino, E. D. La Relación entre la Autonomía y la Integridad en la Ética Médica. In: OrGantzação Panamericana da Saúde. Bioética, Temas y Perspectivas. Washington: OPS, 1990.

RatTo, K. Matemidade Leila Diniz (1994 a 1996): nascimento de um novo profissional de saúde?, 1997. Tese de Mestrado, Rio de Janeiro: Instituto Fernandes Figueira/Fiocruz.

Rros, J. O. O Direito como Instrumento de Mobilização Social-um estudo de caso: o movimento pela conquista e aplicação do Código de Defesa do Consumidor, 1997. Tese de Mestrado, São Paulo: Faculdade de Direito, PUC. 
RUTSTEIN, D. D. et al. Measuring the quality of medical care: a clinical method. The New England Joumal of Medicine 294(1 1):582-588, 1976.

ScochI, M. J. Municipalização e Avaliação de Qualidade de Serviços de Saúde: uma análise localizada, 1996. Tese de Doutorado, Rio de Janeiro: Ensp/Fiocruz.

SILVER, L. \& HoLANDA, R. M. Monitoramenloe Avaliação Rotineira da Qualidade e Distribuição da Assistência Obstétrica Hospitalar: estudo do potencial do sistema de informação existente e eslimaliva de cuslo ao Sistema Único de Saúde da epidemia de partos cesáreas desnecessários. Relatório de Pesquisa. Rio de Janeiro: Fiocruz, 1996.

Silver, L. \& Pizzo, E. Antibióticos fora da norma. Consumidor S. A. 6:4-5, mar. 1996.

SIIVER, L. et al. Testes de gravidez nem sempre são confiáveis. Consumidor S. A. 10:18-21, jul. 1996.

SIIVER, L. et al. Camisinhas: há boas opções. É só ter cuidado. ConsumidorS. A. 14:11-14, nov 1996.

SousA, A. I. ASatisfação da População comos Seniŗos Locais de Saúde: municipio de Ialacarambi (MG), 1996. Dissertação de Mestrado, Rio de Janeiro: Ensp/Fiocruz.

OrGanização MUNDiAL DA SAÚde. Collaborative Study of Cardiovascular Disease and Steroid Hormone Contraception. Venous Thromboembolic Disease and Combines oral Contraceptives: results of international multi-centre case-control study. Lancet 346:1575-1582, 1995a.

Organização Mundial da Saúde. Collaborative Study of Cardiovascular Disease and Steroid Hormone Contraception. Effects of different progestogens in low oestrogen oral contraceptives on venous thromboembolic disease. Lancet 346:1582-1588, $1995 \mathrm{~b}$.

WoRLDBANK World Development Report 1993: investinginhealth. New York: Oxford University Press, 1993. 



\section{Desenvolvimento e Implementação do Pasis no Brasil}

\section{Ana Maria Costa}

Comentam-se, aqui, aspectos conjunturais que permitiram o desenvolvimento do Programa de Assistência Integral à Saúde da Mulher (PAISM) pelo Ministério da Saúde. Faz-se necessário destacar que o fato de a autora ter sido personagem deste processo teve seu peso e fica explícito na forma testemunhal pela qual, muitas vezes, as informações são apresentadas.

Ao analisar o processo de implementação do PASM serão pontuados alguns impasses e desafios, especialmente nos aspectos relativos à implantação do Sistema Único de Saúde (SUS). É mister assinalarque a possibilidade efetiva de existência do PASM, com a conseqüente melhora nos indicadores de saúde da população feminina, está condicionada aos avanços rumoà consolidação do SUS. Isto implica na restruturaçãodo modelo assistencial de saúde, processo que envolve situações muito complexas a serem efetuadas no âmbito das três esferas de governo-federal, estadual e municipal. Entre as ferramentas a serem utilizadas, é prioritária a criação de instrumentos de gestão e de regulação para o sistema de saúde, aliados ao redirecionamento da lógica assistencial com o efetivo exercício do controle social.

\section{Do materno infantilismo à assistência integral à saúde das mulheres: antecedentes}

Até o início dos anos 80, a política governamental para a assistência à saúde das mulheres restringia-se ao ciclo gravídico-puerperal-o atendimento ao pré-natal, parto e puerpério-preconizado pelo Programa de Saúde Materno Infantil (PSMI), inspirado 
nas recomendações da Organização Pan-Americana da Saúde (OpAs), pautado pela estratégia da intervenção priorizada a grupos de risco ou situações de vulnerabilidade. Dessa forma, o PSMI foi criado no final dos anos 60 pela Divisão de Saúde Materno-Infantil da Secrelaria Nacional de Programas Especiais de Saúde do Ministério da Saúde - (Dinsami/ SNPES) e implementado pelas secretarias estaduais de Saúde.

Ressalte-se que, àquela ćpoca, os programas de saúde caracterizavam-se pela verticalidade, ou seja, a partir da adoção de estratégias e recursos próprios - no mais das vezes, sem articulações entre as suas distintas propostas de implementação. O PSMI, tipicamente direcionado ao cuidado de grupo populacional vulnerável, coexistia com outros programas destinados ao controle de patologias, sem a conseqüente e necessária articulação entre as suas ações estratégicas.

Nessa ocasião, o conceito de verticalidade com centralização do sistema foi praticado na radicalidade, caracterizando-se pelo estabelecimento de metas operacionais para os serviços a partir de definições centrais formuladas pelo Ministério da Saúde, sem qualquer relação com as necessidades identificadas por meio de avaliação da epidemiologia local. Caracteriza-se, ainda, pela vinculação de recursos financeiros específicos ao cumprimento destas metas. O que significa que os recursos já chegavam aos estados e municípios predestinados a determinado uso, não permitindo aos gestores locais a programação de ações mais adequadas às reais necessidades de saúde de suas populações.

Na prática, o resultado desta filosofia foi a segmentação da assistência à saúdc e o privilégio da realização de determinadas intervenções, nem sempre as mais necessárias às situações reais de saúde. Além disso, os recursos humanos, tanto no âmbito da coordenação como no de execução, recebiam freqüentemente complementações salariais provenientes destes programas, criando um evidente constrangimento para a gestão estadual. Tais privilégios estruturam o verticalismo de mando direto da federação sobre os estados e municípios, estimulando o clientelismo e dificultando a gestão do sistema.

Longe de se constituir em estratégia adequada na implementação do SUS, a verticalidade programática, característica marcante da cultura sanitária em nosso país, ainda persiste. O exemplo emblemático disso, embora não exclusivo, é o Programa de Controle das Doenças Sexualmente Transmissiveis (DST) e da AsDs que surge e se implementa com estas características. O pânico social diante da epidemia da Aıss permitiu, no Ministério da Saúde, o recrudescimento da intervenção vertical, na contramão dos princípios da reformulação do modelo assistencial necessário ao SUS - que envolve a horizontalização com base na epidemiologia local da programação de saúde, fundada nos princípios da integralidade e da eqüidade.

Ressaltamos, ainda, que outros programas ministeriais, contemporâneos ao PSMI, mesmo oferecendo ações para a assistência a problemas relacionados às mulheres, não se articulavam entre si. Exemplificando: o controle de câncer cérvico-uterino realizado 
pelo Programa de Doenças Crônico-Degenerativas não articulava, na execução, com o PSMI no diagnóstico do câncer ginecológico naquelas oportunidades de contato das mulheres com os serviços nas atividades preconizadas para as atendidas no pré-natal. Desta maneira é que se constata que o mesmo grupo populacional figura como 'alvo' de vários programas governamentais que são implementados isolados e verticalmente. Desta forma, a mesma mulher, para acessar os cuidados para sua saúde, deve buscar, em momentos distintos, equipes e prontuários também distintos - o que, no mínimo, é irracional pelo ponto de vista da gerência e, para as mulheres, dificulta o acesso, ao mesmo tempo em que afasta o serviço do projeto da assistência integral.

Importante salientar que, freqüentemente, tanto no campo da promoção, da prevenção ou da recuperação, muitas ações propostas e realizadas pelos diversos programas eram coincidentes ou paralelas. O planejamento das ações oferecidas era realizado de forma isolada e o desempenho de cada atividade avaliado perse sem qualquer abordagem da eficiência e eficácia para a saúde do grupo atendido. Desta forma, freqüentemente, os programas verticais sobrecarregavam estados e municípios com uma burocracia inconseqüente e inútil, resultando em baixo impacto nos indicadores de saúde.

Na prática, o significado desta situação de segmentação dos programas de saúde reflete a ausência de uma visão integral de saúde e do indivíduo (no caso em análise, às mulheres), ao mesmo tempo consagrando a tendência da especialização nas profissões médicas. A adoção destas lógicas na organização dos serviços compromete resultados de impacto sobre a saúde da população atendida. Nas estruturas gestoras do Ministério da Saúde e das secretarias estaduais era evidente a ausência de integração das equipes responsáveis pelos distintos programas. De modo geral, tais setores estão pautados por uma abordagem restrita a partir de enfoque embaçado sobre os verdadeiros problemas de saúde-institucionais e epidemiológicos - a serem enfrentados. Por outro lado, suas estratégias de intervenção, baseadas em normas e parâmetros ministeriais rígidos, garantiam o desempenho a partir dos objetivos dos programas, raramente coincidentes às necessidades dos serviços e populações atendidas.

Para os serviços, esta situação manifesta-se na irracionalidade e no paralelismo das ações de saúde oferecidas à população. Isto se expressa nas formas de sua organização, distribuição da oferta de atividades, equipe e horários de atendimento, entre outras. As vítimas deste processo, sem dúvida, são os usuários dos serviços, que recebem uma assistência compartimentada, desqualificada e, no mais das vezes, ineficaz. Em linhas gerais, foi muito baixo o impacto epidemiológico destes programas, à exceção daqueles voltados ao controle das doenças infecciosas, preveníveis por imunização.

No que diz respeito especificamente à temática reprodutiva e ao controle da fecundidade, a década de 70 assistiu a um amplo e vigoroso debate sobre as políticas demográficas, polarizadas entre os pró e os anticontrolistas. Isto repercutiu, imobilizando as tímidas e equivocadas iniciativas do Ministério da Saúde sobre a incorporação 
de ações de planejamento familiar no PSMI. A revitalização do debate sobre a temática da população se deu pelo alarde em torno da explosão demográfica. O crescimento demográfico - a princípio apresentado como causa de desenvolvimento - posteriormente passa a ser responsabilizado pela degradação ambiental. No entanto, agora, a distância histórica destes argumentos já permite constatar que os problemas de desenvolvimento ou do meio ambiente não estão resolvidos, apesar da grande redução das atuais taxas de crescimento populacional e da fecundidade.

Como referência setorial para análise das condições que possibilitaram a formulação do PAISM, o processo da reforma sanitária, pano de fundo para as inovações da saúde no Brasil, encontrava-se em plena gestação nos anos 70 e 80. A partir daí, desenvolve-se um conjunto de conceitos e princípios capazes de conferir ao sistema de saúde eficácia e qualidade, com impacto nos indicadores de saúde do País. Entre estes, o princípio da integralidade, que entende a assistência organizada e voltada para o indivíduo na sua singularidade e totalidade holística, envolvendo ainda a implementação de políticas intersetoriais. Nos aspectos específicos da política de assistência à saúde, preconiza a oferta de ações sincronizadas de promoção, proteção e recuperação, ampliando, assim, o então vigente conceito de saúde.

Mesmo com o ambicioso objetivo de reverter os graves coeficientes de mortalidade infantil e materna por intermédio da assistência médico-sanitária, o PSMI focalizava como objeto de suas ações o binômio 'mãe-filho', em que à mãe estavam reservadas ações de assistência ao pré-natal, ao parto e ao puerpério. Timidamente, vez por outra, nas reformulações anuais rotineiramente realizadas do PSMI, eram agregadas orientações para a oferta de ações referentes ao controle da fecundidade. Estas, no entanto, surgiam sob os conceitos de espaçamentos de gestação, planejamento familiar ou de paternidade responsável. Àépoca, o Ministério da Saúde esteve sistematicamente recuado diante do debate social realizado sobre as políticas demográficas - o qual não propiciou uma situação de consenso que permitisse ao Ministério agir no campo reprodutivo, salvo nos aspectos da promoção da natalidade.

Sobre isto vale a pena refletir um pouco mais, tendo como pressuposto que esse tema atraiu, e ainda hoje atrai, divergências localizadas no campo ideológico, moral, religioso e ético e sua discussão desenha um complexo mosaico.

\section{Contando história}

Embora difuso, o discurso do planejamento familiar já se expressava nos primórdios do Brasil colonial, perpassando do Império ao início da República, marcado por uma dissimulada tendência ou um sentimento natalista, agregado à idéia do aperfeiçoamento e da melhoria da raça brasileira (Fonsêca Sobrinho, 1992). 
No período colonial, a Igreja foi a instituição que construiu, quase com exclusividade, o ideário social que se pretendia: português e cristão. O sucesso deste projeto envolveu estratégias tanto no plano do discurso cotidiano normativo como, ainda, decisões em que as mulheres eram impedidas de assumir outro papel que não aquele determinado pela vida familiar (Priori, 1993).

Desta forma, a Igreja promoveu a mentalidade androcêntrica já tão presente naqueles tempos, incentivando as mulheres à obediência e servidão aos homens, incluindo a procriação de tantos filhos quantos Deus ou a natureza determinassem. A posse, pela herança, ficou garantida a partir da descendência controlada e se consolidou o estabelecimento da sociedade familiar.

De forma particular e decisiva, a Igreja teve como grande aliada a medicina. Médicos e padres tinham acesso à intimidade das mulheres, mesmo que com objetivos distintos: um, voltado ao cuidado com a alma; o outro, com o corpo. Ambas as práticas eram marcadas por uma violenta intervenção nas vidas privadas e, no caso da medicina, ainda reforçada por meio da normatização prescritiva sobre o corpo feminino.

Foi resultado desta época a elaboração de uma imagem regular da feminilidade, o que adequava-se aos interesses da Igreja. Para esta, a prática do sexo somente deveria servir à procriação. Todas as marcas do desejo carnal e de animalidade do ato sexual deveriam ser 'apagadas' pela concepção.

As penas da vida conjugal, assim como os sofrimentos decorrentes do parto, eram vistos como oportunidades 'purificadoras', redentoras do pecado, para a ressurreição. Deste modo, relegavam-se à maldição as mulheres infecundas, incapazes de reverter com a pureza da gravidez a dimensão pecaminosa do coito.

Do Brasil colônia ao início da República verifica-se ainda que, implicitamente, uma tendência natalista se expressa a partir da criação do salário-família e do auxílio-natalidade. No desenvolvimentismo pós-guerra, explicita-se mais nitidamente, por parte do Estado de Getúlio, uma tendência pró-natalista.

Enquanto isso, no cenánio internacional, são retomadas as teses do reverendo Thomas Robert Malthus (1766-1834), que alertava sobre os perigos da superpopulação em decorrência do não correspondente crescimento da produção de alimentos. Adespeito do caráter moralista e repressor da sexualidade, explícito nas teses malthusianas, apenas o aspecto da desproporcionalidade quantitativa entre os dois fenômenos - crescimento demográfico e disponibilidade de alimentos - é tomado como referência para a discussão do planejamento familiar.

O outro aspecto em que vários preconizadores do planejamento familiar se fundamentam é o da eugenia ou do aperfeiçoamento da espécie humana, a partir de seleção das raças. O que se destaca neste caso como princípio é a existência de distintas hierarquias qualitativas da raça humana. 
No ano de 1952, Margaret Sanger criou, com sede em Londres, a International Planned Parenthood Federation (IPPF), que contava com o apoio financeiro de diversas instituições interessadas em planejamento familiar, visando ao controle demográficoportanto, restritivo às liberdades de procriação das mulheres ou dos casais. O IPPF passará, nos anos 60, a financiar entidades e outras instituições que realizavam o planejamento familiar no Brasil.

Identifica-se, justamente neste período, o surgimento da polêmica entre as políticas de controle demográfico e as anticontrolistas. A partir da Revolução Cubana, são reforçados o pensamento e a doutrina controlista no Brasil (Fonsêca Sobrinho, 1992). Naquela época, os Estados Unidos formularam uma política de ajuda aos países latinoamericanos, cuja condição para obtenção de ajuda econômica era a adoção, por parte do país solicitante, de estratégias voltadas à redução do crescimento demográfico.

A argumentação favorável ao controle demográfico sustentava que o crescimento econômico e o próprio desenvolvimento só seriam possíveis com intervenções dirigidas à redução do ritmo do crescimento demográfico. Movimentos sociais, partidos políticos clandestinos e outros setores da sociedade progressista indignaram-se com os princípios defendidos pelos controlistas, ainda mobilizados no debate sobre o avanço imperialista, na extensão do território nacional, na baixa densidade demográfica e na necessidade de sua ocupação como estratégia de autonomia nacional.

A este debate comparecia, naturalmente, a Igreja, com o seu conjunto de razões de ordem moral e religiosa, vinculando sexo à procriação. Essa posição será relativamente flexibilizada no final dos anos 70, quando a Igreja passa a admitir um 'certo controle' da fecundidade, desde que o método utilizado fosse a abstinência periódica da prática de sexo. Esta prática foi denominada pela própria Igreja como 'método natural' e representou um importante avanço na modificação das herméticas idéias consagradas no Concílio de Trento, do século XVII.

Tendo perdurado por longo tempo, diversas nuances podem ser identificadas nas ideologias envolvidas. No campo das políticas públicas, revezavam-se estratégias para a adoção de práticas, mesmo que veladas, para o controle da fecundidade. Todos esses movimentos fizeram com que, em meados dos anos 70, o Ministério da Saúde incorporasse a paternidade responsável ao PSMI. Em 1977, também no contexto do PSMI, foi elaborado o Programa de Prevenção da Gravidez de Alto Risco (PPGAR), que previa a oferta de contracepção às mulheres com risco gestacional.

O PPGAR teve imediata reação contrária da socicdade, principalmente do movimento de saúde e imprensa 'nanica', de forte expressão na época. A iniciativa do ministério foi entendida como estratégia voltada ao controle demográfico, já que os chamados critérios de risco encaminhavam um controle de nascimentos entre as populações pobre e negra. 
Para a elaboração do PPGAR, o Ministério da Saúde mobilizou diversos professores de universidades brasileiras envolvidos com a temática de saúde reprodutiva. O recuo deste programa, diante das reações sociais que culminaram com o seu arquivamento, resultou em problemas políticos entre esse grupo de médicos - professores das cadeiras de gineco-obstetrícia - e o ministério. Essa situação somente se reverteria tempos depois, no processo de negociação que possibilitou a política atual da assistência integral.

A fragilidade política com que, à época, o Ministério da Saúde enfrentou esta situação permitiu a criação de um vácuo institucional, favorecendo o surgimento e o crescimento de outras instituições que brindavam ações de planejamento familiar às mulheres. Dentre estas, a Sociedade Civil de Bem-Estar Familiar no Brasil (BEMFAM) e o Centro de Pesquisas de Assistência Integrada à Mulher e à Criança (CPAIMC) foram as de maior relevância (Costa, 1996).

A BEMFAM foi criada em novembrode 1965 como uma entidade privada sem fins lucrativos, com sede no Rio de Janeiro, mas com intervenções em quase todo o território nacional. Financiada por capital internacional e filiada ao IPPF, tinha como estratégia o treinamento de profissionais da saúde para a prática do planejamento familiar e a prestação direta de assistência exclusiva em ações contraceptivas, por meio de unidades próprias ou conveniadas com prefeituras, sindicatos, secretarias de saúde e universidades.

No caso do CPAIMC, o financiamento para as suas atividades no Brasil provinha fundamentalmente das instituições vinculadas ao sistema Usaid (United States Agency for International Development) - pela Family Planning International Assistance (FPIA), Pathfinder Foundation e outras. Sua estratégia, no entanto, foi mais agressiva e eficaz na criação e consolidação de uma 'cultura' contraceptiva e intervencionista entre os profissionais da saúde, especialmente os médicos. Para tanto, financiou treinamentos de profissionais vinculados ao ensino da medicina, da enfermagem e de outras áreas afins, além de sustentar - treinando-os, doando o equipamento e subsidiando as suas atividades - uma verdadeira rede de médicos que realizavam esterilizações cirúrgicas por meio da técnica de laparoscopia.

OCPAIMC foi ainda distribuidor de material contraceptivo para diversas outras instituições congêneres, importando insumos a partir do uso de sua prerrogativa para isenção de impostos de importação, em virtude dos benefícios conferidos pelo título de 'utilidade pública, sem fins lucrativos', conferido pelo governo brasileiro.

A ideologia do controle da natalidade, largamente disseminada no chamado Terceiro Mundo e, no caso especial, no Brasil, teve também sua origem nos interesses norteamericanos, que vislumbravam ameaças a seus projetos econômicos e políticos na 'explosão demográfica' do planeta. Isto ficou explicitado a partir da divulgação do documento oficial "Implicações do crescimento da população mundial para a segurança e os interesses dos EUA", de 10 de dezembro de 1974 e só divulgado no Brasil em 1989 , codificado como NSSM-200. 
Este documento foi assinado pelo Sr. Henry Kissinger e dirigido aos secretários de estado americanos. Nele, são discutidos aspectos econômicos, políticos e ecológicos relacionados - e supostamente-ameaçados pelo alardeado crescimento demográfico. Contém a seguinte citação:

Oprincipal fator que está influindo na necessidade de matérias-primas não-agrícolas é o nivel de atividade industrial, regional e mundial. Por exemplo, os EUA, com $6 \%$ da população mundial, consomem aproximadamente um terço dos recursos mundiais (...). (Brasil. Congresso Nacional, 1993)

Mais adiante, o NSSM-200 define algumas estratégias que foram desenvolvidas mais tarde em nosso país. Ao lado da Índia, Bangladesh, Paquistão, Nigéria, México, Indonésia, Filipinas, Tailândia, Egito, Turquia, Etiópia e Colômbia, o Brasil figurava como prioridade.

Coincidentemente, no Brasil dos anos 70 (época marcada pelo endurecimento da ditadura militar), reforça-se entre os militares o discurso da segurança nacional ameaçada pelo grande contingente de pobres e famílias numerosas, 'presas fáceis' para a propaganda de idéias subversivas (Fonsêca Sobrinho, 1992). Ressalte-se, ainda, o recrudescimento de idéias eugênicas expressas, por exemplo, na declaração do general Valdir Vasconcelos sobre a condição de sub-raça de brasileiros que não atingiam as condições físicas e de saúde exigidas para o ingresso no serviço militar, indicando, segundo ele, a premência de controlar nascimentos desta 'subespécie'.

A súbita radicalização do discurso dos militares em relação à temática da população, no início da década de 80, talvez tenha sido o toque necessário para provocar a conformação do cenário que resultou na formulação do PAISM, incluindo novos atores no processo. Um espaço aberto pelo Ministério da Saúde, pelo então secretário-geral Mozart de Abreu e Lima, permitiu que técnicos do setor de reconhecida posição crítica à situação vigente e professores universitários, especialmente da Universidade de Campinas (UnICAMP), formulassem uma proposta preliminar de programa. Na seqüência, esta proposta foi amplamente debatida na comunidade de saúde, no movimento da reforma sanitária e ainda com militantes do incipiente movimento feminista que se estruturava à época no País. Desta forma, a criação do PAIsm neutraliza as polarizações e inclui uma prática de discussão com o grupo populacional objeto da política, ou seja, as mulheres - até então, alheias à discussão. É assim, então, que o PAISM passa a ser um assunto de mulheres (Costa, 1996).

Desde a década de 60, inspiradas no feminismo internacional e no clima da liberdade sexual conferida pela pílula contraceptiva, as mulheres brasileiras vinham processando a ruptura com o clássico e exclusivo papel social que lhes era atribuído desde sempre: a maternidade e a profissão de dona de casa. Gradativamente, crescia o comparecimento feminino no mercado de trabalho e aumentava o número das que ingressavam nas universidades, construindo uma cultura de cidadania feminina. Nesse contexto, elas passam a demandar pelo controle da fecundidade, com claras aspirações por vivências sexuais desvinculadas da procriação. No entanto, os serviços de 
saúde ainda não estavam habilitados ao atendimento destas necessidades, restrito apenas aos serviços - de baixa cobertura e de qualidade duvidosa - oferecidos pelas instituições do tipo BEMFAM ou CPAIMC.

\section{Paism: o desafio da construção do novo}

É no contexto desta conjuntura que surge o novo discurso, costurado no tecido dos direitos e talhado na segurança da saúde e na autonomia das mulheres e dos casais na definição do tamanho de suas proles. Em 1983, o Ministério da Saúde, na figura do então ministro Valdir Arcoverde, anuncia o PAISM em depoimento para Comissão Parlamentar Mista de Inquérito (CPI) que investigava o crescimento populacional no Congresso Nacional. O programa deveria ser desenvolvido pela rede pública e conveniada de saúde e alicerçado nas programações locais, ajustando-se às necessidades eespecificidades epidemiológicas e às prioridades de cada município e sua base populacional.

A moldura que permitiu esta formulação programática foram a reforma sanitária e os princípios do SUS, e sua anunciação como bases para uma ação programática faz do PAISM o primeiro e talvez ainda único programa de saúde adequado aos princípios da descentralização, recusando as estratégias verticalizadoras nas suas bases conceituais e doutrinárias. Isto não significa que as práticas utilizadas em sua implementação tenham sido inovadoras, ou que tenham rompido com a cultura dos programas verticais. Ao contrário, o próprio Ministério da Saúde ainda não processou suas novas funções requeridas pelo SUS e continua, ainda hoje, agindo de forma centralizada e desarticulada.

O PAISM constitui-se de um conjunto de diretrizes e princípios destinados a orientar toda a assistência oferecida às mulheres das distintas faixas etárias, etnias ou classes sociais, nas suas necessidades epidemiologicamente detectáveis - incluindo as demandas específicas do processo reprodutivo. Compreende, ainda, todo o conjunto de patologias e situações que envolvam o controle do risco à saúde e ao bem-estar da população feminina.

Desta forma, as orientações e diretrizes do programa devem estar voltadas transversalmente às distintas áreas de organização da assistência no âmbito das instituições do sistema de saúde. Isto significa a adoção destes princípios e orientações para todo atendimento oferecido às mulheres pela rede de saúde, incluindo as situações de emergência, internação hospitalar, ações de saúde mental, atenção clínica, cirúrgica, ou mesmo nas especificidades ligadas à saúde da mulher trabalhadora. Assim sendo, o PAISM exige ações e estratégias harmonizadas a partir das distintas áreas e setores das instituições do SUS.

As suas linhas estratégicas de intervenção explicitam e aperfeiçoam o conceito da integralidade por meio da oferta de ações educativas, promocionais, preventivas, de diagnóstico e de recuperação da saúdc. O destaque conferido às ações educativas objetiva intervir nas relações de poder das mulheres tanto com os serviços de saúde como 
nas demais situações relacionais assimétricas para as mulheres. Esta estratégia tem por intenção estimular nas mulheres mudanças em relação ao autocuidado e à apropriação de seus corpos e controle de sua saúde.

Ainclusão das ações de planejamento familiarou de controle da fecundidade no PAISM não pode significar qualquer priorização destas ações em detrimento de outras, identificadas no diagnóstico epidemiológico. Este princípio é capaz de permitir uma intervenção efetiva na saúde de uma forma geral e, em particular, nos aspectos da reprodução.

O controle da fecundidade não deve acrescentar nenhum risco à saúde das mulheres. Isto deve ser garantido a partir da abordagem integral, do acompanhamento clínico e ginecológico, tanto na indicação como no seguimento do uso de métodos contraceptivos.

O avanço deste conceito de política de saúde integral para as mulheres coloca o Brasil em uma situação privilegiada internacionalmente. As conquistas recentes sobre os direitos reprodutivos - inscritas nos documentos que emergiram das conferências do Cairo (Conferência Internacional sobre População e Desenvolvimento, 1994) e de Beijing (Conferência sobre a Mulher, 1995) - que recomendam a oferta de programas de saúde sexual e reprodutiva aos homens e mulheres não deveria limitar as políticas brasileiras mas sim amparar os avanços conceituais já institucionalizados aqui.

Reconhecendo no âmbito internacional o grande avanço contido nestas recomendações, é necessário alertar que, no caso brasileiro, não são aceitáveis recuos em relação ao aspecto do conceito da integralidade assistencial. Estes documentos internacionais devem ser usados no reforço e na consolidação da prática desta política. O argumento da inclusão do homem nas ações de saúde reprodutiva, supostamente tido como novidade, está implicitamente contemplado nos princípios do Passme, explicitamente, nas diretrizes que orientam a integralidade assistencial preconizada para todos os indivíduos atendidos pelo SUS.

\section{Saúde Reprodutiva, um conceito em negociação ${ }^{1}$}

Torna-se necessário discutir as origens e circunstâncias dos debates políticos que culminaram na formulação do conceito de saúde reprodutiva no âmbito das Conferências do Sistema Organização das Nações Unidas (ONU).

AConferência de Bucareste, em 1974, teve como grande tema a nova ordem econômica mundial e a discussão sobre a redução de fecundidade como favorecedora do desenvolvimento (antagonizada pelos defensores da posição inversa, ou seja; o desenvolvimento como responsável pela redução da fecundidade). Os países do Sul insistiam

\footnotetext{
${ }^{1}$ A íntegra do Plano de Ação do Cairo é encontrada em LASSONDE, 1997.
} 
na importância do desenvolvimento, ao passo que os industrializados sustentavam que, sem o planejamento familiar a conseqüente queda de fecundidade, as economias dos países do Sul não avançariam.

$\mathrm{Na}$ Conferência do México (1984) é organizada uma petição de grande parte dos países em desenvolvimento, buscando junto à comunidade internacional ajuda técnica e financeira para a implementação de programas de controle da natalidade. Atribuiuse grande importância ao crescimento populacional, relacionando-o à situação de desenvolvimento. Para surpresa geral, os Estados Unidos, naquele momento, assumem outro discurso, diferente do anteriormente explicitado. Afirmam que o crescimento demográfico é evento de efeito neutro no desenvolvimento e que as verdadeiras causas de subdesenvolvimento estavam relacionadas à excessiva centralização de suas economias, que impunha pressões artificiais ao mercado. Claro que esta argumentação estava dirigida especialmente aos países socialistas e comunistas, e sua base estava fundamentada na idéia de que é possível adaptar-se ao crescimento demográfico à medida que os mercados funcionem bem.

Desta forma, os Estados Unidos seguem defendendo as suas idéias sobre o desenvolvimento, mas a redução do crescimento demográfico já não constitui condição para alcançá-lo. Substituindo a orientação de reduzir a fecundidade e o crescimento demográfico, passam a preconizar a liberdade dos intercâmbios comerciais, o espírito empresarial, a ajuda internacional e a diversificação da fontes de investimento.

$\mathrm{Na}$ Conferência do Cairo, os debates assumem uma lógica distinta. A reunião é marcada pela discussão sobre a desigualdade entre os sexos, a luta contra a pobreza, as reivindicações dos movimentos religiosos e a busca de identidade cultural.

Assim, de forma geral, identifica-se que, em que cada conferência, prevalecem cortes ideológicos distintos, desenhando, de forma reduzida, os formatos: em Bucareste evidencia-se o debate Norte/Sul; no México exibe as diferenças entre Leste/Oeste; no Cairo, debate-se a polarização entre os defensores de sociedades laicas e os de concepções teocráticas ou fundamentalistas. É aí que se evidencia a oposição entre os que defendem os direitos sexuais no campo da reprodução e da sexualidade e aqueles que consideram que os estados têm o papel de restringir estes direitos em nome de valores culturais e religiosos.

Estas posições antagônicas e polarizadas imprimem profundidade aos valores sociais e morais na discussão da temática da vida, da sexualidade e da morte em busca de um consenso internacional. Este debate, sem dúvida, foi em parte provocado e sustentado pela forte presença do movimento feminista, que jamais havia alcançado tanto prestígio nas negociações internacionais.

Salienta-se que este prestígio deve-se às alianças que o movimento feminista estabeleceu, em especial com o chamado Grupo População-bastante experiente em negociações similares anteriores, com o próprio governo norte-americano (ator determinante 
nas negociações). O movimento feminista ainda contou com o expressivo trabalho da secretária-geral da conferência, que ofereceu apoio pessoal à temática de interesse para as mulheres (Lassonde, 1997).

OGrupo População é um movimento de origem americana que tem objetivos internacionais. Ele aglutina representantes do meio acadêmico, governamental, das ONGs e dos meios de comunicação. Na Conferência do Meio Ambiente (1992), o Rio de Janeiro começa uma relação deste grupo com as feministas. Primeiro, uma relação de conflito; depois, de aproximação, baseada na discussão sobre o desenvolvimento sustentável e a dimensão demográfica. A posição das feministas é firme sobre a não-inclusão da temática população em uma conferência sobre o meio ambiente, já que isso impediria o avanço social das mulheres. Segundo Louise Lassonde, o argumento de que era necessária a implementação do planejamento familiar-defendida pelo Grupo População-era visto como uma acusação de que o ventre feminino era o responsável pela degradação ambiental. O que estava posto, na verdade, era o ressurgimento do debate sobre o livre arbítrio das mulheres nas decisões reprodutivas contra a intervenção estatal no controle dos nascimentos, desta vez tendo como contraponto o argumento ecológicopreservacionista defendido pelo Grupo.

Importante lembrar ainda que, naquela ocasião, com o objetivo de neutralizar a influência do Grupo População, o movimento feminista se apóia no Vaticano na defesa de uma plataforma comum para limitar a presença do planejamento familiar na Agenda 21, resultante da conferência. O governo americano também dá apoio a esse acordo tático, avaliando as devidas compensações decorrentes da ausência da temática demográfica na Agenda 21 e o fortalecimento de pautas sobre modelos de produção e de consumo, sobre os quais os Estados Unidos mantiveram-se firmes nas negociações de preservação do American way of lije.

Após a Conferência do Rio houve muitas mudanças nas relações entre os grupos de atuação no cenário internacional, configurando as alianças que chegaram ao Cairo. Logo no início da fase de preparação para o Cairo, a aproximação entre as feministas e o Grupo População buscava um acordo comum, que permitisse a conciliação de interesses dos dois grupos e o conseqüente fortalecimento de suas posições na conferência. De uma forma geral, o Grupo População abandona a ênfase em relação ao planejamento familiar, ao adotar a prioridade das feministas: a defesa dos direitos, da saúde e da posição social das mulheres. Do consenso surge a noção de saúde reprodutiva a partir daí adotada pelos dois grupos (Lassonde,1997). Este consenso seria ampliado nos acordos firmados nesta conferência, contabilizando, sem dúvida, grandes avanços para os grupos envolvidos.

No entanto, a criação do conceito de saúde reprodutiva - ainda que vitorioso do ponto de vista da política internacional - não dá conta das múltiplas dimensões e complexidades da saúde. Isto já fica explícito no Programa de Ação emanado pela própria 
conferência, ao definir que "saúde reprodutiva refere-se ao estado de bem-estar físico, mental e social das pessoas relacionados ao aparelho genital e seu funcionamento". Se a definição da saúde adotada pela ONU já era passível de limitações conceituais, fica realmente complicada quando o mesmo conceito é aplicado ao aparelho genital que o reduz ainda mais.

Do ponto de vista operacional, realizar programas ou projetos de assistência à saúde reprodutiva sem uma concomitante abordagem integral pode incorrer em importantes riscos para as mulheres. Isso acontece à medida que fatores e situações relacionados a outros aparelhos ou funções de um indivíduo têm relação direta com as tecnologias usadas nas práticas da abordagem reprodutiva. Isto remete à necessidade de um debate ético para a garantia das reais prioridades dos grupos e dos indivíduos e, principalmente, no controle da iatrogenia médica.

A insistência nesta discussão decorre do fato de que, nos tempos pós-Cairo e pósBeijing, ativistas feministas apegam-se aos acordos decorrentes destas conferências para formular demandas por programas de saúde sexual e reprodutiva descontextualizadas dos princípios da integralidade. É importante delimitar os riscos disso decorrentes, pois, nos anos 70, quando a sociedade brasileira recusou programas verticais de planejamento familiar, já discutia sobre a impropriedade desta abordagem focalizada apenas nos aspectos da reprodução.

A assistência integral, tal como entendida no âmbito do movimento feminista brasileiro, constitui-se em um patrimônio inegociável de discussões e de experiências práticas consubstanciadas no PAISM que deve constituir a referência conceitual e estratégica em saúde para a implementação das ações de saúde reprodutiva.

Para as feministas brasileiras, cm especial aquelas que são também profissionais da saúde - que trilharam um longo percurso na luta pela saúde edireitos reprodutivos das mulheres, agregando suas experiências profissionais como gestoras -, fica o desafio de implementar, na prática da saúde, as conquistas políticas decorrentes dos diversos espaços de luta e de ação pública das mulheres. Só não vale jogaro bebê com a água do banho.

Diante do exposto, verifica-se que, no plano dos conceitos e das políticas para a saúde das mulheres, o PAISM satisfaz inteiramente. No entanto, são necessários ajustes e adequações, de modo a abarcar a dinâmica e complexa realidade epidemiológica-de que a AIDs e as doenças cardiovasculares entre mulheres constituem dois grandes exemplos desafiadores de estratégias do sistema de saúde.

O grande dilema é a sua implementação, configurada em um perturbado cenário macropolítico e setorial de franca e permanente ameaça à consolidação do SUS. Assim é que, apesar de mais de uma década de sua formulação, é ainda preocupante o nível de saúde evidenciado pelos indicadores epidemiológicos, bem como a grande insatisfação das usuárias dos serviços de saúde (Costa, 1992). 
A realidade da saúde da população feminina brasileira demonstra que, apesar de bem formuladas, as políticas não têm sido implementadas. A afirmativa pode ser comprovada tomando-se alguns dos indicadores de saúde reprodutiva como exemplo. A mortalidade materna, oficialmente registrada em 114,2 óbitos por 100.000 nascidosvivos para o ano de 1991, situa o Brasil entre os países de alto risco para os direitos reprodutivos, eśpecialmente no exercício daquela função mais valorizada socialmente para a mulher: a maternidade (a título de curiosidade, ressalta-se que esta taxa é 25 vezes maior do que a canadense).

Os índices muito elevados de esterilização cirúrgica de mulheres - como identificado na Pesquisa Nacional de Amostra Domiciliar (PNAD)/IBGE (1986) - encontram-se em franco processo de crescimento, o que ficou evidenciado pela Pesquisa Nacional sobre Demografia e Saúde (BEMFAM/DHS, 1996). Entre as usuárias de contracepção unidas, 40, 1\% estão esterilizadas. Em 1986, a PNAD/IBGE registrou uma taxa de 27\%. O ritmo galopante da esterilização como método de alternativa contraceptiva evidencia a consolidação de uma cultura reprodutiva construída mediante bases perversas em relação ao universo e às modalidades de escolhas. Mesmo reconhecendo o direito ao método definitivo cirúrgico, fica a indagação sobre as condições nas quais esta escolha se processa.

Estas duas situações - mortalidade matema e esterilizações cirúrgicas - relacionamse diretamente ao uso abusivo das cesarianas no País. Embora a alta incidência de cesáreas seja sobejamente conhecida, ainda não existem mecanismos eficientes para o seu controle c regulação. Esta situação submete mulheres e recém-nascidos a riscos desnecessários e continua sem merecer qualquer atenção especial dos poderes públicos para o seu controle.

\section{A política setorial da saúde - SUS - como base de sustenta- ção para o PAISM}

Em 1988, a Assembléia Nacional Constituinte aprovou a nova Constituição brasileira. Pela primeira vez foi incluída, no texto constitucional, uma seção sobre a saúde (inspirada no debate que vinha acontecendo no País, contextualizado como reforma sanitária). A saúde está inserida no contexto do Sistema de Seguridade Social, um conjunto de políticas e ações dirigidas à proteção social da população, com um financiamento comum. Além do financiamento da Seguridade Social, a saúde tem ainda outras fontes complementares provenientes dos estados, municípios e da própria União. Para a regulamentação e operacionalização dos princípios constitucionais, foi elaborada a Lei Orgânica da Saúde, que organizou e definiu o funcionamento doSUS (Rodriguez, 1994). 
O artigo 198, inciso III da Constituição Federal determina que

as açōes e serviços de saúde integram uma rede regionalizada e hierarquizada e constituem um Sistema Único, organizado de acordo com as seguintes diretrizes: I - descentralização com direção única; Il - atendimento integral, com prioridade para as atividades preventivas, sem prejuízo dos serviços assistenciais; 111 - participação da comunidade.

Os princípios e diretrizes para o SUS definem-se na universalidade, na eqüidade e na integralidade. Isto significa que as ações devem se dirigir ao conjunto da população brasileira de forma eqüitativa e integral-portanto, com qualidade que garanta a resolubilidade dos agravos individuais ou coletivos à saúde. A estratégia principal é a da descentralização municipalizada, com o exercício do controle social e participação da comunidade.

As Conferências de Saúde representam de modo ideal o momento adequado para articular internamente as diversas competências sanitárias atribuídas a determinado nível de governo e, externamente, estas com as demais políticas que interessam à saúde. Os conselhos, de caráter permanente e deliberativo, são órgãos colegiados, integrados por representantes do governo, dos prestadores de serviço, dos profissionais da saúde e dos usuários. Devem atuar na formulação de estratégias e no controle da execução da política de saúde (Dallari, 1994).

Até o presente, o sistema de saúde da maioria dos municípios ainda não realizou todas as transformações necessárias para sua adequação aos mandamentos constitucionais e da Lei Orgânica da Saúde. Para isso, é necessário se mudar a lógica segundo a qual o sistema vem operando, melhorando a qualidade do atendimento e os resultados das ações executadas. OSUS ainda não é o que está sendo praticado, mas o que deve ser construído (Barros, 1994).

É um fenômeno surpreendente a mobilização social em torno do processo de construção do SUS. Isto fica claramente explícito na realização das conferências de saúde, embora seja um processo permanente quando visto na prática do controle social realizada pelos conselhos de saúde municipais ou estaduais.

De fato, a realidade de inúmeras experiências locais tem revelado uma criatividade imensa, demonstrando que desde que haja decisão política e vontade, mesmo com condições financeiras mínimas, muito pode e já tem sido feito no rumo das mudanças do modelo assistencial e na produtividade de recursos. No entanto, deliberadamente ou não, processa-se uma ferrenha crítica ao SUS, com decretação de sua falência. Nisto, especialmente, a mídia tem contribuído sobremaneira, sempre informando a população de forma parcial, sem nunca explicar os fatos vinculando-os às suas verdadeiras questões e causas.

Assim, sacrifica-se a lógica doutrinária do SUS em detrimento da permanente disputa de hegemonia com outras concepções de organização șetorial e com as tentativas de preservação de interesses mercantis propiciados e garantidos pelo modelo vigente. 
A sonegação do repasse à saúde dos recursos financeiros provenientes do Fundo da Seguridade Social, aliada ao processo de 'reforma administrativa' (pautado pelo enfraquecimento do setor público) $\mathrm{c}$ às dificuldades para o repasse direto dos recursos financeiros aos municípios constituem um conjunto de estratégias perversas quc, na prática, têm impedido a consolidação do SUS.

O PaISM deve ser entendido, então, como a política para a assistência às mulheres no contexto do SUS. Sua implementação resulta, em última instância, na qualificação desta assistência e na melhoria dos níveis de saúde da população feminina, consolidando a saúde como direito de cidadania para as mulheres. Assim, as experiências positivas relacionadas à sua implementação devem ser amplamente divulgadas como práticas exemplares para outros municípios e localidades.

Os movimentos sociais, em especial o de mulheres, clássico demandante da implantação do PAISM, devem ocupar as instâncias institucionais do controle social da saúde (conselhos de saúde, conferências etc.), consolidando alianças com os demais setores da luta pela saúde. Esta proposta fundamenta-se no fato de que, apesar da existência de garantias legais e formais tanto para o SUS como para o PAISM, sua consolidação e implantação plena é processo a ser construído cotidianamente nas instituições do SUS dos diversos níveis, o que provavelmente só será assegurado com uma prática eficaz de controle e de pressão dos movimentos sociais.

\section{Referências Bibliográficas}

BARROS, E. O controle social e o processo de descentralização dos serviços de saúde. In: Incentivo à participação popular e controle social no SUS: textos técnicos para conselheiros. Brasília: IEC, 1994.

Bemfam-DHS. Pesquisa Nacional sobre Demografia e Saúde, 1996. Relatório Preliminar, Macro International, Inc., 1997.

BRASIL. Ministério da Saúde. Programa de Assistência Integralà Saúde da Mulher: bases para uma ação programática, 1983.

Brasil. Congresso Nacional. Relatório n. 2 de 1993 - CN. Relatório final da Comissão Parlamentar Mista de Inquérito, destinada a examinar a incidência de esterilização em massa de mulheres no Brasil. Brasília: Centro Gráfico do Senado Federal, 1993.

Costa, A. M. PAISM: uma politica de assistência integral a ser resgatada. São Paulo: Comissão de Cidadania e Reprodução, 1992.

Costa, A. M. Planejamento familiar no Brasil. Bioética, 4(2):209-216, 1996. 
DALLAR, S. G. A Constituição brasileira e o Sistema Único de Saúde. In: Incentivo à Participação Populare Controle Social no SUS: texlos técnicos para conselheiros de saúde. Brasília: Informação, Educação e Comunicação (IEC), 18-28, 1994.

Det Prors, M. Ao Sul do Corpo: condição feminina, matemidade ementalidades no Brasil Colônia. Rio de Janeiro: José Olympio/Edund, 1993.

FONSÊCA SOBRINHO, D. Estado e População: uma história do planejamento familiarno Brasil. Rio de Janeiro: Centro de Desenvolvimento e Planejamento Regional (CEDEPLAR)-UFMG /Rosa dos Tempos, 1991.

LASSONDE, L. Los Desafios de la Demografia (Les défis de la démographie). Éditions La Decouverte, 1996. Edição em espanhol: Ciudad de México: Universidad Nacional Autónoma de México/Fondo de Cultura Económica, 1997.

Rodriguez Neto, E. A Reforma Sanitária e o Sistema Único de Saúde: suas origens, suas propostas, sua implantação, suas dificuldades e perspectivas. In: Incentivo à Participação Populare Controle Social no SUS: textos técnicos para conselheiros. Brasília: IEC, 7-17, 1994. 



\section{Violência de Cênero, Saúde Reprodutiva e Serviços}

Ana Flávia Pires Lucas D'Oliveira \& Lilia Blima Schraiber

\section{Introdução}

Para considerarmos a violência nas relações de gênero como questão implicada nas práticas de saúde, antes de mais nada tomaremos os problemas concementes aos serviços não apenas em função dos cuidados ou orientações objetivamente produzidos, mas ao modo interativo de fazê-lo, privilegiando nessa abordagem os sujeitos ali presentes. Este tem sido o ponto de vista mais atual também nos estudos do campo do planejamento em saúde (Gallo, 1995; Rivera, 1995) e do trabalho em saúde (Schraiber, 1995, 1997; Peduzzi, 1998), o que leva a ultrapassar o usual enfoque da produção assistencial como problemática da organização e da gerência dos serviços. Tais enfoques privilegiaram um olhar mais estrutural acerca dos serviços, gerando a compreensão das práticas e da qualidade dos cuidados como conseqüência da estrutura de sua organização produtiva. Sem negar a importância da organização, buscaremos valorizá-la sob outro olhar. Os serviços ganham abordagem processual e passam a ser vistos como dinâmica de relações interativas, que se dão entre profissionais e entre estes e os usuários, no momento em que se encontram todos dispostos em exercício (aplicação/mútua troca) dos conhecimentos científicos, técnicos e práticos de uns, e das informações científicas adquiridas e saberes práticos de outros.

\footnotetext{
* Agradecemos a Silvia Salvan Strake, Maria Flávia Pallerosi D'Alessandro e Gisele Magalhães Lanferini, pelo trabalho de campo, e às profissionais de enfermagem do setor de adultos do CSE Samuel B. Pessoa pela colaboração.
} 
Com relação aos serviços, assim, temos dois tipos de problemas que, vistos pela dinâmica interativa, estamos tratando em conjunto: de um lado, a organização da produção e arquitetura dos trabalhos, tal como usualmente pensamos os programas de saúde, por exemplo; e de outro, as ações de intervenção técnica, que são processos de trabalho realizadores daquela organização e, nisto, articuladores das necessidades e demandas em saúde, dos saberes e das técnicas, a fim de alcançarem determinados resultados, o que também faz parte dos programas de saúde. E, para darmos conta de nossa pretensão epistemológica, trataremos a dimensão organizativa como problemática interiorizada no plano técnico, abordando as relações dos usuários com o serviço por meio das relações que estabelecem com seus profissionais no transcorrer das intervenções técnicas.

É nesse sentido que uma crítica à qualidade assistencial a demandas que são trazidas pelas mulheres - em particular, neste caso, relativamente a questões de violência de gênero-em nossa abordagem vai além da dimensão mais estrutural da assistência, para se preocupar com a interação entre indivíduos, que se dá pela ação técnica, recortando a própria organização pelo plano das relações entre os profissionais e os usuários dos serviços. É desta perspectiva que deriva a possibilidade de pensarmos os serviços não por sua coerência estrutural, mas por elementos de seu movimento e mudança.

De igual modo, na intervenção técnica, se o processo de trabalho é tomado como ação estruturada pela organização dos serviços em suas determinações técnico-sociais relativas aos objetivos e resultados pressupostos para a intervenção, será pelo exame das relações de seu agente (os profissionais da saúde) com o processo da intervenção-e notadamente da perspectiva do uso concreto do saber na aplicação técnica no cotidiano dos serviços - que buscaremos não só apreender as transformações dos conhecimentos e a criatividade de sujeito trabalhador, mas a própria interatividade (mútuas trocas) dos saberes médicos ou técnico-científicos com os saberes práticos. Tais perspectivas é que, para nós, mesmo focando a problemática do ponto de vista dos serviços, revelarão a interação entre os sujeitos presentes ao ato técnico.

Essas interações serão abordadas pelos diálogos que se dão no interior do ato técnico entre os profissionais e os usuários em relação. Assim, nos aproximaremos das interações pelas falas e suas trocas dialógicas ocorridas no transcorrer daquele ato, que é simultaneamente produção e consumo do serviço. Têm-se, nesse sentido, perpassando o jogo interativo, questões da ordem da produção da prática técnica, tanto quanto as da realização do consumo, que implicam, por exemplo, acesso aos serviços e às tecnologias, recepção, possibilidades de uso reiterado ou continuidades assistenciais, entre outras. Estas se cruzam com questões, por exemplo, da realização, por parte dos usuários, de respostas às suas necessidades e satisfação quanto aos serviços; por parte dos profissionais, da realização do exercício de boas práticas, definindo os os padrões que se usam e com os quais se trabalha, o que definirá o modo pelo qual se estabelecerão relações dadas. Dentre as ordens de questões destacamos: relações entre profissionais e seus 
saberes; entre profissionais e suas condições de trabalho; entre usuários e suas experiências privadas; entre usuários e o serviço organizado para dadas ofertas de produção assistencial; entre usuários e suas expectativas frente ao serviço, tanto de uso, quanto de resolução de problemas - interpretados estes como necessidades de saúde. A medicalização do social, a coisificação do doente como objeto da intervenção técnica e do trabalho, a elitização de profissionais e os interesses corporativos, entre outras, serão, pois, problemáticas dos serviços e sua organização produtiva, com base neste olhar.

Assim sendo, este texto busca se aproximar dos profissionais, usuários, saberes, tecnologias e organização/resolução dos serviços, por meio da tomada específica do diálogo que se estabelece no interior da assistência médico-sanitária, entre mulheres que demandam atenção referida à saúde reprodutiva e profissionais que as assistem.

Partindo teoricamente da noção de que o jogo das falas representa a interatividade entre estes diferentes sujeitos sociais, e ademais, partindo da contribuição habermasiana da aproximação do trabalho como também interação' ', buscaremos, no contexto específico de serviço de saúde, captar de que modo esses sujeitos, ao produzirem distintas falas, valendo-se de seus saberes, suas experiências de vida e suas situações institucionais, colocam-se quanto ao feminino na relação de gênero e algumas de suas questões mais relevantes na interface com a saúde: o corpo, a maternidade e a sexualidade.

Entenderemos que este 'colocar-se' encontra-se em um contexto de uma ação sempre estratégica - que é a do trabalho - pois um dado resultado é buscado nesta ação, a qual, por outro lado, expressa também formas interativas, que nisto podem polarizar-se entre um agir estratégico ou comunicativo quanto à essa interação, transformando as trocas dialógicas em instrumentais e coisificadoras dos sujeitos, ou não. E, neste caso, serão espaços de emancipações e fortalecimentos de cada qual como sujeito-situação esta que entenderemos como de 'empoderamento' da intersubjetividade, ou de comunicação: o oposto da violência.

É interessante destacar que a interatividade neste estudo ancora-se em uma situação singular e instigante: a relação mulheres-mulheres, pois boa parte dos profissionais da saúde são, igualmente, mulheres. Estas, no entanto, são sujeitos também reprodutores de uma ordem e poder de grande dominância na sociedade, o poder médico. Situamse, por isto, no centro de uma tensão ou conflito ímpar como sujeitos: realizar, no cotidiano, pólos distintos e contraditórios de identidades. Não vamos, porém, nos ater ao exame da situação das mulheres-profissionais. Interessa-nos, antes, a própria relação.

\footnotetext{
1 Inspira-nos o quadro referencial $\mathrm{c}$ a metodologia usados por AYRes (1995) para examinar do ponto de vista hermenêutico as narrativas que constam dos discursos produzidos na criação do conceito de risco em epidemiologia como saber e prática de saúde. Para um aprofundamento da abordagem do trabalho em saúde como interação ver, ainda, Schraiber (1997a; 1997b) e Peduzzi (1998).
} 
Esta mostrará, como dissemos, as potencialidades do referencial de gênero para o estudo dos serviços, trazendo questões que não podem ser vistas ou refletidas por outro olhar senão este. Sua grande vantagem será permitir pensar novas tecnologias assis-tenciais para aprimorar a perspectiva emancipatória pretendida pelo movimento social e pelas proposições técnico-científicas que sustentam o Programa de Atenção Integral à Saúde da Mulher (PAISM) ${ }^{2}$. Queremos mostrar a fecundidade científica, tecnológica e ético-política da articulação dessa perspectiva de gênero com o estudo das práticas e dos serviços como temática tradicional do campo da saúde coletiva.

Além disso, é por meio do contexto interativo que apreendemos melhor o mencionado conflito identitário, iluminando, em especial, a tradicional questão da medicalização e da elitização dos profissionais da saúde diante da população, mostrando situações em que a tensão de identidade pode vir a assumir características de um verdadeiro conflito moral (Schraiber, 1997). A resolução deste conflito penderá, ou não, para um posicionamento eticamente perfilado com a busca de emancipação de gênero. A opção, a nosso ver, está na dependência da própria construção existente de prática assistencial e de organização de serviço. Afirmamos que nossos dados mostram que esta ocorrência - em que a opção se dá pela difícil escolha de uma identificação de sujeito com a condição mais 'frágil' ou socialmente dominada como a de sujeito feminino (mulher) - está relacionada às finalidades de uma assistência 'integral', voltada para a emancipação feminina, tal como em parte 'obriga' (porque torna uma exigência tecnológica, prática) a própria estruturação do PAISM.

Por fim, o fato de tomarmos a interação usuárias-profissionais baseia-se na constatação de que o imperativo de optar ética e politicamente dá-se aqui em situação por vezes extremamente dramática: a violência. É neste campo do trágico, quando o poder é radicalizado como barbárie, que observamos o conflito que se estabelece, ganhando a necessidade de optar, por parte das mulheres. A opção realiza-se nas mais diversas direções: mulheres da tradição; mulheres da mudança; mulheres do feminismo; mulheres do 'masculinizado' poder profissional.

Este trabalho está inserido em uma pesquisa maior: Violência e Gênero nas Práticas de Saúde, utilizando, como base empírica, as ações concretamente desenvolvidas na assistência à Saúde da Mulher, tal como produzida cotidianamente no Centro de Saúde

\footnotetext{
${ }^{2}$ Este Programa existe nacionalmente há 13 anos e tem como característica ter sido formulado e implantado com a participação do movimento de mulheres. Baseia-se em referenciais epidemiológicos, com ênfase na atenção primária e nas atividades educativas. Ver d'Olveira, 1996; COSTA, 1992; CoRRÊA, I993.
} 
Escola Samuel B. Pessoa ${ }^{3}$. Este Centro é um serviço público de atenção primária, situado no município de São Paulo e no qual, há pelo menos 10 anos, estão implantadas as diversas ações do PASM.

A escolha do Palsm como ponto de partida deve-se ao fato de ser um programa que pretendeu tecnologicamente explorar questões de gênero, entre as quais, atualmente, incluímos a violência. Estudando esta proposta assistencial (d'Oliveira, 1996) constatamos que sua dimensão educativa é que particularmente se constituiu como capaz de conter técnicas que facilitassem a emergência das questões de violência.

Nossa reflexão se baseia no registro das falas produzidas nas atividades que, no mencionado serviço, formam o conjunto de trabalhos em grupo para a contracepção; controle de câncer ginecológico e doenças sexualmente transmissíveis (DST); e recepção do programa, cujo tema são as necessidades de saúde das mulheres em geral. Em trabalho anterior (d'Oliveira \& Schraiber, 1997), analisamos as situações de violência que emergiram nessas atividades, valendo-nos de categorias formuladas em torno do eixo analítico 'comunicabilidade', adotado para examinar a relação: necessidades apresentadas pelas usuárias - resposta desenvolvida pelo serviço. Este eixo foi tomado como a síntese de três dimensões possíveis da comunicação: a expressão da violência pela usuária e sua apresentação como problema; o acolhimento pelo profissional, dispondo-se em situação dialógica e acatando o problema como demanda; e a proposição de alguma ação pelo profissional, buscando intervir ou resolver a situação de violência como responsabilidade do serviço. A individualização desses momentos para fins analíticos da temática comunicacional traz inegáveis vantagens, distinguindo disposições profissionais de fato diversas nas ações em saúde: ouvir, acolher e tecnicamente intervir. Tendo por base essas diferentes disposições quanto à comunicação, tentaremos discutir de que modo elas correspondem também, a partir do diálogo, a éticas interativas distintas e produção de sentidos diversos para o feminino e suas questões.

O material empírico é composto pela observação de 16 grupos realizados de março a agosto de 1995, contabilizando 115 mulheres observadas. Os grupos foram observados diretamente, com registro em caderno de campo, gravados e transcritos. A maioria dos grupos (11) foi coordenada por auxiliares de enfermagem, sendo cinco coordena-

\footnotetext{
${ }^{3}$ Neste texto apenas trataremos da relação usuários-serviço neste recorte da interação discursiva com os profissionais, valendo-nos dos dados da observação direta e participante da assistência produzida em atividades grupais. A pesquisa em seu todo, que se desenvolve desde 1994 com apoio da Fundação Ford e CNPq, busca conhecer a articulação entre necessidades de saúde e uso/consumo de serviço, nas situações de violência de gênero, valendo-se de diversas aproximações e técnicas de coleta de dados. Por isso, é possível que, ao extrairmos um segmento, deixemos de dar ao leitor o conjunto das questões implicadas nas práticas de saúde, quando a demanda do serviço é relativa à violência. Cremos ter selecionado em especial os aspectos capazes de explorar o trabalho em saúde e a organização dos serviços como interlocutor privilegiado. Nosso intuito é o de destacar a importância desse interlocutor para os estudos de gênero e de violência.
} 
dos por uma médica e uma psicóloga. As usuárias têm de 14 a 53 anos, distribuídas prioritariamente na faixa dos 14 a 30 (69,1\%). Quanto ao estado conjugal, 72,9\% moram com o companheiro, somando-se a categoria de casados e união consensual. A grande maioria estudou até a quarta série primária, trabalha como empregada doméstica, faxineira ou dona de casa e vive em favelas. As oito profissionais observadas têm entre 34 e 50 anos de idade, sendo $75 \%$ casadas. Em termos de escolaridade, uma tem primeiro grau completo; quatro, segundo grau completo; três, nível superior completo. Em sua maioria (sete, das oito), as profissionais moram no mesmo bairro das usuárias ou em bairro ainda mais periférico, mas todas em estrato de renda superior ao das usuárias.

Ilustramos nossa reflexão com as falas rcgistradas no material coletado, apresentadas em itálico.

\section{Violência, poder e saúde}

Nos últimos anos, um conjunto de publicações vem comprovando a associação da violência nas relações de gênero a uma maior ocorrência de diversos problemas de saúde física, reprodutiva e mental, atestando sua alta prevalência e mostrando um uso mais freqüente dos serviços de saúde por parte destas mulheres. Estes trabalhos concluem também que a violência nas relações de gêncro não é investigada nem contabilizada nos diagnósticos realizados, e propõem o incentivo à busca ativa e intervenção sobre o problema pelos profissionais da saúde (McCouley, 1995; Heise, 1994; Stark, 1991).

Perceber a violência pode melhorar a eficácia das ações de saúde já tradicionais no campo da saúde reprodutiva, atingindo especialmente as mulheres que fazem um uso freqüente do serviço por problemas recorrentes. Além disto, trabalhar a violência procura colocar em discussão um sofrimento que vai muito além das patologias a ele associadas. Não buscamos encontrar algum percentual de ocorrência ou prevalência de violência nas relações de gênero. Existem inúmeras investigações que constatam sua magnitude em diversos países e mostram como este tema é ignorado nos diagnósticos e registros médicos. Nosso objetivo é detectar as formas de surgimento espontâneo do problema e a maneira como ele já está sendo 'trabalhado' nos serviços de saúde.

Por este motivo, nosso primeiro desafio consiste em delimitar 'violência' entre as situações relatadas. Ao adotarmos o referencial de relações de gênero para esta análise, observamos que, muitas vezes, questões de gênero e violência são convergentes e tratadas como uma mesma definição conceitual. Para nós, as raízes da violência nas relações de gênero encontram-se nas próprias relações de gênero. Mas a violência é um aspecto extremamente perverso destas, já que corresponde à anulação da relação entre dois sujeitos e a redução de um dos pólos da relação a simples objeto. A relação de poder pode 
ser assimétrica, ser exercida por uns sobre outros, agir sobre o campo de ações do outro (Foucault, 1995), mas precisa deste outro 'como um sujeito'. 'A violência começa quando é potencialmente aniquilada esta 'intransitividade de liberdade' que existe no cerne de cada relação de poder e um dos lados torna-se um corpo inerte, sem possibilidades de reação. Outros estudiosos da violência (Arendt, 1994; Costa, 1986; Chauí, 1984; Habermas, 1984) concordam que esta situação é a coisificação do Outro em uma relação de poder, ainda que com abordagens diversas.

Da perspectiva dialógica, podemos nos valer de Ricoeur (1995:60), para quem a violência é o Outro da linguagem: "a violência tem seu sentido no seu outro: a linguagem. E reciprocamente. A fala, a discussão, a racionalidade adquirem, também para elas, a sua unidade de sentido no fato de serem um empreendimento de redução da violência".

$\mathrm{Na}$ análise do material, percebemos como estes dois planos - relações de poder e violência - estão intimamente entrelaçados, interessando-nos discutir exatamente a possibilidade de reação, diálogo e de produção de alternativas pelo sujeito dominado. Isto porque estaremos nos valendo da noção de que a violência não é apenas um excesso de poder, mas uma situação outra, em que as relações são negadas e não há jogos de poder pelo simples fato de que um dos sujeitos da relação está 'vazio de poder'. Apoiadas em Arendt (1994), entenderemos poder como o positivo exercício da vontade de sujeito e sua capacidade de julgar e optar, exercendo tomadas de decisões. Destituído de qualquer empoderamento nesse sentido, o indivíduo coisificado estará em situação de violência e sua expressão fenomênica é a situação de ruptura comunicacional e interativa: situação de não-linguagem.

Será com base na noção de poder e explorando exatamente uma relação de poder peculiar que analisaremos nosso material sobre violência. Privilegiamos uma relação de poder entre mulheres: as usuárias e as profissionais do serviço observado. Trata-se contudo de relação peculiar pelo menos por duas razões. Primeiro, pelo fato de distinguir desiguais no interior do mesmo gênero; $\mathrm{e}$, segundo, porque esta desigualdade não é permanente, mas é, em contínuo, ao mesmo tempo desfeita e refeita.

Notamos que, quando falam sobre os homens, as mulheres observadas tendem a um só coletivo: perante este Outro-os homens-se identificam a um mesmofemininoqueestranha um Outro. Mas quando se trata de afirmaro feminino, exercerem a si mesmas como mulheres sujeitos-sociais, fazem dividiro Feminino (coletivo) e estranham-se entre si, dividindo-se em mulheres profissionais e mulheres usuárias, com discursos por vezes bem distintos.

\footnotetext{
${ }^{4}$ Isto significa que a assimetria na relação será comunicativamente buscada, e não estrategicamente, isto é, será buscada em trocas de argumentos nas quais ambos os sujeitos vão se colocando de acordo (concordes) com a assimetria, tal qual, por exemplo, em decisões compartilhadas de intervenção médica - satisfeitas, é claro, as exigências de enunciação das falas dentro da perspectiva do agir comunicativo (Habermas, 1989). Para aprofundar essa questão no trabalho em saúde, ver, quanto à relação médico-paciente Schraber (1997b) e quanto ao trabalho em equipe multiprofissional Peduzzi (1998).
} 
Buscamos aqui este movimento de cisão e reunificação, o que mostraremos quando 'mulheres cuidam de mulheres' $\mathrm{e}$ 'mulheres falam dos homens', como os dois segmentos a seguir, enquanto que as situações de violência que examinaremos serão analisadas na última parte do texto, em 'mulheres e violência: o trágico na sítuação de gênero'.

\section{Mulheres cuidam de mulheres}

Há uma diferença fundamental neste universo. De um lado, estão mulheres 'da instituição', que falam um discurso legitimado socialmente, mulheres competentes publicamente, que falam a 'verdade' científica (Chauí, 1993); de outro, estão as usuárias, as que 'não sabem' e, por isso, buscam respostas para seus problemas com quem 'sabe'. Relação em princípio assimétrica quanto ao conhecimento, mas que não necessariamente assim deva ser quanto à competência ético-política sobre o que se fala e a interação no diálogo. Por outro lado, apesar de possuírem situações socioeconômicas diversas, o que nem sempre ocorre, estas mulheres compartilham 'práticas de gênero': compartilham de alguma maneira a experiência de ser mulher na cidade de São Paulo. Em síntese, estas profissionais podem ser vistas como um 'duplo', isto é, femininas por situação de gênero e 'masculinas' por condição tecnológica, reproduzindo na enfermagem o poder médico ${ }^{5}$. Mas este poder é tensionado internamente pela própria proposta do PalsM (d'Oliveira, 1996).

De uma maneira geral, percebemos que o discurso das agentes da instituição é realmente ancorado no PAISM. As falas institucionais estimulam o conhecimento do corpo, o direito ao prazer e a participação masculina na contracepção. O diálogo é instigado como estratégia para a conquista destes objetivos. Entretanto, o diálogo interno ao grupo nem sempre flui. A fala institucional tem mais peso, mais tempo, coondena o grupo, dando e retirando a palavra. Há um estímulo perceptível para a expressão das usuárias, mas a instituição acaba sempre com a palavra final, em falas mais longas.

As usuárias resistem, concordam, defendem, silenciam, desafiam, contrapõem, questionam. Ao falarem de sua educação, sua relação com o corpo, suas negociações com os homens e sua interação com os serviços de saúde, elas falam, no estreito espaço que encontram, de um mundo da vida que não se 'encaixa' exatamente nos modelos que o serviço pode incorporar. Isto ocorre por falta, reducionismo, quando o modelo é

\footnotetext{
${ }^{5}$ A idéia do "masculino" quer fazer referência, claro, à posição de poder da autoridade desta fala, uma vez investida cientificamente. Apesar de estarmos ora trabalhando na polaridade masculino-feminino como metáfora à soberania de um dos sujeitos na relação dominante-subordinado, nem estamos identificando todos os homens mecanicamente a poderes soberanos, nem pretendemos reduzir o feminino (e todas as mulheres) à inexorável condição de subordinação, bem ao gosto de certa vitimização da condição de mulher. A força retórica, neste caso, dá-se apenas como contraste dos termos.
} 
estritamente o biomédico, situação em que o serviço, quando ouve e acolhe o problema - o que não é comum -, não oferece qualquer solução nesse plano do mundo da vida. Por outro lado, quando o modelo busca escapar do reducionismo biológico (como é o caso do pretendido pelo PAISM e pela instituição estudada), o mundo da vida parece também não conseguir penetrar as relações que se dão no serviço-já que as profissionais parecem buscar um tipo idealizado de sujeito tão pouco relacional que na resolução fornecida pelo serviço exige atos e comportamentos jamais pretendidos pelas usuárias, porque significam atos de subversão total do que valorizam e querem para si como mulheres em relação com seus parceiros. Assim, há dificuldades muito concretas à proposta resolutiva oferecida pela instituição e pelo PAISM, paradoxalmente quando há uma tentativa de responder por parte do serviço.

As profissionais da saúde fazem um discurso acerca do corpo que estimula insistentemente o autoconhecimento. As mulheres devem conhecer e tocar suas mamas, e é oferecido um espelho no exame de Papanicolau para verem seu colo do útero. Conhecer e tocar o colo também é necessário para o uso do diafragma, e é estimulado para o controle do DIU pela paciente. Além da anatomia, é ensinada também a fisiologia do aparelho reprodutivo feminino, com ênfase no período fértil e no muco ovulatório, que também deve ser percebido. Chama a atenção na fala das agentes o uso constante de diminutivos e simplificações, infantilizando o discurso com expressões como: bichinho, furinho, coisinha, asinha e outras parecidas. Também percebemos que diversas vezes o convite a se conhecer transforma-se em prescrição:

Vocês lembram que a gente examinou as mamas. Todo mundo examinou as mamas depois em casa? Eu não. Não falei pra todas que era pra fazer isto em casa? (tom de bronca). Não falei que era vocês mesmas que tinham que cuidar do corpo de vocês?

Uma parte das usuárias discorda frontalmente da idéia de se olhar ou se tocar. São mulheres que têm nojo, expressam repugnância, acham o corpo feio, ficam surpresas, não querem nem pensar nisto: "Mulher só é bonita de pé". Outras, a minoria, entusiasmam-se com as novas possibilidades colocadas, ou já as conhecem e querem se aperfeiçoar. De maneira geral, há uma certa desconfiança para com a oferta da oportunidade de cada um 'ser o seu próprio médico'. Esse papel não é visto nem como parte da experiência feminina, nem como parte da experiência de 'leigos' da medicina. A recusa, neste caso, pode ser vista como resultado dessa soma, mas, de qualquer forma, distancia a mulher-profissional que a oferece. O convite a olhar e tocar o próprio corpo parece suspeito, por pretender passar a responsabilidade de escolher o certo e o errado, o normal e o patológico, para as mãos do próprio examinado. Impossível deixar de ver nisso a cumplicidade complementar necessária à tão aceita relação assimétrica com as profissionais. Estas, por sua vez, incorporam o dever à emancipação nos moldes tão técnicos, como o faz o próprio Paism (d'Oliveira, 1996). E isto pode levar, muito 
freqüentemente, ao tratamento estratégico das dimensões comunicativas na interação, uma vez que a emancipação e a liberdade decisória das mulheres usuárias, que as profissionais pretendem inserir como um valor a ser exaltado, torna-se quase uma ordem técnica do serviço (tal como "seja livre!"). É preciso cuidado no sentido de não se resvalar na análise para falácias de cunho demagógico: não se pode ignorar a diferença de saberes - o da experiência científica e o da experiência da vida. Alerta-se tão somente (o que politicamente não é pouco), para a quase imperceptível (do ponto de vista cultural) transposição da autoridade técnica em autoridade moral, impedindo o exercício de escolhas pelo sujeito 'dominado'. Isto sem dúvida torna complexa a proposição ética do PaIsm e difícil seu exercício prático; contudo, não desqualifica a investida política de tentar o encontro da técnica com a ética da emancipação.

Em relação aos métodos contraceptivos, as mulheres reclamam com veemência da insegurança e efeitos colaterais dos métodos disponíveis. Percebem a pílula (ACO) como causadora de inúmeros males, inclusive uma 'massa' que se acumula no útero da mulher, necessitando de curetagem; o DIU como causador de hemorragia, dor nas pernas e câncer; e o diafragma como objeto artificial, extremamente esquisito e trabalhoso. A eficácia do DIU e do diafragma também é muito questionada. Além disto, as mulheres dizem que "tabela não funciona, camisinha os homens não usam", nem vasectomia, e até a laqueadura, única opção mais segura, "pode desfazer". As mulheres parecem bem insatisfeitas e inseguras com as possibilidades de escolha disponíveis. As queixas relativas aos métodos são incisivas, fazendo com que as usuárias desafiem as profissionais quando estas tentam contestá-las. Chegamos a ouvir relatos de mulheres que afirmavam ter "visto a massa de pílulas em um exame de ultra-som", ou de afirmarem conhecerem mulheres que "retiraram várias cartelas de pílulas em curetagens".

As profissionais, por seu lado, ciosas de seu saber, enfrentam o questionamento. Mas o fazem menos pelo diálogo entre diferentes concepções femininas acerca do planejamento reprodutivo e do corpo - para o que trabalham positivamente as distintas imagens do recurso de contracepção disponível, mantendo a identidade de mulher - e mais pela desqualificação do saber prático diante do científico. Permitem alguma expressão das concepções das usuárias, mas depois têm longas falas acerca de anatomia e fisiologia do aparelho reprodutor feminino. Buscam desfazer o que chamam 'mitos' ou 'fantasias' que obstaculizam o caminho da compreensão da verdade anátomo-fisiológica (ainda que bem simplificada, dadas as condições da cena de encontro entre elas). Defendem, em maior ou menor grau, a eficácia e a segurança de todos os métodos, especialmente do DIU. São estimulados também o condom e o diafragma. Pouco dizcm sobre o que elas próprias usam, como experiência de vida com estes métodos, e também pouco tematizam as diversas experiências das usuárias com a contracepção de forma positiva, tratando esta experiência como 'o contexto formador' dos tais mitos. 
O grande desafio das profissionais no grupo é convencer as mulheres de que é possível controlar a capacidade reprodutiva por meio de recomendações técnicas. Enfrentam uma verdadeira oposição de saberes e buscam nunca igualar-se no saber da vida, mantendo-se como técnicas antes de mais nada ${ }^{6}$. Uma das mulheres reclamava de uma gravidez indesejada, quando outra, buscando consolá-la, afirmava que "gravidez nunca vem na hora certa". Mas é a enfermagem que chama a possibilidade do poder feminino, por meio de seu poder de técnico: "Acho que a palavra nunca é muito grande. Eu já vi. Eu trabalho num local que eu tenho contato com grávida, direto! Tem gravidez planejada...". Experiência feminina transmuta-se em poder... ganha maior valor de verdade e de ensinamento moral ${ }^{7}$.

Há, no entanto, uma sensação de batalha perdida. Mesmo as profissionais, apesar da veemência da fala, parecem perceber que a desconfiança com a efetividade dos métodos e o medo dos efeitos danosos à saúde têm base em uma experiência muito concreta, que está na relação com os homens. Esta sim - problemática assumidamente compartilhada por todas as mulheres presentes na cena - passa muito longe da sala de grupos do Centro de Saúde e das informações técnicas, tal como colocado por uma usuária de escolaridade superior:

Eu, quando fiquei menstruada, fui ao ginecologista, eu sei todo ciclo fisiológico e nem por isso deixei de ficar grávida. Não é uma questão cultural, é uma questão de tudo o que acontece, da falta de apoio da mulher. Sei toda a parte glandular, parte hormonal, mesmo assim... Acho que as mulheres que não têm informação ficam se culpando o tempo todo de não ter a informação de tudo, fisiológica, anatômica, eu fui pro brejo (rindo). Porque não éassim, não é problema só delas. É um problema de todas as mulheres de todos os niveis.

A tentativa de tornar as mulheres mais autônomas encontra-se obstaculizada pelo simples fato de que a autonomia não pode ser concedida, nem depende apenas de um conjunto de informações. Se estas informações e este estímulo podem ser responsáveis por ganhos efetivos para as mulheres, também podem instaurar uma nova norma, quase impossível de ser atingida: a mulher independente, que controla a reprodução, tem prazer, conversa com o marido e tem os mesmos direitos do homem. Adificuldade das profissionais encontra-se na resistência de grande parte das usuárias ao modelo de identidade feminina e relações de gênero proposto pelo PAISM. Ao mesmo tempo, há uma segunda dificuldade: como identificar-se com o feminino se a posição institucional

\footnotetext{
${ }^{6}$ Esta dificuldade que as mulheres profissionais têm de, ao mesmo tempo, identificarem-se com o grupo de usuárias e suas questões e defenderem pontos de vistas da instituição, no jogo das diferenças, acirrase nas situações de grupo e na disposição de ações educativas do tipo dialógicas ou comunicacionais. Veja-se interessante estudo sobre esta mesma situação de conflito quando em atividade de educação em sala de espera, em Rodrigues et al., 1996.

${ }^{7}$ Victora (1995), estudando mulheres de classes populares $\mathrm{cm}$ Porto Alegre, mostra que as idéias de gravidez prevista e desejada são muito diversas entre si, adquirindo cada uma sentidos distintos para mulheres e profissionais da saúde.
} 
proporciona uma relação assimétrica, cm que o poder e o saber estão polarizados na profissional, que de um lugar não-identificado como igual ao feminino propõe um novo feminino? É possível, do 'alto deste poder', conceder poder para as mulheres? Parece-nos que não se pode ordenar a alguém que seja livre ou exigir que tenha poder... mesmo quando se pode instigar à emancipação pelo reconhecimento e discussão das condições de subordinação e violência.

\section{Mulheres falam dos homens}

Os homens foram objeto freqüentc das falas nos grupos, em grande parte das vezcs negativas. Houve também algumas referências positivas, mas sempre ao 'meu homem', o parceiro atual. Quando falam dos homens em geral, usuárias e profissionais falam de um só personagem: "machista, ignorante, retrógrado, homem das cavernas". A reclamação é geral: "homem é que nem tatu, não pode ver buraco", "homem é feito de pau". Usuárias e profissionais concordam: além de não se preocupar com contracepção e não assumir os filhos, os homens não se preocupam com a transmissão de DST/Aids e querem determinar as ocasiões e formas de exercício da sexualidade.

Os dois grupos divergem, entretanto, nas estratégias para enfrentar esta situação. As profissionais propõem como solução de mudança o diálogo, a conversa entre o casal. O entendimento e respeito mútuo, buscados por intermédio da conversa poderiam resolver os obstáculos que todas julgam encontrar nas relações com os homens no campo das escolhas reprodutivas e sexuais, com o que parece concordar apenas uma fração minoritária das usuárias. A maioria delas não parece acreditar na possibilidade de um diálogo e, entre as mulheres usuárias, as posições se dividem mais uma vez. Uma parte delas não concorda que as coisas devam mudar. Querem o mesmo, de novo!

Assim, ao se tratar das estratégias de relação com a participação das mulheres e, a partir disto, definir positivamente o que é ser mulher nesta relação com os homens, o feminino é plural. Desta feita... também do lado das usuárias:

"a gente já foi criada naquilo, já tem aquela experiência de velho, então, não tem como a gente mudar mais". "Eu já penso diferente. Eu acho que nada como um dia atrás do outro..."

Ao que o serviço argumenta:

Vocênão vê perspectiva nenhuma? De mudança? Ou você não quer mudar, ou você acha que melhor ficar nessa, porque ai não vai se comprometer? O que você acha disso: que é melhor ficar nessa ou...?

Outra parte das usuárias não concorda com a atual falta de direitos das mulheres. Propõe como estratégia de mudança a ruptura de relações desfavoráveis sempre que possível. Para estas mulhcres, o diálogo não parece uma solução viável. 
Concordar em matéria de homens e discordar das estratégias femininas também é o que ocorre quando o assunto é a maternidade (tratada pelos serviços como o número de filhos e o seu controle racional, com a divisão dos encargos contraceptivos). As profissionais concordam com as usuárias em relação à nả̉o-participação masculina no que se refere à saúde reprodutiva. Todos os grupos de contracepção observados começaram com a proposta do serviço de discutir a necessidade dessa participação. Mas, como os homens não o freqüentam, este papel tem que ser feito por cada mulher, que deve mudar 'seu homem'. Certamente muitas mulheres vão se sentir indefesas com este encargo adicional. Como aumentar o poder em uma relação marcada por desigualdades estruturais somente com a vontade individual? Algumas delas declararam preferir outra estratégia: já que os homens não querem "assumir", elas recusam a aceitar que eles reconheçam a paternidade ou ajudem financeiramente, para não dar a eles "nenhum direito" sobre os filhos.

Em relação à sexualidade, profissionais e usuárias concordam que a mulher tem direito ao prazer, e que o respeito é fundamental para este prazer. Concordam também com a idéia de que os homens, principalmente os maridos, não aceitam uma recusa quando querem sexo: "Homem, quando ele quer, ele quer". Mas, enquanto o serviço chega a considerar "dar-se só para satisfazer a cle" literalmente uma violência, algumas mulheres defendem que "servir a ele" pode ser necessário... para que ele não arranje outra.

O tema da 'outra' é crítico, revelando cisões e rearranjos entre casadas e solteiras (potenciais 'outras'), que se combinam diferentemente com as profissionais. O mais complexo é a atuação destas, em fato flagrado relativamente à difícil situação de 'sexo scguro'... Dois códigos encontraram-sẹ em disputa. Um é o necessário uso da camisinha sempre que há troca de parceiros, ou quando seu parceiro faz trocas (há outras/ outros). O outro é o código milenar da não-publicidade da situação de trocas (chamadas de infidelidades), para além da aceitação desta situação apenas como algo masculino. Não se pode falar dessa possibilidade na negociação. Diante das dificuldades relatadas, as profissionais encontram-se em um impasse. Concordam e vivenciam as dificuldades de negociar o condom, mas têm o dever profissional de recomendar seu uso. Face ao impasse, a estratégia é relativizar a regra técnica mais geral, 'usar condom em todas as relações', revertendo-a na fórmula: 'usar camisinha em relações eventuais ou quando pular a cerca'. Como este 'pular a cerca' é fato que não pode ser reconhecido, a estratégia da relativização da norma técnica revela-se como 'capitulação' - que pode ser perigosa em relação aos rumos de prevenção da epidemia entre mulheres casadas, já que estas vivem relações de poder de extrema desigualdade, sem poderem lançar mão de diálogo e confiança de relações simétricas. Sem eficácia técnica, mas resolução aparentemente técnica com total amparo da moral vigente, a adaptação da regra corresponde essencialmente a uma atitude conformista e, às ocultas, reconhecedora do problema principal, que permanece 'não abordado': a relação com os homens. Daí a razão de que as dificul- 
dades relatadas pelas mulheres - "com eles não tem diálogo" - quase não encontrarem espaço de expressão, sendo, de fato, evitadas.

O caso do tratamento das DST é um exemplo de como esta situação pode ser difícil para os serviços de saúde. A paciente tem corrimento recorrente e o diálogo com a enfermagem é como segue:

"Isso aqui eu levo (exame)?"; "Não, isso fica. Você queria levar? (silêncio) Você melhorou do corrimento ou continua?". "Continua". "Então, agora ele precisa tratar, só você não adianta, tá." "E pra segurar ele? Não adianta!" (pausa) "Ah, ainda não marquei no seu cartãozinho." "Queria fazer uma consulta de... é que eu tô sentindo umas dores de cabeja sabe, não sei se é sinusite."

Este exemplo tem sérias conseqüências para a proposta técnico-política do PAISM. As profissionais limitam-se a fazer o apelo ao diálogo - obstaculizado no interior da própria instituição em relação às dificuldades encontradas para a negociação sexual e seus empecilhos. Acabam por não enfrentar os obstáculos às suas ações, mudando de assunto.

Por que não enfrentam esse problema principal? Essa parece ser a grande questão, em suas situações de 'duplo': as profissionais também precisam manter-se como sujeitos técnicos; querem apoiar as mulheres por meio dessa técnica e, por fim, compartilham, na maioria das vezes, os mesmo códigos e valores morais. São, pois, situações de conflito de deveres, em que não podem apelar a qualquer saber exterior àquele momento da vida-nem o técnico-científico, nem o prático. Impasse moral ${ }^{8}$, cuja resolução parece apenas ser enfrentada nas situações dramáticas da violência.

\section{Situaçōes de violência: o trágico na condição de gênero}

Foram muitas horas com dor... mas a dor é... nunca senti tanta dor na minha vida... No hospital me maltrataram lá embaixo, as enfermeiras: 'Cala a boca, na hora de dar foi bom, não!' Vocêtá com tanta dor que você vai responder o quê?? Já tá doendo. Elas tratam a gente como se não fosse nada. Acho que se nessa hora elas dessem uma palavra de carinho, de amor, mas não... já amenizava. A culpa não é da gente...

Buscamos na análise distinguir situações de violência em que o sujeito estivesse totalmente anulado e, ao mesmo tempo, reconhecer as resistências e exercícios de poder que formam esses contextos que propiciam o surgimento da violência. Como as atividades não foram planejadas para estimular ativamente o relato de violência, nos surpreendemos com a freqüência de situações espontaneamente apresentadas (sete, em 16 grupos). As situações que foram consideradas violência em seu sentido mais estrito emergiram sob diversas formas. Em relação ao espaço doméstico, houve relatos de violência física e

\footnotetext{
${ }^{8}$ Sobre o conflito moral em situações de trabalho para os profissionais em saúde veja-se SCHRAiBER, 1997a.
} 
sexual; em relação ao espaço público, foi relatado um estupro e diversos registros acerca de violência institucional. Estas situações foram identificadas ao se falar de homens e sexualidade (quatro grupos) e sobre episódios de uso de serviços de saúde, especialmente em relação ao parto (três grupos). Um aspecto interessante foi a emergência de mais de um caso naqueles grupos em que havia uma situação de violência relatada. É como se um relato propiciasse outros, em 'bola de neve'.

As reclamações dos serviços de saúde são dirigidas principalmente aos maus tratos recebidos no atendimento ao parto (dois grupos). Muitos foram cometidos por profissionais mulheres. As profissionais do CSE solidarizaram-se com as usuárias e propuseram a resistência: reclamaré a fala recomendada.

Nestas relações instituição hospitalar versus usuárias, entretanto, parece não haver a menor possibilidade de negociação. Em uma cidade como São Paulo, buscar assistência médica hospitalar em caso de parto é quase compulsório, exceto para uma pequena parcela com acesso a opções de outro tipo. Compelidas a buscar assistência, as mulheres encontram uma brutalidade a que, dizem, é melhor "suportar calada ao invés de gritar, reagir ou dar escândalo e correr o risco de represália". "E se eu reclamo e fazem um corte maior, de propósito, só pra infeccionar e eu morrer?"

Independentemente de sua ocorrência, a possibilidade desta imagem é eloqüente para demonstrar o estado das relações entre instituições de saúde e usuárias. Encurraladas em seu campo de opções, a resistência pode lhes custar bem caro.

Deus me defenda! Acho que se eu parisse de novo, um lugar que eu não ia era o hospital. Eles cortam, depois vêm com aquela agulha aplicar (ri). Uma vem com anestesia para aplicar eu digo: 0 quê??! Vocên não vai aplicar injeção nenhuma aqui não! Não mandei vocês me cortarem! eu tinha filho não era preciso isso!, 'Ah, então fica abertona ai!'. Eu digo: Deixa! Não é meu? E fui me embora. Ai me colocaram na cama assim toda aberta, não tinha colocado um ponto. Depois começou a hemorragia. Chegou lá a doutora, queria aplicar, eu digo: Nāo!, 'Então vai de sangue frio mesmo!', eu digo: Tudo bem! Ai me costuraram a sangue frio, mas eu não deixei me aplicar a anestesia.

Chama atenção a falta absurda de diálogo e acolhimento desta mulher que experimentava pela primeira vez rotinas hospitalares. Também notamos que a relativa identidade de gênero e solidariedade, que aparece no contexto do PAISM, contrasta com a insensibilidade de gênero demonstrada pela doutora neste relato.

$\dot{E}$ interessante notar que as profissionais do Centro de Saúde, apesar de acolherem estes relatos e solidarzaremse com as usuárias, estimulando o diálogo e a reação, não têm solução técnica a propor. Em conseqüência, parecem ficar um pouco incomodadas com as criticas, acabando por sempre cortar a discussão e mudar de assunto, sem fazer a tradicional 'fala final', como fazem em todos os outros temas. Dizem apenas 'édificil nossa vida, não é?' e voltam ao tema discutido anteriormente.

Já a violência sexual é acolhida por profissionais e usuárias, contando com a solidariedade de todas. As mulheres que relataram violência doméstica não se colocaram como vítimas, afirmando-se como sujeitos interagindo em situações extremamente 
difíceis, em que a mínima reação pode ser punida fisicamente:

"Não é que ele me batia, a gente se pegava", "o meu for tipo de um estupro, mas elenão era assim tão violento. Tá certo que depois ele me batia, porque eu ficava de cara fechada para mostrar que não estava satisfeita com aquilo. "

Diante do trágico, todas parecem se unir:

Eu tinha um trauma comigo. Quando eu era pequena, tinha nove anos, um cão lá do norte pegou eu, e carregou para o mato, só que como eu era pequena, ele não consegui nada. Aic como eu tava vendo que eu não tava agüentando aquela situasão que ele queria, ai eu meti uma mordida no braso dele saí. Até nas minhas pemas tem uma marca de unha de gato. Você sabe o qué unha de gato, né? É, eu sai correndo nos matos (começa a chorar).

O grupo fica tocado e as outras usuárias tentam alternativas de resolução:

"E se ela passasse num psicólogo, acho que methoria a situação dela", "Sabe, eu passei num psicólogo na gravidez dela porque eu não aceitava minha gravidez, eu sou separada. Eu não aceitava, eu passei na psicóloga, e inclusive me ajudou bastante, tanto ela quanto o médico foram excelentes pessoas comigo. Me ajudou bastante."

A coordenadora do grupo concorda com o 'encaminhamento' proposto pelas usuárias:

Então, depois a gente pode conversar um pouquinho mais sobre isso, elas deram uma sugestão, o que você acha disto? Seria legal? Uma ajuda de um profissional mais especializado, para te ajudar. Junto com você, te ajudar a superar um pouco disto. Você gostaria de ter prazer, um relacionamento sexual legal porque isso te incomoda pelo que vocênos mostrou aqui hoje.

Profissionais e usuárias foram unânimes no acolhimento e na sugestão de intervenção. A possibilidade de solidariedade e da discussão das causas destas situações - "as mulheres ficam em relações violentas por medo", disseram neste grupo duas mulheres que haviam saído de relações violentas -, assim como a afirmação categórica do direito da mulher ao respeito e o seu imperativo para a possibilidade de ter prazer foram o tema da primeira metade deste grupo, quando se discutiu sexualidade e violência. A outra metade foi tomada pela discussão dos métodos contraceptivos, tema principal da atividade. Otema da violência foi trazido pclas próprias usuárias, que insistiram em discutir o prazer sexual no grupo de contracepção. Em contrapartida, a coordenadora do grupo abriu espaço para a discussão, acolhendo a demanda apresentada. Porém, este acolhimento não se mostra suficiente para resolver adequadamente as situações expressas.

É significativa a cena que segue: em um grupo de controle de câncer ginecológico, em que se fornece o resultado do exame de controle, uma das mulheres fica tonta no decorrer da atividade, deita-se e assiste a tudo deitada, sem falar nada. Ao final, depois de dispensar as outras usuárias, a profissional conversa com ela. Neste momento, ela conta que tem "mania de limpeza" e que o marido "bate nela". Ao ouvir isto, a profissional tenta encaminhá-la à saúde mental. A mulher resiste: já foi diversas vezes, não gostou, acha que não adianta conversar. Sem resolução para o caso, a profissional dá alguns conselhos e dedica-se a convencer a mulher a aceitar o encaminhamento. Nesta tentati- 
va, ela bloqueia a escuta e encerra o diálogo. Parece que, não conseguindo responder de modo satisfatório à demanda da paciente, sua angústia por ter algo a oferecer acaba por impedir a continuidade do trabalho de acolhimento que vinha sendo feito. Também parece ter sido mais difícil a situação de consulta individual, já que o grupo, que tinha ido embora, não ouviu e não pôde amparar solidariamente a mulher. Este amparo do grupo aparece como identidade de gênero: "eu também já passei por isso... e sai" -a identidade de seus pares, usuárias facilita a ausência de resolução imediata por parte do serviço.

Em termos gerais, as situações de violência, apesar de não terem muitas opções de resolução, parecem mobilizar bastante os grupos. Impressiona também o contraste destas situações com o restante da orientação técnica, que busca a autonomia sexual e reprodutiva das mulheres. É como se todas as explicações sobre o corpo e o discurso acerca da paternidade responsável e do direito da mulher ao prazer caíssem por terra, diante de uma realidade muito cruel. Ao mesmo tempo, a possibilidade da emergência, acolhimento e tentativa de resolução destas situações é também uma mostra da possibilidade de relações mais simétricas no interior dos serviços. Por isso mesmo, será a partir destas relações, que, a nosso ver, deveremos re-trabalhar os programas assistenciais, explorando as distintas concepções do feminino e de seus caminhos; os diferentes saberes em jogo; e as diversas estratégias de luta e acomodação no sentido de encontrar alternativas mais eficazes para o trabalho. Não se trata de negar a diversidade, mas de reconhecermos o movimento de cisão-reunificação de um feminino em transformação, como o aqui retratado, para que as relações possam ser compreendidas e direcionadas para formas interativas de maiores possibilidades dialógicas. O diálogo, que só pode dar-se na separação da autoridade técnica em relação à moral, evitando que a primeira se transmute na segunda, continua sendo, em nosso ponto de vista, o modode se evitar qualquer forma de violência. Afinal, a violência tem na linguagem e comunicação o seu Outro.

\section{Referências Bibliográficas}

ARENDT, H. Sobrea Violência. Rio de Janeiro: Relume-Dumará, 1994.

Chaui, M. Cultura e Democracia. 6ª ed. São Paulo: Cortez, 1993.

Chaứ, M. Participando do Debate sobre Mulher e Violência. In: CHaú, M. Perspectivas Antropológicas da Mulher 4. Rio de Janeiro: Zahar, 1984.

CORREA, S. PAISM: uma história sem fim. Recife: SOS Corpo, 1993.

Costa, J. F. Violência e Psicanálise. $2^{\mathrm{a}} \mathrm{ed}$. Rio de Janeiro: Graal, 1986.

COSTA, A. M. PAISM: uma política de assistência integral à saúde da mulher a ser resgatada. São Paulo: Comissão de Cidadania Reprodução, 1992. 
D'OlIVeira, A. F. P. L. \& SCHraiber, L. B. Violence against women: a physician's concern? In: OTRESEN, B.; TABOR, A. (Eds.) New Insights in Cynecology \&Obstetrics-research and practice. London/ New York: Parthenon Publishing, 1998.

D'OuveirA A. F. P. L. Gênero V Vilência nas Práticas de Saúde: contribuição ao estudo da atenção integral à saúde da mulher, 1996. Dissertação de Mestrado. São Paulo: Faculdade de Medicina da USP.

Foucautr, M. Osujeito e o poder. In: Rabinow, P.; Drerfus, H. L.\& Foucautr, M. Uma Trajetória Filosófica para além do Estruluralismo e da Hermenêutica. Rio de Janeiro: Forense Universitária, 1995, p. 231-249.

Gallo, E. (Org). Razão e Planejamento: reflexões sobre politica, estratégia e liberdade. São Paulo: HucitecAbrasco, 1995, p. 117-154.

Habermas, J. O conceito de poder de Hannah Arendt. In: FrettaG, B. \& Rouanet, S. P. (Orgs). Habermas - Coleção Grandes Cientistas Sociais (15). São Paulo: Ática, 1980, p.110-118.

HaBermas, J. Consciência Morale Agir Comunicativo. Rio de Janeiro: Tempo Brasileiro. Biblioteca Tempo Universitário n.84, 1989.

HeISE, L. Gender-based Abuse: the global epidemic. Cademos de Saúde Pública, (10):135-145, 1994.

MCauley, J. et al. The "Battering Syndrom": prevalence and clinical characteristics of domestic violence in Primary Care Internal Medicine Practices. Annals of Intemal Medicine, 123 (10): 737-748, 1995.

PEDUZzı, M. Equipe multiprofissional de saúde: a interface entre trabalho interaşão, 1998. Tese de Doutorado. Campinas: Faculdade de Ciências Médicas da Universidade de Campinas.

Ricoeur, P. Violência e linguagem. In: Ricoeur, P. Em Tomo ao Politico. São Paulo: Edições Loyola, 1995.

RIVERA, F. J. U. Agir Comunicativo e Planejamento Social (uma critica ao enfoque estratégico). Rio de Janeiro: Ed. FIOCRUZ, 1995.

RodriGues, L. A. J. et al. Interações com usuários na unidade básica In: Schraiber, L.B.; NEMES, M.I.B. \& MENDEs-GonçALVES, R.B (Org.) Saúde do Adullo: programas eações em unidades básicas. São Paulo: Hucitec/FMUSP, 1996, p. 262-275.

SChraiber, L. B. Medicina Tecnológica e Prálica Profissional Contemporânea: novos desafios, outros dilemas, 1997b. Tese de Livre Docência. São Paulo: Faculdade de Medicina da Universidade de São Paulo. v.I p.210; v.II p.208.

Schraiber, L. B. No encontro da técnica com a ética: o exercício de julgar e decidir no cotidiano do trabalho em medicina. Interface - Comunicação, Saúde, Educação, 1(1):123-140, 1997a. 
Schraber, L. B. Políticas Públicas e Planejamento nas Práticas de Saúde. Saúdeem Debate 47:2835, 1995.

Stark, E. \& Futcraft, A. Spouse abuse. In: RosemberG, M. L. \&. Fenley, M.A. (Eds.) Violence in America: a public health approach. New York: Oxford University Press, 1991. p.123-157.

VICTORA, C. G. Mulher, Sexualidadee Reprodução: representações do corpo em uma vila de classes populares em Porto Alegre, 1995. Dissertação de Mestrado. Porto Alegre: Instituto de Filosofia e Ciências Humanas da Universidade Federal do Rio Grande do Sul. 



\section{Ações de Contracepção e Assistência ao Parto: a experiência do Rio de Janeiro'}

Diana do Prado Valladares

Não serei o poeta de um mundo caduco

Também não cantareiomundo futuro. Estou preso à vida e otho meus companheiros. Estão tacitumos, mas nutrem grandes esperanças Entre eles, considero a enorme realidade.

O presenteé tão grande, não nos afastemos. Nãonos afastemos muito, vamos de mãos dadas. (...)

Carlos Drummond de Andrade

\section{Introdução}

Para aquelas pessoas que trabalham diretamente com outros seres humanos, as palavras de Drummond calam fundo, dando-nos a medida do desafio e da beleza desta tarefa. Daí porque, ao tentarmos traduzir em ações as propostas do Programa de Assistência Integral à Saúde da Mulher (PaISM), do Ministério da Saúde (1984), uma das maiores dificuldades enfrentadas é compreender que, em cada ato, o outro é uma pessoa em toda a sua integralidade e complexidade.

\footnotetext{
* A experiência aqui relatada é fruto de um esforço coletivo. Todos os profissionais que trabalham na ponta são fundamentais para um atendimento de qualidade. Seria impossivel nomeá-los. Da equipe de nível central, sob o risco de omitir injustamente nomes de companheiros e companheiras, gostaria de citar: Carla Brasil, Cristina Boaretto, Elisabeth Cavalcante, Giselle Israel, Jane Q. Monteiro, Jean Ruffier, Katiá Ratto de Lima, Luis Claudio Fraga, Maria Auxiliadora Gomes, Maysa L. Gomes e Teresa Costa. Contamos sempre com a colaboração de: Ana Maria Castro, Inês Rugani, Juraci Ghiaroni, Marcos Dias, Maria Inês Nogueira, Rosa Domingues, Sandra Lobo e Viviane Castello Branco. Respondem pelo Espaço MuLher: Monique Miranda (Coordenadora), Louise Mara da Silva, Luiza Cromack, Regina Celia Brandão e Tania Silva.
} 
Nunca é demais lembrar que o PaISM foi criado em 1983, com base em uma realidade epidemiológica enorteado por princípios democráticos e feministas. As idéias ali colocadas questionavam a relação autoritária profissional de saúde-cliente, insistiam na importância das práticas educativas, apontavam para a necessidade de hierarquização dos serviços, repudiavam políticas demográficas, enfatizavam a importância de uma visão mais integral da mulher. De uma forma bastante geral, podemos dizer que as questões permanecem atuais.

Cumpre-me aqui a tarefa de relatar a experiência da Secretaria Municipal de Saúde do Rio de Janeiro (SMS/RJ), especificamente nas áreas de contracepção e parto, dentro da proposta geral de implantação do PAIsm. É um processo que está em pleno curso e que pretende, ao longo do tempo, propiciar à clientela feminina uma atenção de qualidade em todas as três grandes áreas do PAIsM: clínico-ginecológica, pré-natal e parto.

Não estamos sós nesta caminhada. Outras tentativas têm acontecido e certamente há municípios que, neste momento, cnfrentam este desafio. Apesar de não termos canais de articulação estruturados, ao longo destes anos o intercâmbio tem sido possível por meio de relações pessoais ou de encontros (de variados tipos) do movimento feminista e de seminários, simpósios, congressos da área da saúde ou de outras afins. Esta forma de aprendizagem tem sido muito estimulante, transformando nossa experiência específica, fortalecendo nossa convicção de que somos parte de um movimento maior, de um esforço coletivo de construção de um modelo de atenção à mulher que tenha como base o respeito aos seus direitos de cidadania.

Em uma sociedade em que estes estão garantidos na Constituição Federal mas são desrespeitados nos pequenos atos do cotidiano, é imenso o desafio do PaIsm. A pergunta que nos aflige a cada momento é: como garantir à população feminina um atendimento digno e de qualidade, quando a estrutura dos serviços públicos de saúde e parte significativa dos profissionais estão impregnadas de autoritarismo e preconceito. Não se trata apenas de decisão política. Esta é fundamental, mas só teremos resultados satisfatórios se aqueles que estão 'na ponta', isto é, aqueles responsáveis pelo atendimento direto à população (do funcionário da recepção ao diretor de uma unidade de saúde, por exemplo) passarem por algum processo de reflexão que questione sua própria atuação e, a partir daí, transformem sua prática.

Foi com esta clareza e uma enorme dose de otimismo que, em 1991, no início da gestão do Dr. Ronaldo Gazolla na Secretaria Municipal de Saúde e sob a coordenação da Dra. Cristina Boaretto, um grupo de profissionais fez um diagnóstico inicial das ações até então desenvolvidas pela SMS/RJ (deste grupo faziam parte mulheres profissionais da saúde que já desenvolviam, há algum tempo, propostas de trabalho que incorporavam, dentre outras, práticas educativas com viés feminista e técnicas de psicodrama).

Este primeiro retrato indicava que, apesar de atuarmos em várias áreas (prevenção e controle de câncer cérvico-uterino, pré-natal, parto e puerpério), a cobertura era insatisfatória e a qualidade do atendimento, em boa parte das unidades, questionável. 
As condições de trabalho tampouco eram boas: muitas unidades ambulatoriais estavam em condições precárias e algumas maternidades não só necessitavam reformas na sua estrutura física, como conviviam com graves problemas de equipamento (alguns inexistentes, outros ultrapassados ou, ainda, fora de uso por falta de manutenção). Para agravar o quadro, tínhamos também dificuldades na área gerencial, dificultando ainda mais o bom funcionamento dos serviços. E, por fim, uma questão sempre presente: baixos salários. Assim, cada um(a) atuava da forma que the parecia mais conveniente e/ ou correta, pois não havia diretrizes de atuação. Isto levava a um resultado freqüentemente desastroso, em que um atendimento de qualidade era prestado de forma aleatória, e a satisfação do(a) usuário(a) dependia da 'sorte' de encontrar um(a) profissional mais 'interessado (a)'.

Era preciso, então, traçar uma estratégia que recuperasse a auto-estima do(a) profissional, melhorando, ao mesmo tempo, a qualidade da assistência, aumentando as áreas de atuação do PaIsm e a cobertura das ações. Como pano de fundo para tudo isto era necessária uma política de recursos humanos que acenasse com uma melhoria salarial além de recuperação predial, garantindo condições dignas de trabalho.

\section{Contracepção na rede pública municipal do Rio de Janeiro}

Dentre as várias ações que não eram realizadas na rede pública municipal, encontrava-se a contracepção. Este fato, associado à ocorrência de elevadas taxas de esterilização feminina no Brasil e na cidade do Rio de Janeiro, à carência de serviços públicos de contracepção e a uma reivindicação já antiga das mulheres, determinaram que assumíssemos como prioridade a implantação de um serviço que garantisse à população feminina acesso aos métodos anticoncepcionais com acompanhamento adequado. Como parte deste compromisso, a Secretaria Municipal de Saúde do Rio de Janeiro (SMS/RJ) considerava como sua obrigação o fornecimento dos insumos. Não queríamos depender de Organizações Não-Governamentais (ONGs) de cunho e história controlistas.

Como, então, iniciar este processo?

Algumas premissas estavam claras: as práticas educativas deveriam ser, necessariamente, parte integrante de todo atendimento; o trabalho de grupo seria o locus privilegiado destas práticas educativas; como os(as) profissionais de saúde, na sua imensa maioria, não tinham experiência nesta área, eles(as) deveriam ter a oportunidade de participar de algum tipo de 'treinamento'; 'acesso a método' implicaria em acompanhamento clínico-ginecológico e nunca em simples distribuição de anticoncepcionais.

Pensamos então em organizar um grande seminário, convidando representantes de todas as 72 unidades ambulatoriais da cidade para apresentarmos nossas idéias, propiciar a estes(as) profissionais a oportunidade de vivenciar algumas práticas educativas, e 
também de ouvir algumas experiências de trabalho que se desenvolviam a partir das idéias preconizadas pelo PaISM. Naquele momento, o município de Niterói apresentava proposta semelhante. Desta forma, o seminário Saúde e Reprodução - contracepção e direitos de cidadania foi realizado em parceria, em agosto de 1991, no Instituto Brasileiro de Administração Municipal (IBAM), no Rio de Janeiro. Foi um acontecimento até então inédito na SMS/RJ. Durante três dias, 300 profissionais da saúde das diversas áreas (medicina, enfermagem, saúde mental, serviço social e nutrição) participaram de oficinas de vivência (a metodologia utilizada era a do movimento feminista), trocaram idéias e experiências, tiveram prazer no trabalho. Para coordenar as oficinas, além dos(as) profissionais dos próprios quadros das duas secretarias, foram convidadas feministas que já trabalhavam nesta linha em outros espaços. Poucas vezes, no estado do Rio de Janeiro, o movimento feminista havia contribuído de forma tão intensa, em um único momento, para o serviço público.

\section{A implantação das açōes de contracepção}

A partir deste seminário, iniciou-se o processo de implantação das ações de contracepção que segue até hoje o mesmo fluxo: formação de uma equipe multidisciplinar na unidade de saúde, que elabora a proposta (que deve incluir, pelo menos, os conteúdos a serem trabalhados no grupo e fluxo de atendimento); esta é enviada para a Gerência dos Programas de Saúde da Mulher que, após avaliação, reúne-se com a equipe, tira dúvidas, sugere modificações, discute a proposta do PAISM e apresenta todos os impressos necessários para o desenvolvimento do trabalho. Deste momento em diante, a unidade de saúde está autorizada a iniciar o trabalho, que terá obrigatoriamente duas vertentes: atendimento individual e trabalho de grupo.

O fluxo estabelecido para as mulheres que solicitam métodos anticoncepcionais apresenta variações. Em linhas gerais, podemos dizer que cada cliente é vista pelo menos duas vezes pelo(a) ginecologista (consulta pré e pós-grupo), participa de um grupo, tem ao menos uma citologia colhida (caso não tenha feito este exame recentemente) e, a partir da adoção do método, passa a ser acompanhada periodicamente (Anexo 1).

Para a realização dos trabalhos de grupo nas unidades, a SMS/RJ fornece, de imediato, o material didático básico: uma pélvis de acrílico com os órgãos em tamanho natural; um álbum seriado de papel (enviado pelo Ministério da Saúde); dois bonecos de cartolina que vêm em diversos 'pedaços' para serem montados (uma boneca foi elaborada por equipe da Secretaria Estadual de Saúde de São Paulo na década de 80 e reimpressa em 1997, juntamente com a impressão de um boneco, pela instituição Associação Saúde da Famí- 
lia); folhetos dos métodos anticoncepcionais (adaptados dos produzidos pelo Ministério da Saúde); um conjunto com diversas fitas de vídeo que abordam questões relativas a sexualidade, gênero, DST, AIDS, gestação, parto e puerpério, contracepçãoe adolescência; e um conjunto de métodos que servirão para manuseio no trabalho de grupo.

Os insumos contraceptivos fornecidos pela SMS/RJ são: anticoncepcional hormonal oral, DIU, preservativo, diafragma e geléia espermicida. ASMS/RJ tem se responsabilizado pela compra rotineira dos métodos, excetuando-se o DIU, cujos quantitativos enviados pelo Ministério da Saúde têm sido suficientes para o consumo.

As equipes locais responsáveis pelo trabalho educativo são formadas por profissionais de diversas categorias, destacando-se enfermagem e serviço social. A menor participação de médicos(as) deve-se não só a uma maior dificuldade/resistência destes(as) em desenvolver o trabalho educativo (a formação universitária é reconhecidamente muito limitada neste aspecto, além de freqüentemente incorporar preconceitos ou ignorar questões relativas à saúde e direitos reprodutivos) como por pressão de demanda (às vezes é difícil para o gestor local 'liberar' um médico para um turno de trabalho educativo quando isto significa de 12 a 14 atendimentos individuais a menos).

O número de profissionais que desenvolvem as práticas educativas em cada unidade varia de acordo com a existência desta ou daquela categoria profissional (nem todas as unidades contam com assistentes sociais e/ou profissionais de saúde mental, por exemplo), do interesse, da disponibilidade de tempo (um outro exemplo: uma unidade pode ter uma enfermeira comprometida com a proposta, mas como ela é a única profissional de enfermagem, suas múltiplas obrigações não lhe permitem implantar as ações de contracepção). Estas dificuldades de recursos humanos não se restringem ao Programa da Mulher e sua solução não ocorrerá isoladamente.

A maioria das unidades trabalha com três reuniões por grupo, contando este com uma média de 10 participantes. Os conteúdos mais freqüentemente abordados são: fisiologia do aparelho reprodutor masculino e feminino, métodos anticoncepcionais, sexualidade. As questões relacionadas à Aids ainda não foram incorporadas de forma sistemática, mas identificamos um processo de gradual incorporação do tema. As discussões acerca das relações de gênero acontecem em algumas unidades.

A metodologia e as práticas educativas adotadas apresentam variedade. Há grupos em que a coordenação atua sempre com dinâmicas participativas, estimulando a fala das mulheres, construindo naquele momento conhecimentos coletivos, articulando questões gerais com as vivências de cada participante. Em outros lugares, a coordenação tende a transmitir conhecimentos de uma forma mais tradicional, ainda que garantindo às mulheres algum espaço de participação e reflexão. E é certo que em alguns outros o grupo é visto como um conjunto de mulheres que 'precisam' de informações e estas lhes são transmitidas em palestras - ou seja, uma pessoa fala e as outras 'aprendem'. 
Temos a firme conviç̧ão de que, sem as práticas educativas em grupo, sem a possibilidade de ter acesso à informação de maneira menos formal, em uma linguagem mais próxima, de poder refletir sobre sua sexualidade, sua realidade cotidiana, de esclarecer dúvidas, de trocar experiências, a mulher não terá as condições mínimas para fazer uma escolha de forma um pouco mais autônoma.

A autonomia, um dos objetivos destas ações de contracepção (e do PaISM como um todo) é de difícil avaliação. Permanecem em aberto as perguntas: O trabalho educativo tem efetivamente resultado em uma possibilidade maior de escolha? A relação profissional de saúde-usuária transformou-se, deixando de ser autoritária? A opção por este ou aquele método passou a estar nas mãos da cliente e não mais na daquele(a) que 'sabeo que é melhor para a mulher'?

Uma característica desta estrutura de atendimento foi a criação de impressos específicos onde são anotadas informações relativas aos grupos, à adoção de métodos anticoncepcionais por faixa etária e um cuidadoso controle dos insumos. Os impressos utilizados têm como objetivo garantir informações mínimas para a própria equipe (servindo de base para auto-avaliação do trabalho e permitindo acesso rápido aos dados da população atendida) e propiciar à Gerência dos Programas de Saúde da Mulher condições de conhecer o universo, planejar ações, calcular necessidades de insumos, discutir individualmente com as unidades o trabalho executado (Anexos de 2a 5). Esta organização, bastante detalhada, apesar de enfrentar algumas resistências, tem dado excelentes frutos: muitos profissionais hoje compreendem que a qualidade do atendimento implica também organização e planejamento; outros apropriaram-se da idéia de que na saúde pública o trabalho educativo em grupo deve andar pari passu com o atendimento individual; há os que hoje sabem que nenhum(a) profissional, por mais competente que seja, consegue dar conta sozinho(a) de uma 'atenção integral' e, portanto, a perspectiva multidisciplinaré a possibilidade de responder melhor ao desafio da integralidade; apesar das dificuldades salariais, tem sido possível estimular a auto-estima.

Os dados coletados rotineiramente ao longo destes seis anos apontam para uma distribuição de uso de métodos que nos parece bastante interessante (Tabela 1):

\footnotetext{
1 A tese de doutorado de Auta de Souza (1996) refere-se a estes e outros aspectos das ações de contracepção na rede pública municipal do Rio de Janeiro.
} 


\section{Tabela 1 - Uso de métodos anticoncepcionais por número de mulheres atendidas em 71 unidades da Secretaria Municipal de Saúde do Rio de Janeiro -1992-1997}

\begin{tabular}{lcc}
\hline Método & № de mulheres & $\%$ \\
\hline Plula & 13.054 & 53,0 \\
Preservativo & 5.276 & 21,4 \\
DU & 3.991 & 16,2 \\
Diafragma & 1.839 & 7,5 \\
Espermicida & 253 & 1,0 \\
Métodos Naturais & 209 & 0,9 \\
\hline TOTAL & 24.622 & 100,0 \\
\hline
\end{tabular}

Fonte: Secretania Municipal de Saúdedo Riode Janeiro, S/SSC/CPS/GPM.

Esta distribuição nos leva a algumas reflexões:

- quando apresentada a várias alternativas, a população não se restringe a apenas uma ou duas opções, mas escolhe de forma bastante diversificada, refletindo bem a heterogeneidade de situações vividas;

- esta variedade de escolhas é em boa parte frutodo trabalho educativo, que está permitindo às mulheres espaço para absorver informações e refletir sobre suas questões individuais; - em relação ao preservativo: apesar de os grupos serem abertos à participação masculina, o número de homens que comparecem é mínimo e, por isso, um percentual de $21,4 \%$ do uso de camisinha significa que a maior parte destes usuários optou por este método 'através' de suas esposas, companheiras ou namoradas;

- no que diz respeito ao diafragma: um percentual de 7,5\% de usuárias é uma grande vitória, especialmente quando sabemos das resistências dos(as) profissionais em relação a este método. Ousamos dizer que a mulher que adota um diafragma conseguiu vencer vários obstáculos: o seu desconhecimento; as suas próprias dificuldades em optar por um método pouco falado e pouco utilizado; a eventual resistência do companheiro; algumas vezes, a 'desconfiança' dos(as) próprios(as) coordenadores(as) do grupo com relação ao diafragma; ou, ainda, o possível desestímulo do(a) médico(a) no momento da consulta individual pós-grupo. Adicione-se a tudo isto o fato de que o uso do diafragma pressupõe uma intimidade com o próprio corpo à qual muitas mulheres não estão acostumadas;

- em relação ao percentual de métodos naturais: nossa hipótese mais forte é a de que, aliada à convicção de muitos(as) profissionais da baixa eficácia destes métodos, encontra-se uma desconfiança da própria população (é bastante comum que haja no grupo pelo menos uma mulher que afirme conhecer alguém com quem o método 'falhou'); 
- finalmente, pensamos nos 53,0\% de mulheres que adotaram a pílula. Tendo em vista ser este método amplamente conhecido, de fácil acesso e de alta eficácia, esta percentagem deve ser considerada baixa.

Esta variedade na escolha dos métodos não se dá de forma homogênea em toda a rede, excetuando-se a opção pela pílula, que está sempre em primeiro lugar. Quando olhamos as unidades de saúde individualmente, às vezes é possível identificar 'preferências' que, a nosso ver, refletem opiniões/posições seja da coordenação do grupo, seja do(a) profissional que atende no consultório. Exemplificando: há unidades em que a escolha inicial das usuárias é bastante variada, mas boa parte delas acaba adotando o DIU. Nas unidades em que há regularmente mulheres escolhendo diafragma, identificamos equipes mais compromctidas com os métodos de barreira (nãoé raro que nestes locais também o uso do preservativo seja significativo).

Ao longo destes anos temos procurado conhecer trabalhos semelhantes em outras cidades do País com o intuito de melhor avaliar nosso desempenho e trocar experiências. Infelizmente, não conseguimos obter estas informações. Parece-nos que na maioria das cidades onde o setor público assumiu esta responsabilidade os dados não estão disponíveis (pelo menos na forma que nos permitisse alguma comparação).

Paralelamente à implantação das ações de contracepção na rede básica, a SMS/RJ criou um centro de treinamento, fruto de uma proposta apresentada pelo Ministério da Saúde durante o Seminário Saúde e Direitos Reprodutivos, em 1991.

Naquela oportunidade, foi destacada a importância de se criar um pólo de treinamento para as ações técnicas e educativas na área de saúde da mulher. Observou-se também a necessidade de uma capacitação que utilizasse uma metodologia de trabatho com base no desenvolvimento de práticas educativas e que comportasse espaço para a escuta e expressão da mulher. Esta proposta era parte de uma política do Ministério da Saúde, que se comprometia a fornecer equipamento e instrumental mínimo necessário para o funcionamento de um consultório ginecológico, material educativo (folhetos, álbum seriado) e métodos anticoncepcionais (um tipo de anticoncepcional oral, alguns números de diafragma, geléia espermicida, preservativo e DIU)' ${ }^{\prime}$ A contrapartida do município seria espaço físico, recursos humanos e tudo o mais que se fizesse necessário.

$1 \mathrm{O}$ envio desses insumos foi feito de forma inconstante ao longo dos anos. Em determinado momento, - Ministério da Saúde comunicou que não mais se responsabilizaria pelo fornecimento dos métodos. No entanto, alguns continuaram chegando ao Centro de Treinamento, ainda que de forma irregular. 


\section{O “Espaço Mulher"}

Em dezembro de 1992, inauguramos o Centro de Treinamento em Atenção Integral à Saúde da Mulher - Espaço MuLHER, que passou a funcionar no Centro Municipal de Saúde Milton Fontes Magarão, situado na Zona Norte da cidade.

Levamos algum tempo para definir onde seria este centro de treinamento e compor uma equipe inicial mínima. Esta demora deveu-se a diversos fatores: dificuldade de identificarmos uma unidade de saúde que já tivesse pelo menos alguns profissionais não só trabalhando com práticas educativas, mas, também, com um perfil 'didático' específico para a nossa proposta (não tínhamos condição de contar com nenhum recurso humano fora dos quadros da própria Secretaria). O(a) profissional mais difícil de ser encontrado(a) foi o(a) gineco-obstetra, uma vez que é muito raro (pelo menos na rede municipal do Rio de Janeiro) ter alguém nesta especialidade que alie competência, uma visão da atenção à mulher dentro do que é preconizado pelo PAISM e a capacidade de ensinar. Havia o aspecto da localização geográfica da unidade, pois era importante que estivesse em algum bairro com acesso relativamente fácil para a maioria dos(as) funcionários(as). Um espaço físico adequado foi outro desafio: era necessário garantir um lugar apropriado e acolhedor (por exemplo, uma sala em que fosse possível reunir 20 pessoas de maneira informal) para o desenvolvimento dos trabalhos de grupo-e isto não era fácil, pois a arquitetura tradicional para unidades ambulatoriais não incluía a dimensão das práticas educativas como componente do atendimento. Para finalizar, tínhamos de encontrar uma gerência local que considerasse a criação deste Centro como um avanço na atenção à mulher, compreendendo que ser um espaço de treinamento era algo positivo, que só beneficiaria sua unidade e a população por ela atendida.

A equipe básica inicial compunha-se de uma gineco-obstetra, duas enfermeiras e duas assistentes sociais. Além deste 'núcleo', contávamos com duas psicólogas, uma assistente social e uma auxiliar de enfermagem, que atuavam nos grupos de contracepção e na organização do atendimento individual no consultório.

OEspaço Mulher iniciou suas atividades de treinamento em 1993. O público-alvo era (e permanece sendo) composto de profissionais da rede pública de saúde, mas não necessariamente apenas da SMS/RJ. Nosso Centro de Treinamento é de âmbito estadual, recebendo alunos(as) de outras instituições públicas que funcionam na cidade do Rio de Janeiro e de outros municípios.

Ainda que o principal objetivo fosse capacitar para o trabalho educativo na área da contracepção, a equipe nunca ministrou seus cursos com uma perspectiva limitada apenas a esta questão. Até porque trabalhar assim teria sido negar a proposta de uma atenção integral à mulher. O conteúdo dos cursos tem sofrido modificações ao longo destes anos, refletindo um aprimoramento da coordenação e a incorporação de novos 
temas. Como exemplo, podemos citar o fato de que a temática "Mulher eAins" foi merecendo uma atenção cada vez mais especial; "Adolescência" e "Mortalidade Materna" também foram incorporadas de forma mais específica. É interessante lembrar que os cursos destinam-se a profissionais que estão atuando em serviço, não sendo nossa proposta oferecer nenhum tipo de formação acadêmica (Anexo 6).

Até 1998, haviam sido ministrados 14 cursos regulares para profissionais de nivel superior e três para profissionais de nível médio. Houve uma distribuição bastante variada entre as diversas categorias profissionais: 86 enfermeiras(os), 57 auxiliares de enfermagem, 47 assistentes sociais, 37 gineco-obstetras e 14 psicólogos(as).

Ao longo dos anos, o Espaço Mulher diversificou bastante suas atividades, tendo inclusive produzido um vídeo sobre trabalho educativo com mulheres. Atualmente, além dos cursos, coordena atividades do próprio Programa da Mulher e de outras instituições públicas (especialmente oficinas de vivência), participa da elaboração de projetos, presta assessoria a outros programas, colabora em pesquisas, supervisiona ações de contracepção nas unidades. Em função desta mudança de perfil, o Centro de Treinamento desvinculou-se do CMS Milton Fontes Magarão, passando a estar ligado diretamente ao nível central da SMS/RJ. Às suas atividades de capacitação o Espaço Mulher adicionou a co-coordenação da proposta mais recente do Programa da Mulher na área materno-infantil - a implantação da consulta de enfermagem de pré-natal e da assistência da enfermagem obstétrica no pré-parto e em sala de parto na rede municipal.

A avaliação do desempenho do Espaço Mulher nos permite afirmar que a estratégia de criação de um centro de treinamento foi acertada, ainda que também aqui tenhamos carência de recursos humanos: a equipe hoje existente não consegue responder a todas as demandas, além de reivindicar a incorporação de profissionais das áreas de Saúde Mental e Serviço Social.

\section{Próximos desafios}

Após seis anos de implantação das ações de contracepção, fortalecemos a convicção de que é possível atender com qualidade na rede pública.

No entanto, muitas questões e insatisfações permanecem: ainda estamos longe de ter uma rede que, na sua maioria, compreenda que atender com qualidade é obrigação e não benesse; muitos profissionais da saúde, especialmente os(as) médicos(as), se consideram profissionais liberais e têm dificuldade de aceitar o fato de que uma secretaria municipal de Saúde (seja ela onde for) é uma instituição e, como tal, tem normas próprias que devem ser seguidas; vários são aqueles que insistem em considerar a população usuária do serviço público como de segunda ou terceira categoria e, por isso, a tratam de forma discriminatória, caracterizando uma violência 
institucional ${ }^{2}$; muitos continuam sem entender que as questões de gênero perpassam todo tipo de atendimento à mulher; a grande mobilidade (horizontal e vertical) dentro da própria SMS/RJ leva a interrupções do trabalho que comprometem a qualidade e a cobertura das ações; apesar de estarmos sempre enfatizando que a contracepção não é uma ação isolada, e sim parte do atendimento clínico-ginecológico, há uma tendência dos serviços de se organizarem em turnos específicos para a contracepção.

A cobertura das ações necessita de ampliação, o que significa incorporar mais recursos humanos para o trabalho educativo e para o atendimento clínico (assistentes sociais, enfermeiras, auxiliares de enfermagem, médicos). Na crise por que passa o serviço público neste país, aumento de quadros é sempre um problema de difícil solução e, por isso, esta é, certamente, uma das maiores dificuldades a serem superadas.

A qualificação dos profissionais hoje existentes também é um grande desafio. Neste aspecto, a atuação do Espaço Mulher tende a ser cada vez maior, inclusive com a proposta de treinar, de forma mais constante, os(as) profissionais que atuam diretamente com a atenção ao parto.

\section{Atenção ao parto e ao nascimento}

Em 1993, a Coordenação de Atenção Integral à Saúde, que abrange, entre outros, os programas da Criança, do Adolescente e da Mulher, visitou todas as maternidades públicas na cidade do Rio de Janeiro (com exceção das militares), classificando-as segundo o nível de complexidade. Deste trabalho resultou um documento que tinha por objetivo apresentar uma proposta de recuperação, ampliação e qualificação da assistência obstétrica no município do Rio de Janeiro. Este diagnóstico apontava para :

uma redução dos leitos obstétricos públicos devido, principalmente, à menor participação das instituições federais e estaduais no volume de internações obstétricas. Tal fato tem determinado uma sobrecarga dos serviços públicos municipais, maior utilização de serviços contratados pelo SUS (alguns de qualidade questionável) e uma verdadeira peregrinação de gestantes e recém-natos em busca de assistência adequada. Esta situação tem se refletido nos indicadores de saúde que mostram taxas elevadas de natimortalidade, mortalidade materna, e um grande percentual de óbitos infantis causados por afecções perinatais. (Secretaria Municipal da Saúde, 1994)

\footnotetext{
${ }^{2}$ Luis Fernando Veríssimo, ao se reportar ao assassinato do indio Pataxó Galdino Jesus dos Santos, dizia: "Vivemos entre exemplos diários de desprezo pelo pobre e de autodesprezo do pobre. Temos uma história de desprezo, uma cultura de desprezo, um desprezo atávico e institucional. Nossos sistemas de saúde e penitenciário são formas organizadas de desprezo público." Uornal do Brasil, 23/04/97).
} 
Para a SMS/RJ, este diagnóstico passou a sero norteador na definição de prioridades para a área perinatal: propunha-se a abertura ou reativação de leitos públicos maternos e neonatais a partir de uma distribuição proporcional à população de cada Área Programática (A.P.) ${ }^{3}$ e a correspondentes níveis de complexidade (baixo, médio e alto risco). Esta proposta apresentava algumas limitações, especialmente por tratar de leitos na sua maioria já existentes e cuja distribuição não havia seguido necessariamente critério populacional. Tínhamos, por exemplo, mais leitos obstétricos e neonatais do que o necessário para o total de gestantes residentes na A.P.1 (centro da cidade) o que, no entanto, não significava ociosidade, uma vez que a peregrinação das gestantes de outras áreas da cidade e, inclusive, de outros municípios, acabava levando à sobrecarga das unidades desta área. A distribuição de leitos por níveis de complexidade também refletia a ausência de um planejamento global. Além disso, a reabertura de leitos públicos estaduais e federais, fator fundamental para a solução destes problemas, estava obviamente fora do alcance da SMS/RJ ${ }^{4}$.

Por outro lado, embora a existência de leitos em quantidade suficiente seja précondição para a realização de um atendimento de qualidade, este é resultado de uma complexa trama de fatores.

\section{A Maternidade Leila Diniz}

Ciente das dificuldades enfrentadas pelas gestantes em conseguirem parir com dignidade, a SMS/RJ desenvolve, desde 1993, uma proposta que pretende oferecer à mulher a possibilidade de vivenciar com segurança e prazer este momento crucial de sua sexualidade.

A primeira etapa foi a reabertura da antiga maternidade do hospital Raphael de Paula Souza, do Ministério da Saúde, situada em Jacarepaguá, bairro da Zona Oeste da cidade, onde não havia um único leito obstétrico público. Esta maternidade havia sido desativada dois anos antes por carência de recursos humanos. Foi precisamente aí que a equipe da Supcrintendência de Saúde Coletiva identificou a possibilidade de implantar um serviço que se diferenciasse dos demais na forma de atender a mulher e a criança. Preconizávamos:

\footnotetext{
${ }^{3}$ A SMS/RJ dividiu o município, para fins de planejamento e implantação de serviços, em 10 Áreas Programáticas que englobam uma ou mais regiões administrativas.

${ }^{4}$ Em 1993, a SMS/RJ tinha sob sua responsabilidade direta a gerência de quatro maternidades: Instituto Municipal da Mulher Fernando Magalhães, Maternidade Herculano Pinheiro (mais tarde denominada Unidade Integrada de Saúde Herculano Pinheiro) e as maternidades dos hospitais Miguel Couto e Paulino Werneck. O Ministério da Saúde respondia por seis, a Secretaria Estadual de Saúde por quatro e existiam três maternidades ligadas a hospitais universitários.
} 
- um ambiente agradável e acolhedor em toda a maternidade;

- o direito da mulher de optar por um(a) acompanhante durante o pré-parto e o parto; - o estímulo à deambulação;

- um espaço adequado para banho, com uso de um banquinho para aquelas que desejassem relaxar sob uma ducha fria ou morna;

- a utilização de uma banheira para as mulheres que desejassem relaxar durante o trabalho de parto;

- um cuidadoso acompanhamento do trabalho de parto, respeitando as necessidades físicas e emocionais da parturiente;

- a possibilidade de a mulher escolher em qual posição gostaria de parir (deitada, verticalizada, recostada);

- uma assistência ao trabalho de parto e parto com o mínimo de intervenção possível, em que cada procedimento fosse tecnicamente justificado;

- uma participação efetiva da enfermagem obstétrica no pré-parto e no parto;

- uma equipe integrada (auxiliar de enfermagem, enfermeira, obstetra, pediatra), comprometida com uma assistência que priorizasse a clientela e não os interesses do grupo ou a rotina;

- o compromisso da equipe em estimular, ainda na sala de parto, o aleitamento materno e a formação do vínculo mãe-filho(a);

- o manuseio do recém-nato da forma mais suave possível, evitando procedimentos desnecessários;

- a presença do bebê ao lado da mãe de forma ininterrupta, a partir do nascimento, anulando o período de 'observação' em berçário específico;

- a presença do pai, sem restrições, durante todo o tempo de internação (utilizou-se o slogan "Pai não é visita");

- o alojamento conjunto em enfermarias agradáveis e acolhedoras;

- um trabalho 'leito a leito' com relação ao aleitamento materno, não só para tirar dúvidas, estimular a formação do vínculo, ensinar como amamentar, mas, também, dar suporte emocional em momento tão delicado para a mulher e o bebê.

Para aquelas pessoas que têm alguma experiência nesta área, a leitura da 'lista' anterior permite imaginar imediatamente o nível de resistência encontrado. Esta proposta, na realidade, significava (e continua significando) uma reviravolta em um modelo de assistência que prioriza o serviço; que freqüentemente utiliza procedimentos desnecessários ou mesmo prejudiciais para a mulher e a criança (OMS, 1996); que se baseia em uma estrutura hierárquica em que o poder médico ocupa o topo da pirâmide e no qual a mulher deve se adaptar ao que cada unidade estabeleça como rotina, independentemente das suas necessidades. 
Conscientes do que nos esperava, optamos por uma estratégia de sensibilização, acreditando que, com técnicas de oficina de vivência, apresentação e discussão de dados e experiências de outros lugares, seria possível 'conquistar' alguns profissionais que atuariam, ao longo do tempo, como estimuladores de uma mudança profunda. Sabíamos que nossa proposta era inovadora dentro da SMS/RJ, mas insistíamos com os profissionais que, na verdade, não trazíamos nada de muito novo. Desde a década de 60, os trabalhos pioneiros de Caldeyro-Barcia, Moyses e Cláudio Paciornick e Galba Araújo apontavam para as vantagens do parto vertical, para mãe e bebê (Sabatino; Dunn \& Caldeyro-Barcia, 1992). Em 1985, a Organização Mundial de Saúde recomendava uma assistência nos mesmos moldes que só agora estamos propondo (OMS, 1966). As pesquisas de Hugo Sabatino, em Campinas, só vieram reforçar estas posições (Sabatino; Dunn \& Caldeyro-Bacia, 1992). No Rio de Janeiro, na Maternidade Praça XV, o dr. Fernando Estelita Lins estimulou o parto vertical durante muitos anos. A belíssima ação cotidiana das doutoras Esther Vilela e Lívia Carneiro em Ceres, Goiás, nos davam a certeza de que era possível atender com competência e uma enorme dose de humanismo (Núcleo de Saúde da Mulher, 1993). O trabalho pioneiro e profundamente questionador de Michel Odent (1984) também era fonte de inspiração para a equipe da SMS/RJ. O modelo assistencial de alguns países desenvolvidos, como Holanda, Inglaterra e Alemanha, há muito já colocava a atenção ao parto normal nas mãos da midwife, parteira com formação específica, geralmente em um curso de quatro anos; ao médico compete assumir os partos em que ocorre alguma complicação. Também nestes países é pressuposto que este é um momento extremamente importante na vida da mulher, momento de grande intensidade emocional, que exige da equipe que a está acompanhando não só competência como respeito às suas necessidades 5 .

Foi assim que no primeiro semestre de 1994 elaboramos uma programação para todos(as) aqueles(as) que iriam trabalhar na maternidade. Montamos uma série de oficinas de vivência e organizamos um seminário para o qual convidamos profissionais que tinham experiência dentro da proposta que queríamos implementar. Estimulamos, ainda, uma intensa discussão em torno da enfermagem obstétrica, visando a propiciar a atuação desta no pré-parto e na sala de parto. Paralelamente, definimos as mudanças na área física da unidade que, com a reforma, passou a oferecer às clientes uma área individualizada para o pré-parto (permitindo maior privacidade e a presença de acompanhante), um espaço para deambulação, uma banheira própria para trabalho de parto e parto e um módulo obstétrico para parto vertical. Tudo isto e mais todo o resto da unidade pintado em cores agradáveis,

${ }^{5}$ Os artigos de Domingues (1996), UMberLino (1996) e Silva (1996) mais tarde possibilitaram um conhecimento mais detalhado destas realidades. 
criando um espaço mais acolhedor. O berçário e o centro cirúrgico também receberam o tratamento adequado, dentro dos parâmetros de uma maternidade que não era de risco.

Em junho de 1994, (re)inauguramos a Maternidade Leila Diniz com 33 leitos obstétricos. Hoje, com 65 leitos maternos e 15 leitos intensivos neonatais, ela apresenta as seguintes características:

- a incorporação do(a) acompanhante no pré-parto e na sala de parto (para parto normal) tem garantido à parturiente um apoio fundamental;

- o parto vertical representa $5 \%$ do total de partos normais;

- a enfermagem atua na sala de parto, apesar de o número de enfermeiras obstétricas estar aquém do descjado. Além disso, as enfermeiras não só são as grandes responsáveis pelo estímulo ao parto vertical, como algumas delas já treinaram profissionais médicos(as) na arte de acompanhar a mulher nesta forma de parir;

- a presença do pai nas enfermarias e na UTI neonatal, a qualquer hora, não sofre mais questionamentos importantes;

- há um trabalho consistente de incentivo ao aleitamento materno, inclusive nos casos das crianças que estão no berçário (Vaitsman, 1997);

- a atuação especial de uma médica de saúde pública permitiu a criação de instrumentos de registro que integram à visão epidemiológica um olhar mais sensível para as questões da mulher;

- a direção da unidade vem implantando diferentes instrumentos para avaliação da intervenção obstétrica (para entender de que maneira esta vem acontecendo e como atuar a partir deste conhecimento), e para análise de dados de produtividade, mortalidade materna e perinatal e perfil da assistência (Dias, 1996). Alguns destes instrumentos passaram a ser utilizados nas outras maternidades do município.

Uma avaliação bastante resumida diria que a experiência destes quatro anos tem apontado não só para novos caminhos como para os limites e dificuldades impostos pela realidade institucional (o ponto mais contundente foi a carência de anestesiologistas, cujo número insuficiente trouxe graves transtornos durante um período bastante longo) e pela atuação dos nossos profissionais. Nesse tempo, confirmamos a hipótese de que mudanças na forma de atender a mulher e a criança são possíveis, ao mesmo tempo em que aprendemos a exercitar a paciência. Um conhecimento maior do processo vivenciado pelos(as) profissionais da Maternidade Leila Diniz a partir das propostas da SMS/RJ é o conteúdo da dissertação de mestrado de Katia Ratto de Lima (1997). 


\section{Desdobramentos}

Um dos resultados mais importantes desta experiência foi o processo de expansão deste modelo para outras maternidades da rede municipal. Não alcançamos ainda as metas propostas, mas não há dúvidas de que avançamos bastante. Ao longo do tempo, resistências e preconceitos vêm sendo superados, em ritmo mais lento do que o desejado, mas de forma consistente.

Em 1995, a SMS/RJ absorveu três grandes maternidades do Ministério da Saúde, dentro do processo de municipalização (maternidades Alexander Fleming, Carmela Dutra e Praça XV). Assim, contamos hoje com oito unidades, localizadas em diferentes áreas da cidade e com níveis diferenciados de complexidade.

Nos últimos cinco anos, duas maternidades foram reinauguradas, sendo uma de baixo risco (U.I.S. Herculano Pinheiro) e outra de alto risco (Instituto Municipal da Mulher Fernando Magalhães). Foram obras de grande porte, que exigiram o fechamento provisório destas unidades. Do ponto de vista arquitetônico e de equipamento elas são diferentes, mas foram reformadas partindo dos princípios de humanização e de respeito aos direitos de cidadania pelos quais nos pautamos desde a proposta da Maternidade Leila Diniz.

Assim, na U.I.S. Herculano Pinheiro o pré-parto é individualizado; o centro obstétrico inclui uma sala para relaxamento e uma banheira; construiu-se um solário; dentro da maternidade há uma sala para reuniões com a clientela; houve um cuidadoso tratamento cromático em todos os espaços; toda a unidade é climatizada (o que não é um luxo, considerando tratar-se de uma das regiões mais quentes da cidade).

Em 1998, foram lotadas enfermeiras obstétricas em todos os plantões, com a função de acompanharo pré-parto e assistir os partos normais. Esta lotação é parte da proposta de implantaçãodo novo modelo assistencial na rede e incluiu a MaternidadeAlexander Fleming, além de também institucionalizar a consulta de enfermagem de pré-natal em toda a rede ambulatorial da Área Programática $3.3^{6}$. Para poder concretizar esta proposta, a SMS/RJvem contando com a inestimável colaboração da Faculdade de Enfermagem da Universidade do Estado do Rio de Janeiro (UER), que assumiu a responsabilidade pela reciclagem e formação de enfermeiras obstétricas e pelo treinamento em serviço, juntamente com o Espaço Muthere com enfermeiras obstétricas dos quadros da própria secretaria.

A reforma da planta física da U. I. S Herculano Pinheiro foi fundamental, mas obviamente não garantiu por si só um atendimento digno e de qualidade. O grande desafio do momento é a implantação de novas rotinas, que representam, em grande parte, as mudanças propostas. As dificuldades são variadas: existe ainda uma considerável resis-

\footnotetext{
- Esta é uma área geográfica que conta com o maior número de gestantes do município, aproximadamente 20.000 .
} 
tência à presença do(a) acompanhante, principalmente por parte dos(as) profissionais médicos(as); apesar de a Câmara Técnica de Obstetrícia ${ }^{7}$ ter redefinido rotinas baseadas em evidências científicas (por exemplo, tricotomia e enteróclise só serão feitas por indicação precisa, assim como o uso de ocitócicos), boa parte do corpo clínico ainda não as incorporou; a participação efetiva da enfermagem tem enfrentado muitos questionamentos por parte dos(as) médicos(as), mas o respaldo legal e um insistente trabalho de discussão vêm tornando possível avançar nesta área da assistência.

No caso do Instituto Municipal da Mulher Fernando Magalhães, as obras também incorporaram estas idéias e apresentaram algumas inovações muito interessantes, como é o caso do pré-parto. A própria equipe da maternidade propôs que se substituíssem os dois ambientes - pré-parto e sala de parto - por um único onde, em boxes individualizados, as parturientes vivenciassem o trabalho de parto e o parto evitando, entre outras coisas, o desconforto da locomoção para a sala de parto. Para tal, foi necessário comprar camas importadas de alto custo, que propiciam conforto e permitem a adoção de diversas posições de parir. Durante boa parte da obra, todas as chefias da maternidade se reuniram de forma sistemática para aprofundar a discussão em torno do novo modelo assistencial proposto. Não foi tarefa simples, sobretudo porque o I. M. M. Fernando Magalhães é a principal maternidade de risco da rede pública municipal, o que significa adequar condições de atendimento altamente sofisticadas e freqüentemente muito invasivas a propostas que enfatizam os menores índices de intervenção possíveis.

Também nesta maternidade as propostas ainda não foram totalmente incorporadas por todos os plantões, principalmente as que se referem ao (à) acompanhante e aos procedimentos de rotina obstétrica. A atuação da enfermagem obstétrica não sofre muitos questionamentos porque esta é uma unidade em que este tipo de assistência já se desenvolve há 10 anos.

Além destas duas unidades hospitalares, outras duas maternidades passaram por algum tipo de reforma nos últimos cinco anos. A maternidade do Hospital Municipal Miguel Couto não pôde fazer modificações profundas em virtude de limitações de espaço, mas melhorou consideravelmente seu aspecto fisico. AMatemidade Alexander Fleming havia iniciado obras importantes antes de ser municipalizada e já vivenciava um esforço de melhorar sua qualidade. Foi a primeira maternidade pública no município do Rio de Janeiro a ser credenciada, em 1996, como Amiga da Criança e de receber o selo de Maternidade Segura (ambos são atestados de qualidade emitidos a partir de avaliações cuidadosas do Fundo das Nações Unidas para a Infância - UNICEF -, do Ministério da Saúde e da Secretaria Estadual de Saúde).

\footnotetext{
${ }^{7}$ A Câmara Técnica de Obstetrícia é formada pelas chefias de obstetrícia e enfermagem das oito maternidades municipais.
} 
Como dito anteriormente, em 1998 a Maternidade Alexander Fleming recebeu enfermeiras (os) para atuação no pré-parto e parto. Apesar de algumas dificuldades iniciais, estes(as) profissionais integraram-se gradualmente aos plantões, e hoje já estão podendo trabalhar com mais autonomia. Aquestão do(a) acompanhante também está sendo resolvida de maneira gradual.

Ainda em 1998, a Maternidade da Praça XV reformou parte do seu centro obstétrico, criando um espaço de pré-parto individualizado, podendo assim receber acompanhante. Na verdade, esta unidade já permitia acompanhante para as gestantes adolescentes e para as mulheres que haviam sido submetidas à cesariana. Esta reforma serviu para ampliar esta possibilidade e não encontrou maiores resistências por parte dos(as) profissionais.

No início de 1999, a Maternidade Carmela Dutra passou a permitir a presença de uma pessoa do sexo feminino nas salas de pré-parto. Esta limitação deve-se ao fato do ambiente não oferecer as condições mínimas de privacidade.

\section{Perspectivas}

Hoje, em seis das oito maternidades do município do Rio de Janeiro, existe a oportunidade de haver uma pessoa ao lado da parturiente. Como, no entanto, esta presença não se dá de forma homogênea, o esforço agora é no sentido de que isto aconteça em todos os plantões, de todas as unidades, sem restrições de sexo.

A atuação da enfermagem obstétrica é outro desafio que ainda precisa ser vencido. Atualmente, contamos com este tipo de assistência em quatro maternidades, e também aqui necessitamos continuar investindo. É necessário consolidar o trabalho iniciado e expandi-lo para as outras unidades municipais.

A mudança nas rotinas obstétricas é objetivo a ser alcançado a médio/longo prazo, pois implica questionar práticas médicas arraigadas, em transformar conteúdos da própria formação acadêmica. Será preciso um trabalho constante de atualização dos conhecimentos científicos e discussões aprofundadas com as equipes.

Os próximos três anos serão cruciais para as propostas ora em implantação nas unidades municipais. Resultados maternos e neonatais serão indicadores fundamentais de avaliação, acoplados a outras formas de análise da qualidade do serviço ${ }^{8}$.

Se o setor público (e é sempre bom lembrar que este abrange também as esferas estadual e federal) se propõe a efetivamente resolver a atenção ao parto e ao nascimento, é necessário, antes de qualquer outra coisa, que ofereça leitos obstétricos e neonatais

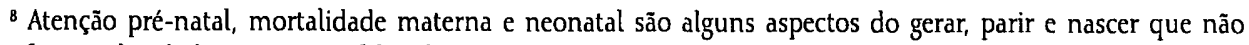
foram abordados aqui por falta de espaço. São, porém, alvo de nossas preocupações: a melhoria da qualidade da assistência ao pré-natal já é um dos objetivos da SMS/RJ para os próximos três anos, assim como a prevenção, o controle e a diminuição da mortalidade materna e neonatal.
} 
em quantidade suficiente e dentro de um sistema hierarquizado com relação a risco materno e fetal. Se, além da oferta de leitos, este mesmo setor público pretende garantir uma assistência de qualidade à mulher è criança, diminuindo de forma efetiva os índices de morbi-mortalidade materna e neonatal, é necessário modificar o modelo assistencial vigente, revendo a prática médica e da enfermagem, recolocando a mulher no centro do processo, diminuindo ao máximo os procedimentos intervencionistas desnecessários.

Nada disto é de fácil execução: a decisão política, para ter algum efeito real, pressupõe razoáveis níveis de investimentos tanto em obras e equipamentos como em recursos humanos. $\mathrm{Na}$ área de pessoal, não basta contratar em número suficiente. É preciso transformar este(a) profissional-e isto, como se tentou demonstrar aqui, é desafio para ser enfrentado ao longo de vários anos. Acreditamos que a experiência do município do Rio de Janeiro aponta caminhos e sinaliza para a possibilidade de mudanças.

\section{Referências Bibliográficas}

BRASIL. Ministério da Saúde. Assistência Integral à Saúdeda Mulher: bases de aşão programática. Brasília: Centro de Documentação do Ministério da Saúde, 1984.

DiAs, M. A. B. Avaliação da intervenção obstétrica na maternidade Leila Diniz. Saúdeem Foco. Ano V, n.14, nov. 1996. Rio de Janeiro: Secretaria Municipal de Saúde. p.40-41.

DOMINGUES, R. M. S. Holanda: o modelo de assistência ao parto e nascimento. Saúdeem Foco. AnoV, n.14, nov. 1996. Rio de Janeiro: Secretaria Municipal de Saúde. p.12-14.

Lima, K. M. R. de. Matemidade Leila Diniz (1994 a 1996): nascimento de um novo profissional de saúde?, 1997. Dissertação de Mestrado. Rio de Janeiro: Escola Nacional de Saúde Pública/ Fiocruz.

Núcleo de SAÚde da MulHER. A vida pede passagem. Goiás, 1993. (Vídeo).

Odent, M. Birth Rebom. Londres: Souvenir Press, 1984.

OrGanizAÇão Mundial de SAÚdE. Appropriate Technology for Birth. Lancet, 1985.ii 436-437. Versão em português: Saúde em Foco, Ano V, n. 14, nov. 1966. Rio de Janeiro: Secretaria Municipal de Saúde. p.52-55.

OrGanização Mundial de SaÚde. Care in Normal Birth: a practical guide. Série Safe Motherhood. Genebra: (WHO/FRH/MSM/96.24), 1996.

Sabatino, H.; DunN, P.M. \& CaLDEYro-BarCiA, R. (Orgs.) Parto Humanizado: formas alternativas. Campinas: Editora da UnCAMP, 1992.

SeCREtaRia Municipal de Saúde. Assistência Obstétrica e Neonatal no Município do Rio de Janeiro. Rio de Janeiro: 1994 (Cópia Reprográfica). 
SiIvA, A. G. da. Modelos de Atenção ao Parto e Nascimento. In: $2^{\circ}$ Seminánio sobre Parto e Nascimento. Secretaria Municipal de Saúde, Rio de Janeiro: 20, 21 e 22 de nov. de 1996.

Souza, A. I. S. A Contracepsão: singularidades de uma política social, 1996. Tese de Doutorado. Rio de Janeiro: Escola Nacional de Saúde Pública/Fiocruz.

UMBERLINO, M. Inglaterra: o modelo de assistência à gestação, ao parto e ao nascimento. In: Saúde em Foco. Ano V, n. 14, nov. 1996. Rio de Janeiro: Secretaria Municipal de Saúde. p.15-17.

Vartsman, H. O calor do corpo que salva. O Globo, 6 de abril de 1997. 


\section{A Atenção Integral e a Caixa de Pandora:}

notas sobre a experiência do Coletivo Feminista Sexualidade Saúde

Simone Grilo Diniz

\section{O movimento de mulheres e o conceito de atenção integral}

O movimento internacional de mulheres, nas últimas décadas, tem dedicado especial atenção às questões do corpo e da saúde-dimensões políticas centrais na luta pelo reconhecimento de sua condição de cidadãs e sujeitos éticos, capazes de decidir sobre suas próprias vidas. No Brasil, o movimento tem desempenhado um papel fundamental na crítica dos modelos de atenção à saúde e na proposição de alternativas, demonstrado na formulação e luta pela implementação do Programa de Atenção Integral à Saúde da Mulher (PAISM).

A inspiração política deste programa, expressa pelo movimento no Encontro Nacional de Saúde da Mulher em 1984 pela Carta de Itapecerica, parte da afirmação crítica de que "o conceito que caracteriza as ações de saúde convencionais centra suas explicações e práticas no indivíduo e na doença, enfatizando uma dimensão biológica e impessoal, sem história e sem o conceito social do problema" põe em xeque a redução das mulheres ao seu papel na reprodução, a alienação dos serviços diante da realidade concreta da vida das mulheres, "refletindo o caráter tecnocrático, desumanizante e machista do nosso sistema sociopolítico, econômico e de saúde"; e propõe que a saúde seja imaginada como "algo dinâmico e indivisível, que leva em conta as características individuais do ser humano, interagindo com as características sociais, sexuais e de classe à qual pertence" (Labra, 1989). O conceito de integralidade proposto reivindicava a atenção para todas as fases da vida da mulher e às dimensões sociais e psicológicas da 
saúde, e incorporava os conceitos de ação programática da epidemiologia, assim como as idéias feministas sobre a assistência ao que viria a serchamada saúde sexual e reprodutiva' . Ademanda de que o Estado, por meio de suas políticas sociais - $\mathrm{cm}$ especial as da saúdeincorporasse as reivindicações e perspectivas das mulheres, foi a frente de trabalho central escolhida pelo movimento (Ávila, 1993). Nesta direção, muitas foram as ocasiões em que as próprias integrantes, muitas das quais oriundas da área de saúde, como profissionais e/ ou ativistas, assumissem cargos públicos.

Este modelo foi fundamental no questionamento da prática médica convencional e no impulsionamento de uma reflexão crítica sobre o papel dos serviços de saúde na manutenção da subordinação das mulheres, assim como na viabilização concreta de alternativas mais positivas nas esfera reprodutiva e sexual para as usuárias. Mais do que isto, este modelo teve uma grande influência na inspiração de outras experiências, na formulação de políticas públicas, na formação de recursos humanos e na articulação política do movimento de mulheres (Araújo \& Diniz, 1989). A entrada e a considerável multiplicação de quadros feministas na rede pública de serviços resultou em um número importante de experiências bem-sucedidas, sobretudo quando houve vontade política e sensibilidade de gênero no âmbito local das ações de saúde.

Estas experiências tiveram um papel fundamental na constituição de uma 'cultura' sobre a saúde da mulher no discurso dos serviços de saúde pública, apesar dos grandes limites enfrentados. Mais do que suas reivindicações ao Estado-contidas neste programa - e baseado na demanda por democracia social e pelo direito à assistência à saúde, o movimento buscou, a partir da crítica ao modelo estabelecido, construir alternativas para a experimentação de novos modelos de atenção em serviços conduzidos pelas feministas, onde "pudéssemos passar da teoria à prática, mostrando que é possível construir uma atenção à saúde que considere a mulher como um ser humano" (CFSS, 1986). Neste texto, partilhamos algumas reflexões sobre os limites, possibilidades e impasses de uma experiência feminista não-governamental na construção de uma atenção à saúde a partir desta perspectiva.

No Brasil, o Coletivo Feminista Sexualidade Saúde (CFSS) desenvolve, desde 1985, um trabalho de atenção primária à saúde da mulher com esta perspectiva feminista e humanizada, tendo atendido, desde então, mais de quatro mil mulheres. Inspirado pela

\footnotetext{
' O conceito de atenção integral à saúde, incorporado e enriquecido pelas feministas brasileiras, passou a ser um dos motores de uma poderosa mudança na concepção das ações de saúde em seu papel na transformação social, cujo alcance ainda está por ser totalmente avaliado. Os conceitos mais recentes de saúde reprodutiva e sexual, desenvolvidos no contexto da luta política das mulheres por direitos reprodutivos, cm especial na preparação das conferências de Cairo e de Pequim, ainda que se constituam grandes avanços com relação às concepções mais estreitas e biologicistas que freqüentemente orientam os serviços de saúde da mulher, ao nosso entender, não superam nem substituem, e sim complementam a noção mais ampla de integralidade da assistência.
} 
experiência curopéia, sobretudo pelo Dispensaire des Femmes, de Genebra ${ }^{2}$, o método utilizado desde a capacitação das primeiras trabalhadoras, foi o da crítica ao modelo médico da gineco-obstetrícia. Nosso modelo vem propondo uma 'medicina suave' - dos tratamentos naturais e menos agressivos - e de preocupação com o conhecimento do corpo como um dos elementos centrais para a saúde. A mulher/usuária é percebida como um indivíduo, o "sujeito da ação de saúde, capaz de entender, decidir e cuidar do próprio corpo e da própria vida" (CFSS, 1994-96). Neste contexto, o trabalho com contracepção priorizou a ampliação da autonomia das mulheres diante dos médicos e parceiros; o conhecimento; e a 'amizade' com o próprio corpo.

Este foco, ao re-descrever de maneira crítica e 'expandida' às dimensões biológicas, permitiu o 'descolamento' do modelo do binômio mãe(potencial)-filhos e foi muito útil na problematização das prioridades da intervenção e na redescrição dos problemas e abordagens a serem priorizadas. Apesar dos grandes avanços que o modelo propiciou na experiência do Coletivo com o atendimento às usuárias, ele foi-se mostrando insuficiente na compreensão dos vínculos entre a saúde e as relações sociais daquela muther concreta. Apesar da dimensão relacional de sua vida estar sempre presente no trabalho, esteve virtualmente ausente nos primeiros prontuários (anamneses) do serviço, que continham pouca (ou nenhuma) informação sobre as parcerias afetivas e sexuais, estado civil, relações de trabalho ou raça-ainda que algumas destas informações constassem de uma ficha social que não acompanhava a anamnese. A participação masculina era estimulada no discurso, mas mostrou-se regular apenas na atenção pré-natal.

Apesar destes limites da abordagem, o Coletivo, por ser um serviço feminista, recebeu, identificou, atendeu e referiu um enorme leque de problemas de saúde ligados às relações de gênero, para além do que o modelo de trabalho estava preparado para lidar. Entre eles, situações de coerção sexual, estupro, incesto, problemas no cuidado com os filhos, várias formas de sofrimento emocional, problemas na relação com serviços de saúde, gravidez indesejada, desrespeito aos direitos trabalhistas e discriminação racial e por preferência sexual. Além das necessidades práticas e imediatas (por exemplo: como resolver um problema de contracepção ou uma infecção vaginal), outras necessidades foram surgindo, tornando necessária a busca das respostas possíveis (como a criação de grupos de reflexão, atendimento em saúde mental e o trabalho de referência/contrareferência a outros serviços e recursos). Estes temas, problematizados direta ou indiretamente como questões de saúde pelas usuárias, foram-se incorporando à prática e se transformando formal ou informalmente em problemas/diagnósticos (embora, no início, de maneira pouco sistemática e tendo o registro subestimado diante dos diagnósticos e condutas 'de saúde' imediatamente referidas a este biológico 'expandido'). A

\footnotetext{
${ }^{2}$ As linhas básicas do trabalho do Dispensaire, que inspirou várias outras experiências similares, podem ser apreciadas na recente tradução para o português do livro Ginecologia Natural para Mulheres, de Rina Nissin.
} 
questão que se coloca desde então é a complexa tarefa de manter uma postura crítica, um questionamento constante diante da definição da problemática a ser tratada, mantendo o conteúdo radical do feminismo de que a mudança nas condições de saúde sempre incluirá a luta pela mudança nas relações sociais (Barroso, 1989).

\section{Problematizando o problema: as questóes de saúde da mu- lher da perspectiva das mulheres}

Estas mudanças no modelo de trabalho foram alimentadas no decorrer da década de 80 por duas frentes: pelo esforço em avançar na produção de conhecimento e fundamentar a intervenção, representado pela incorporação dos conceitos de relações de gênero e de direitos reprodutivos; e pela agenda do movimento de saúde das mulheres, que passa a incluir, de maneira menos ou mais enfática, as questões da violência doméstica e sexual e da AiDs. Estas duas questões já se apresentam de maneira diferenciada, por remeterem imediatamente às relações sociais de gênero, para além da 'tradução' meramente biológica que possam chegar a ter nos serviços.

Tanto o conceito de relações de gênero - vindo das feministas na academia e sendo incorporado pelo movimento - quanto o de direitos reprodutivos, nascido do movimento internacional de saúde das mulheres, têm motivado uma fértil discussão conceitual em diversos campos de conhecimento. Nas ações de saúde, o conceito de gênero tem recebido renovada atenção a partir das formulações sobre qualidade da atenção a partir da perspectiva das usuárias (Gomez-Gomez, 1993). Estes trabalhos, pensados principalmente para a avaliação de serviços dirigidos à população geral, mostram que os sintomas das mulheres são levados menos a sério do que os dos homens; que elas recebem menos informação; esperam mais tempo; têm menos alternativas de tratamento; recebem menor seguimento; e, além disso, os profissionais e serviços reforçam relações de gênero que prejudicam a saúde da mulher, ao invés de promover a autonomia e fortalecê-la em seu meio social (Pittman \& Hartigan, 1995). OCFSS tem participado ativamente do processo de redefinição destes enfoques ${ }^{3}$, sendo um interlocutor constante de organismos internacionais e formuladores de políticas públicas, recebendo uma demanda crescente de consultoria sobre o tema.

Os novos enfoques procuram inscrever novos problemas e superar a avaliação quantitativa dos serviços de saúde, com base na produtividade dos serviços e centrada nas dimensões biológicas. A partir do movimento, surgem as propostas de que a qualidade

\footnotetext{
${ }^{3}$ A discussão destes enfoques tem sido sistematizada em alguns encontros temáticos produzidos pelo movimento, em especial no Relatório do Seminário de Práticas Educativas na Implantação do PAISM, CFSS, 1996, São Paulo.
} 
do serviço seja identificada a partir da incorporação de elementos que favoreçam a assistência à saúde integral e elevem o poder das mulheres sobre suas vidas, exigindo, portanto, o manejo de questões psicológicas e sociais (CFSS, 1996). A qualidade da atenção da perspectiva de gênero é considerada a partir de uma visão de integralidade da saúde reprodutiva, inscrita nos marcos éticos dos direitos humanos e, em particular, dos direitos sexuais e reprodutivos (Matamala, 1995).

A partir da Conferência Internacional sobre População e Desenvolvimento (CIPD)/ Cairo, estes conceitos passam a se inscrever no desenho das ações, demandando dos serviços de saúde reprodutiva uma revisão do seu modelo de trabalho para adequar-se a este novo enfoque. Quando nos referimos ao modelo de trabalho, consideramos que o objeto das práticas de saúde é construído historicamente, "não havendo nada, rigorosamente nada, que seja sempre, por si mesmo, parte ou substrato de uma necessidade de saúde 'geral'" (Mendes Gonçalves, 1992:44). Repensar o trabalho em saúde exige que o repensemos como modelo, na consistência prática entre as finalidades, os objetos de trabalho, instrumentos e a ação dos agentes. Assim, a incorporação de marcos políticos para a ação de saúde pode propiciar a experimentação de novos modelos como 'utopias produtivas', servindo como "balizas para a análise de situações concretas e para a descoberta das possibilidades objetivas de introdução de mudanças nessas situações orientadas para ele, que então irá, se chegar a ser, se efetivando como modelo real, certamente diferente do projeto que terá orientado seus começos" (Mendes Gonçalves, 1992:46).

Neste contexto de ação e reflexão, iniciamos um conjunto de experimentações na formulação das finalidades, dos instrumentos e dos resultados das ações de saúde reprodutiva e sexual. Este conjunto se traduz em modelos experimentais de consulta individual/história clínica/anamnese, assim como no sistema de informação do serviço-em que dados como renda, raça, escolaridade, preferência sexual, procedência, entre outros, possam ser úteis na compreensão das dimensões sociais da saúde e na construção de respostas aos problemas apontados.

Estas reflexões sobre a definição do problema são também influenciadas pelas discussões trazidas por três experiências recentes desenvolvidas no CFSS em parceria com outras instituições. A primeira é a pesquisa realizada pela equipe brasileira do IRRRAG (International Reproductive Rights Research Action Group; em português, Grupo de Pesquisa e Ação Internacional em Direitos Reprodutivos). Ao analisar as intensas mudanças na vida reprodutiva das mulheres nas últimas décadas, esta pesquisa indica que o contato das mulheres com matrizes discursivas que reconheçam e reafirmem seus direitos tem uma importância central na busca ativa de soluções concretas para os seus problemas. A afirmação do caráter coletivo dos problemas e da legitimidade do sentimento de injustiça das mulheres (diante de situações de opressão em qualquer esfera da vida - em particular no âmbito reprodutivo e sexual), propicia uma redescrição da experiência vivida. Neste estudo, a resistência ao que é considerado injusto é, muitas 
vezes, percebida como transgressão, a ser vivida em silêncio sob o risco de represálias, deixando as mulheres especialmente isoladas e vulneráveis. A direção da mudança é que a resistência possa ser assumida em seu caráter coletivo; não apenas como uma argumentação individual, oposta ao coletivo, mas uma relativa a um novo grupo de referência, propiciando uma recriação de padrões de relacionamento social (IRRRAG, 1996). Com base nesta experiência (e a partir do marco da indivisibilidade dos direitos reprodutivos como direitos simultaneamente individuais e sociais) acrescentamos ao modelo de trabalho e à anamnese questões relativas à informação, percepção e acesso aos direitos; à capacidade de buscar ajuda; ao sentimento de injustiça diante de situações reconhecidas como violentas, entre outros. Também ajustamos alguns dos insights da pesquisa à anamnese como 'indicadores experimentais' e iniciamos a organização da referência a outros serviços e instituições que lidam com os problemas detectados.

A segunda experiência foi a da incorporação de rotina de questões sobre violência e cocrção sexual na anamnese-o que resultou em um projeto mais amplo de capacitação, referência e investigação sobre violência de gênero e ações de saúde, em parceria com o Departamento de Medicina Preventiva da Faculdade de Medicina da Universidade de São Paulo (FMUSP) ${ }^{4}$. Este projeto nos levou a testar conjuntos de perguntas que pudessem facilitar, para a usuária, a conversa e a atenção sobre o tema, assim como a identificação de situações agudas, propondo a referência interna ao serviço e para outras instituições. Ao mesmo tempo, o componente 'capacitação' ampliou a discussão com o conjunto da equipe sobre gênero e saúde, em especial as relações entre a situação violenta e a saúde reprodutiva e sexual, partindo da evidência de que mulheres que experimentam tais situações freqüentemente têm mais dificuldade em cuidar de sua própria saúde. Nestes termos, entendemos o momento agudo da violência (a agressão propriamente dita) não como o objeto de trabalho em si, mas como um indicador de uma especial vulnerabilidade a um amplo conjunto de questões de saúde. Mais uma vez, se impuseram ao trabalho a dimensão relacional da situação violenta e a dificuldade de lidar com os parceiros - problema para o qual ainda buscamos soluções para além da organização da referência e contra-referência para serviços que lidam com homens. A inclusão destas questões na consulta se fundam não apenas na crença de que todos os seres humamos têm o direito a estar livres da violência e da coerção, mas, também, que os serviços de saúde são um recurso privilegiado para lidar com este problema.

A terceira experiência tem sido a revisão dos procedimentos de contracepção e de infeccões vaginais a partir da pandemia de AIDs, que resultou no projeto Cuidando do Prazer, apoiado pela Fundação Lévi-Strauss. Este trabalho nos levou a um esforço adicional para lidar com as contradições entre nossa prioridade no trabalho com o diafragma

\footnotetext{
4 Estas reflexões estão contidas nos relatórios do "Projeto de Capacitação e Desenvolvimento de Tecnologia para a Atenção a Mulheres em Situação de Violência nos Serviços de Saúde", apoiado pela Fundação Ford.
} 
vaginal-método que amplia a autonomia da mulher em relaçãoà sua reprodução, mas não necessariamente em termos da proteção contra as doenças sexualmente transmissíveis (DST) e à AIDS. Apesarde existirem evidências consideráveis sobre o papel protetor do diafragma diante de certas DST - provavelmente mais relacionadas à consistência do uso do que com as características desta barreira-a camisinha, até prova em contrário, é o método que melhor propicia, simultaneamente, a prevenção de DST/AIDS e de gravidez indesejada. O trabalho com o diafragma, especialmente em um país onde o aborto é ilegal, arriscadoe caro, se centrou, muito justificadamente, na sua eficácia contraceptiva, associada a menos riscos à saúde e ao conhecimento do próprio corpo, tendo alcançado resultados muito positivos nestes aspectos. Mas o contexto da relação sexual e o papel do parceiro, a promoção da comunicação e da partilha de responsabilidades no terreno afetivo, reprodutivo e sexual podiam ser menos problematizados do que no caso do uso da camisinha. Assim, buscamos incluir na consulta e na anamnese questões que pudessem facilitar para as usuárias a discussão sobre o direito ao cuidado e ao prazer, avaliando aquilo que no decorrer do trabalho passamos a chamar, provisoriamente, de 'vulnerabilidade sexual e reprodutiva', para orientar a busca de respostas possíveis na superação desta vulnerabilidade.

Neste contexto de re-descrição dos problemas e possíveis respostas, organizamos, com parceiros, dois encontros temáticos sobre procedimentos e duas sessões de brainstorm sobre os conceitos, para a sistematização de problemas. Nestas ocasiões, pudemos discutir e trocar experiências sobre o tema e apresentar os primeiros resultados tabulados no sistema de informação ${ }^{5}$.

A discussão que enfrentamos nos levou a considerar os limites da quantificaçãomesmo que assumidamente experimental-destes eventos de saúde; a nossa ansiedade cartesiana por 'prescrições'; e as dificuldades na escuta da usuária, apresentada por esta "ansiedade prescritiva". Mesmo correndo todos estes riscos, no decorrer deste processo partimos para uma reformulação dos 'instrumentos' de trabalho na consulta - a ficha clínica e os roteiros de procedimentos. Novas questões foram incorporadas ao atendimento (como versões revistas da pesquisa de rotina de situações de violência doméstica, sexual e institucional e uma especial atenção à avaliação da vulnerabilidade das mulheres às DST e à ArDs). Ambas denotaram um impacto importante na mudança dos procedimentos de rotina. Em todas as consultas (especialmente nas de contracepção) foram incorporadas informações sobre prevenção de DST/AIDS, com ênfase no uso de métodos de barreira (em especial da camisinha) e no desenvolvimento de habilidades de negociação com parceiros nos casos que o demandassem.

\footnotetext{
${ }^{5}$ Estes foram sobre "Contracepção em tempos de AIDS", "Infeç̧ões vaginais em tempos de AIDS", "Operacionalizando o conceito de gênero nas ações de saúde" e "Para pensar o conceito de vulnerabilidade em saúde reprodutiva e sexual", com a participação de parceiros e convidados, como o Centro de Saúde Escola do Butantã/ FMUSP, Centro de Saúde Escola da Barra Funda, Instituto de Saúde, Nepaids, Casa Lilith, Casa da Mulher do Grajaú , Cemicamp e CRT/ Aids.
} 
Em termos quantitativos, realizamos, entre 1994 e 1996, 2.944 consultas ginecológicas; 469 psicológicas, incluindo os casos de atenção às mulheres em situaçãode violência; 28 atendimentos em nutrição; e 414 consultas de pré-natal, além de dezenas de sessões de grupos de reflexão sobre diversos temas. O perfil das pacientes atendidas peloColetivoé descrito posteriormente e selecionamos, também, informações constantes do novo modelo de ficha clínica (anamnese) do CFSS. Os dados se referem a uma amostra de um mês de consultas no final de 1995 utilizada para a experimentação do banco de dados.

Na interpretação destes dados, é importante considerar que as características de nossas usuárias não corresponde ao perfil da população em geral: o próprio fato de buscar um serviço desta natureza já constitui um viés da amostra. Acreditamos que nossas usuárias formam um grupo representativo-são mulheres que 'mais resistem do que se acomodam' em relação às experiências sexuais e reprodutivas, refletindo, assim, certos movimentos de mudança, referentes à construção de alternativas sexuais e reprodutivas mais empowered, mais assertivas e autônomas. As informações refletem o viés das perguntas que definimos como importantes. Desta forma, é possível, por exemplo, que a prevalência da violência apareça com índices tão elevados simplesmente porque perguntamos a todas as usuárias a este respeito; ou que haja um viés relativo a uma maior confiança da usuária na instituição, que permite que mais mulheres se sintam mais à vontade para responder afirmativamente sobre situações de ilegalidade, como a prática do aborto e o uso de drogas.

Nos últimos anos, registramos uma tendência ao 'empobrecimento' da demanda, refletida na queda da renda mensal per capita das nossas usuárias. Em 1994, a porcentagem de mulheres com renda de até três salários mínimos era de 60\%; em 1995, aumentou para 63\%; em 1996, subiu para 73\%. Do total da demanda de 1996, 59\% declararam renda pessoal de até um salário mínimo. Acreditamos que este empobrecimento se deva mais a mudanças na nossa demanda, ainda que de fato haja um empobrecimento da população em geral.

A cor destas mulheres, autodefinida, em 1994: 54,5\% brancas; 17,5\% pardas; 10,1\% negras; e 2,7\% orientais; $15,2 \%$ não definiram sua cor. Com relação à idade, $22,9 \%$ têm até 20 anos; $35,4 \%$, entre 21 e 30; 27,1\%, entre 31 e 40; e 14,6\%, mais de 40 anos. Mais de $3 / 4$ (78\%) têm trabalho remunerado (dados de 1994 a 96 ).

No que se refere a saúde e estilo de vida, $40,4 \%$ das usuárias disseram ter boa saúde, vindo ao serviço para informação e prevenção; $51,1 \%$ se consideraram 'mais ou menos' saudáveis; e apenas $8,5 \%$ se declararam com má saúde. Mais da metade $(55,3 \%)$ declarou 'boa alimentação'. Um dado que chama a atenção: 40,9\% das mulheres tinham queixas relativas ao sono. Um pouco menos da metade $(48,9 \%)$ pratica exercícios físicos regularmente; $42,8 \%$ são fumantes; $21,7 \%$ declararam tomar bebidas alcoólicas regularmente; $\mathrm{e}$ $42,6 \%$ usavam ou fizeram uso de drogas ilegais, especialmente maconha. Os problemas de saúde relacionados ao trabalho foram referidos por $30 \%$ das usuárias. 
Em termos do uso de métodos contraceptivos, opção de $84 \%$ das usuárias, notamos uma tendência clara e significativa. Entre 1991 e 1994, a camisinha era usada por 14\% das usuárias; o diafragma, por $61 \%$; a pílula por $16 \%$; os outros métodos somavam apenas $9 \%$. A partir de 1995, houve um grande aumento do uso da camisinha (também estimulado pelo nosso serviço), alcançando, hoje, 38,5\%; o uso do diafragma caiu para $25 \%$,o da pílula, para $9,4 \%$. Ainda que o uso de métodos de barreira tenha se mantido muito alto $(63,5 \%)$ - sobretudo se comparado com a população geral - há uma clara tendência ao aumento do uso da camisinha em detrimento do uso do diafragma, já que as evidências sugerem que o condom seria mais seguro na prevenção das DST/ AIDS, apesar de estar menos "sob o controle" da mulher. Entre 1991 e 1994, a laqueadura era o método de cerca de $4 \%$ das usuárias. No período mais recente, a taxa chegou a $13 \%$, refletindo, talvez de maneira tardia, o aumento da prevalência deste método, que na população geral atinge aproximadamente $45 \%$ das mulheres que usam contracepção. Outro dado surpreendente é que $78 \%$ das usuárias referem pelo menos um aborto. Isto pode refletir tanto o 'viés' de uma demanda altamente selecionada, como um grau de sinceridade maior nas respostas por se tratar de um serviço feminista.

As questões experimentais incluídas na nova anamnese se mostraram muito instigantes. Um dado que nos chama a atenção é que $63 \%$ não se consideravam expostas ao risco de contrair a AIDS - perguntadas sobre se tomavam alguma medida de prevenção, a resposta majoritária foi "não se consideram expostas ao risco" ou "consideram que se previnem" porque têm um único parceiro (o que evidencia uma flagrante contradição-na nossa demanda de mulheres supostamente mais assertivas - com a realidade epidemiológica, pois a maioria das mulheres contaminadas no município de São Paulo tem parceiro fixo e é monogâmica). Entre as usuárias do CFSS, 26,1\% declaravam já ter tido alguma DST; 20,5\% disseram jamais conversar com seus parceiros sobre sua vida sexual; e 43,5\% relataram não estar satisfeitas, ou estarem mais ou menos insatisfeitas com sua vida sexual. Outro dado relevante é que 38,3\% afirmaram já ter tido relações sexuais contra a sua vontade (por coerção sexual, como nos casos de evitar desentendimentos com o parceiro, até situações de estupro, registrado em $12,3 \%$ do total dos casos). A violência física foi declarada por 30,4\% das usuárias. Os agressores foram, na maioria das vezes, os parceiros, mas também foram mencionados os pais e estranhos na rua. Das que sofreram violência física ou sexual, $28,6 \%$ jamais haviam conversado sobre o fato com alguém antes da consulta no Coletivo. Apenas uma mulher procurou um serviço de saúde por este motivo. Uma das questões mais relevantes surgidas neste percurso foi a da violência na relação com serviços de saúde e a necessidade do desenvolvimento de alternativas na negociação das usuárias com os serviços. As principais questões trazidas foram: primeiro, a invisibilidade das questões de violência nos serviços, ou como os serviços 'filtram' o social das questões biológicas, de forma a desconsiderar a violência e suas repercussões na vida e na saúde das mulheres; em 
segundo lugar, como as instituições promovem e perpetram a violência de gênero através de sua suposta neutralidade, sobretudo através do desrespeito ao direito das mulheres à sua condição de pessoa, assim como na sistemática violação do direito das mulheres à sua integridade corporal, o que se processa por meio de procedimentos invasivos, inúteis e arriscados, mais centrados nos interesses corporativos e institucionais do que nas necessidades das mulheres (Diniz, 1997).

O trabalho relativo à violência de gênero tem sido consideravelmente ampliado com a formação de uma rede de referência de dezenas de serviços no município e pela publicação de mil exemplares, já esgotados, de um Guia de Serviços.

\section{Novos problemas e a caixa de Pandora: questōes para os serviços}

A abertura para estes novos temas, foi como abrir uma 'caixa de Pandora' ${ }^{\prime 6}$, exigindo um complexo conjunto de transformações no atendimento, como novas demandas de formação; mudanças no modelo de consulta e nos procedimentos de rotina; necessidade de contratação de novas trabalhadoras; a organização de sistemas ágeis de referência a outros serviços; grande necessidade de atualização e produção de conhecimento; avaliação do trabalho; supervisão; consultoria; e suporte psicológico para as trabalhadoras, entre outros.

Nesta área, nos encontramos em plena 'crise de crescimento', motivada pela incorporação de novos temas ao trabalho e a conseqüente expansão da demanda de usuárias. Encontramos muito sucesso e várias frustrações: temos um 'empobrecimento' da demanda e uma redução de sua capacidade de pagar pelos serviços, mesmo a preços bem reduzidos. Isto vem contribuindo para uma diminuição da capacidade institucional de financiamento desta área, apesar dos constantes esforços de suplementar financeiramente o atendimento com novos projetos.

Este quadro se agrava rapidamente com a retirada do investimento público para as políticas de saúde e com a falência - no caso dos serviços do município de São Paulo, da destruição-do Sistema Único de Saúde (SUS). Esta situação faz com que os serviços, esvaziados de profissionais e recursos, tenham de encaminhar muito dos casos que poderiam ser atendidos pelos serviços públicos, caso estes funcionassem. Felizmente encontramos no serviço público algumas 'ilhas' de resistência com as quais estabelecemos excelentes parcerias, como, por exemplo, o Centro de Referência e Treinamento de

\footnotetext{
- A Caixa de Pandora é um mito que se presta a várias interpretações. Na versão mais corrente, Pandora, um dos nomes da deusa-mãe grega Rhea, teria se tornado um equivalente, na antigüidade clássica, da Eva da cultura judaico-cristã, ou seja, a mulher curiosa que por sua desobediência condena a humanidade a todos os males, ao abrir uma caixa (ou um vaso) onde estes males estão guardados; no fundo do vaso, resta a esperança. Numa interpretação menos misógina do mito, Pandora (literalmente a doadora de todas as coisas), teria apenas reconhecido os problemas e as soluções, sendo culpabilizada por explicitar a complexidade dos fatos humanos (WALKER, 1981).
} 
Aids (CRT), o Centro de Saúde-Escola do Butantã, da USP, e a Casa Eliane de Grammont. A ampliação de nossa capacidade de estabelecer parcerias é um dos saltos de qualidade do trabalho, tanto com relação ao atendimento com os serviços citados, como nas atividades de formação, com grupos de mulheres e instituições de ensino e pesquisa.

As atividades de assistência são apenas uma parcela do trabalho de promoção da assistência integral, pois um dos maiores esforços do Coletivo tom sido o de influir na construção de políticas públicas. Com relação às atividades externas, o grande crescimento do Coletivo em termos de reconhecimento institucional, nacional e internacional, pode ser atestado pela participação nas principais instâncias do movimento de mutheres e na interlocução permanente com instituições como Secretarias de Saúde, Ministério da Saúde e agências do sistema Nações Unidas. O papel do Coletivo na proposição de políticas públicas também se expressa na participação nos Comitês de Mortalidade Materna e na solicitação de consultoria sobre organização de serviços que nos é feita.

Como decorrência de uma experiência bem-sucedida, o crescimento da demanda de trabalho e de responsabilidades não foi acompanhado de um aumento equivalente da capacidade instituicional de gerenciar e ampliaros recursos. Trata-se, então, de uma saudável 'crise de crescimento', pois reconhecemos que, como mostra Natalie Lebrum, em estudo sobre o funcionamento de Organizações Não-Governamentais (ONGs) fẹministas em São Paulo, sua estrutura é despreparada para o crescimento. Em parte, este problema se deve à herança 'radical' de horizontalidade e autogestão-que orientaram o trabalho desde o início -, implicando em grandes dificuldade para o ajuste de um modelo autogestionário às novas necessidades gerenciais de planejamento de uma ONG 'em crescimento'.

Manter um serviço não-governamental desta natureza é um desafio gerencial ainda por resolver. No que se refere às lições mais importantes aprendidas a partir de nossa experiência, citamos a consciência da necessidade de um planejamento estratégico situacional que viabilize o crescimento da instituição, preserve seus princípios políticos e garanta mais segurança e satisfação para suas trabalhadoras. Esteé um ponto central, porque nos encontramos com uma enorme sobrecarga de trabalho, com evidentes prejuízos para nossa própria saúde e bem-estar. Além disso, mesmo sendo um grupo que trabalha com saúde e direitos reprodutivos, a crescente defasagem entre trabalho previstoe orçamento institucional implica que as trabalhadoras não tenham garantidos, em termos orçamentários, qualquer seguro de saúde ou direitos reprodutivos básicos, como a licença-maternidade.

Com base na experiência, nos nossos objetivos de longo prazo e nos recursos disponíveis, nossas metas para os próximos anos são: a ampliação da capacidade institucional de responder às novas demandas - e de mobilizar recursos humanos e materiais necessários para este fim; e o registro e sistematização global da nossa experiência e reflexão na área de atenção integral à saúde da mulher, incluindo as novas questões incorporadas, com a finalidade de divulgar mais amplamente o nosso trabalho - que, em nossa avaliação, tem se mostrado muito fértil na inspiração de outras iniciativas na promoção da saúde e dos direitos das mulheres. 


\section{Referências Bibliográficas}

Araujo, M. J. \& Diniz, C. S. G. Mortalidade Materna: do técnico ao político. In: Red Global de Mujeres por los Derechos Reproductrvos. Elegimos Vivir. Amsterdam: Boletin Especial de la Campana contra la Mortalidad Materna, 1989.

ÁviLA, M. B. Modemīidade e Cidadania Reprodutiva. Dossiê Mulher e Direitos Reprodutivos. Estudos Feministas, 1 (2): 382-393 1993. Rio de Janeiro: CIEC/ECO/UFRJ.

BARROSO, C. Mortalidade Materna: uma questão política. In: Quando a PacienteéMulher. Brasília: Conselho Nacional dos Direitos da Mulher, 1989.

Colettvo Feminista Sexualdade Saúde. Relatónio de Atividades, São Paulo:1986.

Colettro Feminista Sexualdade Saúde. Relatónio de Atividades, São Paulo: 1988.

Coletivo Feminista Sexualdade Saúde. Relatónio de Atividades. São Paulo: 1994-96.

Coletrvo Feminista Sexualidade Saúde. Relatónio do II Seminário de Práticas Educativas na Implantação do PaISM. São Paulo, 1996.

Diniz, C. S. G. O que funciona e o que é justo: notas sobre a violência na assistência do parto. In: Curso de Capacitação para a Atenção a Mulheres em Situação de Violência. São Paulo: DMPFMUSP e CFSS, 1997.

Gomez-Gomez, E. (Org.). Género, Mujery Salud en las Américas. Washington DC: Organización Panamericana de Salud, 1993.

InIERNATONAL Reproductive Rights Research Action Group (IRRRAG). Not Like Our Mother. Relatóniode Pesquisa. Equipe do Brasil. Recife, 1996 (Mimeo.).

LABRA, M. E. A Saúde da Mulher no Brasil. Coleção Saúde e Realidade Brasileira. Co-edição Abrasco. Petrópolis: Vozes, 1989.

LEBON, N. The labor of love and bread: profissionalizated and volunteer activism in the São Paulo women's health movement, 1998. PhD Dissertation. University of Florida.

Matamala, M. Hay que Fortalecer la Condición de las Mujeres en Equidad con los Hombres. Dossier sobre calidad de la atención. In: Revista Mujer Salud mar-abr/1995, Red de Salud de las Mujeres Latinoamericanas y del Caribe.

Mendes Gonçalves, R. B. Práticas de Saúde: processo de trabalho e necessidades. In: Edições CEFOR, n² 1 . São Paulo: 1992.

PITTMAn, P. \& HartTGan, P. Calidad de la Atención de la Perspecliva de Género. Dossier sobre calidad de la atención. Revista MujerSalud mar-abr/1995, Red de Salud de las Mujeres Latinoamericanas y del Caribe.

WALKER, B. The Woman's Encydopaedia of Miths and Secrets. San Francisco: Harper\& Row, Publishers, 1983. 


\section{Anexo 1}

Prefeitura da Cidade do Rio de Janeiro

Secretaria Municipal de Saúde

Superintendência de Saúde Coletiva

Coordenaçáo de Programas de Atendimento Integral à Saúde

Gerência de Programas de Saúde da Mulher

\section{Modelo de Fluxograma}

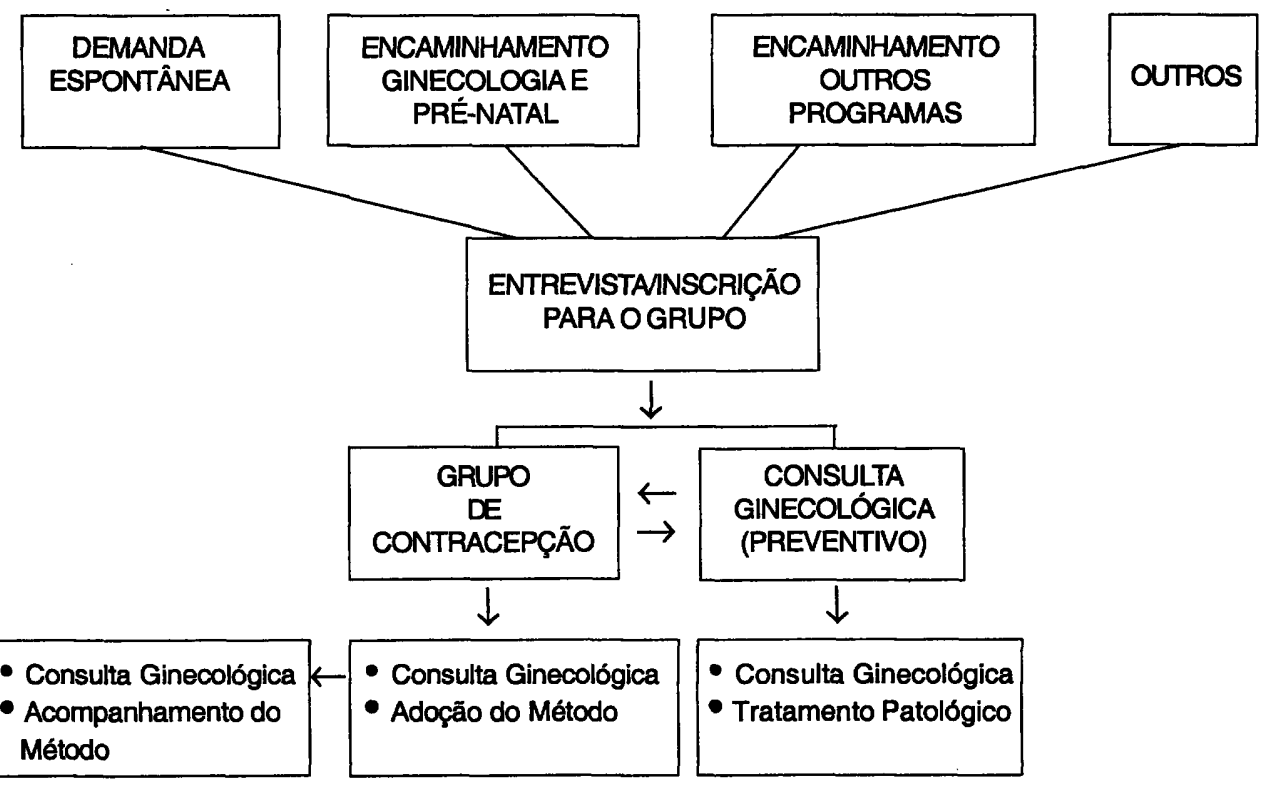




\section{Prefeitura da Cidade do Rio de Janeiro}

Secretaria Municipal de Saúde

Superintendência de Saúde Coletiva

Coordenação de Programas de Atendimento Integral à Saúde

Gerência de Programas de Saúde da Mulher

Unidade:

Ap:

Mês:

Ano:

\begin{tabular}{|l|c|c|c|c|c|c|}
\hline \multicolumn{7}{|c|}{ Trabalho de Grupo } \\
\hline GRUPO & $\begin{array}{c}\text { Data da Última } \\
\text { Reunião }\end{array}$ & $\begin{array}{c}\text { No de Mulheres } \\
\text { Inscritas }\end{array}$ & $\begin{array}{c}\text { No de } \\
\text { Reunióes }\end{array}$ & $\begin{array}{c}\text { No de Participantes } \\
\text { Início }\end{array}$ & Final & OBSERVAÇOES \\
\hline 01 & & & & & & \\
\hline 02 & & & & & & \\
\hline 03 & & & & & & \\
\hline 04 & & & & & & \\
\hline 05 & & & & & & \\
\hline TOTAL & & & & & & \\
\hline
\end{tabular}

\begin{tabular}{|c|c|c|c|c|c|c|}
\hline \multicolumn{7}{|c|}{ Método Adotado (Não incluir método de espera) } \\
\hline Método & \multicolumn{6}{|c|}{ № de Mulheres por Faixa Etária } \\
\hline Natural (1) & $15-19$ & $20-29$ & $30-39$ & $40-44$ & 45 e mais & TOTAL \\
\hline Preservativo (2) & & & & & & \\
\hline Espermicida & & & & & & \\
\hline Diafragma (3) & & & & & & \\
\hline Pflula & & & & & & \\
\hline DIU & & & & & & \\
\hline TOTAL & & & & & & \\
\hline
\end{tabular}

(1)Tabela; muco; temperatura; associação de métodos naturais; método(s) natural(is) + espermicida

(2) Preservativo; preservativo + métodos naturais; preservativo + espermicida

(3) Diafragma; diafragma + preservativo; diafragma + métodos naturais

Atenção: Quando a adoção de método for "Diafragma e Preservativo" não esquecer de colocar no quadro correspondente ao do diafragma.

\begin{tabular}{|l|c|c|c|}
\hline \multicolumn{4}{|c|}{ Mudança de Método Anticoncepcional } \\
\hline Método Anterior & Método Atual & $N^{2}$ de Mulheres & Idade \\
\hline & & & \\
\hline & & & \\
\hline
\end{tabular}

Informe abaixo a existência de usuárias que compareceram para reinserção de DIU ou reposição de diafragma.

\begin{tabular}{|l|c|c|}
\hline Método & \multicolumn{1}{c|}{ INo de Mulheres } \\
\hline Reinserção de DIU & & \\
\hline Reposição de Diafragma & & \\
\hline Total & & \\
\hline RESPONSÁVEL: & Mat:: \\
\hline
\end{tabular}




\section{Anexo 3}

Prefeitura da Cidade do Rio de Janeiro

Secretaria Municipal de Saúde

Superintendência de Saúde Coletiva

Coordenação de Programas de Atendimento Integral à Saúde

Gerência de Programas de Saúde da Mulher

\section{Registro de Clientes do Serviço de Contracepção}

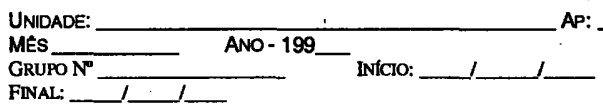

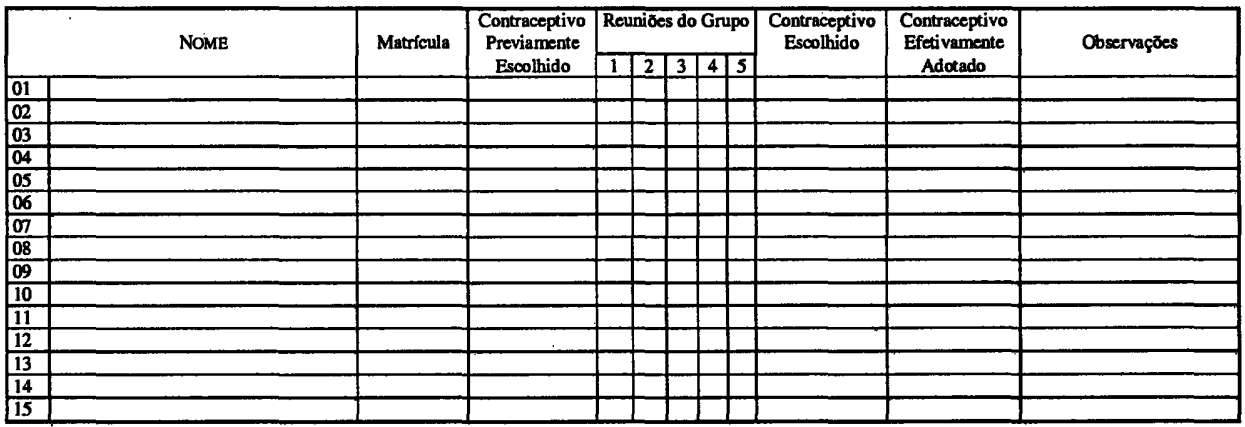

Assinatura do responsável:

Mat. 


\section{Anexo 4}

Enviar para S/SSC/CPS

Gerência de Programas

de Saúde da Mulher

Prefeitura da Cidade do Rio de Janeiro

Secretaria Municipal de Saúde

Superintendência de Saúde Coletiva

Coordenação de Programas de Atendimento Integral à Saúde

Gerência de Programas de Saúde da Mulher

\section{Controle de Estoque de Contraceptivos}

UNIDADE:

ANO - 199

\begin{tabular}{|c|c|c|c|c|c|c|c|c|c|}
\hline & \multirow[t]{2}{*}{ CONTRACEPTIVO } & \multicolumn{2}{|c|}{$\begin{array}{l}\text { ESTOQUE } \\
\text { INICIAL }\end{array}$} & \multicolumn{2}{|c|}{ RECEBIDOS } & \multirow[t]{2}{*}{ SUBTOTAL } & \multirow{2}{*}{$\begin{array}{c}\text { ENTREGUES A } \\
\text { CLIENTELA }\end{array}$} & \multirow{2}{*}{$\begin{array}{c}\text { ESTOQUE } \\
\text { ATUAL }\end{array}$} & \multirow[t]{2}{*}{ OBSERVAÇOES } \\
\hline & & Data & Quant. & Data & Quant & & & & \\
\hline \multicolumn{10}{|c|}{ 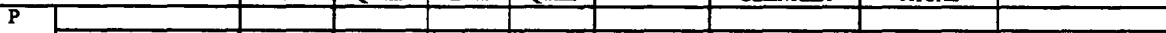 } \\
\hline \multicolumn{10}{|l|}{ I } \\
\hline \multirow{2}{*}{\multicolumn{10}{|c|}{ U }} \\
\hline & & & & & & & & & \\
\hline$L$ & \\
\hline A & TOTAL & & & & & & & & \\
\hline \multicolumn{10}{|l|}{$\bar{D}$} \\
\hline \multicolumn{10}{|c|}{$\mathrm{N}^{\circ} 65$} \\
\hline \multirow{2}{*}{\multicolumn{10}{|c|}{\begin{tabular}{|l|}
$N^{0} 70$ \\
$N^{0} 75$ \\
\end{tabular}}} \\
\hline & $N^{0} 75$ & & & & & & & & \\
\hline \multirow{3}{*}{$\begin{array}{l}\mathbf{A} \\
\mathbf{G} \\
\mathbf{M} \\
\mathbf{A}\end{array}$} & $N^{2} 80$ & & & & & & & & \\
\hline & $N^{2} 85$ & & & & & & & & \\
\hline & TOTAL & & & & & & & & \\
\hline \multirow{2}{*}{\multicolumn{10}{|c|}{$\begin{array}{l}\text { GELÉlA } \\
\text { PRESERVATIVO }\end{array}$}} \\
\hline & & & & & & & & & \\
\hline & DIU & & & & & & & & \\
\hline
\end{tabular}

Assinatura do responsável:

Mat.
AP: MEs 


\section{Anexo 5}

Prefeitura da Cidade do Rio de Janeiro

Secretaria Municipal de Saúde

Superintendência de Saúde Coletiva

Coordenação de Programas de Atenção Integral à Saúde

Gerências de Programas de Saúde da Mulher e do Adolescente

Unidade:

Ap:

Mês

Ano - 199

\section{Informaçōes sobre as Adolescentes que Adotaram \\ Métodos Anticoncepcionais \\ (Importante completar todos os itens)}

№ do prontuário

Idade

Idade da menarca

Gesta

Para

Filhos vivos ( )

Abortos espontâneos ( )

Abortos provocados ( )

Estuda?

( ) Sim, cursa a _ série do ___ grau grau

Com quem mora?

( ) Pais

( ) Só com companheiro

( ) Companheiro e pais ou sogros

( ) Outros

Uso anterior de anticoncepcionais ( ) Não

( ) Sim Qual (is)?

Método adotado

Data

Motivo da escolha do método atual 
Prefeitura da Cidade do Rio de Janeiro

Secretaria Municipal de Saúde

Superintendência de Saúde Coletiva

Coordenação de Programas de Atendimento Integral à Saúde

Gerência de Programas de Saúde da Mulher

\section{$11^{\circ}$ Curso do PaISM - Contracepção}

Início: 05 de maio de 1997

Dias e Horários: $2^{\mathrm{a}}$ e $5^{\mathrm{a}}$ das $8: 30$ às 17 horas

Carga Horária: $96 \mathrm{~h}\left(1^{\circ}, 2^{\circ}\right.$ e $3^{\circ}$ módulos)

72 h ( $1^{\circ}$ e $2^{2}$ módulos)

Local e Endereço: Fundação João Goulart

Av. Pres. Vargas, $914-4^{\circ}$ andar / sala 4

Coordenação: Centro de Treinamento em Atenção Integral à Saúde da Mulher-Espaço-MurHer.

\section{PROGRAMAÇĀO}

\section{MódULO - Vivência/Discussōes Teóricas}

$\begin{array}{llll}\text {. Abertura / PAISM } & 05 / 05 \text { (manhã) } & \text {. Adolescência } & 15 / 05 \text { (manhã) } \\ \text {. Gênero/Sexualidade } & 05 / 05 \text { (tarde) } & \text {. Mortalidade Materna } & 15 / 05 \text { (tarde) } \\ \text {. Sexualidade/Climatério } & 08 / 05 \text { (manhã) } & \text {. Seminário:Métodos Contraceptivos } & 19 / 05 \text { (manhã) } \\ \text {.DST } & 08 / 05 \text { (tarde) } & \text {. Seminário:Métodos Contraceptivos } & 19 / 05 \text { (tarde) } \\ \text {. Mulher e AIDS } & 12 / 05 \text { (manhã) } & \text {. Serviço de Contracepção } & 22 / 05 \text { (manhã) } \\ \text {. Aborto } & 12 / 05 \text { (tarde) } & \text {. Práticas Educativas } & 22 / 05 \text { (tarde) }\end{array}$

OBS.:O profissional de saúde que faltar no primeiro dia do curso terá sua inscrição automaticamente cancelada

\section{MODULO - Estágio Supervisionado nos Grupos de Contracepção}

Participação nos grupos de contracepção desenvolvidos em algumas unidades da rede municipal, identificadas como campo de estágio.

Carga horária prevista: 1 turno por semana, durante 3 a 6 semanas de acordo com a programação das unidades de estágio.

Carga horária total - Estágio supervisionado mais 1 turno para avaliação e encerramento.

\section{MÓDULO - Estágio Supervisionado em Ambulatório de Ginecologia (exclusivamente para médicos)}

Treinamento em ambulatório de contracepção com o objetivo de desenvolver todos os procedimentos técnicos necessários para uma consulta contraceptiva.

Carga horária prevista: 1 a 2 turnos por semana, em um total de aproximadamente 8 turnos, a serem definidos de acordo com a disponibilidade do treinando e da unidade campo de estágio.

Para profissionais da Secretaria Municipal de Saúde do Rio de Janeiro

- Contactar a Direção da Unidade

Para profissionais de saúde de outras Instituições e/ou Municípios

- Contactar a Secretaria Estadual de Saúde - Coordenação do Programa de Assistência Integral à Saúde da Mulher, Criança e Adolescente. (PAISMCA) 


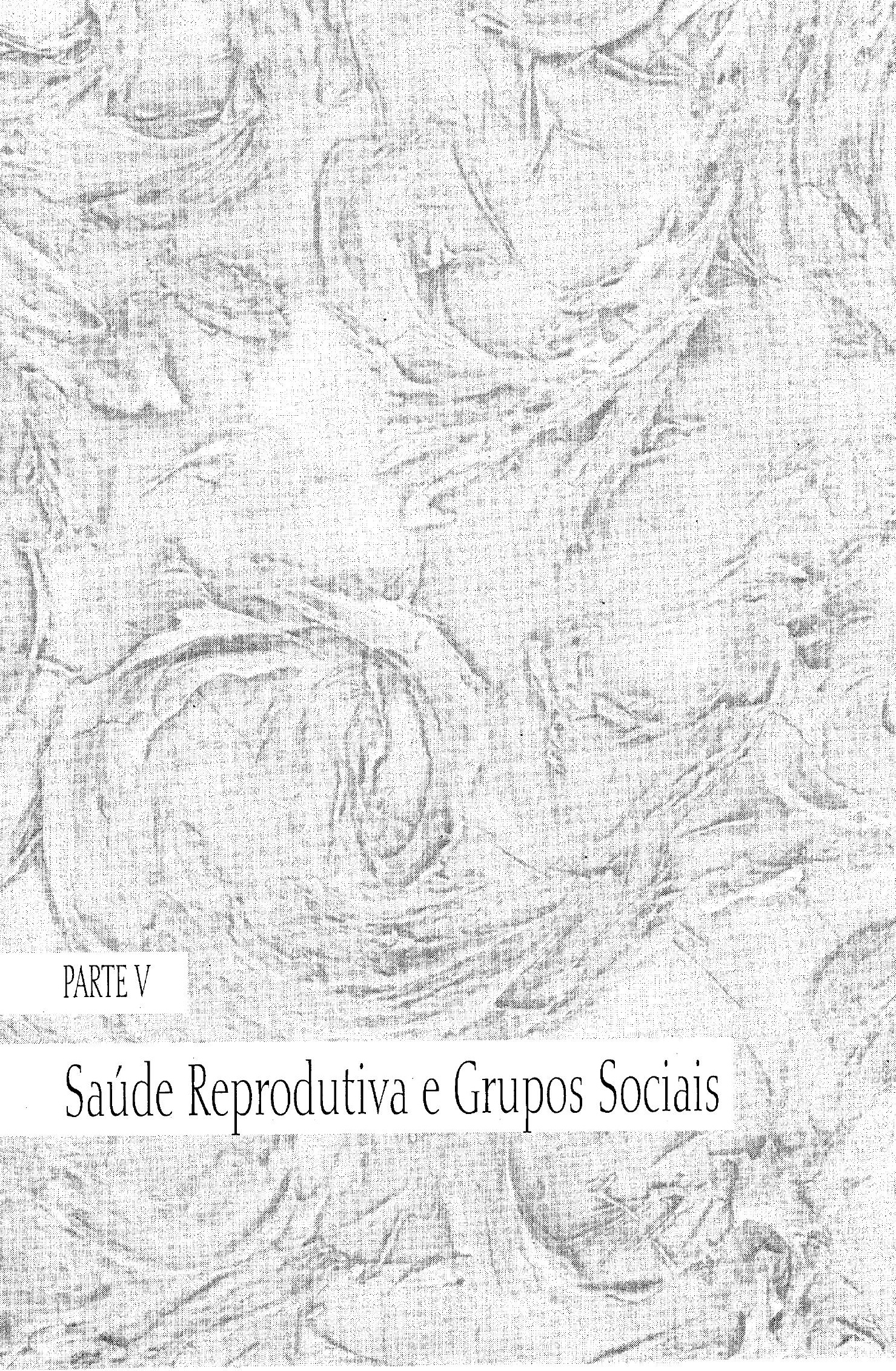





\section{1}

\section{Condiçães de Saúde de Funcionánios de Banco Estatal:} aspectos ligados à reprodução

Dóra Chor, Maria de Jesus Mendes da Fonseca, Milena Piraccini Duchiade, Célia Regina de
Andrade \& Kaizô Iwakami Belträo

\section{Introdução}

Nos últimos 50 anos, o Brasil sofreu profundas transformações, passando de um país essencialmente agrário a uma sociedade urbana moderna, com um grande parque industrial e um vasto setor de serviços. O modelo econômico adotado, entretanto, levou a uma das mais perversas estruturas de distribuição de renda do mundo, extremamente concentrada, só superada em termos de desigualdade por países como o Kuwait ou Botswana (Banco Mundial, 1993). É possível identificar, portanto, um mosaico de situações distintas, que vão desde ilhas de prosperidade semelhantes aos nichos mais ricos dos países desenvolvidos, até comunidades que sobrevivem no quase completo abandono, tanto no interior de grandes metrópoles, quanto isoladas no interior do País.

O padrão brasileiro tornou-se tão peculiar que, recentemente, analistas econômicos internacionais passaram a utilizar o conceito de 'brasilificação' como sinônimo do processo "no qual os ricos ficam cada vez mais ricos, os pobres cada vez mais pobres, e a classe média tende progressivamente a desaparecer". Nesse contexto, compreende-se facilmente que grande parcela dos cientistas sociais tenha voltado suas lentes para o

\footnotetext{
- Agradecemos aos funcionários do Banco do Brasil que compuseram o Grupo de Trabalho Cassi (Caixa de Assistência dos Funcionários do Banco do Brasil) - Pesquisas Epidemiológicas e Grupo da Terceira Idade: Eneida Favre, Heitor Rodrigues de Assis Filho, Gisele da Silva Fernandes, Rosångela Fátima de Oliveira Machado, Carlos Henrique da Conceição Santos, Renato Rademaker Grunewald.
} 
estudo prioritário das camadas populares, que compõem a maioria da população. Assim tem sido nos últimos anos, não apenas na saúde pública, mas nas demais áreas ligadas às ciências humanas.

Entre os extremos de abundância e desperdício, ou escassez e miséria, sobrevivem, como podem, as camadas mćdias. Embora pequenas do ponto de vista percentual, represcntam contigente populacional considerável, por sua magnitude. Apesar de heterogêneas do ponto de vista socioeconômico, constituem, provavelmente, a face mais visível da sociedade brasileira, por serem compostas de elementos que, em sua maioria, conseguiram ter acesso a um grau de instrução mais elevado e por tentarem se manter no mercado formal de trabalho. Incluem desde o pequeno funcionário público, com pouca ou nenhuma qualificação, até a professora primária, o profissional universitário, o pequeno comerciante, o bancário, o vendedor de automóveis ou o corretor de seguros. É a parcela da população que aparece nas novclas, lê jornais, consome não só bens duráveis, mas também medicamentos ou lazer, eque, de certo modo, éformadora de opinião. Em função de todas essas condições, começam a serdivulgados hoje, no País, estudos a seu respeito.

Investigações de tendências que surgem no seio da classe média podem ajudar a compreender comportamentos que, paulatinamente, vão se disseminar para as camadas populares um pouco mais tarde. Assim ocorreu, por exemplo, no caso da substituição do leite materno pelo leite em pó, na década de 50, quando ficou evidente o papel de 'arauto' representado pelas mulheres de classe média, rapidamente imitadas pelas parcelas mais pobres. É interessante notar que, nesse episódio, as mulheres de classe média também foram as precursoras do comportamento inverso, já que voltaram a adotar a amamentação natural, mais de duas décadas depois, propagandeando seu retorno nos meios de comunicação.

Nesse contexto, insere-se o interesse em estudar um grupo relativamente homogêneo, tal qual o das bancárias, funcionárias de um banco estatal. Estas podem ser consideradas como 'grupo-sentinela', ou seja, como grupo que anuncia o que está ocorrendo ou pode vir a ocorrer em breve em outros segmentos sociais. Tal abordagem visa a detectar problemas ou anunciar tendências que seriam muito dificeis de demonstrar para o conjunto da população, sobretudo em uma época em que escasseiam as verbas para pesquisas de base populacional em um país do tamanho do Brasil. De fato, nos países desenvolvidos, descobriu-se, há muito tempo, a vantagem da realização de pesquisas em grupos menores - como os empregados de uma empresa ou os associados de um seguro-saúde - não apenas por causa dos custos relativamente mais baixos e operacionalização mais fácil, mas, principalmente, em função da maior adesão por parte dos entrevistados, o que favorece a validade das informações.

Embora pesquisas sobre fecundidade e anticoncepção venham sendo realizadas no Brasil, as oportunidades de estudar com mais detalhes os estratos urbanos de renda média do país são mais raras (Duchiade, 1996). Partindo destas premissas, apresenta- 
mos resultados de amplo estudo sobre as condições de saúde dos funcionários de um banco estatal que trabalham no estado do Rio de Janeiro. Além dos dados específicos sobre práticas de anticoncepção, objeto principal desta publicação, outras informações serão fornecidas com o objetivo de caracterizar a população estudada do ponto de vista social, demográfico e, também, o uso de serviços de saúde e práticas de prevenção.

As questões relacionadas à reprodução (desde a sexualidade, até as enfermidades específicas e sua prevenção) acompanham as mulheres ao longo de toda a sua existência. A gravidez não planejada - talvez a mais duradoura dentre todas as preocupações femininas, na esfera reprodutiva - tem sido fonte de preocupação e ansiedade femininas nas mais diversas sociedades. Práticas de anticoncepção tradicionais vêm sendo substituídas poroutras, mais modernas, mas o método ideal-eficaz, reversível e sem efeitos indesejáveis - ainda não está disponível. A esterilização voluntária, que não constitui, de fato, uma forma de regular a fertilidade - e sim de extingui-la -é o método mais utilizado para o planejamento familiar em todo o mundo (Church \& Geller, 1990). A crescente participação feminina no mercado de trabalho, o padrão de famílias pequenas e, também, a oferta de serviços que realizam a laqueadura, aliados à falta de disponibilidade de outros métodos seguros e à situação ilegal do aborto são apontados como determinantes da ampla utilização da esterilização (Vieira \& Ford, 1996; Duchiade, 1995; Giffin, 1992; 1994).

No Brasil, a situaçãoé ainda mais surpreendente, não só pela proporção de mulheres esterilizadas, mas por todo o contexto que cerca o procedimento: grande parte realiza a laqueadura até os 30 anos, a intervenção não é oficial (pois não é registrada em prontuários médicos) e, muitas vezes, requer pagamento específico, complementando procedimentos gratuitos (cesáreas realizadas em hospitais públicos). Apesar de todas essas irregularidades, a esterilização parece tornar-se cada vez mais a única solução confiável - embora radical, porque irreversível-para as mulheres que não desejam mais ter filhos (embora muitas acreditem que o procedimento possa ser revertido).

Recente pesquisa nacional estimou que $40,1 \%$ das brasileiras unidas, que usam métodos anticoncepcionais, optaram pela esterilização. Em 1986, essa proporção era de 26,9\% (BEMFAM/ DHS, 1996). Assim, o incremento de $17 \%$ no uso desses métodos "decorreu quase exclusivamente do aumento da esterilização, uma vez que a pilula e os métodos tradicionais apresentaram redução de seus percentuais". A idade avançada e o grande número de filhos não justificam a freqüência da laqueadura. A ligadura passou a ser realizada mais cedo, já que a idade mediana do procedimento caiu de 31,4 anos na pesquisa de 1986 para 28,9, dez anos depois. O número de filhos também não parece ser uma justificativa plausível para a laqueadura: $42,6 \%$ das mulheres em união, com dois filhos, já se encontravam esterilizadas.

A esterilização voluntária, da forma como que vem sendo praticada no Brasil, constitui mais um indicador da distância entre a realidade das práticas de anticoncepção e o ideal justo e humano do que vem sendo definido como 'saúde sexual e reprodutiva': 
em primeiro lugar, que a população tenha capacidade de ter filhos, bem como de regular sua fertilidade de forma segura e efetiva; significa que o resultado da gravidez nãoé somente desejado, mas também que deve ser bem sucedido, em termos do bem-estar da mãe e da criança, incluindo o pleno desenvolvimento de seu potencial; significa que os casais possam compreender e desfrutar de sua sexualidade, livres do medo de uma gravidez indesejada ou de contrair enfermidades, e também livres da condenação social que tem acompanhado a sexualidade há muito tempo (Barzellato, 1996).

\section{O estudo das condiçóes de saúde de bancários}

Com o objetivo de reformular os serviços de assistência à saúde oferecidos pela Caixa de Assistência dos Funcionários, o estudo das condições de saúde de seus associados, em que se incluiu a saúde reprodutiva, foi realizado entre agosto e dezembro de 1994. A populaçãoalvo foram as carreiras administrativa (bancários propriamente ditos) e técnica (médicos, advogados). Foi excluída a carreira de apoio (contínuos), por contar com poucos funcionários (está em extinção) e pela dificuldade que apresentaram, nos estudos-piloto, de preencher o questionário. Uma amostra probabilística de 2.415 bancários - 1.024 mulheres-, estratificada de acordo com os três tipos de dependências do banco (agências, centros de processamento, serviços e informações - CESEC - e direção geral), foi sorteada para preencher questionário auto-respondido no ambiente de trabalho. No caso das agências localizadas em cidades de grande e médio porte, uma amostra por conglomerado em dois estágios foi aplicada, enquanto nas cidades pequenas, todos os funcionários preencheram o questionário (censo). Nos dois outros tipos de dependências (CESEC e direção geral), utilizou-se amostragem aleatória simples. Em função das diferentes frações amostrais, as estimativas para o conjunto da amostra foram ponderadas por fator de expansão específico.

Além do questionário geral, respondido por homens e mulheres, as funcionárias preencheram formulário específico, voltado para tópicos como história reprodutiva, anticoncepção e prevenção de neoplasias. Salienta-se que a adesão do funcionalismo à pesquisa foi excelente, com menos de $5 \%$ de recusa ao preenchimento do questionário. O fato de ter sido patrocinada pela Caixa de Assistência dos funcionários e a expectativa de que seus resultados revertam em seu benefício constituíram fatores importantes para tal índice de adesão. Além disso, a identificação voluntária e a garantia de sigilo contribuíram para a fidedignidade das respostas, cuja validade é sugerida pelas informações obtidas a partir de questões sensíveis - como consumo de bebidas alcoólicas e abortos - compatíveis com a literatura. Detalhes metodológicos e intervalos de confiança serão fornecidos apenas para as variáveis principais, já que a apresentação dos resultados para cada um dos estratos estaria fora do espaço disponível para este capítulo. Informações complementares poderão ser obtidas em outra publicação (Beltrão, 1996). 


\section{Características sociodemográficas}

Uma breve descrição das características sociodemográficas será fornecida inicialmente, de modo a permitir uma compreensão melhor do grupo estudado e para facilitar comparações com o conjunto da população brasileira.

Trata-se de um grupo de adultos jovens, cuja média de idade foi de 38,27 anos para as mulheres, e de 37,13 para os homens. A idade mediana foi de 39,02 e 38,25 para mulheres e homens, respectivamente. Para o conjunto da população, a máxima foi de 59,20; a mínima, de 21,30 anos. Na prática, as diferenças são poucas. Além disso, aproximadamente $60 \%$ dos funcionários encontrava-se entre 35 e 45 anos (Tabela 1).

\section{Tabela 1 - Distribuição etária por sexo}

\begin{tabular}{lccc}
\hline Idade & Homem (\%) & Mulher (\%) & TOTAL (\%) \\
\hline $20-29$ & 21,1 & 8,3 & 16,1 \\
$30-34$ & 14,5 & 15,6 & 14,9 \\
$35-39$ & 24,9 & 33,9 & 28,4 \\
$40-44$ & 26,8 & 36,0 & 30,4 \\
45 e + & 12,7 & 6,3 & 10,2 \\
\hline TOTAL & 100,0 & 100,0 & 100,0 \\
\hline
\end{tabular}

Nota:

Total de respostas $(n)=2.415$

Enquanto o salário médio foi maior entre os homens-R\$1.126,13-do que entre as mulheres-R $\$ 909,27$-, a renda familiar percapita média foi ligeiramente superior para as mulheres-R $\$ 660,00$-comparada à masculina - $R \$ 627,00$. Este resultado sugere que as bancárias somam seus salários à renda familiar, o que provavelmente não acontece com muitos dos homens, que sustentam sozinhos suas famílias.

Além do nível de renda, a escolaridade também revela a diferenciação desse grupo profissional em relação à população em geral: $85,5 \%$ dos funcionários chegou a ingressar na universidade (Tabela 2). Maior proporção de mulheres $(64,1 \%)$ concluiu curso superior - a taxa masculina foi de $45,7 \%$. Este grau de instrução é justificado pelo critério de seleção de seus funcionários, que passou a exigir pelo menos o segundo grau completo nos últimos concursos. 
Tabela 2 - Escolaridade segundo sexo

\begin{tabular}{lcccc}
\hline $\begin{array}{l}\text { Grau } \\
\text { atingido* }\end{array}$ & $\begin{array}{c}2^{\circ} \text { Grau completo } \\
\text { ou incompleto (\%) }\end{array}$ & Superior incompleto (\%) & Superior completo (\%) & TOTAL (\%) \\
\hline Homens & 17,1 & 37,2 & 45,7 & 100,0 \\
Mulheres & 10,6 & 25,3 & 64,1 & 100,0 \\
\hline TOTAL & 14,5 & 32,5 & 53,0 & 100,0 \\
\hline
\end{tabular}

Notas:

Total de respostas $(n)=2415$ (Total)

Total de respostas $(n)=1391$ (Homens)

Total de respostas $(n)=1024$ (Mulheres)

*Obs.: Mais alto grau atingido.

A maior parte da população encontrava-se casada. No entanto, o percentual de mulheres sós, por separação ou viuvez (18,7\%), foi superior a registrada entre os homens7,3\% (Tabela 3).

Tabela 3 - Situação conjugal segundo sexo

\begin{tabular}{|c|c|c|c|c|c|}
\hline Situação conjugal & Solteiro (\%) & Casado* (\%) & Viúvo (\%) & Separado (\%) & TOTAL (\%) \\
\hline $\begin{array}{l}\text { Homens } \\
\text { Mulheres }\end{array}$ & $\begin{array}{l}23,3 \\
20,1 \\
\end{array}$ & $\begin{array}{l}69,4 \\
61,2 \\
\end{array}$ & $\begin{array}{l}0,1 \\
1,5 \\
\end{array}$ & $\begin{array}{r}7,2 \\
17,2 \\
\end{array}$ & $\begin{array}{l}100,0 \\
100,0 \\
\end{array}$ \\
\hline TOTAL & 22,0 & 66,2 & 0,7 & 11,2 & 100,0 \\
\hline
\end{tabular}

Notas:

Total de respostas $(n)=2.415$

${ }^{*}$ Casados ou unidos consensualmente

\section{Utilização de serviços de saúde}

O estudo da utilização de serviços de saúde desta população revela a realidade de um grupo populacional com amplo acesso a serviços credenciados e à restituição integral ou parcial dos gastos com saúde. Assim, por exemplo, 21,4\% dos funcionários haviam sido internados (considerando-se como internação a permanência em clínica ou hospital, mesmo que por algumas horas) por motivos clínicos ou cirúrgicos nos 12 meses anteriores à aplicação do questionário. Entre os funcionários que passaram por alguma internação, nota-se nítida diferença entre os sexos, já que mais da metade das mulheres foi submetida a pelo menos uma intervenção cirúrgica $(52,8 \%)$, o que ocorreu com apenas um terço dos homens $(32,1 \%)$. 
A avaliação das especialidades médico-cirúrgicas envolvidas na cirurgia mais recente do último ano confirma marcada diferenciação entre os sexos (Tabela 4), já que duas das principais especialidades envolvidas nas cirurgias femininas estão relacionadas ao aparelho reprodutivo: ginecologia e obstetrícia. Estas comesponderam a 46,9\% das cirurgias, enquanto a ortopedia aparece em primeiro lugar para os homens, com quase um quarto do total. Vale notar que as cesarianas estavam explicitamente referidas como sinônimo de 'obstetrícia', e foram informadas isoladamente por 17,3\% das mulheres (Tabela 4).

\section{Tabela 4 - Especialidades médico-cirúrgicas envolvidas na cirurgia mais recente dos últimos 12 meses}

\begin{tabular}{|c|c|c|c|c|c|}
\hline Especialidades & Homens (\%) & Ordem & Mulheres (\%) & Ordem & TOTAL (\%) \\
\hline Ginecologia & - & - & 29,6 & . $1^{\circ}$ & 21,3 \\
\hline Ortopedia & 28,1 & 10 & 6,4 & $6^{9}$ & 12,4 \\
\hline Obstetrícia & - & - & 17,3 & $3^{\circ}$ & 12,5 \\
\hline Cirurgia plástica & 3,9 & $8^{\circ}$ & 18,2 & $2^{o}$ & 14,2 \\
\hline Oftalmologia & 10,1 & $3^{\circ}$ & 1,3 & $13^{\circ}$ & 3,8 \\
\hline Cirurgia geral & 10,5 & $2^{\circ}$ & 2,3 & $11^{\circ}$ & 4,6 \\
\hline Urologia & 10,1 & $3^{9}$ & - & - & 2,8 \\
\hline Gastroenterologia & 8,7 & $4^{\circ}$ & 1,1 & $15^{\circ}$ & 3,2 \\
\hline Angiologia & 1,8 & $10^{\circ}$ & 8,9 & 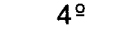 & 6,9 \\
\hline Mastologia & - & - & 7,6 & $5^{\circ}$ & 5,5 \\
\hline Dermatologia & 7,7 & $5^{\circ}$ & 3,0 & $8^{\circ}$ & 4,3 \\
\hline Otorrinolaringologia & 1,7 & $11^{\circ}$ & 2,4 & $10^{\circ}$ & 2,2 \\
\hline Proctologia & 7,0 & $7^{\circ}$ & 2,8 & $9^{\circ}$ & 4,0 \\
\hline Nefrologia & 2,8 & $9^{\circ}$ & 0,1 & $16^{\circ}$ & 0,9 \\
\hline Neurocirurgia & 0,7 & $12^{\circ}$ & 1,8 & $12^{\circ}$ & 1,5 \\
\hline Endocrinologia & - & - & 1,2 & $14^{\circ}$ & 0,9 \\
\hline Cardiologia & - & - & 1,3 & $13^{\circ}$ & 1,0 \\
\hline Outra especialidade & 7,3 & $6^{\circ}$ & 6,2 & $7^{\circ}$ & 6,5 \\
\hline
\end{tabular}

Notas:

Total de respostas $(n)=78$ homens

Total de respostas $(n)=120$ mulheres

A alta freqüência de parto operatório pode ser confirmada pelo número de partos cesáreos declarados $-76,8 \%$ das mulheres que tiveram filhos referiram pelo menos uma cesárea-e pelo percentual de cesarianas realizadas no primeiro parto: 64\%. Este percentual torna-se ainda mais surpreendente ao avaliarmos suas principais razões (Gráfico 1): apenas 37\% deles são classificados como indicações médicas formais, passíveis de indicação cirúrgica: sofrimento fetal (10,8\%); posição do bebê (13,4\%); indicação médica por doença $(7,6 \%)$; emergência com complicações $(4,0 \%)$ e parto gemelar $(1,1 \%)$. As alegações de "falta de passagem", "trabalho longo", "passou da data", "idade", "médico achou melhor", "medo da dor", "não queria cortar o períneo" e "o médico só fazia cesarianas" (sic) constituíram 63\% e são de difícil avaliação objetiva. 


\section{Gráfico 1 -Motivos de realização de cesárea no primeiro parto. Funcionárias de banco estatal}

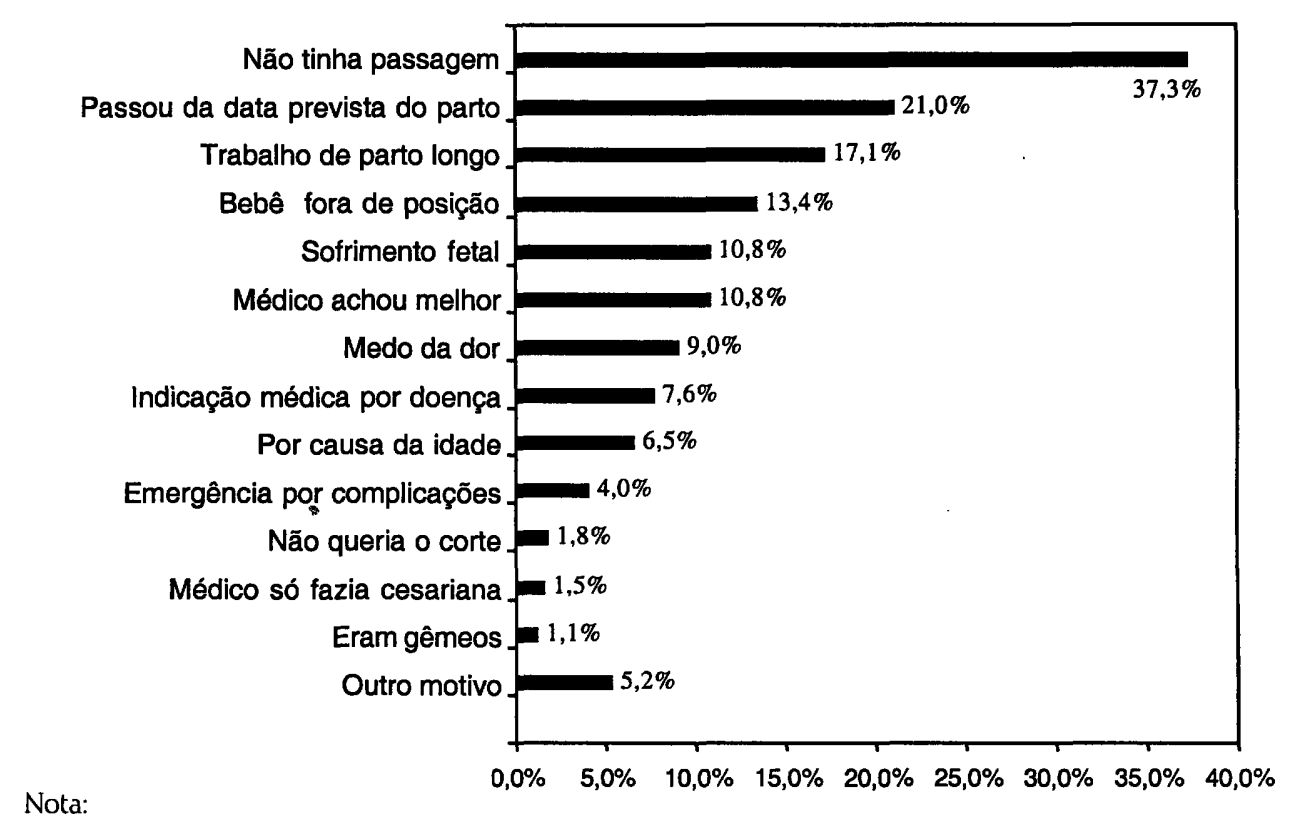

Total de respostas $(n)=426$

A avaliação da prática de cesáreas de acordo com a idade das bancárias sugere um gradiente decrescente com o aumento da idade. Considerando-se apenas as mulheres que tiveram filhos, $83,8 \%$ das funcionárias até os 35 anos fizeram pelo menos uma cesariana. Esta proporçãoé de 75,7\% no grupo de 35 a 44 anos e de 68,0\% acima dos 45 . Ressaltamos que a tendência inversa seria esperada, já que, com o aumento da idade, a probabilidade de um maior número de partos - e entre eles, as cesáreas - deveria aumentar. Ainda que um estudo longitudinal fosse necessário para confirmar a hipótese, é possível supor que a prática de partos operatórios esteja se tornando ainda mais freqüente entre as mulheres mais jovens, quando comparadas às gerações mais idosas, quase como uma escolha de rotina, passando o parto normal à condição de exceção. A associação deste 'hábito' com a prática de laqueadura tubária, já apontada por outros autores (Barros, 1991), será comentada posteriormente. 


\section{Prevenção de neoplasias ginecológicas}

Outra característica que diferencia as funcionárias do Banco do Brasil do conjunto das mulheres brasileiras refere-se aos procedimentos envolvidos na prevenção de cânceres ginecológicos. O câncer de mama é a principal enfermidade de origem neoplásica a afetar as mulheres que trabalham no banco, de acordo com estudo sobre a mortalidade dos funcionários daquela instituição no período compreendido entre 1940 e 1990 (Beltrão \& Duchiade, 1992). Este resultado é compatível com o que vem ocorrendo entre as mulheres das camadas médias urbanas no País e em outros países, nas quais o câncer de mama constitui a neoplasia mais freqüente (Ministério da Saúde, 1991).

A grande maioria das funcionárias foi examinada por médico no último ano, enquanto 26,3\% realizou o exame há mais tempo (Gráfico 2). Apenas 1,1\% declarou nunca ter realizado exame de mamas, sendo em sua maioria funcionárias jovens, com idade entre 20 e 29 anos.

\section{Gráfico 2- Último exame de mamas realizado por médico. Funcionárias de banco estatal}

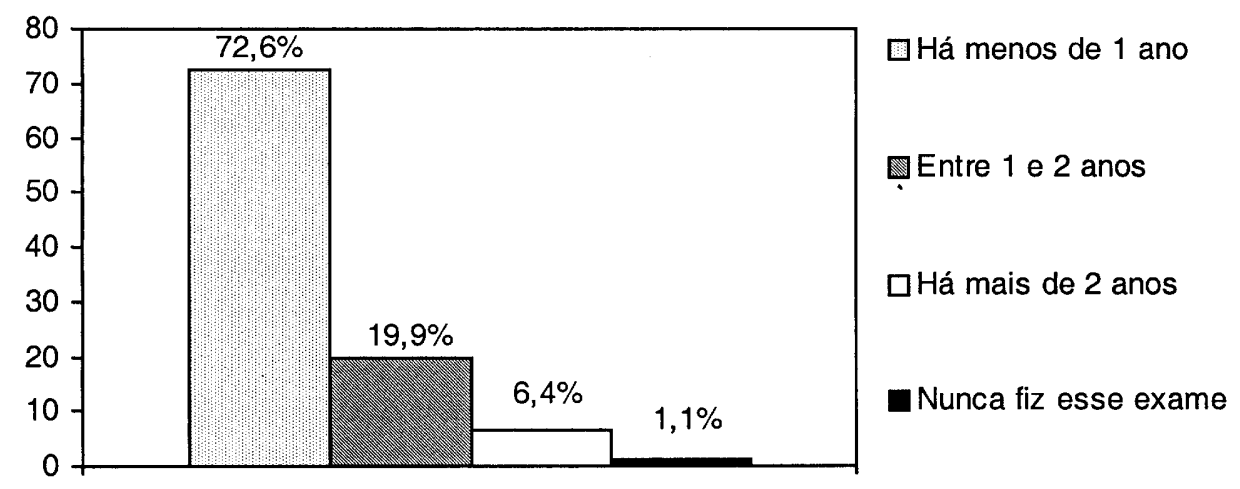

Nota:

Total de respostas $(\mathrm{n})=1.013$

Realidade diversa encontramos em relação ao auto-exame das mamas. Embora a grande maioria das entrevistadas $(88,3 \%$ ) afirme saber como se faz a auto-palpação, apenas 38,5\% têm esta prática (Gráfico 3). O auto-exame revelou-se uma prática regular de pouco mais de $1 / 3$ das bancárias, o que demonstra que até mesmo em um grupo altamente diferenciado em termos socioeconômicos este hábito não foi incorporado. 


\section{Gráfico 3-Prática de auto-exame de mamas. Funcionárias de banco estatal}

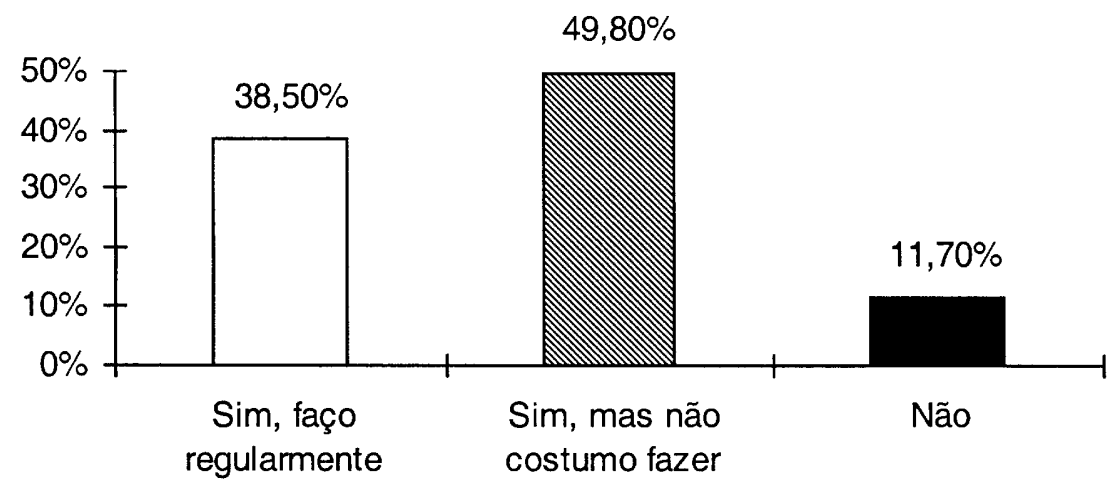

Notas:

Total de respostas $(n)=1014$

Pergunta: "Você sabe fazer auto-exame de palpação dos seios para prevenção do câncer de mama?"

Por outro lado, mais de $2 / 3$ das funcionárias $(67,9 \%)$ já realizaram pelo menos uma vez a mamografia, solicitada no exame periódico de saúde - realizado anualmente para mulheres com 40 anos ou mais. Mesmo considerando esta rotina, esta proporção nos parece elevada - mais da metade das funcionárias tinha menos de 40 anos (Tabela 1). A observação dos motivos pelos quais a mamografia foi feita (Gráfico 4) aparentemente reforça esta hipótese: menos de $20 \%$ aconteceram por indicação médica, devido a algum problema. Sem menosprezar a importância da mamografia, particularmente para as mulheres mais velhas, o uso de exames complementares complexos pode estar sendo abusivo, como acontece em outros campos da prática médica, substituindo ou complementando, quase que obrigatoriamente, a inspeção clínica criteriosa. 


\section{Gráfico 4-Motivos da realização de mamografia. Funcionárias de banco estatal}

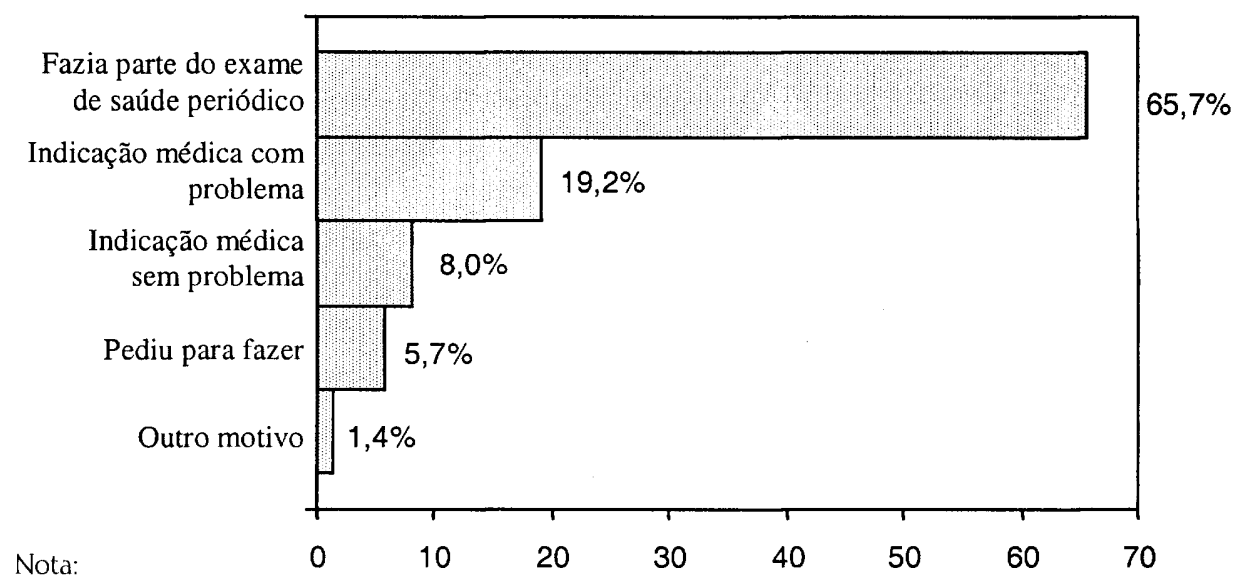

Total de respostas $(n)=726$

Por fim, a realização do Papanicolau, para prevenção do câncer cérvico-uterino, está implantada na rotina de screening das funcionárias do banco: $91,0 \%$ das funcionárias relataram o exame nos últimos dois anos (Gráfico 5). Trata-se de percentual bastante satisfatório, muito diferente da realidade da maior parte das mulheres brasileiras.

\section{Gráfico 5- Último exame para prevenção de câncer cérvico- uterino. Funcionárias de banco estatal}

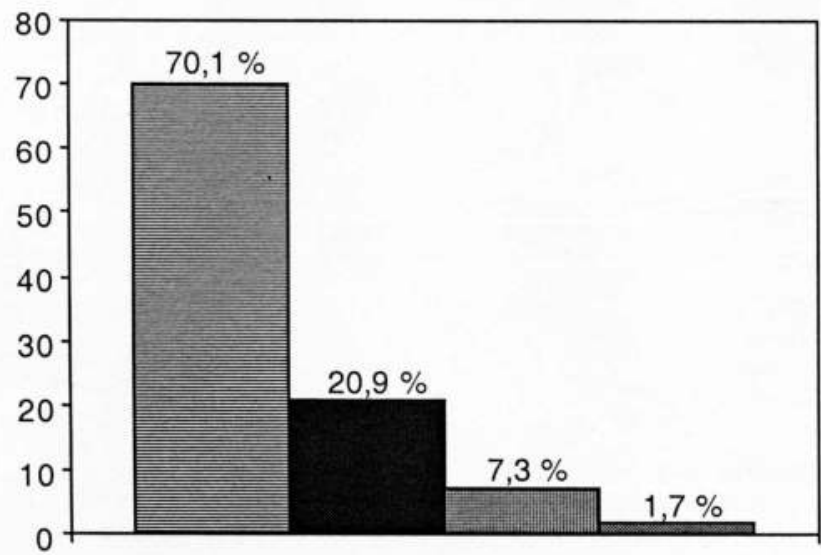

目 Há menos de 1 ano

- Entre 1 e 2 anos

ㅁaㅇ de 2 anos

- Nunca fiz esse exame

Nota:

Total de respostas $(n)=1.003$ 


\section{História reprodutiva}

A maior parte das funcionárias -aproximadamente $80 \%$-já engravidou pelo menos uma vez (Tabela 5). Dentre essas, 59,7\% engravidaram duas ou três vezes. Somente 2,9\% apontaram mais de cinco gestações. Note-se que a distribuição do número de gravidezes é muito concentrada, com mediana e moda coincidentes - iguais a dois (apenas duas gravidezes) - chegando à média de 2,3 gestações.

Como era esperado entre mulheres urbanas, com alto nível de escolaridade, a maioria das funcionárias teve poucos filhos - um ou dois - e apenas $20,5 \%$ três filhos ou mais máximo de cinco (Tabela 5). Considere-se também que 29,4\% relataram nunca ter tido filhos. Isto torna possível confirmar a opção por famílias pouco numerosas, característica desse estrato social. Salienta-se ainda que o percentual de mulheres sem nenhum filho $(29,4 \%)$ é superior ao de mulheres que nunca engravidaram $(17,6 \%)$, sugerindo a existência de abortos espontâneos ou provocados. Embora os dados da Tabela 5 não discriminem os filhos nascidos vivos dos natimortos, o percentual informado de natimortalidade foi muito baixo $(0,9 \%)$, tornando dispensável, portanto, a exclusão dos natimortos.

\section{Tabela 5 - Número de gestaçōes* e de filhos**}

\begin{tabular}{|c|c|c|c|c|}
\hline № de filhos & $\begin{array}{c}\mathrm{N}^{\mathrm{N}} \text { gestações } \\
\%\end{array}$ & $\begin{array}{c}\text { № gestações (2) } \\
\%\end{array}$ & $\begin{array}{c}\mathrm{N}^{9} \text { de filhos } \\
\%\end{array}$ & $\begin{array}{c}\text { № de filhos }{ }^{(4)} \\
\%\end{array}$ \\
\hline 1 & 16,5 & 20,1 & 21,6 & 30,6 \\
\hline 2 & 28,5 & 34,5 & 34,5 & 48,9 \\
\hline 3 & 20,7 & 25,2 & 13,1 & 18,5 \\
\hline 4 & 8,9 & 10,8 & 1,2 & 1,8 \\
\hline 5 & 5,2 & 6,3 & 0,1 & 0,2 \\
\hline $6-11$ & 2,4 & 2,9 & - & - \\
\hline Não sabe & 0,2 & 0,2 & - & - \\
\hline Nenhum(a) & 17,6 & - & 29,4 & - \\
\hline Subtotal & - & 100,0 & - & 100,0 \\
\hline TOTAL & 100,0 & - & 100,0 & - \\
\hline
\end{tabular}

\footnotetext{
Notas:

(1) Incluindo as que nunca engravidaram.

(2) Excluindo as que nunca engravidaram.

(3) Incluindo as que nunca tiveram filhos.

(4) Excluindo as que nunca tiveram fithos.

* Mesmo aquelas gestações que não resultaram em nascimento vivo.

** No de filhos, tanto nascidos vivos quanto natimortos.

Total de respostas $(n)=981$ para ${ }_{(2)}^{(1)}$

Total de respostas $(n)=801$ para $^{(2)}$

Total de respostas $(n)=1.022$ para $^{(3)}$

Total de respostas $(n)=721$ para $^{(4)}$
} 
Considerando-se o conjunto das trabalhadoras, o número médio de filhos foi inferior a dois (Tabela 6). De acordo com o esperado, esta média aumenta de acordo com a idade das mulheres, mas é possível suspeitar que as mais jovens tenham comportamento distinto das mais velhas (um efeito de coorte), optando por um número menor de filhos. Isto, porque nenhuma das funcionárias com menos de 35 anos tinha mais de três filhos, quando se sabe que o pico da fecundidade, no Brasil, ocorre entre 25 e 29 anos (Simões \& Oliveira, 1988). Embora possamos admitir que as mais jovens ainda não tiveram todos os filhos desejados, a alta freqüência de laqueadura tubária entre elas enfraquece esta hipótese, como veremos posteriormente.

\section{Tabela 6 - Estatísticas-resumo do número de filhos por mu- lher*, segundo grupo etário}

\begin{tabular}{lrrrrrr}
\hline & \multicolumn{7}{c}{ Grupo etário } \\
\cline { 2 - 7 } № de filhos & $20-29$ & $30-34$ & $35-39$ & $40-44$ & 45 e + & TOTAL \\
\hline Média & 1,34 & 1,65 & 1,93 & 1,98 & 2,33 & 1,92 \\
Coeficiente de variação & $40,07 \%$ & $41,58 \%$ & $38,00 \%$ & $37,84 \%$ & $33,33 \%$ & $39,18 \%$ \\
Moda & 1,00 & 1,00 & 2,00 & 2,00 & 2,00 & 2,00 \\
Mediana & 1,00 & 2,00 & 2,00 & 2,00 & 2,00 & 2,00 \\
19 quartil $^{\text {9o quartil }}$ & 1,00 & 1,00 & 1,00 & 1,00 & 2,00 & 1,00 \\
\hline
\end{tabular}

Notas: Total de respostas $=707$

* Excluídas as que nunca engravidaram.

Obs.: Coeficiente de variação = desvio-padrão dividido pela média, vezes 100 .

\section{Anticoncepção}

Como já apontavam os níveis baixos de fecundidade das funcionárias do banco, o controle da concepção é elevado. Se forem incluídas as mulheres que realizaram laqueadura de trompas e aquelas cujos companheiros são vasectomizados, 74,8\% do total usam algum método anticoncepcional (Tabela 7). Este índice é semelhante ao estimado, recentemente, para o conjunto das mulheres brasileiras 'unidas' $(76,7 \%)$. No entanto, é bem superior à estimativa para o conjunto da população feminina, sem considerar o estado conjugal, que é de 55,4\% (BEMFAM/DHS, 1996). Exceção feita a laqueadura e vasectomia - por não serem considerados estritamente métodos anticonceptivos $-36 \%$ das funcionárias utilizam algum método. 
Tabela 7 - Utilização de métodos de anticoncepção

\begin{tabular}{lcc}
\hline Usando método & $\%{ }^{(1)}$ & $\%(2)$ \\
\hline Sim & 36,1 & 74,8 \\
Não & 63,9 & 25,2 \\
\hline TOTAL & 100,0 & 100,0 \\
\hline
\end{tabular}

Notas:

Total de respostas $(n)=969$ mulheres

(1) Excluídas as mulheres com laqueadura ou com companheiro vasectomizado.

${ }^{(2)}$ Incluídas as que sofreram laqueadura ou têm companheiro vasectomizado.

Ao investigarmos os métodos utilizados, diversos resultados surpreenderam: a alta prevalência de laqueaduras tubárias, com $44,1 \%$ de todas as mulheres que evitam filhos (Gráfico 6) ${ }^{1}$; a freqüência de utilização da 'tabela' (18,1\%), por tratar-se de procedimento tradicional, e que é considerado pouco eficaz; o uso dos preservativos, declarado por 13,5\%; e, finalmente, em quarta posição, a pílula, com 11,7\%.

Vale destacar que métodos modernos, de eficácia reconhecida, como o DIU e o diafragma, são relativamente pouco utilizados $-7,6 \%$ e $6,3 \%$, respectivamente-eque apenas $0,7 \%$ das funcionárias que evitam filhos declararam que seus parceiros são vasectomizados. Esta pequena proporção tampouco era esperada, já que considera-se que a prevalência de esterilização masculina cresce com o aumento da escolaridade (BEMFAM/DHS, 1996).

Comparando-se os resultados relativos às práticas de anticoncepção das bancárias com o conjunto das mulheres do País, observamos que aquelas se assemelham às estimativas da parcela de brasileiras unidas em função da faixa etária e do estado conjugal (mais da metade das bancárias encontrava-se casada). Assim, a proporção de mulheres que evitam filhos é semelhante: $74,8 \%$, entre as bancárias; e 76,7\% em nível nacional (BEMFAM /DHS, 1996). A mesma proporcionalidade é verificada em relação à parcela de mulheres esterilizadas entre as que evitam filhos: $40,1 \%$, na população geral; e $44,1 \%$ entre as bancárias. Ressalta-se também que, enquanto a pilula éo segundo método mais freqüente entre o conjunto das brasileiras, as bancárias a utilizam menos, dando preferência a métodos tradicionais como a 'tabela'.

I Ver também prevalências específicas por dependência, no Anexo 1. 


\section{Gráfico 6-Métodos utilizados para evitar gravidez. Funcionárias de banco estatal}

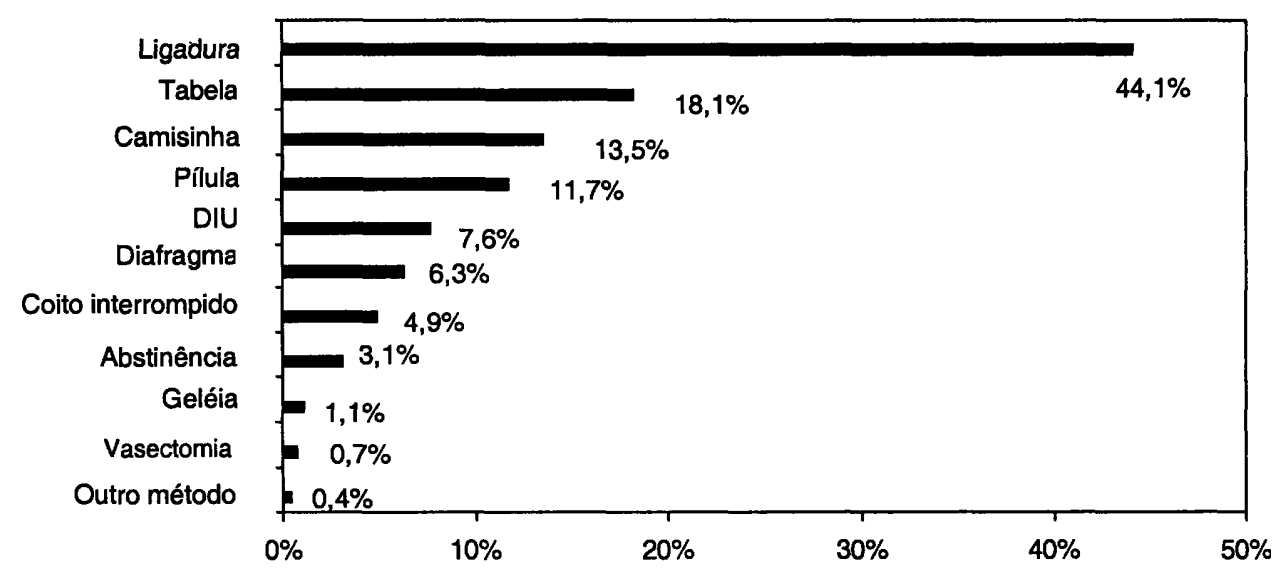

Notas:

Total de respostas $(n)=732$

O número suficiente de filhos foi o motivo declarado por cerca de $80 \%$ das funcionárias para a laqueadura, ao passo que ter realizado duas ou mais cesarianas aparece em segundo lugar, para 36,5\% (Gráfico 7). Entre os outros motivos citados pelas bancárias, destaca-se que os problemas financeiros foram declarados por aproximadamente $10 \%$ das mulheres esterilizadas. A maior parte das funcionárias $(63,7 \%)$ declarou mais de um motivo: a maioria optou pela combinação entre "número suficiente de filhos" $\mathrm{e}$ "muitas cesáreas". Confirma-se, assim, a associação entre a prática de cesarianas e de laqueadura, já apontada em outros estudos. Entre mulheres norte-americanas, por exemplo, demonstrou-se que aquelas submetidas a partos cesáreos apresentaram probabilidade duas vezes maior de sofrer esterilização simultânea pós-parto do que mulheres que tiveram partos por via vaginal (Placek, 1981). No caso das bancárias, entre as que já tiveram pelo menos um parto cesáreo, $68,8 \%$ ligaram as trompas, ao passo que $45,5 \%$ entre as que nunca tiveram parto operatório optaram pela esterilização. Já que a maioria das mulheres teve no máximo dois filhos, podemos supor que, por ocasião do segundo parto, boa parte delas 'optou' pela cesariana como via de acesso para a laqueadura. A pequena proporção de funcionárias esterilizadas sem cesariana $(14,1 \%)$ revela que a ligadura por laparoscopia é pouco utilizada pelas bancárias. 


\section{Gráfico 7-Distribuição dos motivos que levaram à laqueadura. Funcionárias de banco estatal}

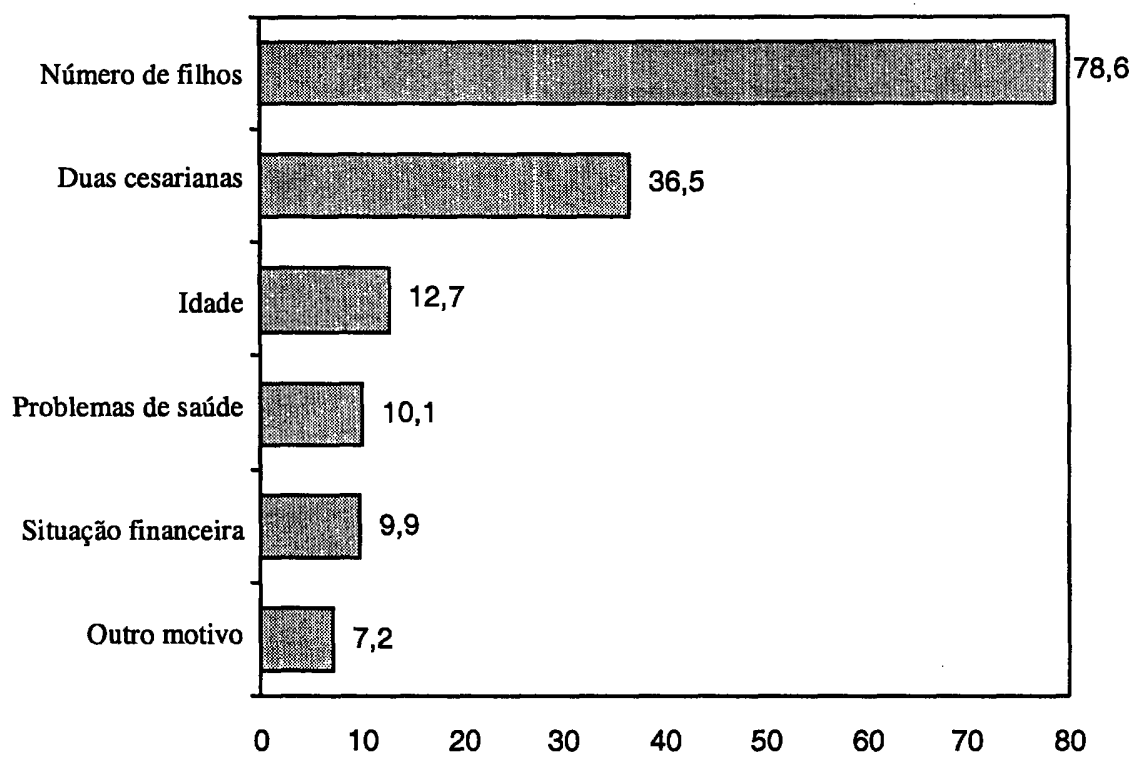

Nota:

Total de respostas $(n)=325$

Ao investigar os motivos para a realização da laqueadura mais detalhadamente, observamos que cerca de $64 \%$ das funcionárias tinham um ou dois filhos na época em que a realizaram (Tabela 8). Além disso, eram bastante jovens (o índice de opção pela ligadura antes dos 30 anos atingiu 41\%) (Tabela 9); e 79\% tinham no máximo 34 anos ao optar pela esterilização. Assim, devemos interpretar que "número suficiente de filhos" significou dois filhos - na grande maioria dos casos - e que "muitas cesáreas" (também duas, no máximo, para a grande maioria) de fato não parecem justificar esta decisão radical, indicada para multíparas idosas (acima de 35 anos) ou mulheres com grave risco gestacional, de acordo com a prática médica criteriosa.

Tabela 8 - Mulheres esterilizadas* segundo número de filhos

\begin{tabular}{lcccccc}
\hline Ligadura de trompas & \multicolumn{7}{c}{ Número de filhos (\%) } \\
\cline { 2 - 7 } & 1 & 2 & 3 & 4 & 5 & TOTAL \\
\hline Não & 45,3 & 40,6 & 11,5 & 2,6 & 0,0 & 100,0 \\
Sim & 4,7 & 59,1 & 33,7 & 2,2 & 0,3 & 100,0 \\
\hline TOTAL & 19,2 & 52,5 & 25,8 & 2,3 & 0,2 & 100,0 \\
\hline
\end{tabular}

Notas:

Total de respostas $(n)=483$

* Mulheres que fizeram laqueadura tubária. 


\section{Tabela 9 - Idade na ligadura de trompas}

\begin{tabular}{lrc}
\hline Idade & $\%$ & \% acumulado \\
\hline$<25$ & 4,5 & 4,5 \\
$25-29$ & 36,2 & 40,7 \\
$30-34$ & 38,4 & 79,1 \\
$35-39$ & 18,2 & 97,3 \\
40 e + & 2,7 & 100,0 \\
\hline TOTAL & 100,0 & - \\
\hline
\end{tabular}

Nota:

Total de respostas $(\mathrm{n})=319$

\section{Aborto}

Considerando-se todo o constrangimento que o tema envolve, por motivos religiosos, legais ou morais, e também em função da pesquisa não ter sido desenhada com este objetivo específico, optamos por não fazer distinção entre abortos provocados ou espontâneos. O tópico foi abordado pela pergunta "alguma de suas gestações resultou em aborto espontâneo ou provocado?" Entre as funcionárias que engravidaram alguma vez, 50,2\% responderam afirmativamente, o que corresponde a uma ocorrência bastante comum neste grupo populacional. Embora saiba-se que entre 10 e $15 \%$ das gestações podem ser interrompidas espontaneamente-devido a malformações congênitas, alterações de implantação do embrião ou problemas de saúde da mãe (Rezende, 1976) não é provável um percentual tão elevado de abortos inevitáveis em um grupo com as características sociais descritas. Assim, é razoável supor que a maior parte destes abortamentos tenha sido, de fato, provocado, considerando-se ainda que o percentual pode estar subestimado, por dificuldade de declaração ou, até, pelo não-desejo das mulheres em recordar o evento.

De toda forma, trata-se de um número muito expressivo, se considerarmos que este é um grupo diferenciado de mulheres, com acesso praticamente irrestrito a todos os métodos contraceptivos disponíveis no mercado. A prática do aborto parece se justificar não somente pela falta de informação ou de acesso à anticoncepção, mas também pela falha dos métodos disponíveis aliada à ambigüidade relacionada à maternidade, tão comum na sociedade moderna. Estes resultados mais uma vez confirmam a freqüência da prática do aborto, fato sabido mas não reconhecido - que nenhuma mulher deseja conscientemente-mas ao qual acaba recorrendo em algum momento da vida. 


\section{Comentários finais}

Se é inegável o avanço que a disseminação de métodos contraceptivos representou para a maior liberdade da mulher no que tange à sua entrada no mercado de trabalho, constatamos, também, que esta liberdade vem se expressando no Brasil sobretudo pela opção de 'não ter filhos', ao invés de 'ter o número desejado de filhos'.

Não podemos deixar de estranhar o tipo de regulação da concepção em vigor entre as funcionárias do banco (teoricamente não esperado, pois o predomínio das ligaduras tubárias se aproxima daquele vigente na média da população feminina do País, que não tem, em muitos casos, emprego, o nível de escolaridade ou o amplo acesso à tecnologia e serviços de saúde das bancárias). Apesar do perfil diferenciado deste grupo, que é comparável ao de mulheres de países desenvolvidos, as funcionárias preferem, em sua grande maioria, a ligadura de trompas, e não métodos reversíveis, disponíveis para elas. Assim, a necessidade (e desejo?) de abolir para sempre gestações indesejadas parece igualar as mulheres brasileiras, que, ainda jovens e, em geral, com um ou dois filhos, estão optando pela esterilização.

Os motivos alegados não parecem explicar esta preferência tão acentuada pela laqueadura. Afinal, se uma funcionária do banco tem o número de filhos que considera suficiente, ou se já fez duas cesáreas, e mesmo que não tolere a pilula, daí não decorre obrigatoriamente que a única (ou principal) alternativa deva ser a laqueadura. A esfera de motivações que determina, de fato, tal decisão parece ser outra-e, embora não tenha constituído objeto de investigação deste trabalho, merece ser comentada. Dentre estas, vale comentar que a geração de mulheres que têm hoje entre 30 e 35 anos de idade quando a maior parte daquelas que evitam filhos já se encontra esterilizada - não conheceram, em sua vida adulta, períodos prolongados de crescimento econômico, quando a ausência duradoura de crises econômicas e políticas possibilita o florescimento da esperança em um futuro melhor para o País. Ao investigar, na mesma pesquisa, o nível de satisfação dos funcionários com suas condições de vida e trabalho, constatamos que aproximadamente $95 \%$ das mulheres estavam insatisfeitas com o "estado da lei e da ordem" e com os "padrões morais e valores do País". Em relação ao banco, entre 18 itens, "as perspectivas de ascensão" apresentou o índice mais alto de insatisfação, depois do nível salarial. Isso nos leva a supor que este éo pano de fundo da 'opção' pela esterilização precoce, que aproxima as funcionárias do Banco do Brasil (antes considerado um bom emprego, seguro para toda a vida) do conjunto das brasileiras: a ausência de esperança em um futuro melhor para o Brasil, do ponto de vista moral ou econômico. Fazendo parte desse quadro, as condições de vida, no dia-a-dia das grandes cidades, tornaram-se mais difíceis nas últimas décadas, com o crescimento da violência e deterioração dos serviços de educação e saúde públicos. 
A partir desse cenário comum, o peso dos motivos que parecem justificar a decisão da laqueadura pode variar para os diferentes grupos sociais, segundo a disponibilidade de métodos reversíveis - que, no caso das bancárias, é ampla - e da qualidade da informação fornecida pelos médicos a respeito das conseqüências 'conhecidas' da esterilização sobre o corpo ou sobre a imagem que a mulher tem de seu corpo. No caso das bancárias, podemos supor que as falhas dos métodos, o desconforto que geram (ou seus efeitos colaterais), aliados às restrições legais e morais ao aborto, contribuem para a proporção exagerada de mulheres jovens esterilizadas. Note-se que esta proporção espanta ainda mais por se tratar de uma decisão 'para sempre', tomada em tempos de instabilidade das relações conjugais, quando um novo casamento ou outro filho podem fazer parte do futuro de qualquer mulher.

Embora tenhamos analisado esta população por meio de um estudo transversal, 'congelando' um instante no tempo - c, portanto, sem a perspectiva de um período mais longo - a reversão desses padrões reprodutivos é pouco provável, sobretudo se lembrarmos que a média de idade das bancárias beira os 40 anos e considerarmos a preferência pelas laqueaduras. De fato, os resultados aqui apresentados não são uma peculiaridade das bancárias, mas confirmam o que foi encontrado em estudos nacionais recentes: a preferência pela laqueadura não é uma característica das camadas médias, ela está ocorrendo no Brasil de modo generalizado. Cabe a um conjunto de disciplinas a discussão e divulgação desta tendência, pois o tamanho da família - que, aparentemente, é decidido intimamente por cada casal-depende, também, do contexto social mais amplo. Em ambas as esferas, pública ou privada, as determinações são múltiplas e muitas delas sequer explícitas ou conscientes.

\section{Referências Bibliográficas}

BARROS, F. C. et al. Epidemic of cesarian sections in Brazil. Lancet, 338: 167, 1991.

Banco Mundial. Banco Intemacional de Reconstrução e Desenvolvimento. Relatónio sobre o Desenvolvimento Mundial 1993: investindo em saúde. Rio de Janeiro: Fundação Getúlio Vargas/ Banco Mundial, 1993.

BARZELATTO, J. Desde el control de la natalidad hacia la salud sexual y reprodutiva: la evolución de un concepto a nivel internacional. In: Seminário Saúde Reprodutiva na América Latina e no Caribe: temas e problemas. 1996. (Mimeo)

Betrrão, K et al. Condições de saúde dos associados da Caixa de Assistência dos Funcionários do Banco do Brasil (CASSI). Relatório de Pesquisa, 1996.

BeLTRão, K. \& Duchiade, M. P. Estudo da mortalidade dos funcionários do Banco do Brasil. Relatório Final, 1992 (Mimeo.) 
Bemfam/DHS. Programa de Pesquisas de Demografia e Saúde. Pesquisa Nacional sobre Demografia e Saúde. Relatónio Preliminar, 1996.

BraSIL. Ministério da Saúde. Instituto Nacional do Câncer. Programa de Oncologia. Registro Nacional de Patologia Tumoral-Diagnósticos de Câncer, Brasil-1981/1985. Rio de Janeiro: INCa. ProOnco, 1991.

ChURCh, C. A. \& Geller, J. S. Voluntary Female Sterilization: number one and growing. Population Reports, series C. Baltimore: John Hopkins University, 1990.

DuchIADE, M. P. População Brasileira: um retrato em movimento. In: MinaYo, M.C. Os Muitos Brasis: saúde e população na década de 80. São Paulo: Abrasco - Hucitec, 1995, p. 14-56.

DuchiADE, M. P. et al. Saúde Reprodutiva em Funcionárias de Banco Estatal. In: X Encontro Nacional de Estudos Populacionais. Anais. ABEP, 1996.

GIFFI, K. M. A Modernidade Perversa e a Reprodução Humana no Brasil. In: LEAL, M.C. etal. (Orgs.) Saúde, Meio Ambientee Desenvolvimento. v. 2. São Paulo:Abrasco-Hucitec, 1992. p.199-219.

GrFFin, K. M. Women's health and the privatization of fertility control in Brazil. Social Science and Medicine, 39(3):355-360, 1994.

PlaceK, P. J.; TAFFEL, S.N. \& SMITH, J.C. Postpartum sterilization in cesarean section and noncesarean section delivery: United States, 1970-1975. American Joumal of Public Health, 71(11): $1258-1261,1981$.

ReZENDE, J. \& Monteiro, C. A. B. Obstetríia Fundamental. Rio de Janeiro: Guanabara Koogan, 1976. $630 \mathrm{p}$.

SIMÕES, C. C. S. \&OLIERA, L. A. P. A Situação da Fecundidade: determinantes geraise características da transição recente. Perfil estatístico de crianças e mães no Brasil. Rio de Janeiro: Fundação Instituto Brasileiro de Geografia e Estatística (IBGE), 1988. 64p.

VIEIRA, E. M. \& FoRD, N. J. The provision of female sterilization in São Paulo, Brazil: a study among low income women. Social Science and Medicine, 42(10): 1427-1432. 


\section{Anexo 1}

Prevalência de ligadura de trompas entre as bancárias com vida sexual ativa que não estavam utilizando outros métodos anticonceptivos por tipo de dependência

\begin{tabular}{lcc}
\hline Dependência & Prevalência (\%) & Intervalo de confiança 95\% \\
\hline Direção geral & 48,3 & $39,0-57,7$ \\
CESEC & 56,3 & $48,4-63,9$ \\
Agências* grandes & 48,1 & $38,5-57,8$ \\
Agências* médias & 56,0 & $45,3-66,5$ \\
Agências* pequenas & 50,0 & - \\
\hline
\end{tabular}

Notas:

$n=619$

*Agências localizadas em cidades grandes, médias ou pequenas.

Obs.: Nas agências pequenas todos os funcionários preencheram o questionário. 



\section{Recorte Racial/Étnico e a Saúde Reprodutiva: mulheres negras'}

Fátima Oliveira

\section{Introdução}

Cresce a compreensão nos meios científicos de que as imagens epidemiológicas necessitam incorporar a interpenetração das variáveis sexo/gênero, raça/etnia e classe social para retratar a realidade com maior fidelidade. Esta tríade deve ser analisada considerando-se a vivência do racismo e as condições sociais e materiais nas quais a pessoa vive, além de ressaltar que a condição biológica nãoé mais ou menos importante, apenas indispensável quando tratamos do ser humano. Estamos, pois, diante de um desafio: a necessidade da elaboração de um novo paradigma capaz de explicar o que a 'ciência normal' do nosso tempo não tem conseguido.

Neste ensaio especulativo, abordamos a importância do 'quesito cor' como dado de identificação pessoal nos serviços de saúde. Isto, por tratar-se de um indicador/pista fundamental para o entendimento de agravantes ou atenuantes de doenças, possibilitando diagnósticos mais precisos e precoces e atenção adequada - sobretudo no caso de doenças denominadas "raciais/étnicas", que concorrem para aumentar a morbi-mortalidade das mulheres em idade reprodutiva. Entre elas, a anemia falciforme e doenças

\footnotetext{
* Este capitulo possui tantas co-autorias que sinto-me impossibilitada de enumerá-las, por medo de, do esquecer algum nome, cometer injustiças. Minha gratidão a todas as pessoas que participaram de todos os momentos e ocasiões em que tive o privilégio de pensar, repensar e discutir este assunto e contar com inúmeras contribuições. Agradeço pelas críticas, sugestões, discussões sem fim e sobretudo pela solidariedade, às professoras Elza Berquó e Eliane Azevedo; às bolsistas do Programa Saúde Reprodutiva da Mulher Negra Magda, Raquel, Dida e Vera; e ao Grupo de Estudos sobre a Saúde da População Negra/ Sindicato dos Médicos do Estado de São Paulo: Lurdinha, Gilka, Hegles, Tito e João Elias.
} 
de componentes comprovadamente poligênicos - nas quais o recorte racial/étnico parece ser importante, como diabetes tipo II, miomas uterinos e hipertensão arterial. Analisamos, ao mesmo tempo, como a variável classe social ao lado do recorte racial/étnico parece determinante no prognóstico desfavorável em praticamente todas as enfermidades femininas, em especial nos casos de câncer uterino e de mama; e no acesso aos serviços públicos de saúde, particularmente na contracepção, pré-natal e prevenção do câncer.

\section{Consideraçōes gerais}

Os estudos contemporâneos sobre a saúde da população negra brasileira têm como referência obrigatória os trabalhos pioneiros de Elza Berquó et al., na área de demografia, realizados pelo Núcleo de Estudos da População da Universidade Estadual de Campinas (NEPO/Unicamp). A delimitação das pesquisas no campo da saúde reprodutiva tem como marco o ano de 1991, a partir da criação do Programa Saúde Reprodutiva da Mulher Negra (PSRMN) pela área de População e Sociedade do Centro Brasileiro de Análise e Planejamento (CEBRAP) - coordenada por Berquó - que realiza pesquisas e prepara estudantes negras na área de saúde reprodutiva da população negra.

Existem dados comprobatórios de que algumas doenças surgem com mais freqüência - ou quase exclusividade - em negros, brancos e amarelos, ou, ainda, em alguns grupos étnicos, como ciganos, judeus, entre outros. Tal constatação indica a possibilidade de catalogação de algumas doenças como 'raciais' ou 'étnicas'. A anemia falciforme é um exemplo. Originária da África, prevalece em negros-o que nos permite afirmar que é uma 'doença racial'. Análises de DNA revelam vários tipos de anemia falciforme. Três são oriundos de focos denominados 'geográficos' - Benin, Senegal, Camarões - cujos grupos populacionais são diferenciados (inclusive culturalmente); $\mathrm{e}$ um coincide com um grupo étnico (Banto).

\section{Afinal, o que é raça e o que é etnia?}

Embora este capítulo não pretenda discutir tais conceitos, não podemos nos furtar a tecer ligeiras considerações sobre eles, pois o que se diz é que raças humanas são, na verdade, variações sobre o mesmo tema: Homo sapiens. Raça, como termo, encerra sempre um significado biológico, embora não possua o fatalismo genético de sexo e não seja uma categoria biológica. A inexistência de raças humanas é uma verdade científica das biociências contemporâneas. As pesquisas da genética demonstram que a espécie humana (Homo sapiens) é uma só; e que, dentro da espécie, a variabilidade genética im- 
põe, como padrão de normalidade da natureza, a realidade de que cada ser humano é geneticamente único. Geneticamente não existem raças humanas. Os saberes da genética molecular dizem que, considerando-se o DNA como o material hereditário e o gene como unidade de análise biológica, é impossivel dizer se estas estruturas pertencem a uma pessoa negra, branca ou amarela. Isso é o óbvio, pois o gene carrega possibilidades de caracteres, e não os caracteres. O conceito dito 'científico' de raça foi construído pela ideologia racista - e a palavra 'raça' e o conteúdo histórico deste conceito referem-se a algo que não existe.

Quanto a etnia e vocábulos correlatos (étnico, etnicidade, grupo étnico), as polêmicas também são inúmeras. São palavras pouco utilizadas fora dos meios acadêmicos brasileiros. Existem resistências a seu emprego. Para muitas pessoas, 'etnia' é uma terminologia que serve para escamotear e encobrir o racismo. É como se, ao se usar a palavra 'etnia', a ideologia racista deixasse de existir. Etnia é uma palavra e, também, um conceito, que incorpora a condição biológica humana sem as gradações de superioridade e inferioridade - hierarquização inerente à 'raça dos racistas' - ao mesmo tempo em que agrega os ambientes físico e cultural, em todas as suas dimensões.

As classificações raciais existem desde Linneu (1738) e nos utilizamos delas nos estudos-embora não haja uma classificação racial 'precisa' e todas sejam arbitrárias e partam da semelhança fenotípica ou genotípica em humanos. Em todas as tentativas de classificação racial, o 'quesito cor' (cor da pele) aparece como característica básica, como critério em si, ou ainda por conta da região geográfica nas quais as pessoas moram.

\section{A condição e a predisposição biológica humana}

Considerar a predisposição biológica não é o mesmo que compreender que somente a condição biológica com a qual alguém nasce define tudo o que este alguém será biológica (fatalismo genético) e socialmente. No entanto, é essencial que façamos uma reflexão elementar, mas necessária. Se isolarmos o ser humano da sua condição biológica, com certeza, não estaremos nos referindo ao 'ser humano', pois somos 'seres biológicos'. Se o isolarmos da sua cultura (hábitos e costumes), e considerarmos apenas a condição biológica, não estaremos tratando do ser humano, mas de um outro animal, já que o 'ser humano' é 'Homo' pela condição biológica e 'sapiens' pelas interferências culturais.

No momento, considera-se a existência de uma base genética que predispõe para doenças como diabetes, febre reumática, cárie dentária e hipertensão arterial, dentre outras. As pessoas predispostas poderão desenvolverou não tais doenças, dependendo de como se der a interação destas com as condições de vida (favoráveis ou desfavoráveis). Algumas predisposições biológicas aparecem mais em alguns grupos raciais ou étnicos. 
O isolamento geográfico e/ou social, relativo ou absoluto, dos agrupamentos humanos em um dado momento de suas histórias, por largos períodos, criou situações que só permitiram a troca de genes no interior do próprio grupo. Hoje, o isolamento geográfico é quase inexistente, mas persistem os mecanismos sociais de barragens - que, sob a forma de isolamento cultural, racialétnico, religioso ou econômico-dificultam a mestiçagem.

\section{O 'quesito cor' e alguns indicadores da variável raça/etnia}

No Brasil, a classificação adotada atualmente é a da Fundação Instituto Brasileiro de Geografia e Estatística (IBGE), que coleta a cor da pele ('quesito cor') como dado que permite a identificação racial a partir da autoclassificação - a pessoa entrevistada é quem 'escolhe' qual a sua cor dentre cinco itens: preta, parda, branca, amarela e indígena. A junção da população preta com a população parda que possibilita a definição da população negra. A 'cor' amarela identifica povos de origem asiática. Quanto aos indígenas, estão circunscritas diferentes ctnias. Apesar de haver muitos prós e contras nesta metodologia, ela é de muita utilidade. O 'quesito cor' é um dado necessário para o estudo da saúde da população negra em nosso país.

Alguns sinais, condições e doenças aparecem com mais freqüência em um grupo populacional racial ou étnico do que em outros. Como exemplo, podem ser citados a mancha mongólica (mancha arroxeada que aparece na região dorsal/nádegas de crianças negras, orientais e indígenas); a gemelaridade, mais freqüente na raça negra (os percentuais médios são de $1 / 79$ para mulheres negras; $1 / 100$ mulheres brancas e 1/155 orientais) ${ }^{1}$; os miomas (várias pesquisas demonstraram alta incidência em mulheres

\footnotetext{
' Borges-Osório et al. (1993) informam que: "A freqüência de gêmeos monozigóticos mostra pouca freqüência entre as populações, sendo 1/300 nascimentos (3-4/1.000 nascimentos), independentemente da raça e outros fatores (...) A freqüência de gêmeos dizigóticos, por sua vez, é bastante variável, sendo influenciada por diversos fatores como: raça: a freqüência é maior em negróides (16-20/1.000 nascimentos), média nos caucasóides (6-10/1.000 nascimentos) e menor nos orientais (2-4/1.000 nascimentos); idade materna: a freqüência de gêmeos dizigóticos aumenta com a idade até ao redor de 37 anos, quando cai bruscamente (a causa é o aumento de FSH - gonadotrofina - com a idade, o que pode aumentar a tendência à poliovulação); genótipo: há uma predisposição genética para a poliovulação, relacionada com os altos

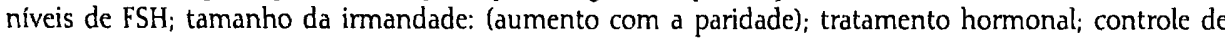
natalidade; aberrações cromossômicas: a freqüência de nascimentos gemelares é mais alta em famílias com indivíduos aneuplóides (síndrome de Down, síndrome de Turner, por exemplo)". Beiguelman (1994) diz sobrc a freqüência de partos gemelares: "A incidência de gêmeos nas populações humanas mostra grandes variações, com valores que vão de 5,9 por mil recém-nascidos vivos no Japão, até 52 por mil nascimentos na Nigéria". Tais variações dependem da frequêencia variável de nascimentos dizigóticos, pois a de monozigóticos é constante (em torno de 3-4/1000). Prossegue Beiguelman: "O nascimento de dizigóticos depende evidentemente, da ocorrência de poliovulação, a qual, por sua vez, depende do nível do hormônio folículo estimulante (FSH) que é mais alto em mulheres negróides e está relacionado ao tamanho da hipófise, cujo peso máximo é atingido aos 40 anos de idade, e, obviamente, à fecundidade".
} 
negras - fazendo com que seja uma das causas mais apontadas para a prática de histerectomia em negras em vários países); e a hipertensão arterial, que, segundo Zago (1994), "é mais freqüente e mais grave em negros que em brancos, pelo menos nos Estados Unidos. Desenvolve-se mais precocemente e a mortalidade é principalmente devida a derrame, muito mais do que à doença coronariana".

\section{O conceito de doenças raciais/étnicas. Um novo paradigma?}

É do reconhecimento da condição e da predisposição biológica que deriva o conceito de doenças raciais/étnicas - assim denominadas as doenças que aparecem mais ou são exclusivas de determinados grupos raciais/étnicos (negros, brancos, amarelos, judeus, ciganos, entre outros) e em mestiços 'recentes' de tais grupos. Podemos falar também em características raciais/étnicas, quando nos referimos às condições biológicas que ocorrem mais em um grupo populacional delimitado por raça/etnia ou nacionalidade.

O conceito de doenças raciais/étnicas tem gerado polêmicas acirradas... e apaixonantes. É o mínimo que poderia se esperar quando da construção de um novo paradigma teórico, segundo a acepção kunhiana (Kuhn, 1970). Mas não podemos esquecer que o conhecimento empírico, ou a verdade científica do 'momento' - em particular no tocante às biociências - possui a singularidade de ser efêmero e relativo (Martins, 1995). É oportuno revisitar o 'atributo da refutabilidade de Popper' e a superação da 'ciência realizada em períodos de normalidade' pelas 'revoluções científicas' (Kuhn, 1970) para compreender a razão de algumas verdades científicas, ou até 'modismos científicos' (que na maioria das vezes necessitam de fundamentação científica) de alguns períodos históricos serem substituídos por outros. À título de ilustração: doenças como a tuberculose, raquitismo, febre reumática, pelagra (deficiência de niacina) já foram consideradas genéticas, hereditárias etc. inclusive como exclusividades raciais/étnicas, à parte da compreensão de interação com as condições materiais e sociais de vida.

\section{A interação das variáveis 'classe', 'sexo/gênero' e 'raça/etnia' na manutenção da saúde e produção das doenças}

Os atuais modelos explicativos de sanidade e enfermidade avalizados pela comunidade científica são limitados e parciais e revelam-se insuficientes:

- modelo genético, muito em 'moda', tenta ser o único e verdadeiro caminho que responderá e desvendará todos os mistérios da vida, ao reduzir o destino das pessoas ao que portam os seus genes, pois deles depende a forma como as proteínas das pessoas são produzidas; 
- modelo econômico, que 'reduz' o destino das pessoas às condições econômicas nas quais elas vivem, de maneira que essa explicação só considera a produção social das doenças;

- modelo ambientalista, que 'reduz' o destino das pessoas às condições do ambiente em que vivem, isto é, o meio ambiente é o determinante da saúde e da doença;

- modelo ecológico, que 'reduz' o destino das pessoas ao estilo de vida que elas adotam, ou seja, a relação delas com o ambiente é o determinante para a sanidade e a enfermidade; - modelo ou 'visão' holística, que baseia-se em uma compreensão integral, de interação entre a condição biológica do ser humano somada ao meio ambiente físico, cultural e social. Apesar da abrangência e da visão de integralidade, algumas correntes do holismo às vezes não compreendem que a desestabilização de uma destas variáveis pode ser suficiente para desencadear ou determinar o processo de doença (por exemplo, em determinadas circuntâncias, basta um problema em um gene, ou parde genes, para que haja uma doença, caso da anemia falciforme). Ou seja, entendem que o 'todo' - a visão de conjunto, a interdependência - sempre sobrepuja as partes (Oliveira, 1997).

Precisamos de novos e mais completos modelos para explicar o processo saúde/ doença, que considerem a condição biológica; as opressões de gênero e racial/étnica; e as condições e locais onde as pessoas vivam. Necessitamos de um novo paradigma, cujo alicerce é o entendimento de que as doenças raciais/étnicas encontram-se no interior da compreensão da interpenetração de 'classe', 'sexo/gênero' e 'raça/etnia'. Aqui, a filosofia poderá elucidar muitas coisas. A memória histórica é pródiga em explicitar que um novo paradigma não se estabelece sem que, de posse de novos dados, nos disponhamos a 'filosofar e filosofar' sobre eles.

\section{A saúde da população negra versus eugenia}

Os estudos sobre a condição biológica e a saúde da população negra, no mundo, aparecem entrelaçados, de alguma forma, à eugenia. Para compreender tal fenômeno, necessitamos 'beber na fonte' da experiência histórica ocorrida nos Estados Unidos e Alemanha. Em território norte-americano, as leis que determinavam a esterilização de "retardados, insanos, sifilíticos, alcoólatras, epilépticos e criminosos" e a Lei de Imigração, de 1924, constituíam uma proposta de higienização da raça daquela sociedade. $\mathrm{Na}$ Alemanha - na época o maior centro da ciência mundial-a eugenia se desenvolveu, desde o começo do século XX, sob o nome de Higiene Racial. O grande destaque aconteceu em 1913, quando Eugene Fischer, professor da Universidade de Freiburg, publicou um grande clássico da eugenia: Os Bastardos de Rehobotheo Problema do Abastardamento do Ser Humano, em cujas páginas explicita as bases ditas 'científicas' para a proibição de casamentos entre pessoas de raças diferentes. Outro clássico é A Ciência da Hereditariedade Humana 
e Higiene Racial, de Erwin Baur, Fritz Lenz e Eugene Fischer. A obra, lida por Hitler na prisão de Landsberg em 1923, foi admitida, em depoimento do ditador, como fonte de aprendizado para a corporificação da tese de que a raça ariana seria pura e superior.

Uma contribuição teórica importante para os racistas foi o livro O Crime, suas Causase Remédios, de Cesare Lombroso (1836-1909), criador da antropologia criminal e da tese da hereditariedade do comportamento criminal: a biotipologia do criminoso nato e irrecuperável (determinismo genético para o crime). Outra obra fundamental para a eugenia foi Ensaio sobre a Desigualdade das Raças Humanas (1853), do Conde Joseph-Arthur de Gobineau (1816-1882), francês que atuou como diplomata no Brasil.

Breve revisão em bibliografia brasileira evidencia que os discursos de escravagistas e abolicionistas estavam impregnados da perspectiva evolucionista, derivada do darwinismo social: sua maior esperança consistia em 'redimir' o povo brasileiro por via do embranquecimento e do fim da mestiçagem (Skidmore, 1987; Schwarcz, 1993).

Tais idéias foram desenvolvidas por médicos e advogados nos principais centros culturais da época: Rio de Janeiro, Bahia e Pernambuco. As opiniões eugenistas, na Bahia, fundem-se ao desenvolvimento da medicina legal, coordenado pelo médico e sociólogo maranhense Nina Rodrigues (1862-1906). No Rio, o movimento surgiu como uma decorrência 'natural' das idéias higienistas, contando com o apoio de renomados médicos, destacando-se os psiquiatras. Miguel Couto (1865-1934) foi um entusiasta de primeira hora desse movimento. Em Recife, com o apoio de advogados e de professores da Faculdade de Direito, nasceu outro pólo. Célebres figuras dos mundos literário e jurídico e das ciências sociais e biológicas concordavam que a mestiçagem levava à 'degeneração da raça' e era um entrave ao desenvolvimento do País (Schwarcz, 1993).

O modelo higienista adotado aqui, tal como o europeu, baseava-se na moralidade sanitária e em uma proposta de educação em saúde alicerçada no 'patrulhamento sanitário' dos 'desregrados' por meio de uma política de saúde disciplinadora das condições de vida - sobretudo da moradia - dos pobres nos centros urbanos (Bizzo, 1994; Marques, 1994). A 'ciência eugênica' e a moralidade higienista consolidaram-se nos meios universitários brasileiros pelos trabalhos de Erasmo Braga, Horácio de Carvalhoe João Ribeiro (Faculdade de Medicina do Rio de Janeiro). Alexandre Tepedino, em 1914, e Clodoaldo de Magalhães Avelino, em 1924 apresentaram, respectivamente, as teses Eugenia e Eugenia e Casamento à Faculdade de Medicina da Bahia.

Em 1923, foi fundada a Liga Brasileira de Higiene Mental (LBHM) no Rio de Janeiro, pelo psiquiatra Gustavo Riedel. Estes profissionais estavam convencidos de que a degradação moral e social dos povos advinha dos vícios, da ociosidade e da miscigenação racial. Isto explica por que os psiquiatras passaram a cuidar da higiene do povo e a ter como centro de seu trabalho a preocupação com a 'constituição étnica do povo brasileiro'. Cabe ressaltar o cunho racista de uma articulação higienista/eugenista estabelecida entre a Liga Pró-Saneamento (fundada em 1917, em 
São Paulo) e a Sociedade Eugênica de São Paulo (fundada em 15 de janeiro de 1918), cuja 'preocupação higienizadora' estava apoiada no tripé saneamento-eugenia-civilização como condição indispensável para construir uma nação desenvolvida e livre de 'raças inferiores' (Marques, 1994).

Em 1929, o médico Renato Kelh (fundador da Sociedade Eugênica de São Paulo e da Comissão Brasileira de Eugenia, Rio, 1931), no Boletim Eugenia, divulgava os feitos eugênicos nos países ricos; condenava a mestiçagem por considerá-la uma degeneração das melhores raças e se posicionava contra os casamentos inter-raciais (Oliveira, 1995).

Os estudos sobre a saúde da população negra no Brasil, até meados da década de 60, não existem fora da preocupação de extermínio de uma 'raça impura e inferior'. Costa (1989), em pesquisa realizada sobre a saúde dos negros na época da escravidão, concluiu que as altas taxas de morbidade e de mortalidade daquela população deviase à precariedade de suas condições de vida. Sem dúvida, apesar da seriedade, do brilhantismo e do resgate de dados que constituem uma grande contribuição teórica, esta é uma visão em que só se consideram as relações sociais de produção (classe). O estudo, ao abordar a medicina popular dos negros, demonstra, ainda, que aquela população (exceção feita aos saberes africanos) não tinha a quem recorrer para o tratamento de suas doenças.

Os dados obtidos por Costa constituem-se em informação reveladora de uma situação importante: a medicina brasileira não tem muita experiência em saúde da população negra, pois somentc há aproximadamente 50 anos dedica-se a cuidar dos negros doentes. Até hoje, o acesso destas pessoas aos serviços médicos de boa qualidade é dificultado; além disso, as pesquisas com recorte racial são escassas. Deve-se reconhecer que, se não levarmos em consideração as repercussões da vivência estressante do racismo - ainda que 'cordial', 'sutil', ou 'camuflado'... - na saúde física e mental das pessoas, não resgataremos a incomensurável dívida da medicina ocidental para com povos/etnias discriminadas.

\section{Estudos atuais sobre a saúde da população negra}

Revisão bibliográfica feita por Souza (1995) enfatiza, no Brasil, os trabalhos desenvolvidos no NEPO/UnICAMP por Berquó, Bercovich e Tamburo/Cunha; e por Morell e Silva (1989). Na área de aleitamento materno, dados interessantes são encontrados em Réa (1990) e Mota (1990). As pesquisas citadas constituem referências indispensáveis para o estudo da saúde da população negra brasileira. 
Merecem destaque as conclusões do Documento Final da Mesa Redonda sobre a Saúde da População Negra (Ministério da Saúde, 1996):

A população negra brasileira é muito particular do ponto de vista genético. Não corresponde a nenhuma outra população de qualquer parte do mundo (...) Os dados históricos são bem conhecidos; estudos demonstram que essas diferenças, quanto a seus aspectos biológicos, persistem até hoje (...). Como consequuência, a população negra brasileira é única do ponto de vista genético. Da perspectiva médica, isso significa que o conhecimento a respeito de todos os aspectos biológicos ligados às etnias negras, incluindo as doenças, podem ter no Brasil características próprias; particularmente as doenças podem ter comportamentos diversos daqueles observados, quer na África, quer em outros países da América ou da Europa (...). Até hoje os estudos que analisam as populações afro-brasileiras são muito escassos (...).

Neste documento, publicou-se um quadro, proposto por Zago (1996) sobre as nosologias das populações afro-brasileiras:

\section{Quadro 1 - Nosologias das populaçóes afro-brasileiras}

\begin{tabular}{|c|c|}
\hline $\begin{array}{l}\text { Condições geneticamente } \\
\text { determinadas, dependentes de elevada } \\
\text { freqüência de gene(s) responsável pela } \\
\text { doença ou a ela associada }\end{array}$ & $\begin{array}{l}\text { Anemia falciforme } \\
\text { Hipertensāo arterial } \\
\text { Diabete melito } \\
\text { Deficiência de glicose-6-fosfato desidrogenase }\end{array}$ \\
\hline $\begin{array}{l}\text { Condições adquiridas, derivadas de } \\
\text { condições sócio-econômicas e } \\
\text { educacionais desfavoráveis e intensa } \\
\text { pressão social }\end{array}$ & $\begin{array}{l}\text { Alcoolismo } \\
\text { Toxicomania } \\
\text { Desnutrição } \\
\text { Mortalidade infantil elevada } \\
\text { Abortos sépticos } \\
\text { Anemia ferropriva } \\
\text { DST/AIDS } \\
\text { Doenças do trabalho } \\
\text { Transtornos mentais }\end{array}$ \\
\hline $\begin{array}{l}\text { Doenças cuja evolução é agravada } \\
\text { ou o tratamento é dificultado pelas } \\
\text { condições ambientais indicadas }\end{array}$ & $\begin{array}{l}\text { Hipertensão arterial } \\
\text { Diabete melito } \\
\text { Coronariopatias } \\
\text { Insuficiência renal crônica } \\
\text { Cânceres } \\
\text { Miomas }\end{array}$ \\
\hline $\begin{array}{l}\text { Condições fisiológicas que sofrem } \\
\text { interferência das condições ambientais } \\
\text { citadas, contribuindo para sua evolução } \\
\text { para doenças }\end{array}$ & $\begin{array}{l}\text { Crescimento } \\
\text { Gravidez } \\
\text { Parto } \\
\text { Envelhecimento }\end{array}$ \\
\hline
\end{tabular}

Fonte: ZAGO, 1996. 
Vários países têm realizado estudos sobre a saúde da população negra, em especial sobre anemia falciforme-inegavelmente, os Estados Unidos são o país que mais tem produzido neste setor, conforme várias citações neste capítulo.

\section{Principais doenças com interfaces definidas com a saúde reprodutiva da mulher negra}

Diabetes tipo II, miomas, hipertensão arterial e anemia falciforme são doenças nas quais os dados empíricos são suficientes para demonstrar o recorte racial/étnico relativo à população negra. Neste capítulo, a abordagem sobre anemia falciforme será mais detalhada pelo fato de a doença ter sido objeto de elaboração, em outubro de 1996, de um trabalho específico por parte do Ministério da Saúde, o Programa de Anemia Falciforme. Além disso, constitui um problema de saúde pública que não tem recebido a merecida atenção por parte de governantes, profissionais da saúde e do aparelho formador da área - ao contrário de outras doenças (mesmo quando os profissionais não reconhecem o recorte racial/étnico, mas acabam por saber lidar com elas), o que acontece com a anemia falciforme é quase um total desconhecimento - o que tem impedido e/ou dificultado o diagnóstico e a aplicação do tratamento adequado.

- Diabetes tipo II

Atualmente sabemos que sob o rótulo de diabetes estão agrupadas várias doenças crônicas, de fundo genético multifatorial. A sindrome diabética compreende: diabetes tipo I (infanto-juvenil/insulino-dependente-DMID), prevalente em brancos; diabetes tipo Il (ou adulta/não-insulino-dependente-DMNID), que prevalece em negros; e os tipos caracterizados pelo aparecimento ocasional, diabetes gestacional, e diabetes secundária a várias doenças. Encontramos, ainda, duas situações definidas como de 'risco potencial à diabetes': tolerância à glicose diminuída e a anormalidade potencial da tolerância à glicose (Dornbrand et al., 1990).

- Miomas

Os miomas são os tumores uterinos mais comuns - atingem 20\% das mulheres entre a primeira menstruação e a menopausa. Em geral são 'silenciosos'; não apresentam sintomas; são benignos (menos de $1 \%$ se torna maligno); têm crescimento lento; $\mathrm{e}$ a maioria diminui de tamanho, naturalmente, após a menopausa.

A pesquisa de Souza (1995) demonstra a alta incidência e reincidência de miomas em mulheres negras brasileiras, e revela que a proporção de histerectomias nas negras foi quase cinco vezes superior às brancas. A literatura médica norte-americana afirma 
que a prevalência de miomas em negras é cinco vezes maior do que em brancas e duas vezes superior em brancas judias do leste europeu do que nas demais mulheres brancas (Lauersen \& Whitney, 1990).

\section{- Hipertensão arterial}

Estima-se que de 10 a $20 \%$ das pessoas adultas sejam hipertensas. A hipertensão arterial é a principal causa de insuficiência cardíaca e renal; de morte súbita; e está ligada, direta ou indiretamente, a 12 a 14\% das causas de todas as mortes no Brasil.

Estudos da década de 60, realizados pelos pesquisadores japoneses Okamoto e Aoki com ratos de linhagem SHR (spontaneous hipertensive rats/ratos com hipertensão espontâneaque desenvolvem hipertensão arterial semelhante à humana entre três ou quatro meses de vida), demonstraram que uma alteração genética pode ser responsável pela hipertensão arterial essencial e que, como no caso de humanos, os ratos não nascem hipertensos, mas desenvolvem a hipertensão ao atingirem certa maturidade (Krieger \& Krieger, 1994).

Em geral, a pressão arterial é mais alta nos homens e prevalente em negros de ambos os sexos.

Na população negra, aparece mais cedo, é mais grave e tende a ser mais complicada. "Na faixa de idade entre 19 e 76 anos, ocorre em 9-16\% nos indivíduos de raça branca e 22-30\% na raça negra" (Penna, s. d.). A hipertensão é duas vezes mais incidente em diabéticos do que na população em geral. Segundo Araújo (1994):

Os dados da Secretaria Municipal de Saúde de São Paulo, que se referem à demanda do Sistema de Saúde, pesquisados através de queixa da população, revelam que na parcela da população negra atendida com queixa de doenças cardiovasculares, a hipertensão alcança nas mulheres negras um índice de $9,2 \%$ superior ao apresentado pelas pardas e brancas.

Uma em cada dez mulheres que engravidam pela primeira vez tem hipertensão. A doença durante a gestação e a morte materna por toxemia gravídica (eclâmpsia/hipertensão) são as principais causas de mortalidade materna no Brasil. Tal situação nos obriga a analisar a cobertura e a qualidade da assistência pré-natal, ocasião privilegiada para a descoberta do risco gestacional. Estimativas nacionais indicam que 50\% das mulheres de baixa renda não recebem a cobertura pré-natal necessária. Levantamentos da Secretaria Municipal de Saúde de São Paulo, após a implantação do quesito cor, revelam que as negras têm menor acesso ao pré-natal. Quando o fazem, começam em geral mais tarde do que as brancas.

Martins et al. (1994), ao analisarem dados coletados pelo Comitê de Mortalidade Materna do Paraná, em 1993 - onde o quesito cor foi preenchido de acordo com a classificação do IBGE, mas não atendeu ao critério da autoclassificação, pois quem designou a cor foi o(a) investigador(a) ou o(a) profissional de saúde que atendeu a cliente-, constataram que $26,36 \%$ dos óbitos ocorreram em mulheres negras ( $90 \%$ situadas 
na faixa de renda familiar de até dois salários mínimos; e 85\%com até quatro anos de estudo). Esta pesquisa, entre outras conclusões, evidenciou que a principal causa de mortalidade materna naquele estado em 1993 foi a Doença Hipertensiva Específica da Gravidez/ Eclâmpsia (DHEG). O resultado não difere de outros estudos realizados no restante do País. A novidade consiste em ter trazido à tona dois fatos importantes: $50 \%$ dos óbitos de mulheres ncgras ocorreram por eclâmpsia e 26,36\% da totalidade dos óbitos foram de mulheres negras. Estes sãodados relevantes, pois, conforme a Pesquisa Nacional de Amostra de Domicílio (PNAD) de 1989, o percentual da população negra no Paranáé de apenas 23,73\%. Temos, então, duas cvidências: a DHEG atingiu mais as mulheres negras do que as brancas e mortalidade materna geral nas negras foi maior do que nos demais grupos raciais.

\section{- Anemia falciforme}

As anemias hereditárias são as doenças genéticas mais comuns da humanidade. A anemia falciforme, por sua vez, é uma anemia hereditária e constitui-se na doença genética mais comum da população negra em todo o mundo. Resulta de uma mutação na molécula de hemoglobina que altera a sua estrutura pela substituição do aminoácido 'ácido glutâmico' pela 'valina', ' o que confere à hemoglobina S, quando desoxigenada, a capacidade de se agregar, formando fibras de hemoglobina $S$ que deformam a hemácia, conferindo-lhe $\mathrm{o}$ aspecto de meia lua ou de foice (o que dá origem ao nome anemia falciforme). A doença também é conhecida como 'drepanocitose' ou 'siclemia' (do inglês sickling, falciforme; derivado de sickle, foice; siclemia).

Exemplo clássico da seleção natural de Darwin/Wallace, a anemia falciforme surgiu na África, em zonas endêmicas de malária, chegando ao Brasil e a toda a América via tráfico de escravos. Trata-se de uma resposta da natureza, que preservou a espécie humana no habitat malárico-pois pessoas com anemia falciforme não desenvolvem aquela doença. A explicação de tal fenômeno é que o Plasmodium consome oxigênio em grande quantidade e, na medida em que solicita mais oxigênio, a hemácia assume a forma de foice. Ao adquirir esta forma, é destruída pelos lcucócitos, o que destrói, também, os parasitas da malária. Afirma-se que mesmo o(a) portador(a) do traço falciforme não adquire a malária pelo fato de possuir parte de suas hemácias com hemoglobina $\mathrm{S}$ (cerca de 22 a 45\% da hemoglobina total). Estas, nas condições de desoxigenação impostas pelo Plasmodium, sofrem falcização - condição letal para o parasita.

As mutações gênicas na hemoglobina são originárias de focos geográficos distintos, todos de zonas endêmicas de malária, que determinam diferentes tipos de hemoglobinopatias hereditárias. Existem quatro focos africanos definidores da anemia falciforme: o da região do Senegal; do Benin; de Camarões; e o foco do grupo étnico

${ }^{2}$ Hemoglobina A ou HbA: hemoglobina normal; Hemoglobina S ou HbS: hemoglobina siclêmica ou falciforme. 
Banto $^{3}$. O foco de hemoglobinopatias hereditárias da Ásia origina as anemias hereditárias denominadas talassemias ou anemia do Mediterrâneo - cuja alteração ocorre na síntese da hemoglobina - e que incide sobre populações da Sardenha (Itália, Chipre e Grécia); e orientais, sobretudo na Tailândia, Laos, Camboja, Malásia, algumas regiões da Índia e sudeste da China. ${ }^{4} \mathrm{Na}$ Índia também existem síndromes falciformes (Zago, 1996).

\section{Variedades da doença}

A anemia falciforme é uma descoberta da 'velha genética' (ou 'genética clássica'). Foi a primeira doença molecular humana a ser descoberta (pelo médico James Herrick, em 1910, Chicago, no sangue de um estudante de medicina negro nascido nas Antilhas).

Por meio de técnicas de DNA, a anemia falciforme é classificada, conforme o foco original, em cinco tipos: Senegal (de média gravidade); Benin (de pouca gravidade); Banto (o mais grave); e Camarões e Árabe-indiano (ambos de forma clínica dita 'benigna'). No Brasil, predomina a do tipo Banto (70\%). A explicaçãoé elementar: a prevalência deste grupo étnico na formação de nossa população. Apenas 1\% dos diagnósticos em nosso país é do tipo Senegal.

As duas principais formas clínicas da síndrome falciforme são: doença falciforme ou anemia falciforme - pessoa com dois genes para anemia falciforme, um originário da mãe e outro do pai (HbS/HbS); e traço falciforme - pessoa com um gene para a doença, herdado ou do pai ou da mãe (HbS/HbA).

Outras formas clínicas de anemia hereditária integram o rol das síndromes falciformes ou doenças das células falciformes, conceitualmente explicadas pela presença de dois genes anormais para a hemoglobina, sendo um deles um gene para hemoglobina S. Isto quer dizer que são síndromes resultantes da associação da célula

\footnotetext{
${ }^{3}$ Banto - são povos da região da República Centro Africana e povoam sobretudo a África do Sul, Ruanda, Moçambique, Botswana, Congo e Angola. Benin - originários da Costa Oeste da África: Benim, Gana, Nigéria, Togo e Costa do Marfim. Senegal - do Senegal, Serra Leoa e Gâmbia.

4 Talassemia (do grego: thalassa: mar; c hemos: sangue). Também conhecida por anemia de Cooley, ou mcditerrânea, por causa da alta incidência $\mathrm{em}$ pessoas da região do Mediterrâneo: turcos, gregos e italianos. As taxas de incidências são altas também na Índia e Oriente Médio. Atualmente, cura-se a doença com enxerto de medula óssea logo após o nascimento. O defeito genético que origina a talassemia em geral não ocorre na estrutura da hemoglobina (como na anemia falciforme), mas sim na sintese das cadeias de globina. Por esta razão, o enxerto 'funciona', curando a doença. As talassemias consistem em mutações na sintese das cadeias da globina (alfa ou beta), e classificam-se em alfatalassemias e beta-talassemias, de acordo com o local da mutação. As síndromes talassêmicas são constituídas pelas alfa e beta-talassemias, além da delta-beta-talassemias e talassemias interativas. Alfa-talassemias ocorrem populações asiáticas e negróides e as beta-talassemias no Mediterrâneo, Índia, Oriente Médio, regiões maláricas da África e países que receberam migrantes de tais regiões.
} 
falciforme com outras mutações da hemoglobina (uma vez que existem centenas de hemoglobinopatias estruturais e dezenas de hemoglobinopatias de alteração de síntese da hemoglobina).

No Brasil, as síndromes falciformes mais comuns são a associação da hemoglobinopatia $\mathrm{S}$ com a hemoglobinopatia $\mathrm{C}$, resultando na doença SC e a associação da hemoglobinopatia S com talassemia, S-talassemia - ST. Também é freqüente a associação de hemoglobinopatia C com talassemia, C-talassemia-CT. Pessoas com anemia falciforme apresentam maior suscetibilidade às infecções fatais, especialmente na primeira infância, e podem até morrer, se não recebem cuidados adequados.

A sintomatologia da anemia falciforme é variável. No entanto, o que chama mais atenção é a anemia hemolítica crônica, ocasionada pelas crises freqüentes de falcização - devidas a "aglomerações de células falciformes, obstrução vasculare infartos dolorosos em vários tecidos como ossos, baço, pulmões" (Borges-Osório et al., 1993).

Existem controvérsias sobre a morbidade do traço falciforme. Sabemos que podem ocorrer complicações (às vezes letais) durante anestesia geral, infecção grave, esforço físico excessivo, desidratação, vôo em aviões sem pressurização, em episódios de acidose... Muitos autores fazem referências à associação de traço falciforme a docnças ósteo-articulares, renais (hipostenúria, hematúria), cardíacas (alterações eletrocardiográficas, sobrecarga do ventrículo esquerdo) e neurológicas (Ramalho, 1978). Também não devem ser esquecidos os chamados 'riscos reprodutivos' (Teixeira, 1993) em casamento entre duas pessoas heterozigotas; e as conseqüências de transfusões de sangue que contenha hemoglobina $S$, como reação hemolítica, morte em exsangüíneo-transfusão (Silva, 1995).

\section{Incidência}

Estimativa citada por Wilkie (1994) diz que, segundo a Organização Mundial da Saúde (OMS), em 1983 havia no mundo 242 milhões de portadores de uma cópia de um gene para anemia falciforme ou talassemia; que nascem na África aproximadamente 100 mil crianças falcêmicas/ano; nos EUA, 1.500/ano (1 para cada 400 negros); no Caribe, 700/ano e no Reino Unido, 140/ano; no Brasil, aproximadamente 2.500/ano. Ou seja, um em cada mil nascidos -vivos. Em cada mil nascidos-vivos, 30 são portadores do traço falciforme. Triagens de gestantes no pré-natal demostraram que, em cada mil, 30 são portadoras do traço falcêmico.

\footnotetext{
${ }^{5}$ Hemoglobina S - mutação resultante da substituição do aminoácido ácido glutâmico pela valina na cadeia beta da globina. Ocorrência: África Equatorial e países que receberam escravos destas regiões; Mediterrânio e Índia. Hemoglobina C - mutação resultante da substituição do aminoácido ácido glutâmico pela lisina na cadeia beta da globina. Ocorre nas mesmas regiões da HbS e África Equatorial.
} 
De acordo com Zago (1996), estimativas do mesmo ano atestam que nascem no Brasil, anualmente, de 700 a mil pessoas com doenças falciformes, e que devem existir aproximadamente oito mil pessoas falcêmicas (com dois genes para anemia falciforme) e, pelo menos, dois milhões de portadores de um gene da doença. A prevalência de heterozigotos (portadores de um gene) é de $2 \%$ na população geral e salta para 6-12\% entre negros.

\section{Pontuando algumas constataçôes, conclusōes, saídas e impasses}

Embora não tenham sido abordados aqui assuntos importantes para a saúde reprodutiva das mulheres em geral, como a anticoncepção, as Doenças Sexualmente Transmissíveis e a infertilidade, consideramos necessário alertar a respeito da anticoncepção em mulheres hipertensas, diabéticas, falcêmicas e com miomas, pois existem muitas dúvidas e controvérsias sobre o uso de métodos hormonais e do DIU nestas condições. O que parece mais prudente do ponto de vista científico e ético é que, na dúvida, tais pessoas não devam ser submetidas ao uso de método sobre o qual paire qualquer dúvida de risco para a sua saúde e a sua vida.

O abortamento espontâneo é freqüente entre mulheres portadoras de diabetes, miomas submucosos e anemia falciforme ${ }^{6}$. O mesmo acontece com a prematuridade dos partos. A perda fetal decorrente da anemia falciforme varia de $24 \%$ a $50 \%$ nos Estados Unidos; $48 \%$ no Brasil; $30 \%$ na Jamaica e $31 \%$ na Nigéria.

A mortalidade materna, em nosso País, tem como a principal causa a toxemia, uma decorrência de hipertensão arterial na gravidez (Costa, 1992). Se as mulheres negras são mais propensas a esta doença, é muito provável, portanto, que sejam as mais acometidas por toxemia e as que mais morram tendo como causa subjacente a hipertensão arterial na gravidez. Como os atestados de óbito, até 1996, não traziam o 'quesito cor' ${ }^{7}$, não podemos comprovar tal hipótese com base em dados anteriores àquele ano.

\footnotetext{
- Etiologia do abortamento espontâneo: 50\%-60\% - anomalias do embrião; $15 \%$ - afecções maternas: trauma, infecções, deficiência dietética, diabetes; hipotiroidismo e malformações anatômicas; 25\%-35\% - causa indeterminada. (PenNa, s/d).

${ }^{7}$ Decreto do Ministério da Saúde, de março de 1996, dispõe sobre a padronização de informações sobre raça e cor dos cidadãos brasileiros e estrangeiros residentes no país. Art. 32. "Os documentos civis e militares que terão a inclusão obrigatória do quesito raça/cor, com seus desdobramentos são: declaração de nascido-vivo; certidão de nascimento; carteira de identificação civil e militar; autorização de internação hospitalar (AIH); prontuário médico; certidão de casamento; certidão de reservista; título eleitoral; boletim de ocorrência policial; declaração de óbito; certidão de óbito". Extraído do Relatório de Atuação do Grupo de Trabalho Interministerial para Valorização da População Negra (GTI).
} 
Pessoas falcêmicas - em qualquer idade - são suscetíveis às infecções. Em geral, esta é a sua causa mortis. As mulheres falcêmicas podem ser acometidas por infecções variadas no período gravídico, sobretudo pielonefrites e pneumonias, o que poderá aumentar substancialmente o número de mortes por septicemia. A mortalidade materna, entre elas, parece ser maior do que entre as não-portadoras (Zago, 1994).

Diferentes estudos, no Brasil e no exterior, demonstram sobejamente que o desenvolvimento pôndero-estatural, a maturação sexual e a saúde sexual e reprodutiva de pessoas portadoras de anemia falciforme sofrem interferências significativas, conforme a gravidade das manifestações clínicas da doença. Destacam, ainda, que nos homens as crises de falcização duradouras e freqüentes podem causar priapismo, condição que poderá resultar em impotência sexual temporária ou definitiva.

Hutz \& Salzano (1981), em pesquisa com 209 mulheres falcêmicas da cidade do Rio de Janeiro, concluíram que em termos de número médio de filhos nascidos-vivos elas apresentavam desvantagem reprodutiva em relação às não-portadoras, pois

117 (56\%) encontravam-se no periodo reprodutivo, apenas 21 tinham tido pelo menos 1 filho vivo. A média de filhos vivos foi de (1,7 mais ou menos), o que demonstra um grau de subfertilidade ao observado em outras populações. Verificou-se nesta amostra uma taxa de perda fetal de $48 \%$, devido principalmente aos abortos espontâneos que foi de $31 \%$. O número médio de filhos nascidos vivos das mulheres falcêmicas que têm mais de 40 anos é de apenas 0,6, enquanto que na população geral é de 3,4 filhos.

Análise de Berquó (1995) considera que, embora Hutz e Salzano tenham trabalhado com uma amostra de sobreviventes e a expectativa de vida da falcêmica é mais baixa, estes achados registram a necessidade de pesquisas de tipo follow-up.

A discriminação contra as mulheres na ciência e nos serviços de saúde tem sido muito pesquisada nos últimos anos e está documentada o bastante para que não haja mais dúvida quanto a esta realidade (Keller, 1991). No entanto, pelo menos no Brasil, a discriminação racial nos serviços de saúde precisa ser mais estudada. Fala-se muito na sua existência, e, embora existam muitas evidências de que realmente aconteça, não há 'provas documentais'.

Para atender condignamente à mulher negra na área de saúde reprodutiva é necessário que profissionais da saúde e instituições de pesquisa e prestadoras de serviços conheçam, dominem e tenham como da mais alta relevância as condições e especificidades por ela vivenciadas -inclusive a desigualdade perante a morte, como tão bem chama a atenção Cunha (1995):

No caso de mortalidade adulta feminina constatou-se que a probabilidade de sobreviver de mulheres entre 25 e 75 anos, classificadas como brancas, são sistematicamente maiores do que a das mulheres negras (...). Em menores niveis de mortalidade adulta feminina, maiores perdas são constatadas entre as mulheres negras. 


\section{Eis um indicador de alerta!}

Em geral, credita-se a morbidade e a mortalidade alta e precoce entre os negros no Brasil apenas às péssimas condições de vida. Esta visão, hegemônica entre profissionais da saúde, é uma abstração, pois prescinde da análise da condição humana como também um fato biológico - e, como tal, regido também por leis biológicas. Ou seja, a postura simplista e economicista de que negros padecem mais e precocemente de algumas doenças e de que morrem mais e 'antes do tempo' tão-somente porque são pobres é parcial e insustentável. Em diferentes estudos, demonstrou-se que ser pobre e negra determina prognóstico desfavorável em quase todas as enfermidades, a começar pela dificuldade de acesso aos serviços de saúde. Faltam pesquisas no Brasil sobre o papel desempenhado pela anemia falciforme na morbi-mortalidade infantil e adulta e pelos miomas, hipertensão e diabetes no abortamento, taxa de natimortos e infertilidade.

Para mudar o cenário da ausência de diagnóstico, e conseqüentemente da falta de dados e da alta taxa de morbi-mortalidade, urge sensibilizar clínicos(as), pediatras, ginecologistas e obstetras (estamos falando de profissionais comuns, do atendimento básico e cotidiano da medicina, nada de superespecialistas) e o aparelho formador na área de saúde (sobretudo medicina e enfermagem) para a essencialidade da compreensão da singularidade do "recorte racial/étnico" para o ensino, a pesquisa biomédica e a prática da medicina.

Os impasses dizem respeito à definição de projetos para o futuro, aos rumos que imprimiremos ao debate e à luta para que, efetivamente, tenhamos no Brasil serviços públicos de saúde de boa qualidade para todas as pessoas. Fora de um modelo assistencial que tenha como pilares a justiça, a eqüidade e o acesso universal, qualquer política pública de saúde, de ciência e de tecnologia que pretenda conferir maiores oportunidades de vida com dignidade e autonomia para populações tradicionalmente alijadas dos direitos de cidadania social e política será inviabilizada.

\section{Referências Bibliográficas}

Araújo, M. J. As reflexões no movimento feminista. Cadernos de Pesquisa Cebrap, 2: 49-55, 1994. AzEvEDO, E. Raça: conceito e preconceito. São Paulo: Ática, 1990.

Azevedo, E. Raça é uma categoria biológica? Cadernos de Pesquisa CeBrap, 2: 27-32, 1994.

Begueluan, B. Dinâmica dos Genes nas Famílias enas Populações. São Paulo: Sociedade Brasileira de Genética, 1994.

BerCONCH, A. Fecundidade da mulher negra: constatações e questões. Texros NEPO, 11:47$102,1987$. 
BERQUÓ, E. Demografia da desigualdadc - algumas considerações sobre os negros no Brasil. Novos Estudos CEBRAP 21:74-84, 1980.

BERQuó, E. Nupcialidade da população negra no Brasil. TEXTos NEPO: 11:08-43, 1987.

Berquó, E.; Berconch, A. \& Garcia, M. E. Estudo da Dinâmica da População Negra no Brasil. TEXTOS NEPO: 11:08-43, 1987.

Bızzo, N. M. V. Meninos do Brasil: idéias sobre reprodução, eugenia e cidadania na escola. 1994. Tese de Mestrado. São Paulo: Faculdade de Educação da Universidade de São Paulo.

CosTA, A. M. PAISM: uma políitca de assistência integral à saúde da mulher a ser resgalada. São Paulo: Comissão de Cidadania e Reprodução, 1992.

Costa, E. V. Da Senzalaà Colônia. São Paulo: Brasiliense, 1989.

CunHa, E. M. G. de P. O Quadro da Discriminação Racial da Mortalidade Adulta Feminina no Brasil. VII Encontro Nacional de Estudos Populacionais. AsSOCIAÇÃO BRASILERADE ESTUDOS POPULACIONAIS (ABEP) 3: 387-406, 1990.

CUnHa, E. M. G. de P. Raça: um aspecto esquecido da ineqüidade na saúde no Brasil. Paper apresentado no III Congresso Brasileiro e II Congresso Ibero Americano e I Congresso Latino-americano de Epidemiologia, no painel: Gênero e raça em epidemiologia: uma articulação necessária na busca da cqüidade em saúde, Salvador, 25 a 28 de abril de 1995.

DoRnBRAND, L. et al. Manual de Medicina Ambulatorial. Rio de Janeiro: Medsi Editora Médica e Científica Ltda.,1990.

Hutz, M. \& SAIZANO, F. Fecundidade em uma amostra brasileira de mulheres com anemia falciforme. Revista da Associação Médica Brasileira, 29 (3-4), 1983.

KeuER, E. F. Reflexiones sobre Género y Ciencia. Espanha: Edicions Alfons el Magnànim/Instituició Valenciana D'Estudis y Investigació, 1991.

KuHn, T. S. A Estrutura das Revoluções Cienlificas. São Paulo: Perspectiva, 1994.

KRIEGER, J. E. \& KRIEGER, E. M. Hipertensão Arterial. Ciência Hoje 18(103): 76-79, 1994.

LAUERSEN, N. \&WHITNEY, S. O Corpo da Mulher. São Paulo: Abril S.A., 1990.

MARQues, V. R. B. A Medicalizaçãoda Raça: médicos, educadores ediscurso eugênico. Campinas: Editora da UNICAMP, 1994.

MARTINS, A. L. \&CORRÉA, A. M. Moralidade Malerna nas Mulheres Negrasno Estadodo Paraná. 1994, 15 p. (Mimeo.)

MARTINS, R. C. Filosofia da Ciência e Feminismo: uma ligação natural? In: SCAVONE, L. (Org.) Tecnologias Reprodutivas: gênero e ciência. São Paulo: Editora UnEsP, 1996, p.15-31. 
MoReLL, M. G. G. \& SIIVA, R. de S. Mortalidade Intra-uterina por Cor: incidência e características. VI Encontro Nacional de Estudos Populacionais. ABEP, Olinda 3:359-392, 1988.

MotA, J. A. C. Ideologia Implícita no Discurso da Amamentação Matema e Estudo Retrospectivo Comparando Crescimento e Morbidade de Lactenles em Uso de Leite Humano L Leite de Vaca, 1990. Tese de Mestrado. Belo Horizonte: Faculdade de Medicina, Universidade Federal de Minas Gerais.

Olveira, F. Os múltiplos significados e implicações do fatalismo genético. Cadermos de Pesquisa CeBrap (2): 15-22, 1994.

OuverRA, F. Engenharia Genética: o sétimo dia da criação. São Paulo: Moderna, 1995.

OLvEtra, F. Sexo/gênero eraça/etnia: uma articulaçãonecessánia na busca da eqüidade em saúde. 1995 (Mimeo) OLveirA, F. Bioélica: uma face da cidadania. São Paulo: Moderna, 1997.

Ouveira, F. Oficinas Mulher Negra e Saúde. Belo Horizonte: Mazza Edições, 1998.

OsÓRo-Borges, M. R. \& RoBinson, W. M. Genética Humana. Porto Alegre: Editora da UniversidadeUFRGS, 1993.

PenNa, D. O. (Coord.) Hipertensão Arterial. In: Guia Prático de Diagnóstico e Tratamento. Compendium Ciba-Gegr, $\mathrm{s} / \mathrm{d}$.

RamalHo, A. S. Estudo médico de polimorfismos genélicos de importância clinica no Brasil, 1978. Tese de Doutorado, Campinas: Faculdade de Ciências Médicas da Unicamp.

RÉA, M. F. Amamentação na População de Raça Negra em São Paulo. VI Encontro Nacional de Estudos Populacionais, ABEP, Olinda (3): 393-412, 1988.

Shwarcz, L. M. O Espetáculo das Raças. São Paulo: Companhia das Letras, 1993.

SkIDMORE, T. E. Preto no Branco. São Paulo: Paz e Terra, 1987.

SiLVA, R. B. de P. Efeitos da orientação genética fornecida a doadores de sangue com traço falciforme: riscose beneficios, 1995. Tese de Doutorado. Campinas: Faculdade de Ciências Médicas da UnICaMP.

SouzA, V.C. de. Mulher Negra e Miomas: uma incursãona área da saúde, raça/etnia, 1995. Dissertação de Mestrado. São Paulo: Programa de Ciências Sociais, PUC.

Tamburo, E. M. Mortalidade Infantil na População Negra Brasileira. Textos Nepo, (11):104$128,1987$.

TEIXEIRA, R. C. Viabilidadee eficiência de um programa de hemoglobinopatias hereditárias em uma comunidade brasileira (Araras, SP) abordada a partirdegestantes, 1993. Tese de Doutorado. Campinas: Instituto de Biologia da Unicamp.

WILKE, T. Projeto Genoma Humano: um conhecimento perigoso. Rio de Janeiro: Jorge Zahar Editor, 1994.

ZAGO, M.A. Seminário Social x Biológico, CEBRAP. São Paulo, janeiro de 1993. 
ZAGO, M. A. Quadro mundial das enfermidades e doenças consideradas genéticas. Cadernos de Pesquisa Cebrap (2): 3-14, 1994.

ZaGo, M. A. Problemas de Saúde das Populações Negras no Brasil. O papel da anemia falciforme e de outras doenças de natureza genética. In: Mesa Redonda sobre a Saúde da População Negra, Brasília, abril de 1996. (Paper) 


\section{3}

\section{Drama da Mulher no Mundo do Trabalho:}

\section{o ser e 0 estar}

Eleonora Menicucci de Oliveira

\section{Introdução}

Este trabalho é parte de uma reflexão elaborada a partir de duas pesquisas realizadas em São Paulo (Brasil) e em Milão (Itália) com trabalhadoras assalariadas, nos anos de 1992, 1994 e 1995. Os estudos tiveram por objetivo-a partir da perspectiva internacional comparada - apontar as convergências e diferenças entre as realidades dos dois países, no que diz respeito aos impactos das condições e da organização social e sexual do trabalho (Dejours, 1988)' na vida sexual e reprodutiva das trabalhadoras.

No Brasil, foram entrevistadas 66 mulheres, de diferentes categorias profissionais. Na Itália, 102, de cinco categorias ${ }^{2}$.

\footnotetext{
' Segundo Dejours, "as condições de trabalho, influenciam o corpo dos trabalhadores, enquanto a organização social do trabalho, faz recair o peso sobre a saúde ou funcionamento mental".

${ }^{2} \mathrm{O}$ que discutimos aqui sobre a relação do trabalho com a vida sexual e reprodutiva das trabalhadoras e assalariadas faz parte da tese de Livre Docência apresentada ao Departamento de Práticas em Saúde Pública da Faculdade de Saúde Pública da USP em novembro de 1996.
} 


\section{A vida reprodutiva e o trabalho}

Existem amplas bibliografias nacional e internacional (com as quais concordo) que consideram o trabalho doméstico não pago como um trabalho-apesarde não produzir bens e serviços vendáveis no mercado. No entanto, deve ser analisado como um conjunto de processos de trabalho combinados que se articulam com o processo de produção e o subsidiam.

É esclarecedor da discriminação de gênero apontaro trabalho doméstico sem remuneração como trabalho, mesmo porque sabe-se que o impacto sobre a saúde provoca morbidades semelhantes entre as trabalhadoras que estão no mercado de trabalho e as que não estão.

Se considerarmos trabalho como característica capaz de transformar permanentemente o meio ambiente e a si mesmo, percebemos que a sua divisão e dos poderes sociais e políticos vividos por homens e mulheres, ao longo do desenvolvimento das sociedades, dentro e fora da casa, foram e são invenções culturais.

De maneira recorrente e variada, as formas de divisão social do trabalho excluem e discriminam a mulher, tendo por base seus atributos biológicos, como os relacionados ao ciclo vital: menstruação, gestação, parto e puerpério, amamentação, climatério e menopausa. No caso específico da gestação, parto e amamentação, consideramos tais eventos como trabalho-ampliando, assim, o significado desta categoria sempre associada a uma força que tem valor de troca, sendo vendida no mercado de trabalho.

Dentro desta ótica, trata-se de um trabalho que despende energia, exige uma especialização, comporta a transformação do corpo e das condições sociais, exige a cooperação e a atividade de uma mulher para levar a termo.

Pensar a mulher como trabalhadora é pensá-la na sua integralidade, como sujeito da produção e da reprodução. A assimetria necessária e relativa aos direitos e às condições de trabalho dos homens e mulheres não pode ser considerada neutra. As mais diversas formas concretas de existência (muitas vezes consideradas invisiveis) edas representações de trabalho e saúde incluem formas de adoecere morrerque só podem sercompreendidas se levadas em consideração as relações de gênero, sempre suscetíveis às transformações culturais.

As palavras das trabalhadoras que participaram dos nossos dois estudos indicam que a escolha da maternidadeé um fator "obstaculizante" para a carreira; e que não é suficiente estar garantida por leis - já que nos dois países existem legislações que "protegem e tutelam" os direitos da mulher-mãe no local do trabalho. ${ }^{3}$ A lei italiana Tutela della maternità

\footnotetext{
${ }^{3}$ A lei italiana 1.204, de 30 de dezembro de 1971, sobre a "tutela della lavoratrice madre", inclui trabalhadoras do serviço público e privado, agricolas e em algumas normativas as trabalhadoras a domicílio e aos serviços familiares. Uniformizou a licença à maternidade (parto, puerpério e aleitamento) e depois do parto, por doença da criança. Durante seis meses a mulher tem garantido o salário integral, que vai gradativamente diminuindo, até completar um ano de licença. A lei brasileira 8.213/91 da Previdência Social está contida no Art. $7^{\circ}$ da Constituição Federal de 1988: - licença à gestante sem prejuízo do emprego e do salário, com a duração de 120 dias; Art. 120 - os planos de Previdência; além de incorporar a reivindicação do movimento feminista da Licença à Paternidade no Art.7- inciso XIX - com as seguintes disposições transitórias : Art. $10, \S 1^{\mathfrak{a}}$ - até que a lei venha disciplinar o disposto no Art. $7^{\circ}$ inciso XIX, o prazo de licença-paternidade é de cinco dias.
} 
nei luoghi di lavoro e os serviços sanitários asseguram os exames diagnósticos para assistência à gravidez e ao parto gratuito. Segundo Pizzini (1996), esta lei parece ser uma das melhores do continente europeu, tanto que, há não muito tempo, discutiu-se sobre a necessidade de algumas limitações em seu conteúdo, para adequá-la ao protocolo da Comunidade Européia. No entanto, uma forte mobilização de protesto das mulheres italianas barrou a tentativa ${ }^{4}$. A legislação brasileira referente à mulher-mãe no local do trabalho encontra-se ameaçada pelas reformas neoliberais que objetivam o ajuste fiscal, mas o que queremos apontar como discussão é a semelhança dos pressupostos que sustentam as duas leis: a noção de tutelagem e proteção. Isto nos remete ao uso do conceito "proteger e tutelar", que pressupõe uma relação assimétrica, em que o 'Outro ou a Outra' é considerado/a incapaz de decidir pela sua própria vida.

Como afirma Todorov (1993), é uma relação não de alteridade, mas de dominação e opressão, em que as singularidades das identidades construídas subjetiva e objetivamente não têm lugar. Ambas as leis não garantem direitos de cidadania; ao contrário, reforçam a linguagem patriarcal e biologicista da gravidez como doença e da mulher como cidadã voltada para a maternidade. Aqui o uso da linguagem de gênero pode explicitar a diferença entre tutelar/proteger e garantir direitos. Algumas das narrativas são exemplares sobre este aspecto.

As mulheres não fazem carreira porque existe um estereótipo masculino segundo o qual as mulheres antes ou depois de entrarem no mercado de trabalho engravidam. (Trabalhadora da área da saúde de Milão).

Assim, a linguagem de gênero reforça a cultura de que a maternidade estrutura negativamente o acesso das mulheres à carreira no mercado de trabalho e é estruturante na discriminação diferenciada entre as mulheres que têm e as que não têm filhos - "os patrões não confiam nas que têm filhos" (trabalhadora brasileira do setor metalúrgico).

\footnotetext{
${ }^{4}$ Os princípios fundamentais desta Lei: 1) proibição desde o início da gravidez e por 7 meses depois do parto de efetuar trabalhos considerados perigosos, fatigosos ou insalubres (elencados na lei, ou solicitados pela gestante) - a trabalhadora pode solicitar a ausência do trabalho noturno por este período; 2) a ausência obrigatória do trabalho pode ser antecipada se a mulher apresentar alguma morbidade ou periculosidade para a gravidez e é retribuída com $80 \%$ do salário; 3 ) a licença obrigatória do trabalho é prevista por 2 meses antes e 3 meses depois do parto, com $80 \%$ do salário - previsto também para trabalhadoras sem contrato fixo de trabalho; 4) no fim da licença obrigatória, a trabalhadora pode ainda pedir para se ausentar do trabalho por seis meses, até o primeiro ano do filho, com $30 \%$ do salário. Também existe o direito de redução do horário de trabalho por duas horas ao dia sobre as 40 horas semanais até o primeiro ano da criança para a amamentação; no fim do terceiro ano de idade da criança. A mãe tem o direito de se licenciar do trabalho quando o filho adoecer, apresentando um atestado médico; 5) é prevista a proibição de demissão da trabalhadora desde o início da gravidez até a criança completar um ano, exceto nos casos de térmico da empresa ou de culpa grave da trabalhadora. Outra lei, n²903, de 9-12-77, prevê a ausência facultativa do pai ao trabalho ou a redução do horário para que possa também cuidar da criança.
} 
Como apontaram Hirata $(1988,1993)$ e Kergoat $(1988,1993)$ em um diálogo com Dejours $(1988,1993)$, a construção da masculinidade e feminilidade no trabalho está diretamente ligada à divisão social de sexo, que dá às atividades desempenhadas pelos homens a representação do perigo e às desempenhadas pelas mulheres, a da fragilidade (unicamente por causa de sua capacidade reprodutiva).

A abordagem de gênero provoca, em primeiro lugar, uma ruptura radical com as explicações que recolocam a questão da saúde apenas nos determinantes biológicos e sociais; em segundo lugar, aponta para a afirmação de que a dimensão sexual das relações trabalho e saúde são construções culturais e sociais; e, em terceiro lugar, indica o reconhecimento de que estas relações repousam sobre uma hierarquia e sobre uma forma de poder entre os sexos, fundadas na divisão sexual do trabalho, que constituem um dos pilares das relações sociais de sexo (Kergoat, 1992).

A formação da subjetividade feminina que se configura a partir de um aprendizado de "menor valor" - e que nega esta condição como uma estratégia defensiva -é considerada por diversos estudos como um obstáculo às ações políticas mais organizadas entre mulhcres no sentido da atenuação da feminilidade como campo de conquista de novos direitos no interior do mundo do trabalho.

Nesse caminho, reforçamos a idéia de Dejours (1988) referente à sobrecarga psíquica das mulheres, como a primeira diferença decorrente da responsabilidade do trabalho doméstico, porque interpela de maneira diferente os homens e as mulheres e cria uma discriminação entre as mulheres que têm filhos e as que não os têm.

\section{A vergonha de estar grávida, sentimento de ambivalência e de indignidade}

A vivência das mulheres em relação à maternidade eà sexualidade tem sido marcada pelo signo da negatividade, construído na tríade vergonha, medo e culpa.

Em nossas pesquisas, dos $49 \%$ de mulheres milanesas que responderam negativamente sobre a relação da vida reprodutiva com o trabalho, a grande maioria não tem filhos ou eles já são maiores e independentes. No entanto, as diversas maneiras usadas para relatar que a maternidade interfere no trabalho reforçam nossa tese da clivagem de gênero no mundo do trabalho-sobretudo, porque a categorização de gênero continua sendo desconhecida pela maioria dos estudos e as mulheres desconsideradas como sujeito estruturante das relações sociais de produção e da organização social do trabalho. Das $53(52,6 \%)$ trabalhadoras italianas com filhos, 48 (90,5\%) têm um ou dois filhos; e somente cinco $(9,5 \%)$ têm até três. Para nós, isto significa a confirmação da baixa taxa de natalidade naquele país: $0,4 \%$. Os filhos, na maioria, têm mais de 10 anos. 
Das 66 sindicalistas brasileiras, 40\% têm mais de 3 filhos; 60\% não têm. O alto índice de mulheres sem filhos em nosso país pode ser explicado pelo fato de as sindicalistas serem, em sua maioria, jovens e terem a militância política sindical como prioritária à maternidade.

Um dado que aponta para uma diferenciação entre os dois países do ponto de vista cultural e social em relação à maternidade refere-se ao tipo de parto: do total de 102 milanesas, $52, \%$ tiveram filhos ( $64,2 \%$ fizeram parto normal e $35,8 \%$, cesariana). Entre as 66 brasileiras, das $48,6 \%$ que tiveram filhos, $44,4 \%$ fizeram cesárea e 55,6\% tiveram parto normal. O que nos chama atenção é o fato de que entre as mulheres que fizeram cesárea, $68,8 \%$ consideraram ofato normal.

Das sindicalistas que participaram da pesquisa no Brasil e que fazem uso de algum contraceptivo, 41 (55,5\% do total) repetem o comportamento contraceptivo da maioria das mulheres brasileiras: $21 \%$, pílula; $19 \%$, esterilização; $7,5 \%$, abstinência sexual; $3,5 \%$, método billings e camisinha; 3,0\% têm maridos e/ou companheiros vasectomizados e 1,5\%, optou pelo método injetável. As mulheres que fizeram a esterilização alegaram como motivo o medo de engravidar, o alto número de filhos, o fato de trabalharem fora de casa, a falta de escolha contraceptiva e problemas financeiros.

No Brasil, 40,1\% das mulheres estão esterilizadas, segundo dados da Pesquisa Nacional sobre Demografia e Saúde da Sociedade do Bem Estar Familiar (BEMFAM) em 800 municípios (FolhadeS. Paulo, out./1996). No entanto, é importante ressaltarque, embora os serviços de Atenção Integral à Saúde da Mulher estejam involuindo em todo o País, as mulheres adquiriram a consciência da sobrecarga da maternidade - em uma sociedade onde as relações de gênero estruturam as práticas sociais. Dessa maneira, pode-se concluir queo perfil contraceptivo não apresentou diferenças significativas no País em relação aos dados de 1986, quando $22 \%$ das mulheres utilizavam pílula e $29 \%$ estavam esterilizadas.

Entre as trabalhadoras milanesas que fazem uso de algum contraceptivo (77, ou $75,5 \%$ do total) observamos o seguinte comportamento quanto à prática contraceptiva: $30 \%$ usam a pílula; $25 \%$, o método billings ou tabelinha; $12 \%$, o coito interrompido; $13 \%$, o DIU; $8 \%$, camisinha; $4 \%$ optaram pela esterilização.

O fato de $35,1 \%$ das mulheres milanesas que participaram da pesquisa estarem na faixa entre dois a três anos de uso do método contraceptivo, seguidas por 19,3\% na faixa entre quatro a cinco anos, demonstra que elas, além de mudarem de método contraceptivo em períodos mais curtos, não utilizam métodos invasivos ao corpo. Este quadro representa a realidade da contracepção entre as mulheres italianas, confirmada por Pizzini (1996):

nos anos 90 nasceram na região da Lombardia, norte da Itália, 74.705 crianças e foram realizados 24.682 interrupçōes voluntárias da gravidez. A taxa de natalidade nesta região é $0,5 \%$ entre mulheres em idade reprodutiva, sendo a mais baixa do país e inclusive entre outros países europeus. A diminuição da natalidade se acentua entre as jovens de 20 a 29 anos e estacionou entre as mulheres na faixa de 30 a 39 anos. 
Segundo a autora, muitos são os fatores que influenciam neste comportamento, destacando-se o aumento da escolaridade das mulheres e sua entrada maciça no mercado de trabalho.

No que se refere à contracepção, salta aos olhos uma diferenciação na cultura contraceptiva. Os dados mostram que no Brasil ela é medicalizada e invasiva, ao contrário da ltália. Cremos que estas diferenças podem ser compreendidas por diversos ângulos, como a clandestinidade do aborto e a involução das ações de saúde da mulher, decorrente do descaso com que os governos têm lidado com as políticas públicas de saúde.

A legalização do aborto na Itália na década 70 mudou qualitativamente o quadro da saúde da mulher naquele país, provocando uma mudança no perfil epidemiológico da morbi-mortalidade feminina, embora no que se refira à mentalidade dos profissionais da saúde esta ainda continue bastante conservadora. Sob forte pressão da Igreja Católica, as forças progressistas - entre elas as organizações de mulheres - vêm enfrentando situações que podem ameaçar as conquistas de 20 anos atrás, uma vez que, no sul da Itália, onde a população é mais carente, os serviços de saúde não têm oferecido assistência de qualidade às mulheres, principalmente nos casos de abortamento, quando os médicos alegam objeção de consciência e se recusam a fazê-lo.

Do total das trabalhadoras milanesas, $71,7 \%$ responderam que são submetidas a controle (grifo nosso) de saúde durante o período da gravidez; $28,3 \%$ responderam negativamente.

O cuidar do corpo, para a maioria das trabalhadoras dos dois países (60\%), significa apenas a prevenção do câncer do colo uterino. Essas mulheres declararam ter ido ao ginecologista em um periodo que variou de dois meses a um ano, somente para realizar o exame de Papanicolau. Entre as milanesas que disseram não fazer esse teste com regularidade, a maior freqüência foi encontrada entre as profissionais da saúde (17\%). Este resultado é preocupante: mostrou-nos uma tendência destas mulheres a negligenciar a prevençãoda saúde e o cuidado com o corpo. Este comportamento pode estar relacionado com o fato de estarem envolvidas, cotidianamente, com a saúde-doença do/a outro/ae, muitas vezes, viverem em condições de completa insalubridade no local de trabalho.

É na relação entre maternidade e trabalho que as relações de gênero se evidenciam, uma vez que são estruturantes da participação da mulher no mundo do trabalho assalariado. Se as mulheres, na década de 70, entraram em massa para o mercado de trabalho, é certo que a grande maioria delas não conseguiu ocupar postos de chefia, ascender na carreira e receber salários iguais aos dos homens - mesmo quando mais qualificadas e ocupam funções semelhantes. Dados da Fundação Sistema Estadual de Análise de Dados/ SP-SEADE - (1996) indicam que as mulheres recebem 60\% a menos do que os homens.

A nova organização social do trabalho nas sociedades ditas 'modernas e globalizadas' renomeia a divisão sexual, a partir de dispositivos estratégicos (que controlam por meio da 'naturalização' da maternidade a circulação das mulheres na hierarquia dos postos de trabalho). É o que nos diz uma trabalhadora sindicalista de Milão: 
o stress devido ao trabalho diante do video terminal e também a dupla jomada de trabalho incidem na minha vida reprodutiva e na diminuição do desejo sexual. Ultimamente, muitas mulheres têm solicitado o part-time. No futuro, penso que teremos uma redução do horário para melhorar a qualidade de vida.

A discussão do part-time tem assumido proporções significativas com o avanço das políticas neoliberais. Ressaltamos que estes projetos políticos se baseiam na lógica do mercado, em detrimento das políticas sociais que garantem a qualidade de vida das pessoas e, sobretudo, das mulheres, que são as mais penalizadas, por arcarem com a dupla jornada de trabalho (Hirata, 1996).

É na subjetividade feminina que está enraizado o sentimento construído social e culturalmente de que a responsabilidade pela maternidade, além de ser compartilhada na maioria dos casos só com as avós, 'incapacita' as mulheres para o desempenho das tarefas fora de casa. Sentem-se humilhadas e sem nenhum esquema individual ou coletivo de suporte que as ajudem a decidir entre a maternidade e o trabalho, quando são colocadas diante de situações de conflito que se assemelham ao drama da "escolha de Sofia".

Se usamos a técnica de complementação de frases ditas por elas, confirmamos nossa análise:

tenho um filho e amamentei por 3 meses quando já trabalhava. Vivi muito mal o retomo ao trabalho, pois me senti colocada em uma posição menos qualificada que aquela ocupada antes da gravidez. Deixava a filha com a avó (...).

Quando a opção por não ter filhos é influenciada pelo trabalho: "trabalho no setor agro-alimentar, sou muito ocupada, por isso não tenho filhos. Hoje gostaria de tê-los, mas é muito dificil ter filhos e trabalhar (...)"; uma das trabalhadoras metalúrgicas nos conta, analisando sua decisão: "eu não tenho filho, porque quem tem filho tem mais dificuldades de trabalhar por causa dos turnos e deve por força deixar os filhos com qualquer um (...)".

Dois relatos nos trazem de volta o drama vivido pelas mulheres na relação entre a maternidade e o trabalho, isto é, o drama de não conseguirem resolver a fronteira entre o espaço público do mundo do trabalho e o espaço privado do mundo doméstico (ressalte-se que socialmente, para as mulheres, não existe separação entre eles, uma vez que elas estão submetidas a dispositivos de controle que operam na esfera da subjetividade e obstaculizam o exercício de sua autodeterminação): “(...) As mulheres que trabalham e querem ter filhos não são compreendidas; não se percebem as exigências de uma mulher que quer trabalhar e ter filhos (...)", nos conta uma trabalhadora metalúrgica de Milão.

"É um problema de tempo", afirma a trabalhadora da saúde, pois ela acredita que "conseguindo maior flexibilidade no horário a fim de permitir a mulher poder estar com os filhos quando necessário", a discriminação sexual pode diminuir.

Esta afirmação, se indica uma vontade de potência das mulheres em transformar as relações hierárquicas de poder entre os sexos, buscando ạ eqüidade de direitos, também demonstra, a nosso ver, que a flexibilidade de horário pode servir como álibi para 
um maior desemprego das mulheres ou à sujeição à salários mais baixos e funções mais desqualificadas. Este álibi ć sustentado no discurso discriminatório de que a maternidade impede a produtividade das mulheres. Neste caso, é salutar lembrar a importância que as mudanças de mentalidades exerce nas transformações das relações de classe, gênero e raça.

Exemplar da discriminação que sofrem as mulheres-mães é o relato de uma trabalhadora da saúde italiana:

não tenho fithos porque não posso tề-los, mas não éu uma escolha minha. Era consciente de que se tivessef fithos seria reduzido o meu empenho no trabalho, por causa dos diversos problemas que têm as mulheres mães. Para quem retoma ao trabalhoédificil manter o duplo papel de mãee trabalhadora, precisa, por forşa, sacrificar um ou outro e isto também porque as mulheres tendem a dar sempre mais importância ao privado, à familia e estão sempre dispostas a sacrificar o trabalho pela serenidade da familia (...).

A maioria dos relatos nos remete a três considerações: a escolha entre trabalho e maternidade se coloca entre o que Dejours (1988) chamou de 'riscos residuais', porque são quase sempre as mulheres que têm de buscar soluções para dar conta da sobrecarga de trabalho imposta pelas diferentes jornadas; esta escolha, também se situa entre os 'riscos supostos', istoé, supõe que a mulher-mãe deve ter garantidos seus direitos como trabalhadora pelas Leis de Tutela e de Proteção, mas, na verdade, em nenhum dos casos, este risco é controlado e assumido pelas empresas ou pelo Estado; e finalmente, recuperamos o conceito de autodeterminação como ideário da autonomia e do exercício da plena cidadania: qualidade de vida implica em educação, moradia, saneamento, emprego, salário, saúde, bem estar social, sexualidade sem restrições, lazer, ética e dignidade na vida e na morte.

A representação da maternidade para essas trabalhadoras é marcada pelo conflito entre o desejo de ser mãe e o sentimento de que estão cometendo um crime, pelo qual são penalizadas. Elas sabem que não existe neutralidade na relação empresa e maternidade (do ponto de vista da 'eficácia da produção').

A afirmação de uma trabalhadora milanesa expressa o significado desta indignação: "somente se forem fortes as mulheres conseguem se fazer ouvir, enquanto os homens, mesmos sendo medíocres, são ouvidos (...)".

Outra, com expressões de revolta contra a representação social da mulher-mãe no mercado de trabalho como improdutiva, nos conta: "as mulheres não fazem carreira porque existe um estereótipo masculino segundo o qual elas, antes ou depois de entrarem no mercado de trabalho, têm filhos, por isto não se pode confiar nelas (...)".

Estas falas nos remetem à clivagem da divisão sexual como uma ineqüidade de gênero - e lembramos aqui a definição de Scott (1988) para 'gênero': "que as conseqüências da hierarquia de poder vão para além do espaço doméstico, como no mundo do trabalho (...)." As narrativas também nos indicam a dimensão cultural e social dos pro- 
cessos destrutivos que formam as vivências depressivas das mulheres - que muitas vezes não conseguem romper com as primeiras experiências de submissão que acontecem na infância, como analisaram Hirata (1988) e Kergoat (1993).

A 'consciência' da discriminação sexual pode levar ao estado de liminaridade, isto é, a mulher sabe da discriminação, limitando-se a constatá-la, como nos disse uma das italianas entrevistadas: "a situação não muda, obstante a solicitação de eliminá-la (...)". Esta construção cultural do significado da submissão da mulher nos remete às construções diferenciadas dos medos, prazeres, culpa e vergonha. O medo da perda do emprego, para a mulher, está relacionado à sobrevivência, à perda do único espaço de liberdade e de socialização fora do ambiente familiar. O emprego, para muitas mulheres, assume o significado de estratégias defensivas contra a cotidianiedade da opressão doméstica e sexual.

\section{Trabalho, corpo e sexualidade: uma mediação a ser feita}

Se procurarmos resgatar as respostas, verificamos que a percepção que as trabalhadoras têm do corpo está relacionada a um modelo binário do corpo produtivo e estético. Este modelo se contrapõe a uma imagem que revela as representações sociais da saúde ao corpo reprodutivo/doente: $85 \%$ das trabalhadoras brasileiras e $83 \%$ das milanesas responderam que gostam do corpo; as respostas negativas atingiram, respectivamente $8 \%$ e $17 \%$. Não responderam à questão $9 \%$ das brasileiras.

Para as mulheres ligadas à área de serviços, como as bancárias, cuidar do corpo faz parte de uma preocupação com a estética e o psicológico: "me cuido superficialmente, sou gorda, bebo e fumo demais"; outra fala desloca o cuidado do corpo para a dimensão do "cuidar-se psicologicamente para agüentar o tranco", como um dos processos protetores contra o desencadeamento de sintomas relacionados com o sofrimento patogênico, isto é, a transformação de vivências depressivas em doença.

Entre as trabalhadoras rurais, apenas uma respondeu que não gosta de seu corpo. A concepção do corpo como produtivo fica evidente quando uma delas afirma: "meu corpo é minha ferramenta e sobrevivência". Outras trabalhadoras rurais completam a relação: "meu corpo me dá prazer, mas clandestinamente"; "não gosto de meu corpo, sou desajeitada". O corpo, como ferramenta, é o instrumento de trabalho mais precioso e produtivo que essas mulheres possuem. A relação com o trabalho, para algumas, é uma relação de prazer, na medida em que é no mundo do trabalho que elas se percebem como sujeito com auto-estima, em uma relação circular de poder entre diferentes atores sociais. 
A dimensão do corpo essencialmente ligada à capacidade reprodutiva apareceu junto da maioria das trabalhadoras milanesas. Entre as brasileiras, junto às metalúrgicas (uma delas afirmou que "gosto de meu corpo não pela estética, mas pela biologia que possibilita a maternidade e me dá um prazer de ser mãe").

A ótica das relações de gênero permite pensar na questão da igualdade e diferença entre os sexos, apontando para eqüidade de direitos entre mulheres c homens, uma vez que as mulheres têm especificidades que as diferenciam dos homens. Trata-se, assim, de preservar a diferença entre os sexos, introduzindo uma outra cultura de trabalho a partir das mulheres.

Sabemos que a incorporação da noção da diferença como um direito individual e coletivo pode transformar as desigualdades existentes nas relações sociais de sexo no trabalho, rompendo com a argumentação tradicional e essencialista que explica a diferença de carreira masculina e feminina pela maternidade, e que repousa no 'privilégio dos valores domésticos' para a mulher.

A construção do tempo, para elas, relaciona-se à dupla jornada de trabalho, ou melhor, à jornada extensiva de trabalho - que começa em casa, passa pelo mundo do trabalho e vai terminar novamente em casa. É uma construção que inexoravelmente passa pela sexualidade, isto é, o tempo da sexualidade corre simultaneamente ao tempo da rigidez das tarefas.

Algumas falas comuns entre as trabalhadoras dos dois países indicam e reforçam essa interpretação: "bem, eu não tenho tempo nem para sonhar" (rural brasileira); "a sexualidade fica em segundo plano pela militância e pela dupla jornada de trabalho" (dirigente sindical brasileira); "a falta de tempo, o cansaço interferem tanto na militância como no trabalho e o companheiro não entende" (dirigente sindical italiana).

As mulheres rurais brasileiras foram unânimes em afirmar que vivem a sexualidade de forma escondida e clandestina e que esta é uma vivência muito complexa. Algumas falas exprimem uma tensão na vivência da sexualidade "vivo bem, normal c clandestina". Isto reafirma a dimensão da sexualidade como um ponto nodal de tensão na vida das mulheres, que vivenciam esses conflitos de maneira bastante solitária-porém, como um cspaço de liberdade. Dessa maneira, é possível compreender o processo de construção social do corpo feminino, como um corpo silenciado e marcado.

A vivência da sexualidade "como um momento liberatório, com muitos problemas cotidianos" basicamente se referia a carga da dupla jornada de trabalho e aos ritmos das tarefas que desenvolve e "ao mesmo tempo a confirmação de uma forte e intensa ligação com o companheiro sem necessidade de muita conversa".

Entre os $71 \%$ de trabalhadoras milanesas que responderam à questão, $31 \%$ afirmaram que o trabalho influencia na vida sexual e $40 \%$, que não influencia. Faremos um exercício de interpretação a partir das falas, buscando reconhecer no sentido desconstrucionista de Bachelard (1996) e no âmbito do gênero como uma relação de 
poder que transcende as relações da esfera doméstica e estruturam as múltiplas redes de relações sociais, em dois sentidos. Um, quando o trabalho funciona como suporte para melhorar a qualidade de vida sexual; o outro, quando atua como processo destrutivo da vida sexual. Entre as mulheres que afirmaram ter problemas, 34\% alegaram ausência de desejo sexual e menor freqüência de relações sexuais; $8 \%$ disseram que, por causa do trabalho, as relações sexuais são extremamente breves.

$\mathrm{Na}$ busca de qualificar nossas informações, usamos trechos das narrativas que nos contam sobre a vivência sexual. Entre as sindicalistas milanesas o que sobressai são referências aos processos destrutivos do trabalho sobre a vida sexual: "... o trabalho incide sobre a menstruação, quando estou tensa sofro mais , quando estou de férias não tenho as dores na coluna, pernas e abdome durante a menstruação ...".

No trecho a seguir, a relação com o lazer evidencia os processos estressantes que as condições de trabalho provocam:

o trabalho repetitivo e o stress de quem trabalha no Hospital repercute na vida sexual quando retomo à casa a noite, estou cansada e ainda devo fazer comida, passar as roupas, por isto, depois tenho sono e não tenho vontade de fazer amor. Tenho dores de coluna porque estou sempre sentada e também o ar condicionada me faz mal. Quando fico nervosa por causa do trabalho, a menstruação fica muito irregular.

Nesta vivência, a trabalhadora já interpreta e indica que a dupla jornada de trabalho é a carga penosa que as mulheres sofrem durante toda a vida; mostra que a sexualidade não é um apêndice na vida das pessoas, ou um botão, como em uma máquina, que basta ser acionado para que o desejo emerja: "falta sempre tempo para o sexo, infelizmente apagada, neste período vivo mal"; "satisfatória, quando não estou muito cansada e estressada", nos disse uma trabalhadora da indústria alimentícia.

Alguns processos atuam como protetores nas situações de sofrimento mental. Dentre eles, destacamos a desconstrução da identidade feminina, marcada pela violência da exclusão e do silêncio imposto, em identidade autodeterminada. Esta transformação de identidade representa para as mulheres a recuperação do saber e do controle sobre o corpo, permitindo-lhes assumir atitudes que podem ser caracterizadas como transformadoras das práticas sociais e do exercício de cidadania - o que pode ser ilustrado por estas narrativas:

"penso que se alguém vive o trabalho como restrição ou um peso, élógico que ele toma muito estressante a vida $($...)" ; "seé para o prazer estou sempre disposta, mesmo que sobrem só as noites e o final da semana (...)".

Indica, também, uma abertura psicológica ao prazer e ao encontro com o outro: "tento viver de forma mais honesta, me reconhecendo e transformando". Estes depoimentos reforçam nosso pressuposto de que o conhecimento do corpo é a base para a construção da autodeterminação das mulheres: "depende do momento, seja mentalmente ou fisicamente, ora tranqüilamente, mas no passado tive problemas porque não conhecia meu corpo". Continuando na mesma linha, "ainda estou a descobri-la", nos disse outra trabalhadora. 
O trabalho influencia na vida sexual. As narrativas indicam que desencadeia um aumento da tensão pré-menstrual e irregularidades no ciclo menstrual, sobretudo pelo excesso de trabalho, por pressão da chefia e da própria organização da produção. Cansaço, ansiedade, tensão, ritmo das tarefas e pressão da chefia também foram apontados como desencadeantes das vivências de sofrimento mental no trabalho:

às vezes não tenho desejo sexual por causa do cansaço, mas procuro não deixar que o trabalho me estresse tanto.

Os riscos maiores no meu trabalho como operária de produşão metalúrgica estão relacionados com os ritmos da produşão que descontrolam meu ritmo biológico da menstruasão (...).

Outra operária nos conta que o problema da menopausa pode ser acentuado pelas condições de trabalho,

mas se busca não dramatizá-lo entre as companheiras de trabalho com as quais eu converso muito. Seguramente a pressão do trabalhoé mais forte, principalmente porque na minha seção as mulheres às vezes são levadas a ficarem sempre de pé sem conversar com ninguém (...).

Este depoimento, ao ser interpretado, aponta para questões no âmbito da construção de estratégias de resistência - conversar entre as colegas sobre os problemas que as afligem (e que são considerados menos importantes para o mundo masculino), permitem romper com o silêncio imposto às mulheres pelas relações de poder entre os gêneros. É o que Molyneux (1985) chamou de interesses práticos das mulheres, ao construírem em espaços moleculares e localizados, resistências singulares de sobrevivência.

Outro ponto é a denúncia das condições de trabalho das mulheres - ficar de pé sem conversar com ninguém, constituindo a representação da 'solidão da fábrica'. Se falar sobre a menstruação já é uma coisa bastante complicada e eivada de preconceitos, o que dirá falar sobre a menopausa? Significa quebrar o mito da juventude e o tabu do envelhecimento, em um mundo onde a população está envelhecendo e a taxa de mulheres velhas chefes de família se aproxima dos $79,9 \%$, ao passo que a dos homens gira em torno de $72,8 \%$ (Folha de S. Paulo, 10/7/1996).

Entre as trabalhadoras milanesas da área da saúde, encontramos referência explícita à relação do trabalho com a vida sexual "a minha vida sexual é menos ativa quando trabalho, porque retorno à casa cansada, porque é um trabalho pesado para as mulheres". Surpreende, nesta narrativa, a avaliação do trabalho como uma sobrecarga para as mulheres. Isto nos permite inferir que elas próprias consideram que devam fazer trabalhos mais leves - levando-nos, assim, a concordar, em parte, com Dejours (1988), quando faz a análise da representação social do trabalho masculino, afirmando que, quanto mais perigoso, mais viril e mais prazeroso.

Um aspecto interessante a ressaltar nas falas das dirigentes sindicais brasileiras é a relação com a militância, que passa a ter um significado de sofrimento e dever, quando deparada com a sexualidade: "... a sexualidade fica em segundo plano por causa da militância e da dupla jornada de trabalho ...". É como se, entre as duas atividades, não 
existisse possibilidade de conciliação: "só o sindicato interfere na minha vida procriativa"; "sim, a falta de tempo interfere na vida sexual". A militância como um dos inúmeros dispositivos de controle e de normatização - "por causa das atividades de militância, tenho dificuldade de sentir prazer" - exercido mesmo que subliminarmente na sexualidade das sindicalistas: "o trabalho e a militância interferem na minha vida sexual"; ou, ainda, as viagens em função da militância "interferem na vida sexual, porque viajo muito pela política".

Uma narrativa de uma dirigente sindical milanesa nos chamou atenção pelo significado de poder que expressa em relação à divisão sexual enraizada, também, na militância: "interfere, tanto a militância quanto o trabalho, e o companheiro não entende, exige".

O significado da sexualidade dependente do parceiro foi expressa com mais freqüência entre as milanesas. "de modo satisfatório, mais em relação a capacidade intuitiva do parceiro"; "bem, porque vivo uma relação fixa (...)." A vivência da sexualidade com pouca fantasia, por sua vez, expressou-se como uma das dificuldades para articulação da militância e da vida sexual: "com pouca fantasia, porque os companheiros de sindicato são difíceis (...)".

É interessante notar que as condições de trabalho no sindicato desencadeiam sintomas de sofrimento que interferem na renúncia do exercício da sexualidade, como nos conta uma trabalhadora: "... na minha sexualidade, porque vivo sempre ansiosa e tensa pela pressão do trabalho sindical ...". Em contrapartida, se está relaxada, ou em férias, "com disponibilidade para a fantasia e romantismo (...)", a sexualidade the traz prazer. Ou, ainda, quando é transferida de função, mesmo no sindicato, "com serenidade, se depois tiver mudado de funções no ofício, o desejo diminui $(. .$.$) ".$

\section{Algumas reflexōes finais}

A abordagem comparativa neste estudo não tratou de realidades iguais, pois as pesquisas foram realizadas em épocas diferentes e com populações de trabalhadoras de distintas categorias profissionais em diferentes países. Essa postura metodológica responde à problemática relacional dos fenômenos com os quais trabalhamos, nos possibilitando abordar, em um mesmo plano de análise, dois níveis de realidades: na esfera internacional, a lógica da divisão sexual no trabalho permitiu compreender como as relações sociais de trabalho redesenham os lugares dos homens e das mulheres na vivência da sociedade global. Desta maneira ressaltamos as convergências entre as duas realidades estudadas: 
- as precariedades das Leis de Tutela e Proteção à mulher-mãe no local de trabalho, que não garantem o pleno exercício do direito ao trabalho das mulheres que optam por ter filhos e por amamentar;

- a dupla jornada de trabalho das mulheres, que torna precárias as condições de vida, de realização do prazer e da sexualidade;

- a ausência de informação sobre os fatores de risco e sobre as pesquisas desenvolvidas nas diferentes áreas;

- a precarização do trabalho das mulheres, agravada com a internacionalização-que impõe reduções da jomada de trabalho como o part-ime e a flexibilização do emprego, entre outros.

E na esfera local, em relação com a dimensão globalizante, ressaltamos aquilo que o estudo apontou como diferenças: a contracepção. Na Itália, onde a taxa de natalidade é de $0,5 \%$, as mulheres já conquistaram direitos que lhes possibilitaram o uso de métodos menos invasivos à saúde e ao corpo.

Ao discutir as condições e a organização social e sexual do trabalho sob a ótica das relações de gênero na perspectiva internacional comparada, este estudo:

- apontou a urgência de uma reflexão sobre a dimensão daética vivida no cotidianodas trabalhadoras (Oliveira, 1996), como princípio que informa o respeito aos direitos ao trabalho, às condições de vida e saúde, à informação sobre os riscos e o conhecimento cientifico nas negociações individuais e coletivas e na construçãoda solidariedade individual e coletiva;

- redefine e amplia o leque de necessidades consideradas básicas para a melhoria da qualidade de vida da mulheres no trabalho e fora dele, introduzindo a dimensão da subjetividade, do prazer e da sexualidade.

No que se refere à solidariedade coletiva, observamos que, quando uma trabalhadora apresenta sintomas de doença, nenhuma delas se interessa- ao contrário, se afastam, por uma imposição quase que oculta das chefias, expressa em diferentes formas de controle. As trabalhadoras se afastam daquela que apresenta algum sintoma de doença, em uma demonstração clara de medo de contágio- que, no imaginário coletivo, representa a possibilidade da perda do emprego.

Neste sentido, a vivência com as/os trabalhadoras/es nos permite apontar outras formas de apoio e solidariedade por eles buscadas, na medida em que expressam um cansaço e uma total desesperança em relação ao Estado, às empresas e, alguns casos, até em relação aos sindicatos. É por isto que os grupos de discussão no local de trabalho funcionam como estratégias criativas de defesas individuais e coletivas.

Finalmente, salientamos quatro relações, com base nesta pesquisa e vivência com o universo dos trabalhadores e trabalhadoras: a primeira é a da dignidade da vida no mundo do trabalho e no mundo da casa, restabelecendo, assim, os direitos reprodutivos e sexuais como direitos de cidadania - portanto, um exercício de qualificação de todas as atividades invisíveis que as mulheres desenvolvem. A segunda (que deve estar em conexão direta com a primeira) é a inclusão das mulheres no mundo dos direitos como sujeitos com 
autonomia para decidirem sobre seus próprios caminhos, sabendo que 'decidir' implica em informações para poder escolher. A terceira é a ruptura no mundo do trabalho eem casa com o estado de heteronomia em que as mulheres têm sido colocadas; $\mathrm{e}$, finalmente, a quarta é a qualificação do trabalho doméstico como trabalho que vai interferir positiva ou negativamente na relação das mulheres com o conteúdo das tarefas desenvolvidas e, fundamentalmente, na insatisfação que elas têm com o trabalho fora de casa.

Como escreve Dejours (1988), "é do contato forçado com uma tarefa desinteressante que nasce uma imagem de indignidade". Caminhando junto com a reflexão de Hirata (1988) e Kergoat (1993), essas tarefas são sexualmente construídas e distribuídas, produzindo imagens de indignidade marcadas e clivadas pelas relações de poder entre os gêneros.

\section{Referências Bibliográficas}

BACHelaRd, G. A Formação do Espirito Cientifico. Rio de Janeiro: Ed. Contraponto, 1996, p.314.

Dejours, C. A Loucura do Trabalho: estudo depsicopatologia do trabalho. São Paulo: Cortez/Oboré, 1996, p.23, 25 e 26.

Dejours, C. Souffrance et Plaisir au Travail: l'approche par la psychopathologie du travail In: Dejours, C. (Dir). Plaisirel Souffrance dans le Travail. Tomme 1. Paris: Edition de l'AOCIP, 1988/ 1993, p. 23.

Hirata, H. Psychopathologie du travail et division sexuelle: convergences e differences. In: Dejours, C. (dir). Plaisiret souffrance Dans le Travail. Tomme 2. Paris: Edition de l' AOCIP, 1988/ 1993, p.133 e 138.

KERGOAT, D. La psychopathologie du travail dans son approche de la souffrance et du plaisir au travail, peut-elle faire l'économie des rapports sociaux de sexe? Quelques exemples précis. In: Dejours, C. (dir). Plaisir et souffrance dans le travail. Tomme 2. Paris: Edition de l'AOCIP, 1988/1993. p. 145 e 161.

Molyneux, M. La Mujer, el Estado y la Revolución: el caso de Nicaragua. Feminist Studies, 1985. p.23-37.

Oliveira, M. E; Carneiro, F. \& Stort, R. Gênero, Saúdee Trabalho: a dimensão oculla. São Paulo: Editora Brasiliense e Sindicato dos Bancários de São Paulo, 1996.p. 15 e 16

Ouverra, M. E Psicopatologia Sexualizada do Trabalho: a reconstruçãode um conceito, 1996. Tese de Livre Docência, São Paulo: Departamento de Práticas em Saúde Pública, Faculdade de Saúde Pública, USP, 1996, p 88, 89 e 132.

PIZZINI, F. Le Politiche Sociali Italiane sulla Riproduzione. 1996 (Mimeo.) 
Scort, J. Gênero: uma categoria útil de análise histórica. In: Scom, J. Gender and the Politics of History. New York: Columbia University Press, 1988. Tradução: SOS Corpo. Recife, 1991. p. 33 e 34.

ToDOROV, T. Nós es Outros: a reflexão francesa sobre a diversidade humana. Vol. 1. Rio de Janeiro: Zahar Editora, 1989. p.12-13. 


\section{4}

\section{Homens, Saúde Reprodutiva e Gênero: o desafio da inclusãa}

\section{Margareth Arilha}

A preocupação com a população masculina vem crescendo no Brasil, especialmente entre os formuladores de políticas que dedicam-se nacional e internacionalmente ao campo da saúde reprodutiva. Isso tem ocorrido em conseqüência da constatação da insuficiência dos resultados obtidos em torno da saúde reprodutiva das mulheres e da identificação do 'homem' como sujeito de necessidades específicas nesse campo. Esse contexto tem sido crescentemente reforçado pela produção de conhecimentos teóricos e de metodologias de intervenção, que vem sendo desenvolvido por Organizações NãoGovernamentais (ONGs) e em trabalhos acadêmicos no campo da sexualidade, da saúde reprodutiva, dos direitos sexuais e dos direitos reprodutivos.

Este capítulo tem como objetivo apontar idéias que surgem a partir do desenvolvimento de uma pesquisa: "O papel da reprodução na construção da masculinidade", situando-o como conseqüência desse processo histórico que caracteriza-se por produzir um olhar mais focalizado para a problemática masculina.

\section{Introdução}

As conferências internacionais da década de 90, realizadas pela Organização das Nações Unidas (ONU) - especialmente a Conferência Internacional de População e Desenvolvimento do Cairo (CIPD), de 1994 - contribuíram para o florescimento da pers-

\footnotetext{
* Agradeço a Silvani Arruda e Rosana Gregori pelas leituras críticas e sugestões feitas a este texto, bem como pelo entusiasmo cotidiano com que têm abraçado,' ao lado de José Roberto Simonetti, a pesquisa que originou este artigo.
} 
pectiva de inclusão explícita das palavras 'homens/masculino' em textos que estariam tratando de temas associados tradicionalmente às problemáticas 'femininas'. Isso pode ser observado, especialmente, nos capítulos 7 e 8 do documento final da CIPD, relacionados ao campo da saúde reprodutiva e direitos reprodutivos. Isso ocorreu como conseqüência do processo de discussão preliminar à Conferência, quando ficou patente que a transformação nos indicadores de saúde das mulheres só poderia ser concretizada na medida em que a população masculina-jovem e adulta-também modificasse seus padrões de comportamento, por exemplo, em relação à transmissão das doenças sexualmente transmissíveis - em especial a AiDs - e ao uso de contraceptivos.

Paralelamente ao processo desenvolvido por meio da CIPD-que foi movido especialmente pela organização e mobilização internacional feminista; pela participação do establishment que opera sobre as questões populacionais; governos; e agências de cooperação internacional do sistema ONU -, crescia, sobretudo na Europa, Canadá e Estados Unidos, a organização de grupos de homens reunidos para pensar suas vidas diante das mudanças que as mulheres têm provocado no interior de suas relações afetivas e sexuais. Ao mesmo tempo, crescia o número de núcleos de estudos sobre 'masculinidades' nas universidades americanas, canadenses e europćias e o movimento gay-indicando a urgência de produzir conhecimento sobre o universo dos homens homossexuais, sobretudo diante da problemática da ArDs.

Houve, portanto, uma convergência de situações. Ao mesmo tempo em que cresciam as áreas de estudo sobre masculinidades (Kimmell, 1992), desenvolvia-se uma reflexão internacional sobre o papel dos homens na busca da melhoria dos indicadores de saúde para as mulheres, incrementada pela construção de um cenário em que eles também começam a ser vistos como cidadãos com necessidades e direitos na esfera da vida sexual e reprodutiva.

Esse processo acabou tendo alguns reflexos no Brasil, como o surgimento de terapeutas especializados no trabalho com homens', e a crescente tendência em desenvolver estudos com o público masculino, ainda que muitos deles tenham se concretizado no contexto de trabalhocom Ams. ${ }^{2}$ Esse cenário indica transformações. Deve-se lembrar que, na década de 80, ocorreram poucas e isoladas iniciativas de inclusão de homens - tanto como objeto de produção teórica, quanto objeto de projetos de assistência ou intervenção. Desse período, destaca-se um seminário realizado pelo Conselho Estadual da Condição Feminina (CECF) de São Paulo, em 1984, montado a partir de grupos de discussão

\footnotetext{
' Destaque-se aqui o papel de terapeutas como Sócrates Nolasco no Rio de Janeiro e Luiz Cushnir em São Paulo.

2 Deve-se destacar o Núcleo de Estudos da Universidade Federal do Rio Grande do Sul, coordenado pela Dra. Ondina Fachel Leal, muito provavelmente um dos primeiros a pensar "masculinidades" no Brasil. o Instituto de Medicina Social da Universidade Estadual do Rio de Janeiro, desenvolveu também importantes trabalhos de pesquisa sobre sexualidade e gênero, estimulados sobretudo pelo Dr. Richard Parker.
} 
desenvolvidos com homens reconhecidamente 'cúmplices' em relação à chamada 'questão das mulheres' e 'sensíveis' a ela. Muitos eram parceiros de feministas. No caso do atendimentoà população masculina em serviços, existiram relacionados ao planejamento familiar, em grandes empresas e voltados especialmente para a realização de vasectomias (CECF, 1986). Foram reduzidos os trabalhos de intervenção em sexualidade e saúde reprodutiva dirigidos a homens adultos jovens, quadro que se modifica na década de $90^{3}$.

No caso da produção acadêmica - além de poucos-, os estudos realizados na década de 80 e início dos anos 90 apontaram muito mais para o campo da sexualidade do que para o campo da reprodução (Leal et al., 1995). Para conhecer um pouco mais a vinculação Homem/Reprodução, a pesquisa descrita a seguir foi proposta.

\section{Homens e a reprodução}

A ONG Ecos (Estudos e Comunicação em Sexualidade e Reprodução Humana) desenvolve uma pesquisa que investiga o papel da reprodução na construção da(s) masculinidade(s). Tendo o construcionismo social como perspectiva epistemológica, e operando no campo da Psicologia Social, parte-se das seguintes questões :

- até que ponto os homens consideram o seu corpo como um corpo reprodutivo?

- quais são, atualmente, as atitudes e os comportamentos sexuais e reprodutivos que homens adultos possuem e praticam por meio do seu corpo (sexual/reprodutivo) antes e depois do casamento?

- quais as implicações desses resultados para a vivência da paternidade?

No caso específico da saúde reprodutiva, torna-se relevante pensar se e como o campo da reprodução está presente no imaginário masculino. Qual seria o conjunto de repertórios produzido sobre o tema 'homens e reprodução'? Que impacto têm esses repertórios sobre a imagem de necessidades de saúde que esse grupo populacional formula para si? Se a reprodução é aprendida e apreendida pela maior parte das pessoas como um processo biológico que se concretiza essencialmente em um corpo do sexo feminino, como provocar novas linguagens no universo das mentalidades de mulheres e de homens acerca da reprodução? Seria possível valorizar menos a gestação e mais a concepção, apontando para uma posição compartilhada, em termos de significados, de mulheres e homens diante da reprodução biológica da vida? Como lidar com o fato de que é o corpo feminino que desenvolve o trabalho da reprodução? Afinal, de quem éo papel mais relevante no processo da reprodução biológica?

\footnotetext{
S Destaca-se o trabalho desenvolvido por Ecos, GTPOS e NEPAIDS que sempre incorporaram adolescentes de ambos os sexos em seus trabalhos de educação sexual.
} 
Apesar de serem geneticamente igualmente participantes, homens e mulheres não têm igualdade de participação no processo reprodutivo em termos do volume de trabalho corporal que a reprodução acarreta para cada um dos sexos. Não obstante, uma representação gráfica do processo reprodutivo, circulante no século XVII (Demarest \& Sciarra, s/d), mostra como, naquele período, considerava-se o homem como agente produtor do feto-introduzido no corpo feminino já praticamente formado, apenas esperando para ser desenvolvido. Essa concepção indica um estágio do conhecimento científico que deixa marcas no imaginário social até os dias atuais: é bastante comum ouvir-se, ainda hoje, histórias em que os homens são descritos como 'agricultores que espalham a semente na terra'. Concomitantemente, de maneira curiosa, a reprodução é vista como 'algo' do universo feminino.

Figueroa Perea (1996) busca ampliar o conceito de reprodução, trabalhando-o na perspectiva de relação. Considera como muito relevante a distinção entre aparelho, comportamento e processos reprodutivos. Observa que, se considerado o equilíbrio da participação entre mulheres e homens na reprodução em função do grau em que a biologia de cada um é solicitada a participar, seria razoável seguir trabalhando, sobretudo, com as mulheres. Ao mesmo tempo, afirma que se a reprodução for pensada em um espaço de relação-e é esta a sua perspectiva -, o comportamento e o processo reprodutivo estarão referenciados a uma visão dinâmica de encontros e desencontros, através da qual será mais fácil fazer referência às dimensões psicológicas e sociais da reprodução.

As transformações conceituais em torno do universo da reprodução estão acontecendo à luz do que Frykman (1996) indica no texto The Transformation of Masculinity in the 20th Century Culture. Esse autor reforçou o argumento da existência da diversidade daquilo que hoje se pode chamar de 'masculinidade' - construída, segundo ele, sobretudo em torno do que se convencionou considerar como home. Chama de home, ou 'lar', a 'arena' na qual novas definições do que é feminino e masculino estariam em construção. Nesses momentos de transição, como pensar o significado da reprodução, dos processos reprodutivos, para determinados grupos de homens?

Um dos possíveis caminhos é identificar, conhecer e analisar os comportamentos sexuais e reprodutivos masculinos, e entender a relação que as pessoas do sexo masculino -sobretudo com comportamentos predominantemente heterossexuais-estabelecem com sua perspectiva diante da reprodução. Até que ponto o corpo masculino está representado para homens e mulheres como um corpo que tem significados semelhantes no âmbito da reprodução? Teria a fertilidade um sentido diferente para cada um dos sexos?

É nesse universo conceitual que a pesquisa vem sendo realizada. Os elementos aqui destacados são preliminares, tendo sido construídos a partir de falas de homens que participaram de grupos focais e de respostas a um questionário aplicado a trabalhadores da indústria metalúrgica. O grupo focal é uma técnica de pesquisa qualitativa que permite captar elementos da cultura, valores, atitudes e comportamentos das pessoas 
cujo perfil se pretende analisar. Por meio desta tćcnica, podem-se obter idéias e concepções compartilhadas sobre temas previamente determinados e introduzidos na discussão, por intermédio de roteiro específico. Quanto mais homogêneo o perfil dos componentes dos grupos, maior a confiabilidade dos dados obtidos. O trabalho ainda prevê a realização de entrevistas individuais com homens adultos jovens, escolhidos dentre os participantes dos grupos focais, para maior aprofundamento.

A pesquisa iniciou-se com pré-testes e survey, realizado em empresa metalúrgica da cidade de São Paulo. Foram abordados 84 funcionários. Destes, 18 faziam parte do setor administrativo - caracterizados como sendo dos estratos B-C - e 66 da produção. Mais do que um instrumento de pesquisa, o survey tinha por objetivo identificar necessidades dos funcionários no campo da informação em educação para a sexualidade e orientação para a saúde reprodutiva. Alguns dos assuntos escolhidos para o levantamento foram: grau de conhecimento dos funcionários da empresa sobre fertilidade feminina e masculina; mecanismos femininos e masculinos de reprodução; conhecimento e uso de métodos anticoncepcionais; doenças sexualmente transmissíveis/AIDS; violência sexual e experiências em torno do aborto.

Para os funcionários da produção, dada a impossibilidade de auto-aplicação do questionário, o ato de preenchimento dos mesmos por pesquisadores (do sexo feminino e masculino) acabou se transformando em um processo de interação em que estabeleceram-se ricos diálogos sobre os temas propostos pelas questões, não havendo distinção entre as impressões obtidas pelo pesquisadore pela pesquisadora. Considerando a totalidade dos funcionários que responderam o questionário, aproximadamente $14 \%$ tinham até 20 anos; $17 \%$, entre 20 e $24 ; 26 \%$, de 25 a $34 ; 29 \%$ de 35 a 44 ; e $14 \%$ mais do que 45 anos. Dentre os funcionários da produção, 35\% eram casados; 62\%, solteiros (a maioria situada na faixa etária de 25 a 44 anos).

No geral, os entrevistados da produção demonstraram muito interesse em ter mais informações, considerando não ser suficiente o que já sabem no campo da sexualidade e saúde reprodutiva. A maioria deles tem possui $1^{2}$ grau incompleto e demonstram ter poucos conhecimentos sobre métodos contraceptivos. Dentre os que são casados, a maior parte usa a pílula anticoncepcional ou são vasectomizados. Os solteiros usam a camisinha (ou nenhum método anticoncepcional). Chama a atenção a relevância do coito interrompido como alternativa anticoncepcional, sobretudo entre os homens casados: Observou-se entre este grupo, também, a preocupação com o impacto da contracepção e do parto/cesariana sobre a saúde da mulher. As respostas sobre contracepção evidenciaram um discurso comum a todos: preferia-se a vasectomia a outras medidas contraceptivas, por diminuir os problemas de saúde para as mulheres.

Como já citamos anteriormente, além do questionário foram realizados grupos focais. Dentre os 11 grupos realizados, três foram feitos entre funcionários do setor administrativo da empresa e outros oito organizados por intermédio de empresa de 
recrutamento. Todos os grupos foram constituídos com homens dos estratos B-C, sendo focalizadas, basicamente, três faixas etárias: 20 a 24; 25 a 34; e 35 a 44 anos. Todos os grupos das faixas etárias foram compostos por homens solteiros e casados, com filhos e sem filhos. Foram obedecidos alguns critérios: todos os homens casados deveriam estar envolvidos em primeiros casamentos, e suas esposas deveriam trabalhar fora de casa.

Com relação aos dados colhidos entre os grupos focais, é possivel apreender algumas questões bastante relevantes. Uma delas foi o fato de não existir definição homogênea sobre o que significa ser homem, indicando diversidade de padrões de masculinidades que estão sendo vivenciados. Trata-se de um padrão em transformação, que coloca dificuldades para os homens precisarem seu próprio papel de gênero. Também chama atenção o fato de que mesmo quando a responsabilidade pelo cotidiano é compartilhada - divisão de tarefas domésticas e financeira dos gastos que o casal/familia possui -o homem ainda se sente responsável pela manutenção da autoridade moral familiar, de acordo com o que afirma Sarty (1996) para a população dos estratos mais baixos da sociedade. Os homens entrevistados conseguem flexibilizar a relevância dos recursos financeiros que obtêm com seu trabalho - até porque as dificuldades impostas pelo mercado exigem que compartilhem a renda familiar com as parceiras - porém, precisam reafirmar que é sua a 'responsabilidade' pelas decisões de condução da família. Algumas citações dos homens nos grupos retratam essa perspectiva:

Estamos dividindo as despesas, os sentimentos, tudo isso, sem dúvida, mas sempre o homem vai ser o chefe da casa. Ele acaba sempre dando (...) não as decisões (...) pois essas cabem aos dois de comum acordo. Mas ele tem sempre um conceito de estar, assim, sei lá (...) comandando a casa, entende? ... Eu já fui sustentado por ela durante 3 ou 4 meses, e ela entrava com a parte financeira, só que as decisões a tomar a gente sempre discutia juntos ... Acho que a própria mulher acaba colocando ele ali à frente. A decisão final ou algo assim tipo em que ficou em dúvida, ela fala: 'Tá, resolve você!' (D., 21 anos., casado, c/ filho)

Tem muitas coisas que, às vezes, a mulher não tem a coragem de chegar e se impor, ou seja, o homem já sabe que quando ele chegar ele vai ter um pouco mais de cabeça de assumir as coisas que têm que ser feitas, certo? (C., 24 anos, casado, s/ filhos)

Os dados preliminares obtidos na investigação indicam que para os homens dos estratos B-C a preocupação com a reprodução - relevante para a construção de uma identidade moral masculina - se constrói no contexto social, e não na relação com seu próprio corpo. A vida reprodutiva de um homem não diz respeito, portanto, à relação direta que estabelece com sua saúde reprodutiva. De maneira completamente diversa do que ocorre com as mulheres, a reprodução, para os homens, não diz respeito a um processo de intimidade e de interação com seu próprio corpo. Não haveria uma espécie de consciência reprodutiva, representada como uma experiência corporal que cria e desenvolve marcas no imaginário masculino no decorrer de sua adolescência e início da vida adulta. 
Rosane Souza (1994), em sua tese de doutorado Paternidade em Transformação, mostra que a paternidade não é tão óbvia quanto a maternidade. O adolescente não perde sangue todos os meses, de modo a, mesmo que de modo fugaz, saber-se potencialmente genitor. Ainda que ejacule, associa-o ao prazer, e não a um potencial criativo. O trabalho salienta que as meninas podem se perceber como potenciais geradoras de bebês, ao passo que os meninos poucas evidências têm de si mesmos como potenciais geradores de bebês, isto é, 'pais'. Souza cita Neubauer (1989) que, ao trabalhar o texto O Pequeno Hans, de Freud, comenta criticamente que ele não foi informado de seu potencial criativo, assim como os meninos e os adolescentes não têm esta informação na sua perspectiva desenvolvimentista. O mesmo autor afirma que há um grande contraste entre os rituais de passagem estruturados pela sociedade para os adolescentes do sexo masculino e do sexo feminino; e levanta como hipótese que a obviedade e a repetitividade da menstruação já atestariam o poder gerador das mulheres. Em contraposição, as ejaculações aconteceriam no universo privado masculino, e de forma alguma permitiriam antever a possibilidade procriativa nele contida.

No entanto, é possível encontrar nos dados de nossa pesquisa uma condensação de significados feita entre potência, fertilidade e sexualidade, que indica pistas relevantes para um longo caminho de ensino e intervenção entre os grupos populacionais masculinos.

Essa concepção da sexualidade masculina, cujo sentido (tanto para homens quanto para as mulheres) estaria voltado para a conquista, para as relações sem limite e para o prazer quase selvagem - como tão bem mostram os estudos de Vilela \& Barbosa (1996) - de certa forma traria implicações para o tipo de interesse cognitivo que rapazes e garotas têm apresentado quando inseridos em contexto de educação para a sexualidadee saúde reprodutiva. Paiva (1996) encontrou nos rapazes um grande interesse pelo 'corpo sexual do/a outro/a'; nas garotas, um interesse pelo corpo reprodutivo, mais do que no corpo sexua//erótico.

Esses dados são reforçados pelo material obtido por Costa (1996) na pesquisa A Face Masculina do Planejamento Familiar, realizada entre operários da construção civil do Ceará. O projeto foi desenvolvido com 250 trabalhadores, em sua maioria de origem rural e de baixa escolaridade. Aproximadamente $42 \%$ dos homens entrevistados tinham de 20 a 29 anos; e 38\%, entre 30 e 39. Da totalidade dos entrevistados, $66 \%$ tinham $1^{1}$ grau incompleto; e $16 \%$ nunca haviam estudado. Cerca de $86 \%$ dos entrevistados eram casados. Chama atenção o fato de $52 \%$ não saberem como a mulher engravida; $57 \%$ não sabem quando o corpo do homem é capaz de engravidar uma mulher-porém, 55\% sabem dizer quando a mulher é capaz de engravidar.

De certa forma, tais resultados confirmam os dados encontrados em pesquisa de opinião pública realizada pela Comissão de Cidadania e Reprodução ${ }^{4}$ (CCR), por meio do Instituto Data-Folha (1995). Foram entrevistadas 1.964 pessoas, maiores de 16 anos,

\footnotetext{
${ }^{4}$ A Comissão de Cidadania e Reprodução é uma organização da sociedade civil, de caráter nacional e que reúne pessoas e instituições que defendem direitos sexuais e direitos reprodutivos da população brasileira.
} 
de ambos os sexos, em São Paulo, Belo Horizonte, Porto Alegre e Recife. Foram surpreendentes os resultados à pergunta: "Todos os meses a mulher tem um período fértil e pode engravidar. Pelo que você sabe, durante quantos dias por mês o homem é fértil?" Erraram 66\% das mulheres e 52\% dos homens. Acertaram a resposta 32\% do total dos entrevistados. Cinqüenta e nove por cento disseram que não sabiam responder, e $9 \%$ erraram. Entre os homens, o índice de acerto foi de $38 \%$, contra $26 \%$ das mulheres. Os mais jovens tiveram uma freqüência maior de erros e, dentre estes, foi o grupo de mulheres entre 16 e 25 anos o que mais surpreendeu: $76 \%$ erraram ou disseram não saber a resposta. De maneira geral, quanto maior a escolaridade, maior o índice de acertos. Mesmo assim, apenas 30\% das mulheres com segundo grau completo e $62 \%$ com grau superior acertaram, ao passo que entre os homens os índices encontrados foram $47 \%$ e $75 \%$, respectivamente. É interessante observar que $23 \%$ dos homens com curso superior não souberam responder. Entre as mulheres, o índice chega a $34 \%$.

A vida sexual dos homens e, portanto, também sua saúde sexual é apresentada entre os participantes como algo muito simples, cuja centralidade reside no funcionamento do pênis, isto é, em sua ereção. Os homens consideram que, diferentemente do que ocorre com as mulheres, não haveria tanto o que aprender sobre o funcionamento de seus corpos. Estão voltados para o mecanismo da ereção, caracterizado por um funcionamento externo. Movidos por esse tipo de lógica, os entrevistados encontram uma facilidade muito maior para discorrer sobre o funcionamento do corpo feminino - voltados que estão para a conquista sexual e amorosa -e, também, por estarem dirigidos para a saúde das mulheres na perspectiva da solidariedade. No discurso dos homens participantes da pesquisa é possível identificar uma noção não tão claramente explicitada, mas evidente, de que as mulhcres merecem atenção e cuidado, porque são 'complexas' e devem ser conquistadas. Assim, corpo e psiquismo femininos são representados em oposição aos masculinos ('simples') e dos quais, por prudência, devem se afastar. Fica presente, sempre, o fantasma de ser identificado como homossexual.

O homem, nesse aspecto, já é meio relaxado, né? Acho que pelo nosso órgão genital não ser, assim, tão complexo, tão minucioso como o da mulher, geralmente, o homem só vai conhecer uma doença sexual quando ele pega uma gonorréia, etc. Ai ele vai atrás! (C., 24 anos, casado, s/ filhos)

Ah! Acho que eu cabulei essa aula (...). Porque, veja bem, você chegar numa aula de ciências onde o professor vai explicar o órgão reprodutor masculino... é dose, né? (N., 21 anos, casado, s/ filhos)

Essas questões e as que serão apresentadas a seguir têm implicações para iniciar um processo de reflexão sobre como poderiam ser desenvolvidas as políticas públicas no campo da educação para a saúde reprodutiva e sexualidade.

No campo das decisões sobre a vida reprodutiva, os homens entrevistados indicaram que as mulheres são aquelas que efetivamente "coordenam os processos reprodutivos". Acreditam serem elas que agenciam os processos que efetivamente acon- 
tecem basicamente em seus corpos. Os homens sentem que, muitas vezes, acabam sendo obrigados a modificar o rumo de suas vidas porque aceitaram a liderança feminina no processo reprodutivo - e esta, com freqüência, acaba desembocando em algo que não desejavam: ser pai. Mas, diante da realidade, vêem-se obrigados a reafirmar um aspecto que parece imutável, mesmo quando se pensa em diferentes masculinidades: 'assumir responsabilidades'. Este processo de assumir responsabilidades é que determinará o 'grau de seriedade de um homem'. Assumir um filho pode determinar a passagem de uma vida de "zoeira e irresponsabilidade, aprendizagem, molecagem" para uma de compromissos, perda de amizades, perda ou limitação da vivência da sexualidade como uma sexualidade do prazer, sem limites. O casamento apareceria, para os homens, como 'instância reguladora' do comportamento sexual e reprodutivo. ${ }^{5} \mathrm{~A}$ idéia/ intenção de ser pai, diferentemente do que julgam acontecer com as mulheres, viria com a maturidade, com o casamento. Se o filho aparece antes do casamento, parece ser claro que ele vem antes da 'vontade de ser pai'. Os homens que participaram da pesquisa indicam que quando são 'vitimados' por esse processo de liderança reprodutiva das mulheres, que thes acarreta paternidade prematura, vão se tornando, a posteriori, mais eficientes no controle da fertilidade. Isso poderá determinar maior preocupação com o uso de contraceptivos, em especial do condom.

Minha mulher dizia que não gostava de criança e tal e não queria ter, e eu que sempre insistia, falava que um dia iríamos ter etc. Até que um dia ela resolveu pôr na cabeça e faz um filho sem me consultar (...). (F., 23 anos, casado, c/ filhos)

Tentando desnudar um pouco mais este universo das relações entre mulheres e homens e seus processos reprodutivos, Villa (1996) realizou um estudo com homens de baixa renda na cidade de Buenos Aires. Nele, é possível perceber a complexidade da dinâmica de construção das representações masculinas sobre fecundidade e contracepção. São explorados os significados que a fecundidade adquire para os homens na constituição e organização da família, bem como se constituem as representações sobre a contracepção no espaço doméstico. Geralmente contraditórios e conflituosos, os significados são bastante diversos quando se trata de pensar a sexualidade no universo da família ou fora dela. Segundo os resultados do autor, o desejo de fecundidade da mulher torna-se, ao mesmo tempo, um desafio e uma ameaça. Desafio, porque é a fecundidade feminina que torna a sexualidade masculina socialmente aceita e personifica sua vivência sexual; ameaça, porque o afasta do mundo de seus pares, que the confere a identidade de gênero, relacionada a uma sexualidade impessoal, inserida na cultura masculina compartilhada. Tal sexualidade teria como produto 'os

\footnotetext{
${ }^{5}$ Esta passagem parece coincidir com o casamento, embora não seja necessariamente associada a ele. Pode estar vinculada a uma relação em que de alguma forma esteja definido um certo compromisso afetivo e sexual. Agradeço a Regina Maria Barbosa por este comentário.
} 
filhos por ai', inerentes a 'qualquer homem'. Os homens viveriam, então, um dilema entre a busca de uma identidade pessoal e a necessidade de se submeter a uma cultura masculina impessoal, aceita por outros homens. De um lado, estariam o mundo masculino e uma sexualidade exercida de forma marginal, compartilhada pelos homens, mas não socialmente aceita. De outro, a sexualidade exercida dentro do espaço doméstico, de certa forma submissa ao 'desejo de fecundidade das mulheres', que teria como produto os filhos. A mulher teria dentro do casamento, portanto, um papel moralizador da sexualidade masculina. Ao mesmo tempo que eles 'roubam sua sexualidade', elas a tornam socialmente aceita, e a singularizam. Neste contexto, a contracepção dentro da família torna-se uma contradição: são os filhos que dão visibilidade à 'sexualidade personificada e moralizada'.

De qualquer maneira, parece haver diferenças entre homens e mulheres sobre o que é mais interessante em relação aos processos reprodutivos. Mulheres desejam o filho; homens desejam a família. A idéia/desejo/vontade/aspiração de ser pai viria com a maturidade e com o casamento e não determina o filho, ao contrário do que parece ocorrer com as mulheres. Para muitas delas, a legitimidade de sua feminilidade ainda se dá pelo filho, ao passo que a legitimidade da masculinidade se fundamenta na família. Segundo Nolasco (1993), muitos homens têm filhos como se estivessem cumprindo mais uma etapa de suas vidas, reafirmando sua virilidade ou esclarecendo dúvidas sobre sua identidade sexual. Ter sucesso financeiro e ter a intenção de ser bom pai e um bom marido seriam elementos básicos, que definiriam para um homem o caminho rumo à paternidade, condição esta que raramente se definiria a partir de necessidades internas.

Desse ponto de vista, é bastante curiosa a posição masculina sobre o aborto. Mesmo considerando que são as mulheres que, em última instância, definem o que irá ocorrer em seus corpos, os homens entrevistados parecem considerar que suas palavras têm muito poder e podem direcionar a atitude das mulheres, inclusive em relação à decisão de abortar. No entanto, entre os participantes da pesquisa, há uma explicitação de que o homem que incentiva a mulher a abortar poderia estar se eximindo da responsabilidade reprodutiva e, portanto, eximindo-se da sua obrigação de se comportar como 'homem'. Conforme Victora (1982), os meninos são socializados para buscarem na rua o sustento para a casa. Esse menino que, para tornar-se um homem, deverá tornar-se pai e provedor, precisa pois, ter um filho e assumi-lo, para ver consagrada sua posição de homem adulto. Jardim (1995) afirma que a masculinidade é algo que deve ser comprovado continuamente por meio de diferentes estratégias e os filhos apareceriam como um dos elementos que 'provam' que o homem foi ativo na vida. 'Fazer filhos' seria uma capacidade de todo homem, mas sustentar e prover de respeito seria um passo importante na obtenção de status mais elevado entrc os pares. Surge, então, o conflito. Incentivar o aborto seria uma manifestação possível, quando o homem ainda não se identifica 
como 'homem pleno de responsabilidades'. Essa percepção explica os dados encontrados na pesquisa de opinião pública em que os homens declaram que devem tentar influir sobre a decisão das mulheres de abortar. (CCR, 1995).

Nos grupos focais, essas idéias são explicitadas:

Ai que nós voltamos ali para o início da nossa conversa, 'o que é ser homem', certo? Acho que o cara que foge de uma realidade dessas, prá mim, não é homem! Acho que hoje em dia você tem que ser homem para assumiro que vocêfaz! (L., 33 anos, casado, c/ filhos)

É mais fäcil ele induzir ela a fazê-lo. É dificil o cara chegare dizer: Ah, vai ser bonitinho, que legal e tal. (A., 25 anos, casado, s/ filhos)

E outra coisa, por incrivel que pareça. Mas quando pinta o negócio do aborto, é sempre o cara que vai atrás, é c cara que leva a mulher, é o cara que está do lado, é companheiro. Duas horas depois, ele pōe no ônibus e diz: Vai com Deus, filha! A maioria das vezes é assim. (R., 32 anos, casado, s/ filhos)

\section{Consideraçōes finais}

Os dados obtidos nessa pesquisa indicam que, no campo da sexualidade e da saúde reprodutiva, não será possível a permanência da focalização nas mulheres como objeto exclusivo do debate teórico e político. Não se trata, com isso, de esquecer que a análise das relações subjetivas e intersubjetivas deve considerar as hierarquias de gênero, mas, sim, de tentar promover uma compreensão relacional mais substantiva. No caso do Brasil, mudanças nas políticas macroeconômicas, que têm provocado alterações no mercado de trabalho com conseqüências importantes para os homens, como baixos salários (ou até mesmo desemprego), são fatores adicionais que reforçam a indicação de que há necessidade de maior compreensão dos possíveis novos significados das relações entre homens e mulheres (Giffin, 1994). A inclusão dos homens não deve ser feita apenas como ponto de apoio para a promoção do bem-estar das mulheres.

Continuar insistindo no discurso de que os homens não estão preenchendo adequadamente seus papéis e nem desempenhando tudo o que deles se espera não permitirá aproximar mulheres e homens para um processo de reconstrução de processos sociais e mentalidades (Barker et al., 1996).

O quadro apresentado aqui nos coloca em posição que exigirá certa ousadia. No caso do Brasil, trazer os homens para a cena da saúde e dos direitos reprodutivos de maneira mais substantiva supõe desafios no campo da conceituação e ação política e, também, na esfera da formulação, desenvolvimento e avaliação de políticas públicas.

Alguns profissionais da saúde, queoperam junto aos serviços de saúde pública, têm alertado para o fato de que seria mais fácil continuar a estimular os homens a serem colaboradores dos processos de saúde das parceiras. Será isso o desejável? Homens, de todas as faixas 
etárias, não deveriam também se tornar sujcitos de direitos no campo dos direitos sexuais e reprodutivos? O que isto significaria concretamente? Que mudanças na formulação das políticas deveriam serdesenvolvidas? É necessário que estes temas e debates sejam enfrentados, até porque, a partir dos dados obtidos nesta pesquisa, percebe-se que a reproduçãoe sua ligação com a saúde-parece ser um universo bastante distante dos homens, cujo reflexo nas demandas no campo da saúde reprodutiva deverá serdiretamente estimulado.

Uma lição já foi claramente aprendida a partir desta pesquisa: os dados remetem para a necessidade de se pensarem estratégias informativas diferenciadas para cada um dos sexos, uma vez que as motivações sexuais - o sentido que mulheres e homens parecem dar ao corpo sexual e reprodutivo são diferenciados. Há, portanto, um campo enorme de intervenção diferenciada em educação para a sexualidade e saúde reprodutiva para homens e para mulheres.

Pode-se afirmar, também, a necessidade premente de desmistificar, entre os homens, a concepção de que o corpo masculino é simples, mecânico e que, por isso, não precisa ser conhecido ou estudado. Também é relevante reverter a lógica de que se deva conhecer o funcionamento corporal apenas para conquistas amorosas. Deve-se conhecêlo para poder cuidar, tratar, e viver com mais qualidade e dignidade.

Outro aspecto bastante relevante (e que é um estímulo para a ação) é o fato de que homens condensam, simbolicamente, o sentido de fertilidade, potência/ereção do pênis e sexualidade. Desfazer esse emaranhado torna-se necessário e urgente para que novos processos cognitivos, comportamentais e afetivo-sexuais possam se desenvolver.

Esse processo de produção contínua de conhecimento teórico e de metodologias de intervenção deverá ser desenvolvido pelo conjunto de ONGs que hoje já operam no campo da sexualidade e saúde reprodutiva, sendo que o papel das universidades será extremamente significativo.

\section{Referências Bibliográficas}

BARKER, G. \& LOWENSTEIN, I. Where the Boys are: promoling greater male involvement in sexuality education: conclusions from Qualitative Research in Rio de Janeiro, Brazil. Relatório de Pesquisa. Rio de Janciro: CEDUS, 1996.

Comissão de Cidadanta e Reprodução. Sexualidade, Saúdee Direitos Reprodulivos do Homem. Relatório de Pesquisa. São Paulo, 1995.

Conselho Estadual da Condição Feminina. Clínicas de Esterilização. A Quem Servem? São Paulo, 1986.

Costa, M. A. G. da. A Face Masculina do Planejamento Familiar: Relato de Experiências. Relatório de projeto financiado pela Fundação MacArthur/Conselho Cearense dos Direitos da Mulher, Ceará, 1996. 
Demarest, R. J. \& Sciarra, J. J. Fisiologia do Sexo e Controle da Nalalidade - uma apresenlação visual. Rio de Janeiro: Editora Nacional, 1977.

Figueroa Perea, J. G. Algunos elemenlos para interprelar la presencia de los varones en los procesos de salud reproductiva. Primeira versão de texto preparado para la Revista Cadernos de Saúde Pública (Brasil), 1996, México.

FrYKMAN, J. Space for a Men: The Transformation of Masculinity in 20th Century Culture. Reproductive Heallh Matters, 7:11-18, 1996.

GIFFn, K Esfera de Reprodução em uma visão masculina: considerações sobre a articulação da produçãoe da reprodução, de classce de gênero. Physis-Revisla de SaúdeColetiva, 4 (1):23-40, 1994.

JARDIM, D. F. Performances, reprodução e produção dos corpos masculinos. In: LEAL, O. F. (Org.). Corpo e Significado. Ensaios de Antropologia Social. Porto Alegre: Editora da Universidade (NuPACS/UFRGS), 1995.

Kimmel, M. La produción teórica sobre la masculinidad: nuevos aportes. Fin de Siglo-Géneroy Cambio Civilizatorio, 17, 1992.

LeAl, O. F. \& Boff, A. de M. Insultos, Queixas, Sedução e Sexualidade: fragmentos de identidade masculina em uma perspectiva relacional. In: PARKER, R. \& BARBOSA, R. M. (Orgs.) Sexualidades Brasileiras. Rio de Janeiro: Relume-Dumará, 1996, p. 119-136.

Neubauer, P. B. Efeitos recíprocos da "Paternagem" sobre genitor e criança. In: Fogel, L. \& LieBert, R. Psicología Masculina. Novas perspectivas Psicanalílicas. Porto Alegre: Editora Artes MédiCas, 1989. p. 191-203.

Nolasco, S. O Milo da Masculinidade. Rio de Janeiro: Editora Rocco, 1993.

PaIVA, V. Sexualidades adolescentes: escolaridade, gênero c o sujeito sexual. In: Parker, R. \& Barbosa, R. M. (Orgs.) Sexualidades Brasileiras. Rio de Janciro: Relume-Dumará, 1996, p. 213-234.

SARTY, C. A. A Familia como Espelho: um estudo sobre a moral dos pobres. São Paulo: Editora Autores Associados, 1996.

SouzA, R. M. Paternidade em Transformação: o pai singular esua familia. 1994, 224 p. Tese de Doutorado em Psicologia Clínica, São Paulo: PUC.

Victora, C. As Relações de Gênero na Vila Divina Providência. Cadernos de Antropologia, (7): 15 28, 1992, Porto Alegre.

VILLA, A. M. Fecundidad y Masculinidad: algunos dilemas subjetivos en la construcción de genero de los varones. Buenos Aires, 1996.

VILEIA, W.V. \& BARbOSA, R. M. Repensando as relações entre gênero e sexualidade. In: PARkER, R. \& Barbosa, R. M. (Orgs.) Sexualidades Brasileiras. Rio de Janeiro: Relume-Dumará, 1996, p. 189-200. 
Formato: $16 \times 23 \mathrm{~cm}$

Tipologia: Calligraphic 810 BT

American Garamond BT

Papel: Pólen Bold $70 \mathrm{~g} / \mathrm{m}^{2}$ (miolo)

Cartão Supremo $250 \mathrm{~g} / \mathrm{m}^{2}$ (capa)

Fotolitos: Laser vegetal (miolo)

Engenho e Arte Editoração Gráfica Ltda. (capa)

Impressãoe acabamento: Zoomgraf-KLtda.

Rio de Janeiro, agosto de 1999

Não encontrando nossos títulos em livrarias, contactar a EDTORA FIOCRUZ:

Rua Leopoldo Bulhões, 1.480, térreo-Manguinhos.

Rio de Janeiro, RJ. CEP: 21041-210.

Tel.: (21) 560-6608, ramal 3030 .

Fax: (21) 560-6608, ramal 2009.

E-mail:editora@fiocruz.br 